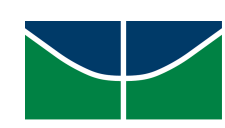

\title{
UnB
}

UNIVERSIDADE DE BRASÍLIA (UnB)

CENTRO DE DESENVOLVIMENTO SUSTENTÁVEL (CDS)

\section{A influência do movimento ambientalista nas políticas públicas: um estudo comparado entre Brasil e Estados Unidos}

Bruno Taitson Bueno

Orientador: Fabiano Toni

Tese de doutorado

Brasília, abril de 2016. 
Taitson Bueno, Bruno

A influência do movimento ambientalista nas políticas públicas:

um estudo comparado entre Brasil e Estados Unidos/ Bruno Taitson Bueno

Brasília, 2016

314 p.: il.

Tese de Doutorado. Centro de Desenvolvimento Sustentável.

Universidade de Brasília, Brasília.

1. Ambientalismo. 2. movimento ambientalista 3. ONGs. 4. lobby ambiental. 5. política ambiental brasileira. 6. política ambiental norteamericana

Universidade de Brasília.

CDS.

II. Título.

É concedida à Universidade de Brasília permissão para reproduzir cópias desta Tese e emprestar ou vender tais cópias, somente para propósitos acadêmicos e científicos. A autora reserva outros direitos de publicação e nenhuma parte desta Tese de doutorado pode ser reproduzida sem a autorização por escrito da autora.

Bruno Taitson Bueno 


\section{A influência do movimento ambientalista nas políticas públicas: um estudo comparado entre Brasil e Estados Unidos}

Bruno Taitson Bueno

Tese de doutoramento submetida ao Centro de Desenvolvimento Sustentável da Universidade de Brasília, como parte dos requisitos necessários para a obtenção de Grau de Doutor em Desenvolvimento Sustentável, linha de pesquisa "Políticas Públicas, Cultura e Sustentabilidade".

Aprovado por:

Fabiano Toni, Doutor (CDS-UnB)

(Orientador)

Doris Aleida Villamizar Sayago, Doutora (CDS-UnB)

(Examinadora interna)

José Augusto Leitão Drummond, Doutor (CDS-UnB)

(Examinador interno)

Marisa von Bülow, Doutora (IPOL-UnB)

(Examinadora externa)

Antônio Herman de Vasconcellos e Benjamin, Doutor (STJ/TSE)

(Examinador externo)

Brasília (DF), 20 de abril de 2016. 
Para Talita, sinônimo de apoio incondicional e dona do sorriso que alimenta minha alma todos os dias.

Para meus pais, Oswaldo e Elizabeth, por razões que as palavras não são capazes de descrever.

Para Beatriz, Gabriela, Vinícius e Arthur, com a esperança de que possam crescer em uma sociedade que dê mais valor a um piquenique no meio do mato do que a um dia de compras no shopping. 


\section{AGRADECIMENTOS}

Ao meu orientador, Prof. Fabiano Toni, pelo inestimável apoio ao longo de quatro anos. Os valiosos conselhos sobre bibliografia, estrutura da tese e entrevistados, a disciplina Governança Ambiental, o permanente incentivo ao doutorado-sanduíche e os cafés e almoços nas reuniões de orientação ficarão para sempre guardados na memória!

Aos professores do Centro de Desenvolvimento Sustentável da Universidade de Brasília, pelas disciplinas lecionadas, conversas de corredor, conselhos e dicas de bibliografia.

Aos funcionários do Centro de Desenvolvimento Sustentável, pelo permanente suporte dado aos alunos. Agradeço especialmente ao Antônio, pela eficiência e pela gentileza com as quais exerce seu trabalho.

À universidade pública, que torna possível a milhares de brasileiros e estrangeiros o acesso à educação superior gratuita.

À querida UnB, que possibilitou a realização do meu doutorado.

À Georgetown University, que me recebeu como pesquisador visitante durante 12 meses, viabilizando a parte norte-americana de meu estudo comparado.

Ao professor Jeffry Burnam, meu orientador na Georgetown University durante o doutorado-sanduíche, pelo apoio, pelas valiosas reuniões no The Tombs, pelas longas e interessantíssimas conversas sobre política norte-americana e pelo acolhimento.

À Capes, que me concedeu bolsa de estudos durante a maior parte do doutorado e viabilizou meu doutorado-sanduíche nos EUA.

À Luluca e ao Tony, por terem me hospedado durante os primeiros meses do doutorado-sanduíche e pelo carinho e amizade de sempre.

À Talita, pelo incentivo aos meus retiros em Cachoeira do Campo e Alto Paraíso de Goiás para redigir a tese e pela imensa ajuda com quadros, figuras e diagramação do trabalho.

A todos os entrevistados e entrevistadas, que gentilmente doaram parte de seu tempo para minha pesquisa, aportando informações indispensáveis à elaboração desta tese.

Ao WWF-Brasil, por ter aberto para mim, em 2006, as portas do ambientalismo.

Aos meus irmãos, Guilherme e Letícia, pela amizade, pelo companheirismo, pela paciência e, principalmente, pelos bons exemplos ao longo da vida.

Ao gato Lelo, pela companhia durante longas horas de leitura, estudos e redação da tese. 
They paved paradise And put up a parking lot With a pink hotel, a boutique And a swinging hot spot

Don't it always seem to go That you don't know what you've got Till it's gone

They paved paradise And put up a parking lot

They took all the trees Put 'em in a tree museum And they charged the people A dollar and a half just to see 'em

Don't it always seem to go That you don't know what you've got Till it's gone

They paved paradise And put up a parking lot

Hey farmer farmer Put away that DDT now Give me spots on my apples But leave me the birds and the bees

Please!

Trecho da música Big Yellow Taxi, composta pela canadense Joni Mitchell em 1970. A canção se tornou, à época, uma espécie de hino do movimento ambientalista mundial. 


\section{RESUMO}

A presente tese apresenta e analisa os principais repertórios utilizados pelo movimento ambientalista para influenciar políticas públicas no Brasil e nos Estados Unidos, duas democracias presidencialistas. Nos dois países, as ONGs ambientalistas conseguem, de maneira efetiva, exercer influência sobre a formulação, a aprovação e a implementação da legislação ambiental. No Brasil, a maior efetividade se dá por meio de projetos de campo que acabam se transformando em políticas. Nos EUA, as organizações se destacam, sobretudo, pela prática do lobby e pela bem-sucedida mobilização de cidadãos para influenciar processos decisórios. Em ambos os países, a presença de tomadores de decisão comprometidos com a questão ambiental, especialmente no poder Executivo, se mostrou determinante para o sucesso do movimento. Adicionalmente, o elevado grau de profissionalização e a reconhecida expertise científica do movimento brasileiro e norte-americano foram constatados, contribuindo enormemente para legitimar as organizações como importantes atores nos processos políticos.

Palavras-Chave: Ambientalismo, movimento ambientalista, ONGs, lobby ambiental, política ambiental brasileira, política ambiental norte-americana 


\begin{abstract}
This dissertation aims at listing and analyzing the main repertoires employed by the environmental movement to influence policy-making in Brazil and in the United States, two presidential democracies. The research reached the conclusion that environmental groups are able to effectively influence the making, the approval, and the implementation of environmental legislation in both countries. In Brazil, a higher effectiveness was noted in transforming field projects in policy. In the U.S., green groups' best performance was perceived in lobbying and in mobilizing citizens to influence decision-making. In both countries the presence of decisionmakers that are sensitive to the environmental cause, especially in the Executive branch, was seen as essential to the success of the environmental movement in influencing policy. Additionally, the high levels of professionalization and the scientific expertise in the environmental NGOs, in Brazil and in the U.S., were seen as key to legitimize the environmental groups as important actors in the political process.
\end{abstract}

Keywords: Environmentalism, environmental movement, NGOs, green lobby, Brazilian environmental policy, American environmental policy 


\section{LISTA DE FIGURAS}

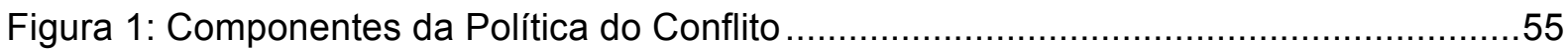

Figura 2: Modelo Simplificado do sistema político (polity) …..........................................56

Figura 3: Linha do tempo - Políticas ambientais nos Estados Unidos ................................ 85

Figura 4: Linha do tempo - Políticas ambientais no Brasil ...............................................120

Figura 5: Davi ou Golias? Situando as ONGs na política ..............................................135

Figura 6: Ranking da LCV, que mostra como deputados se posicionaram diante de questões

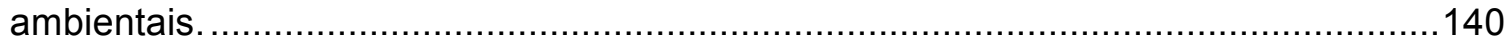

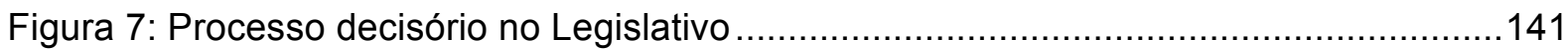

Figura 8: Peça de campanha do Greenpeace Brasil .....................................................143

Figura 9: Segunda peça de campanha do Greenpeace .................................................144

Figura 10: Peça final de campanha do Greenpeace Brasil ...............................................144

Figura 11: Campanha contra a exploração de petróleo no Ártico .....................................146

Figura 12: Peça da campanha Veta, Dilma estrelada por Gisele Bündchen em 2012 ........147

Figura 13: Peça da LCV agradecendo senadores por votarem contra o oleoduto Keystone150

Figura 14: Peça da LCV com critica a senador que votou contra regulação ambiental.......150

Figura 15: Peça da campanha das ONGs que expôs políticos favoráveis às mudanças no

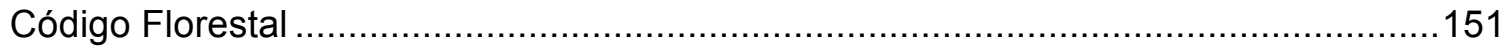

Figura 16: Peça de campanha da Defenders of Wildlife para a proteção dos lobos. ..........160

Figura 17: Capa do Estadão de 26/1/2008, com manchete sobre estudo do IMAZON .......161

Figura 18: Esquema de funcionamento do programa Habitat Exchange ...........................165

Figura 19: Audiência pública da EPA sobre emissões de ozônio ........................................171

Figura 20: Ator Marcos Palmeira em peça de campanha contrária à PEC 215.................182

Figura 21: Apenas um dos 12 candidatos da lista suja da LCV foi eleito nas eleições de 2012

Figura 22: Peça da Friends of the Earth com endosso ao pré-candidato Bernie Sanders à Casa Branca 194

Figura 23: Peça sobre bloqueio à passagem do navio da Shell rumo ao Ártico e apelo ao presidente para proibir a exploração de petróleo na região. 200

Figura 24: Protesto do Greenpeace em frente ao Planalto pede incentivos à energia solar201 
Figura 25: Material do EDF afirmando que a parceria com o Walmart, em seis anos, evitou a emissão de 28 milhões de toneladas métricas de $\mathrm{CO} 2$.

Figura 26: Anúncio do WWF no Politico, jornal dirigido a tomadores de decisão em Washington, reivindicando leis mais duras em relação à origem do pescado importado pelos EUA.211

Figura 27: Campanha denunciando suposta determinação do Partido Republicano em destruir a EPA.

Figura 28: Campanha online pela rejeição do PLS 654, do Senado, que flexibiliza o licenciamento ambiental. 212

Figura 29: Crítica ao governador de São Paulo, Geraldo Alckmin, em alusão à crise hídrica.212

Figura 30: crítica à presidente Dilma Rousseff durante aprovação do novo Código Florestal.213

Figura 31: Presidente Obama "lacra" as pretensões dos defensores da construção do oleoduto Keystone. 


\section{LISTA DE QUADROS}

Quadro 1: Oportunidade política, ameaça política e seus impactos ..................................47

Quadro 2: Proposição 65 - a força de Hollywood ........................................................147

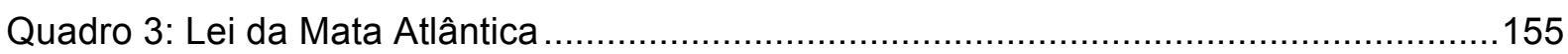

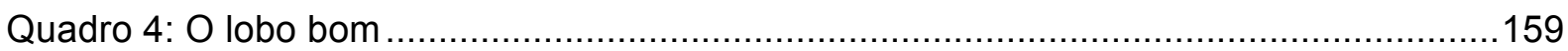

Quadro 5: Desmatamento com recurso público ............................................................160

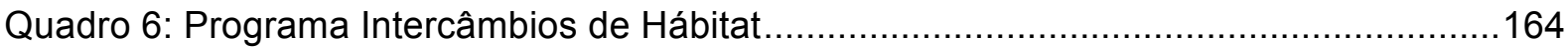

Quadro 7: CAR: Quando projetos locais ganham escala e viram políticas.........................168

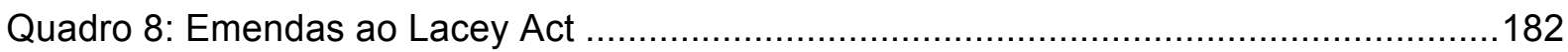

Quadro 9: Lei de Gestão de Florestas Públicas ...........................................................183

Quadro 10: Nos tribunais pelos índios Panará ...........................................................191

Quadro 11: Vencendo nas cortes a indústria do cimento .............................................192

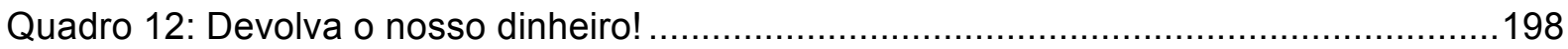

Quadro 13: O oleoduto Keystone: vitória após sete anos de luta ...................................214 


\section{LISTA DE ABREVIATURAS E SIGLAS}

ABONG: Organizações em Defesa dos Direitos e Bens Comuns, antiga Associação Brasileira de Organizações Não Governamentais

ACCCE: American Coalition for Clean Coal Energy, ou Coalizão Americana pela Energia Limpa a Carvão.

ADEMA: Associação de Defesa do Meio Ambiente

ADI ou ADIN: Ação Direta de Inconstitucionalidade.

AGAPAN: Associação Gaúcha de Proteção ao Ambiente Natural

AGU: Advocacia Geral da União

AIMEX: Associação das Indústrias Exportadoras de Madeira

AMDA: Associação Mineira de Defesa do Ambiente

ANWR: Refúgio da Vida Selvagem do Ártico, ou Arctic National Wildlife Refuge.

APP: Área de Preservação Permanente

APROSOJA: Associação dos Produtores de Soja do Brasil

ARA: Articulação Regional Amazônica

ASIBAMA: Associação dos Servidores do IBAMA

BLM: Escritório de Administração Fundiária, ou Bureau of Land Management

BNDES: Banco Nacional de Desenvolvimento Econômico e Social

CAR: Cadastro Ambiental Rural

CDSA: Companhia de Desenvolvimento de Serviços Ambientais do Estado do Acre

CEQ: Conselho da Qualidade Ambiental, ou Council of Environmental Quality

CHEJ: Center for Health, Environment and Justice

$\mathrm{Cl}$ : Conservation International

CI Brasil: Conservação Internacional - Brasil

CNA: Confederação Nacional da Agricultura e Pecuária do Brasil

CNBB: Conferência Nacional dos Bispos do Brasil

CNMA: Conferência Nacional de Meio Ambiente

CNPE: Conselho Nacional de Política Energética

CONAMA: Conselho Nacional do Meio Ambiente

CONSEMA: Conselho Estadual do Meio Ambiente (São Paulo)

CUT: Central Única dos Trabalhadores

DEM: Partido Democratas

EDF: Environmental Defense Fund

EMBRAPA: Empresa Brasileira de Pesquisa Agropecuária

EOP: Estrutura de Oportunidades Políticas

EPA: Agência de Proteção Ambiental, ou Environmental Protection Agency

ESA: Endangered Species Act, ou Lei das Espécies Ameaçadas.

ESEC: Estação Ecológica

FBCN: Fundação Brasileira para a Conservação da Natureza 
FoE: Friends of the Earth, ou Amigos da Terra

FSC: Conselho de Manejo Floresta, ou Forest Stewardship Council

FUNAI: Fundação Nacional do índio

FUNBIO: Fundo Brasileiro para a Biodiversidade

FVA: Fundação Vitória Amazônica

FWS: Fish and Wildlife Service, ou Serviço de Pesca e Vida Selvagem.

GEE: Gases de Efeito Estufa

GEF: Fundo Global para o Meio Ambiente, ou Global Environment Facility

GTA: Grupo de Trabalho Amazônico

IBAMA: Instituto Brasileiro do Meio Ambiente e dos Recursos Naturais Renováveis

IBDF: Instituto Brasileiro de Desenvolvimento Florestal

IBGE: Instituto Brasileiro de Geografia e Estatística

ICLEl: Governos Locais pela Sustentabilidade

ICMBIO: Instituto Chico Mendes de Conservação da Biodiversidade

ICV: Instituto Centro de Vida

IIEB: Instituto Internacional de Educação do Brasil

IMAFLORA: Instituto de Manejo e Certificação Florestal e Agrícola

IMAZON: Instituto do Homem e Meio Ambiente da Amazônia

IPAM: Instituto de Pesquisa Ambiental da Amazônia

IPCC: Painel Intergovernamental sobre Mudanças Climáticas

ISA: Instituto Socioambiental

IWPA: International Wood Products Association, ou Associação Internacional de Produtos Madeireiros

$\mathrm{KfW}$ : Banco de Desenvolvimento da Alemanha, ou Kreditanstalt für Wiederaufbau

LCV: League of Conservation Voters, ou Liga dos Eleitores Conservacionistas

MAPA: Ministério da Agricultura, Pecuária e Abastecimento

MCTI: Ministério da Ciência, Tecnologia e Inovação

MDA: Ministério do Desenvolvimento Agrário

MDIC: Ministério do Desenvolvimento, Indústria e Comércio

MDS: Ministério do Desenvolvimento Social e Combate à Fome

MJ: Ministério da justiça

MMA: Ministério do Meio Ambiente

MME: Ministério de Minas e Energia

MP: Ministério Público

MST: Movimento dos Trabalhadores Rurais Sem-Terra

NACA: National Agricultural Chemical Association, ou Associação Nacional de Química Agrícola

NEPA: National Environmental Policy Act, ou Lei Nacional da Política Ambiental

NMA: National Mining Association, ou Associação Nacional da Mineração

NPS: National Park Service, ou Serviço de Parques Nacionais. 
NRDC: Natural Resources Defense Council

NWF: National Wildlife Federation

OAB: Ordem dos Advogados do Brasil

OC: Observatório do Clima

OCB: Organização das Cooperativas Brasileiras

ONG: Organização não governamental

PAC: Political Action Committee, ou Comitê de Ação Política

PCdoB: Partido Comunista do Brasil

PEC: Proposta de Emenda à Constituição

PESACRE: Grupo de Pesquisa e Extensão em Sistemas Agroflorestais do Acre

PGR: Procuradoria Geral da República

PN: Parque Nacional

PNMA: Política Nacional do meio Ambiente

PP: Partido Progressista

PPCDAM: Plano de Ação para a Prevenção e Controle do Desmatamento na Amazônia Legal

PPG-7: Programa Piloto para a Proteção das Florestas Tropicais do Brasil

PSA: Pagamento por Serviços Ambientais

PSB: Partido Socialista Brasileiro

PSDB: Partido da Social Democracia Brasileiro

PSOL: Partido Socialismo e Liberdade

PT: Partido dos Trabalhadores

PV: Partido Verde

RDS: Reserva de Desenvolvimento Sustentável

RESEX: Reserva Extrativista

$\mathrm{RL}$ : Reserva Legal

RPPN: Reserva Particular do Patrimônio Natural

SAD: Sistema de Alerta do Desmatamento

SEEG: Sistema de Estimativas de Emissões de Gases de Efeito Estufa

SEMA: Secretaria Especial do Meio Ambiente

SFB: Serviço Florestal Brasileiro

SIG: Sistema de Informação Geográfica

SISA: Sistema de Incentivos a Serviços Ambientais

SISNAMA: Sistema Nacional do Meio Ambiente

SNUC: Sistema Nacional de Unidades de Conservação

STF: Supremo Tribunal Federal

TAC: Termo de Ajuste de Conduta

TCU: Tribunal de Contas da União

TNC: The Nature Conservancy

TWS: The Wilderness Society 
UC: Unidade de Conservação

USDA: United States Department of Agriculture, ou Departamento de Agricultura dos Estados Unidos

USFS: United States Forest Service, ou Serviço Florestal dos Estados Unidos.

WRI: World Resources Institute

WWF: World Wide Fund for Nature

ZEE: Zoneamento Ecológico-Econômico 


\section{SUMÁRIO}

INTRODUÇÃO

1. PERSPECTIVAS TEÓRICAS: O DESAFIO DO ENQUADRAMENTO DE ONGS A TEORIAS

E O CAMINHO ENTRE MOVIMENTO SOCIAL E ORGANIZAÇÃO EMPRESARIAL 39

1.1 TEORIAS CLÁSSICAS DOS MOVIMENTOS SOCIAIS ...................................... 42

1.2 TEORIA DA MOBILIZAÇÃO DE RECURSOS …................................................ 43

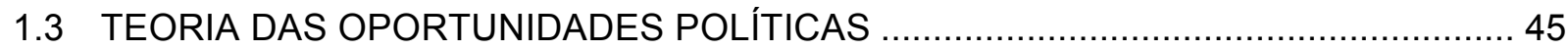

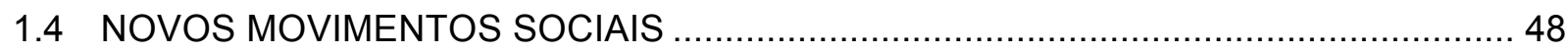

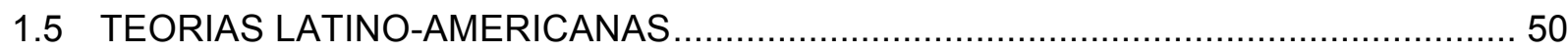

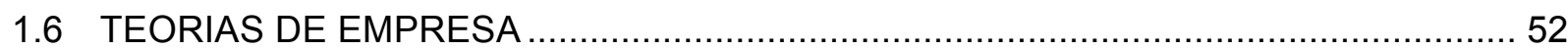

1.7 POLÍTICA DO CONFLITO: QUESTIONANDO O STATUS QUO POR VIAS

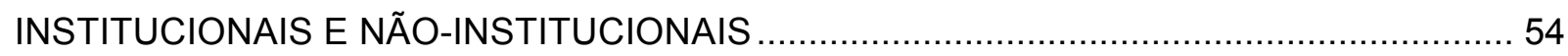

1.8 ABORDAGENS DE REDES E MODELO DAS COALIZÕES DE ADVOCACY ............ 58

1.9 CONCEITO DE FRAMING E O ENQUADRAMENTO DOS DISCURSOS EM BUSCA

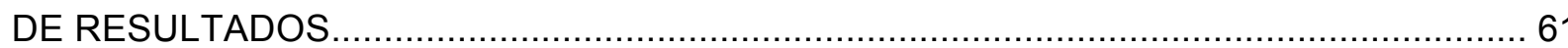

1.10 PROIBIR HOJE PARA NÃO FALTAR AMANHÃ: O CARÁTER SUI GENERIS DAS

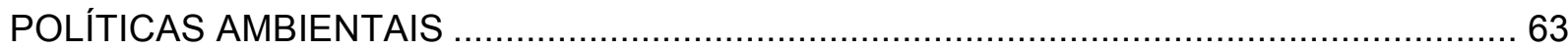

2. AS POLÍTICAS AMBIENTAIS E O MOVIMENTO AMBIENTALISTA NOS EUA..............69

2.1 EVOLUÇÃO DAS POLÍTICAS AMBIENTAIS NOS ESTADOS UNIDOS .....................69

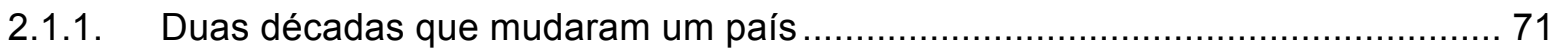

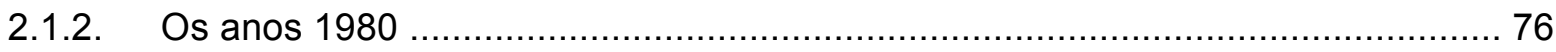

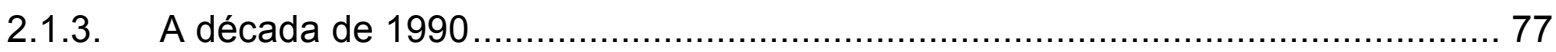

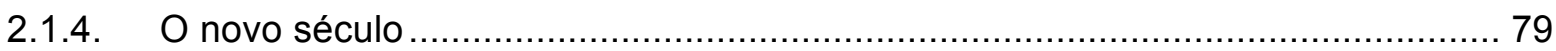

2.1.5. Linha do tempo - Políticas ambientais nos Estados Unidos ............................ 83

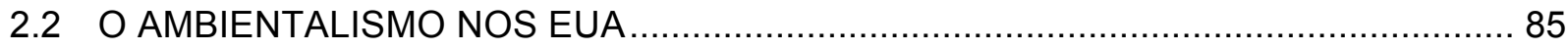

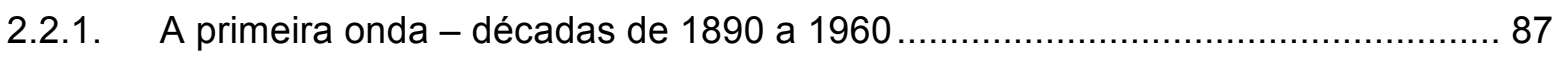

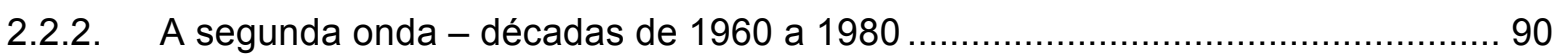

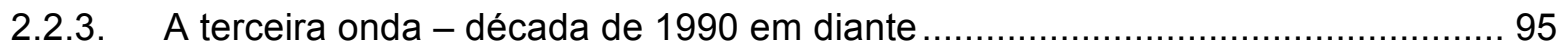

3. AS POLÍTICAS AMBIENTAIS E O MOVIMENTO AMBIENTALISTA NO BRASIL .......... 99

3.1 EVOLUÇÃO DAS POLÍTICAS AMBIENTAIS NO BRASIL ...................................... 99 
3.1.1. Período das proteções fragmentadas................................................................ 100

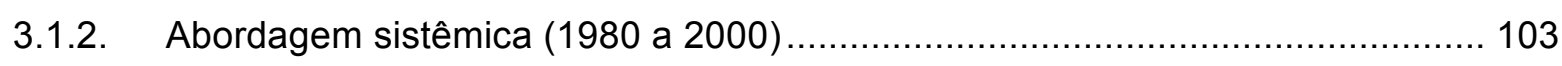

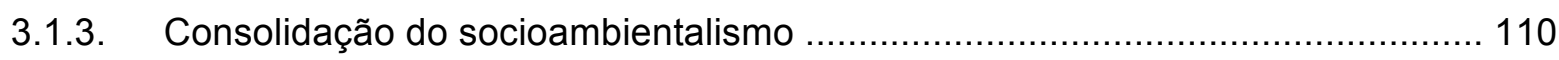

3.1.4. Linha do tempo - Políticas ambientais no Brasil ......................................... 117

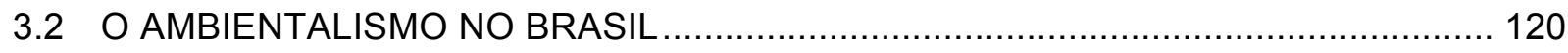

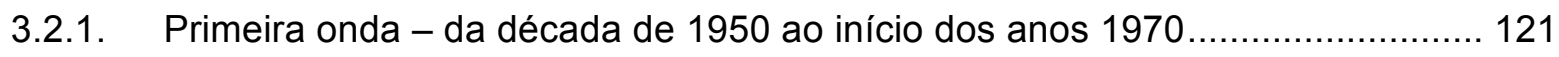

3.2.2. Segunda onda - segunda metade dos anos 1970 ao final dos anos $1980 \ldots \ldots . .123$

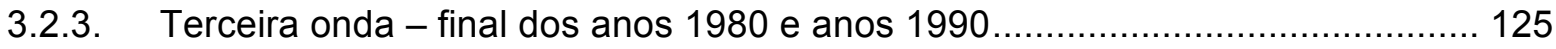

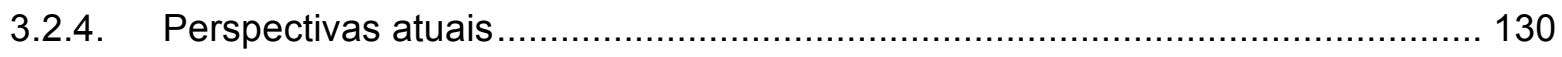

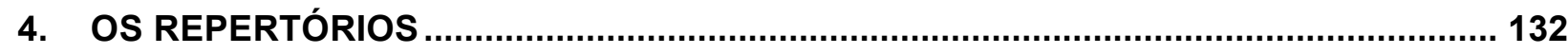

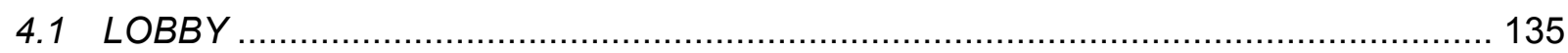

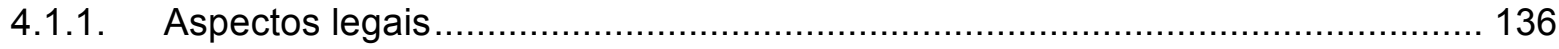

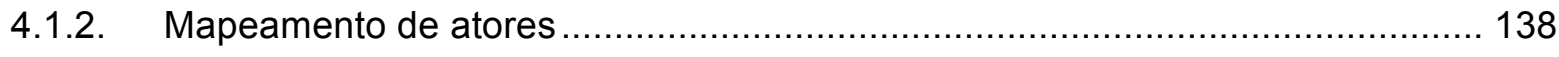

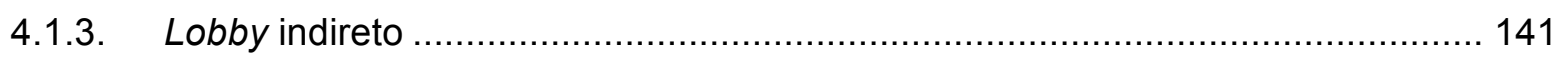

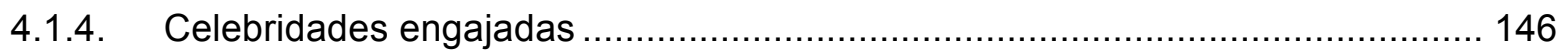

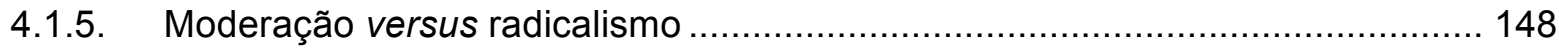

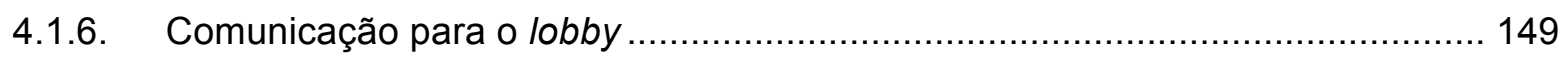

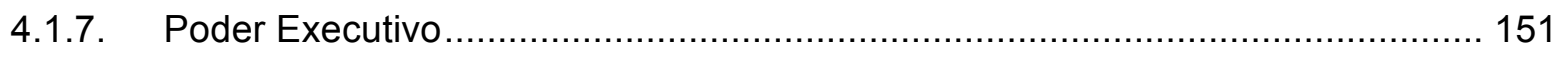

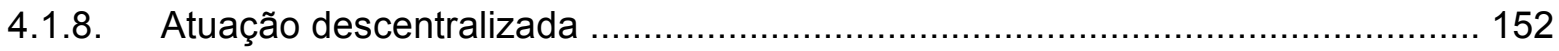

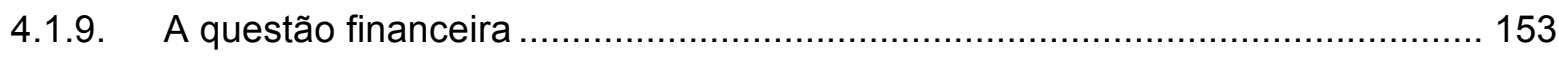

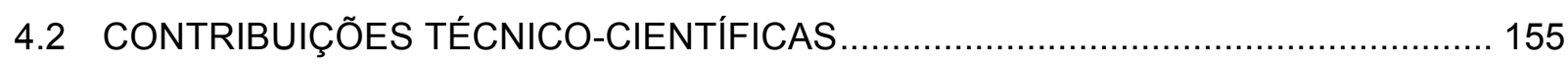

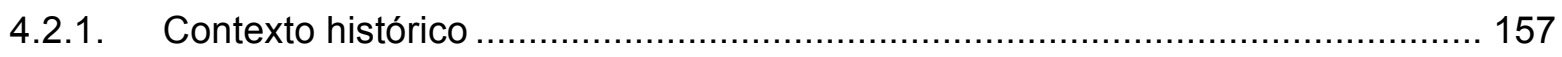

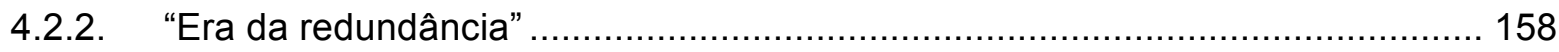

4.3 PROJETOS DE CAMPO QUE VIRAM POLÍTICAS .......................................... 161

4.4 ESPAÇOS INSTITUCIONAIS: CONSELHOS, COMITÊS, COMISSÕES E AUDIÊNCIAS

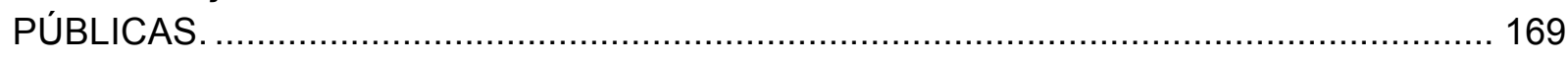

4.5 FORNECENDO QUADROS QUALIFICADOS PARA O ESTADO ............................ 174

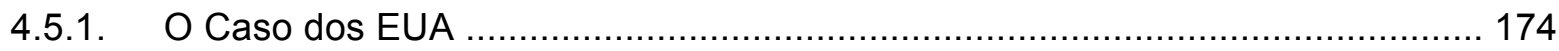

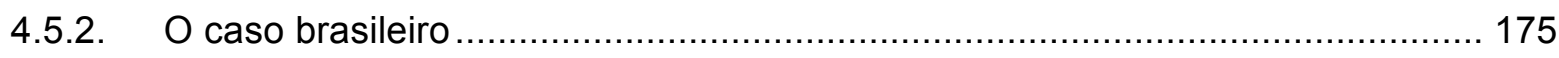


4.6 JUNTOS CHEGAREMOS LÁ: ALIANÇAS E COALIZÕES ................................... 178

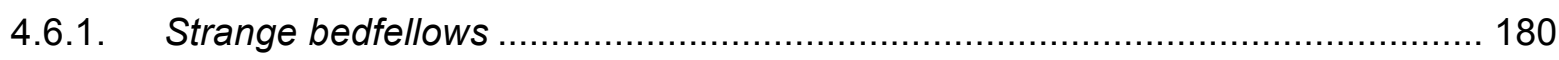

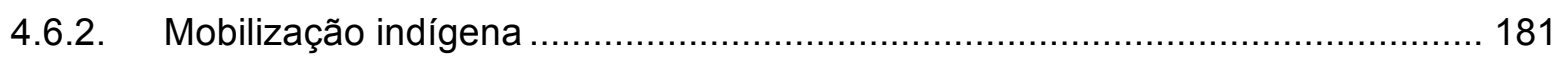

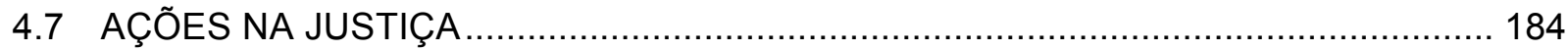

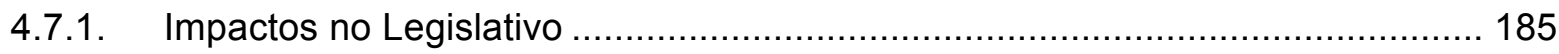

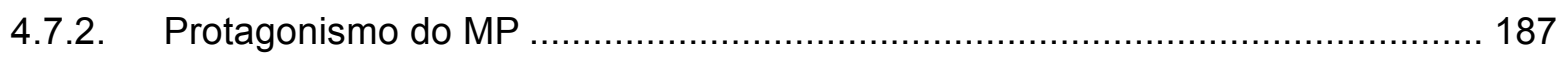

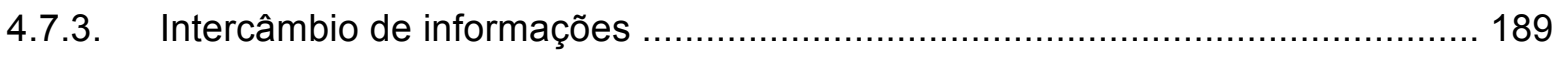

4.8 CAMPANHAS ELEITORAIS: ESVERDEANDO O LEGISLATIVO E O EXECUTIVO.. 192

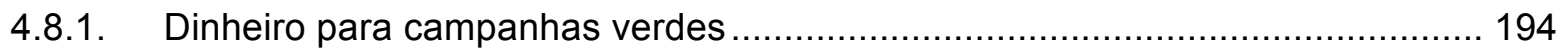

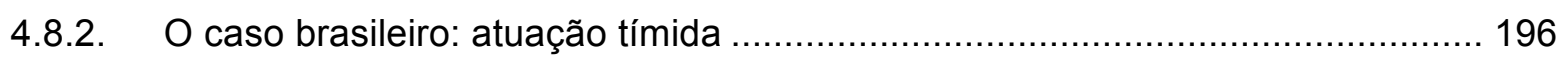

4.9 DENÚNCIAS, AÇÃO DIRETA, BOICOTES E PROTESTOS: ORGANIZAÇÕES CÃES

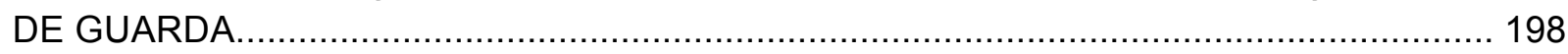

4.10 GRANDES EMPRESAS, GRANDES ALIADOS ................................................... 202

4.11 COMUNICAÇÃO PARA SENSIBILIZAR E MOBILIZAR ….................................... 207

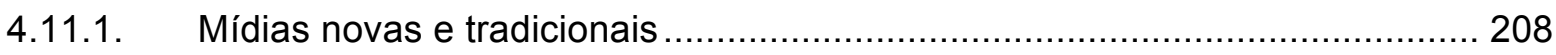

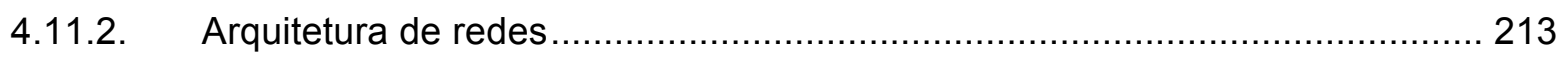

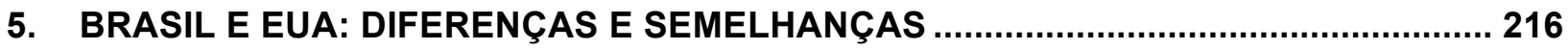

5.1 A ESTRUTURA DAS ORGANIZAÇÕES E SEUS IMPACTOS ............................... 218

5.2 O CONTEXTO POLÍTICO DETERMINANDO ESTRATÉGIAS E RESULTADOS ....... 222

5.3 O PESO DAS QUESTÕES LEGAIS, HISTÓRICAS E CULTURAIS .......................... 232

5.4 APOIO PÚBLICO: TRUNFO NOS EUA, OBSTÁCULO NO BRASIL ......................... 239

5.5 A INFLUÊNCIA DO SISTEMA POLÍTICO E ELEITORAL .................................... 243

5.6 O MOVIMENTO E O ESTADO: PARCERIA, SUBSTITUIÇÃO E ENFRENTAMENTO249

5.7 O ENQUADRAMENTO DAS MENSAGENS: QUEM VENCE A GUERRA DA

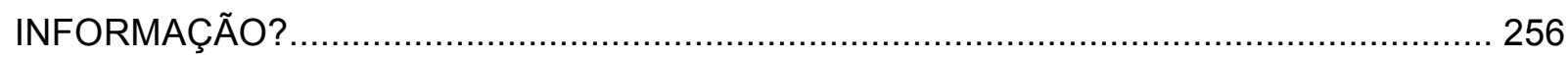

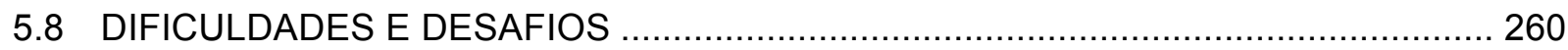

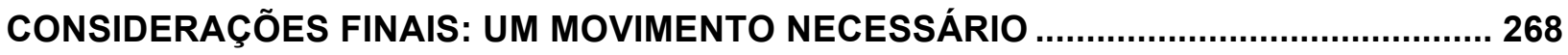

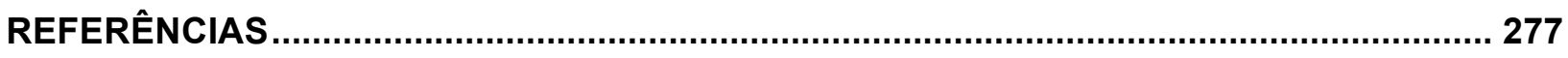

REPORTAGENS E POSTAGENS EM BLOGS/PLATAFORMAS ONLINE ...................... 289 
ANEXO I - LISTA DE ENTREVISTAS. 


\section{INTRODUÇÃO}

Este trabalho tem como objetivo levantar e analisar os principais repertórios ${ }^{1}$ utilizados pelo movimento ambientalista para influenciar políticas públicas no âmbito doméstico em duas democracias presidencialistas: Brasil e Estados Unidos. Foram pesquisadas ações, bem-sucedidas ou não, por parte das chamadas organizações não governamentais com atuação na área do meio ambiente, que tivessem como objetivo fazer com que tomadores de decisão formulem, modifiquem, mantenham, aprovem, rejeitem ou implementem políticas com implicações ambientais nos dois países.

Em outras palavras, procurou-se aqui identificar as maneiras com que organizações da sociedade civil, no segmento socioambiental, buscam convencer membros das esferas institucionalizadas do Estado (poderes Executivo, Legislativo e Judiciário) a tomar decisões em consonância com os objetivos e visões desses grupos ambientalistas. Nos EUA, as primeiras manifestações de organizações na área ambiental se dão a partir do final do Século 19 e, no Brasil, na segunda metade do Século 20.

Nas páginas seguintes busquei demonstrar que o movimento ambientalista vem sendo um importante ator no sentido de aportar relevantes contribuições para as políticas públicas com impacto ambiental. Nos EUA, apesar de importantes conquistas desde o final do Século 19 , este protagonismo se inicia nos anos 1960, intensificando-se na década seguinte. No Brasil, nota-se uma participação importante do movimento ambientalista a partir da segunda metade da década de 1980, quando o país inicia o período da redemocratização, consolidada pela Constituição de 1988 e pelas primeiras eleições diretas para presidente desde 1960, ocorridas em 1989.

Algumas das ações empregadas pelas organizações ambientalistas para influenciar políticas, observadas durante a pesquisa, foram:

- lobby dirigido ao Legislativo, especialmente junto a parlamentares e seus gabinetes, ou a tomadores de decisão na esfera do Executivo, em ministérios, secretarias, agências e governos federal, estadual, municipal, de condados etc.;

- ações judiciais contra governos e instituições que não estariam aplicando a legislação ambiental;

\footnotetext{
${ }^{1}$ Como repertório entende-se o "conjunto de formas de ação" (Alonso 2012, p.23). No caso específico deste trabalho, o termo repertório é utilizado para agrupar as diversas táticas utilizadas pelas ONGs ambientalistas para atingir objetivos ligados ao campo das políticas públicas.
} 
- parcerias com o Ministério Público ou com associações comunitárias para subsidiar ações na Justiça em defesa de comunidades, recursos naturais e ecossistemas;

- mobilização do público para que determinados atores sejam convencidos, via pressão popular, a tomar determinada decisão;

- participação em fóruns institucionalizados como audiências públicas, conselhos estaduais, locais ou municipais, comissões especiais na Câmara ou no Senado, comitês de bacias, reuniões com tomadores de decisão no Executivo e outras instâncias que envolvam a discussão de políticas ambientais;

- utilização de celebridades para sensibilizar tomadores de decisões e o público;

- apoio, via endosso formal ou contribuições financeiras, ou rejeição formal, a candidatos a cargos eletivos;

- estudos técnicos e científicos para embasar a formulação, aprovação, rejeição ou implementação de políticas por tomadores de decisão em um dos três poderes;

- denúncias, manifestações, marchas, boicotes e protestos;

- fornecimento ao Estado de quadros, por um lado, tecnicamente qualificados e, por outro, alinhados com as causas defendidas pelo movimento, para trabalharem e tomarem decisões envolvendo políticas ambientais;

- projetos de campo, também chamados de piloto, que ganham escala e se transformam em políticas públicas, nas esferas municipal, estadual e federal;

- coalizões entre organizações ambientais e de outras áreas, bem como empresas, capazes de influenciar tomadores de decisão e

- ações de comunicação para influenciar opinião pública, imprensa, formadores de opinião e, em última análise, tomadores de decisão que lidem com a questão ambiental.

A pesquisa, portanto, tem foco nos repertórios e nas ferramentas empregados pelo movimento ambientalista, no Brasil e nos EUA, para atingir seus objetivos estratégicos no campo das políticas públicas. A partir de pesquisas bibliográficas, consulta a veículos de comunicação e entrevistas, vários exemplos desses repertórios foram elencados, destacando-se aqueles mais ou menos utilizados pelas diferentes instituições pesquisadas nos dois países.

Foi possível notar que o cardápio à disposição das organizações ambientalistas - e dos grupos de interesse e organizações da sociedade civil, em geral - não varia enormemente entre as instituições analisadas e os países estudados. Os resultados desta pesquisa foram na mesma direção do que já fora demonstrado por Tilly (2008): as ações 
empregadas pelos movimentos para levar adiante suas reivindicações podem variar, mas essas variações normalmente obedecem a um repertório adotado ao longo da história por organizações que atuam em espaços e segmentos similares (pp.14-15).

\section{Brasil e EUA como objetos de estudo}

Cabe aqui observar que a escolha de Brasil e Estados Unidos para esta pesquisa se deu, inclusive, por semelhanças demográficas, políticas e geográficas, fundamentais à realização de um estudo comparado no campo das políticas ligadas ao tema do desenvolvimento sustentável. Os países contam com extensão territorial semelhantes (Brasil: 8,5 milhões de km2; EUA: 9,3 milhões de $\mathrm{km} 2$ ) e têm grande população, caracterizada pela diversidade étnica, os EUA com aproximadamente 320 milhões de habitantes e, o Brasil, com cerca de 200 milhões $^{2}$.

Do ponto de vista ambiental, aspecto-chave desta pesquisa, Brasil e Estados Unidos são importantes atores no cenário mundial. Ambos integram o grupo dos 17 países megadiversos, denominação dada aos que contam com maior biodiversidade no mundo. $\mathrm{O}$ Brasil, por exemplo, responde por cerca de $12 \%$ de todas as espécies animais e vegetais do planeta $^{3}$.

Os Estados Unidos, embora já tenham acumulado níveis de desmatamento maiores que os brasileiros, contam com uma extensa rede de áreas protegidas de aproximadamente 2,6 milhões de quilômetros quadrados ${ }^{4}$. Adicionalmente, os EUA têm significativa relevância política e econômica (maior PIB mundial) para o planeta e respondem pelo primeiro lugar no ranking mundial de emissões de gases de efeito estufa por habitante (a China é o principal emissor em números absolutos). As principais políticas adotadas nos Estados Unidos, econômicas ou ambientais, sejam elas de alcance interno ou externo, costumam ter desdobramentos em outras partes do mundo, o que aumenta a importância do país no cenário mundial e, portanto, o torna ainda mais relevante para uma investigação ligada a políticas ambientais.

\footnotetext{
${ }^{2}$ Os dados referentes a população e território brasileiros são do IBGE e estão disponíveis no site http://www.ibge.gov.br/home/geociencias/cartografia/default territ area.shtm (acesso em 20/08/2015). As informações dos EUA foram consultadas no site do United States Census Bureau: http://quickfacts.census.gov/qfd/states/00000.html (acesso em 20/08/2015).

3 De acordo com o site da organização Conservação Internacional, "os 17 países megadiversos estão distribuídos em quatro continentes. A maioria deles está nas Américas, o continente mais rico de todos, com as maiores áreas de hábitats naturais intactos: Brasil, Colômbia, México, Venezuela, Equador, Peru e Estados Unidos. Os demais são a África do Sul, Madagascar, República Democrática do Congo (ex-Zaire), Indonésia, China, Papua Nova Guiné, Índia, Malásia, Filipinas e Austrália" (disponível em http://www.conservation.org.br/como/index.php?id=11 - acesso em 29 de novembro de 2013).
}

\footnotetext{
${ }^{4}$ Unep (http://www.unep-wcmc.org/\#?country=US\&dashboard=show - consulta em 15/08/2015)
} 
Adicionalmente, ambos os países ocupam posição de protagonismo no cenário internacional nas negociações ligadas às mudanças climáticas e biodiversidade (Kasa et al 2008 e Mittermeier et al 2010). No caso norte-americano, tal posição de destaque é notada na maior parte dos assuntos discutidos internacionalmente. Em relação ao Brasil, o país se destaca em alguns temas, estando o meio ambiente incluído nesta lista.

Em relação ao sistema político - aspecto fundamental para um trabalho que discute a influência de organizações da sociedade civil em políticas públicas - Brasil e Estados Unidos também guardam semelhanças que vão além da condição de democracias ocidentais estáveis, conforme observado por Lemos (2005):

São regimes presidencialistas, federativos, bicamerais, com uma semelhante divisão interna de trabalho nos seus legislativos e com instrumentos de controle simétricos. Além disso, a constituição e várias instituições brasileiras foram desenhadas sob influência do constitucionalismo norte-americano (p.17).

Este aspecto é fundamental, pois certamente uma comparação da atuação de organizações no campo de jogo da política seria praticamente inviável em países com diferentes sistemas políticos, ou caso um dos cenários escolhidos fosse um Estado sob regime ditatorial ou no qual a atuação da sociedade civil fosse proibida, restrita ou comprometida.

Os dois sistemas contam com algum grau de abertura para a atuação da sociedade civil, e têm um grande número de organizações ambientalistas, algumas delas atuando nos dois países, como é o caso de Conservação Internacional, Environmental Defense Fund, The Nature Conservancy, WRI e WWF. Há ainda, no Brasil e nos EUA, organizações locais, que buscam levar adiante agendas de interesse local. Há, também, instituições do poder Executivo (no Brasil, ministérios, secretarias e órgãos ambientais; nos EUA, as chamadas agências, como a EPA) razoavelmente estruturadas e com legitimidade diante da sociedade.

Estas condições mostram que o principal objeto deste estudo - as grandes organizações ambientalistas de Brasil e EUA - atuam dentro de condições semelhantes em sistemas políticos que produzem decisões com impactos nas vidas de milhões de pessoas internamente e, por que não dizer, de bilhões de pessoas em todo o planeta.

Os dois países que fazem parte desta pesquisa contam com processos históricos que guardam entre si diversas semelhanças no que diz respeito à ocupação do território e à relação com populações nativas, recursos naturais, fauna e flora. Tanto Brasil quanto Estados Unidos vivenciaram um processo de colonização estimulado pelo Estado, 
envolvendo o desbravamento de terras na direção Oeste. Povos locais, espécies animais e arbóreas e os ativos naturais, de maneira geral, eram vistos como obstáculos a serem superados e até eliminados, ou como recursos a serem explorados de maneira ilimitada.

Nos Estados Unidos, a doutrina do "destino manifesto", referendada inclusive pelo Congresso no Século 18, dava o aval político, sob justificativas religiosas, à expansão territorial do país, mesmo que fosse à custa do extermínio de indivíduos, comunidades e espécies animais, ou mesmo avançando sobre terras pertencentes a países vizinhos soberanos (Brown 1971, p.8; Wills 2013, pp.4, 28, 35).

No Brasil, processo similar ocorreu. A ocupação das regiões do Cerrado e da Amazônia se deu sem maiores preocupações sociais ou ambientais, também com aval do Poder Público e muitas vezes com verdadeiros massacres contra povos autóctones. A conquista de territórios pertencentes a países vizinhos também aconteceu (Monteiro 1981, pp.12, 106; Vieira 2006, p.53; Villas Bôas e Villas Bôas 2012, pp.33-34), embora em escala menor que no caso norte-americano.

Outro ponto em comum aos dois países - este mais diretamente relacionado à minha pesquisa - é a presença de arcabouços legais robustos na área ambiental. Os Estados Unidos desenvolveram, ao longo da história, leis voltadas para a conservação dos recursos hídricos, para padrões de qualidade do ar, proteção de espécies ameaçadas, licenciamento ambiental, criação e implementação de unidades de conservação (Kubasek e Silverman 2005, p.127). No Brasil, os anos 1980, 1990 e 2000 assistiram à aprovação de diversas peças de legislação ambiental.

Indiscutível também parece ser a importância das organizações ambientais da sociedade civil, tanto no Brasil como nos EUA, no sentido de participar - com incidência e efetividade variadas ao longo da história - da construção dessa rede de políticas voltadas para a proteção e o uso racional de recursos naturais e para a regulação de atividades que gerem impactos ao ambiente.

Ampla literatura comprova que a área da governança ambiental é uma das que assistiram a um marcante protagonismo dos setores não-governamentais, com uma multiplicação não apenas dos atores, mas também de sua relevância em temas ambientais, notadamente a partir da década de 1970. As principais consequências desses processos foram "a diversificação das arenas em que a política é praticada (...) e a descentralização da autoridade política em relação às questões ambientais" (Bridge e Perreault 2009, p.481).

Pesquisadores brasileiros chegaram a similar constatação. A participação do Terceiro Setor na vida pública e nos processos políticos, de forma sistemática, foi classificada por Ricardo Arnt e Steve Schwartzman (1992), em obra sobre o ambientalismo no Brasil, como 
"um dos grandes fatos novos na vida política nacional e mundial", que caracteriza, ainda segundo os autores, "uma recusa do monopólio estatal de formulação e gestão de políticas que afetam a sociedade em seu todo" (p.19).

Há, naturalmente, algumas diferenças importantes entre os dois países do ponto de vista histórico. Os EUA podem ser considerados uma democracia mais madura que a brasileira, uma vez que experimentaram por mais tempo regimes garantidores dos direitos civis, políticos e, em maior grau que no Brasil, sociais.

É importante observar, também, que foram apuradas significativas diferenças entre as organizações nos dois países, mas as principais distinções foram em termos de intensidade, eficiência, frequência e maneiras como uma e outra ferramenta é aplicada, uma vez que o menu de repertórios não varia tanto. Foram observadas diferenças, também, nos resultados obtidos, que dependem dos distintos contextos nacionais. Se o escopo tivesse sido ampliado para organizações menores, de atuação exclusivamente local, as diferenças entre repertórios provavelmente teriam sido maiores.

\section{Ambientalismo}

A título de conceituação, o termo ambientalista (termo da língua portuguesa para environmentalist) foi cunhado pela imprensa norte-americana em 1970, para classificar os cerca de 20 milhões de ativistas que participaram do histórico Dia da Terra (Hoffman e Bertels 2010). O evento, organizado em 22 de abril de 1970, envolveu comunidades, escolas, universidades e movimentos, com objetivo de chamar a atenção da sociedade e das autoridades para a importância do meio ambiente (Wellock 2008, p.175).

Optei por adotar a denominação ONG ambientalista assumindo o risco de cometer eventuais imprecisões. Além de escolher categorização seguida majoritariamente por pesquisadores, pelas próprias organizações e por veículos de imprensa, entendo que o termo ambientalista é o que melhor consegue englobar as organizações que atuam no setor, mesmo as que se autodenominam socioambientais, conservacionistas, preservacionistas, ecológicas e de justiça ambiental, entre outras categorias.

Importante salientar, com objetivo de esclarecer o recorte selecionado para a pesquisa que, por compartilharem ideias, visões e soluções, por combaterem, ainda que de formas diferentes, problemas comuns e, ainda, por terem "adversários" iguais, as organizações escolhidas podem ser agrupadas sob a categoria de um movimento. Aproveito aqui a definição de Wapner (2010), que afirma que, a despeito das diferenças, o movimento ambientalista compartilha o conjunto de princípios que motivaram sua fundação, ligados à proteção do planeta e à manutenção de sua viabilidade como morada da humanidade e das demais espécies (p.51). 
Adicionalmente, devido à amplitude do que se convencionou chamar de movimento ambientalista, envolvendo milhares de organizações de diversos portes e enfoques, foi necessário limitar o escopo da pesquisa. O recorte se deu em torno das chamadas ONGs ambientalistas com maior alcance, que são justamente aquelas com presença observada em manifestações públicas, ações judiciais, iniciativas de comunicação, veículos de imprensa, mídias sociais, audiências públicas e ações de lobby nos parlamentos, ministérios, órgãos públicos e governos e que acabam sendo, também, as organizações que mais influenciam as políticas ligadas ao desenvolvimento sustentável.

No caso brasileiro, embora durante a pesquisa tenham sido levantadas informações sobre organizações menores, de atuação exclusivamente local, foram elencadas e analisadas na tese táticas empregadas por ONGs cuja atuação impacte, em diferentes graus, políticas ambientais no âmbito nacional, como Amigos da Terra Amazônia Brasileira, AMDA, Conservação Internacional, Greenpeace, Grupo de Trabalho Amazônico, Instituto Centro de Vida, Instituto Socioambiental, IMAZON, Instituto de Pesquisa Ambiental da Amazônia, TNC e WWF-Brasil, entre outras.

Nos Estados Unidos, onde a quantidade de organizações da sociedade civil, e consequentemente ambientais, é significativamente maior que no Brasil ${ }^{5}$, o critério foi mantido. Embora o trabalho também tenha acessado o trabalho de ONGs locais, com elevado grau de sucesso, foram pesquisadas com maior dedicação as estratégias e os repertórios utilizados por grupos como Center for Health, Environment \& Justice, Conservation International, Defenders of Wildlife, Earthjustice, Environmental Defense Fund, Friends of the Earth, Greenpeace, League of Conservation Voters, National Wildlife Federation, Natural Resources Defense Council, Sierra Club, The Nature Conservancy, The Wilderness Society, WWF-EUA e 350.org, entre outras.

\section{Efetividade}

Além de elencar os principais repertórios, outro objetivo deste estudo é discutir, do ponto de vista da efetividade, essas ações empregadas pelas organizações ambientalistas nos dois países. Uma análise simplista poderia levar à constatação de que, para se avaliar a efetividade de uma estratégia do movimento ambientalista na área das políticas públicas, bastar-se-ia observar se determinada legislação, apoiada pelas organizações, foi aprovada

\footnotetext{
${ }^{5}$ De acordo com a ABONG, segundo números de 2012, havia cerca de 290 mil fundações privadas e associações sem fins lucrativos no Brasil (disponível em http://www.abong.org.br/ongs.php?id=18, acesso em 28/08/2015); nos EUA, números também de 2012 do Departamento de Estado apontam para 1,5 milhão de ONGs operando no país (disponível em http://www.humanrights.gov/fact-sheet-non-governmental-organizationsngos-in-the-united-states.html, acesso em 28/08/2015).
} 
no Congresso, ou adotada pelo Poder Executivo, ou se uma ação ingressada na Justiça foi vencedora em última instância. Ou, caso uma política vista pelos ambientalistas como contrária à conservação de ecossistemas ou ao desenvolvimento sustentável fosse aprovada, ficaria caracterizado, automaticamente, o fracasso.

Outra abordagem que não responde satisfatoriamente à complexidade das questões socioambientais, mas vez por outra é utilizada para avaliar o desempenho das ONGs ambientalistas, é a que leva em conta, isoladamente, as condições do ambiente em que as sociedades vivem. De acordo com esta lógica, poder-se-ia dizer que o movimento socioambiental não é efetivo porque as emissões globais e a crise climática estão se agravando, conforme atestam o desaparecimento de espécies, o aumento das temperaturas e o derretimento das geleiras, entre outros sinais (Devall 2006, p.171).

A linha pela qual optei nesta tese é bastante diferente das mostradas nos dois parágrafos acima. Se fizessem sentido, fundamentariam o entendimento de que, por exemplo, o movimento feminista não é efetivo na medida em que, ainda hoje, os salários das mulheres, em média, são mais baixos que os dos homens. Ou que as organizações voltadas para o alívio à pobreza são incompetentes pelo fato de a fome e a miséria permanecerem no dia-a-dia de bilhões de pessoas no mundo.

Entendo que o sucesso dos movimentos reivindicatórios - pelos direitos das mulheres, por salários mais justos, pela extensão dos direitos civis a grupos marginalizados ou pelo desenvolvimento sustentável — deve ser medido por outros critérios. Trata-se, não há dúvidas, de uma mensuração complexa e, às vezes, subjetiva, que envolve inúmeros fatores, atores e componentes de difícil quantificação.

Um exemplo que bem ilustra esta complexidade são as modificações no Código Florestal brasileiro, aprovadas pelo Legislativo e pelo Executivo federais no período entre 2011 e 2012. A maior parte dos ambientalistas, legisladores e acadêmicos entrevistados entende que as mudanças foram, em sua maioria, negativas do ponto de vista socioambiental. Entretanto, a maioria também se pôs de acordo ao avaliar que, a despeito de erros estratégicos cometidos, o movimento ambientalista teve atuação fundamental no sentido de evitar a aprovação de um texto muitíssimo pior, o que denota certo grau de sucesso das organizações.

Os ambientalistas também contribuíram, apesar da derrota em Plenário, para levar à sociedade brasileira um debate mais qualificado sobre o meio ambiente e sobre a importância da legislação ambiental. Assim, o simples fato de um substitutivo de lei ruim para o meio ambiente - no ponto de vista das organizações ambientalistas - ter sido 
aprovado não basta para dizer que os ambientalistas fracassaram em suas estratégias para influenciar determinada política.

Segundo Gunter Jr. (2004), que realizou detalhada análise do trabalho de ONGs norteamericanas voltadas para a proteção da biodiversidade, definir efetividade é uma tarefa árdua. O autor, agregando questões simbólicas e com algum grau de subjetividade - como a mobilização da opinião pública ou o estabelecimento de um debate na sociedade em torno de temas relevantes para o movimento - definiu que "medidas de efetividade política buscam mudanças no comportamento de atores e em interesses, e reconhecem ações voltadas para atingir objetivos. O objetivo, em si, não tem que ser atingido" (p.41 - tradução minha).

Gunter Jr. (2004) estabeleceu quatro indicadores de efetividade para as organizações não-governamentais que atuam na área ambiental:

1- A ONG define um assunto e esta definição prevalece; 2- A ONG mobiliza seu staff e seus filiados/apoiadores em torno do assunto; 3A ONG consegue articular a inserção daquele assunto nos processos de formulação de políticas no momento certo junto aos atores certos e 4- A ONG dá assistência à implementação (pp.40-51 - tradução minha).

Assim, as definições de efetividade de Gunter Jr. auxiliaram a análise contida neste estudo e ajudaram a corroborar a tese de que, tanto no Brasil como nos EUA, o movimento ambientalista vem sendo historicamente efetivo - naturalmente, com oscilações no tempo e no espaço - no sentido de influenciar políticas públicas.

\section{Relevância do tema}

Entendo ser relevante o tema desta pesquisa por uma série de razões. Do ponto de vista teórico, não há ainda grande quantidade de estudos, especialmente na academia brasileira, que se propõem a analisar a diferença que organizações da sociedade civil têm feito no sentido de modificar os rumos dos processos decisórios voltados para o desenvolvimento sustentável. Definitivamente, os estudos voltados para a influência que os movimentos sociais exercem nas políticas são mais numerosos que aqueles dedicados a discutir a atuação do movimento ambientalista.

Um ponto que me motivou a pesquisar políticas ambientais do ponto de vista da influência de grupos organizados é o fato de que os problemas nesta área têm afetado de maneira intensa todas as regiões do mundo. A poluição atmosférica e das águas é uma realidade, especialmente em grandes cidades. A crise hídrica é observada não apenas na Califórnia e em São Paulo, mas em diversas regiões do planeta. O descarte de resíduos 
sólidos, a extinção de espécies e o desmatamento seguem como problemas graves. Conforme divulgado pelo IPCC em seu quinto relatório, feito a partir do trabalho de mais de 800 cientistas, com base em mais de 3 mil artigos científicos, o aquecimento do sistema climático é inequívoco e a influência humana neste processo é clara (IPCC 2014).

Diante de uma realidade em que a crise climática afeta um número cada vez maior de pessoas, com profundos impactos sociais e econômicos, especificamente nas áreas de saúde, segurança alimentar, segurança hídrica, biodiversidade, restringindo o exercício de direitos civis e sociais, estudos que debatem a questão das políticas para o desenvolvimento sustentável assumem importância cada vez maior.

Outro aspecto que confere relevância ao tema escolhido é o potencial de as políticas públicas ambientais modificarem positivamente realidades nos âmbitos local, regional, nacional e global. O próprio relatório do IPCC salienta que "respostas efetivas de adaptação e mitigação dependerão de políticas e medidas em múltiplas escalas: internacional, regional, nacional e sub-nacional" (2014, p.29).

Conforme pude verificar nesta pesquisa, as organizações não-governamentais, especialmente aquelas melhor estruturadas do ponto de vista financeiro, técnico e científico, com uma forte base de apoio junto à sociedade, conseguem bons resultados no sentido de influenciar as políticas públicas. Os métodos utilizados pelo movimento ambientalista para que este objetivo seja atingido merecem um estudo um pouco mais aprofundado, e são um tema ainda pouco explorado pela academia brasileira.

Bomberg e Schlosberg (2009), em obra sobre a evolução do ambientalismo norteamericano, observaram que as organizações compartilham uma inquietação diante da permanente necessidade de se fazer a escolha das melhores estratégias a serem empregadas "Entre as principais preocupações estão a de quando mudar do ativismo de base para o protesto, daí para a ênfase em uma advocacy profissionalizada, para conseguir adeptos que tragam contribuições financeiras" (p.152 - tradução minha).

As inquietações expostas pelos autores se agravam diante de limitações ligadas a recursos financeiros e humanos, associadas ao crescente número de frentes que demandam a atuação das ONGs ambientalistas. Esse cenário faz com que as escolhas dos repertórios a serem utilizados para influenciar políticas públicas seja da maior relevância estratégica, com impactos diretos nos resultados alcançados e, por que não dizer, na qualidade de vida de comunidades e populações inteiras.

Acredito, ainda, que uma pesquisa que analise tanto as práticas do movimento ambientalista do Brasil, quanto os métodos usados por um movimento ambientalista como o norte-americano, mais experiente que o brasileiro, em uma sociedade em que as práticas de 
lobby, associação e participação direcionadas a processos políticos ocorrem há mais tempo e de forma contínua na história do país (diferentemente do Brasil), pode trazer algumas contribuições para o planejamento estratégico do movimento brasileiro. Afinal, os embates envolvendo discussões de políticas ambientais vêm sendo marcados por uma correlação de forças frequentemente desigual, com vantagens do ponto de vista financeiro e da influência política para grupos que se opõem às organizações ambientalistas. Diante disso, entendo que a a análise e a produção de conhecimento sobre as dinâmicas do debate ambiental nos diferentes fóruns de tomada de decisão, em dois importantes países no cenário mundial, poderá fornecer subsídios para o movimento ambientalista em futuras ações no terreno das políticas públicas.

Adicionalmente, estudar os processos de formulação, aprovação e implementação de políticas públicas em uma área de crescente importância, como a ambiental, a partir das estratégias das ONGs ambientalistas - organizações peculiares que mesclam características de movimentos sociais, grupos de interesse e, por vezes empresas - é algo instigante. Afinal, esses grupos não se enquadram, de forma integral, nas caracterizações e análises convencionais dos movimentos sociais, de grupos de interesse que representam segmentos industriais ou de mercado, e tampouco nas características das empresas.

Yaziji e Doh (2009) classificam as organizações não-governamentais ambientalistas como agentes que desempenham múltiplas funções, dentro de um espectro bastante amplo de ações. As atividades variam desde o lobby tradicional, passando por "consultoria" técnica a tomadores de decisão, pesquisa científica, monitoramento e implementação de políticas, mobilização social, denúncia de ações incorretas, organização de eventos educativos, protestos e marchas, ações em tribunais, até boicotes a empresas e governos ambientalmente incorretos e parcerias com grandes empresas com objetivo de reduzir impactos de atividades produtivas (pp.8-9).

A despeito desta diversidade de funções desempenhadas pelas ONGs ambientalistas, acredito que uma das características das democracias saudáveis seja a presença de uma grande quantidade de organizações da sociedade civil fortes e atuantes. Julie Fisher aponta, em duas obras escritas nos anos 1990, que ONGs tendem a promover accountability ${ }^{6}$ e capacidade de resposta (responsiveness) nos governos, além de "fortalecer as instituições

\footnotetext{
${ }^{6}$ Neste trabalho optei por manter o termo original do inglês por não haver verbete que traduza bem o seu significado no português. Segundo Cordeiro (2013), accountability política "está ligada à prestação de contas pelas ações do governo central, dos ministérios e de outros órgãos. Deve ser praticada por políticos e funcionários públicos" (p.5).
} 
da sociedade civil que fazem a mediação entre indivíduos e Estado" (1998, p.2), aumentando as oportunidades de interação sociedade-governos (1993, p.17).

Brian O'Connell (1999), por sua vez, entende que uma das pré-condições essenciais a uma sociedade livre e participativa é o "impacto do cidadão em políticas públicas" (p.4). E uma das formas de se viabilizar este impacto é por meio de organizações fortalecidas, que representem os diversos interesses presentes no mosaico social de um país, estado, região, município, condado ou comunidade.

Entendo que, em uma democracia em vias de consolidação, como a brasileira, as situações em que atores públicos levam em conta contribuições da sociedade civil - seja de fora para dentro, quando os movimentos fornecem dados ou pressionam o Estado, seja por meio da presença das organizações no próprio seio do Estado, conforme observado por Abers e Von Bülow (2011, p.66) - devem ser vistas de forma positiva. Assim, uma pesquisa em torno da atuação do movimento ambientalista para gerar políticas mais adequadas pode se tornar fonte de informação para outros pesquisadores, gestores e representantes de organizações que trabalhem com a temática do desenvolvimento sustentável.

\section{Perguntas de pesquisa}

Após quase seis anos trabalhando na ONG WWF-Brasil, entre 2006 e 2012, atuando nas áreas de políticas públicas e comunicação, período antecedido por um mestrado em políticas públicas na Universidade de Erfurt (Alemanha), decidi desligar-me do Terceiro Setor exatamente para estudá-lo mais a fundo em uma pesquisa de doutoramento no Centro de Desenvolvimento Sustentável da Universidade de Brasília.

Durante os debates em torno das mudanças no Código Florestal, intensificados entre 2009 e 2012, bem como em outras discussões no âmbito do Legislativo e do Executivo, ficou clara, para mim, a dificuldade do movimento ambientalista brasileiro em acompanhar com regularidade e atuar com intensidade na área de políticas públicas, mesmo atingindo resultados extremamente positivos em uma série de casos e evitando retrocessos em inúmeras situações. A situação é agravada quando se leva em conta que, conforme mencionado anteriormente, os grupos de interesse que costumam defender posições diversas daquelas dos ambientalistas são, em geral, melhor estruturados, mais ricos e contam com maior representatividade nos núcleos decisórios existentes no Estado.

Assim, me propus a identificar de que formas o movimento ambientalista influencia ou tenta influenciar as políticas públicas. A escolha da modalidade estudo comparado, embora muito mais desafiante e trazendo consigo complexidades e dificuldades de se analisarem duas realidades distintas durante os quatro anos do doutorado, me pareceu essencial no sentido de possibilitar a análise de dois movimentos ambientalistas em diferentes graus de 
maturidade, mas com diversas interseções entre si, inclusive com organizações e redes com atuação nos dois países estudados.

Para Tilly (1984, citado por Balestro et al 2007), "a estratégia comparativa permite, por meio da exploração das semelhanças e diferenças, encontrar os princípios de variação de um determinado fenômeno ou os padrões mais gerais de um fenômeno em um grau maior de abstração". A partir da pesquisa em ambos os países, foi possível detectar essas variações.

O objetivo principal seria identificar, ao longo da pesquisa, os principais repertórios utilizados pelo movimento ambientalista nos dois países selecionados, averiguando os porquês das escolhas e alguns dos resultados alcançados. Com o subsídio de correntes teóricas dos movimentos sociais - por exemplo, a da Mobilização de Recursos - e a observação empírica do trabalho das ONGs, consegui algumas respostas para explicar o papel que a estruturação das organizações, representada pelo elevado grau de profissionalismo, expertise técnica e capacidade administrativa, desempenha nos processos políticos, especialmente em sistemas decisórios como o brasileiro e o americano.

Outra resposta que consegui obter a partir da pesquisa de campo e da teoria das oportunidades políticas foi sobre a relevância dos contextos políticos para os resultados alcançados pelas organizações ambientalistas. Procurava entender até que ponto as coalizões, as maiorias e as minorias nos parlamentos, bem como o partido político e as visões dos chefes do Executivo e de suas equipes, definiam as possiblidades de sucesso das ONGs nos processos decisórios. E, como será visto mais adiante, tais contextos, frequentemente responsáveis pela criação de oportunidades políticas para a atuação dos movimentos, se demonstraram extremamente relevantes não apenas para a escolha das estratégias adotadas, como também para muitos dos resultados obtidos pelas organizações.

Também busquei entender, até que ponto, e de que formas, a cultura da participação política e do associativismo - bastante diferente nas sociedades brasileira e norteamericana - interfere nos métodos empregados pelo movimento ambientalista em cada país, assim como nos resultados alcançados. Ou seja, a pergunta de pesquisa neste particular dizia respeito ao fato de, se nos EUA, onde o associativismo e a participação popular na vida política são uma clara realidade, as organizações estudadas teriam mais facilidade de mobilizar a sociedade em torno de suas causas do que no Brasil, onde o grau de engajamento em grupos cívicos é extremamente baixo (Rennó et al 2011, p.196).

Outra questão fundamental para a qual procurei respostas neste trabalho foi acerca da efetividade das organizações para exercer influência nas políticas públicas em ambos os países. Em princípio, a partir de minha experiência profissional, intuía que o movimento, no 
Brasil, era efetivo, a despeito de inúmeras dificuldades. Nesse sentido, o estudo da realidade norte-americana foi fundamental para estabelecer parâmetros externos de comparação que permitissem uma avaliação mais realista do ponto de vista da efetividade das organizações brasileiras, e vice-versa.

\section{Procedimentos metodológicos}

Este trabalho busca, inicialmente, elencar os principais repertórios utilizados pelo movimento ambientalista no Brasil e nos Estados Unidos - a partir do recorte das chamadas grandes ONGs ambientalistas - para influenciar políticas públicas nos dois países. O segundo passo, como mencionado nesta introdução, consiste em discutir a efetividade desses repertórios.

Para alcançar esses objetivos, optei pelo método comparativo, em uma abordagem empírico-indutiva, por meio de um extenso estudo de casos no Brasil e nos Estados Unidos. A opção por uma análise comparada foi feita nos momentos iniciais da pesquisa, após a decisão de que estudaria a influência das ONGs ambientalistas nas políticas públicas. Nada mais apropriado que analisar o trabalho do movimento brasileiro fazendo uma comparação com o mesmo segmento, em um país com dimensões, população e sistema político semelhantes, importância significativa no cenário ambiental e com um ambiente político propício ao trabalho das organizações do Terceiro Setor.

De acordo com Reinhard Bendix (1963, citado por Balestro et al 2007),

Quando uma mesma questão ou fenômeno pode ser encontrado em diferentes sociedades, os estudos comparativos mostram como estas diferentes sociedades lidaram com a esta questão, exibindo o escopo de soluções encontradas para o mesmo problema. A comparação também previne (...) generalizações espúrias, tendo em vista que certos conceitos são formulados com base em um corpo limitado de evidência empírica. Como terceira contribuição, abordagem comparativa permite visualizar padrões ao aumentar a visibilidade de uma estrutura ao contrastá-la com outra (p.3).

Assim, era necessário buscar considerável volume de informações sobre as organizações ambientalistas em fontes primárias e secundárias. Foi feita pesquisa bibliográfica e em veículos de imprensa acerca da atuação do movimento. A meta era encontrar o maior número possível de casos em que as ONGs procuraram, de alguma forma, se envolver em processos ligados às políticas públicas ambientais.

Também busquei conhecer a trajetória histórica desses movimentos nos dois países, ponto em que algumas das diferenças começaram a aparecer: nos EUA, tem-se registros de 
grupos ligados a questões ambientais influenciando políticas públicas desde o Século 19, reflexo da tradição de participação da sociedade na vida política do país. No Brasil, que tem uma vivência democrática significativamente menor que os Estados Unidos, as primeiras manifestações de influência do movimento ambientalista nas políticas nacionais começam a aparecer, de forma incipiente, nas décadas de 1960 e 1970, mas se consolidam apenas na segunda metade da década de 1980.

Os casos analisados no Capítulo 4, em sua maioria, aconteceram na história recente, notadamente, no Século 21, embora a consolidação dos repertórios utilizados atualmente pelas organizações nos dois países tenha se dado ao longo da história do movimento. Há, portanto, exemplos analisados, especialmente nos capítulos que discutem o histórico das políticas ambientais e do movimento ambientalista, que aconteceram em épocas anteriores. Houve a necessidade de revisitar o passado para compreender melhor os repertórios usados atualmente pelas organizações para influenciar as políticas públicas.

Seria, assim, fundamental conhecer mais de perto essas organizações, especialmente aquelas nos EUA. Em relação às brasileiras, durante seis anos de trabalho no WWF-Brasil pude participar diretamente do planejamento e da execução de estratégias voltadas para políticas públicas. Também tive a oportunidade de atuar em uma grande quantidade de reuniões e interações de diversas naturezas com os grupos ambientalistas brasileiros e tomadores de decisão em escalas municipal, estadual, regional e federal, no Executivo, Legislativo e, com menor frequência, Judiciário.

Naturalmente, era necessário ampliar o conhecimento do movimento no Brasil, mas, principalmente, seria fundamental desenvolver uma pesquisa em sua contraparte nos Estados Unidos, pelo fato de se tratar de um estudo comparado. Assim, além de extensivas pesquisas bibliográficas, em veículos de imprensa e nos sites das próprias organizações ambientalistas dos dois países, seria fundamental realizar uma abordagem de campo, conversando diretamente com representantes das organizações, pesquisadores da área, acadêmicos e tomadores de decisão nos Estados Unidos.

Essa possibilidade tornou-se real a partir de uma bolsa de doutorado-sanduíche, viabilizada pela CAPES. Fui aceito como pesquisador visitante no Departamento de Governo da Georgetown University, em Washington, D.C., o que me possibilitou um contato próximo com as principais organizações ambientalistas daquele país, bem como com importantes tomadores de decisão nos poderes Executivo, Legislativo e Judiciário.

Foram feitas, entre março de 2014 e fevereiro de 2015, 27 entrevistas com representantes (e ex-representantes) do movimento ambientalista norte-americano. Nessas conversas, procurei apurar os principais repertórios utilizados pela respectiva organização 
ao longo da história para influenciar políticas públicas domésticas, o grau de sucesso obtido, as principais dificuldades encontradas, a importância do contexto político para a definição das estratégias e para os resultados alcançados.

Também consegui visualizar como as ONGs se posicionavam nas disputas no campo das políticas públicas e no amplo espectro do movimento ambientalista, do ponto de vista da aproximação de empresas e governos, apoio a iniciativas ligadas à chamada economia verde (defesa de uma visão de mercado para valorizar recursos naturais) e repertórios de ação restritos às esferas institucionalizadas versus utilização de técnicas conflitivas ou de desobediência civil e confronto.

Levantei, também, como a organização define o enquadramento (ou framing) das principais mensagens para obter os resultados desejados junto ao público e aos tomadores de decisão. Foram coletadas, ainda, diversas informações acerca das organizações, como receita, número de afiliados ou apoiadores, principais projetos, locais de atuação etc.

Porém, para se discutir a efetividade da atuação das ONGs, não seria suficiente entrevistar somente representantes das próprias organizações falando de seu trabalho. Seria fundamental, também, ouvir aqueles que recebem a influência do movimento ambientalista, no sentido de avaliarem qual o peso que as contribuições recebidas têm em seu processo decisório. Consegui conversar com assessores diretos de 10 parlamentares norte-americanos, entre senadores e representatives (o equivalente ao deputado federal no Brasil), Democratas, Republicanos e um Independente, de diferentes estados do país.

Importante observar que nos EUA não é usual que os parlamentares diretamente concedam entrevistas para pesquisas acadêmicas; ademais, as entrevistas com assessores - geralmente muito qualificados professional e intelectualmente - são consideradas mais ricas e proveitosas, uma vez que esses profissionais são responsáveis pela interação direta com lobistas, grupos de interesse e eleitores, filtrando demandas e passando-as adiante para o político.

Foram realizadas, também, entrevistas com profissionais que atuaram na Environmental Protection Agency (órgão americano que exerce algumas das funções do Ministério do Meio Ambiente no Brasil) e no Departamento de Estado americano, bem como pesquisadores da área de políticas ambientais. Consegui, também, conversar com representantes de duas entidades que defendem, também junto ao Legislativo, Executivo e Judiciário, interesses de grupos com causas normalmente opostas às do movimento ambientalista, para obter mais informações sobre as disputas no campo de jogo das políticas públicas. 
No Brasil, processo similar aconteceu. Entre julho de 2014 e novembro de 2015 foram feitas 26 entrevistas com representantes e ex-representantes de ONGs ambientalistas. Foi possível entrevistar, ainda, cinco deputados federais, um ex-deputado federal, três senadores (dois deles ex-governadores de estados amazônicos), uma ex-senadora e exministra do Meio Ambiente, um ex-ministro do meio ambiente e ex-secretário estadual de Meio Ambiente, dois ex-presidentes do IBAMA, o presidente do ICMBIO e um ex-presidente do ICMBIO, além de dois funcionários de primeiro escalão na área ambiental de governos estaduais na Amazônia.

Também entrevistei a representante de uma organização que defende, junto aos três poderes, interesses frequentemente distintos daqueles defendidos pelos ambientalistas. Adicionalmente, ouvi um procurador do Ministério Público, para comentar a interação entre as ONGs e o MP, órgão com marcante atuação em temas relacionados ao desenvolvimento sustentável no Brasil.

Com as entrevistas, obtive um panorama das principais táticas empregadas pelas organizações ambientalistas nos dois países, bem como subsídios para avaliar a efetividade desses repertórios junto a importantes tomadores de decisão em diversas esferas.

Durante os seis anos em que trabalhei no WWF-Brasil e ao longo do trabalho de campo nos dois países, pude frequentar reuniões estratégicas de alianças entre organizações socioambientais e audiências públicas em que as ONGs tinham como interlocutores parlamentares, ministros e outros representantes do Executivo e do Legislativo. Entendo que, com essas diversas iniciativas de campo, tenha conseguido capturar quantidade significativa de repertórios utilizadas pelas grandes ONGs ambientalistas nos dois países para influenciar políticas.

Nos dois países, a ideia central, em relação às ONGs, foi a de entrevistar profissionais que, atualmente ou em um passado próximo, estão ou estiveram envolvidas na elaboração e na execução de estratégias ligadas às políticas públicas. Assim, tive a oportunidade de ouvir representantes nas áreas de comunicação, políticas públicas, lobby, relações governamentais, direito, conservação, além de diretores(as) e CEOs, envolvidos(as) com as estratégias macro da organização.

\section{Estrutura do trabalho}

A tese está estruturada em seis capítulos. No Capítulo 1, apresento referencial teórico que possa explicar o surgimento, a estruturação e o comportamento das ONGs ambientalistas. Recorri a teorias dos movimentos sociais, enfatizando duas correntes que, em minha visão, conseguem explicar o sucesso de determinadas organizações nas disputas travados no campo de jogo da política. 
A primeira é a teoria da mobilização de recursos, que, entre diversos aspectos, reforça a necessidade de os movimentos se estruturarem do ponto de vista administrativo, financeiro e profissional para conseguirem levar adiante seus pleitos. A segunda é a teoria das oportunidades políticas, que enfatiza contextos políticos, especialmente nacionais e regionais, que facilitam ou dificultam o êxito das organizações reivindicatórias, como regime político aberto ou fechado, líderes políticos mais ou menos receptivos a contribuições externas, momentos de modificações no arcabouço legal etc.

Também procurei demonstrar que, em alguns contextos, teorias referentes à formação de coalizões (Modelo das Coalizões de Advocacy) conseguem explicar algumas das táticas do movimento ambientalista, que frequentemente atua em alianças para ganhar a força necessária para gerar mudanças ou brecar retrocessos nas políticas ambientais. Outra linha teórica que explica parte dos comportamentos das ONGs, especialmente daquelas de maior porte que contam com staff mais numeroso e qualificado, grande estrutura administrativa e de comunicação, é a corrente das teorias de empresas, que guarda algumas semelhanças com a teoria da mobilização de recursos. A teoria das empresas explica o comportamento das instituições a partir da necessidade de sobrevivência política e financeira em um mercado competitivo que demanda sofisticados arranjos voltados para arrecadação de recursos e angariamento de apoios.

No segundo capítulo procuro analisar o histórico das principais políticas ambientais nos Estados Unidos, assim como o surgimento e a evolução do movimento ambientalista norte-americano. O Capítulo 3 faz semelhante discussão, porém tendo como conteúdo um histórico das políticas ambientais e do movimento ambientalista no Brasil. Nos capítulos 2 e 3 são disponibilizadas linhas do tempo das principais leis voltadas para o meio ambiente nos dois países. A ideia é que, a partir de uma contextualização histórica, sejam colocadas melhores condições de iniciar o debate sobre a atuação das ONGs ambientalistas, considerando a evolução dos marcos legais, das principais políticas nacionais ligadas ao desenvolvimento sustentável, bem como observando a situação política de ambos os países e a consolidação do ambientalismo.

A relação dos principais repertórios utilizados pelas organizações, juntamente com alguns dos resultados obtidos por meio desses repertórios, está presente no Capítulo 4, o mais extenso desta tese, devido à variedade de iniciativas levantadas durante a pesquisa. As ações das ONGs foram categorizadas a partir das esferas responsáveis pelas políticas que as organizações buscam influenciar em ambos os países: no caso, Executivo, Legislativo e Judiciário. Assim, o item 4.1, por exemplo, vai apresentar ações empregadas 
pelas ONGs para influenciar parlamentares e tomadores de decisão no Executivo por meio de lobby.

Nas seções seguintes serão discutidos outros repertórios, como estudos técnicos e científicos, projetos de campo, atuação em espaços participativos como audiências e comitês, fornecimento de quadros técnicos para governos, alianças e coalizões, ações na Justiça, apoio a candidaturas comprometidas com as causas ambientais, denúncias e manifestações, parcerias com empresas e ações de comunicação.

O Capítulo 5 traz a análise que compara os repertórios adotados pelo movimento ambientalista em cada um dos países, salientando principais semelhanças e diferenças. Serão observadas questões que podem influenciar as escolhas feitas pelas ONGs, assim como fatores que podem determinar os resultados alcançados pelo movimento. Foi possível observar que ambos os movimentos são efetivos no sentido de influenciar políticas públicas, com algumas importantes diferenças entre os dois países analisados.

Por fim, são colocadas considerações finais acerca da pesquisa, como uma síntese das principais conclusões. Também é feita uma breve discussão acerca do atual momento das políticas ambientais no Brasil e nos Estados Unidos, com algumas recomendações para potencializar a efetividade das organizações no sentido de influenciar políticas públicas. 


\section{PERSPECTIVAS TEÓRICAS: O DESAFIO DO ENQUADRAMENTO DE ONGS A TEORIAS E O CAMINHO ENTRE MOVIMENTO SOCIAL E ORGANIZAÇÃO EMPRESARIAL}

Para uma melhor compreensão da estrutura e dos papéis das organizações nãogovernamentais ambientalistas, em regimes democráticos ocidentais como Brasil e Estados Unidos, é prudente analisar diferentes correntes teóricas. No prefácio de seu conhecido livro Greening Brazil, que analisa historicamente o ativismo ambiental no Brasil, Hochstetler e Keck dão a entender que o ambientalismo não se encaixa nos compartimentos ou nichos teóricos convencionais (2007, p.ix).

Afinal, frequentemente, as ONGs ambientalistas defendem causas similares às das organizações que representam grupos sociais, como quando representam comunidades tradicionais na luta contra a construção de uma hidrelétrica, por exemplo. Porém, no outro extremo, também se comportam como prestadoras de serviços para governos e empresas, quando colocam sua expertise técnica para executar projetos de campo ou para assessorar a implementação de processos produtivos sustentáveis, recebendo recursos para isso.

Abers e Von Bülow (2011), por exemplo, analisam literatura que se refere ao movimento ambientalista como parte dos "novos movimentos sociais" (p.64), juntamente com o ativismo feminista. Embora não sejam compostas por segmentos marginalizados ou vítima de injustiças sociais, as organizações acabam fazendo reivindicações que envolvem causas de importância social. De fato, as ONGs ambientalistas desempenham, frequentemente, funções típicas dos movimentos sociais, levando adiante interesses coletivos ou de grupos sociais específicos, algumas vezes com atuação em fóruns participativos como conselhos de meio ambiente, de bacias hidrográficas ou equivalentes e, até mesmo, convocando protestos e marchas para pressionar tomadores de decisão.

O comportamento típico de movimento social também se dá, por exemplo, quando o movimento ambientalista norte-americano mobiliza comunidades inteiras para defender, em Washington, D.C., limites mais rigorosos para a emissão de poluentes por diferentes segmentos industriais. Ou, no Brasil, quando ONGs ambientalistas se mobilizam para defender direitos de povos indígenas ou levam milhares de ativistas à Esplanada dos Ministérios, em Brasília, para protestar contra mudanças na legislação ambiental.

Adicionalmente, não raro encontram-se classificações das organizações do movimento ambientalista como integrantes da sociedade civil, termo que, muitas vezes, se confunde com movimento social (Abers e Von Bülow 2011, p.54).

Por sua vez, Opp (2009) não hesita em incluir organizações do movimento 
ambientalista na categoria de movimentos sociais: "É claro que grandes grupos ou organizações cuja meta é impedir o uso de energia nuclear, instituir direitos iguais para brancos e negros, evitar guerras ou proteger o meio ambiente são movimentos sociais" (p.34 - tradução minha).

Outras classificações frequentemente encontradas para as organizações do terceiro setor atribuem às ONGs uma diversidade de categorias, conforme descrito por McGann e Johnstone (2008): "O termo ONG descreve uma ampla variedade de organizações diversamente conhecidas como organizações voluntárias privadas, organizações da sociedade civil e organizações sem fins lucrativos" (p.66 - tradução minha).

Cabe ainda acrescentar que grandes ONGs, incluindo as principais organizações da área ambiental, frequentemente se comportam como empresas, lutando pela sobrevivência, buscando arrecadar mesmo sem terem o lucro como objetivo final (Prakash e Gugerty 2010). Ao contratarem consultorias multinacionais para a elaboração de planejamentos estratégicos, terceirizarem serviços de recrutamento e seleção para reduzir custos e contratarem executivos oriundos do mercado financeiro, essas instituições acabam abraçando uma lógica muito próxima da corporativa.

Ronald Libby (1998) se refere aos integrantes do movimento ambientalista como "organizações do movimento social". E salienta o caráter híbrido desses grupos:

De um lado, eles têm as propriedades de grupos de interesse no sentido de que são formalmente organizados; têm dinheiro, expertise, uma agenda política, acesso a formuladores de políticas públicas; e constroem campanhas com viés político para influenciar políticas públicas. Por outro lado, têm propriedades de organizações dos movimentos sociais no sentido de que mobilizam cidadãos para protestar por mudanças sociais. Em outras palavras, em algumas campanhas eles assumem um papel de liderança, elaborando estratégias e táticas para influenciar políticas públicas; em outras situações assumem o papel secundário de mobilizar cidadãos (pp.19-20 - tradução minha).

Diante dessa diversidade de enquadramentos e definições, fez-se aqui opção por iniciar a fundamentação teórica deste trabalho a partir das principais teorias de movimentos sociais, desenvolvidas nos Estados Unidos, Europa e América Latina ao longo do Século 20. O estudo dos repertórios adotados por organizações não-governamentais ambientalistas propósito principal deste trabalho - não poderia ser feito sem uma discussão, ainda que breve, de como e por que razões as pessoas se unem em torno de causas coletivas.

Assim, as escolas norte-americanas - teorias clássicas, mobilização de recursos e 
oportunidades políticas - serão, por uma questão de cronologia, abordadas inicialmente. Em seguida, será feita uma discussão acerca da teoria dos novos movimentos sociais, de origem europeia, com a escola latino-americana dando prosseguimento à seção. Os preceitos da chamada escola clássica e da escola latino-americana, embora tenham menor aplicação às organizações aqui estudadas - a estrutura e a organização das grandes ONGs ambientalistas, tanto no Brasil como nos EUA, nitidamente segue o modelo norte-americano - também serão abordados para efeito de contextualização histórica do estudo dos movimentos sociais e da discussão do modus operandi das ONGs ambientalistas.

Importante salientar que as quatro principais correntes teóricas relativas aos movimentos sociais consideradas para este trabalho - teorias clássicas, da mobilização de recursos, das oportunidades políticas e dos novos movimentos sociais - não são excludentes entre si, antes, complementares. Conforme Toni (2001), "nenhum dos enfoques (...) pode ser considerado superior do ponto de vista empírico ou teórico que os outros" (p.97). A escola latino-americana não aparece aqui como uma teoria, por se tratar mais de uma leitura da realidade dos movimentos sociais da região do que propriamente uma corrente teórica.

As teorias abordadas analisam aspectos diferentes em relação aos movimentos sociais. Algumas procuraram enfocar o aspecto psicossocial, outras se concentraram na estruturação das organizações e outras nas identidades e natureza das reivindicações. Assim, é possível também deduzir que nenhum dos modelos é completo no sentido de explicar origem, consolidação, manutenção e declínio de grupos ligados aos movimentos sociais.

Na sequência, será aberto espaço para análises que avaliam os movimentos ambientais sob a ótica empresarial. Ou seja, que encaram as organizações como entes que buscam conquistar clientes, reduzir custos, ampliar o fluxo de recursos e qualificar os quadros para uma atuação mais profissionalizada.

Um passo adiante estão conceitos e formulações teóricas aplicadas, que ajudam a explicar algumas ações concretas das ONGs aqui trabalhadas. Será abordado o conceito de política de conflitos (contentious politics), que discute repertórios utilizados para a obtenção de objetivos por meio de instrumentos políticos, ponto central desta pesquisa. As coalizões, amplamente utilizadas pelo movimento ambientalista para influenciar políticas públicas, serão analisadas a partir do modelo das coalizões de advocacy (advocacy coalition framework). Será, posteriormente, discutida a teoria de framing, ou do enquadramento, fundamental no sentido de compreender as mensagens utilizadas pelas organizações pesquisadas para atingir seus objetivos. 
Por fim, o capítulo apresentará uma caracterização do que são políticas ambientais, com especial foco em suas diferenças em relação a outros tipos de políticas públicas. Entre outros pontos, será discutido o fato de que as leis e regulações ligadas ao meio ambiente, além de envolverem um amplo espectro de atores e segmentos interessados, em geral lidam com uma elevada complexidade científica e uma escala temporal ampliada, com impactos de médio e longo prazo, frequentemente de difícil mensuração no presente.

\subsection{TEORIAS CLÁSSICAS DOS MOVIMENTOS SOCIAIS}

As teorias clássicas predominaram nos Estados Unidos, desde a década de 1910 até o início dos anos 1970. Foram elaboradas tendo como pano de fundo o sistema pluralista norte-americano. Em resumo, um modelo em que cidadãos se veem representados nos processos decisórios por políticos democrática e periodicamente eleitos, bem como por grupos de interesse que encontram espaço para influenciar a formulação de políticas públicas em um sistema político poroso e permeável, que seria capaz, a partir dessa interação de forças distintas, de encontrar os melhores resultados para a coletividade.

Assim, as ações coletivas e, consequentemente, os movimentos sociais, seriam desequilíbrios momentâneos na sociedade, a partir de frustrações, prejuízos ao status ou privações vividas por cidadãos. Diante dessas situações críticas, que podem ser caracterizadas por tensões e carências a partir de crises econômicas e rupturas políticas ou sociais, indivíduos reagem de forma pontual, questionando determinada situação.

Ou seja, as ações coletivas questionadoras eram classificadas como anormalidades a serem contornadas e superadas pelo sistema político. Uma das maneiras de se evitarem essas disfunções, além do bom funcionamento do sistema político plural, era por meio de lideranças responsáveis e apaziguadoras, que evitariam os conflitos supostamente danosos ao equilíbrio da sociedade (Gohn 2006, p.29).

Entretanto, as teorias clássicas não conseguem explicar os porquês de pessoas sem privações materiais se reunirem em torno de causas como direitos civis, pacifismo, feminismo ou ambientalismo, este último o meu objeto de estudo. No caso das organizações que se preocupavam com a preservação das paisagens naturais, os primeiros registros nos EUA se dariam a partir da segunda metade do Século 19. O movimento ganha força ao longo do Século 20, e se torna um ator poderoso na cena política dos Estados Unidos a partir da Década de 1960 (Martinez 2014, pp.167 e 178). Tratava-se de grupos de estudantes e intelectuais interessados em uma causa cuja luta não previa benefícios individuais diretos e tangíveis, pelo menos em curto e médios prazos. 
De acordo com Toni (2001), "os atores engajados nesses conflitos não lembravam em nada indivíduos isolados, alienados e anômicos descritos pelos autores das teorias clássicas" (p.82). Assim, o envolvimento coletivo voluntário em questões sociais, étnicas, ambientais ou de gênero era ignorado pelas teorias clássicas e a formação e consolidação do ativismo ambiental, objeto de estudo nesta pesquisa, não é explicado pelas teorias clássicas.

\subsection{TEORIA DA MOBILIZAÇÃO DE RECURSOS}

Diante da incapacidade das teorias clássicas em explicar as razões pelas quais indivíduos racionais se organizam em torno de causas, as teorias clássicas e a centralidade na psicologia foram rejeitados pelos teóricos dos anos 1960 e 1970. Os movimentos sociais passam a ser abordados como grupos de interesse, nos moldes de partidos políticos, sindicatos ou associações empresariais.

Para os teóricos da corrente norte-americana da mobilização de recursos, a atuação dos movimentos só pode existir e ter relevância se houver uma estrutura para participar do jogo político, ou seja, recursos financeiros e humanos, expertise administrativa e capacidade de levantar dinheiro e persuadir potenciais apoiadores. Afinal, o bom funcionamento da teoria pluralista, defendido pelos teóricos clássicos, dava mostras de não ser uma realidade, uma vez que alguns atores - especialmente aqueles ligados ao Estado e às grandes corporações - conseguiam desequilibrar o jogo a seu favor, não deixando espaço para grupos desarticulados e desprovidos de recursos.

De acordo com Gohn (2006), a teoria da mobilização de recursos coloca os movimentos sociais no mesmo patamar que partidos políticos, lobbies e outros grupos de interesse no teatro de operações do jogo político. Para a autora, ainda, os movimentos sociais "jogam e disputam seu público consumidor, de adeptos ou financiadores, num mesmo campo. Eles também competem entre si pelas mesmas fontes de recursos e oportunidades" (p.51). Esta visão se assemelha em vários aspectos às teorias de empresas, que serão discutidas mais adiante neste capítulo.

McAdam (1982) resume a teoria da mobilização de recursos de modo simples: "é o estudo da relação entre o descontentamento constante no tempo e o aumento de recursos que permite aos grupos se mobilizar" (p.84 - tradução minha).

Neste contexto, o neopluralismo é visto como mais eficiente no sentido de explicar o jogo político norte-americano, talvez por reconhecer que o fato da multiplicação de grupos de interesse, isoladamente, não implica uma representação justa dos diversos segmentos 
da sociedade (McFarland, 2007, p.54).

Toni (2001) observa que essa discrepância de recursos entre elites financeiras e o restante da população acaba criando uma enorme disparidade nos processos de formulação de políticas públicas. "O efeito desse desequilíbrio é a exclusão da maioria dos segmentos da sociedade de qualquer papel significativo no exercício do poder político" (p.84).

Por isso, os grupos descontentes com alguma situação ou que buscam modificar o status quo se veem obrigados a se articular no sentido de criar uma estrutura para fazer frente aos players mais poderosos no cenário político. Muitas vezes, essa institucionalização dos movimentos sociais passa por um apoio de representantes das elites, que tenham mais facilidade em angariar recursos, apoios e até mesmo espaço nos veículos de imprensa e nas mídias sociais para determinado movimento, grupo ou causa defendida (Jenkins e Perrow 1977, pp.249-250).

Essa teoria faz uma adequação à realidade do sistema político norte-americano que se consolidou no Século 20, caracterizado, entre outros aspectos, pela abertura a influências de grupos de interesse, mas, também, por uma exigência de organização da parte daqueles que desejarem participar com um mínimo de possibilidades de sucesso do jogo político no âmbito legislativo. Não é exagero afirmar que, no caso brasileiro, cada vez mais, tal estruturação se faz também necessária, devido ao elevado grau de profissionalização dos grupos de interesse.

Portanto, a teoria da mobilização de recursos consegue explicar parte do sucesso das ONGs pertencentes a grandes redes internacionais, como é o caso de Conservação Internacional, Greenpeace, TNC, e WWF, que contam com know-how, profissionalização, credibilidade e aportes financeiros de diversos países para organizar uma estrutura capaz de atuar com eficácia e constância nos parlamentos.

Mesmo ONGs de atuação essencialmente nacional, tanto nos EUA como no Brasil, se enquadrariam nessa caracterização prevista pela teoria da mobilização de recursos, por terem conseguido se profissionalizar e angariar recursos suficientes para uma atuação com maior incidência nas políticas públicas. Exemplos de organizações nacionais bemsucedidas, com atuação predominantemente no nível doméstico, não faltam, em nenhum dos dois países: Defenders of Wildlife, Earthjustice, Environmental Defense Fund, League of Conservation Voters, National Wildlife Federation, Natural Resources Defense Council, Sierra Club, The Wilderness Society (Estados Unidos) e, no caso brasileiro, Instituto Socioambiental, IPAM, SOS Mata Atlântica, Instituto Centro de Vida e IMAZON, entre outras.

McAdam e Scott (em Davis, 2005) salientam a relevância da mobilização de recursos 
e a conexão desta corrente teórica com as análises das organizações.

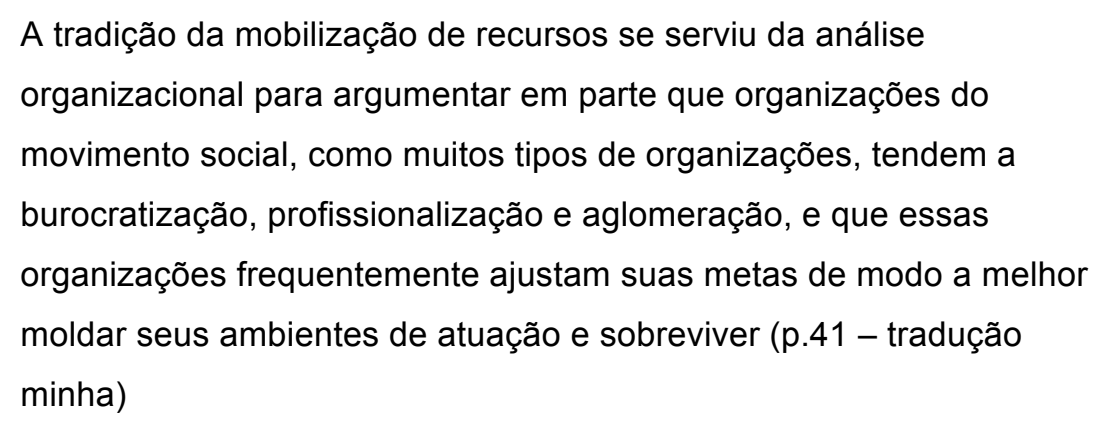

Uma das principais críticas feitas à teoria da mobilização de recursos está no fato de não levar em consideração movimentos que representem grupos excluídos das sociedades, que não contam com recursos para se organizarem e, por isso, utilizam vias nãoinstitucionais para reivindicar seus direitos. Essa peculiaridade talvez se deva ao fato de a corrente teórica ter sido elaborada dentro do contexto dos EUA dos anos 1960 e 1970, em que as desigualdades econômicas não eram consideradas um grave problema no país, que apresentava - e ainda apresenta, mas em menor escala que no Século 20 - uma ampla maioria populacional de classe média.

Mesmo no Brasil, a estruturação dos atores que protagonizam esta pesquisa grandes ONGs ambientalistas - pode ser explicada em grande medida pela teoria da mobilização de recursos, uma vez que boa parte dos espaços decisórios de políticas ambientais no Brasil requer atuação profissionalizada, com demandas por quadros especializados em direito, ciência política, comunicação, meio ambiente, desenvolvimento sustentável, energia e as diversas ciências da terra.

Também foram abordadas, nesta pesquisa, organizações com atuação mais regionalizada, como Center for Health, Environment and Justice, nos EUA, Liga Ambiental e redes como Grupo de Trabalho Amazônico (GTA), que por vezes demonstram que a influência em políticas públicas pode acontecer a partir de pressões, denúncias e ações judiciais feitas "de baixo para cima", sem enormes estruturas profissionais. Porém, mesmo movimentando orçamentos menores que as grandes organizações e utilizando métodos ligados à mobilização de públicos locais afetados por determinada questão ambiental, essas organizações tiveram que se articular, profissionalizar e desenvolver meios de arrecadação que permitam sua sobrevivência.

\subsection{TEORIA DAS OPORTUNIDADES POLÍTICAS}

A teoria das oportunidades políticas pode ser encarada como complementar à teoria da mobilização de recursos (Gohn 2006, p.69). Esta corrente teórica analisa o trabalho dos 
movimentos a partir das situações que permitem ou oportunizam mobilização, protestos ou ações propositivas, a partir do cenário político, social ou econômico de determinada região. Também utiliza como pano de fundo, predominantemente, sistemas democráticos ocidentais, mais notadamente o sistema político norte-americano, em que diferentes grupos de interesse disputam espaço e recursos no processo de formulação de políticas públicas, embora também possa ser aplicada a outros regimes.

Porém, enquanto a teoria da mobilização de recursos enfatiza as organizações e suas estruturas, com foco no aspecto econômico, administrativo e organizacional, a das oportunidades políticas analisa as oportunidades para esses grupos agirem tentando modificar determinada realidade.

Campbell (2005) destaca a importância das oportunidades políticas para a ação dos movimentos. Para o autor, "o conjunto de condições políticas formais e informais (...) encoraja, desencoraja, canaliza e afeta as atividades do movimento" (p.44 - tradução minha).

As oportunidades podem ser construídas pelos próprios movimentos sociais, mas em geral advêm de mudanças nos modelos políticos. Tarrow (citado por Toni 2001) aponta cinco dimensões das oportunidades políticas:

- Liberalização do sistema político (oportunidades crescentes para participação);

- Evidências de realinhamento político dentro do sistema;

- Aparecimento de aliados fortes;

- Divisões entre as elites;

- Declínio na capacidade do Estado de reprimir dissensões

Nota-se uma variedade de categorias de oportunidades. Diante dessa classificação, Toni (2001) observa que os contextos políticos favoráveis às mobilizações criam os chamados ciclos de protesto, quando manifestações se propagam gerando "ondas" que se espalham dentro de uma sociedade ou até por diferentes regiões e países (p.87). Pode-se dizer que os anos 1960 viram um dos mais significativos ciclos de protesto da história mundial, durante o qual as condições políticas propiciaram manifestações na Europa, nos Estados Unidos e na América Latina.

Tilly (2008) também apresenta uma análise da estrutura de oportunidades políticas, elencando seis componentes que podem oportunizar ou dificultar ações reivindicatórias por parte dos movimentos: 
Quadro 1: Oportunidade política, ameaça política e seus impactos

Mudança de oportunidades - Transformações no ambiente dos atores políticos que sinalizam mudanças nas prováveis consequências das diferentes interações com outros atores.

Categoria

- Abertura do regime Coerência

das elites

- Estabilidade dos arranjos

políticos

- Disponibilidade de aliados (dos movimentos) dentro do Estado

- Repressão ou facilitação

- Ritmo das mudanças

\section{Oportunidade crescente}

Regime se torna progressivamente mais aberto

Aumento nas divisões entre as elites

Instabilidade crescente

Disponibilidade, dentro do regime, de

novos aliados dos desafiantes

Facilidades crescentes, repressão

decrescente

Aceleração em qualquer dos itens acima

\section{Ameaça crescente}

Fechamento do regime

Crescente solidariedade entre as elites

Crescente estabilidade

Aliados potenciais desaparecem

ou perdem poder

Facilidades decrescentes, repressão crescente

Desaceleração em qualquer dos itens acima

Isso também se aplica transversalmente: Se o regime A é mais aberto, suas elites mais divididas, o regime é mais instável de maneira geral, mais rico em aliados potenciais e menos repressivo que o regime $B$, desafiantes vão optar mais pelo conflito de forma mais efetiva no regime $A$.

Fonte: Tilly (2008), (p.91-92 - tradução minha)

Como já visto anteriormente, a teoria das oportunidades políticas mantém algumas características da teoria da mobilização de recursos, como a necessidade de uma estruturação formal por parte dos grupos que queiram participar do jogo político, que demanda recursos financeiros e humanos, além de articulação. Porém, introduz na análise, além da questão das oportunidades, aspectos ligados à identidade coletiva. Deste modo, os três conceitos básicos da mobilização política são mobilização de estruturas (similar à teoria de mobilização de recursos), frames e oportunidades políticas. (Gohn 2006, p.72).

Outra interseção crucial da teoria das oportunidades políticas com o tema principal desta pesquisa está, exatamente, na participação do contexto político na escolha dessas estratégias pelas organizações. Assim, dependendo do quadro, uma mesma organização pode optar por canais institucionais ou pelo confronto para atingir determinado objetivo.

De acordo com Hadden (2015), "mudanças nas oportunidades políticas são um importante indicador de ações contenciosas [voltadas para o confronto], porque organizações convencionais tendem a avaliar racionalmente as oportunidades políticas" (p.156 - tradução minha).

Uma das novidades introduzidas pela teoria das oportunidades políticas é a importância estratégica da mídia para que as oportunidades de ação dos movimentos sejam criadas ou consolidadas (Gohn 2006. P. 75), a partir do enquadramento dos discursos a serem utilizados buscando-se atingir determinado objetivo (framing). De acordo com a comunicação utilizada e o recorte escolhido para uma mensagem, pode-se conquistar mais ou menos apoiadores, além de ser possível mobilizar a opinião pública no sentido de se criar ou consolidar alguma oportunidade política para a ação dos movimentos. A teoria de framing será abordada de forma um pouco mais aprofundada ainda neste capítulo. 
Importante ressaltar que, tanto a pesquisa de campo, quanto a bibliográfica/midiática, realizadas para este trabalho, demonstraram, inequivocamente, a relevância das oportunidades políticas para a atuação dos movimentos ambientalistas no Brasil e nos EUA. Como será abordado mais adiante, representantes de ONGs que atuam nos Estados Unidos enalteceram os espaços abertos pela administração Democrata de Barack Obama para a participação do movimento ambientalista em alguns processos decisórios, especialmente no âmbito da EPA (Environmental Protection Agency, órgão com algumas funções semelhantes às do Ministério do Meio Ambiente brasileiro).

Analogamente, no Brasil, praticamente todas as organizações ouvidas indicaram um momento desfavorável à atuação do movimento no âmbito do Executivo Federal devido a um fechamento do Ministério do Meio Ambiente - e das demais áreas do Governo - à participação da sociedade civil, especialmente na década de 2010. Ao mesmo tempo, elogiam o período entre 2003 e 2008, que teve Marina Silva à frente do MMA, quando os movimentos tinham enorme acesso às instâncias decisórias do ministério.

Em caminho convergente, Alonso e colegas (2007) correlacionam a consolidação do movimento ambientalista brasileiro a três momentos, pelos autores denominados "estruturas de oportunidades políticas": a redemocratização do país, na década de 1980, a Constituinte de 1988 e a conferência Rio 92 (p.153).

\subsection{NOVOS MOVIMENTOS SOCIAIS}

A principal corrente teórica de movimentos sociais de origem europeia foi a dos novos movimentos sociais (NMS). Inovou no sentido de centralizar sua análise nas identidades, considerando os participantes dos movimentos, pela primeira vez, como atores sociais (Gohn 2006, p.123). Esse paradigma surgiu a partir dos movimentos sociais dos anos 1960 e 1970, que se diferenciavam dos movimentos em prol dos direitos trabalhistas, por exemplo, e que não poderiam ser explicados plena e adequadamente pelas correntes anteriores.

Movimentos como o ambientalista, feminista, de homossexuais ou por direitos civis não resultavam de privações materiais ou de descontentamentos ligados ao status de grupos ou indivíduos insatisfeitos. Tratava-se, muitas vezes, de cidadãos conscientes (frequentemente estudantes e professores), que não passavam por necessidades, mas deliberadamente abraçaram identidades e causas que julgavam ter o potencial de melhorar a coletividade. Além do mais, nem sempre agiam dentro das vias institucionalizadas, como o parlamento ou os mecanismos previstos no sistema político. 
Enquanto os paradigmas norte-americanos analisaram os movimentos a partir de suas estruturas e, principalmente, como instituições inseridas em um sistema político plural, a escola europeia dedica boa parte de sua análise às razões pelas quais cidadãos e grupos constroem identidades coletivas capazes de atrair a atenção de apoiadores e da própria mídia.

De acordo com Toni (2001), as lutas dos novos movimentos sociais não se resumiam a ganhos concretos dentro dos processos políticos institucionalizados.

Em termos gramscianos, os novos movimentos sociais engajam-se em uma guerra de posições no âmbito da sociedade civil, e não em uma confrontação direta ao Estado (...). Organizar-se em novos grupos é um fim em si mesmo [pois] o estabelecimento de uma identidade grupal significa a legitimação do grupo na sociedade como um todo (p.89).

Novamente, ganha força o conceito de framing, diante dessa necessidade da construção de identidades, não só aceitas internamente, no âmbito do grupo, como também externamente, pela sociedade. Morris (2000, citado por Campbell 2005) dá um interessante exemplo de framing no contexto dos novos movimentos sociais:

Martin Luther King Jr. Compôs um recorte para o movimento dos direitos civis mesclando a doutrina cristã de amor com os princípios morais da liberdade e da justiça, um enquadramento que conseguiu ressonância com a cultura da igreja afro-americana, cujos membros ele tentava mobilizar (p.56 - tradução minha).

Os movimentos surgidos nos anos 1960 e 1970 colocaram em xeque os canais institucionais para a obtenção de conquistas por parte de setores marginalizados da sociedade. Em outras palavras, percebeu-se que as barganhas e negociações inerentes aos processos políticos convencionais, via parlamentos ou Poder Executivo, atendiam apenas parte das necessidades de alguns movimentos, especialmente aqueles mais estruturados e com ramificações entre as elites. Segundo Johnston e colegas (1994, citado por Gohn 2006), a "organização e a proliferação dos NMS estão relacionadas com a crise de credibilidade dos canais convencionais de participação nas democracias ocidentais" (p.127). A sociedade civil, como agente de reivindicações, mobilizações e mudanças, ganha força.

Não à toa, as teorias dos novos movimentos sociais encontraram bastante suporte entre teóricos latino-americanos, uma vez que encontravam ressonância no contexto de mobilizações de indígenas, negros, mulheres e camponeses. Adicionalmente, a fraqueza e a falta de representatividade popular das instituições políticas dos países latinos acabam também por forçar os movimentos sociais locais a criarem novos espaços de mobilização. 
Isso se deu, por exemplo, na Amazônia dos anos 1970 e 1980, quando líderes como Chico Mendes, por meio de intensa mobilização popular e alianças com diversas organizações e redes nacionais e internacionais, "cavaram" espaços até pouco tempo antes inexistentes, para pressionar tomadores de decisão em diversas esferas.

As críticas ao paradigma dos novos movimentos sociais são centradas em dois aspectos principais (Toni 2001): não ter abordado as lutas sociais que se desenrolam no âmbito do Estado, nos embates travados nas arenas institucionalizadas (partidos políticos, parlamentos, governos) e a ausência de uma explicação de como os indivíduos se juntam em torno dos movimentos. A teoria acaba dedicando mais tempo a explicar como um grupo, já constituído, se articula para construir, consolidar ou modificar sua identidade, mas não busca explicar como, quando e a partir de quais motivações aquelas pessoas se juntaram.

Por um lado, constata-se que as ONGs analisadas neste trabalho geralmente se valem de canais institucionais para reivindicar. Mas a teoria dos NMS pode auxiliar a compreensão de algumas estratégias de caráter conflituoso ou de confronto, usadas por algumas organizações, tanto no Brasil como nos EUA, bem como alguns repertórios usados por setores do movimento ambientalista em diferentes momentos da história, inclusive no Brasil e nos Estados Unidos. No caso do Código Florestal, por exemplo, uma ONG como o WWF-Brasil, normalmente adepta das táticas negociadas e pragmáticas, apoiou institucionalmente diversas ações de protesto e enfrentamento, embora seus integrantes não estivessem diretamente envolvidos nos episódios.

Em duas democracias consolidadas, como são os casos da brasileira e da norteamericana, as ações pautadas pela desobediência civil ou pelo confronto, ultrapassando as vias institucionais dos conselhos, comissões legislativas, lobby, campanhas, petições, emails e ações na Justiça, se tornaram cada vez mais raras no movimento ambientalista, especialmente no âmbito das grandes organizações, conforme constatado nesta pesquisa.

A teoria dos novos movimentos sociais pode ser útil, ainda, no sentido de demonstrar que os ativistas frequentemente se reúnem em torno de organizações ambientalistas por questões de identidade e identificação com determinadas causas, em lugar de motivações materialistas, como os integrantes de uma cooperativa ou de um sindicato, que buscam benefícios pessoais com a filiação.

\subsection{TEORIAS LATINO-AMERICANAS}

De forte influência marxista, os teóricos latino-americanos analisaram os movimentos locais a partir de contextos específicos do continente: regimes autoritários, elevados índices 
de exclusão social e instituições políticas pouco permeáveis à participação coletiva e dominadas pelas elites. Segundo Ruth Cardoso (1987), os integrantes da escola latinoamericana apontavam uma incapacidade das correntes teóricas europeias e norteamericanas em decifrar a realidade dos países em desenvolvimento. A autora não considera adequado classificar como teoria a vertente surgida nos anos 1970 na América Latina para explicar os movimentos sociais, uma vez que as pesquisas eram focadas em estudos de caso:

...chegamos aos anos 70 com uma vocação para a pesquisa de campo, uma desconfiança das macroteorias disponíveis e uma perplexidade dos novos processos sociais que despertavam na América Latina e que, negando as previsões de crescente exclusão, apontavam para a necessidade de estudar a participação popular (p.27).

Houve uma rejeição inicial às correntes teóricas norte-americanas, conforme lembrado por Toni (2001):

Para alguns críticos, o modelo de mobilização de recursos é um manual para a inclusão de movimentos de grupos de classe média no sistema político norte-americano, um processo marcado por barganhas e alianças e, sobretudo, por ter uma característica pacífica (p.91).

Tem-se, nitidamente, a impressão de que as teorias do hemisfério Norte se baseavam em realidades política e socialmente estáveis, diversas do que predominava no hemisfério Sul.

Gohn (2006) também destaca essa posição: "As teorias norte-americanas, fundadas nas ações coletivas dos comportamentos sociais, tradicionalmente consideradas funcionalistas, conservadoras e utilitaristas, não eram nem lembradas [nos países em desenvolvimento]" (p.216).

A questão das identidades coletivas, posta pelos teóricos europeus dos novos movimentos sociais, também foi acolhida pela corrente latino-americana, especialmente a partir dos anos 1980. O tema das identidades coletivas, observada nos movimentos latinoamericanos de mulheres, negros, indígenas e homossexuais, entre outros grupos, torna-se forte entre os teóricos da região.

Cabe observar que a corrente latino-americana não chegou a desenvolver, a exemplo dos paradigmas estudados nas seções acima, uma teoria que traçasse novos conceitos a respeito do surgimento e da atuação dos movimentos sociais no continente. Tratou-se, 
muito mais, de uma adequação de outras teorias às peculiaridades dos movimentos surgidos na América Latina que, de fato, não poderiam ser estudados com sucesso apenas com base nas teorias anteriores, mais adequadas à realidade de países desenvolvidos no século passado.

Para efeito desta pesquisa de doutorado, a corrente latino-americana terá uma importância mais reduzida que as demais, uma vez que as organizações analisadas:

- surgiram em contextos europeus e norte-americanos, como é o caso de $\mathrm{Cl}$, Defenders of Wildlife, EDF, Greenpeace, NRDC, NWF, Sierra Club, TNC, TWS, WWF, 350.org etc ou - surgiram no Brasil, mas sempre operaram em um ambiente estável e democrático, muitas vezes com conexão, apoio ou inspiração no movimento norte-americano e europeu, como são os casos de ICV, IMAZON, IPAM, ISA e SOS Mata Atlântica.

Adicionalmente, o movimento ambientalista se estrutura em torno de direitos difusos e bens e serviços marcadamente públicos, de cujos benefícios ninguém pode ser excluído. Em outras palavras, não se trata de movimento motivado por interesses materiais de grupos específicos.

Importante notar, ainda, que todas as organizações analisadas neste trabalho contam com boa capacidade de mobilizar apoios e recursos, mesmo que em diferentes escalas. São instituições que se mantêm, pelo menos, há mais de uma década, e se consolidaram como referências no ambientalismo em seus respectivos países.

\subsection{TEORIAS DE EMPRESA}

Algumas das ONGs aqui estudadas movimentam mais recursos do que empresas consideradas de médio ou grande porte. Muitas contam com centenas de funcionários e atuação em diferentes estados, ou pertencem a redes internacionais com presença em todos os continentes. São mais de 30 milhões de pessoas envolvidas com ONGs de diversas áreas no mundo, entre funcionários e voluntários e, se fosse um país, o Terceiro Setor corresponderia à oitava economia do mundo (Nelson 2007, p.3).

Com tamanho volume de recursos, capilaridade e influência em instâncias decisórias, seria natural o surgimento da necessidade de estruturas profissionais qualificadas, com mecanismos de arrecadação de recursos e construção de imagem institucional, a exemplo de grandes corporações. Esse quadro leva, automaticamente, as organizações a se comportarem, ao menos em alguns momentos, como firmas, que buscam reduzir despesas, aumentar recursos e, até mesmo, enfrentar concorrentes. 
Assim, frequentemente as organizações do movimento ambientalista são tratadas como empreendimentos, que lidam o produto "bem público" e têm como concorrentes as outras organizações do segmento ambiental, que competem por recursos de fontes similares, como doadores pessoa física, jurídica ou de governo. Os clientes dessas organizações de advocacy, assim denominadas pelo mesmo autor, seriam "indivíduos, fundações, empresas e outras associações" (Young 2010, pp.32,36 - tradução minha) ${ }^{7}$.

De acordo com Barakso (2010), as organizações, assim como as companhias, praticam o exercício de avaliar custos e benefícios de suas ações. "Para firmas, os lucros são monetários, enquanto para os grupos [ONGs], os lucros tomam a forma de sucessos no campo das políticas" (p.155 - tradução minha).

Lang (2013) caminha em direção semelhante e vincula o sucesso das organizações não-governamentais ambientalistas no campo da influência nas políticas públicas ao grau de institucionalização desses grupos:

...institucionalização engloba todas as tentativas de estabilizar uma organização. Refere-se ao desenvolvimento de normas, funções e rotinas das organizações, de modo a assegurar sua sobrevivência. $O$ processo decisório torna-se um conjunto estabelecido de passos organizados em gráficos; rotinas de ações repetitivas se enraízam por meio do aprendizado institucional, e medidas são tomadas para garantir que a sobrevivência da organização não dependa da presença de indivíduos específicos ( $p .73$ - tradução minha).

A pesquisa que fundamenta este trabalho constatou que as teorias das firmas podem explicar, com maior ou menor grau de correspondência, diversos padrões de comportamento das ONGs pesquisadas, especialmente daquelas que concentram suas ações nas vias institucionais, sem o emprego de técnicas voltadas para o confronto.

No Brasil, foi constatado que organizações como WWF, Conservação Internacional e TNC, em maior escala, Greenpeace, ISA, IPAM, IMAZON e SOS Mata Atlântica, vêm se profissionalizando cada vez mais e contam com estruturas administrativas de relativa complexidade, além de concentrarem esforços - em diferentes escalas - em projetos voltados para a captação de recursos, junto a fundações, empresas privadas, governos e indivíduos. No caso específico do Greenpeace, a organização se mantém, essencialmente, por meio de doações feitas por pessoas físicas, fazendo com que a estrutura de captação

\footnotetext{
${ }^{7}$ Young ressalta que as teorias de comportamento das firmas (theories of firm behavior) se tornam cada vez mais relevantes para explicar o desenvolvimento das organizações ambientais que atuam no campo das políticas públicas, devido ao seu alto grau de dependência de quadros profissionais e pequena participação dos afiliados (2010, p.34).
} 
de filiados seja priorizada.

Em relação às ONGs norte-americanas, esta pesquisa demonstrou que o grau de profissionalização e estruturação, de maneira geral, é ainda maior que no Brasil. Mesmo organizações caracterizadas como mais ativistas, radicais ou adeptas de táticas de confronto contam com escritórios em Washington, D.C., e equipes profissionais qualificadas. Certamente, as teorias de firmas conseguem explicar alguns importantes comportamentos das organizações aqui estudadas.

\subsection{POLÍTICA DO CONFLITO: QUESTIONANDO O STATUS QUO POR VIAS INSTITUCIONAIS E NÃO-INSTITUCIONAIS}

As interações que grupos sociais travam com distintos atores para levar adiante seus objetivos podem ser enquadradas no campo da política do conflito ${ }^{8}$, de acordo com Mc Adam, Tarrow e Tilly (2001 e 2007). Os autores descreveram política do conflito como uma interação episódica, pública e coletiva entre autores de reivindicações e seus objetos, desde que haja envolvimento governamental, e que as reivindicações afetem os interesses de pelo menos uma das partes envolvidas. "A grosso modo, a definição se refere a lutas políticas coletivas" (2001, p.5).

Mais tarde, em 2008, Tilly e Tarrow aprimoram a definição, admitindo que, nem sempre, as reivindicações conflituosas (contentious claims) envolvem governos, pois podem se dar entre diferentes organizações da sociedade civil (p.6). Os autores observam, também que, para haver a política do conflito (politics of contention), é necessário que se tenha a interseção entre ação coletiva, conflito e política, conforme a Figura 1 (Mc Adam, Tarrow e Tilly, 2001, p.7).

\footnotetext{
${ }^{8} \mathrm{O}$ termo em inglês é denominado politics of contention, ou dynamics of contention, que poderia ser traduzido como políticas ou dinâmicas conflituosas. Optei aqui por seguir a tradução feita por Abers e Von Bülow (2011), que adotaram o termo política do conflito. Mais adiante, reproduzirei outras traduções feitas pelas mesmas autoras a outros dois termos: contained contention (interação contida) e transgressive contention (interação transgressora).
} 


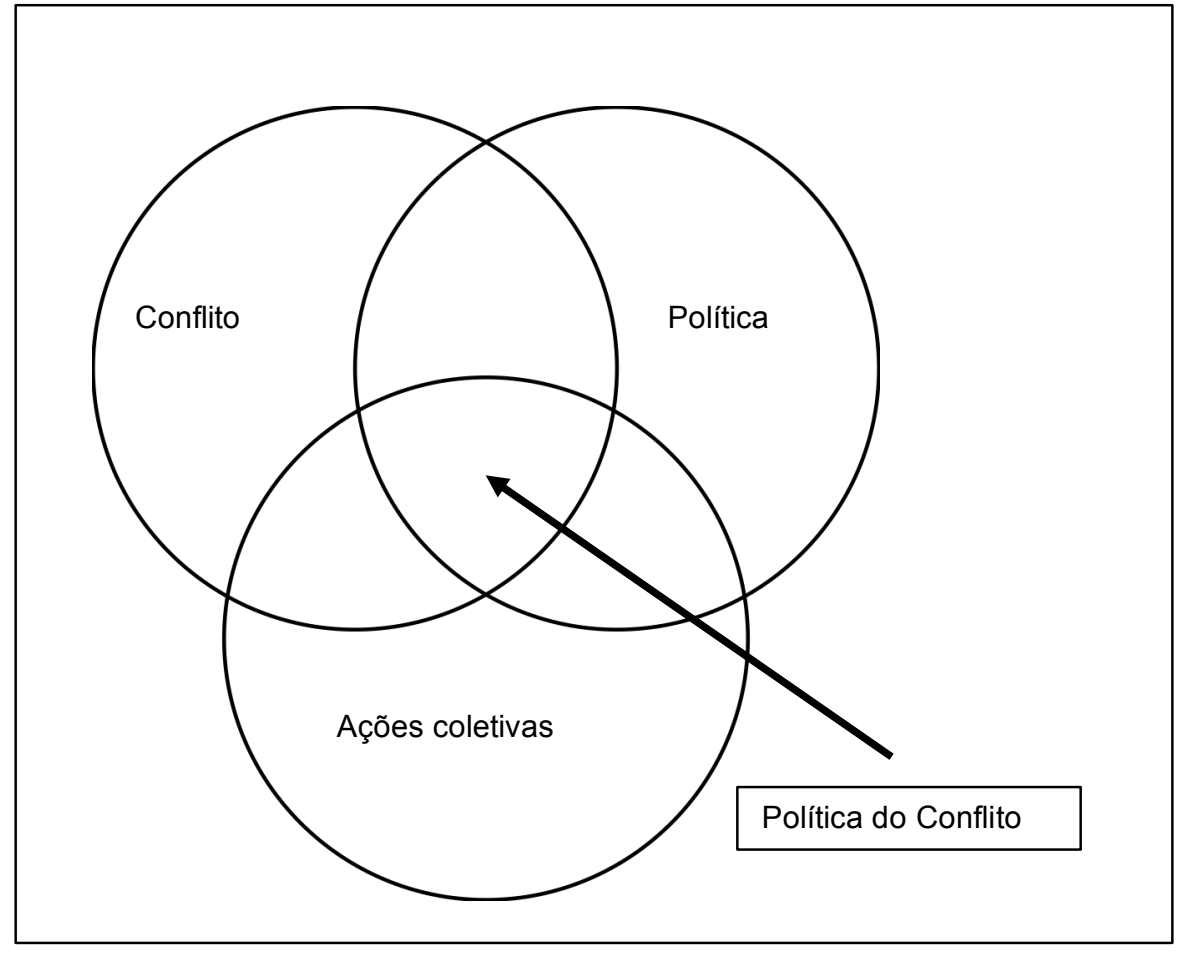

Figura 1: Componentes da Política do Conflito Fonte: Mc Adam, Tarrow e Tilly, 2001, p.7

A política do conflito envolve parcela significativa dos repertórios utilizados pelas grandes ONGs ambientalistas, que levam adiante suas reivindicações por vias distintas, mas que geralmente:

(i) envolvem causas coletivas (da preservação de espécies, passando pela criação e implementação de unidades de conservação, até a luta pela derrubada de um projeto de lei que reduz as proteções ao meio ambiente);

(ii) buscam atingir tomadores de decisão (aspecto político) e

(iii) procuram mudar alguma realidade ou evitar a mudança de determinada situação (conflito).

Ainda segundo Mc Adam, Tarrow e Tilly (2001), as interações conflituosas podem ser categorizadas como contidas (contained) ou transgressoras (transgressive). As interações contidas requerem que as partes envolvidas sejam previamente reconhecidas como atores políticos. Já as interações transgressoras devem incluir novos atores ou ações inovadoras, que envolvam meios inéditos ou proibidos (pp.7-8).

Um maior detalhamento das estratégias usadas por movimentos para influenciar políticas é feito considerando três diferentes esferas de atuação (Mc Adam, Tarrow e Tilly 2001, pp.11-12), conforme Figura 2. A primeira esfera é localizada dentro do Estado. As organizações que transitam dentro das instâncias decisórias realizam uma interação política chamada de pública. Um exemplo disso seriam as ONGs ambientalistas que assinam convênios e parcerias diretamente com órgãos de governo, exercendo influência sobre as políticas de dentro do próprio Estado. 
A outra esfera está fora do Estado, mas ainda dentro dos limites de atuação do governo. Nessa esfera estão as organizações que atuam como desafiantes (challengers), praticando a chamada política do conflito (contentious politics). Exemplo desse tipo de interação seriam ações judiciais contra o Estado, para que este cumpra a legislação ambiental, ou manifestações de organizações demandando uma posição do Legislativo ou do Executivo diante de determinada política pública.

Por fim, na esfera localizada fora da jurisdição governamental estão aqueles grupos que praticam as chamadas interações transgressoras, por vezes valendo-se de meios nãoconvencionais ou, até mesmo, considerados fora-da-lei, para atingir seus objetivos.

Episódios de ações diretas, como o fechamento ou a ocupação de edifícios públicos ou instalações empresariais são exemplos das interações nesta esfera.

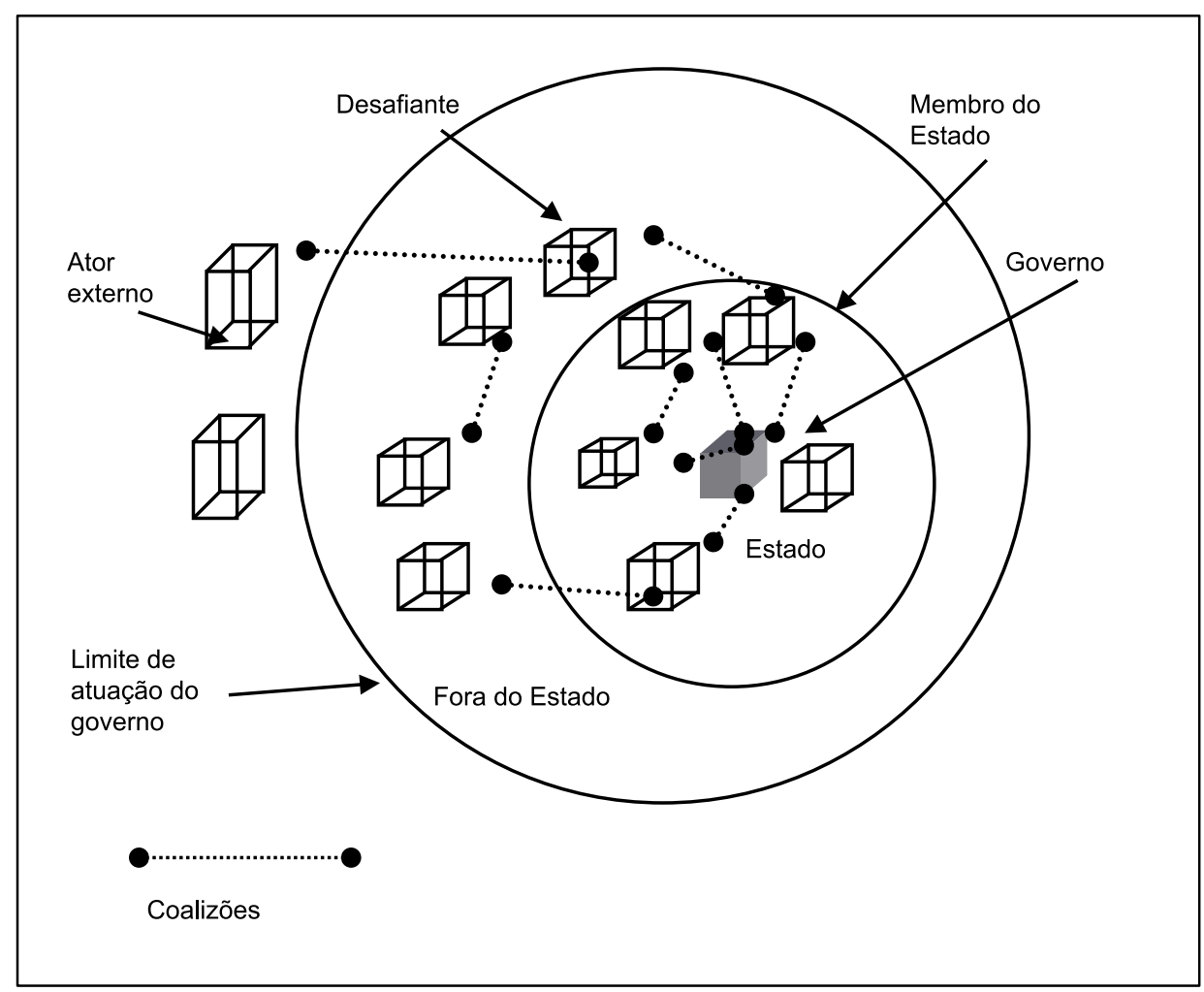

Figura 2: Modelo Simplificado do sistema político (polity) Fonte: Mc Adam, Tarrow e Tilly, 2001, p.11-12 (tradução minha)

É possível, considerando as organizações pesquisadas, que um mesmo grupo de organizações atue nas três esferas. O WWF-Brasil, por exemplo, tem diversos convênios com o Estado brasileiro e um projeto de conservação custeado pela Fundação Banco do Brasil. Mas a ONG também pressiona o Estado brasileiro, notadamente o Legislativo e o Executivo, a formular e implementar políticas ambientais. E chegou a fazer, em parceria com outras organizações do movimento social, durante as discussões do Código Florestal, ações claramente de confronto, com uma dose de transgressão, como o fechamento simbólico do 
Ministério do Meio Ambiente, derrubando sacas de soja e pés de cana-de-açúcar na entrada do prédio do MMA, em Brasília9.

Nos Estados Unidos, o conjunto de organizações pesquisadas atua, predominantemente, nas esferas localizadas dentro da jurisdição do Estado. Apenas duas das instituições estudadas - Friends of the Earth e Greenpeace - desenvolveram nos últimos anos ações que poderiam ser classificadas como transgressoras ou de confronto. Ainda assim, nos EUA e no Brasil, mesmo as ações conflitivas não ocorrem com a intensidade vista, por exemplo, na Ásia, quando navios do Greenpeace impedem fisicamente o trabalho das tripulações de embarcações dedicadas à pesca predatória.

Outro ponto-chave ligado à política de conflito são os conceitos de performances e repertórios de conflito, mais detalhados em outra obra de Tilly e Tarrow (2008). Para os autores, as performances seriam ações específicas para levar adiante as reivindicações pretendidas por uma ou mais organizações, como petições, marchas, ou mesmo um atentado a bomba (pp.14-15). Um conjunto de performances utilizadas por determinado ator ou grupo de atores seria, então, denominado de repertório:

A existência de um repertório significa que a parte reivindicadora tem mais de uma forma de fazer reivindicações coletivas em relação a um objeto. As mesmas pessoas que fazem passeatas nas ruas também assinam petições, as mesmas pessoas que conduzem ataques armados também sentam à mesa para negociar (p.14 tradução minha).

O grau de inovação dentro dos repertórios existentes é reduzido e os grupos que exercem ações coletivas costumam escolher como levar adiante seus pleitos a partir de um menu já conhecido pelos movimentos (Tilly e Tarrow 2008, p.15). A literatura dos movimentos sociais tem demonstrado que, ao longo dos séculos 20 e 21 , os repertórios utilizados pela sociedade civil para reivindicar não são muito variados. A variação se dá, em maior medida, nos instrumentos usados para atingir objetivos, especialmente com o surgimento de novas tecnologias. Esta pesquisa, feita em um universo de mais de 30 organizações ambientalistas, também revelou um menu relativamente limitado de táticas e ações empregadas pelas ONGs.

Tilly e Tarrow também reconhecem que as chamadas estruturas de oportunidades políticas (abordadas anteriormente neste capítulo) são de fundamental importância para

\footnotetext{
${ }^{9}$ Movimento social "fecha" Ministério do Meio Ambiente. Em http://www.wwf.org.br/wwf brasil/?30302/Movimento-social-fecha-Ministrio-do-Meio-Ambiente (acesso em 16 de julho de 2015)
} 
favorecer ou dificultar a política do conflito, sobretudo aquelas nas esferas local e nacional (2007, p.22). Regimes autoritários, governos abertos a interações com a sociedade civil, crises econômicas e legislaturas progressistas ou conservadoras podem ditar o tipo de repertório a ser adotado pelos movimentos sociais. Trata-se, pois, de mais uma confirmação da relevância da teoria das Oportunidades Políticas para este trabalho.

\subsection{ABORDAGENS DE REDES E MODELO DAS COALIZÕES DE ADVOCACY}

Durante esta pesquisa consegui observar que, tanto no Brasil como nos Estados Unidos, o movimento ambientalista atua com enorme frequência em coalizões para atingir seus objetivos. Trabalhando em redes, as organizações buscam aumentar o poder de suas reivindicações diante de correlações de força desfavoráveis. Maurício Guetta, advogado do programa Política e Direito Socioambiental do Instituto Socioambiental (ISA), afirmou, em entrevista para esta pesquisa ${ }^{10}$ : "Em termos de força política e econômica, o lobby do setor empresarial é maior que o nosso. Se não atuarmos conjuntamente, a gente perde de lavada".

A mesma opinião foi obtida em entrevista com Jessica McGlyn, lobista do WWF-EUA entre 2006 e $2010^{11}$ : "Há muito pouco que uma organização sozinha pode fazer para gerar mudança, a maior parte é feita por meio de coalizões", disse.

Outra razão para as organizações se associarem pode ser a redução de custos. Naturalmente, a manutenção de equipes de advogados, o desenvolvimento de campanhas e a realização de estudos técnico-científicos, bem como a organização de manifestações e o acompanhamento de atividades no Congresso, custam tempo, dinheiro e recursos humanos. Com as alianças, as organizações podem se quotizar para cobrir esses custos, bem como compor um pool de profissionais com diferentes expertises para fazer frente a determinada ameaça ou levar adiante uma agenda comum.

Hadden (2015), realizou um detalhado estudo sobre o papel do movimento ambientalista nas conferências do clima. "Organizações tendem a adotar estratégias de protesto quando os parceiros já o tenham feito e harmonizam suas táticas com seus pares em virtude de compartilhamento de informação, recursos e influência" (p.186 - tradução minha).

A autora entrevistou cerca de 90 representantes de organizações não-governamentais ambientalistas, que confirmaram a importância das redes para definir comportamentos e

\footnotetext{
${ }^{10}$ Entrevista concedida em 8 de julho de 2015.

${ }^{11}$ Entrevista concedida em 27 de maio de 2014.
} 
escolhas de estratégias e repertórios. "As entrevistas revelam como suas decisões táticas são guiadas pelos mecanismos relacionais de compartilhamento de informação, união de recursos e influência dos pares" (Hadden 2015, p.119 - tradução minha).

O modelo de coalizões de advocacy (advocacy coalition framework), que tem em Paul Sabatier seu principal autor, traz um aprofundamento das teorias de redes. O locus principal de tomada de decisão quanto às políticas públicas são os "subsistemas das políticas" (policy subsystems), dentro dos quais há uma interação de integrantes de elites políticas, compostas por tomadores de decisão (membros do governo, parlamentares, assessores etc), de coalizões de advocacy (formadas por organizações, grupos de interesse e atores envolvidos com os assuntos), além de jornalistas, cientistas e integrantes da academia, que podem, inclusive, ser parte das coalizões. "Mudanças de políticas ocorrem em função da competição dentro dos subsistemas e eventos externos ao subsistema" (Sabatier, 2007, pp.9-10 - tradução minha).

Essa competição no interior dos subsistemas ocorre por meio da propagação de informações e da persuasão, por diversas formas, dos tomadores de decisão, por meio de lobbies, estudos técnicos, estratégias de comunicação e mobilização, pressão popular, celebridades, especialistas, ações judiciais e outros meios. As coalizões se constroem a partir da aglutinação de grupos com interesses parecidos naquela temática. O grau de articulação dentro da coalizão varia de caso a caso, podendo contar com reuniões constantes e elaboração de documentos conjuntos, ou encontros esporádicos e baixo grau de concertação.

Já os eventos externos ao subsistema, mencionados por Sabatier, seriam situações, geralmente fora da rotina ou extremas, que contribuem para a introdução ou aceleração de alguma mudança em curso, devido aos impactos. Exemplos no campo ambiental não faltam:

- O vazamento de petróleo na baía de Santa Bárbara, Califórnia, em 1969, levou à aprovação de uma moratória na extração de petróleo offshore ${ }^{12}$;

- O acidente nuclear em Fukushima, Japão, em 2011, levou a Alemanha a decretar uma moratória ao uso da energia nuclear, com gradual fechamento de todas as usinas nucleares do país até $2022^{13}$.

\footnotetext{
${ }^{12}$ Reportagem publicada em 22 de junho de 2010 na Revista Time: Is the oil spill good for the environmentalism?, listando uma série de desastres ambientais que ocasionaram avanços na legislação ambiental ou aumento de apoio para o movimento ambientalista.

${ }^{13}$ Reportagem publicada em 9 de março de 2012 na revista Focus: Wie sich Deutschland gegen Atomkraft entschied, mostrando as repercussões, no país, do acidente nuclear de Fukushima.
} 
O fato de as mudanças climáticas acontecerem em uma escala temporal mais estendida e menos abrupta que os desastres naturais ou industriais certamente explica parte das dificuldades encontradas pelo movimento ambientalista para mobilizar grandes parcelas da sociedade em torno de causas que possam se converter em políticas públicas ambientais consistentes. Conforme observado por Al Gore no filme Uma Verdade Inconveniente (2006), as mudanças climáticas podem ser comparadas à alegoria do sapo dentro da panela de água que aos poucos vai se aquecendo, cozinhando lentamente o anfíbio, que não sente o aumento da temperatura e, portanto, não reage. Na falta de um evento de grandes proporções e impactos, as coalizões de advocacy lideradas pelo movimento ambientalista não encontram facilidade em aglutinar o apoio popular que pressionaria ou sensibilizaria os subsistemas das políticas de forma mais rápida e eficiente.

O provimento de informações qualificadas para os tomadores de decisão é um importante diferencial que pode determinar o sucesso de uma coalizão dentro do processo de formulação de políticas. Assim, as organizações não-governamentais ambientalistas, por serem detentoras de conhecimentos técnicos e científicos, carregarem o apoio de importantes formadores de opinião e, especialmente no caso norte-americano, por trazerem consigo o aval de milhares de filiados, são parte dos subsistemas das políticas, e se tornaram relevantes membros das coalizões de advocacy. Esse quadro credencia os movimentos ambientalistas como importantes players dentro de um campo de jogo mais horizontalizado e aberto.

Esse cenário, caracterizado por espaços de tomadas de decisão ocupados por diversos setores da sociedade — não mais apenas por governos recebendo pressões externas de grupos de interesse - vai ao encontro de novas leituras dos processos decisórios, que apontam para uma espécie de esmaecimento das fronteiras entre Estado e movimentos.

Nas discussões ligadas ao Código Florestal, as organizações da sociedade civil brasileiras se uniram em torno de coalizões, o que contribuiu para um aumento da intensidade das pressões sobre tomadores de decisão, tanto no Legislativo quanto no Executivo.

Abers e Von Bülow (2001) apontam como incompletas as análises que caracterizam o Estado como um bloco monolítico, ou homogêneo, agindo de forma separada dos demais atores, assim como os modelos que descrevem os movimentos sociais como agentes que sempre se colocam como contraponto ao Estado, pressionando-o de fora para dentro (pp.64-65). As autoras chamam a atenção para a "incorporação de ativistas de movimentos sociais em cargos governamentais e a formação de novos movimentos sociais a partir da 
interlocução de ativistas dentro e fora do Estado". Dentre outros exemplos, citam a presença de ambientalistas em instâncias decisórias do Executivo Federal, fenômeno notado desde os governos militares, mas intensificado durante a gestão de Marina Silva frente ao Ministério do Meio Ambiente (pp.65-67).

Kenis e Schneider (1991), citados por Sabatier (2007), falam em redes de políticas (policy networks), "uma nova forma de governança caracterizada pela predominância de relações informais, decentralizadas e horizontais" (pp.131-132), algo próximo do conceito de subsistemas de políticas. Os governos perdem parte de seu protagonismo nos processos políticos, diante do obscurecimento das fronteiras entre Estado e sociedade, conforme demonstrado também por Abers e Von Bülow (2001).

Há, portanto, um maior protagonismo das ONGs ambientalistas, criando melhores condições para que o movimento influencie políticas públicas. Além disso, a situação fortalece a estratégia de coalizões e parcerias entre as organizações - inclusive de outros segmentos da sociedade civil — conforme demonstrado nesta pesquisa, tanto no Brasil quanto nos Estados Unidos.

\subsection{CONCEITO DE FRAMING E O ENQUADRAMENTO DOS DISCURSOS EM BUSCA DE RESULTADOS}

Um aspecto presente em algumas das correntes teóricas aqui abordadas é a necessidade do enquadramento (framing) dos discursos dos movimentos para angariar apoiadores e colaboradores para as organizações, bem como para obter o reconhecimento e o apoio aos pleitos dos movimentos sociais, seja em processos institucionalizados, no âmbito do Estado, seja em mobilizações externas ao sistema político.

Entende-se, pelo conceito de framing, a apresentação de ideias com determinado recorte voltado para que o público receptor da informação forme determinada opinião acerca dos temas comunicados. Goffman (1974) foi um dos primeiros autores a analisar a temática do framing, que ele definiu como "modelos ou esquemas de interpretação (...) que permitem ao interlocutor localizar, perceber, identificar e rotular uma infinidade de ocorrências concretas"... (p.21 - tradução minha). Definição similar de framing foi feita por Opp (2009): "modelo mental que consiste em elementos cognitivos e (...) também inclui normas, valores, atitudes e metas" (pp.235-236 - tradução minha).

Goffman (1974) divide os frames entre naturais, que ele classifica como "nãoorientados", e "puramente físicos", "sem sanções positivas ou negativas envolvidas". Seriam os modelos descritivos, sem um objetivo a ser alcançado. A outra categoria - que se 
correlaciona com esta pesquisa - seria a dos "frames sociais", que "proveem um entendimento de background para eventos que incorporam desejos, intenções e um esforço de controle" (p.22 - tradução minha). Seriam os enquadramentos mais interpretativos e opinativos, acompanhados de juízo de valor e buscando determinado resultado.

O aspecto estratégico dos frames e sua aplicação às organizações do movimento social foram discutidos por Snow e colegas (1986). Os autores pontuaram a necessidade de as organizações, que buscam apoio para suas reivindicações, promoverem o alinhamento de frames, ou a "conexão entre as orientações interpretativas de indivíduos e das organizações, de modo que alguns interesses, valores e crenças se tornem congruentes e complementares com as atividades, metas e ideologia da organização" (p.464 - tradução minha).

Seria prudente para uma organização ambientalista, por exemplo, utilizar a Encíclica de maio de 2015 do Papa Francisco, que tratou amplamente da questão ambiental, para promover o alinhamento de frames com um grupo de católicos praticantes. Mas, se o objetivo for persuadir um grupo de professores universitários a assinar uma petição, a ONG deve utilizar argumentos científicos para promover o alinhamento de frames, uma decisão estratégica que determinará o tipo de mensagem a ser utilizada e, certamente, os resultados a serem alcançados.

De acordo com Druckman (2001), o processo de framing envolve enfatizar um conjunto de considerações em uma mensagem, de modo que os indivíduos possam focar nessa visão específica ao construir suas próprias opiniões sobre o assunto em questão (p.246 - tradução minha). Para Entman (1993), que discute o tema do ponto de vista da comunicação, framing se trata de "selecionar alguns aspectos de uma realidade percebida fazendo-os mais salientes em um texto de comunicação, de forma a promover uma definição particular de determinado problema" (p.52 - tradução minha).

Snow (2004) discute os frames de ação coletiva, que dão um passo além da mera persuasão, introduzindo um importantíssimo componente para as estratégias das organizações dos movimentos sociais: a chamada para a ação. Para ele, os frames de ação coletiva (collective action frames) têm como objetivo

...ativar adesões, transformar espectadores em apoiadores, extrair concessões e desmobilizar adversários. (...) Não apenas desempenham uma função interpretativa (...), mas também têm definitivamente um caráter conflitivo e de agência, demandando ações que problematizam e desafiam visões autoritárias existentes e frames da realidade (p.385 - tradução minha).

O aspecto estratégico dos frames nos processos de formulação, aprovação e 
implementação de políticas públicas é reforçado por Chong e Druckman (2007): "se um lado consegue estabelecer os termos relevantes de um debate sobre determinado tema, ele terá sucesso ao persuadir indivíduos para apoiar sua posição" (p.102 - tradução minha).

As ONGs ambientalistas, por exemplo, ao procurar influenciar os processos de formulação de políticas públicas, frequentemente buscam em suas ações de comunicação gerar mudança de opinião. Essa mudança pode ser tanto por parte de tomadores de decisão no sentido de elaborar, aprovar ou implementar políticas tidas como ambientalmente amigáveis, quanto por parte do público ou da imprensa, que pressionariam os políticos, dependente de votos e de aprovação popular, a tomar decisões em consonância com a conservação ambiental e o uso racional dos recursos naturais.

Um exemplo simples de frames diferenciados para um mesmo assunto pôde ser observado durante as discussões do Código Florestal brasileiro, entre 2008 e 2012. No dia da votação da matéria na Câmara, a Confederação da Agricultura e Pecuária do Brasil (CNA) publicou matéria com o seguinte título: "Modernização do Código Florestal deverá ser votada hoje". No dia seguinte, a ONG ambientalista Greenpeace divulgou lista com nomes de deputados, intitulada "Quem aprovou a destruição do Código Florestal". Ou seja, a mesma legislação foi descrita como "modernização" e "destruição", demonstrando os diferentes enquadramentos dados a uma mesma questão, por dois atores com distintos interesses dentro do debate.

Uma vez que este trabalho se propõe a analisar as estratégias adotadas por ONGs ambientalistas diante de políticas com impactos ambientais no Brasil e nos EUA, a análise das mensagens e ferramentas de comunicação adotadas para convencer a sociedade e os tomadores de decisão será fundamental. A teoria de framing fornece importantes subsídios para se verificarem as razões pelas quais determinadas mensagens conseguiram ou não atingir seus objetivos.

\subsection{PROIBIR HOJE PARA NÃO FALTAR AMANHÃ: O CARÁTER SUI GENERIS DAS POLÍTICAS AMBIENTAIS}

Segundo observou Hardin (1968), em seu célebre artigo "A Tragédia dos Bens Comuns" (The Tragedy of the Commons, título original do inglês), pessoas que compartilham determinado bem de uso coletivo e dele auferem ganhos tenderão a intensificar o uso com o objetivo de maximizar benefícios individuais. Porém, com o passar do tempo, a utilização massiva por parte dos usuários poderá inviabilizar a atividade como um todo, seja por limitação de unidades disponíveis ou por impossibilidade de manutenção 
do recém-ampliado modelo. "A liberdade diante de bens de uso comum traz a ruína de todos" (p.1244 - tradução minha). Ostrom (1990), por sua vez, destaca que, sem algum tipo de limitação para o uso de recursos naturais, sua existência no longo prazo ficaria comprometida (p.32).

Ainda de acordo com Hardin (1968), a única possibilidade de prevenção ou solução para a tragédia dos comuns, no caso de bens que não podem ser privatizados, como ar, água e biodiversidade, seria a criação de "leis coercitivas ou mecanismos tributários" (p.1245).

Hardin destaca, também, que a tragédia dos bens comuns não existe apenas quando determinado recurso público é utilizado de forma excessiva, mas também quando algum agente prejudica, por finalidades pessoais, um bem de uso público. Um exemplo é a emissão de poluentes em rios ou na atmosfera (Hardin 1968, p.1245).

Neste contexto, o conceito de externalidade se torna de especial importância. Segundo Bursztyn e Bursztyn (2013), os impactos causados por determinada atividade, quando afetam (positiva ou negativamente) uma ou mais partes, podem ser classificados como externalidades. Segundo os autores, o

...exemplo do lançamento de cargas poluidoras num rio pode ser representativo. Na medida em que os produtores e as comunidades despejam os seus efluentes sem prévia depuração, os mesmos economizam o custo de tratamento, que é externalizado sob a forma de custo social e se manifesta sob a forma deterioração do rio (p.214).

Exemplo recente de externalidade negativa de enorme escala, causada por atividade industrial, foi o rompimento da barragem de Fundão, que continha rejeitos da produção de minério de ferro da mineradora Samarco, no município mineiro de Mariana, em 5 de novembro de 2015. Além de pelo menos 16 mortos, o desastre fez com que cerca de 600 moradores ficassem desabrigados, além de afetar atividades agrícolas e pesqueiras, bem como o acesso a água em diversos municípios nos estados de Minas Gerais e Espírito Santo ${ }^{14}$. Neste caso, políticas ambientais seriam fundamentais para evitar, por meio de regulação, o ocorrido, e após o desastre, para minimizar os danos e promover a adaptação por parte de comunidades impactadas.

\footnotetext{
14 Informações sobre o desastre extraídas de notícia do Portal Uol, disponível no link http://noticias.uol.com.br/cotidiano/ultimas-noticias/2015/11/06/o-que-se-sabe-sobre-o-rompimento-dasbarragens-em-mariana-mg.htm Acesso em 2 de fevereiro de 2016.
} 
Assim, dois dos principais mecanismos tradicionalmente utilizados por formuladores de políticas públicas para lidar com o problema da utilização desequilibrada de bens de uso comum envolvem regulação e incentivos. Para Lowi (1995), políticas regulatórias buscam elevar os custos de uma atividade, limitando as alternativas de determinado grupo em relação a certo recurso e, eventualmente, aumentando as de outros grupos em situação de desfavorecimento real ou iminente. A "decisão regulatória envolve uma escolha direta daqueles que receberão concessões e os que serão privados do uso" (p.16).

Outro fator que contribui para a complexidade do assunto aqui analisado é que as políticas ambientais, com frequência, envolvem renúncias a benefícios imediatos em troca de resultados positivos em médio e longo prazos. Muitas vezes, a racionalidade de tomadores de decisões cuja permanência no cargo dependa do voto pode relegar a segundo plano questões que não possam render benefícios eleitorais imediatos.

Considerando que os ciclos eleitorais duram dois anos para deputados e seis para senadores, nos EUA, quatro anos para deputados e oito para senadores, no Brasil, e quatro anos para chefes do Executivo em ambos os países, essa mentalidade de curto prazo representa um risco para as políticas ambientais, especialmente aquelas com efeitos futuros ou cuja mensuração de resultados envolve numerosas variáveis e uma escala temporal mais ampliada.

As questões ambientais ganham, ainda, um elemento adicional de complexidade, quando é levada em conta a diversidade de grupos de interesse envolvidos, direta ou indiretamente, com temas ambientais, conforme descrito por McFarland (2007):

Em uma área específica como a de regulação da poluição atmosférica, podem estar envolvidos o setor de geração de energia, companhias mineradoras, a indústria automotiva, o sindicato de trabalhadores do setor automotivo, o setor do transporte ferroviário, grupos ambientalistas, a American Lung Association [ONG norteamericana que lida com o tema da poluição do ar], a Associação Americana de Saúde Pública, vários governos estaduais, a associação que representa os reguladores das concessionárias de serviços públicos e, provavelmente, outros grupos (p.55 - tradução minha).

Para o segmento das ONGs ambientalistas, a atuação no sentido de influenciar tomadores de decisão envolvidos com o tema é marcada por algumas dificuldades que merecem menção. Em uma questão como a demarcação de terras indígenas, o movimento ambientalista brasileiro enfrenta, além da conhecida bancada ruralista, o forte lobby da Confederação Nacional da Agricultura e Pecuária do Brasil (CNA). Em casos ligados à 
rotulagem de organismos geneticamente modificados, a agroindústria, outro poderoso ator no jogo político, possivelmente estará contra a posição das organizações verdes. E, em um assunto como a recente reforma do Código Florestal, o movimento ambientalista enfrentou disputas com os grupos acima mencionados, mais o Ministério da Agricultura, Pecuária e Abastecimento (MAPA), a Organização das Cooperativas Brasileiras (OCB) e diversos governos estaduais e municipais.

Assim, é possível afirmar que esses embates exigem estruturas e táticas sofisticadas, por serem travados com uma diversidade de atores, observando-se variadas correlações de força. Isso reforça a importância da teoria da mobilização de recursos para o tema desta pesquisa: frequentemente, organizações com estruturas mais modestas e desprovidas de aliados poderosos não conseguem influenciar processos decisórios complexos. Os opositores do movimento ambientalista, via de regra, costumam contar com mais recursos para as disputas no campo das políticas públicas ambientais (Schreurs 2002, p.26), como já ressaltado em páginas anteriores e como detalharei mais adiante.

Não que as grandes organizações ambientalistas, no Brasil e nos Estados Unidos, tenham orçamentos sempre baixos ou não contem com boa estrutura física e administrativa e com profissionais qualificados. Durante esta pesquisa, percebi que é mais correto afirmar que os grupos contrários às causas defendidas pelos ambientalistas são, geralmente, muito bem financiados, tanto no Brasil como nos EUA, criando uma disparidade no comparativo com as ONGs, mesmo levando-se em conta aquelas que não passam por "apertos" financeiros.

Além disso, um aspecto determinante para essa correlação de forças desigual é o fato de as ONGs terem que aplicar seus recursos em uma diversidade de frentes, como projetos voltados para a conservação e para o desenvolvimento sustentável, sendo a influência em políticas públicas apenas mais uma de suas atividades.

Outro ponto que influencia enormemente os processos de tomada de decisão ligados ao desenvolvimento sustentável é a inevitável sujeição dos debates ambientais a fatores cujos ciclos costumam ser mais curtos que o tempo necessário para o monitoramento e a avaliação das ações na área ambiental. Conforme Vig e Kraft (2006), recessões econômicas e crises energéticas são exemplos de "eventos de curto prazo que podem reforçar ou enfraquecer tendências de longo prazo que possam apoiar a proteção do meio ambiente" (p.10 - tradução minha).

Os autores citam que a crise do petróleo de 1979 fez com que o ímpeto do então presidente Jimmy Carter em favor de regulações ambientais fosse freado (Vig e Kraft 2006, p.10). Mais adiante, os atentados de 11 de setembro de 2001 fariam com que a questão 
ambiental desaparecesse da agenda política norte-americana, diante de um quasemonopólio das discussões sobre prevenção e combate ao terrorismo.

Também a dimensão espacial dos problemas ambientais tem relevante papel nas discussões do tema, demandando soluções que transcendam as fronteiras locais, estaduais ou nacionais, que normalmente são a referência utilizada para determinar o alcance das políticas públicas. O problema do free-rider, discutido no texto de Hardin, pode fazer com que o esforço de um país em reduzir danos ao meio ambiente caia por terra, pelo fato de outros países seguirem emitindo e gerando impactos sentidos por todos.

Conforme definido por Stone (2010),

...propostas de caráter ambiental tipicamente implicam bens públicos, portanto, coordenação de esforços entre diferentes atores. (...) Os EUA podem fazer cortes nas emissões de mercúrio por suas fábricas, e rapidamente verificar que os progressos atingidos nessa questão foram simplesmente relegados à irrelevância por poluentes originários da China (p.144 - tradução minha).

Lazarus (2004), entende que o processo de elaboração, aprovação e implementação de políticas ambientais apresenta "desafios únicos de caráter institucional e social", em virtude de dificuldades para se comprovarem causas e consequências de determinadas medidas, associadas às múltiplas instâncias pelas quais uma política precisa passar antes de ser posta em prática, principalmente no contexto das democracias ocidentais (pp.129135).

Segundo o autor, afirmações de que "apenas um estado fascista poderia vencer o desafio de efetivamente regular a poluição ambiental" (Lazarus 2004, p.135 - tradução minha) não eram incomuns. Certamente, pensou-se aqui na frequência com que medidas impopulares, que geram perdas a setores influentes, ou de difícil compreensão para o grande público, precisam ser tomadas quando se busca assegurar um ambiente mais seguro e saudável para as atuais e futuras gerações.

Não é equivocado afirmar que parte dessas dificuldades se deve ao fato de que considerável parcela da legislação ambiental consiste em modificar padrões historicamente estabelecidos de produção, consumo e descarte, punir organizações e indivíduos por práticas anteriormente consideradas normais, mas que passam a ser classificadas como nocivas ou predatórias, em limitar ou proibir a utilização de algum bem anteriormente acessível de forma mais livre ou mais barata e em realocar recursos públicos ou privados que outrora se destinavam a outro setor (Libby 1998, p.176). 
$\mathrm{Na}$ entrevista feita com Marina Silva para esta pesquisa ${ }^{15}$, a ex-ministra do Meio Ambiente e ex-senadora salientou a maneira como essa peculiaridade da política ambiental influencia o trabalho do movimento ambientalista $\mathrm{e}$ dos tomadores de decisão comprometidos com o desenvolvimento sustentável:

O que ainda não é estabelecido precisa ser provado técnica e cientificamente que é viável. O que está estabelecido e de acordo com o sistema não precisa ser justificado, o que está querendo se estabelecer é sempre taxado de ser sonho, utopia, ideologia.

Em similar direção segue a análise de Little (2003): "Mudar as práticas vigentes de desenvolvimento requer que as formas atuais de atividade produtiva, sustentadas por pesados interesses econômicos, sejam confrontadas" (p.19). Não há dúvidas de que os defensores de causas que impliquem grandes mudanças de rumo, como é o caso do movimento ambientalista, têm pela frente tarefa muito mais árdua que aqueles que buscam a manutenção do status quo. No capítulo seguinte, por meio de uma contextualização das principais políticas ambientais e de um histórico do ambientalismo nos dois países estudados, essas peculiaridades ficarão mais claras.

Considerando que o estudo das organizações não governamentais é algo relativamente recente, sem uma ou mais teorias explicativas que estejam consolidadas ou pactuadas entre os pesquisadores, foi necessário fazer um levantamento de algumas correntes teóricas que ajudam a entender a organização e o comportamento das ONGs estudadas. Todas as teorias discutidas neste capítulo podem se aplicar, em algum grau, ao movimento ambientalista. Porém, algumas se mostraram mais úteis para a discussão do papel das organizações estudadas no sentido de influenciar políticas públicas no Brasil e nos EUA. Foi possível constatar que as teorias de mobilização de recursos, das oportunidades políticas e de empresas são de grande utilidade para explicar a estruturação, a consolidação e a atuação do movimento ambientalista, temas explorados nos capítulos 2 , 3 e 4 . As teorias ligadas à política do conflito, às coalizões de advocacy e ao framing, por sua vez, se mostraram úteis para explicar a opção das organizações por determinados repertórios em lugar de outros, discussão que se faz presente, principalmente, no Capítulo 4 deste trabalho.

\footnotetext{
${ }^{15}$ Entrevista concedida no dia 31 de julho de 2015.
} 


\section{AS POLÍTICAS AMBIENTAIS E O MOVIMENTO AMBIENTALISTA NOS EUA}

Numerosas organizações governamentais e de cidadãos se formaram para promover causas ambientais e para ativamente proteger a natureza. O resultado foi uma variedade de (...) leis ambientais e agências concebidas para incorporar o ambientalismo na arena política. O apoio público floresceu na sociedade... (Kline 2011, p. 111 - tradução minha)

Neste capítulo serão apresentadas, cronologicamente, as principais políticas ambientais adotadas pelos Estados Unidos, e como esse tipo de legislação evoluiu no país. Será possível observar o grau de pioneirismo dos EUA no estabelecimento de regulamentos e proteções ao meio ambiente, que serviram de inspiração para diversos países. Mais adiante será mostrado um breve histórico do movimento ambientalista norte-americano, cujas primeiras manifestações se dão nos últimos anos do Século 19, com a consolidação observada nas décadas de 1970 e 1980.

Ao final do capítulo, os principais momentos históricos descritos nas próximas páginas serão resumidos em uma linha do tempo, que tem como objetivo demonstrar o processo de construção do contexto no qual as ONGs ambientalistas operam no país.

\subsection{EVOLUÇÃO DAS POLÍTICAS AMBIENTAIS NOS ESTADOS UNIDOS}

Até a primeira metade do Século 20, segundo Kubasek e Silverman (2005), o único tipo de proteção legal desenhado com o objetivo de minimizar os efeitos nocivos de desastres ambientais, poluição do ar, solo e de recursos hídricos, nos EUA, ficava por conta de ações de reparação por danos causados (tort law, em inglês), seja por indústrias, governos ou mesmo indivíduos (pp.130-131).

Havia, ainda, uma série de políticas voltadas para a conservação das paisagens naturais, geralmente por representarem áreas de recreação para as famílias americanas ou por se tratarem de local de beleza cênica, que poderiam ser apreciados por futuras gerações. Assim, já em 1872 é criado o primeiro parque nacional do país (Yellowstone) e em 1890 cria-se o conhecido Parque Nacional de Yosemite.

Outro objetivo das políticas ambientais dos EUA àquela época era assegurar que não faltaria matéria-prima para o desenvolvimento do país, especialmente recursos madeireiros, que serviam para construir casas no campo e nas cidades e benfeitorias em propriedades rurais, além de fornecerem combustível para aquecimento, transporte ferroviário e maquinário industrial. 
Assim, já no Século 17, criam-se leis, no âmbito regional, para limitar o percentual de supressão de vegetação dentro das propriedades (Neuzil e Kovarik 1996). Há, também, leis que impõem limitações à caça de algumas espécies, formuladas ao longo dos séculos 18 e 19.

De acordo com Brulle (2009), as políticas destinadas a garantir a continuidade das atividades de caça e pesca esportiva também encontravam espaço desde meados do Século 19. Há registros de grupos de caçadores e pescadores recreativos que se mobilizavam para demandar das autoridades limites nas quantidades de animais a serem abatidos e capturados, bem como a proibição da atividade em determinados períodos. Segundo o autor, tratava-se das primeiras sementes daquilo seria mais tarde denominado movimento ambientalista. (pp.212-213).

De forma inovadora, aliando o objetivo de regular para que não faltassem matériasprimas, com a preservação de áreas de grande beleza estética para gerações futuras, o presidente Theodore Roosevelt criava, em 1905, o Serviço Florestal dos EUA (USFS). Mas o principal objetivo do novo órgão era fazer com que as florestas nacionais - áreas em que é permitido, sob gestão da União, extrair recursos naturais - passassem a ser administradas de forma centralizada, para evitar a exaustão dos ativos florestais.

Em 1916, o presidente Woodrow Wilson assinou a criação de um sistema nacional de parques, juntamente com o Serviço de Parques Nacionais (NPS) (Bosso 2005, p.27). Grande parte dessas iniciativas ocorreu muito mais para preservar áreas de grande beleza estética, que começavam a ser valorizadas pela sociedade norte-americana. Não tinha força, ainda, a visão de conservação de paisagens, ecossistemas e biodiversidade.

No pós-guerra, o desenvolvimento do país caminhava a passos largos, com o acelerado crescimento da indústria, consolidando a supremacia econômica e militar em relação à Europa, destruída pelo maior conflito de toda a história. Mas essa pujança industrial cobrou um alto preço do ponto de vista ambiental. Wills (2013) avalia que "a construção de uma América urbana e industrial envolveu massivo descaso com o meio ambiente" (p.28 - tradução minha).

A agricultura do país também se desenvolvia enormemente, valendo-se dos grandes avanços da indústria química e gerando profundos impactos no meio ambiente. Ainda de acordo com Wills, "o emprego de pesticidas nos Estados Unidos esteve muito atrelado à sobrevivência da nação agrária no Século 20. (...) Agentes químicos, como o DDT, eram vendidos como produtos milagrosos, capazes de revolucionar uma fazenda americana comum" (Wills 2013, p.85 - tradução minha). 
O crescimento do movimento ambientalista dos EUA nos anos 1960-1970, conforme será explorado com maior profundidade ainda neste capítulo, tem relação direta com uma reação de parte da sociedade norte-americana a um modelo de expansão industrial e agrícola sem maiores cuidados com o meio ambiente. (Wellock 2008, pp.8-9; Wills 2013, p.28).

\subsubsection{Duas décadas que mudaram um país}

A década de 1960 assistiria a expressivas mudanças políticas e sociais não apenas nos EUA, mas em várias partes do mundo. A publicação do livro Primavera Silenciosa (Silent Spring, no título original), de Rachel Carson, em 1962, expôs os danos causados pelo uso do DDT. As famílias norte-americanas tomaram conhecimento dos mais diversos impactos dos pesticidas na saúde humana, na água, no solo, na fauna e na flora:

Como podem seres inteligentes tentar controlar algumas poucas espécies indesejadas com um método que contamina todo o meio ambiente e que ameaça com doenças e morte a sua própria espécie? (Carson 2002, p.8 - tradução minha).

Os impactos de Primavera Silenciosa foram numerosos e imediatos. O então presidente dos EUA, John F. Kennedy, criou uma comissão presidencial para analisar os efeitos nocivos do DDT (Wellock 2008, p.86).

Em 1963, após o assassinato de Kennedy, assume a Presidência o vice Lyndon B. Johnson, que assina no ano seguinte a Lei dos Direitos Civis (Civil Rights Act), considerando ilegal qualquer tipo de segregação racial no país. Os Estados Unidos experimentam um período de radicais mudanças sociais e de fortalecimento da sociedade civil.

Em parte, graças à pressão exercida pelo ainda pouco expressivo movimento ambientalista, Johnson assina em 1964 a primeira grande legislação de caráter ambiental dos EUA: a Lei das Áreas Silvestres (Wilderness Act), que designou 3,6 milhões de hectares como áreas estritamente protegidas e estabeleceu critérios para a proteção de áreas públicas (Del Mar 2006, p.106).

De acordo com Chase Huntley, diretor da ONG The Wilderness Society (TWS), em entrevista para esta pesquisa ${ }^{16}$, a Lei das Áreas Silvestres foi de extrema importância para a conservação. "A lei deixou claro que somente o Congresso poderia criar áreas protegidas de natureza selvagem", afirmou. Huntley lembrou que, graças a essa lei, a TWS consegue, há

\footnotetext{
${ }^{16}$ Entrevista concedida em 13 de janeiro de 2015.
} 
50 anos, desenvolver um trabalho baseado em inventários e estudos técnicos, que busca gerar as evidências científicas necessárias para justificar a proteção legal dessas áreas, de extrema importância para a conservação.

A sociedade norte-americana assistiu, com perplexidade, a uma série de desastres decorrentes da falta de cuidados com o meio ambiente. As principais causas eram a utilização indiscriminada de recursos naturais e a negligência, por parte da indústria e do estado, em relação à emissão e ao descarte de resíduos sólidos, líquidos e gasosos, além de outras externalidades negativas advindas dos processos produtivos.

Em grande medida devido aos desastres ambientais e a publicações que denunciaram a degradação do ambiente, como o livro de Rachel Carson, a partir do final nos anos 1960 e, principalmente, nos anos 1970 surgiram diversas leis especificamente voltadas para questões ambientais nos Estados Unidos. (Vig e Kraft 2006, pp.1-3; Kubasek e Silverman 2005, pp.136-137).

Já em 1966, em virtude dos alarmantes níveis de poluição atmosférica nas grandes cidades - Los Angeles, Nova York e Filadélfia, para citar algumas - o Congresso aprova a primeira legislação para estabelecer controle de emissões veiculares, criando limites para veículos fabricados a partir de 1968 (EPA 1994).

Em 1969, ano marcado pelo fascínio do mundo ocidental em relação aos avanços tecnológicos, materializados pela chegada do homem à Lua, dois desastres ambientais carregados de simbolismo tiveram lugar nos EUA: o vazamento de petróleo na baía de Santa Bárbara, Califórnia, em janeiro, e o incêndio nas águas do rio Cuyahoga, em Ohio, em virtude de poluentes inflamáveis descartados ao longo de décadas pela indústria naquele curso d'água ${ }^{17}$.

Em reportagem escrita em 1989 para o Los Angeles Times, utilizando fontes da academia e do movimento ambientalista, o repórter Miles Corwin salientou a importância do vazamento de óleo em Santa Bárbara para que o tema ambiental entrasse na agenda política dos EUA: "Nos anos seguintes foram aprovadas mais leis ambientais que em qualquer outra época da história do país", relatou a matéria jornalística.

Os temas ambientais alcançaram uma relevância sem precedentes, tornando-se uma agenda abraçada tanto por Republicanos quanto por Democratas. Isso permitiu significativas conquistas no âmbito legislativo, "criando-se um grande aparato regulatório

\footnotetext{
${ }^{17}$ Reportagens da revista Time e do Los Angeles Times descrevem os desastres mencionados: http://time.com/3921976/cuyahoga-fire/ e http://articles.latimes.com/1989-01-28/news/mn-1162_1_oil-spill (acesso em 14 de outubro de 2015)
} 
nos âmbitos local, estadual e federal" (Wellock 2008, p.4). Como será visto adiante, após a década de 1970 esse amplo consenso bipartidário - algo extremamente significativo em um sistema político como o dos EUA - jamais voltaria a ocorrer na história do país em torno de políticas ambientais (e em torno da maioria dos grandes temas, diga-se de passagem).

Os desastres ambientais, certamente, contribuíram para a aprovação de uma das principais peças de legislação ambiental da história dos Estados Unidos: a Lei Nacional da Política Ambiental (NEPA), votada no Congresso em 1969 e sancionada pelo presidente Richard Nixon em 1970, determinou de forma inovadora a obrigatoriedade da avaliação de impacto ambiental para projetos que envolvam o Governo Federal. Outra importante novidade da NEPA foi a criação do Conselho da Qualidade Ambiental (CEQ), órgão consultivo ligado à Casa Branca, que assessora o presidente da República em relação ao meio ambiente.

Iniciava-se aquela que seria chamada de "a década ambiental", marcada por uma sociedade que começou a exigir "ações governamentais abrangentes e vigorosas para diminuir a degradação do meio ambiente" (Vig e Kraft 2006, p.12). Lazarus (2004) descreve aquele que, certamente, foi o mais fértil período da história dos EUA em termos de políticas voltadas para a proteção do meio ambiente:

Durante os anos seguintes, o Congresso adicionou leis ambientais abrangentes e ambiciosas, voltadas para o controle da contaminação da água, manejo de resíduos sólidos e tóxicos, proteção de espécies ameaçadas e outros objetivos regulatórios. Cada um desses programas federais contemplou, promoveu e às vezes obrigou os estados a criarem programas e políticas ambientais (pp.714-717 tradução minha).

Ainda em 1970, a Lei do Ar Puro (Clean Air Act) é votada no Congresso e sancionada pelo presidente. Mas o principal legado ambiental do presidente Richard Nixon, um Republicano, foi a criação, também em 1970, da Agência de Proteção Ambiental (EPA, ou Environmental Protection Agency, nome original em inglês), cuja missão era de "controlar e reduzir a poluição e a contaminação do ar, da água, por resíduos sólidos, pesticidas, radiação e substâncias tóxicas". Tinha como mandato "montar um ataque coordenado e integrado à degradação do meio ambiente em cooperação com estados e governos locais" (Kubasek e Silverman 2005, p.106 - tradução minha). A EPA serviu de referência e inspiração para a concepção de órgãos ambientais similares em diversas partes do mundo (Bursztyn e Bursztyn 2013, p.179). 
Posteriormente, em 1972, aprovou-se a Lei da Água Limpa (Clean Water Act), também votada no Congresso em um acordo bipartidário. Steve Schwartzman, diretor de política florestal da ONG Environmental Defense Fund, uma das maiores do EUA, comentou, em entrevista para esta pesquisa ${ }^{18}$, o contexto em que esses avanços foram obtidos:

Tanto a Lei da Água Limpa quanto a Lei do Ar Puro aconteceram em um governo Republicano, que também criou a Agência de Proteção Ambiental e o Conselho da Qualidade Ambiental. (...) O rio Potomac era horrivel nos anos 1950, ele fedia. A Lei da Água Limpa fez uma grande diferença. Havia enorme poluição na Pensilvânia, e nos anos 1960 dezenas de pessoas morreram ali de uma vez em uma cidade industrial devido à poluição $(s m o g)$. Tinha muita poluição também nos grandes centros como Los Angeles. O Congresso, então, passou a Lei do Ar Puro. Isso criou um senso comum na opinião pública de que água limpa e ar puro são importantes.

Lazarus (2004, pp.1332-1335) reforça que, de maneira sem precedentes, as duas legislações voltadas para a qualidade hídrica e atmosférica impuseram parâmetros nacionais, portanto impedindo estados de negligenciar os cuidados com esses recursos naturais. Os novos padrões de qualidade para ar e água deveriam ser fiscalizados pelas distintas esferas do Poder Público.

Outras leis foram aprovadas durante esta "onda verde" que varreu a sociedade norteamericana nos anos 1970. Uma inovadora política aprovada em 1973 foi a Lei das Espécies Ameaçadas (Endangered Species Act). A legislação permitiu um nível de proteção à fauna e à flora jamais vista no país e tinha como objetivo central a preservação de ecossistemas (Yaffee 1994, p.12).

[A lei] oferecia proteção a espécies ameaçadas, subespécies, populações isoladas de animais ou plantas em iminente perigo de extinção ou ameaçadas, além de organismos que possam correr risco no futuro. (...) [O]s órgãos federais passariam a ter a obrigação de fazer o que fosse necessário para proteger espécies que constassem da lista, (...) [inclusive] retirando áreas previamente destinadas para o manejo de uso múltiplo (Yaffee 1994, pp.12-14 tradução minha).

Libby (1998), em seu abrangente estudo sobre campanhas organizadas pelo movimento ambientalista nos EUA, defendeu que é possível classificar a Lei das Espécies

\footnotetext{
${ }^{18}$ Entrevista concedida em 21 de janeiro de 2015.
} 
Ameaçadas (ESA) como "a mais poderosa legislação ambiental do país" (p.170). Ele lembra que, uma vez que o Serviço de Pesca e Vida Selvagem (FWS, ou Fish and Wildlife Service, agência vinculada à Secretaria do Interior) lista determinada espécie animal ou vegetal como em perigo ou ameaçada de extinção, o Estado tem obrigação de responsabilizar um proprietário caso a espécie sofra danos dentro de suas terras ( $p .171)$. Assim, o ESA criou restrições ao uso da propriedade privada, urbana e rural, algo pouco comum no aparato legal dos Estados Unidos.

Nos anos seguintes, outras legislações deram continuidade ao momento favorável às políticas ambientais no país. Foram aprovadas leis voltadas para qualidade da água potável (Safe Drinking Water Act, 1974), conservação e recuperação de recursos naturais (Resource Conservation and Restoration Act, 1976), manejo em florestas nacionais (National Forest Management Act, 1976), recuperação e controle da mineração a céu aberto (Surface Mining Control and Reclamation Act, 1977), além de uma ampliação das leis do Ar Puro e da Água Limpa (1977).

Por fim, em 1980, já ao término da legislatura, os parlamentares aprovaram duas importantes leis ambientais:

- a Lei de Conservação de Terras de Interesse Nacional do Alaska, que reafirmava a autoridade da União sobre vastas áreas naturais no estado ártico e restringia diversos usos com potencial impacto ambiental naquela região, jogando uma ducha de água fria nas pretensões de setores como petróleo, gás e mineração; e

- a transformadora lei apelidada de Superfundo (Superfund), que responsabilizava legal e financeiramente indústrias que geravam, transportavam e descartavam substâncias perigosas, além de criar um fundo para bancar a limpeza de locais que receberam descartes de resíduos tóxicos, custeado por impostos sobre a indústria química (Lazarus 2004, pp.1543-1556).

Uma das motivações para a aprovação da Lei do Superfundo foram as reivindicações de organizações de base comunitária, que a partir da célebre mobilização realizada na comunidade de Love Canal, em Buffalo, estado de Nova York, passaram a questionar, coletivamente, depósitos de lixo tóxico em regiões residenciais, feitos por indústrias. A mobilização ganhou escala e chamou atenção da mídia, das autoridades e da opinião pública (Lazarus 2004, pp.1543-1556), e obteve, na justiça, a remoção de todas as famílias que ali viviam para novas casas em locais seguros. 
Em entrevista para esta pesquisa, a principal líder responsável pelo movimento do Love Canal, Lois Gibbs ${ }^{19}$, afirmou que esse tipo de mobilização só alcança sucesso devido a um robusto movimento de organizações de base comunitária, bastante numerosas nos EUA.

Cabe observar que as condições que proporcionaram o ambiente adequado para essa sequência de políticas ambientais foram geradas por uma opinião pública favorável, um movimento ambientalista forte e com apoio da sociedade, bem como por atores políticos capazes de ler esse cenário e organizar arranjos bipartidários para levar adiante as mudanças no arcabouço legal do país.

Mesmo com as crises energéticas do início e do final dos anos 1970, que criaram entraves ao impulso pelas políticas ambientais (Stine 1998, p.191), o momento amplamente favorável à proteção do meio ambiente na opinião pública não apenas impediu retrocessos legais, como também assegurou que novas conquistas fossem aprovadas no Congresso e sancionadas na Casa Branca.

\subsubsection{Os anos 1980}

Com a eleição do conservador Ronald Reagan, as perspectivas para os ambientalistas não eram as melhores. O movimento havia dado um apoio, mesmo que tímido, à reeleição de Jimmy Carter (Stine 1998, p.193; Lazarus 2004, p.1417), o presidente responsável pela pioneira ideia, repleta de simbolismo, de colocar painéis solares na Casa Branca ${ }^{20}$. $\mathrm{O}$ candidato Republicano, por sua vez, já havia feito declarações públicas contra algumas das leis pró-meio ambiente aprovadas na década de 1970 (Lazarus 2004, p.1428).

Os temores dos verdes em relação à gestão Reagan não eram sem razão. O presidente indicou, a partir de critérios políticos, nomes refratários à questão ambiental para comandar o principal órgão ambiental do país (EPA) e os departamentos de Energia, de Agricultura e do Interior. Realizou cortes de pessoal e no orçamento destinado a programas ambientais e encaminhou ao Congresso propostas de flexibilização da legislação ambiental (Kubasek e Silverman 2005, pp.137-138; Vig e Kraft 2006, pp.14 e 15; Lazarus 2004, pp.1453-1465).

Os cortes de pessoal e de recursos para a regulação da atividade industrial e proteção do meio ambiente reduziram o poder do Estado de aplicar as leis e de fiscalizar violações

\footnotetext{
${ }^{19}$ Entrevista feita em 5 de fevereiro de 2015, na sede do Center for Health, Environment, and Justice, organização dirigida por Lois Gibbs.

${ }^{20}$ Carter colocou 32 painéis solares na Casa Branca para o aquecimento de água. Seu sucessor, Ronald Reagan, os retirou em 1986, e Barack Obama os colocou de volta em 2013 (Barron-Lopez 2014).
} 
(Kubasek e Silverman 2005, p.137). Porém, a reação do Congresso frustrou as expectativas da Casa Branca, conforme demonstra o seguinte relato:

O Congresso, inicialmente, cooperou com Reagan, particularmente na aprovação dos cortes no orçamento, mas rapidamente retornou à sua costumeira defesa da legislação ambiental existente, frequentemente criticando a gestão da EPA e do Departamento de Interior (Vig e Kraft 2006, p.15 - tradução minha).

As organizações ambientalistas também reagiram e ingressaram com diversas ações na Justiça, questionando as decisões do presidente. O Judiciário, na maioria das vezes, acatou os pleitos das ONGs e inviabilizou as iniciativas da administração federal (Lazarus 2004, pp.1477-1483).

$\mathrm{Na}$ sequência, o Congresso fortaleceu, em 1984, a Lei de Conservação e Recuperação de Recursos Naturais (Resource Conservation and Restoration Act, cuja primeira versão data de 1976) e reeditou, em 1986, a lei do Superfundo, aprovada inicialmente em 1980 (Vig e Kraft 2006, p.15). O novo Superfundo saltava de US\$ 1.6 bilhão para US\$ 4 bilhões, recurso arrecadado a partir de taxação da indústria química e utilizado para limpar áreas contaminadas por resíduos tóxicos. Segundo Lazarus (2004), as emendas eram tão rigorosas "que os assessores da Casa Branca recomendaram que Reagan vetasse o projeto", o que acabou não acontecendo devido à proximidade das eleições para o Legislativo (pp.1586-1588).

\subsubsection{A década de 1990}

George H.W. Bush (de agora em diante referido como Bush pai) elevou a EPA ao status de gabinete ministerial. Mas o ponto alto da administração foi a aprovação das emendas à Lei do Ar Puro (Clean Air Act), em 1990, com amplo apoio da Casa Branca e após uma coalizão de Republicanos e Democratas, estes em maioria nas duas casas legislativas, e influência direta do movimento ambientalista. As emendas de 1990 ao Clean Air Act tiveram como principais objetivos "reduzir a chuva ácida, melhorar a qualidade do ar e reduzir substâncias tóxicas na atmosfera" e consistiram em "uma conquista significativa em termos de metas ambiciosas" (Schreurs 2002, p.105 - tradução minha).

De acordo com Steve Schwartzman ${ }^{21}$, diretor de política florestal do EDF, ONG que esteve presente nas discussões para a aprovação da lei, uma das importantes inovações das emendas ao Clean Air Act foi a introdução de mecanismos de comercialização de

\footnotetext{
${ }^{21}$ Entrevista realizada no dia 21 de janeiro de 2015.
} 
créditos de carbono, que pela primeira vez faziam parte de uma peça de legislação no planeta.

Ainda segundo Schwartzman,

o EDF propôs e conseguiu que fosse incluído na lei um sistema de limitação e comércio de emissões [conhecido como cap and trade] para o dióxido de enxofre (SO2), um importante causador da chuva ácida, emitido por usinas de energia a carvão. Propusemos um limite nessas emissões, que decresceria com o tempo.

Porém, a segunda metade do mandato de Bush pai acabou seguindo outros rumos, atendendo claramente às demandas dos setores da economia que eram alvo das regulações ambientais (Lazarus 2004, pp.1808-1809). Já em 21 de maio de 1990 portanto, na primeira metade do mandato presidencial - um editorial da revista Time $^{22}$ afirmou que Bush "sofreu pesadas críticas por fracassar na promessa [de campanha] de ser o presidente ambiental" (tradução minha).

A participação norte-americana na preparação para a conferência Rio-92 - momento em que o acordo a ser assinado pelos países foi delineado — reforçou a impressão negativa por parte de ambientalistas. Matéria publicada pela revista Time cerca de três meses antes da conferência relatou que o "maior incômodo vem sendo causado pela resistência da Casa Branca a quaisquer metas ou cronogramas para reduzir a emissão de gases de efeito estufa como o dióxido de carbono, que pode causar o aquecimento global" (Lemonick 1992 tradução minha).

Nas eleições de 1992, os Democratas retomam a Casa Branca com Bill Clinton. Para o movimento ambientalista, a vitória foi motivo de celebração, por vários motivos. Além da performance questionável do governo Bush pai em relação às políticas ambientais, Clinton fez uma importante sinalização para o movimento ambientalista: indicou para vice o senador Al Gore, do Tennessee, um dos principais defensores das causas ambientais no Capitólio (Lazarus 2004, p.1828; Vig e Kraft 2006, p.15) e autor de livro em que denunciou a degradação do meio ambiente.

A despeito das perspectivas favoráveis, a década de 1990 foi marcada por pouquíssimos avanços na legislação ambiental e por diversas tentativas de flexibilizar as regulações introduzidas nas décadas anteriores. A recessão econômica do final dos anos 1980 contribuiu para praticamente extinguir os poucos pontos de consenso que ainda

\footnotetext{
22 Disponível em http://content.time.com/time/subscriber/article/0,33009,970127,00.html, acesso em 22 de outubro de 2015
} 
existiam entre Democratas e Republicanos em relação às políticas ambientais. O Judiciário também adotou nova postura, conforme relatado por Lazarus (2004):

$$
\begin{aligned}
& \text { Líderes no Congresso e juízes influentes simultaneamente } \\
& \text { evidenciaram seu crescente ceticismo em relação à eficácia da } \\
& \text { legislação ambiental, e muitas lideranças nesses dois poderes se } \\
& \text { tornaram proponentes de mudanças fundamentais na legislação } \\
& \text { ambiental" (pp.1828; 2200-2204 - tradução minha). }
\end{aligned}
$$

Diante dessas circunstâncias, Clinton acabou lançando mão dos poderes legais do chefe do Executivo Federal para criar novas áreas protegidas e empoderar agências que lidam com temas ambientais (Vig e Kraft 2006, p.110). O presidente acabou, também, usando seu poder de veto para barrar legislações hostis ao meio ambiente, como em 1995, quando as duas casas aprovaram lei que viabilizava a extração de petróleo em área natural denominada Refúgio Nacional da Vida Selvagem no Ártico (Arctic National Wildlife Refuge, ANWR), no estado do Alaska, após seguidas tentativas desde a década de 1970.

Trata-se, segundo Turek (1999), da mais polêmica disputa ambiental de todos os tempos no Alaska (p.195). Naquela que foi a única vez na história em que Câmara e Senado aprovaram a matéria, o veto de Clinton engavetou a lei (Shogren 2005).

\subsubsection{O novo século}

Os anos 2000 começaram com a volta dos Republicanos à Casa Branca, via George W. Bush, político com fortes vínculos com a indústria do petróleo, importante segmento econômico no Texas, seu estado natal. Ademais, ainda no primeiro ano do mandato, os atentados de 11 de setembro fizeram com que relevantes temas nacionais - como o meio ambiente — fossem eclipsados pela nova prioridade do país: o combate ao terrorismo.

Mas mesmo antes dos ataques de 2001, a gestão republicana dava mostras de que não seria lembrada pela ousadia nas políticas ambientais. O presidente iniciou o mandato indicando nomes intimamente ligados ao setor industrial para cargos com responsabilidades ambientais, reduziu o orçamento da EPA, anunciou apoio à decisão do Senado de não ratificar o Protocolo de Quioto (do qual os EUA, sob o governo Clinton, foram um dos proponentes em 1997) e colocou sob revisão uma série de medidas de regulação ambiental aprovadas por seu antecessor. "Várias terras públicas foram abertas para a exploração de petróleo e gás, e numerosas restrições ambientais à produção de energia foram relaxadas" (Vig e Kraft 2006, pp.113-115 - tradução minha).

Em 2008, Barack Obama é eleito com apoio do movimento ambientalista. Dentre as dezenas de entrevistas com representantes das ONGs, houve menções positivas ao 
presidente Democrata em todas as conversas em que a gestão Obama foi discutida. Os elogios se deram em diferentes gradações, mas não foi incomum ouvir referências como a de que "temos um amigo na Casa Branca", ou que este governo tem usado muito bem suas atribuições constitucionais para ampliar a proteção ao meio ambiente.

Em termos legislativos, poucos avanços ocorreram no nível federal, seguindo uma tendência observada desde meados dos anos 1990 de uma atuação tímida do Legislativo Federal em relação às políticas ambientais, especialmente em comparação com as décadas de 1960, 1970 e 1980 (Stone 2010, p.150). Além disso, os Republicanos ampliaram sua participação no Congresso ao longo da administração Obama ${ }^{23}$.

Após do CEO da ONG The Nature Conservancy, Mark Tercek, na Universidade de Georgetown, em abril de 2014, perguntei a ele sobre o sucesso do movimento no sentido de influenciar o legislativo americano. Tercek respondeu que a organização tem muito sucesso "no âmbito das cidades e dos estados, mas não muito no Congresso Nacional".

Diante de um legislativo federal polarizado, caracterizado pela oposição da maior parte dos Republicanos à agenda ambiental, a Casa Branca fracassou na tentativa de aprovar uma lei para combater as mudanças climáticas entre 2009 e 2010. Diante desta perspectiva desfavorável no Congresso, Obama adotou o que foi caracterizado por uma reportagem da revista Time como um "plano B": utilizar os poderes atribuídos ao chefe do Executivo pela Lei do Ar Puro (Clean Air Act) para, administrativamente, criar regras para que as agências federais, principalmente a EPA, regulem as emissões da indústria e a agricultura, reduzindo os impactos desses setores no meio ambiente, naquele que poderia se tornar "o mais abrangente esquema regulatório da história americana" (Walsh 2011 - tradução minha).

Tim Aiken, assessor do deputado federal Jim Moran, considerado um aliado pelos ambientalistas, disse em entrevista para esta tese ${ }^{24}$ que "a Lei do Ar Puro autoriza que a administração federal restrinja as emissões de usinas de energia a carvão", e que "boa parte da assessoria para a elaboração dessas regras foi dada por integrantes da comunidade dos ambientalistas".

Assim, lançando mão das prerrogativas presidenciais, geralmente por meio da EPA, a gestão Obama criou normas federais com as seguintes determinações:

\footnotetext{
${ }^{23}$ Na legislatura 2009-2011, os Democratas tinham ampla maioria na Câmara e maioria apertada no Senado; em 2011-2013, os Republicanos conquistaram a Câmara com folga e o Senado diminuiu sua frente no Senado; entre 2013 e 2015, a maioria Republicana foi mantida na Câmara e os Democratas mantinham uma pequena frente no Senado; para a legislatura atual (2015-2017), os Republicanos conquistaram a maioria nas duas casas.

${ }^{24}$ Entrevista concedida em 24 de novembro de 2014.
} 
- menor consumo de combustíveis por parte de veículos automotores (2009);

- significativas restrições nas emissões de gases de efeito estufa e tóxicos por refinarias e usinas termelétricas a carvão (2011-2014);

- menor consumo por parte de caminhões e veículos pesados (2014);

- menor consumo por parte de aeronaves (2014);

- designação de diversas terras públicas como áreas protegidas, portanto vedando o uso para extração de petróleo, gás e mineração (2014-2015);

- restrições no uso de recursos hídricos, especialmente para agricultura e indústria, em reservatórios e cursos d'água (2014) e

- maiores investimentos pela indústria da mineração para recuperar áreas danificadas pela atividade e monitoramento rigoroso da qualidade da água em nascentes impactadas por mineradoras (Restuccia, junho de 2015; Eilperin 2015, pp.A1 e A14; Guillén 2015)

As medidas, amplamente elogiadas pelos ambientalistas, despertaram a fúria de representantes da indústria de petróleo, mineração e energia, parlamentares, governadores e outras lideranças do Partido Republicano, que acusam a Casa Branca de arbitrariedade e irresponsabilidade, fazendo previsões sombrias a respeito da segurança energética do país diante das novas regras (Eilperin 2015, pp. A1 e A14; Colman 2015, p.8).

Apenas o plano para reduzir emissões das usinas a carvão busca "reduzir, até 2030, a emissões advindas da geração de energia em $30 \%$, considerando níveis de 2005 , por meio de maior eficiência nas usinas, da expansão de fontes renováveis, usando mais gás natural e promovendo eficiência energética por parte dos consumidores" (Colman 2015, p.8 tradução minha). Segundo Steve Schwartzman, da ONG ambientalista EDF, em entrevista para esta tese, as regras sobre emissões pelas usinas a carvão foram "o mais importante passo em termos de regulação ambiental dado desde os anos 1970".

Em relação à proteção de diversas áreas no Alaska, impedindo a atuação das indústrias de petróleo, gás e mineração, o presidente sofreu fortes ataques da bancada daquele estado no Congresso. A senadora Lisa Murkowski acusou o presidente de declarar "guerra ao Alaska", alegando que a administração Obama não conhece a realidade da população local, que precisa de empregos e de energia. Em uma entrevista coletiva no Senado norte-americano, dia 26 de janeiro, Murkowski declarou que a Casa Branca "quer negociar com o Irã, mas não negocia com o Alaska" (Restuccia, janeiro de 2015).

Obama, diante de um Congresso hostil às questões ambientais, inaugurou uma nova forma de desenvolver políticas ambientais sem depender do Legislativo, e de forma 
constitucional - as cortes federais, acionadas com certa frequência por associações representativas da indústria, vêm mantendo as regras estabelecidas pela Casa Branca. $\mathrm{O}$ movimento ambientalista norte-americano - tema central das próximas páginas - aliado a significativa parcela da bancada Democrata nas duas casas legislativas, vem conseguindo manter o sólido arcabouço legal ambiental do país. Steve Schwartzman afirmou, na entrevista para esta pesquisa, que "o movimento ambientalista teve que gastar muita energia protegendo as conquistas já alcançadas".

É importante ressaltar que a legislação ambiental norte-americana, construída essencialmente nas décadas de 1960, 1970 e 1980, serviu de exemplo para políticas em várias partes do mundo, conforme observado por Schreurs (2002), diretora do Centro de Pesquisas em Políticas Ambientais da Universidade de Berlim, na Alemanha:

Os EUA foram o país líder na promoção de rígidas leis ambientais em diversas áreas, desde a criação de parques, passando pelo controle de poluentes de ar, água e solo, até o controle de substâncias cancerígenas (...). Os EUA têm sido, tradicionalmente, o precursor internacional em políticas ambientais (pp.23,259 tradução minha).

$\mathrm{Na}$ sequência, uma linha do tempo sintetiza as principais políticas ambientais mencionadas neste capítulo. 


\subsubsection{Linha do tempo - Políticas ambientais nos Estados Unidos}

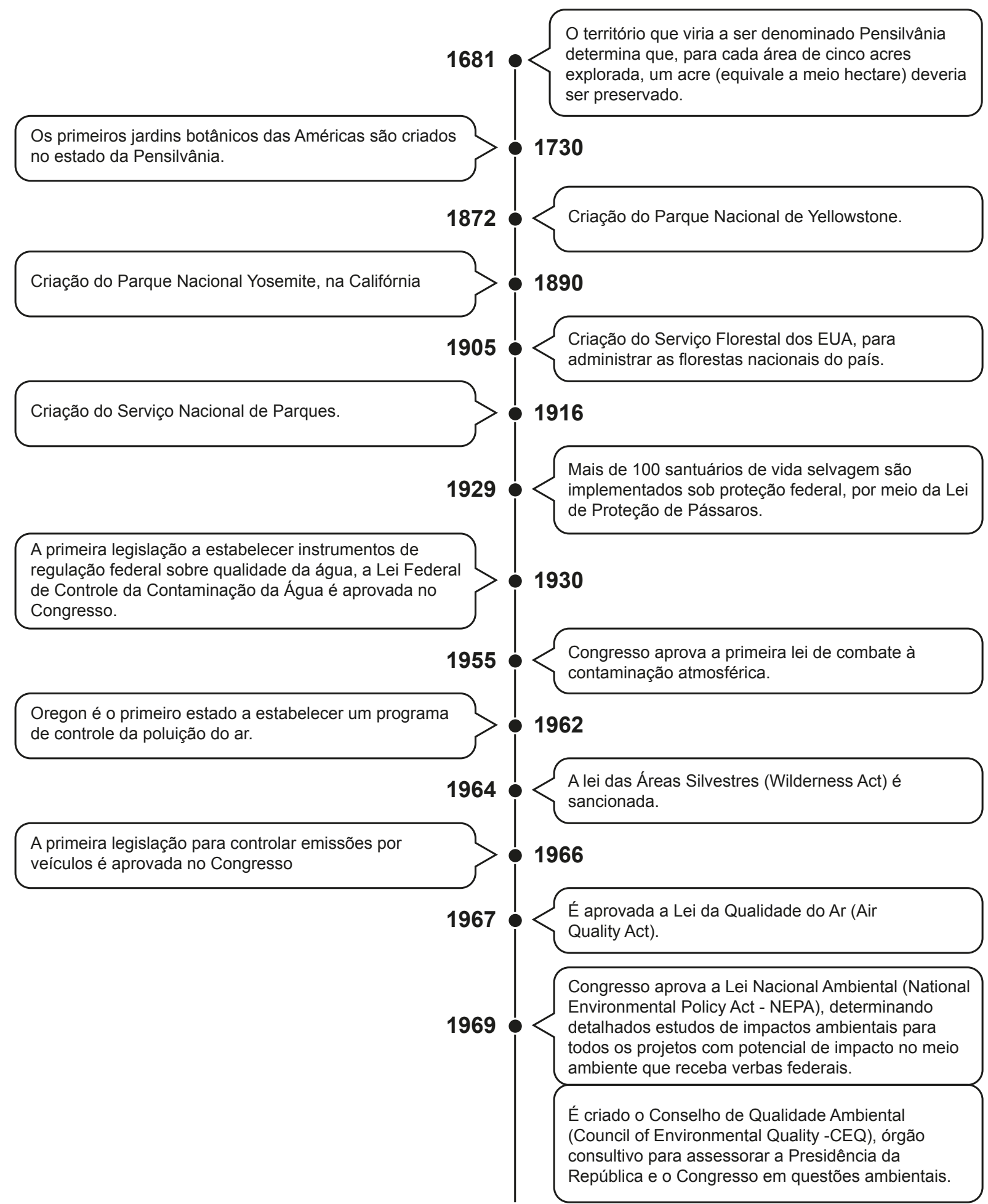




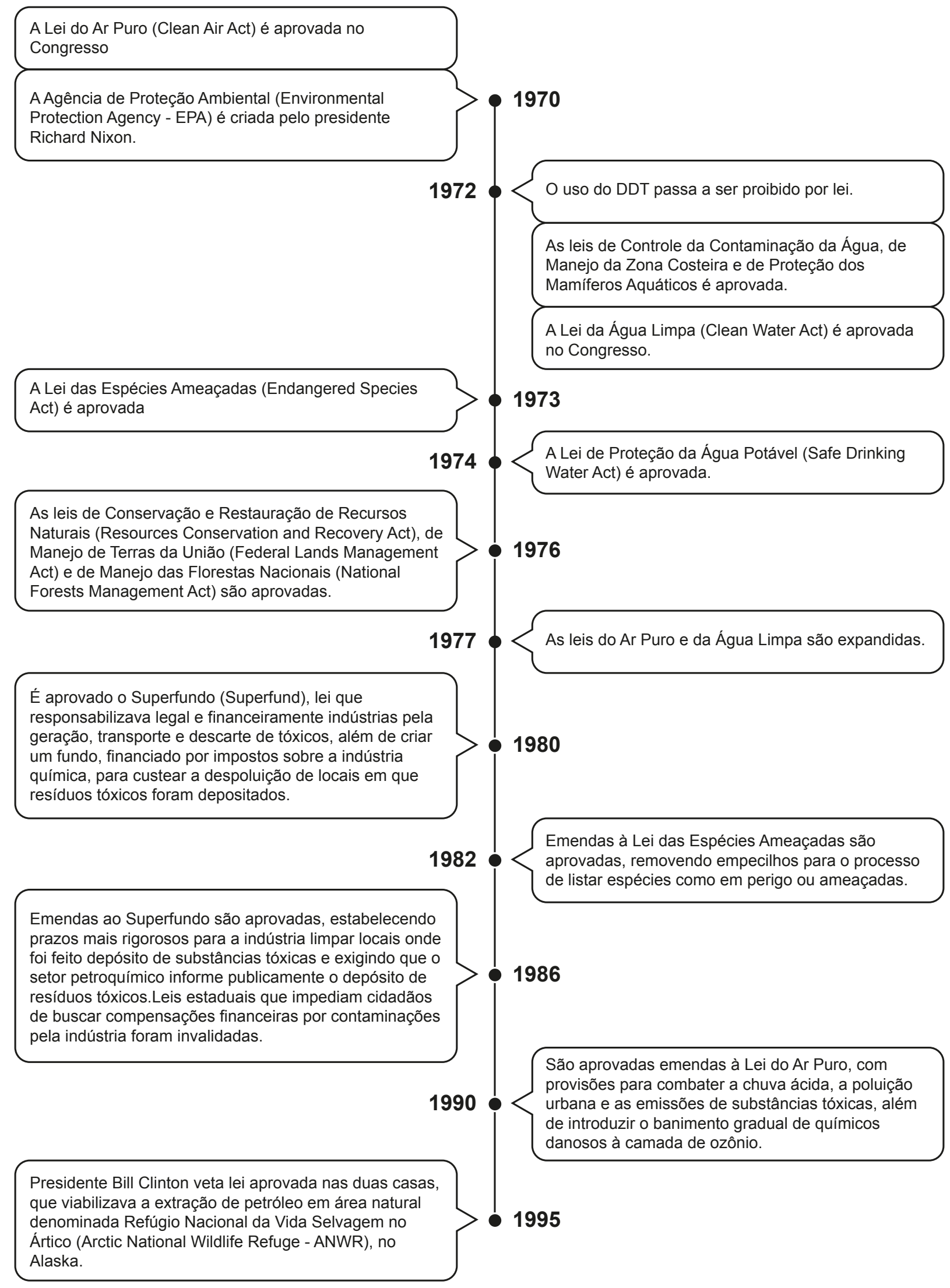


Os EUA são um dos proponentes do Protocolo de Quioto, que prevê reduções das emissões de $\mathrm{CO} 2$ dos países industrializados. Porém, a Casa Branca não consegue convencer o Legislativo a ratificar o acordo.

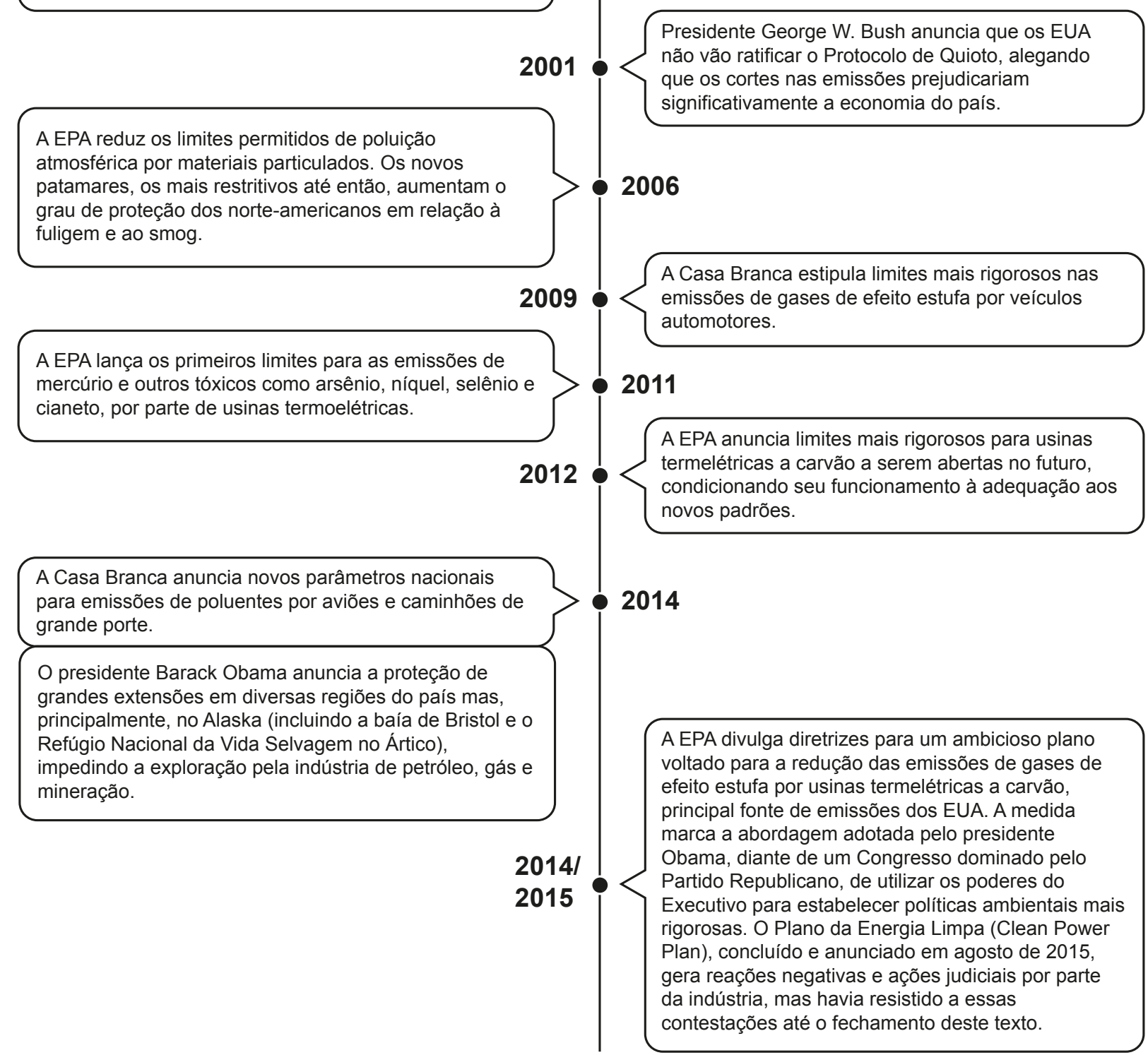

Figura 3: Linha do tempo - Políticas ambientais nos Estados Unidos

Fontes: Neuzil e Kovarik 1996; Schreurs 2002; Kubasek e Silverman 2005; National Wildlife Federation (http://nwf.org/Who-We-Are/History-and-Heritage/Legislative-Victories.aspx , acessado em 14 de outubro de 2015), Public Broadcast Station (http://www.pbs.org/wgbh/americanexperience/features/timeline/earthdays/2/, acessado em 14 de outubro de 2015), Worldwatch Institute

(https://www.worldwatch.org/brain/features/timeline/timeline.htm, acessado em 14 de outubro de 2015) e EPA (http://www2.epa.gov/aboutepa/epa-history, acessado em 14 de outubro de 2015)

\subsection{O AMBIENTALISMO NOS EUA}

Assim como o arcabouço legal norte-americano voltado para a proteção do meio ambiente e para o uso racional dos recursos naturais serviu de base para leis em diversas 
partes do mundo, o movimento ambientalista dos EUA também inspirou a criação de organizações similares em outros países. Segundo Snow (1992), os Estados Unidos podem ser vistos como o berço do movimento ambientalista, que a partir das últimas décadas do Século 20 se fez presente em escala global (p.xxvi).

Um sistema político desenhado para estimular a participação direta e indireta da sociedade nas diferentes fases dos processos legislativos (Wood 2012, pp.183-184) teve como um de seus legados a promoção do associativismo, conforme relatado por Tocqueville (1998 [1835]) ainda no início do Século 19 no clássico Democracia na América.

Adicionalmente, o surgimento das preocupações com o meio ambiente nos EUA utilizou-se de uma base filosófica consolidada especialmente ao longo do Século 19 com o trabalho dos chamados filósofos transcendentalistas, entre os quais se destacaram, notadamente, Ralph Waldo Emerson e Henry David Thoreau. O grupo defendia o respeito às diversas formas de vida e a convivência harmônica entre seres humanos e natureza, além de criticar o aspecto desumanizante da modernidade (Martinez 2014, p.150).

Thoreau, por exemplo, em 1845, se isolou da civilização, representada por sua cidade natal (Concord, Massachusetts), vivendo por dois anos em uma cabana por ele construída na floresta, às margens de um lago. Naquele período o autor escreveu sua mais renomada obra, Walden, em que relatou sua experiência vivendo apenas de seu próprio trabalho e dos recursos naturais disponíveis. Ainda de acordo com Martinez (2014), Thoreau pode ser considerado "a mais reconhecida figura do ambientalismo americano" daquela época (p.150).

A descrição de um contexto no qual iniciavam-se as preocupações da sociedade americana diante da rápida destruição de recursos naturais deve, necessariamente, incluir também as políticas ambientais que começavam a ser implementadas no país, conforme visto em páginas anteriores deste capítulo. Ao final do Século 19 os primeiros parques nacionais foram criados, e no início do Século 20, surgem o Serviço Florestal e o Serviço de Parques Nacionais.

A mais usual divisão das etapas do ambientalismo norte-americano entre pesquisadores envolve três principais ondas (Dowie 1995, p.18; Bendell 2000, p.8; Vig e Kraft 2006). A primeira onda, que duraria até os anos 1960, foi caracterizada por uma visão romântica da natureza, em reação aos impactos da Revolução Industrial. Nessa etapa, as organizações tiveram como um de seus principais objetivos proteger o meio ambiente, seja devido a seu valor estético (preservacionismo), seja para que os recursos naturais pudessem ser usados de forma racional, gerando prosperidade e renda, mas não se 
esgotassem (conservacionismo). Na prática, a primeira onda deixou importantes legados, sendo o maior deles a criação de reservas e parques nacionais.

A segunda onda do ambientalismo, iniciada nos anos 1960, consistiu na priorização, por parte dos movimentos, da formulação de políticas regulatórias das atividades produtivas, industriais ou agrícolas, buscando reduzir os impactos da produção em comunidades, ecossistemas, florestas, fauna, flora e recursos hídricos. Durante este período, encerrado em meados dos anos 1980, surgiu a maior parte das organizações norte-americanas analisadas neste estudo, assim como as principais peças de legislação ambiental dos EUA e a estrutura administrativa necessária para sua implementação e fiscalização.

A terceira onda ambientalista, que começou ao final da década de 1980, teve como principal característica o pragmatismo das organizações ambientalistas, que se profissionalizaram e buscaram parcerias com grandes empresas no sentido de reduzir os impactos da produção.

Na sequencia faço uma análise mais detalhada destes três momentos do movimento ambientalista norte-americano.

\subsubsection{A primeira onda - décadas de 1890 a 1960}

Em relação ao que viria posteriormente a ser chamado de movimento ambientalista, as ideias transcendentalistas de Thoreau e Emerson influenciaram a criação, em 1892, da primeira grande organização voltada para questões ambientais dos Estados Unidos: o Sierra Club. Segundo Mc Cormick (1999), foi a segunda a surgir no mundo, três anos depois da Sociedade para Proteção de Pássaros, na Inglaterra (p.57). O objetivo inicial do Sierra Club, que em sua criação tinha 182 integrantes e se tornou uma das maiores ONGs ambientalistas da atualidade, era lutar pela preservação do então recém-criado parque de Yosemite, na Califórnia (Bosso 2005, p.23).

Mas John Muir, o principal fundador do Sierra Club, um explorador escocês radicado nos EUA, já escrevia textos classificando o acelerado crescimento industrial e a consequente degradação ambiental como uma "clara e crível ameaça aos abundantes, mas finitos, recursos naturais do país" (Martinez 2014, p.165).

Brulle (2009), que tem no movimento ambientalista norte-americano uma de suas áreas de pesquisa, salienta que os primeiros grupos da sociedade civil a se preocuparem com questões ambientais tinham, inicialmente, a motivação de evitar a escassez das espécies cobiçadas pelos caçadores (p.212). Outra preocupação presente à época conforme os objetivos de fundação do Sierra Club - era a criação e a implementação 
parques e reservas, para proteger as belezas cênicas e os espaços naturais usados para o lazer e o relaxamento das presentes e futuras gerações.

A divisão entre preservacionistas e conservacionistas se representava claramente nas figuras de John Muir, fundador do Sierra Club, que advogava prioritariamente a preservação dos ambientes selvagens, e Gifford Pinchot, primeiro diretor do Serviço Florestal dos EUA, que defendia o manejo dos recursos naturais e a "conservação voltada para o uso" (Miller 1992, p.6 - tradução minha).

Em 1896 surge a National Audubon Society, organização que perdura até os dias de hoje, com ampla presença nacional ${ }^{25}$, cujo nome homenageava John James Audubon, artista que pintara mais de 400 quadros retratando a avifauna dos Estados Unidos. A recémcriada organização dedicava-se à proteção dos pássaros, e teve como primeira ação uma campanha contra o uso de plumagens em roupas e adereços femininos (Bosso 2005, p.25).

Havia, já ao início do Século 20, conforme lembra Wellock (2008), além das primeiras organizações especificamente voltadas para a proteção do meio ambiente, a Associação Americana de Ornitologistas, grupos de caçadores, associações de mulheres e clubes esportivos que já se envolviam com questões ambientais, inclusive com tentativas concretas, frequentemente bem-sucedidas, de influenciar políticas públicas ( $p .53)$.

As primeiras associações com atuação no campo ambiental surgiram em um contexto político favorável, marcado por uma "explosão no surgimento de organizações nos níveis local e estadual, incluindo associações cívicas, grupos profissionais, clubes femininos, grupos promotores de boas práticas nos governos (good government groups) e ligas de eleitores" (Bosso 2005, p.23).

É importante salientar que, já em suas origens, o ambientalismo surge como um movimento composto, predominantemente, por intelectuais, pertencentes a uma classe média ou rica, urbana, geralmente dispostos a lutar pela conservação de espaços de lazer junto à natureza (Dowie 1995, pp.2,15; Bosso 2005, p.23).

Já em 1903, o Sierra Club protagoniza aquela que poderia ser classificada como a primeira ação de lobby de uma organização ambientalista. O então presidente dos Estados Unidos, Theodore Roosevelt, foi convencido por John Muir, fundador do Sierra Club, a apresentar um projeto de lei para proteger todo o vale do Yosemite — onde já estava situado o segundo parque nacional da história dos EUA - e seu entorno, impedindo atividades de potencial impacto ambiental (Dowie 1995, p.17).

\footnotetext{
${ }^{25}$ Para informações gerais sobre as principais organizações ambientalistas citadas neste trabalho, consultar a Tabela Geral de ONGs, disponibilizada ao final da tese.
} 
Outro caso emblemático que caracteriza um movimento ambientalista norte-americano já atuante no sentido de influenciar políticas públicas é o do vale Hetch-Hetchy, que havia sido incluído nas fronteiras do Parque Nacional Yosemite. Em 1903, a administração da cidade de San Francisco enviou ao Governo Federal uma solicitação para fazer uma barragem no rio Tuolumne, localizado no vale, para fornecer água para sua população. Sierra Club liderou a oposição ao projeto que, embora aprovado pelo Departamento de Interior, chegou ao Congresso (Wellock 2008, pp.63-64).

Parlamentares receberam uma enxurrada de cartas, enviadas por cidadãos mobilizados pela organização ambientalista. O Sierra Club também conseguiu expor seu ponto de vista também em diversos veículos de imprensa, colocando pressão nos tomadores de decisão. Os parlamentares, apenas em 1913, autorizaram a barragem, após uma grande polêmica (Wellock 2008, pp.63-64).

Porém, analistas viram a derrota no parlamento como uma vitória do jovem movimento. Wellock (2008) descreveu o que representou aquele episódio:

...a mais impressionante parte da disputa foi o fato de ela ter
ocorrido. Muitos norte-americanos lutaram por um vale que eles
nunca haviam visto. Mesmo os políticos que votaram em favor da
barragem se sentiram compelidos a externar seu amor à natureza
selvagem. O culto à natureza continuou a crescer ao longo do
século. Os preservacionistas perderam a batalha, mas
estabeleceram o precedente de que os parques, em sua maioria,
deveriam permanecer fora dos limites dos projetos
desenvolvimentistas (pp.64-65-tradução minha).

Em 1922, foi fundada a Izaak Walton League, uma organização de base (grassroots), que em cinco anos alcançou a significativa marca de 100 mil filiados e uma presença em 43 estados americanos. A organização, hoje com menos filiados e menor presença geográfica, buscava à época de sua fundação proteger a fauna selvagem dos efeitos negativos da poluição industrial. Empregava desde então técnicas de lobby, usando seus filiados como instrumento de pressão junto a tomadores de decisão (Bosso 2005, p.29; Neuzil e Kovarik 1996, p.208).

Na década de 1930 merece menção o surgimento de três importantes organizações ambientalistas norte-americanas: (i) The Wilderness Society, em 1935, dedicada à preservação de áreas naturais, ameaçadas pelas obras de infraestrutura do New Deal; (ii) National Wildlife Federation, em 1936, criada em Washington, D.C., com o objetivo de influenciar políticas públicas ligadas à proteção da vida selvagem e (iii) Ducks Unlimited, em 
1937, também para proteger bacias, áreas alagadas e hábitats de vida selvagem, inclusive adquirindo terras para esta finalidade (Bosso 2005, pp.30-32).

O período pós Segunda Guerra Mundial assistiu ao surgimento de um grande número de organizações não-governamentais ambientalistas (Mc Cormick 1999, p.55). Em um contexto marcado pelo espantoso crescimento econômico do país e pelo aumento dos padrões de consumo da classe média, o movimento ambientalista, maior e mais diversificado, passou e se preocupar com outros aspectos além da proteção de hábitats e espécies.

Libby (1998) descreve esse momento:

Ar puro, qualidade da água, vida selvagem, saúde e recreação se tornaram, na realidade, produtos demandados pelos americanos que tinham acesso a segurança financeira e lazer. Assim, qualidade ambiental se tornou parte da concepção de uma melhor qualidade de vida da classe média americana (p.89 - tradução minha).

Em 1947 surge a Defenders of Wildlife, dedicada à proteção de espécies e hábitats, que também viria a se tornar uma das mais atuantes organizações do país. Em 1951, é fundada a The Nature Conservancy, também baseada na ideia de que a aquisição de grandes extensões de áreas naturais é a melhor forma de conservá-las, que se torna uma das maiores ONGs ambientalistas do mundo.

Os discursos da qualidade de vida urbana e da proteção da biodiversidade começam a se fundir dentro de um movimento ambientalista que já ocupava espaço de destaque na sociedade norte-americana (Zelko 2006, p.24). Nos anos seguintes, o ambientalismo cresce em abrangência, arrecadação, apoio e influência no país.

\subsubsection{A segunda onda - décadas de 1960 a 1980}

Com o conforto material proporcionado pelo crescimento pós Segunda Guerra - os EUA foram o único país entre os protagonistas do combate, considerando vencedores e perdedores, que não teve que ser reconstruído - a sociedade podia se preocupar com aspectos não-materiais. Essa situação criou condições para que novos grupos surgissem, com apoio de relevante parcela da classe média e poder de influenciar de maneira decisiva tomadores de decisão.

Outro aspecto que contribuiu para o crescimento da consciência ambiental na sociedade americana, com consequente incremento no apoio público dado ao ambientalismo, foi a clara constatação - seja por meio de desastres ecológicos ou publicações que alertavam para riscos do uso desregrado de recursos, como Primavera 
Silenciosa, de Rachel Carson - de que as atividades produtivas estavam causando danos irreparáveis ao planeta e às comunidades.

Em 1961 surge na Inglaterra o WWF, que se tornaria, em termos de alcance geográfico, a maior rede de organizações ambientalistas do mundo. A ONG chega aos EUA no mesmo ano, e inicialmente desenvolve um trabalho voltado para a preservação de áreas naturais e espécies ameaçadas. Posteriormente, com a ampliação das áreas de atuação, o WWF passa a trabalhar em praticamente todas as áreas do ambientalismo: desenvolvimento sustentável, mudanças climáticas, políticas públicas, produção sustentável etc.

Wellock (2008) relata que a adesão ao movimento ambientalista cresceu de forma significativa, em grande medida graças ao público jovem. "Os protestos e o ativismo dos anos 1960 ampliaram a base de apoio para a juventude americana e diversificaram as táticas adotadas" (p.10 - tradução minha).

Conforme observado em páginas anteriores deste capítulo, o período compreendido entre as décadas de 1960 e 1980 foi aquele em que a maior quantidade de leis favoráveis à proteção do meio ambiente foi aprovada nos EUA. E o movimento ambientalista teve participação direta nesta rica fase da história ambiental do mundo, chamada por Bosso (2005) de "a era ambiental".

A Lei das Áreas Silvestres (Wilderness Act), de 1964, foi aprovada pelo Congresso e sancionada pelo presidente Lyndon $B$. Johnson em grande medida graças ao lobby realizado pela The Wilderness Society e pelo Sierra Club (Wellock 2008, p.124; Martinez 2014, p.178). Outras peças de legislação foram formuladas e aprovadas com a participação das organizações, como as leis da Água Limpa (1965) e do Ar Puro (1967), além da Lei da Política Nacional do Meio Ambiente (NEPA), de 1969, que estabeleceu a obrigatoriedade de elaboração de estudos de impacto ambiental para obras e projetos de infraestrutura.

A NEPA também criou condições para que a sociedade civil pudesse questionar judicialmente o não-cumprimento da legislação ambiental, tanto por parte de empresas mas, principalmente, por parte do Estado, que passava a ser responsabilizado tanto por não cumprir, como também por não fazer cumprir a lei. "Nos anos 1960, ações na Justiça surgiram como uma estratégia política para bloquear projetos que ameaçavam os valores estéticos do meio ambiente" (Libby 1998, p.90 - tradução minha). Os tribunais passaram a dar ganhos de causa a organizações e associações diversas, empoderando o movimento ambientalista.

Neste contexto surgem organizações como o Environmental Defense Fund (EDF, 1967), Natural Resources Defense Council (NRDC, 1970) e Earthjustice (1971, a partir de 
uma subdivisão interna do Sierra Club). Todas com um propósito em comum: assegurar o cumprimento da legislação ambiental por meio de ações na Justiça.

Além de ampliar a atuação no campo judicial, o movimento ambientalista percebe que, para obter vitórias mais significativas no campo político e, para que conquistas fossem mantidas, era necessário exercer influência nos processos eleitorais. Em 1969 surge a League of Conservation Voters (LCV, ou Liga dos Eleitores Conservacionistas), que realiza, até os dias atuais, um trabalho de endossar ou contraindicar candidaturas a partir de critérios ambientais. Além disso, a ONG avalia, anualmente, a atuação de todos os parlamentares norte-americanos, atribuindo notas de zero a 100 a cada um, de acordo com os votos que deram no ano anterior para matérias de impacto ambiental. A LCV também arrecada doações para candidatos considerados "verdes" pela organização.

Outros pontos que chamam atenção durante a segunda onda do ambientalismo são o surgimento de organizações com perfil mais ativista e militante e a guinada em uma direção mais radical por parte de algumas ONGs já existentes (Zelko 2006, p.29). O evento que marcou esta transformação foi o Dia da Terra (Earth Day), que reuniu, em 22 de abril de 1970, 20 milhões de pessoas em todo o país, em manifestações, palestras, aulas públicas e marchas em defesa das causas ambientais ${ }^{26}$.

No livro de memórias escrito pelo ativista ambiental Dave Foreman, um dos fundadores em 1979 da organização Earthfirst, que utiliza métodos de desobediência civil e ação direta, descreveu a radicalização do movimento naquela década:

Após o primeiro Dia da Terra o movimento ambientalista receberia seu primeiro influxo de radicais antiestablishment, quando os manifestantes contrários à guerra do Vietnã acharam uma nova causa - o meio ambiente. De repente, barbas apareceram nas reuniões de organizações conservacionistas ao lado de cabelos curtos - e o discurso ganhou força. (1991, p.12 - tradução minha)

Peter Kirby, advogado ambiental com mais de 40 anos de atuação no movimento, em entrevista para esta pesquisa ${ }^{27}$, atribuiu ao Dia da Terra em 1970 um marco na ampla disseminação das questões ambientais na sociedade dos EUA. "Foi um grande evento educacional que ensinou às pessoas a respeito da contaminação da água e da atmosfera, e da necessidade de se fazer algo em relação a isso", recordou.

\footnotetext{
${ }^{26}$ Fonte: http://topics.nytimes.com/top/reference/timestopics/subjects/e/earth_day/index.html, acesso em 17 de novembro de 2015.

${ }^{27}$ Entrevista concedida em 20 de junho de 2014.
} 
A década de 1970, de fato, foi marcada pela popularização dos temas ligados ao meio ambiente. O movimento adotou diferentes enquadramentos das mensagens para atrair grupos que, até então, não estavam envolvidos com a temática. Foi dado destaque aos impactos negativos da ciência e da tecnologia, especialmente para a saúde humana, e à fragilidade do planeta diante de tantas ameaças (Libby 1998, pp.89-90).

Os problemas ligados à degradação dos ecossistemas e da qualidade de vida urbana entraram de tal forma na agenda da sociedade dos EUA que a revista Time, que há décadas seleciona a personalidade do ano, na edição de 4 de janeiro de 1971 escolheu o meio ambiente como "assunto do ano", juntamente com o chanceler alemão à época, Willy Brandt, como o homem do ano. A revista Life, do mesmo grupo editorial, escolhera 1970 como a década ambiental (Hayward 2001, p.250).

Cabe observar que o novo caráter contestatório do movimento trouxe para o campo de jogo um público composto por jovens, estudantes e grupos anti-capitalistas. Novas organizações, como Earthfirst e Greenpeace, nitidamente mais radicais, com repertórios ligados a protestos, desobediência civil e ação direta, diversificaram o espectro do movimento. O Greenpeace, que surgiu em 1971, e hoje é uma das maiores e mais conhecidas organizações ambientalistas do mundo, tem como marca o protesto e o ativismo via ação direta, e sequer aceita contribuições de empresas.

Robert Hunter, um dos primeiros ativistas do Greenpeace, recorda em livro que escreveu sobre a organização, que dois de seus principais fundadores eram pacifistas que fugiram dos EUA para que seus filhos não fossem alistados para lutar no Vietnã, e criaram a ONG no Canadá. A primeira missão foi tentar impedir testes nucleares norte-americanos nas ilhas Aleutas, próximas do Alaska. Os testes previstos foram feitos, mas os seguintes acabaram cancelados (2004, pp.15-16; 226-229).

Outro destaque durante a segunda onda do ambientalismo foi a consolidação de uma série de organizações de base (grassroots), que se fortaleceram e conseguiram diversas conquistas, principalmente no âmbito local, mas também no nacional. Foram realizadas diversas mobilizações, muitas delas com resultados efetivos, para responsabilizar indústrias por depósitos de lixo tóxico próximos a comunidades, poluição do ar, contaminação de rios, reservatórios e lençóis freáticos, entre outras questões.

A ativista Lois Gibbs, diretora do Center for Health, Environment, and Justice, em entrevista para esta pesquisa ${ }^{28}$, observou que os movimentos de base foram fundamentais

\footnotetext{
${ }^{28}$ Entrevista concedida em 5 de fevereiro de 2015.
} 
para uma série de mudanças de políticas públicas e práticas empresariais na década de 1980:

...as pessoas aprenderam sobre comunidades de lixo tóxico. As corporações queriam continuar a construir depósitos de lixo tóxico para se livrarem de seu lixo e foram os movimentos de base que não permitiram que eles construíssem, porque ninguém os queria em seus quintais. $E$ isso forçou as indústrias a lidar com isso de forma diferente. Elas substituíram os químicos de modo a não usar tantos tóxicos. Ou o lixo seria reutilizado, ou tratado na própria planta. É uma enorme vitória. O último depósito de lixo tóxico dos EUA foi construído no Colorado em 1984 ou 1985.

Libby (1998) descreve o novo e diverso panorama do ambientalismo norte-americano durante a segunda onda, marcada tanto por uma radicalização quanto pela profissionalização das ONGs:

Organizações do movimento social como Greenpeace, Amigos da Terra, Environmental Policy Institute, Earthfirst e a League of Conservation Voters surgiram com uma agenda política radical. Algumas dessas organizações dedicavam-se a proteger o meio ambiente por meio de ação direta (...), desobediência civil e ecosabotagem. Outras estabeleceram equipes de advogados, lobistas, economistas, arrecadadores, cientistas e profissionais de comunicação para influenciar políticas governamentais (p.91 tradução minha).

Uma das consequências da radicalização trazida pelas novas organizações e pelos novos ativistas foi o distanciamento dos públicos mais conservadores em relação ao movimento ambientalista e suas bandeiras. Wellock (2008) ressalta a mudança no cenário político americano em relação aos temas ambientais:

...a base [de sustentação política] do movimento se estreitou na medida em que os Republicanos se tornaram mais conservadores e menos abertos à regulação das atividades produtivas. O movimento ambientalista se viu representado pelos Democratas (p.10 - tradução minha)

Este contexto de polarização se consolidou e vem se agravando ao longo do tempo (Guber 2003, p.107). Paul Hansen lançou em 2013 o livro Green Gridlock (Impasse Verde, em tradução livre), no qual afirma que o debate sobre meio ambiente nos EUA se tornou "histericamente polarizado" (p.12) e lembrou que esta polarização está "destruindo rapidamente o tecido social do país e seu meio ambiente (p.25 - tradução minha)". Para 
ilustrar sua tese, Hansen relata que, desde as emendas à Lei do Ar Puro aprovadas em 1990, nenhuma das grandes legislações ambientais do país foi atualizada no Congresso devido a esse impasse (pp.16-17).

Os anos 1980, embora menos profícuos para o ambientalismo norte-americano em termos de vitórias legislativas que as décadas anteriores, assistiram a um crescimento por parte das organizações, tanto em termos de filiados, quanto de arrecadação (Garfield 2013, p.217). As medidas com objetivo de afrouxar as regulações do setor produtivo na gestão Reagan fizeram com que o movimento se organizasse para combater o que foi caracterizado como graves ameaças às proteções contra a poluição da água e do ar, bem como aos parques e áreas protegidas. $O$ resultado foi positivo e o movimento se expandiu ainda mais (Vig e Kraft 2006, p.15).

\subsubsection{A terceira onda - década de 1990 em diante}

O surgimento da Conservation International (CI), em 1987, coincide com a transição entre os períodos denominados segunda e terceira onda do ambientalismo dos EUA. A organização, que se expandiria para cerca de 30 países, começou seu trabalho viabilizando operações denominadas "conversões dívida-natureza" (em inglês, debt-for-nature-swaps), que preveem o perdão de parcelas da dívida externa de nações em desenvolvimento em troca da conservação - coordenada por grandes ONGs - de áreas naturais naqueles países. Considerado um dos idealizadores desse tipo de política, o cientista Thomas Lovejoy foi um dos fundadores da $\mathrm{Cl}$.

Uma intensa profissionalização e especialização das organizações ambientalistas marca a terceira onda, mas o principal aspecto que a diferencia das demais fases é uma relação mais próxima entre as grandes organizações do movimento e o setor privado. Segundo Dowie (1995), algumas das palavras de ordem do movimento ambientalista eram "incentivos de base mercadológica, gerenciamento de demanda, diálogo não-conflitivo flexibilidade regulatória [e] engajamento construtivo" (p.106 - tradução minha).

Fato é que o ambientalismo assume uma postura mais pragmática. A premissa adotada é a de que, para gerar mudanças significativas, em escalas que transformem realidades, os diferentes processos produtivos e setores industriais precisam fazer parte das soluções.

Além do mais, os ambientalistas começam a sentir grandes dificuldades em promover avanços legislativos no Congresso, e os juízes conservadores nomeados durante três mandatos do Partido Republicano (gestões Reagan entre 1981 e 1988 e gestão Bush pai entre 1989 e 1992) passam a dificultar, também, vitórias dos verdes nas cortes. Assim, a 
busca por outros caminhos para influenciar políticas e práticas ambientalmente corretas se torna uma escolha natural.

Nas eleições para o Legislativo em 1994 os Republicanos conquistaram a Câmara (House of Representatives), reduzindo a força da agenda ambiental. O processo se consolidou com a eleição de George W. Bush para a Presidência em 2000. "Com seus tradicionais aliados do Partido Democrata enfraquecidos, as ONGs ambientalistas dirigiram os esforços para a mudança do comportamento corporativo" (Lyon 2007, p.7 - tradução minha).

Outro obstáculo surgido nos anos 1990 para o ambientalismo foi o movimento do "uso racional" (wise use movement), composto por organizações e indivíduos de diferentes setores da economia, como agropecuária, petróleo, indústria e energia. O objetivo central era reduzir as regulações sobre a indústria e as atividades agropecuárias, sob o argumento de que políticas ambientais eliminavam empregos e freavam o desenvolvimento do país. Houve, inclusive, registros de "intimidação, vandalismo e violência contra ativistas dos movimentos sociais de base" (Helvarg 1994, pp.9, 13).

Adicionalmente, a conferência Rio-92, por meio da Agenda 21 - assinada por 179 países, entre eles os Estados Unidos e o Brasil - definiu um papel de protagonismo às organizações da sociedade civil nos processos decisórios. Com isso, fundações, frequentemente vinculadas a grandes empresas, passaram a financiar, via ONGs, projetos voltados para o desenvolvimento sustentável. Isso promoveu, por um lado, um maior fluxo de recursos para o Terceiro Setor. Por outro, fez com que muitas organizações passassem a ter uma agenda menos contenciosa e mais conciliatória.

Um modelo que se desenvolveu com importantes resultados durante a chamada terceira onda foi o das certificações de práticas industriais. As organizações ambientalistas, em parceira com empresas e governos, desenvolveram padrões produtivos auditados, com base em princípios de sustentabilidade, observando critérios econômicos, sociais e ambientais. Os selos que atestam conformidade conferem ganhos de imagem e possibilidade de maiores receitas por parte da indústria, com a contrapartida de menores impactos ambientais.

Foi nos anos 1990 que diversas organizações, como WWF, Greenpeace e NRDC, entre outras, se envolveram com esse tipo de iniciativa, conforme lembrado por Elkington e Beloe (2010):

Campanhas dirigidas à indústria de produtos florestais do Noroeste dos EUA foram particularmente efetivas porque as ONGs puderam indicar parâmetros para a prática industrial que lidavam com 
preocupações socioambientais, por meio da certificação do Conselho de Manejo Florestal (FSC) (p.41 - tradução minha).

Há, ainda, algumas correntes que apontam para o surgimento de uma quarta onda, a partir da segunda metade dos anos 1990, intensificando-se no novo século (Dowie, 1995, p.8). Este período seria marcado pelo crescimento das organizações de base, de juventude, minorias e estudantes, voltadas para a temática da justiça ambiental ${ }^{29}$. Outra característica das ONGs integrantes da chamada quarta onda seria a utilização de novas tecnologias, especialmente mídias sociais, para mobilizar cidadãos em torno de causas socioambientais.

O exemplo mais bem-sucedido deste grupo, sem dúvida, seria a ONG 350.org, fundada em 2008 por um grupo de amigos liderados pelo ambientalista Bill Mc Kibben, autor de um dos primeiros livros a alertar sobre o problema do aquecimento global (The end of Nature, lançado em 1989). A organização se dedica, essencialmente, a campanhas online e mobilizações globais em torno de questões ambientais. A 350.org é uma das principais organizadoras do evento Marcha pelo Clima, que em 2014 levou 400 mil pessoas às ruas de Nova York e outros milhares em 162 países.

Não há dúvidas quanto ao aproveitamento de novas tecnologias para mobilizar segmentos da sociedade, tanto por organizações ambientais criadas recentemente como pelas mais antigas. Também se registra o surgimento de uma série de novas redes e organizações voltadas para questões ambientais, com foco específico nas novas ferramentas online de mobilização e, muitas vezes, ligadas à questão da justiça ambiental.

Porém, não me parece adequado classificar como uma nova onda do movimento ambientalista essencialmente pelo surgimento de novos instrumentos para mobilizar pessoas em torno da causa. Na realidade, muitas das organizações de base surgidas nas décadas de 1960, 1970 e 1980 já se preocupavam com o tema da justiça ambiental, desempenhavam um papel de protagonismo dentro do movimento ambientalista e atuavam em redes para conseguir amplificar seus pleitos, com elevado grau de sucesso, não sendo, portanto, um fenômeno registrado a partir dos anos 1990 .

Segundo Herculano (2013), já

\footnotetext{
${ }^{29}$ A Agência Ambiental Norte-Americana (EPA) define justiça ambiental como "o tratamento justo e o envolvimento significativo de todas as pessoas, sem distinção de raça, cor, nacionalidade ou renda, no desenvolvimento, na implementação e na fiscalização de legislações, regulamentos e políticas ambientais" (http://iaspub.epa.gov/sor_internet/registry/termreg/searchandretrieve/termsandacronyms/search.do, acesso em 14 de novembro de 2015).
} 
...nos anos 1980, o movimento ambientalista começou a desenvolver em seu seio uma perspectiva étnica e de classe, que passa a sustentar que os efeitos da poluição industrial e seus riscos tóxicos não são homogêneos, recaindo sobre populações pobres e mais vulneráveis, tais como negros e chicanos, nos Estados Unidos (p.171).

De toda forma, independentemente da categorização em três ou quatro ondas, é razoável afirmar que, ao longo da história, a sociedade civil norte-americana conseguiu construir um movimento ambientalista forte, com uma diversidade de organizações dos mais variados tamanhos, alcances e métodos empregados para alcançar seus objetivos. Para o estudo do tema central deste trabalho - os repertórios usados pelas grandes ONGs ambientalistas para influenciar políticas públicas - as organizações que atuam nos EUA fornecem uma riqueza de alternativas, conforme será visto em capítulos posteriores. 


\section{AS POLÍTICAS AMBIENTAIS E O MOVIMENTO AMBIENTALISTA NO BRASIL}

Brasília, 18 de agosto de 1976: ...o líder do Governo na Câmara, José Bonifácio, disse que os comunistas andavam agitando o problema da poluição. (...) Não podemos concordar com a ideia de que aqueles que se preocupam com a poluição sejam considerados como subversivos ou mesmo simples oposicionistas. Poluição nada tem a ver com política partidária.

(Registro no Diário de Paulo Nogueira-Neto - 2009, p.50)

As próximas páginas apresentam um histórico das principais políticas ambientais adotadas no Brasil, importante aspecto para melhor compreender o contexto no qual as organizações aqui estudadas atuam. Legislações como os códigos florestais de 1934,1965 e 2012, a Política Nacional de Meio Ambiente e os capítulos da Constituição de 1988 serão discutidos. Na sequência, o trabalho contará uma breve história do movimento ambientalista brasileiro.

\subsection{EVOLUÇÃO DAS POLÍTICAS AMBIENTAIS NO BRASIL}

Assim como no caso dos Estados Unidos, o Brasil construiu ao longo de sua história um moderno arcabouço legal de proteção ao meio ambiente. Rachel Biderman, diretora do World Resources Institute no Brasil, afirmou categoricamente em entrevista para esta pesquisa ${ }^{30}$ que os principais problemas ambientais do país não passam por marcos regulatórios, e sim pela aplicação das leis.

Assim como mencionado anteriormente, que a legislação ambiental dos EUA serviu de modelo para diversos países, inclusive o Brasil, as disposições constitucionais brasileiras sobre o meio ambiente também foram reproduzidas "em vários países do subcontinente, como Colômbia, Paraguai, Equador, Bolívia, Nicarágua e Guatemala" (Santilli 2005 p.57).

Em relação às origens do pensamento ambientalista no Brasil, Pádua (1987) pontua que, com raríssimas exceções, não havia durante o período colonial brasileiro um debate sobre o uso predatório da natureza e tampouco uma crítica social a respeito do modelo exploratório que prevalecia. O autor também relata uma omissão "em termos de práticas administrativas concretas", com a existência de algumas leis para prevenir a destruição das matas surgindo apenas no Século 18, ainda assim motivadas exclusivamente pela necessidade de assegurar a oferta de madeira para Portugal fazer navios (p.21).

\footnotetext{
${ }^{30}$ Entrevista concedida em 3 de novembro de 2015.
} 
$\mathrm{Na}$ literatura dos séculos 18 e 19, ainda de acordo com Pádua (1987), houve manifestações românticas e também nacionalistas, enaltecendo as belezas naturais do país, mas sem qualquer discussão crítica acerca da degradação do ambiente ou da violência em relação às populações indígenas (pp.22-25).

O historiador cita José Bonifácio ${ }^{31}$, que condenava o desperdício e defendia o "uso social da natureza" (p.31) e, no Século 19, alguns textos de Euclides da Cunha, que continham um "protesto contra a destruição da natureza", dentre outras obras ( $p .43)$. Porém, se nos Estados Unidos os textos dos naturalistas Emerson e Thoreau influenciaram considerável número de cidadãos, o alcance e a disseminação de ideias que defendiam o uso racional dos recursos naturais seria muito menor em um país com $84 \%$ de analfabetos e nenhuma universidade, como era o caso do Brasil em 1872, já passados cinquenta anos da independência (Carvalho 2008, p.23).

Embora haja registros de políticas que impunham limites à exploração de ativos florestais, como o regimento do Pau-Brasil, já em 1605, a afirmação em 1797 na Carta Régia determinando a proteção de rios, encostas e nascentes e o regimento de Cortes de Madeiras, em 1799, todas essas leis tinham uma motivação essencialmente econômica. Em outras palavras, procuravam prevenir a escassez de commodities remetidas para a Coroa portuguesa.

Mesmo esses poucos regulamentos não eram respeitados, uma vez que os responsáveis por essa extração de recursos, sem qualquer preocupação com questões ligadas à preservação, buscavam apenas maximizar os ganhos advindos dessa exploração. Predominava, assim, "um caráter utilitarista e predatório das oligarquias rurais latifundiárias que visavam ao lucro de curto prazo" (Câmara 2013, pp.127-128).

\subsubsection{Período das proteções fragmentadas}

Até a década de 1930, prevaleceu no Brasil o modelo em que as poucas leis ambientais que existiam buscavam apenas assegurar a produtividade, sem nenhum propósito de proteger a natureza ou garantir um ambiente saudável para a população.

A ausência de peças de legislação voltadas para a conservação do meio ambiente é ressaltada por Benjamin (1999), que classifica de "fase de exploração desregrada ou laissez-faire ambiental" (p.51) o período que vai até os anos 1960 .

\footnotetext{
${ }^{31}$ Conhecido intelectual brasileiro nascido em Santos, ministro de Estado entre 1822 e 1823, durante a regência de Dom Pedro I.
} 
Do descobrimento em 1500 até o início da segunda metade do século XX, pouca atenção recebeu a proteção ambiental no Brasil, com exceção de umas poucas normas isoladas que não visavam, na vocação principal, a resguardar o meio ambiente como tal (p.51).

Embora uma maior quantidade de leis ambientais tenha surgido a partir dos anos 1960, décadas antes houve algumas mudanças. A partir dos anos 1930, notadamente na chamada Era Vargas (1930-1945), houve o que Little (2003) classificou de "surto de atividade conservacionista", com a criação dos primeiros parques nacionais e a aprovação dos primeiros códigos ambientais (p.14).

Em 1934 são sancionados o Código Florestal, que regulava a exploração de recursos naturais em terras particulares, primordialmente para conter a derrubada de espécies arbóreas nativas (Garcia 2012, p.56), e o Código das Águas, para frear a utilização desregrada dos recursos hídricos.

Em 1937 o presidente Getúlio Vargas autoriza, com influência do modelo norteamericano de parques (Santilli 2005, p.6), a criação do Parque Nacional de Itatiaia, localizado na fronteira dos estados de Minas Gerais e Rio de Janeiro. Em 1939, são criados outros parques nacionais: Iguaçu (PR) e Serra dos Órgãos (RJ).

De acordo com Câmara (2013), a finalidade das políticas ambientais implementadas nos anos 1930 era evitar a exaustão de recursos de modo a assegurar a continuidade do crescimento industrial. Ou seja, a relação utilitarista com a natureza seguia prevalecendo (p.130).

Benjamin (1999) denominou de "fase fragmentária" o período iniciado nos anos 1960, caracterizada por uma preocupação "com largas categorias de recursos naturais, mas ainda não com o meio ambiente em si mesmo considerado" (p.51). O ponto de vista econômico prevalecia.

O Código Florestal que ficou em vigor até 2012 foi aprovado em 1965 (Lei 4.771/65), já durante o governo militar. Bastante avançada para a época, era a mais sofisticada legislação ambiental já implementada no Brasil, acrescentando ao código anterior a conservação de áreas de risco, instituindo o conceito de áreas de preservação permanente (APPs) (Garcia 2012, p.56) e de reserva legal ${ }^{32}$.

Castro Júnior e colegas (2009) apontam que o novo conjunto de leis dava proteção a topos de morro, margens de rio, nascentes, encostas íngremes e restingas, mas autorizava

\footnotetext{
${ }^{32}$ Porção de terra dentro de propriedade rural, cujos percentuais variam de acordo com o bioma, em que deve ser mantida cobertura florestal, sendo permitida a exploração sustentável por meio do manejo florestal.
} 
a reposição de florestas nativas por plantadas, algo que beneficiou o segmento da indústria florestal (celulose, madeira, móveis etc) (pp.25-26). Houve também, ao longo do regime militar, ampliação das categorias de unidades de conservação, com a criação de estações ecológicas, reservas ecológicas, reservas biológicas e áreas de proteção ambiental (APAs) - anteriormente havia apenas parques nacionais e florestas nacionais.

Outro ponto que merece destaque é a criação de uma grande quantidade de UCs quase metade do total existente hoje - durante o regime militar (1964-1985), em grande medida por motivações de controle territorial (Castro Júnior et al 2009, pp.40-41). Mittermeier e colegas (2005) classificaram o aumento no número de parques nacionais como um momento "verdadeiramente histórico" (p.15).

De acordo com Santilli (2005), durante os governos militares, entre 1964 e 1984, não foi aberto espaço para a discussão de políticas ambientais, o mesmo valendo para projetos de infraestrutura com potenciais impactos no meio ambiente, como estradas, hidrelétricas, polos industriais e portos. Além disso, a sociedade civil organizada foi reprimida, gerando uma "desmobilização da cidadania" (pp.27-28). Assim, o incipiente movimento ambientalista brasileiro - há registro de meia dúzia de organizações voltadas para o meio ambiente até o final dos anos 1970, notadamente ADEMA, FBCN e AGAPAN - contava com pouquíssimo espaço de mobilização e de influência em políticas públicas.

Devido ao crescimento industrial a partir dos anos 1940 e à falta de políticas reguladoras, os problemas ambientais começavam a se multiplicar, com alarmantes índices de poluição atmosférica em grandes centros industriais urbanos (Câmara 2013, p.131). Segundo Menezes (1997), “a industrialização maciça e tardia incorporou padrões tecnológicos (...) ultrapassados no que se refere ao meio ambiente, com escassos elementos tecnológicos de tratamento, reciclagem e reprocessamento" (p.79).

Definitivamente, nos anos 1970, a agenda ambientalista, já tão avançada nos EUA, estava longe de ser uma prioridade no Brasil. Viola (1987) lembra que, durante a gestão do presidente Emílio Garrastazu Médici (1969-1974), o governo brasileiro fazia publicidade em veículos de comunicação de países desenvolvidos - que já contavam com regulações ambientais - "convidando indústrias poluidoras a transferir-se para o Brasil, onde não teriam nenhum gasto em equipamento antipoluente" (pp.83-84). Projetos como a hidrelétrica de Itaipu, a rodovia Transamazônica e o convênio com a Alemanha para a implantação de usinas nucleares no Brasil foram feitos sem que a sociedade fosse ouvida.

Após a conferência de Estocolmo, em 1972, primeiro grande evento internacional para discutir questões ambientais, organismos internacionais de fomento começavam a demandar que projetos de infraestrutura contemplassem questões ambientais para 
conceder empréstimos aos países em desenvolvimento. Em razão disso, o governo brasileiro cria, em 1973, a Secretaria Especial de Meio Ambiente (SEMA), "uma agência marginal do Ministério do Interior" (Viola 1987, p.84) sob comando do pesquisador e ambientalista Paulo Nogueira-Neto.

Em seus diários, publicados na forma de livro em 2009, o ambientalista Paulo Nogueira-Neto, que comandou a SEMA desde sua criação até 1985, dá alguns indícios de que a área ambiental não era priorizada dentro dos governos e o órgão trabalhava com extremas dificuldades. No registro de 7 de outubro de 1975, Nogueira-Neto comentou, em tom de desabafo, o decreto que regulamentava as atribuições da secretaria:

Desgraçadamente alguém tirou da SEMA a atribuição de estabelecer normas e padrões. Quem as estabelece é o Governo Federal. Pensei seriamente em colocar o chapéu na cabeça e ir embora. Nossa luta é, como tenho dito, morro acima e palmo a palmo. Até quando, meu Deus? Valerá a pena assumir a responsabilidade perante o púbico, por coisas sobre as quais não temos controle? (...) Não sou enfeite. Não tenho vocação para ornamento (p.49).

Outros depoimentos de Paulo Nogueira-Neto - que em 1976 comparou os 250 funcionários da SEMA com os 12 mil da EPA norte-americana (p.49) - confirmam a posição periférica da pasta por ele ocupada:

- 8 de maio de 1979: "Na realidade, vivo na corda-bamba; não sei até quando". (p.61)

- 28 de maio de 1979: "Lutamos por cinco anos, mas nosso futuro é mais incerto do que nunca (...) [E]stamos imersos na luta pela sobrevivência, disputando o vil metal” (p.61).

Com o fim do regime militar e a posse de José Sarney, em 1985 - o primeiro presidente civil desde 1964, eleito pelo Congresso - o discurso ambiental continua distante das agendas prioritárias do país (Viola 1987 p.85). No início dos anos 1980 acabava o período chamado por Patriota (2009) de fragmentário, em que as políticas ambientais lidavam com categorias de recursos naturais (água, florestas, rios, por exemplo), e não ao "meio ambiente como um todo. (...) [A] proteção legal era dada apenas quando interesses econômicos estavam ameaçados" (p.612).

\subsubsection{Abordagem sistêmica (1980 a 2000)}

A Lei 6.938, sancionada em 1981, pode ser considerada um importante marco para as políticas ambientais brasileiras. A legislação estabeleceu a Política Nacional do Meio Ambiente (PNMA), instituindo o Sistema Nacional do Meio Ambiente, com mecanismos e instituições necessários para a implementação (Santilli 2005, pp.28-29; Câmara 2013, 
p.132). O meio ambiente era, pela primeira vez, tratado de forma sistêmica pelo Estado brasileiro. Outros indiscutíveis avanços aprovados na PNMA foram a exigência de avaliação de impacto ambiental e de licenciamento para atividades ou projetos com potencial impacto ao meio ambiente (Machado 2011, p.126). De acordo com Benjamin (1999), a PNMA faz com que, de maneira inédita, o meio ambiente receba proteções legais que o considerem um "sistema ecológico integrado (...) e com autonomia valorativa" (p.52).

Também foram instituídas, pela lei de 1981, instâncias participativas para as políticas ambientais, com destaque para o Conselho Nacional do Meio Ambiente (CONAMA), que abriu espaço para que a sociedade civil pudesse, efetivamente, participar dos processos decisórios na área ambiental. Audiências públicas passaram a ser exigidas para uma série de projetos. Câmara (2013) descreve a importância da Política Nacional de Meio Ambiente:

Tal contexto político-institucional propiciou o estabelecimento de uma malha de instituições federais, estaduais e municipais voltadas para a gestão ambiental dos recursos naturais, ampliando o número de participantes nos processos decisórios (p.132).

Diante desse novo cenário, surge uma demanda, há décadas reprimida, para a atuação das organizações da sociedade civil, que começam a se organizar e a estruturar nesta fase, conforme será visto com maior grau de detalhamento no próximo tópico deste capítulo.

Outro importante avanço na legislação brasileira com enormes impactos no campo ambiental foi a aprovação, em 1985, da Lei 7.347, também chamada de Lei dos Interesses Difusos, que criou a ação civil pública e dotou o Ministério Público de instrumentos efetivos para responsabilizar autores de danos ambientais (Santilli 2005, p.29). Além disso, organizações da sociedade civil passaram a poder ingressar com ações civis públicas, algo que contribuiu para a gradual criação de um ambiente mais propício ao fortalecimento do movimento ambientalista.

Silva-Sánchez (2010) nota que a Lei da Ação Civil Pública, ou dos Interesses Difusos, quebrou o paradigma do "direito tradicional, fundamentado na ideologia liberal e, portanto, centrado no indivíduo" (p.83). As associações poderiam se tornar autoras de ações civis públicas, desde que estivessem constituídas há pelo menos um ano e que tivessem "entre suas finalidades institucionais a proteção ao meio ambiente, ao consumidor, ao patrimônio artístico, estético, histórico e paisagístico" (texto da lei). Assim, os ministérios públicos e as ONGs ambientalistas receberam um importante impulso para se organizar e se fortalecer, o que de fato aconteceria nos anos subsequentes. 
É importante mencionar que o significativo progresso no arcabouço legal brasileiro não se deveu a uma súbita boa vontade por parte do Estado. Conforme lembrado por Ferreira (2012), a agenda ambiental, que quase não existia nos governos militares, "não esteve presente também no discurso básico da Nova República" (p.134). Alguns importantes fatores contribuíram para que esses avanços ocorressem.

Segundo Ferreira, casos em que ficavam claras as consequências da degradação ambiental - como os índices alarmantes de poluição atmosférica em Cubatão, São Paulo, com graves consequências à saúde pública - reforçaram, na opinião pública, a necessidade de medidas de regulação da atividade industrial (p.133), gerando maior pressão sobre o Estado. Bastante divulgados pela mídia, esses eventos também contribuíram para que mais pessoas percebessem a importância do movimento ambientalista, agregando legitimidade aos pleitos das organizações.

Outro aspecto fundamental para que os tomadores de decisão, tanto no Executivo como no Legislativo, passassem a dar mais atenção aos temas ambientais, foi uma crescente pressão externa por políticas nessa área. Segundo Arnt e Schwartzman (1992), os primeiros movimentos feitos pelo estado brasileiro no sentido de levar em conta questões socioambientais em grandes projetos de infraestrutura se deram nos anos 1980, essencialmente por pressões de organismos financeiros internacionais como BID, Bird e outras agências de fomento (pp.111-112).

Ou seja, para que empréstimos para estradas, hidrelétricas, portos e outros projetos fossem concedidos, as condicionantes ambientais tinham que ser levadas em conta. Conforme resumido pelos autores, a "pressão internacional impeliu velocidade à emergência do ambientalismo nas políticas públicas" (Arnt e Schwartzman 1992, p.115).

A transparência dos processos decisórios, na medida em que a redemocratização ia acontecendo gradualmente, aumentava. Em 1986, o CONAMA foi fortalecido, e o número de representantes da sociedade civil foi aumentado naquele colegiado. No mesmo ano, a divulgação dos relatórios de impacto ambiental para o público passou a ser obrigatória (Hochstetler e Keck 2007, pp.35-36).

Mas o maior impulso para a consolidação do arcabouço legal voltado ao meio ambiente viria em 1988, com a promulgação da Constituição. Em um de seus artigos, a Carta Magna garante o direito a um meio ambiente ecologicamente equilibrado e que possibilite a sadia qualidade de vida. Foram incorporadas disposições que determinavam os estudos de impacto ambiental para obras e projetos (Machado 2011, pp. 121 e 150) e a floresta amazônica, o Pantanal, a zona costeira e a Mata Atlântica foram declarados patrimônios nacionais (Arnt e Schwartzman 1992, p.121). 
Segundo Santilli (2005), a nova Constituição introduziu questões inovadoras no sistema legal brasileiro, como o "paradigma socioambiental", protegendo "processos ecológicos, espécies e ecossistemas", mas também "a sociodiversidade" (pp.42-43). As futuras gerações passam a ser levadas em conta, agregando os princípios do desenvolvimento sustentável, mundialmente institucionalizados pelo Relatório Brundtland (também chamado de Nosso Futuro Comum), elaborado em 1987 pela Comissão Mundial sobre o Meio Ambiente e o Desenvolvimento das Nações Unidas.

Após o assassinato do seringueiro Chico Mendes a mando de um proprietário de terras em dezembro de 1988, a pressão internacional sobre o Brasil aumentou. Afinal, as autoridades brasileiras assistiram passivamente, mesmo após terem sido diversas vezes comunicadas sobre as inúmeras ameaças de morte ao seringueiro, ao assassinato da principal liderança socioambiental do país, que mantinha conexões com organizações ambientalistas e de direitos humanos da Europa e dos EUA.

Um dos resultados do trágico assassinato de Chico Mendes foi a criação, já em 1989, das reservas extrativistas (RESEX), área protegida em que as comunidades locais são responsáveis pelo manejo dos recursos naturais e pela gestão do espaço (Garfield 2013, pp.225-226 - tradução minha).

$\mathrm{Na}$ década de 1990, o país deu importantes passos para a consolidação da democracia. O primeiro presidente democraticamente eleito desde 1964 - Fernando Collor de Mello - toma posse e, cassado por um processo de impeachment em setembro de 1992, passa a faixa presidencial para seu sucessor constitucional, o vice Itamar Franco. O meio ambiente ganha um ministério, uma série de legislações de caráter ambiental é aprovada e os temas ambientais obtêm mais espaço na agenda nacional (Little 2003, p.15). As instituições nacionais voltadas para implementação das políticas ambientais ganham força.

Uma importante política que contribuiu para esse cenário foi o Programa Piloto para a Proteção das Florestas Tropicais do Brasil (PPG-7), ideia lançada por iniciativa do governo alemão, ainda em 1997, na cúpula dos países do G-7 em Houston, que começou a ser colocada em prática em 1994, no governo Itamar, passando pelos governos Fernando Henrique Cardoso e Luiz Inácio Lula da Silva. Os países desenvolvidos financiariam, via Banco Mundial, iniciativas de combate ao desmatamento, especialmente na Amazônia e na Mata Atlântica (Garfield 2013, p.218; De Antoni 2010, pp.299-300).

O PPG-7, além de contribuir para o fortalecimento das instituições públicas voltadas para a questão ambiental, propiciou um ambiente adequado para o crescimento das ONGs ambientalistas, que se tornaram parceiras do Estado na implementação dos novos 
programas. As linhas de ação do PPG-7 eram "a experimentação e a demonstração de atividades que visam conciliar a conservação e o desenvolvimento; a conservação de áreas protegidas; a demarcação das terras indígenas; a consolidação das instituições públicas responsáveis pelas políticas ambientais; e a pesquisa científica" (De Antoni 2010, p.299).

Os resultados do programa, que envolveu mais de US $\$ 400$ milhões em investimentos dos países do G-7 mais a Holanda, foram importantíssimos. O PPG-7 instituiu a visão de corredores ecológicos, privilegiando a abordagem de paisagens nas ações de conservação (Mittermeier et al 2005, p.19). Foi responsável pela criação de órgãos ambientais em diversos estados amazônicos, de mais de 100 milhões de hectares de áreas protegidas e demarcação de 44 milhões de hectares de terras indígenas, entre outros avanços (De Antoni 2010, p.300).

Segundo Márcio Santilli, ex-deputado federal (1983-1986) e sócio-fundador do Instituto Socioambiental, em entrevista para esta pesquisa ${ }^{33}$, o principal legado do PPG-7 foi a construção de processos participativos na governança ambiental. "O PPG7 trouxe a participação da sociedade civil como importante componente. Alargou a abrangência e a eficácia, contribuiu para uma opinião pública receptiva a esses temas e para a formulação de legislação ambiental", descreveu Santilli.

Outro marco para o ambientalismo brasileiro foi a Conferência das Nações Unidas sobre o Meio Ambiente e o Desenvolvimento (Rio 92 ou Eco 92), organizada no Brasil em 1992, com a presença de mais de 100 chefes de estado. Embora a gestão de Collor não demonstrasse grande preocupação com as questões ambientais, o presidente buscou alcançar, com o evento, a boa vontade da comunidade internacional em relação ao Brasil (Hochstetler e Keck 2007, p.37).

Além disso, a Rio 92 contribuiu para a disseminação da agenda ambiental na sociedade brasileira e, segundo Camargo e colegas (2002), trouxe "um crescimento significativo no nível de informação e preocupação da sociedade brasielira para com as questões relativas à sustentabilidade" (p.35). Possibilitou, ainda, que o movimento ambientalista nacional interagisse com lideranças governamentais e não-governamentais da área ambiental de vários países, e se conectasse com seus pares de diversas partes do mundo. Afinal, a conferência abriu espaço para milhares de ONGs ambientalistas nas diversas discussões realizadas.

A Agenda 21, documento assinado por 179 países participantes da Rio 92, previa que processos participativos passassem a ser adotados nas decisões governamentais

\footnotetext{
${ }^{33}$ Entrevista concedida no dia 16 de junho de 2015.
} 
envolvendo o meio ambiente. Isso também fortaleceu sobremaneira os movimentos socioambientais, de maneira global.

A despeito do indiscutível crescimento da importância da agenda ambiental no Brasil, o tema continuava em posição de vulnerabilidade quando confrontado com interesses do setor produtivo, de maneira geral. Mesmo os tomadores de decisão vinculados a órgãos ambientais eram acusados por ativistas de promover iniciativas prejudiciais ao meio ambiente. Nogueira-Neto (2009) relatou a situação em registro do dia 18 de setembro de 1995 em seu diário:

Há uma grande luta dos ambientalistas contra o ministro Gustavo Krause, do Meio Ambiente, e também contra o Raul Jungman, presidente do Ibama. Estes querem reduzir a extensão da Mata Atlântica pressionados por políticos do PFL de Santa Catarina (com interesses madeireiros $)-(p .685)$

O estabelecimento de políticas ambientais continua ao longo do governo de Fernando Henrique Cardoso. Em 1996, em resposta aos crescentes índices de desmatamento e a frequentes incêndios florestais, o presidente edita uma medida provisória aumentando substancialmente os percentuais de reserva legal. Na Amazônia, o produtor deveria conservar $80 \%$ de sua propriedade (anteriormente, eram $50 \%$ ). Nas áreas de Cerrado dentro da Amazônia Legal, $35 \%$, e no restante dos biomas, $20 \%$.

A medida foi aplaudida pelas organizações ambientalistas, mas enfrentou feroz oposição por parte de entidades representativas do agronegócio e da chamada bancada ruralista, no Congresso Nacional. Em editorial publicado em 4 de setembro de $2001^{34}$, denominado "Ameaça à Floresta Amazônica", o jornal O Estado de São Paulo criticou projetos defendidos por deputados ruralistas para reduzir os percentuais de reserva legal, classificando a proposta apresentada aquele ano pelo deputado Moacir Micheletto como "um convite ao desflorestamento".

Outra política que possibilitou um significativo incremento na aplicação da legislação ambiental foi a Lei de Crimes Ambientais (9.605/98), sancionada em 1998, que instituiu punições severas para infratores, dando ao Ibama e ao Ministério Público poderosos instrumentos de fiscalização, comando e controle na área ambiental (Castro Júnior et al 2009, p.44).

\footnotetext{
${ }^{34}$ Editorial "Ameaça à Floresta Amazônica" in O Estado de S. Paulo, p.3, edição de 4 de setembro de 2001.
} 
Diversas entrevistas feitas para esta pesquisa comprovaram que o conjunto de leis ambientais aprovadas nos anos 1980 e 1990, assim como a construção e o fortalecimento da rede de instituições públicas e não-governamentais voltadas para a proteção do meio ambiente no período, fizeram com que, pela primeira vez na história, os setores que promoviam o desenvolvimento predatório no país se sentissem ameaçados.

Assim, a Política Nacional do Meio Ambiente (1981), a Lei dos Interesses Difusos (1985), os dispositivos ambientais da Constituição de 1988, a Lei de Crimes Ambientais (1998), a criação do Ministério do Meio Ambiente, do Ibama e de diversos órgãos ambientais nos estados e municípios, e a consolidação do Ministério Público, fizeram com que o país presenciasse situações até então pouco vistas: infrações ambientais gerando multas, apreensões de veículos e equipamentos e até prisões.

Outra realidade que se construiu nos anos 1980 e 1990, e que viria a se consolidar nos anos 2000, foi a democratização de diversos espaços decisórios ligados aos temas socioambientais. Segundo Camargo e colegas (2002), "houve um avanço significativo em relação à criação de mecanismos de participação da sociedade civil em alguns fóruns consultivos e decisórios do país" (p.34). Esse cenário de novas leis, uma sociedade civil mais forte e instituições governamentais um pouco mais estruturadas fizeram com que a aplicação da legislação passasse a ocorrer, ainda que de forma longe do ideal, com intensidade jamais vista.

João Paulo Capobianco ${ }^{35}$, ex-diretor executivo do Ministério do Meio Ambiente, afirmou que, finalmente, os "setores do desenvolvimento predatório" começaram a ser constrangidos. Nilo d'Ávila, coordenador de pesquisa do Greenpeace, em entrevista para esta pesquisa $^{36}$, disse que a efetiva aplicação da Lei de Crimes Ambientais nos anos 2000 foi um dos fatores que produziram a reação contrária ao Código Florestal, cujas alterações, sancionadas em 2012 pela presidente Dilma Rousseff, contrariaram frontalmente os interesses defendidos pela maior parte do movimento ambientalista nacional.

Outra importante peça de legislação ambiental aprovada no país no ano 2000 foi a lei 9.985, que definiu o Sistema Nacional de Unidades de Conservação (SNUC). Foram estabelecidos categorias e critérios para criação e implementação de UCs. Segundo Santilli (2005), a grande novidade no SNUC foi a prevalência da inspiração socioambiental, reconhecendo o papel das comunidades tradicionais na conservação da biodiversidade

\footnotetext{
${ }^{35}$ Entrevista concedida no dia 5 de maio de 2015.

${ }^{36}$ Entrevista concedida no dia 22 de maio de 2015.
} 
(p.125), materializado pela regulamentação das reservas extrativistas e de desenvolvimento sustentável (RESEX e RDS).

Com esse sólido arcabouço de leis ambientais construído, o país tinha mais segurança jurídica para avançar com políticas específicas para conter o desmatamento, promover o desenvolvimento sustentável e conservar a biodiversidade e os recursos naturais. Uma rede de organizações ambientalistas já bastante sólida permitiu que parcerias entre Estado e Terceiro Setor multiplicassem, com resultados positivos.

Um exemplo de tais parcerias é o Programa Áreas Protegidas da Amazônia (ARPA). Assinado em 2002, a partir de parceria entre Ministério do Meio Ambiente, a ONG WWFBrasil, Banco de Desenvolvimento da Alemanha (KfW), Fundo Global para o Meio Ambiente (GEF), Fundo Brasileiro para a Biodiversidade (FUNBIO) e Banco Nacional de Desenvolvimento Econômico e Social (BNDES), o ARPA tem o objetivo de apoiar a criação e a implementação de áreas protegidas na Amazônia brasileira.

Até o presente, o ARPA apoiou 95 áreas protegidas, em mais de 50 milhões de hectares ${ }^{37}$, e fomentou a criação de 46 unidades de conservação ${ }^{38}$, números que comprovam o sucesso da iniciativa. José Carlos Carvalho, ministro do Meio Ambiente em 2002, ano da assinatura do ARPA, em entrevista para esta pesquisa ${ }^{39}$, classificou o programa como "uma política pública bem-sucedida, concretamente uma expressão de articulação do poder público com a sociedade civil", ressaltando a expertise técnica e os recursos financeiros aportados pela ONG WWF-Brasil.

\subsubsection{Consolidação do socioambientalismo}

Em 2003, toma posse o presidente Luiz Inácio Lula da Silva, com apoio de numerosos setores do movimento ambientalista. Uma decisão do novo presidente marcaria a história ambiental brasileira: a escolha da senadora Marina Silva, nascida em um seringal no Acre, parceira de Chico Mendes no movimento reivindicatório de direitos dos povos da floresta, para o cargo de ministra do Meio Ambiente.

Iniciou-se um período em que os ambientalistas foram mais ouvidos do que nunca na definição das políticas ambientais brasileiras. Afinal, vários deles assumiram cargos estratégicos no ministério; outros tantos tinham as portas abertas para participar de vários

\footnotetext{
${ }^{37}$ Fonte:

http://www.wwf.org.br/natureza_brasileira/areas_prioritarias/amazonia1/nossas_solucoes_na_amazonia/areas_pr otegidas_na_amazonia/arpa/, acesso em 3 de dezembro de 2015.

${ }^{38}$ Fonte: http://programaarpa.gov.br/pt/

${ }^{39}$ Entrevista concedida em 23 de julho de 2015
} 
processos decisórios, conforme pude ouvir em praticamente todas as entrevistas com representantes do movimento ambientalista, pesquisadores, políticos e burocratas.

João Paulo Capobianco, ex-secretário Executivo e ex-secretário de Floresta e Biodiversidade do Ministério do Meio Ambiente na gestão Marina Silva, descreveu ${ }^{40} \mathrm{o}$ ambiente àquela época: "Marina foi acusada de transformar o MMA em ministério das ONGs. O que houve foi um diálogo permanente, especialmente nos fóruns institucionalizados, mais de uma dezena de conselhos".

De acordo com Raul Valle, advogado ambiental com atuação de 14 anos no Instituto Socioambiental, o movimento ambientalista teve, sob a gestão de Marina Silva, "a primavera da sua influência". Ele lembrou, em entrevista para esta pesquisa ${ }^{41}$, que as organizações da sociedade civil participaram diretamente da elaboração do Programa de Desenvolvimento Socioambiental da Produção Familiar Rural (Proambiente), do Plano de Combate ao Desmatamento na Amazônia (2004) e da Lei de Gestão de Florestas Públicas (2006) e de muitas outras importantes políticas.

A Lei de Gestão de Florestas Públicas foi uma das iniciativas do MMA sob o comando de Marina Silva que mais geraram impactos. Patriota (2009) entende que foi uma legislação inovadora, na medida em que compartilhava o papel da conservação das florestas entre Estado, comunidades e empresas. A lei prevê a outorga de concessões para o uso sustentável de florestas, a partir da prática do manejo florestal, sem custo para as comunidades locais, e mediante pagamento pela iniciativa privada (p.615). Também foi criado o Serviço Florestal Brasileiro (SFB), órgão responsável pelo gerenciamento das florestas concessionadas no âmbito da nova lei.

Rubens Gomes, o Rubão, presidente do Grupo de Trabalho Amazônico, entidade que reúne mais de 600 organizações sociais amazônicas, afirmou, em entrevista para esta pesquisa ${ }^{42}$, que, de fato, a sociedade civil foi protagonista na formulação da Lei de Gestão de Florestas Públicas: "Participamos ativamente, mais de mil organizações participaram. As primeiras reuniões entre o setor madeireiro e o movimento socioambiental foram uma iniciativa do GTA", relatou. Segundo Capobianco, as ONGs e empresas do setor florestal foram um importante aliado do Governo Federal também na defesa da lei no Congresso, ajudando a desmentir o principal argumento usado pelos opositores, de que o projeto significaria a privatização das florestas.

\footnotetext{
${ }^{40}$ Entrevista concedida em 5 de maio de 2015

${ }^{41}$ Entrevista concedida em 15 de janeiro de 2015

${ }^{42}$ Entrevista concedida em 15 de maio de 2015
} 
Foi durante a gestão Marina Silva, ainda, que o IBAMA foi subdividido, com a criação do Instituto Chico Mendes de Conservação da Biodiversidade (ICMBIO). O novo órgão ficaria responsável pela gestão das unidades de conservação federais, enquanto o lbama cuidaria dos processos de licenciamento e de fiscalização da aplicação da legislação ambiental. Boa parte do movimento ambientalista apoiou a iniciativa, que sofreu oposição por parte da Associação dos Servidores do IBAMA (ASIBAMA) e, por ter sido estabelecida via decreto, e não por projeto de lei, a divisão foi classificada por críticos como arbitrária.

A despeito dos múltiplos espaços de participação oportunizados por Marina Silva e das inovadoras políticas implementadas, a pauta ambiental frequentemente era posta em segundo plano diante de interesses de outros setores da economia, especialmente agronegócio e energia. Hochsteller e Keck (2007) descrevem uma desilusão por parte de ambientalistas em relação ao governo Lula, que "concordou com a legalização dos plantios transgênicos de soja sem abrir a questão para discussão pública" (p.180).

O senador João Capiberibe (PSB-AP), histórico aliado político do ex-presidente Lula, em entrevista para esta pesquisa ${ }^{43}$, relatou um sentimento de frustração em relação ao presidente no tocante às políticas ambientais:

Desde que o Lula tomou posse houve um retrocesso enorme das políticas ambientais, apesar da Marina Silva. Em outubro [de 2003] o governo publicou uma Medida Provisória para legalizar os transgênicos contrabandeados para o Brasil. Tive uma angina e levei duas pontes de safena por causa do tamanho da decepção. Renunciei à vice-liderança [do governo no Senado ${ }^{44}$ ]. Não sei se precisa dizer mais nada.

Apesar de dificuldades dentro do próprio governo para levar adiante a agenda ambiental, Marina Silva e sua equipe conseguiram, como visto anteriormente, importantíssimas vitórias. Entretanto, as pressões, lideradas por setores do governo ligados ao agronegócio e à energia cresceram, e contribuíram para que o Ministério do Meio Ambiente perdesse espaço.

\footnotetext{
${ }^{43}$ Entrevista concedida em 23 de junho de 2015.

${ }^{44}$ A decisão do senador amapaense foi reportada em matéria da Folha de São Paulo (http://www1.folha.uol.com.br/folha/brasil/ult96u54042.shtml - acesso em 4 de dezembro de 2015)
} 
Maria Cecília Wey de Brito, secretária de Biodiversidade e Florestas do MMA entre 2007 e 2010, em entrevista para esta pesquisa ${ }^{45}$, descreveu algumas das dificuldades enfrentadas pelo setor ambiental no governo:

Havia muita pressão por parte da mineração, quase sempre via Casa Civil. "Prendiam" a gente em uma sala com o pessoal da mineração e diziam que a questão tinha que ser resolvida. Havia também uma enorme pressão do Ministério da Agricultura e da Embrapa em relação à questão do acesso a recursos genéticos. O MMA era o lado mais fraco na comparação com outros ministérios. O Ministério da Agricultura era nosso inimigo mortal, às vezes também o MDIC.

Uma crítica feita à gestão de Marina Silva frente ao Ministério do Meio Ambiente foi a de um suposto esvaziamento da capacidade crítica dos movimentos ambientalistas em relação ao Governo Federal, consequência da presença de representantes das ONGs em cargos estratégicos do MMA. Raul Valle, advogado ambiental, na entrevista de 15 de janeiro de 2015 para esta pesquisa, entende ter havido um "amortecimento do ímpeto da sociedade civil" durante o governo de Luiz Inácio Lula da Silva, algo que também envolveu o movimento ambientalista: "Não era mais o momento de resistir e de atacar, mas de construir, porque passamos a ter um governo aberto para isso. Em vez de contratar o ativista, as ONGs contrataram o engenheiro", resumiu Raul Valle.

Toni (2007) descreveu um episódio de desmobilização de movimentos sociais na região de Altamira (PA), durante o primeiro mandato de Lula. Grupos anteriormente opostos à construção de barragens baixaram a guarda e não resistiram ao projeto de construção de uma hidrelétrica na região, devido à identificação existente com o Partido dos Trabalhadores. Com isso, os movimentos indígenas ficaram sozinhos na resistência à obra, que acabou sendo realizada (pp.16-17).

Com a clara perda de poder dentro do governo, Marina Silva se demite em maio de 2008. Assume Carlos Minc, outro ambientalista histórico, que levou adiante uma série de projetos iniciados na gestão anterior. Diversos entrevistados entendem que o período do ministro Minc à frente do MMA representou, em muitos aspectos, uma continuidade da administração de Marina Silva, mas que a crescente influência do agronegócio, da mineração e da corrente desenvolvimentista dentro do governo só aumentaria, se consolidando na Presidência de Dilma Rousseff.

\footnotetext{
${ }^{45}$ Entrevista concedida em 5 de maio de 2015
} 
Mário Mantovani, diretor de políticas públicas da ONG SOS Mata Atlântica, em entrevista para esta pesquisa ${ }^{46}$, caracteriza o segundo mandato do presidente Lula como período de reversão de tendência em relação às pautas ambientais.

Tivemos conquistas, como a Lei da Mata Atlântica [2006] e a Lei de Resíduos Sólidos [2010], mas no segundo mandato do Lula houve a grande virada e os retrocessos se intensificaram. Passamos a fazer controle de danos. Até ali ainda houve conquistas. A situação de Marina Silva mostra isso. Ela começou a apanhar muito, até sair.

Roberto Vizentin, que é filiado ao Partido dos Trabalhadores e ocupou a Presidência do ICMBIO entre 2012 e 2014, reconheceu, em entrevista para esta pesquisa ${ }^{47}$, uma clara mudança de rumos no governo petista em relação ao tema ambiental. Ele mencionou a existência de um processo que classificou como um "fechamento" do Ministério do Meio Ambiente ao movimento ambientalista, iniciado após a saída da ministra Marina Silva e intensificado no governo da presidente Dilma Rousseff, eleita em 2010 e empossada em 2011. A nomeação de Izabella Teixeira para o Ministério do Meio Ambiente em abril de 2010 também é importante nesse contexto. Vizentin analisou a situação:

Com a saída da ministra Marina Silva e sua ruptura com o governo, criou-se uma espécie de narrativa de que todos os problemas derivavam da gestão de Marina. As entidades que aderiram ao projeto da Rede ${ }^{48}$ eram vistas como pró-Marina e tidas como opositoras ao governo e isso restringiu o espaço delas no MMA. (...) Izabella tem uma relação direta com Dilma, não iriam trazer aquele tanto de "marinista" para dentro do MMA. Com isso, todos perdemos. Toda essa massa crítica ficou fora do espaço de formulação e de pensamento do MMA.

O ex-presidente do ICMBio - cuja gestão foi caracterizada por ambientalistas entrevistados como aberta ao diálogo com a sociedade civil - entende que o isolamento das ONGs ambientalistas dos processos decisórios do Governo Federal é reflexo do crescente predomínio de setores ligados à "agricultura empresarial de larga escala" no "núcleo hegemônico de sustentação do governo". Segundo Vizentin,

\footnotetext{
${ }^{46}$ Entrevista concedida em 28 de abril de 2015.

${ }^{47}$ Entrevista concedida em 8 de julho de 2015.

${ }^{48}$ Rede Sustentabilidade, partido político cuja principal liderança é Marina Silva, fundado em 2013 e com registro obtido em setembro de 2015.
} 
...qualquer política ambiental com incidência no crescimento livre de qualquer constrangimento ambiental se confronta com os interesses desse setor hegemônico. Isso faz com que a presidenta tenha feito uma escolha consciente de um perfil de ministra que não criasse nenhum tipo de confronto com essa situação.

Essa fragilização da agenda ambiental dentro do Governo Federal, somada aos obstáculos ao desenvolvimento predatório criados por um arcabouço legal moderno e eficiente, e um aparato governamental maior, mais profissional e capilarizado, geraram as condições para que grupos contrários a regulações ambientais intensificassem as investidas para modificar o Código Florestal de 1965, e pela primeira vez, obtivessem sucesso.

Diversos entrevistados, entre ambientalistas, pesquisadores, parlamentares, exministros e burocratas, mencionaram o fato de que, tanto nos governos de Fernando Henrique Cardoso, como de Luiz Inácio Lula da Silva, as tentativas da bancada ruralista pararam no Executivo Federal, por clara intervenção dos presidentes e de seus ministros do Meio Ambiente. Porém, durante o governo Dilma Rousseff, o Planalto optou por não criar empecilhos às investidas ruralistas, e a matéria avançou tendo que superar apenas obstáculos criados por setores da sociedade civil organizada - especialmente o movimento ambientalista —, academia, comunidade internacional e algumas lideranças políticas.

O substitutivo ao Código Florestal, com relatoria do deputado federal Aldo Rebelo (PCdoB-SP), foi aprovado em 24 de maio de 2011, na Câmara, com esmagadora maioria dos votos (410 a favor, 63 contra e uma abstenção). Em matéria publicada no site do Greenpeace no dia da aprovação ${ }^{49}$, a ONG classificou o texto como "massacre da motosserra", "lei de incentivo à expansão desenfreada da agricultura e da pecuária" e "ameaça à biodiversidade e à produção agrícola", entre outros termos.

Os ambientalistas ouvidos nesta pesquisa classificaram a matéria aprovada como um retrocesso e uma derrota, embora muitos pontuassem que, sem a atuação do movimento, o texto teria sido muito pior. De fato, os documentos iniciais discutidos no Congresso contêm propostas muito mais radicais em termos de flexibilização do Código Florestal, como redução de percentuais de reserva legal e fim de APPs.

No Senado, o substitutivo teve a relatoria de Jorge Viana (PT), ex-governador do Acre responsável por uma série de políticas públicas de promoção do desenvolvimento 
sustentável no estado, e Luiz Henrique (PMDB), ex-governador de Santa Catarina e, em geral, aliado aos interesses da bancada ruralista ${ }^{50}$.

Em dezembro de 2011, o texto relatado pelos dois senadores foi aprovado em plenário, por 59 votos favoráveis e sete contrários. Os ambientalistas, embora tenham reconhecido melhorias em relação ao texto da Câmara, ainda consideraram ruim o substitutivo do Senado. Jorge Viana, em entrevista para esta pesquisa ${ }^{51}$, afirmou que , tanto os ambientalistas, como os ruralistas, se colocaram em posições muito radicalizadas, e que coube aos relatores construir esse processo de mediação, a um custo alto: "Lamentavelmente ficou muito esgarçada a relação [com o movimento ambientalista] no Código Florestal, a interlocução ficou danificada", avaliou.

O texto voltou para a Câmara, onde foram feitas algumas alterações, e novamente aprovado, desta vez por 274 votos a 184. O substitutivo foi encaminhado para a sanção presidencial e as ONGs ambientalistas fizeram aquela que foi a maior mobilização popular em torno de uma causa ambiental no país. A campanha Veta, Dilma, que pressionou a presidente para vetar o novo código na íntegra, reuniu cerca de 200 entidades ambientalistas, estudantis, de trabalhadores sem-terra, da agricultura familiar e religiosas, ao redor do Comitê Brasil em Defesa das Florestas.

Foram realizadas marchas e manifestações de rua, campanhas virtuais, debates e publicações alertando a sociedade para potenciais impactos negativos do novo código, e convocando o público a pressionar o Planalto pelo veto total ao texto ${ }^{52}$. Em 24 de maio foram entregues 2 milhões de assinaturas para a presidente Dilma e para a ministra Izabella, pedindo que a chefe do Executivo vetasse a matéria (Aquino 2012).

De acordo com Kenzo Jucá, cientista político e assessor para meio ambiente do Partido Socialista Brasileiro (PSB) na Câmara, o Veta, Dilma estaria entre as quatro maiores mobilizações populares observadas no Brasil pós-democratização. As outras seriam o Diretas Já, em 1983-84, o Fora Collor, em 1992, e a onda de protestos de junho de 2013.

Em 25 de maio de 2012, a presidente vetou 12 artigos do novo Código Florestal, e alterou outros 32 , retomando vários aspectos do texto vindo do Senado, que a Câmara havia rejeitado em segundo turno.

\footnotetext{
${ }^{50}$ http://noticias.r7.com/record-news/jornal-da-record-news/videos/senador-ligado-a-ruralistas-econfirmado-relator-do-novo-codigo-florestal-20102015

${ }^{51}$ Entrevista concedida em 27 de agosto de 2015

52 http://www.wwf.org.br/informacoes/noticias meio_ambiente_e natureza/?30242, acesso em 6 de dezembro de 2015
} 
Segundo Garcia (2012), "a posição do governo ficou no meio do caminho entre os interesses dos produtores e a pressão dos grupos denominados de 'ambientalistas'. Ou seja, ninguém ficará totalmente satisfeito" (p.65). Mas, se for feita uma comparação entre a legislação anteriormente em vigor - o Código Florestal de 1965 - certamente os ruralistas tiveram muito mais a comemorar que as organizações de defesa do meio ambiente.

Depois desse período, houve uma série de propostas na Câmara buscando flexibilizar as proteções ao meio ambiente e às populações tradicionais, como a Proposta de Emenda à Constituição (PEC) 215, que busca passar para o Congresso a atribuição - atualmente do Executivo Federal — de demarcar terras indígenas (TIs).

Raul Valle, advogado ambiental, ressaltou, na entrevista de 15 de janeiro de 2015 para esta pesquisa, que não houve, recentemente, nenhuma legislação ambiental relevante para o meio ambiente na década atual. Márcio Santilli, ex-deputado federal e sócio-fundador do Instituto Socioambiental, ressaltou, na entrevista de 15 de janeiro de 2015, Brasília, DF, que as ameaças vêm aumentando. "Não me lembro de um momento similar nos últimos 30 anos. As forças retrógradas que têm crescido nos últimos anos têm poder suficiente para impor sua agenda. Temos a forte impressão de desmanche. O quadro é de retrocesso", afirmou.

A seguir, o trabalho apresenta uma linha do tempo que busca resumir as principais políticas discutidas nesta seção.

3.1.4. Linha do tempo - Políticas ambientais no Brasil

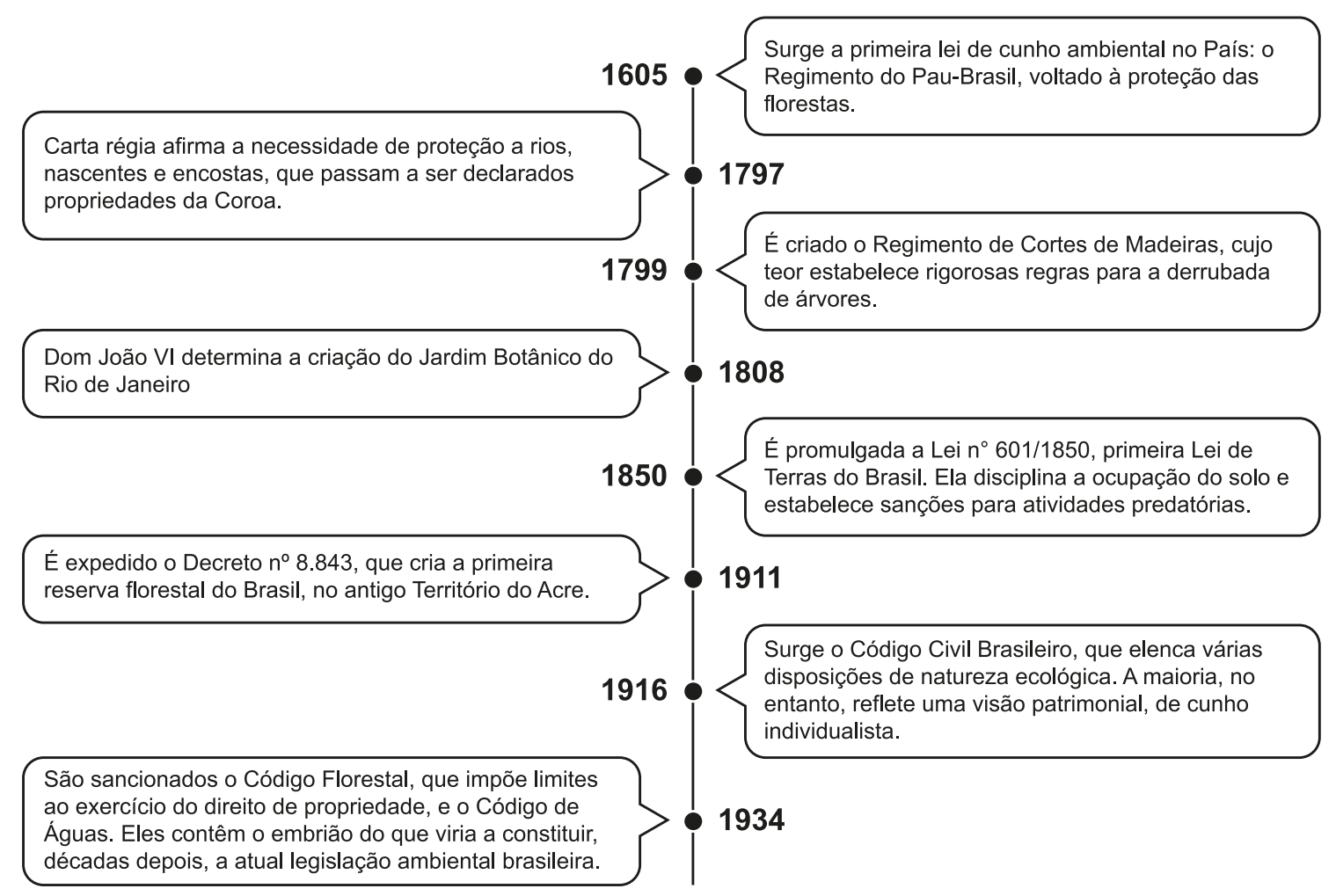




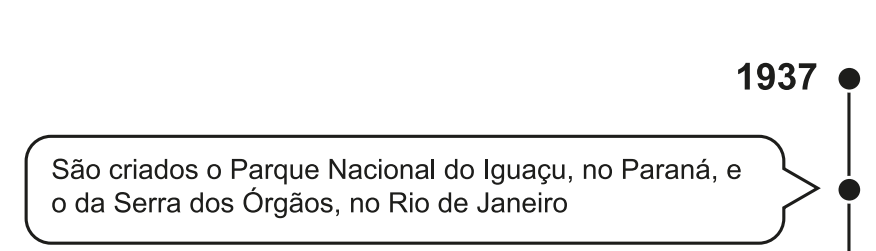
o da Serra dos Órgãos, no Rio de Janeiro

O presidente Getúlio Vargas cria o Parque Nacional de Itatiaia, o primeiro parque nacional brasileiro.

\section{9}

Surge a Associação de Defesa da Flora e da Fauna, que mais tarde foi rebatizada como Associação de Defesa do Meio Ambiente (ADEMA), uma das organizações pioneiras do ambientalismo nacional.

Surge a Fundação Brasileira para a Conservação da Natureza (FCBN), uma das primeiras ONGs ambientalistas brasileiras.

1956

\section{8} Terra. A lei surge como resposta a reivindicações de movimentos sociais, que exigiam mudanças estruturais na propriedade e no uso da terra no Brasil.

Passa a vigorar uma nova versão do Código Florestal, ampliando políticas de proteção e conservação da flora. Inovador, estabelece a proteção das áreas de preservação permanente.

É criada a SEMA (Secretaria Especial do Meio Ambiente), órgão do Governo Federal para lidar com questões ambientais, que ficaria sob o comando de Paulo Nogueira Neto até 1985, quando a Presidência da República voltou a ser ocupada por um civil.

São editados os Códigos de Caça, de Pesca e de Mineração, bem como a Lei de Proteção à Fauna. Uma nova Constituição atribui à União competência para legislar sobre jazidas, florestas, caça, pesca e águas,

cabendo aos Estados tratar de matéria florestal.

\section{5}

\section{3}

É promulgada a Lei 6.453 , que estabelece a
responsabilidade civil em casos de danos provenientes
de atividades nucleares.




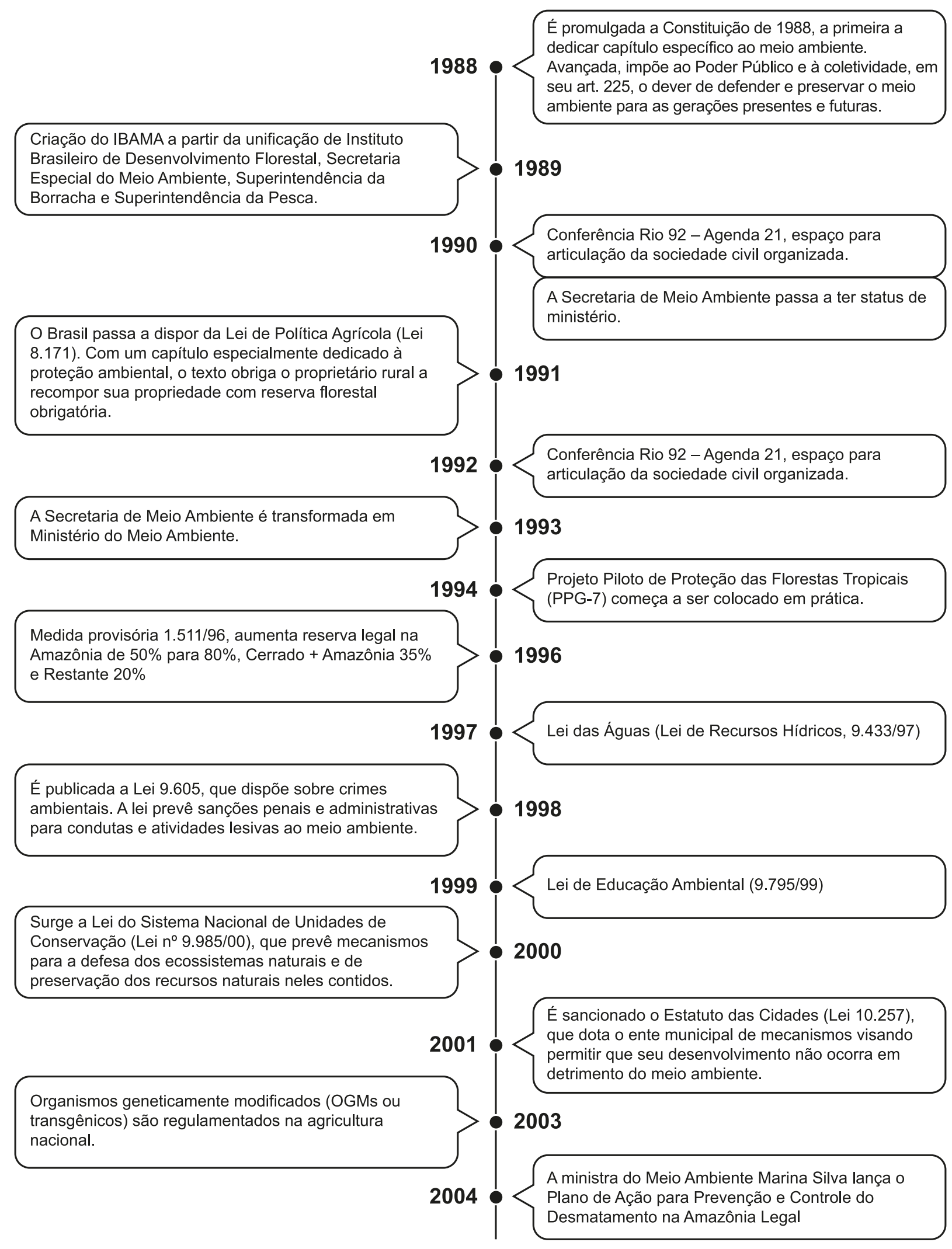




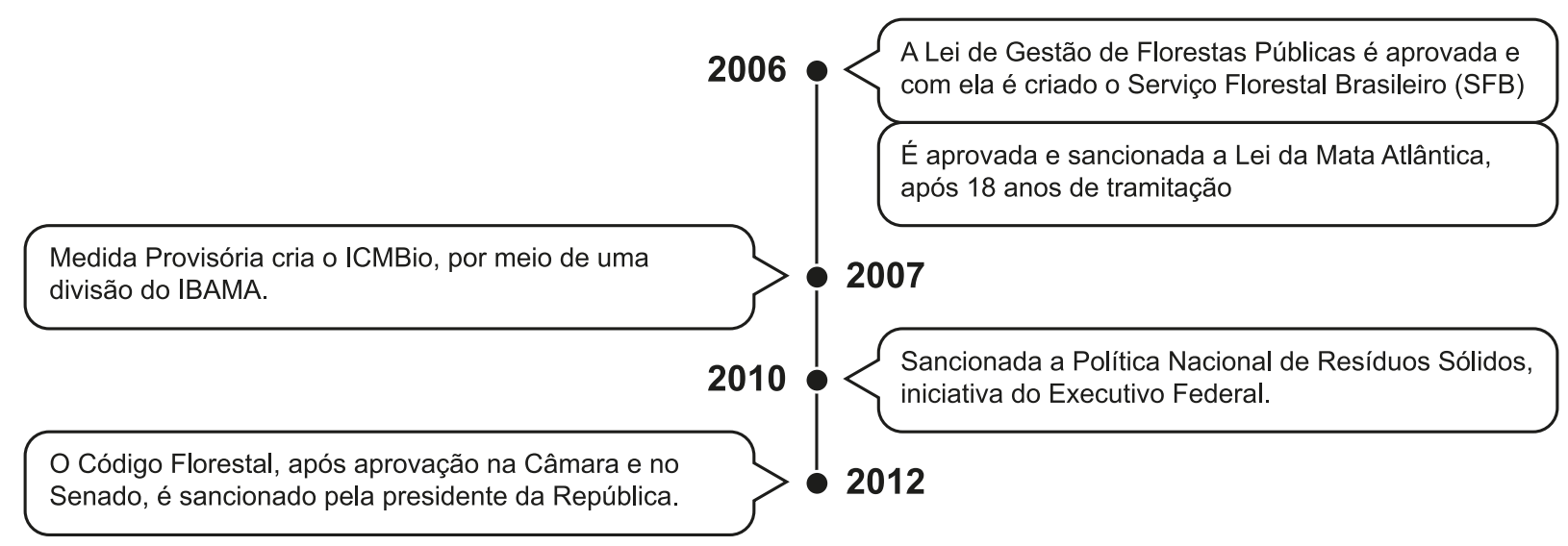

Figura 4: Linha do tempo - Políticas ambientais no Brasil

Fonte: Little 2003; Santilli 2005; Machado 2011; Le Tourneau e Droulers 2010; Site do STJ; Herculano 2013; Duarte Filho 2014; Site do STJ ${ }^{53}$

\subsection{O AMBIENTALISMO NO BRASIL}

O movimento ambientalista brasileiro se desenvolveu, em comparação com o norteamericano, de maneira tardia. Uma das explicações está nos períodos ditatoriais vividos pelo país, que em nada estimularam o desenvolvimento de uma sociedade civil organizada atuante e forte. Apenas considerando-se o Século 20, quando movimentos sociais surgiram e se fortaleceram nas principais democracias do mundo, o Brasil viveu cerca de 36 anos sob regimes que restringiam, de uma forma ou de outra, direitos civis e políticos fundamentais para a existência de movimentos atuantes: entre 1930 e 1945, com Getúlio Vargas, e entre 1964 e 1985, com os militares no poder.

De toda maneira, atualmente, o movimento ambientalista brasileiro, hoje, consegue ser forte e influente, como foi possível verificar ao longo desta pesquisa. Hochstetler e Keck (2007, pp.63-64) dividem a história do ambientalismo no Brasil em três partes. A primeira onda, chamada de "nacionalismo desenvolvimentista", foi observada dos anos 1950 até a primeira metade dos anos 1970, com algumas instituições, não muito numerosas, voltadas para a ciência e a pesquisa. Nesse período, a divisão entre conservacionistas e preservacionistas - inaugurada nos EUA, já ao final do Século 19, prevalecia. Ainda não se falava em socioambientalismo e não seria correto dizer que essas instituições constituíam algo que se pudesse chamar de movimento.

A segunda onda, chamada de "liberalização política", se deu de meados da década de 1970 até a segunda metade dos anos 1980. Houve, nessa fase, um aumento no número de

\footnotetext{
${ }^{53}$ http://www.stj.jus.br/sites/STJ/default/pt_BR/noticias/noticias/\%C3\%9Altimas/Linha-do-tempo:-um-breveresumo-da-evolu\%C3\%A7\%C3\%A3o-da-legisla\%C3\%A7\%C3\%A3o-ambiental-no-Brasil
} 
organizações lidando com a questão ambiental, muitas delas se aliando a movimentos sociais que lutavam por outros direitos e pela democratização. Já a terceira onda surgiu no contexto da redemocratização do país, após mais de vinte anos de regime militar, com um aumento na quantidade de ONGs ambientalistas, especialmente após a conferência Rio 92.

Durante a segunda e a terceira onda foi constituída, conforme visto em páginas anteriores, a maior parte do arcabouço legal brasileiro para assegurar a proteção do meio ambiente. Embora haja outras divisões temporais em torno da história do ambientalismo brasileiro, como em Viola (1987), optei por dividir esta seção de acordo com a categorização de Hochstetler e Keck (2007) explicitada acima.

Importante notar que, mesmo antes das "ondas" acima mencionadas, existiam registros isolados de associações preocupadas com questões ambientais. Nos anos 1930, por exemplo, surgiram organizações pequenas, como a Sociedade Amigos de Alberto Torres, em homenagem ao conhecido intelectual brasileiro do começo do século. A organização "defendia o uso racional dos recursos naturais" (Santilli 2005, p.26). Também surgiu, na mesma década, a Sociedade Amigos de Árvores. Porém, ainda não existia um movimento ambientalista e o alcance desses grupos era mínimo.

\subsubsection{Primeira onda - da década de 1950 ao início dos anos 1970}

De acordo com Nogueira-Neto (2009), a Associação de Defesa da Flora e da Fauna, mais tarde rebatizada como Associação de Defesa do Meio Ambiente (ADEMA), criada em 1956, foi uma das organizações pioneiras do ambientalismo nacional (p.679).

Alguns pesquisadores e ambientalistas, no entanto, entendem que a primeira organização que poderia ser caracterizada como ambientalista, talvez com um DNA um pouco mais próximo do movimento que se consolidou nos anos 80 e 90, tenha sido a Fundação Brasileira para a Conservação da Natureza (FBCN), que surgiu em 1958. Roberto Messias Franco, ex-presidente do IBAMA ${ }^{54}$, a denomina a "vovó do movimento ambientalista brasileiro".

Franco e Drummond (2009) entendem que "somente com o surgimento da FBCN (...) o discurso conservacionista ganha um corpo conceitual mais bem definido" (p.61), fortalecido a partir de 1966, com um boletim editado pela organização. A FBCN se dedicava a estudos científicos e cooperação com governos, buscando estimular a criação e a implementação de unidades de conservação.

\footnotetext{
${ }^{54}$ Entrevista em 3 de junho de 2015 para esta pesquisa.
} 
Porém, os autores ressaltam que a ONG era muito mais um espaço de reuniões e discussões que uma entidade que influenciava políticas, embora a atuação de indivíduos que compunham a diretoria da FBCN, como Victor Abdennur Farah, Paulo Nogueira-Neto e Ibsen Gusmão da Câmara tenha sido observada no Código Florestal de 1965 e em convênios com o IBDF e com a SEMA (Franco e Drummond 2009, pp.64-65).

A década de 1970 representaria uma mudança de rumos, com o início da formação do que poderia, pela primeira vez, ser classificado como um movimento. Segundo Monteiro (1981), nesse período constituíram-se cerca de 80 organizações preocupadas com a temática ambiental (p.11), mas ainda bastante distantes do perfil atual das ONGs ambientalistas.

Em um contexto mundial marcado por discussões sobre os problemas advindos da degradação ambiental (Conferência de Estocolmo, em 1972, por exemplo), aprovação de leis e construção de um aparato estatal para assegurar o cumprimento dessa legislação, a temática não passou em branco no Brasil. Começa a acontecer, ainda segundo Monteiro (1981), uma "tomada de consciência em relação às inúmeras agressões que vêm se multiplicando no Brasil à natureza e aos níveis insatisfatórios da qualidade ambiental" (p.11).

O Governo Federal, conforme abordado na seção anterior deste capítulo, cria a Secretaria Especial de Meio Ambiente que, mesmo desprestigiada, demonstra que o tema aos poucos entrava na agenda nacional. "O ambientalismo no Brasil se estruturou nesse período formativo como um movimento bissetorial, constituído de associações ambientalistas, por um lado, e de agências estatais de meio ambiente, por outro" (Menezes, 1997, p.78).

A Associação Gaúcha de Proteção ao Ambiente Natural (AGAPAN), criada em Porto Alegre em 1971, era a que mais se aproximava ao modelo de ambientalismo que se construía no Ocidente: ONGs que tentavam, tanto via protesto como via convencimento de tomadores de decisão, fazer com que fossem formuladas e implementadas políticas públicas voltadas para a proteção do meio ambiente e para regular indústrias.

Embora tenha obtido significativas vitórias em nível local, como restrições à instalação de usinas nucleares no Rio Grande do Sul (Viola 1987, p.93) e a primeira legislação estadual do país para regulamentar o uso de agrotóxicos (Santilli 2005, p.27), a AGAPAN, assim como as outras organizações ambientalistas da época, não conseguiriam impor obstáculos ao modelo de desenvolvimento levado adiante pelos militares. Na década de 1970 os movimentos não influenciaram as políticas nacionais (Ferreira 2012, p.143).

Segundo Viola (1987), a repressão do regime militar aos movimentos sociais "tornava quase heroica qualquer organização autônoma da sociedade civil que não agisse sob o 
guarda-chuva da Igreja Católica" (p.88). O grande mérito dessas associações foi iniciar o processo de sensibilização da opinião pública em relação aos problemas ambientais causados pelo desenvolvimento industrial (Menezes 1997, p.80).

Apesar do crescimento do movimento, o alcance do ambientalismo, em termos de influenciar políticas públicas, ainda era essencialmente local (Viola 1987, p.99). A exemplo dos resultados alcançados pela AGAPAN no Rio Grande do Sul, outro episódio em que a influência das organizações locais ficou clara foi o cancelamento da construção de um aeroporto em Caucaia do Alto, região de Cotia, na grande São Paulo, em 1978, para que uma área de Mata Atlântica ficasse protegida (Santilli 2005, p.31).

\subsubsection{Segunda onda - segunda metade dos anos 1970 ao final dos anos 1980}

Viola (1987) entende que somente em meados da década de 1970 começaram a se desenvolver no país o que ele chama de "movimentos ecológicos". O início coincidiria com o governo de Ernesto Geisel, (1974-1979), marcado por uma gradual abertura política e "o consequente afrouxamento dos controles estatais sobre a (...) sociedade civil” (p.80).

Nesta fase, o movimento ambientalista se fortaleceu a partir de uma série de fatores. A Lei da Anistia, de 1979, permitiu que intelectuais voltassem do exílio, trazendo ideias, especialmente da Europa, influenciando e oxigenando os movimentos sociais brasileiros (Viola 1987, p.83). A abertura política se intensificou, com eleições diretas para governadores e para o Parlamento em 1982.

O cenário se tornava mais favorável para o estabelecimento de organizações da sociedade civil e uma significativa parcela do movimento ambientalista começava a se envolver com questões de política partidária, lutando para eleger seus representantes nos legislativos e executivos municipais, estaduais e federal, especialmente nas eleições de 1982, 1985 (prefeitos e vereadores) e 1986.

Dentro desse contexto, em 1986, é fundado o Partido Verde, por um grupo com ambientalistas como Fernando Gabeira, Alfredo Sirkis e Carlos Minc, dentre outros. O PV, embora nunca tenha se tornado um partido grande, sempre teve assentos no Parlamento, e chegou a ter em suas fileiras a ex-ministra do Meio Ambiente Marina Silva, que se candidatou a presidente pela legenda em 2010, obtendo quase 20 milhões de votos. No ano seguinte, Marina sairia do partido.

Em 1986 surge a SOS Mata Atlântica, a primeira entre as organizações que se enquadram no objeto de estudo desta pesquisa, as grandes ONGs ambientalistas. Santilli (2005) recorda que a SOS, fundada por ambientalistas como Fábio Feldman, João Paulo Capobianco e Roberto Klabin, dentre outros, tornou-se rapidamente uma organização 
influente, contribuindo para a criação do Conselho de Meio Ambiente (CONSEMA) e da Secretaria de Meio Ambiente do Estado de São Paulo, também em 1986 (p.30).

Outro importante aspecto que marcou os anos 1980 foi a conexão entre ambientalistas e povos da floresta, no contexto de uma Amazônia ocupada de forma predatória por meio de projetos de colonização e obras de infraestrutura pouco ou nada debatidos com a sociedade, incentivando a pecuária extensiva e a concentração de terras (Monteiro 1981, pp.23,44). Alberto Tavares, diretor da Companhia de Desenvolvimento de Serviços Ambientais do Estado do Acre e ex-coordenador do escritório do WWF-Brasil em Rio Branco $(A C)$, em entrevista para esta pesquisa ${ }^{55}$, caracteriza a importância desta coalizão:
A aliança dos Povos da Floresta, nos anos 1980, é um marco do encontro do movimento social com as ONGs ambientalistas e a academia com objetivo de dialogar e alertar governos municipais, estaduais e federal em relação aos direitos dos povos da floresta. Não havendo ressonância nos governos brasileiros, as ONGs internacionais viabilizaram a mensagem no exterior, no âmbito do Bird, BID e do Senado americano. Um exemplo disso é a figura de Steve Schwartzman e do EDF, que tiveram papel importante nesse processo, abrindo portas e microfones para Chico Mendes se posicionar em fóruns de alto nível - articulou agendas para Chico Mendes ir aos Estados Unidos, falar no Banco Mundial e com lideranças locais. O EDF tem um perfil forte de lobby e advocacy. Inseria as pautas na mídia americana quando a mídia brasileira não tinha essas pautas.

Assim, com a fase de redemocratização, iniciada no final dos anos 1970 e concluída com a Constituição de 1988, ocorre a primeira oportunidade política que possibilitou o crescimento e um certo protagonismo por parte do movimento ambientalista no cenário político nacional (Alonso et al 2007, pp.159-160), não apenas no Sul e no Sudeste, mas também em outras regiões do país.

A outra oportunidade política citada por Angela Alonso e colegas, que criou condições para o avanço do ambientalismo no Brasil, foi a própria Constituinte. Inicialmente, por conta dos espaços participativos abertos no processo de elaboração da Carta Magna, como as subcomissões, cujos temas poderiam ser propostos pela sociedade, e as emendas de iniciativa popular, que requeriam apenas 30 mil assinaturas para serem apreciadas pelo parlamento (p.161). Segundo os autores,

\footnotetext{
${ }^{55}$ Entrevista concedida em 19 de agosto de 2015
} 
a EOP [Estrutura de Oportunidades Políticas] da Constituinte foi decisiva na formação do movimento ambientalista na medida em que consolidou vínculos e compromissos entre grupos de ativistas. A existência de um inimigo comum e a necessidade de encontrar aliados forçaram os grupos a suplantar suas diferenças. (p.163)

O frame do socioambientalismo, que considerava as necessidades dos hábitats, ecossistemas, fauna, floras, e a conservação dos recursos naturais, mas que dava igual ou maior importância às comunidades inseridas nos ambientes naturais, se fortalece nesta fase (Alonso et al 2007, pp.159-160; Santilli 2005, p.34), especialmente no contexto da nova Constituição. Em um país com tantas desigualdades socioeconômicas, proteger plantas e espécies ignorando a necessidade de inclusão social poderia gerar repercussões negativas para as organizações.

É também neste período que os movimentos, pela primeira vez desde sua criação, começam a influenciar a política nacional. Em registro do dia 10 de agosto de 1986 em seu diário, Paulo Nogueira-Neto, que passava a coordenação da SEMA para Roberto Messias Franco, deixa claro que as ONGs ambientalistas já "incomodavam":

Critiquei a proposta do Roberto, de transferir Estações Ecológicas para os Estados. Expliquei que isso somente seria possível através de lei, e que esta não seria aprovada devido à oposição dos parlamentares e movimentos conservacionistas (2009, p.98).

3.2.3. Terceira onda - final dos anos 1980 e anos 1990

Em 1987, o relatório Brundtland, da ONU, reforça o aspecto da amplitude global das questões ambientais, lançando o conceito de desenvolvimento sustentável. O movimento ambientalista brasileiro segue em ritmo de crescimento. Em 1988, ano da promulgação da Constituição - cujos capítulos ambientais tiveram participação de ONGs ambientalistas em sua elaboração - a The Nature Conservancy (TNC), entidade norte-americana, abre representação no Brasil, com projetos voltados para a conservação dos ecossistemas.

Em 1989 a Amigos da Terra se instala no Brasil e, no ano seguinte, a Conservação Internacional $(\mathrm{Cl})$, ambas de origem norte-americana e que trazem consigo grande respaldo científico. Também carregam a expertise, amplamente desenvolvida nos EUA, de influenciar políticas públicas por meio de lobby calçado em conhecimento técnico-científico.

Em 1990 surge uma importante ONG brasileira, que também ganharia protagonismo no cenário ambientalista nacional, capitaneada pelos cientistas Adalberto Veríssimo, David McGrath e Paulo Barreto: o Instituto do Homem e de Meio Ambiente da Amazônia (IMAZON), que se autodenomina "um instituto de pesquisa aplicada e multidisciplinar com o 
objetivo de estudar e buscar soluções para os problemas cruciais de uso e conservação dos recursos naturais na Amazônia" 56 .

O final da década de 1980 e o início dos anos 1990 são marcados pelo substancial aumento na quantidade de ONGs ambientalistas estruturadas e pela profissionalização do movimento ambientalista brasileiro. O perfil de luta, voluntariado e denúncia perde força e começa a dar lugar a organizações maiores e mais profissionalizadas, com atuação fundamentada na ciência (Viola 1987, p.90; Menezes 1997, p.88). O movimento ambientalista, tal qual é conhecido hoje, começa a adquirir forma nesse período.

Ao longo dos anos 1990, novas organizações surgem ou passam a trabalhar no Brasil: em 1991, no Mato Grosso, surge o Instituto Centro de Vida, com foco nos biomas Amazônia e Cerrado. No ano seguinte, o Greenpeace - embora já desenvolvesse campanhas no Brasil - abre escritório no país. O Instituto Socioambiental - que esta pesquisa constatou ser uma das mais atuantes organizações no Brasil — é criado em 1994, por ambientalistas de peso como Carlos Frederico Marés, Eduardo Viveiros de Castro, João Paulo Capobianco, Juliana e Márcio Santilli, Mário Mantovani, Ricardo Arnt, Sérgio Leitão e Steve Schwartzman, dentre outros.

O Instituto de Pesquisa Ambiental da Amazônia (IPAM), responsável por importantes projetos de campo e estudos científicos, abre as portas em 1995, assim como o IMAFLORA, organização mais conhecida por projetos de certificação e manejo florestal, com sede em Piracicaba (SP). O WWF-Brasil abre em 1996, e se tornaria a maior organização ambientalista do país em termos de orçamento. Desde 1971 - 25 anos antes da abertura do WWF-Brasil - a Rede WWF já desenvolvia projetos no Brasil, mas sem um escritório local. Assim, ao final dos anos 1990, o país já tem uma robusta rede de organizações ambientalistas, com crescente importância no cenário político e "fortes capacidades científica, analítica e política" (Mittermeier et al 2005, p.18).

As alianças com os movimentos sociais, iniciadas na década de 1980, têm prosseguimento nesse período. Com o assassinato de Chico Mendes em 1988, os olhos brasileiros e estrangeiros se voltam para a Amazônia. Segundo Santilli (2005), essas coalizões entre ambientalistas e integrantes dos movimentos sociais foram as grandes responsáveis pelo surgimento do socioambientalismo no Brasil (p.31).

De acordo com Steve Schwartzman, entrevistado em 21 de janeiro de 2015, um dos grandes diferenciais do ambientalismo brasileiro, em comparação com o norte-americano, são as fortes conexões de importante parcela das ONGs brasileiras com movimentos

\footnotetext{
${ }^{56}$ Fonte: Site do IMAZON (http://imazon.org.br/institucional/fundacao/), acesso em 7 de dezembro de 2015.
} 
sociais, aí incluídos indígenas, extrativistas, ribeirinhos, atingidos por barragens e outras categorias, fenômenos especialmente na região amazônica.

A luta não era tanto para criar espaços protegidos de natureza selvagem. A grande inovação do movimento socioambientalista brasileiro são as alianças com organizações indígenas, populações extrativistas, por meio de organizações como ISA, IPAM, IMAZON e WWF. Essas organizações perceberam que a defesa do território feita por esses grupos se confunde com a própria defesa da Amazônia. Foi feita uma rede de alianças.

A Rio 92 também foi um importante marco para o fortalecimento do ambientalismo brasileiro. De acordo com Alonso e colegas (2007), o frame do neoconservacionismo, que engloba organizações preservacionistas, conservacionistas e socioambientais, se consolidou durante a conferência ocorrida na capital fluminense. Assim, as redes e coalizões, iniciadas na EOP da Constituição, se fortalecem sobremaneira na Rio 92, outra importante oportunidade política para o ambientalismo nacional (p.165).

Dois momentos marcantes da conferência Rio 92 tiveram enorme impacto para o movimento ambientalista brasileiro:

- a Agenda 21, documento assinado por 179 países participantes, que definia, dentre outras questões, que os processos de governança ambiental por parte dos países signatários seriam mais participativos, fazendo com que governos abrissem espaços à sociedade civil, e

- o Fórum Global, espaço de discussões de importantes temas ambientais, com a presença de cerca de 25.000 representantes de governos e organizações ambientalistas, dos quais 4,5 mil eram do Brasil (Little 2003, pp.15-16; Oliveira 2012, p.49).

Paulo Moutinho, diretor-executivo e pesquisador-sênior do IPAM, em entrevista para esta pesquisa ${ }^{57}$, acredita que a Rio 92 tenha sido um divisor de águas para o ambientalismo nacional:

O Brasil se colocou na pauta ambiental mundial, houve um contato com o movimento da Europa e dos EUA. Foram criados programas e secretarias de meio ambiente nos estados e municípios, vimos uma profusão de ONGs reivindicatórias, com poder de influenciar políticas públicas.

\footnotetext{
${ }^{57}$ Entrevista concedida em 10 de agosto de 2015.
} 
O PPG-7, discutido com maior detalhamento na seção anterior deste capítulo, também possibilitou, a partir de 1994, e de forma mais intensa a partir de 1997, com sua plena implementação, uma maior atuação das ONGs ambientalistas, no sentido de se tornarem parceiras do Estado na implementação de políticas. Para Castro Júnior e colegas (2009), nos anos 1990 as ONGs ambientalistas brasileiras tiveram "atuação direta na política de Estado, sendo reais instrumentos de governos na política ambiental" (p.51), com maior oferta de financiamentos nacionais e internacionais (Hochstetler et. al. 2007, p.129).

De fato, conforme visto na seção anterior deste capítulo, a segunda metade dos anos 1990 e a primeira dos anos 2000 assistiram à formulação e à aprovação de diversas peças de legislação fundamentais à proteção do meio ambiente. Vários dos ambientalistas entrevistados para esta pesquisa entendem que, tanto no segundo mandato do presidente Fernando Henrique como no primeiro mandado do presidente Lula, havia espaço para a participação do movimento ambientalista, que influenciou com maior intensidade as políticas públicas nos dois períodos ${ }^{58}$.

Também foi a opinião da grande maioria dos ambientalistas entrevistados que esse espaço se ampliou na gestão de Marina Silva, fase que pode ser claramente identificada como uma importante oportunidade política para a atuação das ONGs. Representantes das organizações tinham a chance de influenciar como insiders, ocupando cargos-chave no MMA, e como outsiders, sendo frequentemente chamados para conversar ou participando de conselhos criados ou fortalecidos àquela época. O período em que a líder acriana comandou o MMA foi classificado por Raul Valle, advogado ambiental que entrevistei, como a "primavera da participação e da influência", conforme citado anteriormente.

Thomson (2014) comenta que importantes medidas ambientais foram tomadas pelo Executivo Federal nos anos 2000, especialmente durante a gestão de Marina Silva à frente do MMA, incluindo melhorias no monitoramento e na fiscalização do desmatamento e outras infrações, restrições ao crédito para responsáveis por atividades predatórias ou ilegais, regularização fundiária, criação de UCs e outras medidas (pp.83-84). Também houve uma série de políticas em nível estadual como planos de redução de desmatamentos e metas

\footnotetext{
${ }^{58}$ Também no quesito criação de UC, importante parâmetro para verificar o compromisso com questões ambientais, os dois presidentes se destacam. Enquanto Fernando Henrique Cardoso foi o presidente que criou mais unidades de conservação (81 contra 77 de seu sucessor), o governo de Luiz Inácio Lula da Silva foi o campeão em termos de área transformada em UCs (26,8 milhões de hectares contra 20,8 milhões de seu antecessor) (Bragança 2014). Quando a comparação se dá entre ministros, Marina Silva é campeã absoluta, com 62 novas UCs. A questão ganha relevância quando se leva em conta que a permanência de Marina foi mais curta que a de Izabella Teixeira, independentemente do tempo que a atual ministra ainda permaneça no cargo.
} 
para diminuir emissões de gases de efeito estufa, muitas delas formuladas e implementadas via parcerias com ONGs ambientalistas.

A atuação no sentido de influenciar políticas públicas por meio de coalizões também foi um traço comum no movimento a partir dos anos 1990, com continuidade nos anos 2000. Segundo Alonso e colegas (2007), eram "redes de ativismo policêntricas e horizontais" (p.166), e teriam como exemplos Rede Mata Atlântica (criada em 1992), Rede Cerrado e GTA (1992), Aguapé-Pantanal e Rede de Educação Ambiental (2002).

Outra característica marcante no movimento, a partir do final da década de 1990 , foi a crescente especialização e profissionalização das organizações, tendência que não mais se reverteria. O jogo político, cada vez mais disputado, não dava lugar para o amadorismo. Os processos de tomada de decisão envolvendo questões ambientais contêm variáveis de crescente complexidade, demandando embasamento técnico, científico e jurídico dos atores envolvidos, como discutido em páginas anteriores desta tese. Embora bastante úteis para a mobilização da sociedade, as organizações de base voluntária, sem staff remunerado e sem uma estrutura administrativa, perdem espaço no sentido de influenciar políticas.

Paulo Moutinho, na entrevista para esta pesquisa, salientou que os financiadores das organizações não governamentais brasileiras deixaram de ser doadores informais e passaram a cobrar uma série de contrapartidas, como projetos bem elaborados, com metas claras e indicadores de performance, além de departamentos administrativo e financeiro para assegurar a correta utilização dos recursos e uma minuciosa prestação de contas. "Há, então, uma profissionalização, uma maior busca por informação e trabalho em conjunto, assistimos a grandes ganhos ambientais com a participação das organizações de 2003 para frente", observou.

Ainda segundo Moutinho, esse sistema de financiamento permitiu que um conjunto de ONGs nacionais conseguisse se estruturar, recrutar e manter equipes qualificadas, assegurar a sobrevivência financeira e exercer considerável influência sobre as políticas ambientais no país. "Cresceu então um movimento de ONGs médias como IPAM e IMAZON, capazes de se manter ao longo de décadas e que são competitivas, têm boas ideias, captam, prestam contas, pegam e usam o recurso sem terem risco financeiro e trabalhista", relatou.

As parcerias com grandes empresas e o aumento da presença de empresários nos conselhos deliberativos ou consultivos das grandes ONGs - brasileiras ou estrangeiras também foram fenômenos que se multiplicaram nos anos 2000. Em favor dessas iniciativas, o argumento de que, em um sistema capitalista, nenhuma mudança de grande escala pode 
acontecer se não alcançar o segmento industrial, responsável por relevante parcela dos danos ao meio ambiente.

Os críticos das parcerias corporativas entendem que, ao se aliarem a grandes empresas e, principalmente, ao obter recursos oriundos dessas organizações, as ONGs perdem a capacidade de criticar essas empresas e, principalmente, o modelo de desenvolvimento baseado no consumo e na produção ilimitados. No próximo capítulo, as parcerias do movimento ambientalista com o setor produtivo serão abordadas com maior grau de detalhamento.

\subsubsection{Perspectivas atuais}

Conforme debatido na seção anterior deste capítulo, após a saída de Marina Silva do Ministério do Meio Ambiente, mais notadamente ao longo do governo Dilma Rousseff, houve uma redução dos espaços de participação das ONGs nas políticas ambientais brasileiras. No primeiro semestre de 2015, duas importantes figuras do ambientalismo brasileiro, que ocupavam posições de destaque nas ONGs WWF-Brasil e TNC, Claudio Maretti e Ana Cristina Barros, respectivamente, aceitaram o convite da ministra Izabella Teixeira para ocupar importantes cargos: Maretti, no momento do fechamento desta tese, é presidente do ICMBIO, e Ana Cristina, secretária de Biodiversidade e Florestas do MMA.

Segundo o senador Jorge Viana, em entrevista para esta pesquisa ${ }^{59}$, a indicação de representantes de ONGs ambientalistas sinaliza uma tentativa de reaproximação da ministra com os movimentos. Outros ambientalistas com os quais conversei entendem que WWFBrasil e, especialmente, a TNC, não têm um perfil crítico em relação ao governo, e por isso os dois ambientalistas foram chamados por Izabella.

Roberto Vizentin, na entrevista para esta pesquisa, acha que a presença de Ana Cristina Barros e Claudio Maretti pode contribuir para que as grandes ONGs ambientalistas, que mantêm projetos e convênios com o MMA, fiquem ainda mais acríticas em relação ao Governo Federal. De toda forma, continua o sentimento de insatisfação na grande maioria das ONGs ambientalistas que pesquisei e com cujos representantes conversei, tanto em relação ao Executivo Federal, quanto ao Congresso Nacional. A percepção de que o país passa por um momento de profundo retrocesso em relação às políticas ambientais é a mais comum entre os ambientalistas entrevistados.

Ainda assim, as organizações brasileiras têm conseguido se fazer presentes em veículos de imprensa e mídias sociais, bem como garantir fontes de financiamento que

\footnotetext{
${ }^{59}$ Entrevista concedida em 27 de agosto de 2015.
} 
assegurem a continuidade de seus projetos e campanhas. É importante observar que, ao longo de sua relativamente curta história, o movimento ambientalista brasileiro - que, segundo Nogueira-Neto (2009), cabia dentro de uma Kombi (p.705) - conseguiu alcançar um certo grau de protagonismo no cenário político brasileiro, e se estabelecer como um dos movimentos relevantes dentro da sociedade. 


\section{OS REPERTÓRIOS}

O Dr. Martin Luther King Jr, em suas ações no movimento pelos direitos civis, era ultrajante.

Ninguém no Sul achava que ia dar certo. Mas ao mesmo tempo, Dr. King se encontrava com parlamentares, com o presidente da República. Há como fazer as duas coisas. É preciso saber influenciar de fora para dentro, mas também é preciso trabalhar dentro do sistema.

(Andrew Linhardt, lobista da ONG Sierra Club, em entrevista no dia 15 de janeiro de 2015)

Tanto nos Estados Unidos como no Brasil, um dos trunfos do movimento ambientalista está exatamente na sua diversidade, tanto em termos das linhas de atuação, como em relação aos repertórios utilizados para influenciar políticas, tema central desta pesquisa e objeto de análise deste capítulo. O movimento conta com organizações que buscam mudar o modelo político vigente, com outras mais pragmáticas que conversam com empresas e governos, além de algumas com atuação local que mobilizam comunidades e com outras mais voltadas para táticas de confronto, apenas para citar algumas categorias. Algo que denomino de 50 tons de verde.

A complexidade dos processos decisórios ligados à questão ambiental, frequentemente, demanda abordagens multifacetadas e multissetoriais, envolvendo diferentes táticas, diferentes atores, variando de acordo com o tema discutido, com o contexto político e socioeconômico, bem como com as instituições e os indivíduos envolvidos nas decisões. Observei que o movimento ambientalista atua, tanto em conjunto como isoladamente, utilizando uma gama de repertórios.

Neste capítulo estão elencados os principais repertórios adotados pelas grandes organizações ambientalistas estudadas, no sentido de influenciar as políticas ambientais no Brasil e nos EUA. Ele se baseia em pesquisa bibliográfica, jornalística, em publicações e no site de organizações ambientalistas, bem como nas 82 entrevistas realizadas, nos dois países, com representantes de ONGs, de organizações ligadas ao lobby da indústria e da agricultura, parlamentares e seus assessores, tomadores de decisão no Executivo e no Judiciário, pesquisadores da área de política ambiental e, por fim, em minha vivência de quase seis anos nas áreas de políticas públicas, comunicação e projetos comunitários de desenvolvimento sustentável da ONG WWF-Brasil, entre 2006 e 2012.

Optei por listar, diante das informações levantadas, 11 grandes repertórios, que contemplam cada um uma série de ações, usados para influenciar as políticas ambientais domésticas: (i) lobby no Executivo e no Legislativo; (ii) contribuições técnicas e científicas; (iii) projetos de campo; (iv) presença em espaços institucionais como conselhos, audiências públicas e comitês; (v) atuação de dentro do Estado, com quadros que migram das ONGs para o governo; (vi) alianças e coalizões, tanto com outras organizações como com 
diferentes setores da sociedade; (vii) ações na Justiça; (viii) participação em campanhas eleitorais; (ix) fiscalização, denúncias, protestos e boicotes; (x) comunicação para sensibilizar e mobilizar e (xi) parcerias com grandes empresas.

Não tenho a pretensão de esgotar as ferramentas adotadas pelas grandes organizações ambientalistas, mas sim de listar os principais e mais efetivos meios pelos quais o movimento busca modificar políticas, observados ao longo desta pesquisa. Há, ainda, uma série de situações em que esses repertórios se misturam e são utilizados simultaneamente. Ciente do risco de relatar de forma compartimentada processos que por vezes se integram, optei por dividir o capítulo entre os 11 repertórios acima com objetivo de facilitar a organização dos dados e proporcionar uma leitura mais agradável.

Os repertórios abaixo analisados são utilizados pelas organizações ambientalistas (não apenas por elas, evidentemente) ao longo das diversas fases que compõem o que Lyon (2010) denomina "ciclo de vida das políticas" (p.4), dividido em quatro fases:

1- Desenvolvimento: o tema sobre o qual a intervenção é necessária é identificado, seja por meio da imprensa, de mídias sociais, de manifestações individuais ou coletivas, ou pela percepção de autoridades que lidam com o problema. Nesta fase, as ONGs têm papel fundamental no sentido de expor problemas e contribuir para qualificar a opinião pública.

2- Politização: processo no qual o apoio político é construído para determinada ação. movimento ambientalista pode ter protagonismo também nesta fase, persuadindo figuras estratégicas para levar determinado problema para instâncias políticas como parlamentos, Poder Executivo e tribunais.

3- Legislação: as políticas são formuladas, aprovadas ou reprovadas e, em caso de aprovação, sancionadas ou vetadas. Nesta fase, os grupos ambientalistas colocam em prática as ações de lobby, buscando persuadir os tomadores de decisão envolvidos e, às vezes, contribuem até mesmo para a redação das leis.

4- Implementação: fase que envolve os passos necessários para colocar em prática, monitorar e fiscalizar determinada política. Aqui, também, o movimento ambientalista tem importante papel, pois frequentemente provê meios para o Estado, é o próprio executor ou exerce o papel de fiscal em prol dos interesses coletivos, cobrando de governos e entes privados o cumprimento da lei. (Lyon 2010, p.4), eventualmente via ações na Justiça.

Dentre os repertórios analisados, estão incluídos aqueles mais ligados a métodos institucionalizados, como lobby, participação em conselhos, comitês e audiências públicas, 
ações na Justiça, convênios com o Estado e estudos científicos, até os métodos voltados para o confronto, ou interações transgressoras, de acordo com Mc Adam e colegas (2001), como protestos, atos de desobediência civil e ações diretas. Segundo os autores, nas ações contidas, as partes são reconhecidas mutuamente como atores políticos e, nas ações transgressoras, os atores, os métodos ou ambos não são considerados legítimos por alguma das partes (pp.7-8).

As organizações buscam, normalmente, fazer parte do que Schreurs (2002) denomina "comunidades políticas ambientais", que são grupos compostos por atores com expertise técnica e científica que influenciam o desenho das políticas relacionadas ao meio ambiente (p.21). Assim, quando, por exemplo, a partir de uma ação de lobby lastreada por um estudo científico e milhares de assinaturas em uma petição, representantes de ONGs são recebidos pela ministra do Meio Ambiente para dar contribuições a um projeto de lei, isso significa que aquelas organizações conseguiram ingressar na comunidade política ambiental que definirá aquele assunto, que pode ter, também, integrantes de outras áreas do governo, representantes da indústria e da agricultura e de outros setores da sociedade.

Outra distinção interessante que se aplica à realidade dos repertórios adotados por organizações é feita por Lang (2013), que divide os processos de advocacy ${ }^{60}$ entre institucionais e públicos. A advocacy institucional, segundo a autora, "é a tentativa de influenciar decisões ganhando um status de insider em instituições que iniciam, preparam, legislam ou executam mudanças nas políticas" (p.22 - tradução minha). A prática, amplamente adotada pelas ONGs presentes neste estudo, consiste em influenciar de dentro para fora, por meio das comunidades políticas ambientais descritas no parágrafo acima.

Já a advocacy pública seria a tentativa de influenciar de fora para dentro, engajando o público para pressionar tomadores de decisão. Pode envolver campanhas, boicotes, petições, e-mails, marchas e manifestações (Lang 2013, p.23) e é utilizada por quase todas as organizações aqui pesquisadas. A maioria claramente prefere a opção institucional, enquanto outras têm em seu DNA a mobilização e o protesto como formas usuais de influenciar políticas, mais notadamente, Greenpeace e Friends of the Earth.

\footnotetext{
${ }^{60}$ Neste trabalho optei por manter o termo advocacy no original do inglês, por entender, assim como outros autores que pesquisei, que não há termo na língua portuguesa com idêntico significado. Alguns autores utilizam o termo advocacia, cujos usos no Brasil fazem com que seja entendido de maneira distinta do advocacy da língua inglesa.
} 


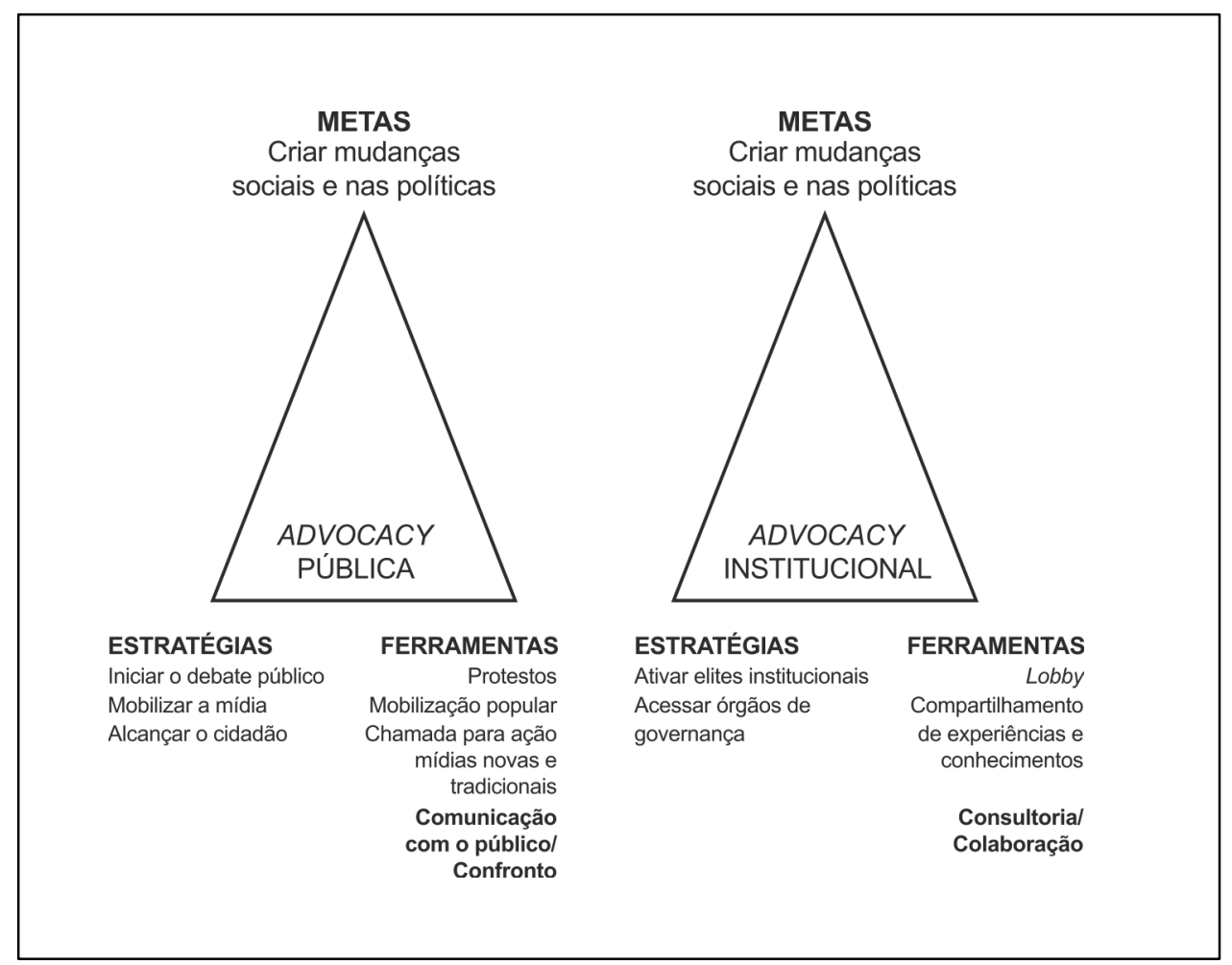

Figura 5: Davi ou Golias? Situando as ONGs na política Fonte: Adaptado de Pettigrew 1990 e Dechalert 1999 (Lang 2013, p. 23 - tradução minha)

Esta pesquisa constatou que, a exemplo do que afirma Lang (2013), as duas formas de advocacy não se excluem e, frequentemente, são utilizadas dentro de um mesmo processo por uma mesma organização (pp.23-24, fig.1). No caso da reforma do Código Florestal brasileiro, por exemplo, claramente as ONGs, após verem que os métodos institucionais não eram suficientes para gerar os resultados esperados, passaram a adotar, simultaneamente e com crescente intensidade, manifestações populares, intervenções por parte de celebridades, petições e campanhas online.

\subsection{LOBBY}

De acordo com Milbrath, citado por Anderson (2015), lobby pode ser definido como "o estímulo e a transmissão de uma comunicação, por alguém que não um cidadão agindo em seu próprio nome, dirigida a um tomador de decisão com objetivo de influenciar sua decisão" (p.58 - tradução minha). Tanto no Brasil como nos Estados Unidos, o movimento ambientalista lança mão do lobby para influenciar tomadores de decisão.

Os primeiros registros de prática de lobby organizado, por parte de organizações ambientalistas, se deram nos EUA nos anos 1950, quando o Sierra Club e a The Wilderness 
Society lutaram no Congresso para evitar que o cânion Echo, em Utah, fosse inundado por uma barragem. A iniciativa foi bem-sucedida. Em 1956, no entanto, outra área natural, o cânion Glen, também em Utah, foi inundado a despeito da oposição das organizações de defesa do meio ambiente (Lee 1995, p.26).

Nos anos 1960, a pressão das organizações ambientalistas, que já mobilizavam pessoas para escrever cartas a congressistas, influenciou a aprovação da lei das Áreas Silvestres (Wilderness Act, 1964), para proteger vastas áreas naturais dos efeitos negativos do desenvolvimento. Em 1967, o lobby do Sierra Club, apoiado por campanhas publicitárias em grandes jornais para sensibilizar a opinião pública e gerar manifestações populares dirigidas aos parlamentares, impediu a construção de outra barragem, desta vez no Grand Canyon. De acordo com Del Mar (2006), um congressista relatou, à época, que a vitória dos verdes foi inevitável, e que desconhecia fúria similar à de um ambientalista determinado (pp.105-106). Ou seja, as ações dos ambientalistas para influenciar legisladores já eram reconhecidas pela sua eficácia e intensidade.

Conforme será visto adiante, a intensidade com que os movimentos utilizam o lobby é diferente nos dois países. Uma distinção primordial está no fato de que a atividade de lobby é regulamentada nos EUA desde 1946 (Haskell et al 2014, p.400), e que no Brasil não existe a regulamentação. Assim, embora seja de conhecimento público que a atividade é amplamente praticada no país, não há regras que definam limites ou diretrizes para a atuação dos lobistas.

\subsubsection{Aspectos legais}

Nos EUA há uma definição legal clara de quais organizações podem praticar a atividade. A maior parte das ONGs ambientalistas se enquadra no grupo de organizações caritativas ${ }^{61}$, que não pagam impostos e, adicionalmente, podem receber contribuições dedutíveis no imposto de renda. Porém, para esses grupos, as atividades de lobby voltadas para influenciar diretamente a decisão de políticos é vedada. Eles podem atuar na educação de parlamentares, mas sem propor diretamente uma posição ou um voto. Essas organizações tampouco podem participar de campanhas eleitorais, no sentido de apoiar ou contraindicar candidaturas.

Porém, a maior parte das ONGs que tem uma forte atuação de lobby e participa ativamente em campanhas eleitorais, cria uma outra organização, em geral de mesmo

\footnotetext{
${ }^{61}$ Também chamadas de organizações 501 c(3), em alusão ao artigo do código tributário que regula sua atuação
} 
nome, mas sob outro regime tributário ${ }^{62}$. Essas entidades pagam impostos e têm a limitação de não poder receber contribuições dedutíveis no imposto de renda, o que dificulta a atração de novos doadores. Mas a atuação no campo político pode ser mais intensa. Sierra Club, NRDC, Greenpeace, National Wildlife Federation, Defenders of Wildlife e a maior parte das ONGs com atuação nos EUA que fazem parte desta pesquisa têm ambos os status, o que flexibiliza suas possibilidades de atuação.

Mancuso e Gozetto (2012) defendem que a atividade seja regulamentada no Brasil, para que o lobby ilícito seja combatido e a atividade se torne mais transparente. Para os autores, a regulamentação "pode contribuir para torná-lo um efetivo instrumento democrático de representação de interesses, desde que seja acompanhada por mecanismos eficazes de fiscalização e punição de eventuais desvios" (p.127).

Além do mais, tornar o lobby uma atividade regular faria com que a população tivesse uma melhor compreensão da atividade e de seu potencial de contribuir para o sistema democrático, permitindo que mais segmentos sociais sejam representados no Executivo e no Legislativo. Como afirmou o senador Jorge Viana (PT-AC), em entrevista para esta pesquisa ${ }^{63}$, lobby no Brasil é considerado um "palavrão", e não é positivo para a democracia que seja visto dessa forma.

Segundo Machado (2011), a atividade de lobby tem um importante papel nos sistemas democráticos, uma vez que "[o]s indivíduos isolados, por mais competentes que sejam, não conseguem ser ouvidos facilmente pelos governos e pelas empresas" (p.107). Em democracias, a interação dos inúmeros grupos de interesse com os tomadores de decisão se torna aspecto indispensável para que as políticas públicas contemplem os distintos segmentos da sociedade.

O lobby dos movimentos ambientalistas, assim como o de outros grupos de interesse, se dirige, via de regra, a integrantes dos poderes Legislativo e Executivo. O lobby ambiental, em virtude da complexidade das questões, muitas vezes tem um forte caráter técnico e científico. Quase a totalidade dos tomadores de decisão com os quais conversei no Brasil e nos EUA - entre deputados, senadores, seus assessores, ex-ministros, presidentes e diretores de órgãos públicos ligados à temática ambiental - afirmou que os números, estudos, pesquisas, artigos científicos e análises levados a eles são de grande utilidade e, frequentemente, levados em conta nos processos de formulação e aprovação de políticas.

\footnotetext{
${ }^{62}$ Essas são as organizações 501 c(4)

${ }^{63}$ Entrevista concedida em 27 de agosto de 2015.
} 
Há, de acordo com Haskel e colegas (2014), duas categorias básicas de lobby, ambas empregadas com frequência pelo movimento ambientalista: o direto, quando um ou mais representantes de organizações conversam diretamente com os tomadores de decisão ou assessores. A outra modalidade é o lobby indireto, quando a organização mobiliza cidadãos, celebridades, autoridades, associações ou especialistas para convencer, via relatos, informação técnica, estudos ou pressões, o tomador de decisão a assumir determinada posição (pp.593-597).

\subsubsection{Mapeamento de atores}

Um passo fundamental para que as organizações obtenham sucesso em ações de lobby é realizar um mapeamento preciso dos tomadores de decisão. A partir das diversas entrevistas com representantes de ONGs, parlamentares e assessores, dividi os atores políticos nas seguintes categorias:

- aliado incondicional, ou champion: políticos considerados ambientalistas, que em $90 \%$ do tempo ou mais agem de acordo com a agenda do movimento ambientalista.

- aliado frequente: políticos que, geralmente, tomam decisões de acordo com as pautas ambientalistas, mas que eventualmente não se alinham com o movimento.

- "em cima do muro": políticos cujas posições variam bastante e são menos previsíveis, costumam atuar de acordo com convicções próprias, pressão de eleitores ou financiadores de campanha, orientação do partido, aliados ou importantes lideranças.

- pouco receptivo: políticos que, na maior parte das vezes, trabalham contra os interesses defendidos pelo movimento ambientalista.

- inimigo da causa: são os políticos que, em mais de $90 \%$ das vezes, atuam contra as causas ambientais. No Brasil, podem ser integrantes da bancada ruralista. Nos EUA, costumam compor as alas mais radicais do Partido Republicano.

Esta categorização se aplica muito mais aos parlamentos, onde pautas ligadas ao meio ambiente são frequentemente discutidas e votadas, possibilitando uma análise mais precisa dos perfis. Assim, a partir da classificação, pode-se planejar melhor as atividades de lobby, definindo o tipo de abordagem para cada parlamentar. Em algumas situações, as organizações optam por não dialogar com alguns políticos, em geral aqueles posicionados nos dois extremos da tabela. Afinal, tanto os aliados incondicionais como os inimigos dificilmente vão mudar suas posições. Por outro lado, os aliados podem ser úteis no sentido de persuadir seus pares que ainda estejam indefinidos ou abertos a mudar de lado. 
Nas entrevistas com parlamentares ou assessores de parlamentares considerados contrários à pauta ambiental, a postura refratária diante do movimento ambientalista ficou clara. Em entrevista para esta pesquisa ${ }^{64}$, o deputado Luiz Carlos Heinze (PP-RS), integrante da bancada ruralista, não poderia ter sido mais claro: "Esses movimentos, que você conhece, tenho posição radicalmente contra. Não admito que aqui dentro do Brasil, tipo WWF, Greenpeace e outras venham fazer pressão com outras intenções, porque eles não fazem isso em outros países". Postura parecida demonstrou o assessor sênior de um deputado (representative) Republicano de um estado produtor de petróleo, entrevistado para esta tese ${ }^{65}$ : "Quanto ao ponto de vista ambiental e os ambientalistas, nós os ignoramos. Não nos importamos com as ONGs ambientalistas. Não nos interessa que eles nos digam algo sobre a moral por trás de se preservar a rena", criticou.

Em outra entrevista ${ }^{66}$, o assessor de uma deputada Republicana de um estado da região central dos EUA, queixou-se de uma suposta radicalização do ambientalismo e da consequência dessa postura:

Os grupos ambientalistas eram vistos como equilibrados. Eles costumavam ser razoáveis. Eles se moveram tanto para a esquerda que quase se tornaram um braço do partido Democrata. Eles não moverão uma agulha no Congresso junto ao partido Republicano.

A situação de polarização política, observada tanto no Congresso americano quanto no brasileiro, faz com que as estratégias de lobby e o mapeamento das tendências dos parlamentares seja ainda mais importante.

Nos Estados Unidos, a League of Conservation Voters (LCV) é uma importante aliada para esse mapeamento do cenário político. A organização elabora, anualmente, o ranking nacional ambiental, que avalia cada parlamentar com notas de 0 a 100, de acordo com os votos dados em matérias de relevância ambiental. A seleção dos projetos de lei e dos votos considerados ambientalmente corretos é feita ao final de cada ano, por um painel composto por representantes de organizações e por pesquisadores. O ranking é amplamente divulgado e disponibilizado em versões online e impressa ${ }^{67}$.

\footnotetext{
${ }^{64}$ Entrevista concedida no dia 10 de junho de 2015.

${ }^{65}$ Entrevista concedida em 23 de janeiro de 2015.

${ }^{66}$ Entrevista concedida em 23 de janeiro de 2015.

${ }^{67}$ Ranking de 2014 disponível em http://scorecard.lcv.org/sites/scorecard.lcv.org/files/2014\%20LCV\%20SCORECARD FINAL.pdf Acesso em 12 de dezembro de 2015
} 


\section{HOUSE VOTES}

KEY

$\checkmark=$ Pro-environment action

$x=$ Anti-environment action

(i) = Ineligible to vote

? = Absence (counts as negative)

\begin{tabular}{|c|c|c|c|c|c|c|c|c|c|c|c|c|c|c|c|c|c|c|}
\hline \multicolumn{19}{|c|}{ ALABAMA } \\
\hline 1 & Byrne & (R) & 0 & 0 & 0 & $x$ & $x$ & $x$ & $x$ & $x$ & $x$ & $x$ & $x$ & $x$ & $x$ & $x$ & $x$ & $x$ \\
\hline 2 & Roby & (R) & 3 & 2 & 5 & $x$ & $x$ & $x$ & $x$ & $x$ & $x$ & $x$ & $x$ & $x$ & $x$ & $x$ & $x$ & $x$ \\
\hline 3 & Rogers, Mike D. & (R) & 0 & 0 & 8 & $x$ & $x$ & $x$ & $x$ & $x$ & $x$ & $x$ & $x$ & $x$ & $x$ & $x$ & $x$ & $x$ \\
\hline 4 & Aderholt & (R) & 3 & 3 & 4 & $?$ & $x$ & $x$ & $x$ & $x$ & $x$ & $\checkmark$ & $x$ & $x$ & $x$ & $x$ & $x$ & $x$ \\
\hline 5 & Brooks, M. & (R) & 3 & 3 & 8 & $x$ & $x$ & $x$ & $x$ & $x$ & $x$ & $\checkmark$ & $x$ & $x$ & $x$ & $x$ & $x$ & $x$ \\
\hline 6 & Bachus, S. & (R) & 3 & 2 & 8 & $x$ & $x$ & $x$ & $x$ & $x$ & $?$ & $\checkmark$ & $x$ & $x$ & $x$ & $x$ & $x$ & $x$ \\
\hline 7 & Sewell & (D) & 77 & 76 & 78 & $\checkmark$ & $\checkmark$ & $x$ & $\checkmark$ & $\checkmark$ & $\checkmark$ & $x$ & $\checkmark$ & $x$ & $\checkmark$ & $\checkmark$ & $\checkmark$ & $\checkmark$ \\
\hline \multicolumn{19}{|c|}{ ALASKA } \\
\hline$A L$ & Young, D. & (R) & 3 & 3 & 9 & $x$ & $x$ & $x$ & $x$ & $x$ & $x$ & $x$ & $x$ & $x$ & $x$ & $x$ & $x$ & $x$ \\
\hline
\end{tabular}

Figura 6: Ranking da LCV, que mostra como deputados se posicionaram diante de questões ambientais. Fonte: Ranking de 2014 disponível em

http://scorecard.lcv.org/sites/scorecard.Icv.org/files/2014\%20LCV\%20SCORECARD_FINAL.pdf Acesso em 12 de dezembro de 2015

Em diversos estados americanos a LCV faz o mesmo ranking com os membros do legislativo estadual. O Sierra Club também realiza esse trabalho em vários estados onde a organização atua. São ferramentas excepcionais para o processo de controle social dos mandatos, sob o ponto de vista ambiental. Alguns assessores de parlamentares do Partido Republicano entrevistados demonstraram incômodo em relação ao ranking da LCV, classificando a iniciativa como radical e inflexível. Dois deles - oriundos de estados produtores de petróleo - afirmaram que, para seus eleitores, quanto mais baixa a nota no ranking da LCV, melhor é considerada a atuação do político.

O modelo criado por Goldstein (1999, p.36) para explicar o processo de tomada de decisão no Legislativo reforça a necessidade do mapeamento dos atores políticos pelas organizações que procuram influenciar os processos políticos. Segundo o autor, se a intensidade do legislador for baixa, a intensidade da participação dos eleitores pode ser um fator decisivo para a decisão que será tomada. Em outras palavras, caso uma parte considerável da base política de um deputado se posicione de maneira incisiva em relação a um tema no qual o deputado não é atuante, provavelmente ele votará de acordo com os 
eleitores. Caso o deputado tenha alta intensidade e discorde dos eleitores, ele levará em conta outros atores para balizar sua decisão (Figura 7).

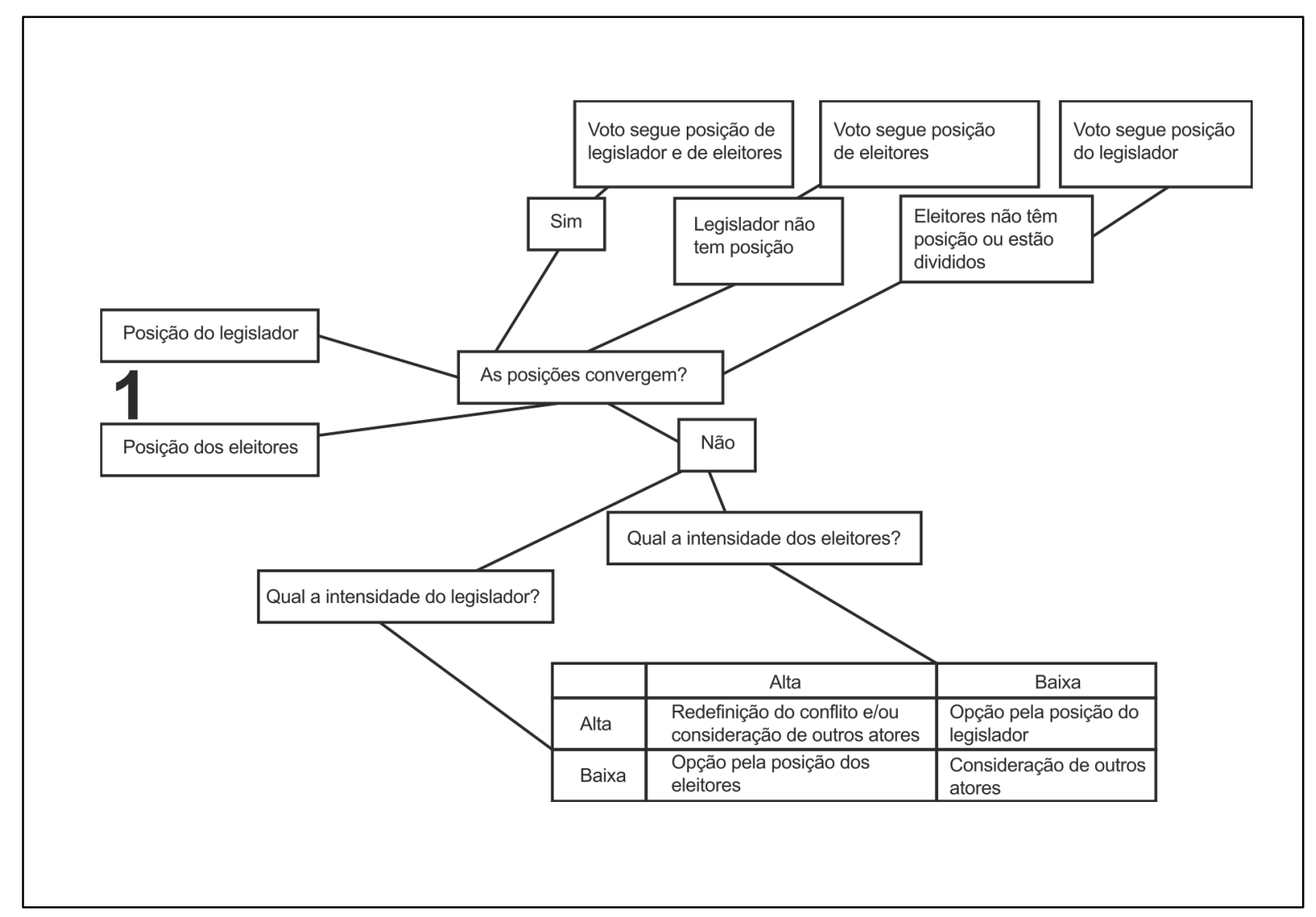

Figura 7: Processo decisório no Legislativo

Fonte: Goldstein 1999, p.37 (tradução minha)

\subsubsection{Lobby indireto}

Outro importante papel desempenhado por organizações ambientalistas no processo de lobby indireto é o de mediador. Não é incomum que as ONGs coloquem o político ou o administrador em contato com as demandas de grupos sociais que, sem esse apoio, teriam dificuldades em levar seus pleitos aos tomadores de decisão. Neste caso, há uma convergência entre as reivindicações das comunidades e da organização ambientalista. Dificilmente, as colônias de pescadores da Amazônia teriam os meios adequados para expressar, em Brasília, seus pensamentos em relação ao seguro-defeso ${ }^{68}$, por exemplo.

\footnotetext{
${ }^{68}$ Política pública que define o pagamento de uma compensação financeira a pescadores durante a época do defeso, quando a pesca de determinadas espécies é proibida para assegurar a manutenção dos estoques pesqueiros.
} 
Igualmente, nos EUA, comunidades indígenas do estado da Dakota do Sul podem ser representadas por organizações socioambientais em Washington para solicitar ao presidente a proibição de se construir um oleoduto que passe pelas terras consideradas sagradas por aquelas etnias. De acordo com o assessor de um deputado federal (representative) da Califórnia, em entrevista para esta pesquisa ${ }^{69}$, o papel desempenhado pelas organizações ambientalistas de conectar grupos sociais com os parlamentares "é muito útil", uma vez que o gabinete não tem condições de organizar esses encontros, mas procura atender aos interesses dessas comunidades.

Dentro de uma lógica similar, outro papel importantíssimo que as organizações norteamericanas têm cumprido - não obtive, nas pesquisas e entrevistas nas ONGs brasileiras, informações de que isso seja feito regularmente no Brasil - é o de promover uma interação continuada entre cidadãos e seus representantes no Parlamento.

Entrevistas com integrantes das organizações ambientalistas norte-americanas revelaram um amplo cardápio de ações no sentido de engajar os eleitores nos processos políticos, agregando maior legitimidade e, algumas vezes, o valioso componente da pressão popular às reivindicações. A petição online - também adotada pelo movimento no Brasil seria a forma mais básica de se atingir este objetivo. Porém, em virtude da impessoalidade desta manifestação, que consiste em uma mensagem pronta, referendada muitas vezes sem grande reflexão pelo internauta e enviada aos políticos pela ONG organizadora, vários gabinetes ouvidos alegaram que, salvo as que contenham número muito expressivo de assinaturas, não recebem muita atenção.

Em diversas ocasiões, as organizações pedem às bases de apoio para encaminhar emails para os gabinetes de parlamentares. Ainda que sejam mensagens prontas e redigidas pela ONG, os assessores já percebem se tratar de uma mobilização um degrau acima das petições, por terem demandado um esforço maior do eleitor.

Mas as outras modalidades demonstram maior sofisticação por parte das organizações, e vêm se potencializando a partir das novas tecnologias. Frequentemente, as ONGs preparam pontos principais para que os eleitores formulem, eles próprios, uma mensagem para o deputado ou senador, ou subsidiam, com informações técnicas, um telefonema do cidadão para o gabinete de seu representante.

Segundo Sara Thomas, estrategista sênior para advocacy digital do WWF-EUA ${ }^{70}$, durante a Marcha Mundial para o Clima, em setembro de 2014, a ONG fez contato com

\footnotetext{
${ }^{69}$ Entrevista concedida em 10 de outubro de 2014.

${ }^{70}$ Entrevista concedida para esta pesquisa em 19 de novembro de 2014.
} 
filiados e ativistas cadastrados de estados com senadores considerados defensores da causa ambiental ou mesmo aqueles "em cima do muro". Foram passadas informações sobre a marcha e sobre a questão climática, juntamente com algumas pautas em discussão no Senado. A ação gerou mais de 1.500 telefonemas de eleitores para seus representantes, passando a mensagem sugerida pelo WWF.

Outra possibilidade, dentro desta mesma linha, é que o cidadão formule uma mensagem para ser publicada nas seções de cartas do jornal ou portal de notícias, na escala local ou mesmo nacional. Durante o evento Hora do Planeta (Earth Hour), organizado mundialmente pela Rede WWF, centenas de cartas de internautas foram publicadas em veículos de comunicação impressos ou online, em várias regiões do país, fazendo com que as mensagens da organização tivessem alcance nacional.

Algumas organizações pesquisadas nos Estados Unidos também promovem reuniões de grupos de eleitores comprometidos com a questão ambiental, filiados às ONGs, com seus representantes no parlamento, levando adiante reivindicações levantadas pelos ambientalistas. Os encontros podem acontecer tanto nos escritórios dos deputados em seus distritos eleitorais ou dos senadores nos respectivos estados, quanto em Washington, D.C.

No Brasil, ações voltadas para estimular o eleitor a entrar em contato com seus representantes acontecem ocasionalmente. No período de debates sobre as mudanças no Código Florestal foram feitos muitos apelos ao público para escrever e-mails a deputados, senadores e à presidente Dilma Rousseff. Há também registros isolados desse tipo de iniciativa, como no caso em que o Greenpeace fez uma campanha - bem-sucedida, por sinal - pedindo ao prefeito de São Paulo, Fernando Haddad, para aumentar o prazo de uma consulta pública a respeito do transporte coletivo na cidade.

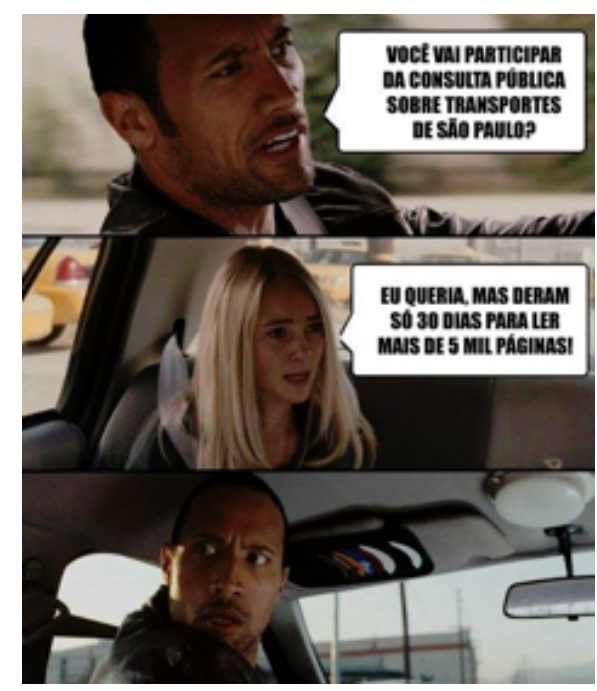

Figura 8: Peça de campanha do Greenpeace Brasil Fonte: Facebook do Greenpeace Brasil, 9/8/2015 


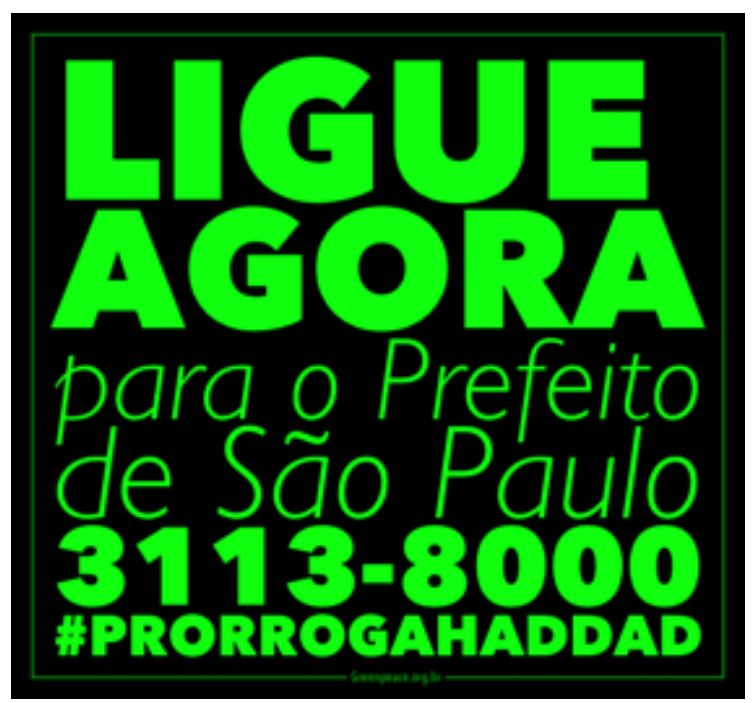

Figura 9: Segunda peça de campanha do Greenpeace

Fonte: Facebook do Greenpeace Brasil, 10/8/2015

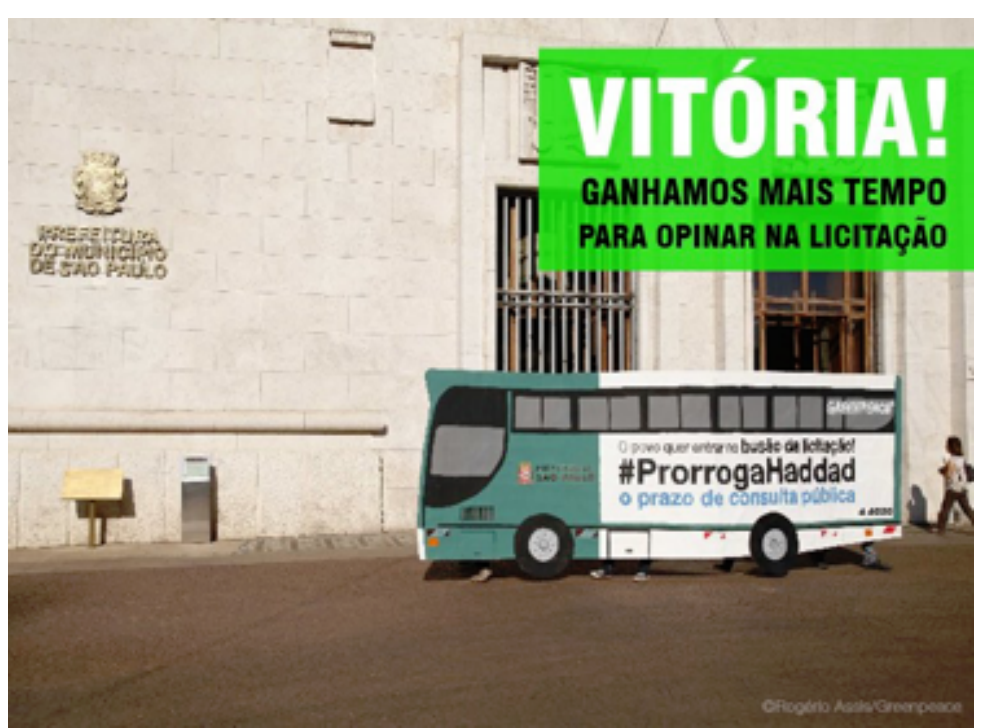

Figura 10: Peça final de campanha do Greenpeace Brasil Fonte: Facebook do Greenpeace Brasil, 11/8/2015

Um dos segredos para o sucesso dessas iniciativas de lobby indireto é o elevado grau de accountability ${ }^{71}$ do Parlamento norte-americano, por uma série de razões. Uma delas, aplicável à Câmara dos Deputados (House of Representatives), é o voto distrital. O fato de a eleição ocorrer em áreas cuja população varia entre 500 mil e 800 mil habitantes, limitadas a

\footnotetext{
${ }^{71}$ Neste trabalho optei por manter o termo original do inglês por não haver verbete que traduza adequadamente seu significado para o português. Segundo Cordeiro (2013), accountability política "está ligada à prestação de contas pelas ações do governo central, dos ministérios e de outros órgãos. Deve ser praticada por políticos e funcionários públicos" (p.5).
} 
distritos eleitorais de dimensões reduzidas, faz com que cidadão e representante estejam próximos, e os mecanismos de cobrança sejam mais efetivos. No caso brasileiro, por exemplo, um deputado federal amazonense pode representar eleitores das cidades de Envira e Parintins, separadas por mais de 1.500 quilômetros.

Adicionalmente, o voto é facultativo nos EUA. Isso faz com que apenas os eleitores mais interessados e preocupados com questões políticas compareçam às urnas (em eleições apenas legislativas, o comparecimento é de aproximadamente 1/3 dos cidadãos habilitados para votar). Em geral, são cidadãos com mais consciência em relação aos processos políticos. Isso, segundo vários assessores parlamentares entrevistados, faz com que o representante ouça atentamente as opiniões dos eleitores que se manifestam. Ou seja, se uma ONG consegue mobilizar um grupo de eleitores dentro de um distrito para reivindicar algo ao seu representante, a chance de que o pleito receba atenção é considerável.

Os mandatos considerados curtos em comparação com outros países - dois anos para deputados e seis para senadores - fazem com que a eleição seguinte sempre esteja próxima, o que aumenta a pressão para que o parlamentar esteja em sintonia com o eleitorado. Todos esses fatores facilitam o trabalho de mobilização da ONG interessada em influenciar o processo, que vai se dirigir apenas aos eleitores do distrito específico do deputado a ser sensibilizado, além de saber que, se for competente o suficiente para convencer o cidadão a se comunicar com seu representante, a possibilidade de um impacto positivo é maior.

O movimento ambientalista também tem o hábito de pedir aos seus aliados dentro do Congresso para que escrevam a chamada carta "caro colega" (dear colleague letter), buscando convencer outros parlamentares a adotar determinada posição. Jessica McGlyn, lobista do WWF-EUA por quatro anos,ressaltou em entrevista ${ }^{72}$ que esse pedido é frequentemente feito aos parlamentares classificados como champions, que se esforçam para convencer outros de que determinada pauta precisa ser aprovada ou rejeitada.

Em muitas ocasiões, um deputado ou senador dará peso maior à comunicação vinda de um par, especialmente se for uma liderança de peso, do que para um pedido de uma ONG ambientalista. Alguns assessores parlamentares entrevistados confirmaram que essa ferramenta pode ser bastante efetiva, e que congressistas mais antigos, presidentes de comissões e líderes de partido costumam influenciar fortemente a decisão de seus colegas.

\footnotetext{
${ }^{72}$ Entrevista concedida em 27 de maio de 2014.
} 


\subsubsection{Celebridades engajadas}

Outra modalidade de lobby indireto bastante comum ao movimento ambiental, nos dois países pesquisados, é o uso de celebridades ou importantes lideranças para sensibilizar tanto a opinião pública quanto tomadores de decisão. A estratégia é denominada grasstops $^{73}$. Nos Estados Unidos, atores como Robert Redford, Sigourney Weaver, Matt Damon, Leonardo DiCaprio e Edward Norton são frequentemente vistos estrelando campanhas para que a população e, em última análise, tomadores de decisão, se posicionem favoravelmente a políticas pela proteção do meio ambiente.

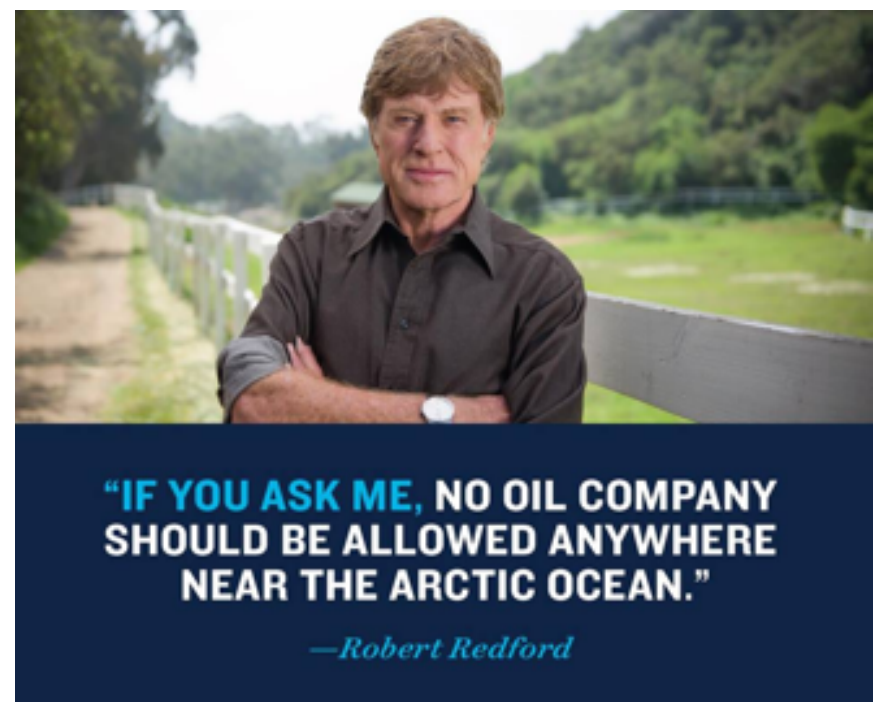

Figura 11: Campanha contra a exploração de petróleo no Ártico Fonte: Facebook da NRDC, 16/7/2015

No Brasil, um caso emblemático em 2012 marcou o envolvimento de celebridades com as questões ambientais. A atriz Camila Pitanga, da Rede Globo, que integra o conselho consultivo da ONG WWF-Brasil, era a mestre de cerimônias de um evento no Rio de Janeiro ${ }^{74}$ com a presença da presidente Dilma Rousseff e do ex-presidente Luiz Inácio Lula da Silva. Após anunciar os presentes, a artista proclamou: "Presidenta, eu vou quebrar o protocolo por um instante, só para te fazer um pedido: veta, Dilma!"75 O pedido de Camila Pitanga consistia no maior pleito do movimento ambientalista brasileiro àquela época: que

\footnotetext{
${ }^{73}$ Trata-se de um termo criado em oposição a grassroots, que consiste em mobilizar as bases. O grasstops denota uma pressão de cima para baixo, a partir do prestígio e da liderança de figuras de destaque na sociedade.

${ }^{74}$ No evento, realizado no dia 4 de maio de 2012, foram concedidos títulos de doutor honoris causa das universidades públicas fluminenses ao ex-presidente Luiz Inácio Lula da Silva.

${ }^{75}$ Vídeo do episódio pode ser acessado em http://tvuol.uol.com.br/video/camila-pitanga-pede-veta-dilma-emcerimonia-oficial-0402CD9C376ECCB92326/ Acesso em 12 de dezembro de 2015.
} 
Dilma Rousseff vetasse o texto do Código Florestal aprovado nas semanas anteriores pelo Congresso.

Também é comum a presença de figuras como Victor Fasano, Christiane Torloni, Marcos Palmeira, Wagner Moura, Gisele Bündchen e Juliana Paes, entre outros, em ações capitaneadas por ONGs ambientalistas.

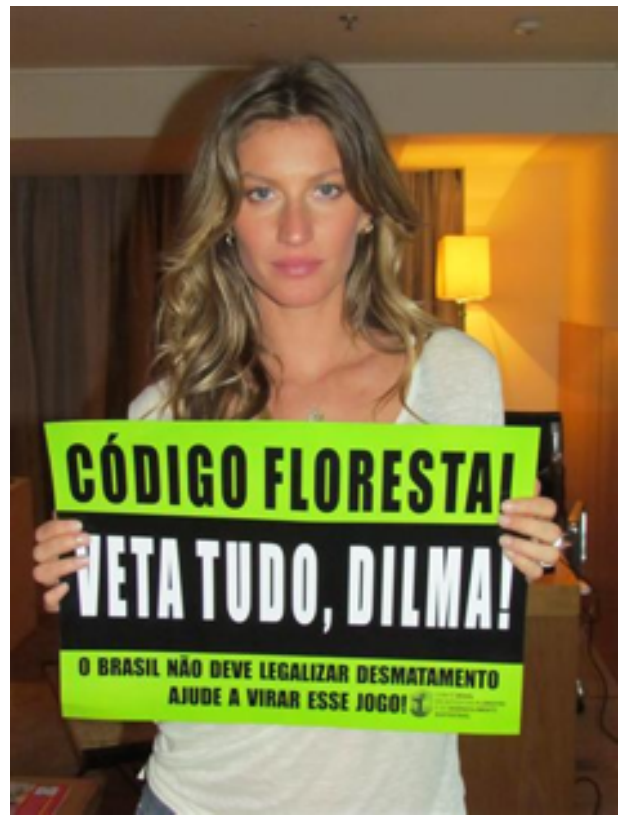

Figura 12: Peça da campanha Veta, Dilma estrelada por Gisele Bündchen em 2012

A estratégia grasstops da organizações ambientalistas também envolve pessoas influentes em outros segmentos, Segundo Wesley Warren, diretor de política e advocacy na ONG NRDC, em entrevista para esta pesquisa ${ }^{76}$, os aliados do movimento podem ser, além de artistas, grandes empresários, militares da reserva e cientistas. Mais de um entrevistado mencionou que os aliados no segmento empresarial são bastante efetivos na comunicação com políticos Republicanos, que normalmente defendem a livre iniciativa e a diminuição do papel do Estado na economia.

Quadro 2: Proposição 65 - a força de Hollywood

Em 1986, foi colocado em votação popular no estado da Califórnia um projeto que proibia o uso, pela indústria e pela agricultura, de diversas substâncias químicas potencialmente causadoras de danos em fetos. Várias ONGs ambientalistas, incluindo Sierra Club, NRDC, EDF e LCV participaram ativamente de uma campanha para a população votar "sim" na consulta popular da Proposição 65. O ativista Tom Hayden e sua então esposa, a atriz Jane Fonda, não só participaram da ação como doaram US\$800 mil para a campanha. Cerca de 40 estrelas de Hollywood, incluindo Robin Williams, Chevy Chase, Whoopi Goldberg e Cher, também aderiram, e percorreram o estado pedindo ao público para aprovar a proposta. A Proposição 65, embora combatida por um forte lobby

\footnotetext{
${ }^{76}$ Entrevista concedida em 15 de janeiro de 2015.
} 
de organizações representantes do comércio, da indústria de alimentos, do agronegócio e de grandes produtores rurais, foi aprovada por $63 \%$ dos eleitores californianos.

Fonte: Libby 1998, pp.91-93; 101

\subsubsection{Moderação versus radicalismo}

Outro aspecto fundamental para o sucesso do lobby é a credibilidade da organização diante dos tomadores de decisão. Segundo o assessor de um senador da Costa Leste americana, se os dados fornecidos pelo movimento se mostrarem incorretos ou imprecisos, dificilmente as organizações conseguirão sucesso no sentido de persuadir novamente um parlamentar. Nesse contexto, as ONGs moderadas acabam levando vantagem sobre aquelas consideradas mais radicais. De acordo com o assessor de um deputado Democrata da Califórnia entrevistado ${ }^{77}$, seu chefe preferirá "nove entre dez vezes, mencionar publicamente as contribuições de ONGs moderadas", por terem maior credibilidade.

Em entrevista para esta pesquisa ${ }^{78}$, Kyle Ash, representante legislativo do Greenpeace-EUA, relatou que o rótulo de organização radical que muitos dão à organização, acaba fechando portas, especialmente no Congresso.

Frequentemente não obtenho respostas de parlamentares para os quais solicito uma reunião. Isso reflete que a cultura norte-americana se torna cada vez menos aberta à desobediência civil. (...) Acho que o Greenpeace, na verdade, não é radical o suficiente. Não somos chamados para audiências no Congresso. O Greenpeace é visto como essa figura polêmica nas correntes políticas dominantes. Acho que nenhum parlamentar vai achar nosso testemunho útil. Os Republicanos, se forem convidar alguma organização ambientalista, vão chamar alguma que seja mais aberta às empresas, que faça parte da corrente dominante, com representantes de terno e cabelo curto. Os Democratas não convidariam o Greenpeace porque não querem ser vistos como um partido radical, e vão acabar chamando alguém do mesmo tipo de ONG que os Republicanos.

O depoimento de Ash — bem como as opiniões dadas por outros entrevistados demonstra que, dependendo da reivindicação feita pelo movimento e dos tomadores de decisão a serem convencidos, as ONGs que têm uma imagem de conciliadoras poderão ter mais sucesso. Em outros aspectos, mais ligados à mudança da opinião pública via

\footnotetext{
${ }^{77}$ Entrevista concedida em 10 de outubro de 2014

${ }^{78}$ Entrevista concedida em 3 de outubro de 2014
} 
denúncias, boicotes e protestos, organizações mais contestadoras, como o próprio Greenpeace, se sairão melhor, conforme será visto mais à frente neste capítulo. Esse cenário reforça a necessidade de o movimento ambientalista ser diversificado, contando com organizações de diversos perfis, com um amplo espectro caracterizado pelo que chamo de 50 tons de verde.

\subsubsection{Comunicação para o lobby}

Um apoio importante para as estratégias de lobby dos ambientalistas, conforme destacado em entrevistas por representantes das ONGs e por tomadores de decisão no Congresso, são as ações de comunicação. Assessores de parlamentares e os próprios deputados e senadores entrevistados afirmaram que temas amplamente divulgados na mídia costumam receber atenção especial por parte dos políticos.

Assim, as ONGs se empenham em conquistar espaços nos veículos de comunicação avaliados como mais estratégicos e influentes. Para isso, equipes qualificadas de jornalistas e profissionais de relações públicas, bem como a disponibilidade de porta-vozes com conhecimento político, técnico e científico dos temas, são fundamentais. Outra estratégia que envolve comunicação é o reconhecimento público dos aliados e o constrangimento público dos opositores.

Para isso, as campanhas em mídias sociais e nos canais oficiais de comunicação das ONGs são cada vez mais utilizadas. Nos EUA, já foi mencionado em páginas anteriores um dos instrumentos que reconhecem o trabalho dos parlamentares que defendem o meio ambiente e expõe aqueles contrários à causa: o ranking feito pela League of Conservation Voters. Mas o movimento vai além. Esta e outras organizações costumam agradecer publicamente os aliados e constranger os "inimigos" por meio de fotos, mensagens e memes ${ }^{79}$ publicados na mídia e, especialmente, nas mídias sociais.

\footnotetext{
${ }^{79}$ Um meme é uma imagem, vídeo ou frase bem-humorada que se espalha na internet como um vírus, de acordo com http://super.abril.com.br/multimidia/memes-682294.shtml Acesso em 3 de fevereiro de 2016.
} 


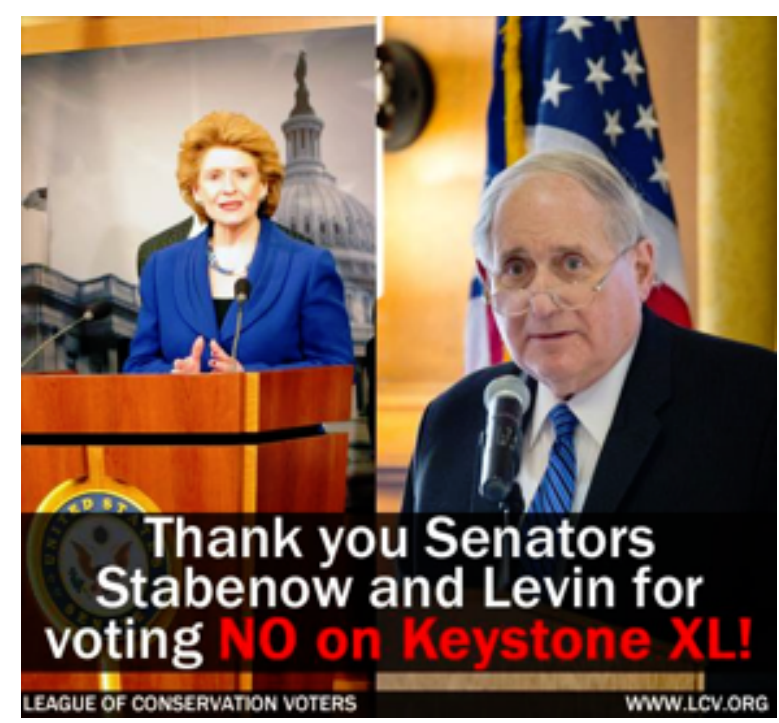

Figura 13: Peça da LCV agradecendo senadores por votarem contra o oleoduto Keystone Fonte: Facebook da LCV, novembro de 2014

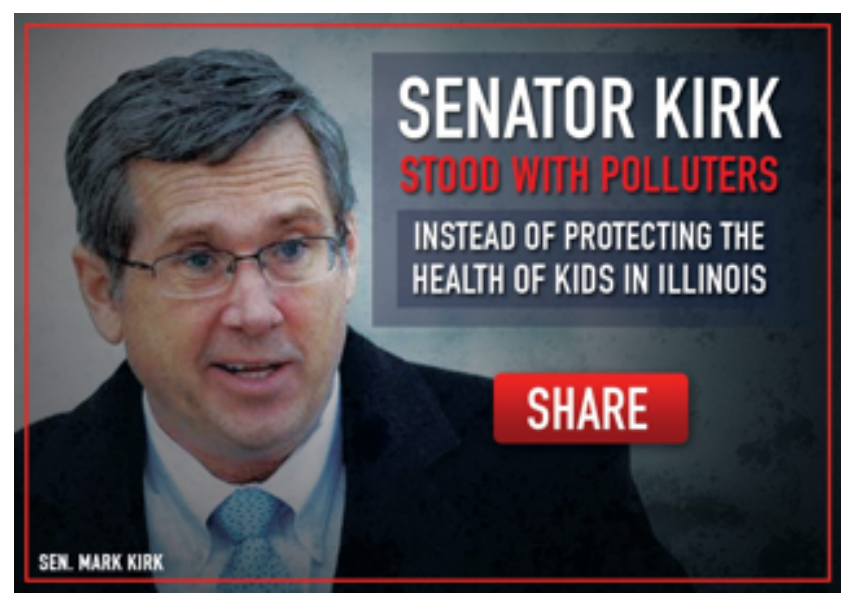

Figura 14: Peça da LCV com critica a senador que votou contra regulação ambiental. Fonte: Facebook da LCV, junho de 2015

No Brasil, embora com frequência menor que nos EUA, há casos em que as organizações ambientalistas também divulgam para o público os nomes de aliados e inimigos. O momento em que isso ocorreu com maior intensidade foi durante as votações do Código Florestal. As ONGs publicaram imagens parabenizando parlamentares contrários ao substitutivo e criticando aqueles que votaram a favor. A coalizão de ONGs ambientais Floresta faz a Diferença lançou, em 2012, a ação "Não Vote em Quem Votou Contra as Florestas", para que os cidadãos não elegessem prefeitos que, quando foram deputados federais, votaram favoravelmente às mudanças na legislação. 


\title{
NÃO VOTE EM QUEM VOTOU CONTRA AS FLORESTAS
}

\author{
*a favor da Lei 12651/12 \\ (novo Código Florestal)
}

Figura 15: Peça da campanha das ONGs que expôs políticos favoráveis às mudanças no Código Florestal Fonte: Comitê Brasil em Defesa das Florestas

\subsubsection{Poder Executivo}

O lobby dirigido ao Poder Executivo também tem bastante força nas organizações ambientais, tanto no Brasil como nos EUA. Ambos têm regimes presidencialistas, com muitos poderes concentrados nas mãos do Executivo. No caso norte-americano, as ações dirigidas à Casa Branca e às agências federais que lidam com o meio ambiente, como a EPA, têm sido amplamente utilizadas, especialmente por duas razões: a dificuldade em se aprovarem leis de proteção do meio ambiente no Congresso, dominado pelo Partido Republicano, e a abertura demonstrada pela administração Obama às pautas ambientais.

Josh Saks, diretor legislativo da National Wildlife Federation (NWF), em entrevista para esta pesquisa ${ }^{80}$, declarou que ele e sua equipe - com sete integrantes que se dedicam exclusivamente ao lobby - conversam "muitas vezes na semana" com o Council of Environmental Quality ${ }^{81}$ : "Durante o governo de George W. Bush era difícil ser convidado por eles. Agora, durante esta administração, tenho dificuldades para que eles me deixem em paz", afirmou de forma bem-humorada, deixando clara a abertura dada ao movimento ambientalista por setores responsáveis pelas políticas ambientais no governo Obama.

\footnotetext{
${ }^{80}$ Entrevista concedida em 22 de janeiro de 2015.

${ }^{81}$ Órgão consultivo da Presidência da República para temas ambientais
} 
No caso brasileiro, conforme visto no Capítulo 3 desta tese, a maior parte das organizações ambientalistas descreve o atual momento como um dos piores da história, devido às extremas dificuldades de se conseguir espaço de atuação, tanto no Legislativo quanto no Executivo Federal. Porém, as tentativas de convencer tomadores de decisão não são interrompidas. No caso do Executivo, frequentemente os ambientalistas buscam interlocutores abertos às contribuições dentro dos órgãos governamentais, como IBAMA e ICMBIO, ou nos níveis estadual e municipal.

Com frequência, o lobby das organizações junto ao Executivo tem o objetivo de pressionar pela implementação das políticas ambientais. Assim, os ambientalistas se dirigem a ministérios, agências, secretarias e órgãos públicos no sentido de propor ações de fiscalização, verba para projetos ou mudanças de rumo em algum programa.

\subsubsection{Atuação descentralizada}

Em países com dimensões continentais como Brasil e Estados Unidos, duas democracias federativas com instâncias decisórias descentralizadas, as ações que buscam influenciar os tomadores de decisão devem ser direcionadas, também, aos poderes Executivo e Legislativo nos níveis estadual e local (municípios, condados ou cidades, dependendo da divisão administrativa existente).

No caso das ONGs norte-americanas, foi possível identificar uma atuação com grande capilaridade. Boa parte das organizações ambientalistas conta com uma estrutura de capítulos, escritórios regionais ou organizações afiliadas em diversos estados. Sierra Club, National Audubon Society, The Wilderness Society, National Wildlife Federation, Ducks Unlimited e The Nature Conservancy, por exemplo, estão presentes em praticamente todos os 50 estados dos EUA. Muitas, como a TNC, chegam a fazer lobby junto aos legislativos de estados, condados e cidades.

A maior parte dessas organizações desenvolve, no nível estadual, o mesmo cardápio de ações de lobby discutido ao longo deste trabalho. Kate Addleson, diretora de conservação do capítulo do Sierra Club no estado da Virgínia, em entrevista ${ }^{82}$, me disse que uma equipe de lobistas atua junto à Câmara e ao Senado estaduais, junto aos órgãos do Executivo e agências reguladoras locais, além de dialogar com os representantes do estado no Legislativo Federal. Adicionalmente, a organização desenvolve um trabalho de treinamento de membros da comunidade para que se tornem "cidadãos lobistas", somando

\footnotetext{
${ }^{82}$ Entrevista concedida em 6 de fevereiro de 2015.
} 
o componente popular ao trabalho de advocacy do Sierra Club em Virgínia, algo também realizado pela ONG em outros estados dos EUA.

No Brasil, não há uma organização ambientalista com presença nacional e atuação nas assembleias legislativas e câmaras de vereadores. Muitas ONGs como WWF-Brasil, IPAM, ISA, Cl e TNC contam com escritórios, em geral espalhados por cidades amazônicas onde ocorrem os projetos de conservação. Em algumas situações - casos de WWF-Brasil no Acre, Cl no Amapá e na Bahia e TNC no Mato Grosso, por exemplo -, as organizações influenciam pontualmente políticas públicas locais, vistas como estratégicas, com competência e efetividade, mas não ocorre o monitoramento e o lobby continuado no contexto das políticas estaduais e municipais.

\subsubsection{A questão financeira}

Em relação ao movimento ambientalista brasileiro, um problema em especial dificulta o acompanhamento das atividades políticas e uma ação de lobby com maior incidência e, consequentemente, efetividade: a dificuldade das organizações em encontrar financiadores para esse tipo de atividade. Assim, uma atividade que demanda - a exemplo do que é feito pelas organizações nos EUA - diversos profissionais acompanhando diariamente as pautas, via de regra é desempenhada por profissionais deslocados de outras funções do dia a dia.

No episódio do Código Florestal ${ }^{83}$, por exemplo, a resposta das ONGs se deu de maneira bastante reativa, quando o texto e as articulações entre o relator, deputado Aldo Rebelo, e a bancada ruralista, já estavam em estágio bastante avançado e as perspectivas de reversão eram reduzidas. Adicionalmente, a impossibilidade de dispor de equipes especificamente de políticas públicas em tempo integral — os salários da maior parte do staff das organizações são vinculados a projetos específicos - é um agravante.

No lado dos opositores, não bastasse ter uma bancada mais numerosa no Parlamento, as equipes de lobistas de entidades representativas do agronegócio e da indústria eram maiores e trabalharam praticamente em dedicação exclusiva à questão, além de terem um volume maior de recursos. Em entrevista com Fabíola Nader Mota ${ }^{84}$, gerente de relações institucionais da Organização das Cooperativas Brasileiras (OCB), órgão que trabalhou pelas mudanças no Código Florestal ao lado da CNA e outras entidades, foi

\footnotetext{
${ }^{83} \mathrm{O}$ relato contido neste parágrafo vem de uma experiência própria, uma vez que atuei diretamente nas discussões do Código Florestal na ONG WWF-Brasil, onde trabalhei entre 2006 e 2012.

${ }^{84}$ Entrevista concedida em 26 de junho de 2015.
} 
possível verificar a impressionante estrutura e o profissionalismo com os quais a instituição atua.

A OCB tem sete profissionais na área de relações institucionais baseados em Brasília e divulga semanalmente uma pauta dirigida aos parlamentares com os principais assuntos em discussão no Legislativo e o posicionamento esperado dos congressistas pela organização. A cada ano, a entidade publica uma agenda com os projetos de interesse em tramitação, declarando apoio, rejeição ou ressalvas. Adicionalmente, a OCB, por meio de suas representações estaduais, comunica-se regularmente com as bancadas de cada unidade da federação, criando uma pressão a partir das bases eleitorais. Em nenhuma das organizações ambientalistas pesquisadas no Brasil algo similar foi observado.

Os entrevistados que fazem ou fizeram parte das ONGs ambientalistas brasileiras pesquisadas, sem exceção, destacaram que as atividades de políticas públicas desempenhadas pelo movimento ambientalista no país são feitas com recursos humanos e financeiros muito aquém do que seria necessário. Embora os orçamentos globais das organizações não sejam baixos, a maior parte do dinheiro vem de grandes fundações, públicas e privadas, ou empresas, que não investem em atividades políticas. "Nenhum financiador quer dar dinheiro para ONG xingar governo e cobrar de deputados", desabafou, em entrevista para esta pesquisa ${ }^{85}$, Maria Dalce Ricas, superintendente da Associação Mineira de Defesa do Ambiente.

No Brasil, os recursos advindos da contribuição voluntária de filiados, que as organizações podem empregar da forma que acharem melhor, sem o engessamento característico do dinheiro repassado a projetos, são muito baixos. Entre as organizações pesquisadas que atuam no país, apenas Greenpeace e SOS Mata Atlântica têm um número de sócios contribuintes superior a 10 mil. Nos EUA, a maior parte das organizações pesquisadas conta com mais de 100 mil filiados, algumas ultrapassando a marca dos milhões. Um hábito difundido entre a sociedade norte-americana é o de contribuir financeiramente para associações, ONGs e fundações, fortalecendo a sociedade civil organizada.

Assim, além de carregarem consigo uma representatividade maior ao negociar com parlamentares e integrantes dos governos, ainda ganham a flexibilidade proporcionada por uma receita livre de amarras, que pode ser aplicada em atividades como lobby e mobilizações.

\footnotetext{
${ }^{85}$ Entrevista concedida em 24 de setembro de 2015
} 
Demorou 14 anos para que o projeto de lei 3.285/92, voltado para a proteção do bioma mais desmatado do Brasil, fosse aprovado no Congresso e sancionado pelo Planalto. A proposta, de autoria do então deputado Fábio Feldmann, um dos mais conhecidos representantes do ambientalismo na história da Câmara, foi modificada diversas vezes e chegou a ser arquivada por pressão de deputados ligados aos setores de energia e agronegócio. A atuação de uma coalizão de mais de 200 ONGs, sob a coordenação da SOS Mata Atlântica, foi decisiva para o avanço da legislação. Foram realizadas inúmeras ações de lobby direto e indireto.

A SOS Mata Atlântica apoiou Fábio Feldmann - que além de deputado, foi um dos fundadores da ONG em 1986 - no processo de redação e defesa da lei em Plenário, e acompanhou de perto, atuando junto aos parlamentares, a tramitação do texto. Paralelamente, foram organizadas ações buscando sensibilizar a opinião pública e, consequentemente, os deputados e senadores (lobby indireto). "Levamos 300 mil desenhos de crianças de escolas públicas para sensibilizar os parlamentares. Celebridades como Marcos Palmeira participaram diretamente e também fizemos várias campanhas publicitárias na internet e em veículos de mídia", recorda Mario Mantovani ${ }^{86}$, diretor de políticas públicas da SOS Mata Atlântica. O projeto foi aprovado na Câmara em 2003 e encaminhado ao Senado, que levou três anos para incluir emendas e votar o texto. De volta à Câmara, a Lei da Mata Atlântica foi aprovado em segundo turno e encaminhado para sanção pelo presidente Luiz Inácio Lula da Silva, em dezembro de 2006. Durante esses 14 anos, o trabalho do movimento ambientalista foi fundamental para o desfecho positivo do processo.

Fonte: Guimarães e Campanili 2012 e depoimento de Mario Mantovani, diretor de políticas públicas da SOS Mata Atlântica.

\subsection{CONTRIBUIÇÕES TÉCNICO-CIENTÍFICAS}

O repertório discutido nesta seção é um daqueles que, conforme observado no início do capítulo, é utilizado em associação ou como suporte para outros repertórios das organizações ambientalistas. A expertise técnica e científica das ONGs, característica presente nas grandes ONGs do movimento ambientalista mundial, frequentemente é o que as credencia a estarem presentes nas chamadas comunidades políticas ambientais (Lang 2013), fóruns dos quais fazem parte os atores governamentais e não governamentais capazes de influenciar as políticas ligadas ao meio ambiente.

As grandes organizações contam com um staff de profissionais qualificados, muitos com doutorados, mestrados e especializações em áreas conectadas ao tema ambiental. Algumas, com viés mais científico, como Conservação International, EDF, IMAZON e IPAM, têm em suas equipes cientistas que publicam regularmente em periódicos científicos de renome.

Essa expertise é um dos principais fatores que fazem com que o movimento ambientalista seja reconhecido como provedor de dados e de informações, o que segundo Maxwell (2010), é o "papel-chave das ONGs no campo das políticas" (p.158 - tradução minha). As pesquisas desenvolvidas ou apoiadas pelas organizações ambientalistas

\footnotetext{
${ }^{86}$ Entrevista concedida em 28 de abril de 2015.
} 
possibilitam a inserção de temas na agenda pública, bem como a definição e a implementação de políticas (Gunter Jr. 2004, p.61).

Embora a academia seja o principal polo gerador de conhecimento científico, as ONGs costumam não apenas produzir um conteúdo próprio, em geral mais adequado às questões práticas com que trabalham, como também fazer a importante ponte entre as universidades e os tomadores de decisão.

De acordo com José Carlos Carvalho, ministro do Meio Ambiente em 2002, em entrevista para esta pesquisa ${ }^{87}$, o movimento ambientalista brasileiro vem dando seguidas mostras de que é capaz de atender às demandas de formuladores de políticas públicas por informação científica qualificada. Ainda segundo o ex-ministro, as contribuições dadas pelas organizações foram fundamentais para a Lei do Sistema Nacional de Unidades de Conservação (2000) e para as peças legais necessárias à regulamentação da Lei de Crimes Ambientais.

Entre tomadores de decisão do Legislativo, as opiniões apontam para a mesma direção. Parlamentares e assessores legislativos entrevistados, tanto no Brasil como nos EUA, ressaltaram a importância dos inputs técnicos e científicos levados pelo movimento ambientalista. O deputado federal NiltoTatto (PT-SP), em entrevista para esta pesquisa ${ }^{88}$, enalteceu o papel de assessoria técnica prestado pelas ONGs, uma vez que os gabinetes precisam lidar com uma variedade de assuntos e, nem sempre, são capazes de levantar informação sobre todos eles.

Nilto Tatto e outros entrevistados, no Brasil e nos EUA, apontaram que as contribuições das organizações têm múltiplas utilidades. Podem demonstrar a necessidade de se colocar um tema em pauta no Congresso, convencer o parlamentar a se posicionar de determinada forma, fornecer argumentos para o político justificar uma posição para seu público ou convencer seus pares a votar a favor ou contra algo e, em alguns casos, até mesmo apresentar o texto pronto para um projeto de lei.

Cabe aqui uma importante ressalva. Como já discutido em outras páginas deste trabalho, os ruralistas, no Brasil, e os Republicanos mais radicais, nos EUA, disseram nas entrevistas que os ambientalistas têm pouco ou nenhum peso em suas decisões. Porém, tanto os políticos "verdes" quanto os considerados "em cima do muro" entrevistados afirmaram (pessoalmente ou por meio de assessores), nos dois países, que dados levados pelas ONGs podem ser extremamente úteis, especialmente em questões ambientais

\footnotetext{
${ }^{87}$ Entrevista concedida em 23 de julho de 2015.

${ }^{88}$ Entrevista concedida em 15 de junho de 2015.
} 
complexas que demandem estudos para comprovar níveis de poluição, contaminação de ecossistemas e impactos ao meio ambiente rural ou urbano, entre outros assuntos.

Para o assessor de um deputado federal (representative) Democrata da Califórnia ${ }^{89}$, as ONGs precisam sintetizar os dados científicos, produzidos na própria organização, advindos de universidades ou centros de pesquisa, e levar ao parlamentar informações novas, um papel que os gabinetes não conseguem fazer.

Robert Buschbacher ${ }^{90}$, coordenador do programa de Conservação da Amazônia da Universidade da Flórida, com 14 anos de trabalho no WWF-Brasil e WWF-EUA, entende que as organizações ambientais mais qualificadas empregam a ciência para definir um problema e, também, para propor um conjunto de soluções. "Com a expertise, os ambientalistas tentam negociar diretamente com os formuladores de políticas, e estar na sala quando os tomadores de decisão estão elaborando as políticas", descreveu.

O conhecimento científico por trás da argumentação das ONGs se torna ainda mais relevante em contextos hostis à manutenção e à ampliação das políticas ambientais, como o panorama atual dos congressos brasileiro e americano, e o Executivo Federal brasileiro. Nesses casos, os argumentos morais em torno da conservação perdem a força e é necessário reforçar os dados e indicadores. Em muitos casos, como em questões ligadas a pagamento por serviços ambientais, criação de áreas protegidas com potencial turístico, conservação de matas ciliares e nascentes, é possível apresentar dados econômicos robustos como justificativa, mas em outros é preciso apresentar sofisticadas - e, frequentemente, caras - projeções baseadas na ciência.

\subsubsection{Contexto histórico}

Segundo Alonso e colegas (2007), foi durante a Assembleia Constituinte de 1988 que o movimento ambientalista brasileiro percebeu que teria maior influência técnica do que política nos processos decisórios. "[O]s ativistas vislumbraram o poder simbólico da expertise técnico-científica que se tornou, daí por diante, sua maneira preferencial de legitimar reivindicações na arena política" (p.162).

Na segunda metade dos anos 1990, medidas bastante polêmicas de proteção ambiental adotadas pelo governo Fernando Henrique, como o aumento dos percentuais de reserva legal e a lei de Crimes Ambientais, precisaram de uma base científica robusta, para que opositores dentro do Governo Federal e do Congresso não conseguissem prevalecer,

\footnotetext{
${ }^{89}$ Entrevista concedida em 10 de outubro de 2015.

${ }^{90}$ Entrevista concedida em 4 de setembro de 2015.
} 
segundo relato de Paulo Barreto, pesquisador do IMAZON"1. "Um artigo que escrevemos para a Folha, com dados do IBGE mostrando a quantidade de áreas subutilizadas pela agropecuária, foi usado pelo ministro da Casa Civil, Pedro Parente, para defender o aumento na reserva legal das duras críticas do agronegócio e dentro do próprio governo", relatou Barreto.

Garfield (2013), em livro sobre a conservação da Amazônia, afirmou categoricamente que a comunidade ambientalista conseguiu protagonismo na missão de proteger a Amazônia, "organizando alegações científicas com dados quantitativos, uma poderosa arma contra a degradação de espécies e o aquecimento global” (p.219).

As organizações ambientalistas tiveram estreita colaboração com o Governo Federal entre 1998 e 2002 para definir áreas prioritárias de conservação no na Amazônia, na Caatinga, nos Campos Sulinos, no Cerrado, na Mata Atlântica e em ecossistemas marinhos, em cumprimento à Convenção sobre Diversidade Biológica (CDB), assinada pelo Brasil em 1992 (Mittermeier et al 2005, p.19). O governo contratou os serviços especializados de várias ONGs, por meio de parcerias ou consultorias técnicas.

Ainda segundo Mittermeier e colegas (2005), as organizações ambientalistas com atuação no Brasil "também auxiliaram a base científica da conservação, frequentemente apoiando o manejo das unidades de conservação, os levantamentos e outras pesquisas em longo prazo, necessários para assegurar uma sólida sustentação científica” (p.18).

Nesse contexto de cooperação técnico-científica, os estados que contavam com lideranças sensíveis à questão ambiental, como o Acre, o Amapá e o Amazonas, se serviram de parcerias com ONGs ambientalistas para levar adiante projetos pioneiros de conservação e desenvolvimento sustentável. Nesses casos, as organizações ambientalistas foram importantes no sentido de emprestar o conhecimento científico para elaborar políticas e programas, bem como para atrair financiadores para essas iniciativas. Essa lógica também se aplicou a alguns municípios brasileiros com prefeitos ou secretários dotados de uma visão mais moderna em relação ao tema ambiental em comparação com a maioria de seus pares.

\subsection{2. "Era da redundância"}

Outro ponto fundamental proporcionado pela crescente expertise técnica do movimento ambientalista foi um aumento na transparência do Estado em relação ao meio ambiente. As ONGs se credenciaram no sentido de, não apenas, contestar informações do

\footnotetext{
${ }^{91}$ Entrevista concedida em 23 de setembro de 2015.
} 
governo, como também de fornecer dados às vezes tão ou mais confiáveis que os números oficiais.

Um exemplo disso são os índices de desmatamento divulgados pelo IMAZON (sistema SAD), baseados em alta tecnologia de imagens de satélite e SIG, que permitem elevada confiabilidade. Não é exagero dizer que os números do IMAZON contribuíram para gerar uma accountability extra para os dados do Governo Federal.

Situação similar é a do Sistema de Estimativas de Emissões de Gases de Efeito Estufa (SEEG), iniciativa do Observatório do Clima $^{92}$ que gera estimativas anuais do total de GEE emitidos pelo Brasil. A medição é feita de acordo com critérios estabelecidos pelo Painel Intergovernamental sobre Mudanças Climáticas (IPCC). Os dados, disponíveis gratuitamente na internet, são divulgados com frequência maior que aquela adotada pelo governo brasileiro.

Segundo Carlos Rittl, secretário executivo do Observatório do Clima, em entrevista para esta pesquisa ${ }^{93}$, as estimativas do SEEG já fizeram com que o Governo Federal, via Ministério da Ciência, Tecnologia e Inovação ( $\mathrm{MCTI}$ ), passasse a divulgar com maior frequência as estimativas oficiais, cujos intervalos mudaram de três para dois anos. O SEEG demonstra que o movimento ambientalista brasileiro está tecnicamente capacitado para gerar mudanças de peso nas políticas ambientais.

De acordo com Paulo Moutinho, diretor do IPAM, em entrevista para esta pesquisa ${ }^{94}$, o domínio das modernas tecnologias pelo movimento faz com que o Estado tenha mais responsabilidade em relação à precisão de dados e informações oficiais. "Estamos vivendo a era da redundância, que quebra a lógica oficial e muitas vezes é melhor que o oficial. Gera mais transparência e dá às organizações mais independência", resumiu.

Quadro 4: O lobo bom

Organizações ambientalistas da área da biodiversidade têm lutado por políticas que promovam a reintrodução do lobo - espécie ameaçada — em áreas silvestres de diversos estados do oeste americano. A ideia sofre oposição de muitos fazendeiros, que temem que seu gado e suas aves sejam devorados pelos lobos. As leis de reintrodução preveem uma indenização paga pelo Estado aos proprietários que tenham animais comidos por um lobo, mas isso não era suficiente para convencer os fazendeiros e, consequentemente, seus representantes no Legislativo. Ainda menos convincente para muitos produtores rurais e parlamentares republicanos é o argumento baseado na importância da preservação da biodiversidade.

\footnotetext{
92 O Observatório do Clima é uma rede com 30 organizações socioambientais com atuação no Brasil, incluindo CI Brasil, Greenpeace, GTA, ICV, IIEB, IMAFLORA, IMAZON, IPAM, ISA, SOS Mata Atlântica, TNC e WWFBrasil (ONGs pesquisadas neste trabalho)

${ }^{93}$ Entrevista concedida em 6 de maio de 2015.

${ }^{94}$ Entrevista concedida em 10 de agosto de 2015.
} 
Mas cientistas da ONG Defenders of Wildlife conseguiram comprovar benefícios indiretos advindos da reintrodução dos lobos, por meio de estudos em localidades onde a experiência foi adotada. As pesquisas demonstraram que, com a presença dos lobos, os cursos d'água eram melhor preservados e a disponibilidade de peixes se multiplicava.

A explicação, embora simples, é engenhosa. Um dos principais responsáveis pela destruição das matas ciliares naquelas regiões eram os alces e os cervos, que por serem espécies consideradas preguiçosas, preferem ficar próximos dos rios para não terem que andar muito para tomar água. Com isso, os animais caminham e pastam sobre a vegetação ciliar, destruindo-a, contribuindo para o assoreamento e o aumento da temperatura das águas e, consequentemente, prejudicando a desova da truta. Os cientistas descobriram que, com a reintrodução dos lobos, os alces e veados não ficavam mais pastando na margem dos lagos — ou seriam devorados - e passaram a circular por áreas mais altas, longe dos lobos. Como consequência, as matas ciliares se regeneraram, a temperatura das águas se manteve estável e a quantidade de trutas, para alegria dos fazendeiros, se multiplicou. Com esses dados, ficou mais fácil convencer fazendeiros e deputados mais resistentes de que os lobos não eram um problema.

Fonte: Depoimento de Tim Aiken, diretor legislativo do gabinete do deputado federal Jim Moran (Democrata de Virgínia) entre 1991 e 2015.

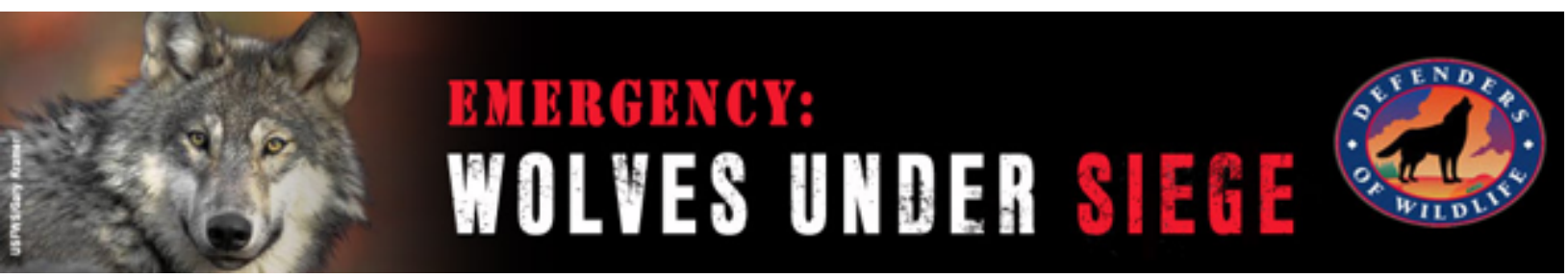

Figura 16: Peça de campanha da Defenders of Wildlife para a proteção dos lobos. Fonte: Site da Defenders of Wildlife

Quadro 5: Desmatamento com recurso público

Em 2008, um estudo conduzido pela ONG IMAZON constatou que diversos empréstimos a juros subsidiados para agricultores e pecuaristas, concedidos por bancos públicos, financiavam o desmatamento ilegal da Amazônia. A pesquisa serviu de base para uma matéria de capa no jornal $\mathrm{O}$ Estado de São Paulo, com a manchete "Crédito oficial facilitou o desmatamento". A reportagem acabou motivando um Termo de Ajustamento de Conduta proposto pelo Ministério Público e assinado por grandes frigoríficos, que se comprometeram a comprar carne apenas de pecuaristas que já haviam iniciado o processo de regularização fundiária de suas propriedades.

Tasso Azevedo, à época diretor do Programa Nacional de Florestas do Ministério do Meio Ambiente, ligou para o pesquisador Paulo Barreto, do IMAZON, pedindo os dados do estudo para uma reunião que teria no dia seguinte com o presidente Luiz Inácio Lula da Silva, o Ministério da Fazenda e o Banco Central. Tasso Azevedo se armou de dados cientificamente comprovados fornecidos pela ONG ambientalista e conseguiu convencer seus interlocutores para que o Conselho Monetário Nacional exigisse a regularização fundiária como condicionante para financiamentos públicos.

Fonte: depoimento do pesquisador Paulo Barreto, do IMAZON 


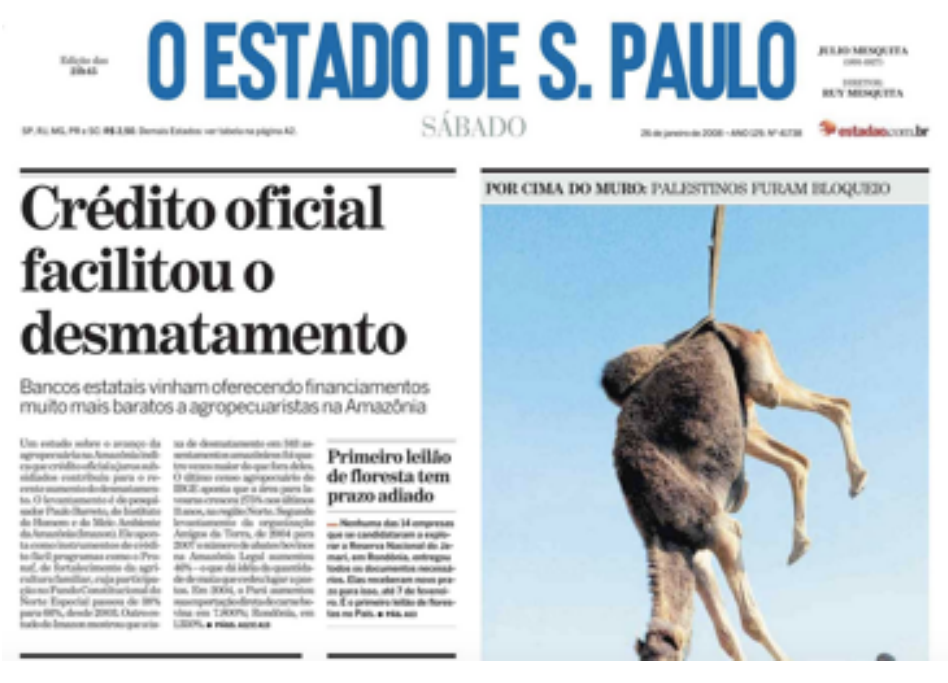

Figura 17: Capa do Estadão de 26/1/2008, com manchete sobre estudo do IMAZON

É importante observar que, tanto no Executivo como no Legislativo, com variações de acordo com o interlocutor envolvido, o movimento ambientalista, no Brasil e nos EUA, conquistou posição de credibilidade nas principais instâncias decisórias. Isso, em grande medida, foi possível por conta do alto grau de profissionalização e especialização das principais organizações que compõem o movimento.

\subsection{PROJETOS DE CAMPO QUE VIRAM POLÍTICAS}

"No começo, poucos acreditaram que a gente ia conseguir pescar de novo nos lagos daqui. Hoje, os lagos estão cheios de peixe e a gente já consegue ganhar uma renda maior com o pirarucu", afirmou em 2010 Geraldo Bispo, pescador no município de Manoel Urbano, no estado do Acre (Taitson 2010). Ele se referia aos resultados de um projeto de campo realizado por meio de parceria entre a colônia de pescadores locais, os governos estadual e municipal, a ONG ambientalista WWF-Brasil e o escritório regional do Ibama, para evitar a extinção do pirarucu ${ }^{95}$ nos lagos da região.

A pesca indiscriminada por pescadores locais e de fora ameaçava a continuidade da espécie naquela área. O projeto estabeleceu acordos de pesca coletivamente construídos, que determinaram a suspensão da captura do pirarucu por três anos, com intensa fiscalização por parte dos próprios pescadores de Manoel Urbano. Os resultados apareceram rapidamente: aumento da população de pirarucus, fazendo com que a pesca

\footnotetext{
${ }^{95} \mathrm{O}$ pirarucu, cujo nome científico é Arapaima gigas, é uma das maiores espécies pesqueiras de água doce do planeta, presente em diversas regiões da Amazônia, fonte de alimentação e de renda para milhares de famílias.
} 
fosse novamente autorizada, e incrementando a renda dos pescadores locais (Taitson 2010). O caso do manejo de pesca em Manoel Urbano ajuda a explicar um dos principais objetivos que envolvem a formulação de políticas ambientais: disciplinar o uso de bens coletivos para que não ocorra a exaustão ou para que o acesso por alguns não impeça que outros utilizem os recursos em questão.

Projetos de manejo de pesca como o acima relatado, desenvolvidos na Amazônia com apoio de organizações como IPAM e WWF-Brasil, deram origem a uma série de políticas públicas. Um dos resultados palpáveis, no caso das iniciativas levadas adiante no Acre, foi a Instrução Normativa no. 1 de 30 de maio de 2008 do IBAMA determinando que apenas os exemplares de pirarucu provenientes de área manejada ou piscicultura poderiam ser pescados, transportados, armazenados e comercializados no estado (Crossa e Oviedo 2011, p.19).

A atuação das ONGs ambientalistas no campo, especialmente no Brasil, tem se mostrado um dos caminhos mais eficazes para mudanças significativas no nível local em prol do desenvolvimento sustentável e de influenciar políticas públicas. Nos Estados Unidos, embora em menor escala que no caso brasileiro, foram observados diversos trabalhos no campo que, ou servem de base para políticas que ampliam seu alcance, ou fazem parte de políticas desenhadas em conjunto pelo Estado e pelos movimentos ambientalistas.

A razão principal para isso, possivelmente, está em deficiências estruturais no Estado brasileiro. Em muitas regiões com situações delicadas em termos de desenvolvimento sustentável -elevados índices de desmatamento e degradação, comunidades tradicionais sem perspectivas econômicas para sobreviver, entre outras - a presença do Estado ainda não se dá de forma plena. Órgãos ambientais federais, estaduais e municipais, frequentemente, estão desaparelhados e carentes de recursos financeiros e humanos. Assim, a presença do movimento ambientalista acaba contribuindo para sanar algumas essas deficiências.

Segundo a ex-senadora e ex-ministra do Meio Ambiente Marina Silva, em entrevista para esta pesquisa ${ }^{96}$, o Estado brasileiro historicamente demonstra

...uma incapacidade do ponto de vista técnico e de recursos humanos [e] as ONGs assumem esse papel. Muitas iniciativas que se transformaram em políticas públicas foram gestadas como experiência piloto no seio de algumas organizações da sociedade

\footnotetext{
${ }^{96}$ Entrevista concedida em 31 de julho de 2015.
} 
civil, do movimento ambientalista, com pouquíssimos recursos e em alguns casos até com recursos externos.

Fisher (1993), em obra sobre o papel do Terceiro Setor para o desenvolvimento sustentável nos países emergentes, coloca algumas razões pelas quais os projetos de campo encabeçados por ONGs ambientalistas têm tamanha influência nas políticas públicas, algo menos visto no caso norte-americano:

O potencial de impacto político de ONGs é maior no Terceiro Mundo do que em países desenvolvidos. Nos Estados Unidos, os governos locais e nacional permanecem como a principal arena política onde as demandas aparecem, assuntos são debatidos e decisões são tomadas, mesmo que organizações voluntárias frequentemente adentram onde os governos têm medo de pisar. Na maior parte do Terceiro Mundo, não apenas governos podem ser pouco efetivos ou corruptos, como também são frequentemente irrelevantes para os principais temas políticos enfrentados pela sociedade ( $p .10)$.

Naturalmente, a análise apresentada por Fisher contém limitações em relação à realidade atual, talvez por ter sido feita há mais de 20 anos. É possível dizer que, tanto o Governo Federal, como a maior parte dos governos estaduais, no Brasil, têm protagonismo em boa parte dos processos decisórios. Ainda assim, é inegável que, em relação às questões ambientais, os aparatos governamentais, embora em condições muito melhores que duas décadas atrás, ainda contam com estrutura, recursos financeiros, humanos e equipamentos muito aquém das demandas por preservação, conservação, uso responsável dos recursos naturais, implementação de UCs e ações de fiscalização, o que cria um enorme espaço para a atuação da sociedade civil organizada.

Os projetos de campo que são tema desta seção variam bastante em alcance. Alguns se restringem à escala local, o que não os torna menos importantes. Outros, acabam subsidiando políticas em nível nacional. Também varia a proporção da participação da ONG ambientalista, que às vezes é protagonista na formulação do projeto, às vezes desempenha a função de captar recursos, fornece o conhecimento técnico e científico necessário, atua na implementação ou faz várias dessas tarefas simultaneamente.

Nos EUA, nitidamente, a maior parte dos projetos de campo das ONGs se dá no apoio a produtores rurais no sentido de promover práticas mais sustentáveis. A National Wildlife Federation (NWF), por exemplo, em parceria com condados e estados, organiza seminários e treinamentos com fazendeiros, com objetivo de disseminar e dar apoio técnico a modelos de produção que economizem água, protejam o solo e, simultaneamente, aumentem a renda e promovam resiliência em relação às mudanças climáticas. 
A NWF também dá apoio a produtores no sentido de acessarem recursos de pagamento por serviços ambientais (PSA) já disponibilizados pelo Estado. As iniciativas podem ser classificadas como influência nas políticas na medida em que a ONG, a partir de experiências bem-sucedidas de produtores que efetivamente passaram a adotar boas práticas produtivas do ponto de vista ambiental, consegue convencer tomadores de decisão, tanto nos condados, como nos estados e em Washington, a aumentar as verbas para PSA ou a criar políticas específicas para determinada cadeia produtiva ou região. Segundo Josh Saks, diretor legislativo da NWF, em entrevista para esta pesquisa ${ }^{97}$, a grande vantagem é que esse tipo de iniciativa sensibiliza políticos Democratas e Republicanos, por se tratar de um mecanismo que incentiva a produção e, ao mesmo tempo, promove conservação.

O Environmental Defense Fund trabalha em direção similar nos EUA. A organização, a exemplo da NWF, desenvolve projetos que incentivam produtores a conservar, envolvendo treinamentos (expertise técnica da ONG) e pagamentos por serviços ambientais, com recursos públicos, privados e da organização (Ruta 2010, p.189). Para viabilizar as iniciativas, são aprovadas políticas públicas que dão escala e multiplicam os resultados.

Com isso, o produtor rural incrementa sua renda, conserva ecossistemas e cria condições favoráveis ao aumento da produtividade; o governo fica mais próximo de alcançar metas de redução de emissões e contribui para a melhoria da qualidade de vida e a nãoexaustão dos recursos naturais; e as empresas, que podem comprar créditos de emissões evitadas pelos produtores, também conseguem se adequar a limites legais de emissões.

Nas entrevistas com representantes de ONGs e com tomadores de decisão do Executivo e do Legislativo ficou claro que a atuação em campo também legitima organizações que buscam influenciar políticas públicas. Nancy Gloman, vice-presidente de campo e conservação da Defenders of Wildlife, me disse em entrevista ${ }^{98}$ que, ao propor uma lei estadual para criar mecanismos de proteção de espécies, sua organização, que trabalha no campo conscientizando produtores rurais, instalando cercas que impeçam espécies selvagens de atacar rebanhos e apoia a implementação de parques e reservas, consegue sentar à mesa com os tomadores de decisão. "Isso ajuda a construir nossa credibilidade e faz com que as pessoas queiram nos ouvir", analisou.

\section{Quadro 6: Programa Intercâmbios de Hábitat}

O Oeste americano abriga diversas espécies de fauna, algumas delas ameaçadas de extinção pela ação humana. A região, por um lado, apresenta grande quantidade de áreas inexploradas e ainda preservadas e por outro, conta com elevada concentração de propriedades rurais. Diante desse

\footnotetext{
${ }^{97}$ Entrevista concedida em 22 de janeiro de 2015.

${ }^{98}$ Entrevista concedida em 9 de janeiro de 2015.
} 
cenário, as ONGs que atuam na área de conservação da biodiversidade concluíram que, sem a participação de produtores rurais, proteger as espécies se tornaria uma missão quase impossível.

O programa Intercâmbios de Hábitat (Habitat Exchanges), desenvolvido pelo Environmental Defense Fund (EDF) em 2014, consiste em treinar, apoiar e remunerar produtores rurais que, em suas propriedades, conservam ambientes propícios para a presença de espécies ameaçadas. A qualidade do hábitat conservado dentro das fazendas é auditada por especialistas das ONGs e por autoridades governamentais, que emitem títulos correspondentes ao tamanho da área.

O pagamento por esses títulos, ou créditos, é feito por empresas responsáveis por projetos de infraestrutura no estado, e faz parte das ações voltadas para mitigar os impactos ambientais causados pelas obras. Assim, a construtora de uma estrada, linha de transmissão ou barragem, paga ao fazendeiro que conservou os hábitats do lobo, da águia ou do galo silvestre. Para que o arranjo seja oficializado, é preciso que passe a ser uma política pública, o que já acontece em estados como Califórnia, Colorado, Nevada e Wyoming. O FWS, agência federal responsável pela lista de espécies em perigo e pelo cumprimento da lei de Espécies Ameaçadas (Endangered Species Act), já reconhece o Habitat Exchanges como iniciativa capaz de contribuir para a preservação da fauna e da flora no país.

Assim, a partir de iniciativas-piloto isoladas, voltadas para capacitar e conscientizar produtores sobre a preservação da biodiversidade, criou-se uma política pública de impacto nacional.

Fonte: Environmental Defense Fund (https://www.edf.org/ecosystems/habitat-exchanges-how-do-they-work)

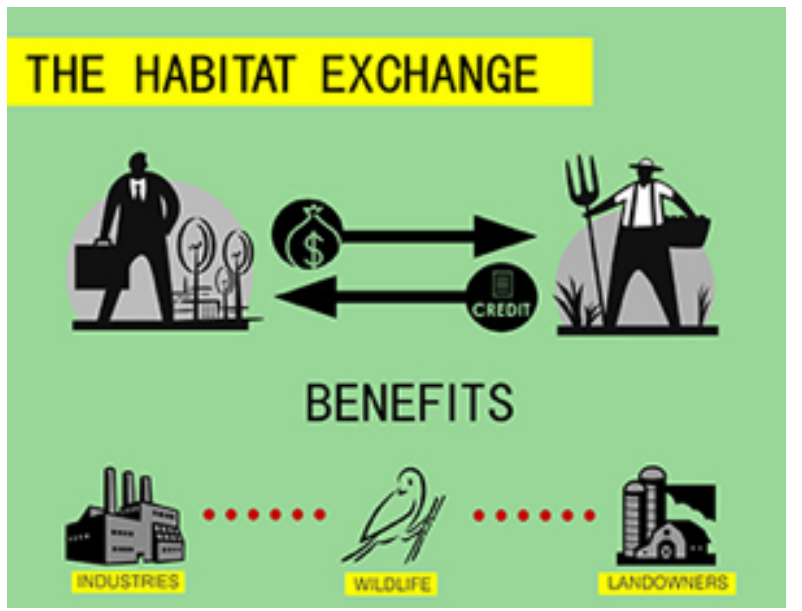

Figura 18: Esquema de funcionamento do programa Habitat Exchange Fonte: Site da EDF, 2014

No Brasil, os projetos de campo respondem por uma parcela ainda mais significativa do portifólio das ONGs ambientalistas que nos Estados Unidos. Praticamente todas as organizações com atuação no Brasil aqui estudadas desenvolvem algum tipo de ação no campo, que frequentemente servem de base para políticas públicas, nos níveis municipal, estadual e federal.

A maior parte dessas iniciativas tem em comum as parcerias com o poder público e, principalmente, o empoderamento de comunidades locais para que elas ajudem a diagnosticar o problema e sejam parte da solução. Wapner (1996) denomina essa estratégia 
de "localismo", e aponta que ONGs como WWF, Cl e TNC a praticam especialmente em países em desenvolvimento (pp.73,74,82).

Inúmeros exemplos da abordagem localista das organizações, redundando em políticas públicas ambientais, podem ser observados no estado do Acre ${ }^{99}$. Em 1999, com a posse de Jorge Viana como governador, o Acre entrou em uma era marcada por múltiplas iniciativas voltadas para a promoção do desenvolvimento sustentável. Grande parte delas viabilizada a partir de parcerias com as organizações da sociedade civil, tanto locais, como SOS Amazônia e PESACRE, quanto nacionais e internacionais, como WWF-Brasil, IPAM, TNC e EDF.

O estado realizou um zoneamento ecológico-econômico (ZEE), que permitiu um planejamento mais adequado das políticas ambientais. Foram criados diversos incentivos econômicos a atividades produtivas sustentáveis, com o objetivo de fixar as comunidades na floresta, promovendo conservação e renda como pagamento do subsídio da borracha e construção, pelo governo do estado, de uma fábrica de preservativos masculinos, para garantir ao seringueiro a venda do látex a preços competitivos; apoio a ações de manejo florestal comunitário, inclusive certificado; construção de uma fábrica de pisos para absorver a produção de maneira explorada com técnicas de manejo florestal; pagamento por serviços ambientais; pagamento de subsídio para a castanha-do-Brasil, além da construção de uma fábrica para processar e embalar a castanha, cuja operação foi repassada a cooperativas de produtores locais.

Nem todas as iniciativas descritas no parágrafo acima são parcerias com organizações não-governamentais, mas demonstram duas importantes questões: o comprometimento da administração estadual com a questão ambiental, algo jamais visto anteriormente no governo do Acre, conforme conversas com diversos atores políticos do estado, mesmo aqueles de corrente política diversa da que governa atualmente, e uma forte presença, baseada na qualificação técnica e no aporte de recursos, do movimento ambientalista.

Alberto Tavares é o diretor da Companhia de Desenvolvimento de Serviços Ambientais do Estado do Acre ${ }^{100}$ e coordenou o escritório do WWF-Brasil em Rio Branco

\footnotetext{
${ }^{99}$ A maior parte das informações sobre as políticas de desenvolvimento sustentável e as parcerias com as ONGs ambientalistas no Acre são fruto de seis anos de minha observação na região, no período entre 2006 e 2012 , quando trabalhei no WWF-Brasil. Embora baseado em Brasília, ia diversas vezes por ano àquele estado, trabalhando diretamente com políticas públicas locais e projetos da ONG voltados para certificação florestal, manejo florestal comunitário e empresarial, manejo de pesca, geração de renda e valorização de cadeias produtivas sustentáveis, muitos deles em parceria com o governo estadual.

${ }^{100}$ Empresa de economia mista, criada por lei estadual em 2010, com objetivo de normatizar e viabilizar técnica e financeiramente os projetos de conservação, credenciando o estado a participar do mercado internacional de créditos de carbono
} 
entre 2007 e 2013. Ele lembrou, em entrevista para esta pesquisa ${ }^{101}$, que a ONG ambientalista realizou estudos técnicos para o ZEE (com participação da TNC) e para a criação de diversas unidades de conservação estaduais, apoiou as políticas de manejo florestal empresarial e comunitário, além de fortalecer diversas organizações do movimento socioambiental local e contribuir para a capacitação de funcionários dos órgãos ambientais do estado.

Juntamente com o IPAM e outras organizações ambientalistas locais, o WWF-Brasil apoiou o governo estadual no desenho do Sistema de Incentivos a Serviços Ambientais (SISA), marco legal que regula a remuneração a produtores rurais, empresas e populações tradicionais por ações que contribuam para a conservação de recursos naturais e ecossistemas. O SISA foi aprovado em 2010 pela Assembleia Legislativa do Acre e consolida uma série de políticas inovadoras de desenvolvimento sustentável do estado, e ajudou o Acre a se posicionar internacionalmente como um dos estados responsáveis por iniciativas subnacionais de conservação, a exemplo da Califórnia e do estado de Chiapas, no México.

No Amapá também foram registradas iniciativas em que a participação do movimento ambientalista foi estratégica para os resultados alcançados. Ana Euler, pesquisadora da EMBRAPA, presidiu o Instituto Estadual de Florestas do Amapá entre 2011 e 2014. Em entrevista para esta pesquisa ${ }^{102}$, ela destacou que alguns governos do estado fizeram parcerias com organizações, locais, nacionais e internacionais, com diferentes resultados.

[A] Conservação Internacional, por exemplo, investiu, em parceria com o governo estadual, na criação e implementação de diversas áreas protegidas. Houve investimentos em cadeias produtivas sustentáveis, com recursos do Walmart, incluindo a elaboração de planos de manejo das UCs. O investimento histórico das grandes ONGs na Amazônia foi no sentido de criar e instalar áreas protegidas, pode-se dizer que essa estratégia foi um sucesso.

Segundo pesquisadores, tomadores de decisão e representantes de ONGs entrevistados, o grande desafio em torno desses projetos-piloto é fazer com que eles saiam da escala apenas local e sejam replicados em outras áreas. "O Acre, por exemplo, deveria

\footnotetext{
${ }^{101}$ Entrevista concedida em 19 de agosto de 2015.

102 Entrevista concedida em 19 de maio de 2015.
} 
ser um piloto para o contexto amazônico, brasileiro ou até outras áreas do planeta, mas infelizmente não é”, analisou em entrevista ${ }^{103}$ Claudio Maretti, presidente do ICMBIO.

Paulo Moutinho, diretor do IPAM, em entrevista para esta pesquisa ${ }^{104}$, observa que diversos projetos-piloto morrem quando as organizações responsáveis deixam o local, seja porque o recurso para a ação não foi renovado, ou porque as prioridades institucionais são mudadas. Ele destaca que a estratégia das ONGs também precisa incluir a criação de políticas e o fortalecimento institucional de movimentos locais, para que possam participar, cobrar de prefeituras e secretarias e manter os projetos em andamento. "O IPAM tem muito essa meta de políticas públicas. Temos restrições em fazer projetos piloto que morrerão quando sairmos da região. As políticas públicas ficam, mesmo sem a gente", resumiu.

O Programa Áreas Protegidas da Amazônia, discutido no Capítulo 3 deste trabalho, é outro exemplo de parceria bem-sucedida entre estado e movimento ambientalista. Em entrevista para esta pesquisa ${ }^{105}$, André Lima, secretário de Meio Ambiente do Distrito Federal, com passagens pelo MMA e pelas ONGs SOS Mata Atlântica e IPAM afirmou que - ARPA é um exemplo de aliança tecnocrática bem-sucedida, com o WWF trazendo expertise técnica e aglutinando recursos financeiros para viabilizar a iniciativa. "Essas grandes ONGs com grande capacidade de aportar recursos humanos e financeiros acabam tendo uma aderência maior dentro do governo", avaliou.

Quadro 7: CAR: Quando projetos locais ganham escala e viram políticas

Apontado como um avanço dentro do novo Código Florestal, mesmo pelos ambientalistas mais descontentes com o texto, o Cadastro Ambiental Rural se consolidou a partir de projetos de campo apoiados pela ONG ambientalista The Nature Conservancy no Brasil. A ideia por trás do CAR é que, para implementar uma política ambiental, o Estado precisa conhecer as propriedades envolvidas em relação a sua extensão, destinação, situação fundiária e proprietário. Algo comparável à Carteira Nacional de Habilitação, demonstrando que o produtor é registrado pelo Estado e atende aos requisitos técnicos e às normas legais para, por exemplo, acessar determinado benefício ou serviço público.

Já estavam em curso, a partir do final da década de 1990, iniciativas de regularização de propriedades rurais nas escalas estadual e municipal, em Mato Grosso, Goiás, Rondônia e Acre. Adicionalmente, a figura do cadastro já estava prevista na Política Nacional do Meio Ambiente, embora não fosse colocada em prática.

A TNC, diante desse volume de experiências ainda desconectadas, ligou os pontos, procurou parceiros públicos e privados, e começou a desenvolver um projeto de cadastro de propriedades rurais em Santarém (PA) e em Lucas do Rio Verde (MT). A organização utilizou a mais avançada tecnologia de SIG disponível e desenvolveu um sistema informatizado para cadastrar os terrenos. A partir do sucesso nas duas localidades, era preciso ampliar o alcance. O cadastro foi aplicado, com bons resultados, em 30 municípios. Adicionalmente, políticas públicas federais como a que que listava os municípios campeões de desmatamento, demonstravam a necessidade do cadastro. Era

\footnotetext{
${ }^{103}$ Entrevista concedida em 28 de abril de 2015.

${ }^{104}$ Entrevista concedida em 10 de agosto de 2015.

${ }^{105}$ Entrevista concedida em 10 de abril de 2015.
} 
preciso, para deixar a lista, que o município reduzisse o desmatamento, mas também estivesse passando pelo cadastramento. Associações de produtores, autoridades municipais e estaduais em outras regiões procuraram o apoio da TNC para regularizar a situação. A iniciativa, testada e aprovada, foi incorporada ao Código Florestal em 2012. O desafio, agora, é sua implementação em escala nacional.

Segundo o pesquisador Christian Brannstrom, os projetos da TNC no Mato Grosso, Pará e Oeste da Bahia representam um bom exemplo da chamada fast policy, quando políticas bemsucedidas são adotadas em outras localidades com problemas similares, beneficiando-se dos erros, acertos e experiências já testadas.

Fontes: Depoimento de Ana Cristina Barros, ex-representante da TNC no Brasil e atual secretária de Biodiversidade e Florestas do Ministério do Meio Ambiente, em 1 de julho de 2014, apresentação feita pelo pesquisador norte-americano Christian Brannstrom ${ }^{106}$.

\subsection{ESPAÇOS INSTITUCIONAIS: CONSELHOS, COMITÊS, COMISSÕES E AUDIÊNCIAS PÚBLICAS.}

Vinte e nove de de janeiro de 2015 era um típico dia de inverno em Washington, D.C. Naquela manhã gelada de quinta-feira, mais de 170 cidadãos compareceram à sede da Environmental Protection Agency - principal órgão federal para assuntos ambientais no país. Aquelas pessoas saíram de suas casas e escritórios para testemunhar em uma audiência pública que serviria de base para os novos padrões de emissões de ozônio de superfície pela indústria americana.

Funcionários da EPA chamavam nominalmente cada um dos cidadãos que se cadastraram - na internet ou ao chegarem ao prédio - para darem seus depoimentos de até 10 minutos sobre impactos da poluição no dia a dia de cada um. Eram mães que se queixaram das constantes crises de asma dos filhos. Professoras falando de crianças terem que deixar as aulas para ir às enfermarias das escolas por problemas respiratórios. Médicos contando sua rotina repleta de idosos e crianças sofrendo com rinite e dores de cabeça. Tudo isso para mostrar que os atuais limites de emissões de gases poluentes não têm sido suficientes para possibilitar uma boa qualidade de vida às famílias norte-americanas.

Também havia, embora em minoria, representantes da indústria dizendo que os padrões atuais devem ser mantidos, pois do contrário, os custos de adaptação seriam muito altos e resultariam em desemprego. Das 174 pessoas que compareceram, a maioria (133) testemunhou em favor de parâmetros mais rigorosos para emissões de ozônio.

Boa parte dos presentes atendeu a apelos de ONGs ambientalistas norte-americanas: a Mom's Clean Air Force, a American Lung Association e, principalmente, o Sierra Club, que organizou uma campanha que envolvia cadastramento de voluntários, sistema de carona

\footnotetext{
${ }^{106}$ Apresentação realizada no 7o. Encontro Nacional da ANPPAS, em 19 de maio de 2015, em Brasília, DF.
} 
oferecida por quem fosse de carro à audiência e até ônibus saindo da sede da ONG para levar pessoas interessadas em testemunhar.

Os limites de emissões vigentes à época - 75 partes por bilhão — foram estabelecidos em 2008, ainda durante a administração Republicana de George W. Bush. Segundo Brian Willis, secretário de comunicação do Sierra Club, o padrão adequado seria de até 60 partes por bilhão, já adotado pela maioria dos países da Europa Ocidental. Em entrevista na sede da $\mathrm{EPA}^{107}$, ele descreveu a estratégia do Sierra Club em relação às audiências:

Buscamos mobilizar o maior número de pessoas para vir aqui e conversar com os funcionários da EPA sobre asma, problemas no sistema nervoso e ataques cardíacos, problemas frequentemente potencializados pelo ar poluído. Boa parte dos esforços em torno do lobby já foi feita. Dissemos várias vezes à EPA que a ciência mostra que 60 partes por bilhão é um limite seguro para proteger a maioria das pessoas, especialmente crianças. Também há a possibilidade de submeter comentários eletronicamente, milhares de pessoas preencheram formulários dizendo à EPA que limites mais rigorosos são necessários. Nossa ideia é que o maior número possível de pessoas envie comentários, tire fotos, converse com repórteres.

A EPA, após colher todos os depoimentos, dessa e de outras audiências em diferentes estados norte-americanos, e analisar a informação científica ao seu dispor, definiu os novos limites em 70 partes por bilhão em outubro de 2015. A medida, diga-se de passagem, desagradou tanto à indústria quanto aos ambientalistas (Daly 2015) e pode ser caracterizada como a solução de meio termo frequentemente adotada por tomadores de decisão quando grupos de interesse opostos conseguem expor seus pontos de vista.

${ }^{107}$ Entrevista concedida em 29 de janeiro de 2015. 


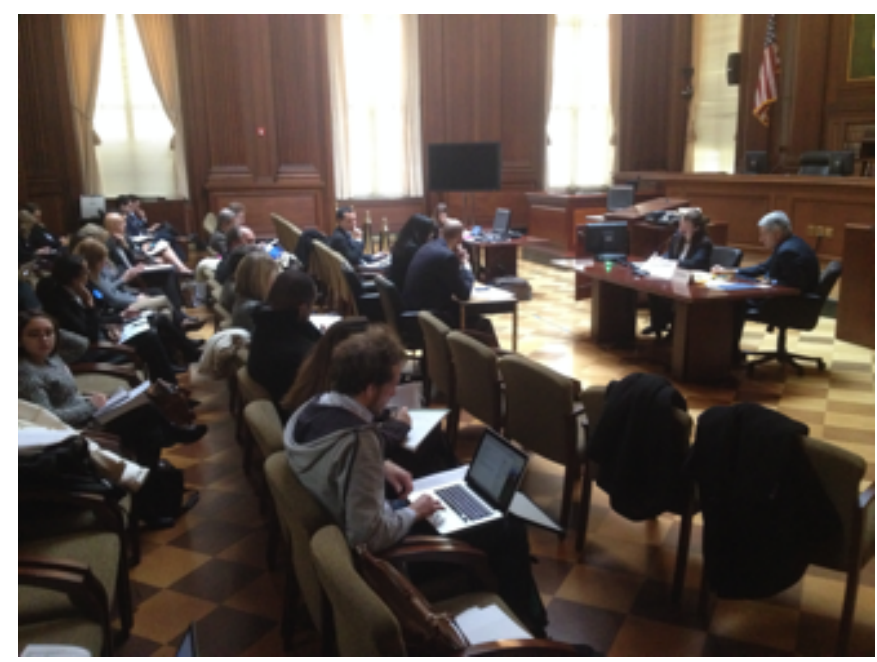

Figura 19: Audiência pública da EPA sobre emissões de ozônio Foto: Bruno Taitson

Audiências como a relatada acima são exemplos de espaços institucionais, previstos em lei, que podem ser ocupados pelo movimento ambientalista para influenciar o Estado a adotar políticas mais adequadas do ponto de vista ambiental. As audiências podem ocorrer no âmbito do Legislativo, do Executivo e do Judiciário, e servem, pelo menos em teoria, para que os processos decisórios sejam participativos.

Outros espaços de participação são as comissões, no Congresso e em outras casas legislativas, além dos conselhos e comitês ambientais nos níveis federal, estadual, local ou de bacias hidrográficas, por exemplo. Tanto a legislação brasileira como a norte-americana preveem esses fóruns de tomada de decisão, alguns deliberativos, outros consultivos.

No caso das comissões no Congresso, as organizações ambientalistas podem participar como testemunhas quando convidadas pelos partidos majoritários, ou nos bastidores, instruindo parlamentares aliados. Em entrevista para esta pesquisa ${ }^{108}$, o assessor legislativo de um deputado federal (representative) Democrata da Califórnia disse o que busca nas ONGs ambientalistas: "Informações sobre o tema debatido, sobre as indústrias que irão testemunhar e, até mesmo, sugestões de perguntas que meu chefe poderá fazer [nas audiências]", disse.

O sistema político norte-americano prevê uma série de instâncias em que a sociedade pode se envolver com o processo de tomada de decisões. Há ainda uma forte descentralização que delega poderes aos estados da federação. Em relação ao meio

\footnotetext{
${ }^{108}$ Entrevista concedida em 10 de outubro de 2015.
} 
ambiente, não é diferente. No caso brasileiro, a governança ambiental também é, de maneira geral, descentralizada.

No Brasil, uma das principais instâncias participativas da governança ambiental é o CONAMA, estabelecido pela Política Nacional de Meio Ambiente de 1981. Trata-se de colegiado composto por representantes de órgãos federais, estaduais e municipais, sociedade civil e setor empresarial. O conselho pode estabelecer resoluções vinculantes, questionar decisões do Executivo e fazer denúncias de violações da lei, e definiu importantes políticas ambientais (Peritore 1999, pp.119-120; Scarcello 2003, p.355).

De acordo com Santilli (2005), a política ambiental brasileira deu destaque especial aos mecanismos de participação social. Além do CONAMA, o Sistema Nacional de Unidades de Conservação também prevê o envolvimento da sociedade nos processos de criação e implementação de UCs. Os estudos de impacto ambiental e processos de licenciamento também demandam audiências públicas e publicidade para documentos e para decisões tomadas (p.159).

Entretanto, a pré-disposição dos tomadores de decisão em levar em conta as opiniões e questionamentos da sociedade é determinante para que os processos sejam, efetivamente, participativos. Machado (2011) destaca que, via de regra, os representantes governamentais são majoritários dentro desses colegiados. "Assim, as organizações nãogovernamentais, ainda que possam apresentar seus argumentos nas discussões, podem ficar vencidas, dando legitimidade, contudo, às decisões tomadas" (p.110).

Chilvers (2009) estabelece sete critérios para avaliar a efetividade da participação em processos decisórios: (i) representatividade e inclusão, ou seja, não deve haver barreiras para a participação dos grupos representativos; (ii) deliberação justa, levando em conta todas as contribuições; (iii) acesso a recursos, com todos os participantes tendo à disposição conhecimento e informação sobre o tema em discussão; (iv) transparência e accountability em relação a objetivos e limitações da participação; (v) aprendizado, com o incremento do aprendizado social de todos os participantes; (vi) independência, no sentido de o processo ser conduzido sem vieses ou preconceitos e (vii) eficiência em relação a tempo e custos (p.408 - tradução minha).

Com base nesses critérios, é possível observar que, com frequência, processos que teriam de ser participativos em sua essência não têm essa característica. Em relação ao CONAMA, por exemplo, diversos ambientalistas e analistas ouvidos apresentaram queixas quanto ao funcionamento atual do colegiado. 
Raul Valle, advogado ambiental, em entrevista para esta pesquisa ${ }^{109}$, avaliou o conselho ao longo das últimas décadas. Segundo ele, na segunda metade dos anos 1990, o órgão colegiado definiu importantes políticas, mediante decisões verdadeiramente coletivas, situação que se repetiu no início dos anos 2000:

Fernando Henrique prestigiou muito o CONAMA. Lula, no primeiro mandato, com a Marina, também, com muitas consultas públicas. Agora não tem mais consulta pública de nada. Os grandes temas recentes foram decididos a portas fechadas, na Casa Civil, no Ministério do Meio Ambiente e outros ministérios, como os decretos de regulamentação das cotas de reserva ambiental e do Código Florestal. O Conama foi escanteado.

No início da gestão Marina Silva foi criada a Conferência Nacional de Meio Ambiente (CNMA), com objetivo de educar ambientalmente os movimentos sociais brasileiros e de incluir o movimento socioambiental no desenho de políticas públicas relacionadas ao desenvolvimento sustentável (Losekann 2012, p.185). Embora tenha sido um espaço que tenha contado, principalmente, com organizações de base - das ONGs que fazem parte deste estudo apenas o ISA participou - e com algumas dificuldades de deliberação, a CNMA demonstrou a disposição do MMA em ouvir a sociedade civil. Outros inúmeros espaços participativos foram abertos na gestão de Marina Silva.

A situação atual de "fechamento" à participação da sociedade civil também parece ocorrer em outras instâncias de participação. No Conselho Nacional de Política Energética (CNPE), importante órgão colegiado, as cadeiras destinadas à sociedade civil e à academia estão vazias. Em agosto de 2015, o GT Infraestrutura, grupo do qual fazem parte instituições como Greenpeace, ICV, International Rivers, TNC e WWF-Brasil, dentre outras, teve uma reunião com o Ministério de Minas e Energia para discutir a pauta energética do país e reivindicar a reativação dos assentos no CNPE.

Segundo Sérgio Guimarães, coordenador do Instituto Centro de Vida (ICV organização que participa do GT), em entrevista para esta pesquisa ${ }^{110}$, o movimento precisa tentar reconquistar esses espaços institucionais. "A estratégia de atuação em rede é fundamental. O momento que estamos vivendo é complicado, há uma assimetria de poder entre os setores. Para que tenhamos alguma capacidade de influenciar, temos que estar juntos", avaliou. Até o fechamento deste capítulo, os assentos da academia e da sociedade civil do CNPE continuavam vazios.

\footnotetext{
${ }^{109}$ Entrevista concedida no dia 15 de janeiro de 2015.

${ }^{110}$ Entrevista concedida em 27 de agosto de 2015.
} 


\subsection{FORNECENDO QUADROS QUALIFICADOS PARA O ESTADO}

Hochstetler e Keck (2007) afirmam que os canais institucionalizados de influência dos movimentos ambientalistas em relação ao governo transcendem a participação em conselhos. "Uma forma mais direta tem sido a de ingressar no próprio Estado" (p.228 tradução minha). Em trabalho no qual discutem formas de interação da sociedade civil com o Estado, Abers e Von Bülow (2011) argumentam que os movimentos "frequentemente cruzam a fronteira entre o Estado e a sociedade" (p.66) e "às vezes (...) buscam alcançar seus objetivos trabalhando a partir de dentro do aparato estatal" (p.78).

Tanto no Brasil como nos Estados Unidos foi possível verificar a presença de ambientalistas nos núcleos decisórios do Poder Executivo, mesmo em alguns governos avaliados por representantes do movimento como menos simpáticos à causa ambiental, como as administrações de Ronald Reagan, George Bush (pai), Dilma Rousseff e durante o regime militar.

\subsubsection{O Caso dos EUA}

Nos EUA, o recrutamento de ambientalistas para posições-chave no Governo Federal é registrado desde o início do Século 20. Gifford Pinchot, figura influente no ambientalismo americano desde o final do Século 19, e primeiro líder da corrente conservacionista do movimento, ocupou a posição de chefe da Divisão de Florestas do Departamento de Agricultura dos Estados Unidos (USDA). Foi, também, o primeiro chefe do Serviço Florestal dos Estados Unidos (USFS), entre 1905 e 1910 (Martinez 2014, pp.167-168).

Embora contasse com alguns integrantes em diferentes governos ao longo do Século 20, foi a partir dos anos 1970 que os ambientalistas passaram a fazer parte de forma consistente do corpo político e administrativo que formulava e implementava políticas ambientais nos EUA. Não por acaso, foi nessa década que as organizações ligadas ao tema ambiental cresceram e se profissionalizaram. O mandato do presidente Democrata Jimmy Carter (1977-1980) foi uma importante marca desse espaço conquistado pelos verdes.

Com o crescimento em importância da EPA e o aumento da capacidade nos movimentos de fornecer quadros qualificados, "os grupos ambientalistas mainstream passaram a se envolver mais na política e no processo de elaboração de políticas" (Kline 2011 p.110 - tradução minha). Representantes oriundos das ONGs EDF e NRDC, entre outras, ocuparam posições na administração Carter e em órgãos ambientais dos estados. Kline (2011) usa o termo envirocrats (algo como burocratas ambientalistas) para descrever a presença dos ambientalistas dentro do governo de Jimmy Carter (p.110). 
Embora em menor quantidade que nas gestões do Partido Democrata, os governos de Ronald Reagan (1981-1988) Bush pai (1989-1992) também tiveram ambientalistas em alguns cargos da administração. Um exemplo foi a nomeação, para coordenar a EPA, de William Reilly, ex-presidente do WWF nos EUA, que teve importante papel para persuadir Bush a apoiar as novas regras de controle da poluição atmosférica em 1990 (Lazarus 2004, pp.1520-1521).

Assim, tornou-se comum dizer que membros do staff das organizações ambientalistas iam e voltavam pelas chamadas "portas giratórias" entre o governo e as ONGs (Bevington 2009, p.25). Segundo Lang (2013), a presença de atores originários das organizações nas esferas decisórias dos governos é um dos três importantes critérios para avaliar o grau de institucionalização do movimento - os outros dois critérios são entidades com estrutura duradoura e oportunidades políticas para participar dos processos ( $p .73)$.

No governo Democrata de Bill Clinton (1993-2000), o número de ambientalistas na administração aumentou novamente, um deles (Al Gore) ocupando, inclusive, a vicepresidência da República. Ao longo do governo de George W. Bush (2001-2008), a tendência se reverte, e os principais cargos ligados ao tema ambiental são ocupados por representantes da indústria (Kline 2011, p.172).

No governo Obama, o movimento ambientalista volta a ser recebido com tapete vermelho na Casa Branca e nas demais agências que lidam com o tema ambiental. Esse protagonismo se fez presente, de forma mais intensa, a partir do segundo mandato do Democrata, que anunciou o meio ambiente como prioridade da gestão. Alguns ambientalistas passaram a ocupar importantes cargos e as ONGs ambientalistas passaram a ter um papel de protagonismo na formulação de políticas, conforme observado nas dezenas de entrevistas feitas com representantes das organizações ambientalistas e tomadores de decisão.

\subsubsection{O caso brasileiro}

No Brasil, o primeiro exemplo de ambientalista ocupando importantes posições no governo é registrado em 1973, quando Paulo Nogueira-Neto é escolhido pelo governo Médici para comandar a Secretaria Especial de Meio Ambiente, que acabara de ser criada. Nogueira-Neto, além de pesquisador, era ativista ambiental, e se manteve à frente da SEMA até 1985, passando pelos governos Geisel e Figueiredo.

No governo de Fernando Collor de Mello (1990-1992), José Lutzemberger, conhecido líder ambientalista nos anos 1970, é nomeado para a Presidência da SEMA, ficando no cargo por mais de dois anos. Nos governos de Itamar Franco e Fernando Henrique Cardoso 
ambientalistas ocupam importantes cargos de segundo e terceiro escalões, "posições que são, fundamentalmente, definidoras de políticas" (Losekann 2012, p.192).

Embora o segundo mandado de Fernando Henrique tenha sido caracterizado pelos ambientalistas que entrevistei como aberto ao movimento, foi no primeiro governo Lula que o segmento de fato colocou os dois pés na administração federal. A começar pela própria ministra do Meio Ambiente, Marina Silva, uma ativista da causa socioambiental na Amazônia, parceira de Chico Mendes nos movimentos sociais no Acre nos anos 1980.

Além da ministra, diversos outros cargos estratégicos foram preenchidos, pela primeira vez, por ambientalistas. Ainda segundo Losekann (2012), em 2007, "do total de seis secretarias constantes no organograma do MMA, quatro estavam sob o comando de quadros oriundos da sociedade civil" (p.192).

João Paulo Capobianco, um ambientalista que ocupou os cargos de secretário nacional de Biodiversidade e Florestas e secretário-executivo do MMA na gestão Marina Silva, disse em entrevista para esta pesquisa ${ }^{111}$ achar natural a presença de quadros advindos do ambientalismo na administração pública. "No Ministério da Agricultura não há muitos agrônomos? No Ministério da Saúde não existem muitos médicos? No MMA, é natural que haja muitos ambientalistas". Capobianco também destaca que o cargo de analista ambiental, criado na gestão Marina Silva, é muito recente, e ainda não houve tempo para se desenvolver um corpo funcional numeroso e experiente como no Ministério do Planejamento ou no Itamaraty, daí a necessidade de se recrutarem quadros juntos aos movimentos.

Atualmente, ex-integrantes do movimento ambientalista continuam presentes no Ministério do Meio Ambiente. Importantes exemplos são Claudio Maretti e Ana Cristina Barros. Maretti era diretor de conservação do WWF-Brasil e Ana Cristina, representante da TNC no Brasil.

Importante ponto a ressaltar é que mais de um entrevistado do movimento ambientalista, tanto no Brasil como nos EUA, admitiram que introduzir quadros dentro de posições estratégicas no Congresso ou na administração pública, é, de fato, uma estratégia das organizações. Adriana Ramos, coordenadora do programa de Política e Direito do Instituto Socioambiental, deixou isso muito claro na entrevista que concedeu para esta pesquisa $^{112}$.

\footnotetext{
${ }^{111}$ Entrevista concedida em 5 de maio de 2015.

${ }^{112}$ Entrevista concedida em 26 de março de 2015.
} 
Para nós, é sim uma estratégia ocupar espaços onde você pode potencializar o trabalho. Fizemos isso em 1995, quando Márcio Santilli [sócio-fundador do ISA] foi presidente da FUNAI, e Fernando Henrique nos chamou para uma discussão. O ISA sempre se colocou dessa forma, a pessoa vai com uma agenda construída aqui. Aquilo faz parte de uma estratégia. Participamos da elaboração dos programas de governo do FHC em 1998 e do Lula em 2002, na parte do meio ambiente. Quando Lula foi eleito, puxamos um abaixoassinado com mais de 700 instituições pedindo que Marina Silva fosse a ministra. Marina foi anunciada pelo Lula e veio convidar alguém do ISA para participar do ministério. Discutimos aqui e achamos que a melhor contribuição para o governo Lula seria na área de biodiversidade e florestas, e que a pessoa com melhores condições de dar essa contribuição seria o João Paulo Capobianco [à época integrante do Conselho Diretor da ONG]. Chamamos lideranças de toda a Amazônia para um evento em Brasília e discutimos qual seria a melhor pauta na área de biodiversidade e florestas.

Adriana Ramos lembra que parte complementar desta mesma estratégia envolve algumas providências para que a organização não perca sua independência e sua capacidade de criticar o governo. "Durante o período em que o Capobianco estava lá, o ISA passou seis anos sem nenhum convênio com o MMA. A nossa independência está nisso, tínhamos independência de criticar". Nesta pesquisa, de fato, encontrei documentos publicados pelo próprio Instituto Socioambiental com críticas incisivas à abordagem da questão ambiental pelo governo Lula ${ }^{113}$.

Interessante observar que, tanto no Brasil como nos Estados Unidos, a presença do movimento ambientalista dentro dos núcleos decisórios parece gerar incômodo em alguns "opositores" do ambientalismo. Em entrevista ${ }^{114}$ com Laura Sheehan, vice-presidente sênior para comunicação da ACCCE, entidade que representa os interesses da indústria da energia a carvão dos EUA, ela disse que os ambientalistas têm sido efetivos em influenciar políticas porque "dormem na mesma cama que a administração federal. NRDC, Sierra Club, LCV, todas elas estão muito próximas desta administração", opinou.

\footnotetext{
${ }^{113} \mathrm{Na}$ avaliação dos primeiros 200 dias da gestão Lula, Márcio Santilli apontou problemas para a agenda ambiental se posicionar no novo governo: http://www.socioambiental.org/esp/novogov/index.shtm Acesso em 16 de dezembro de 2015.

${ }^{114}$ Entrevista concedida em 4 de fevereiro de 2015.
} 
Em entrevista para esta pesquisa, o assessor parlamentar de um deputado federal (representative) Republicano de um estado produtor de petróleo relatou o que chama de uma exagerada presença de ambientalistas na EPA, no Departamento de Interior e em outras agências, embora diga que a situação é esperada. "Se o Partido Republicano vencer as eleições presidenciais de 2016 haverá representantes da indústria. Cada um tem seus amigos", disse.

O senador Ronaldo Caiado (DEM-GO), integrante da bancada ruralista, em entrevista por e-mail ${ }^{115}$ para esta pesquisa, também declarou que no Ministério do Meio Ambiente, IBAMA, ICMBIO e no INCRA, a influência dos ambientalistas pode, sim, ser classificada como excessiva e que, nessas posições, por conta de "resquícios ideológicos que marcaram o início da luta ambientalista", as ONGs ambientalistas "algumas vezes não atinam para a dinamicidade do setor agrícola".

\subsection{JUNTOS CHEGAREMOS LÁ: ALIANÇAS E COALIZÕES}

As alianças têm sido uma importante marca do trabalho das organizações ambientalistas nas democracias ocidentais. Os grupos se unem pela aprovação ou rejeição de um projeto de lei, para fiscalizar governos ou entes privados, para gerar conhecimento científico sobre algum tema relevante, para arrancar compromissos de candidatos a cargos eletivos ou para cobrar de chefes de Estado acordos mais ambiciosos nas conferências internacionais de clima.

As parcerias multilaterais das quais os grupos ambientalistas participam não contam apenas com ambientalistas em sua composição. Conforme Libby (1998), frequentemente os movimentos se aliam a lideranças políticas e, até mesmo, atores governamentais (p.215). Também são frequentes as coalizões dos ambientalistas com outros grupos da sociedade civil organizada e até com o setor privado. Enfim, organizar coalizões é uma tática recorrente no movimento ambientalista, em ambos os países estudados para esta tese.

A primeira e mais fácil aliança a ser feita é entre as próprias organizações ambientalistas. Afinal, os grupos compartilham ideias similares, e muitos indivíduos que integram o movimento trabalharam juntos, seja nas próprias ONGs, governos, academia e institutos de pesquisa, e compartilharam lutas em diferentes épocas e circunstâncias.

As principais razões para organizações se reunirem são pragmáticas: aumentar a capacidade de pressão e aglutinar recursos humanos, técnicos e financeiros. Embora

\footnotetext{
${ }^{115}$ Entrevista concedida em agosto de 2015.
} 
tenham inúmeros pontos comuns em seus valores, missões e metas (Elkington e Beloe 2010, p.29), as diferenças entre elas tornam a opção pelas alianças ainda mais importantes: algumas ONGs se especializam em mobilização popular, outras em pesquisas científicas, outras contam com uma competente equipe de advogados, algumas se especializam em lobby, e assim por diante. Quando elas se unem, o potencial para se construir uma força multidisciplinar, capaz de atacar em múltiplas frentes, cresce.

Os primeiros casos de coalizão com múltiplas organizações ambientalistas de que se tem notícia apareceram nos anos 1980 nos EUA, tanto envolvendo grandes ONGs como também organizações comunitárias de base. "As organizações começaram a compartilhar informação, estratégias políticas, publicações e até funcionários. Essas coalizões permitem aos ativistas aglutinar recursos e expertise, e a falar com uma só voz, mais potente" (Wapner 1996, p.125).

Sabatier, discutido com um pouco mais de profundidade no capítulo teórico deste trabalho, desenvolveu com Jenkins-Smith o modelo de coalizões de advocacy. De acordo com esta teoria, nas democracias pluralistas a variedade de atores - públicos, privados e não-governamentais - envolvidos nos processos decisórios faz com que ocorram múltiplas interações, frequentemente informais e descentralizadas. Esse contexto altamente competitivo favorece o surgimento de alianças entre grupos que compartilham um ou mais interesses (Sabatier 2007, pp.9-10; 131-134).

Em processos decisórios envolvendo temas ambientais, como regulações, mudanças climáticas, pagamento por serviços ambientais, proibições de práticas anteriormente aceitas, entre outras questões, a complexidade frequentemente está presente. Isso faz com que coalizões entre grupos de interesses e expertise distintos sejam um diferencial positivo na tentativa de influenciar a formulação das políticas públicas.

O Green Group, por exemplo, é uma das principais coalizões ambientalistas nos EUA, envolvendo as maiores ONGs, com objetivo principal de fortalecer o lobby verde no Congresso americano (Banks 2010, pp.178-179). Outra situação em que as entidades ambientalistas tipicamente se unem é nas ações judiciais. Michael Senatore, vice-presidente de direito para a conservação na Defenders of Wildlife, em entrevista para esta pesquisa ${ }^{116}$, afirmou que a maioria das ações na Justiça é feita em parceria com outras organizações. Outros representantes de ONGs disseram o mesmo.

No Brasil, embora esta pesquisa tenha constatado que as organizações ambientalistas judicializem menos que suas contrapartes americanas, frequentemente as ações são

\footnotetext{
${ }^{116}$ Entrevista concedida em 9 de janeiro de 2015.
} 
ingressadas por um conjunto de organizações da sociedade civil. O aspecto coletivo dá mais legitimidade ao pleito, enriquece a linha argumentativa (mais fontes de dados e informações) e otimiza o uso de recursos financeiros e humanos.

\subsubsection{Strange bedfellows}

Randall Snograss, atualmente na diretoria do World Resources Institute nos EUA, está há quase 40 anos no movimento ambientalista, foi lobista do WWF e passou pela National Audubon Society e pela The Wilderness Society. Em entrevista para esta pesquisa ${ }^{117}$, observou que as principais vitórias do movimento envolveram a construção de coalizões, e que as alianças mais poderosas são aquelas em que os ambientalistas conseguem envolver segmentos completamente distintos, parcerias impensáveis para um observador externo.

Snodgrass chama essa tática de strange bedfellows, que em uma tradução livre poderia ser entendido como "na cama com estranhos". Ou seja, são alianças vistas como pouco usuais e inesperadas, mas que acabam surpreendendo os tomadores de decisão. diretor da WRI cita como exemplo um projeto de lei no Congresso para proteger vastas extensões de terra no Alaska, apoiado pelos ambientalistas.

Ele trabalhava na The Wilderness Society, e a ONG conseguiu costurar uma aliança com a Igreja Evangélica, sindicatos, cantores e apresentadores famosos, tribos indígenas do Alaska, o governo canadense e outras organizações ambientalistas. "De repente, tem-se uma coalizão de strange bedfellows e os parlamentares dizem: uau, o que é isto? Eles conseguiram atrair todo mundo, de A a Z. E a matéria é aprovada", relatou Snodgrass.

Durante o período desta pesquisa tive acesso a diversos outros casos de coalizões compostas por strange bedfellows. Benjamin Schreiber, diretor do programa de Clima e Energia da Friends of the Earth - organização caracterizada como radical -, me disse em entrevista ${ }^{118}$ que a organização procura deputados Republicanos em uma tática chamada de "tesoura verde":

Trabalhamos com parlamentares que querem cortar qualquer gasto governamental. Eles classificam como desperdício orçamentário alguns programas públicos que nós detestamos por questões ambientais. Tentamos, juntos, derrubar esses programas. Não somos aliados tradicionais, muito pelo contrário, mas naquele tema, o fato de estarmos de acordo é útil.

\footnotetext{
${ }^{117}$ Entrevista concedida em 4 de setembro de 2014.

${ }^{118}$ Entrevista concedida em 23 de dezembro de 2014.
} 
No Brasil, um dos mais recentes exemplos de aliança multissetorial liderada pelo movimento ambientalista foi o Comitê Brasil em Defesa das Florestas, que contou com 97 organizações da sociedade civil contrárias ao substitutivo, sancionado em 2012, que flexibilizou o Código Florestal. A diversidade da coalizão merece destaque: além das principais organizações ambientalistas, o comitê envolveu a Ordem dos Advogados do Brasil (OAB), a Conferência Nacional dos Bispos do Brasil (CNBB), o Movimento dos Trabalhadores Rurais Sem-Terra (MST) e a Central Única dos Trabalhadores (CUT), dentre outras entidades.

Embora não tenha obtido todas as vitórias desejadas nos âmbitos do Legislativo e do Executivo, a coalizão conseguiu mobilizar a sociedade em torno de uma questão ambiental como jamais havia acontecido na história do país, com manifestações de rua, abaixoassinados, petições, e-mails e telefonemas para pressionar tomadores de decisão. Além do mais, a aliança contribuiu para que um texto muito pior não virasse lei.

Paulo Moutinho, diretor do IPAM, em entrevista para esta pesquisa, defendeu a necessidade de o movimento ambientalista dialogar com diversos segmentos da sociedade ligados à questão ambiental. "Temos conexões desde o MST à APROSOJA", exemplificou.

\subsubsection{Mobilização indígena}

Historicamente, setores do movimento ambientalista brasileiro têm se aliado aos povos da floresta, conforme discutido no Capítulo 3 deste trabalho. Atualmente, esta aliança tem representado um importante obstáculo à aprovação da Proposta de Emenda Constitucional 215, que prevê a transferência da atribuição de demarcar terras indígenas do Executivo Federal para o Congresso. A Mobilização dos Povos Indígenas - liderada pelas organizações dos próprios índios e apoiadas por grupos ambientalistas - tem organizado protestos, marchas, manifestações e fóruns públicos de discussão do projeto de lei, inclusive com adesão de artistas e celebridades.

Recentemente, a partir de uma bem-sucedida articulação no Senado com parlamentares aliados do movimento ambientalista, a Mobilização dos Povos Indígenas conseguiu um resultado expressivo: um manifesto assinado por 42 senadores - em um total de 81 - pela rejeição da PEC 215. Segundo o senador João Capiberibe (PSB-AP), que liderou a iniciativa ao lado de Randolfe Rodrigues (Rede-AP) e Cristovam Buarque (PPS-DF), ele mesmo ficou surpreso com tamanha adesão. "Achávamos que conseguiríamos, no máximo, 31 assinaturas", revelou, em entrevista para esta pesquisa ${ }^{119}$.

\footnotetext{
${ }^{119}$ Entrevista concedida em 23 de junho de 2015.
} 


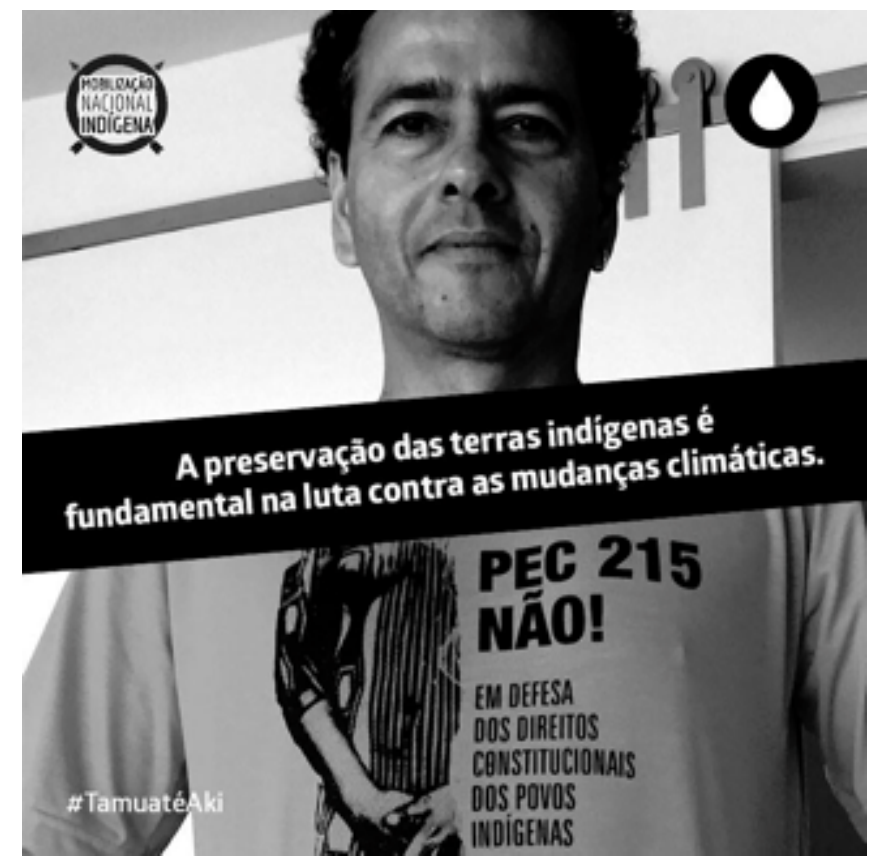

Figura 20: Ator Marcos Palmeira em peça de campanha contrária à PEC 215 Fonte: Mobilização Nacional Indígena

Anteriormente, a união entre indígenas e ambientalistas conseguiu postergar em mais de uma ocasião a construção da hidrelétrica de Belo Monte, anteriormente denominada Kararaô. Outra parceria que merece destaque foi desenvolvida entre os ambientalistas e o Movimento dos Atingidos por Barragens (MAB), para questionar a construção de hidrelétricas que desrespeitam a legislação ambiental e a política energética do país (Santilli 2005, pp.38-39). Embora não tenham conseguido barrar a construção das grandes usinas no longo prazo (apenas foi possível atrasar o processo), os movimentos levaram para a agenda pública o questionamento do frequente discurso do governo brasileiro de que a energia gerada por barragens é limpa.

Também é muito frequente no movimento ambientalista brasileiro a instalação de grupos de trabalho temáticos, quando as organizações se reúnem para discutir grandes questões ambientais, propor soluções e pressionar, em conjunto, tomadores de decisão. $\mathrm{O}$ GT Infraestrutura, abordado em páginas anteriores deste capítulo, é um exemplo desse tipo de arranjo. O coletivo, composto por 20 organizações, propõe novas alternativas para a geração de energia no país, e em agosto de 2015 abriu um canal de interlocução com o Ministério de Minas e Energia.

Quadro 8: Emendas ao Lacey Act

Em 2008, um projeto de lei apresentado no Congresso americano propunha emendas ao Lacey Act, uma legislação de 1900 que proibia o tráfico de animais silvestres no território americano. De 
acordo com a nova proposta, a proibição se estenderia a espécies arbóreas e madeireiras, e para ser autorizado a importar madeira para os EUA, a indústria precisaria provar que a extração ocorreu em conformidade com as leis do país de origem.

O WWF e outras ONGs, em virtude do potencial impacto de redução do desmatamento ilegal em todo o mundo, apoiou a lei e ajudou a construir uma coalizão extremamente diversificada. Para convencer a indústria madeireira local a apoiar a proposta, os ambientalistas mostraram que as importações de madeira clandestina criavam uma concorrência desleal com aqueles que cumprem a lei, ofertando produtos muito mais baratos no mercado.

O WWF colocou na mesa um estudo que mostrava que a madeira ilegal reduzia em $16 \%$ os ganhos do mercado madeireiro no mundo. Gigantes como Hewlett-Packard, Tetra Pak e IKEA entraram na coalizão em favor das novas regras, assim como a Associação Internacional de Produtos Madeireiros (IWPA). Outro argumento que ajudou a angariar apoio de políticos e da própria opinião pública foi o fato de que a entrada de madeira ilegal vinda da África, Ásia e América do Sul ameaçava empregos americanos, uma vez que a indústria local saía perdendo nessa disputa desigual. A matéria foi aprovada em maio de 2008 com confortável maioria.

Fonte: depoimentos de Jéssica McGlyn, lobista do WWF-EUA à época da votação das emendas ao Lacey Act e Vanessa Dick, lobista do WWF-EUA desde 2010.

Quadro 9: Lei de Gestão de Florestas Públicas

Em 2006, o Governo Federal, por meio do MMA, propôs uma legislação tão inovadora quanto polêmica, que criava meios para que as florestas públicas pudessem ser exploradas, de forma sustentável e com base nos princípios do manejo florestal, por comunidades e empresas. Seriam feitas concessões públicas, sem custos para comunidades locais, mas com um custo para empresas privadas, permitindo a utilização racional de ativos florestais como madeira, castanha, e óleos vegetais.

Os opositores da proposta alegavam se tratar de uma privatização das florestas brasileiras, outros diziam que o manejo florestal não é a melhor forma de se proteger os ecossistemas florestais. De maneira mais pragmática, tanto a ministra Marina Silva quanto as diversas organizações da sociedade civil que apoiavam a lei argumentavam que a exploração florestal pelo manejo é, a despeito de problemas, muito superior do ponto de vista ambiental que a exploração convencional. Também afirmavam que não era realista achar que os órgãos públicos federais e estaduais são capazes de fiscalizar todas as florestas, de modo que as comunidades e empresas seriam importantes auxiliares nesta tarefa.

Foi construída, então, uma ampla coalizão, com ONGs ambientalistas, como WWF-Brasil e Greenpeace, Ministério do Meio Ambiente, movimentos sociais da Amazônia, capitaneados pelo GTA, a Associação das Indústrias Exportadoras de Madeira (AIMEX) e o setor de florestas plantadas; os dois últimos desta lista, grupos que mais vezes encontram-se em lado distinto dos ambientalistas do que juntos. A lei foi aprovada no Congresso sem maiores problemas.

Fonte: depoimentos da ex-ministra do Meio Ambiente Marina Silva e do ex-superintendente de conservação do WWF-Brasil, Mauro Armelin.

Em resumo, conforme observado por Gunter Jr. (2004), as coalizões dentro do movimento ambientalista, quando aglutinam uma grande quantidade de organizações com credibilidade, são capazes de tirar um assunto do ostracismo e dar a ele um senso de urgência na agenda coletiva. Adicionalmente, podem contribuir para fortalecer a identidade do grupo enquanto movimento, equacionando eventuais conflitos. Por fim, as alianças no ambientalismo "representam o explícito reconhecimento de que alguns grupos desempenham certas tarefas melhor do que outros. São um esforço articulado para maximizar eficiência e efetividade" (p.146), resumiu. 


\subsection{AÇÕES NA JUSTIÇA}

A atuação judicial vem sendo um importante componente dos repertórios adotados pelo movimento ambientalista para influenciar as políticas públicas, especialmente nos Estados Unidos. Importante lembrar que, conforme discussão no Capítulo 3 desta tese, nos dois países pesquisados o sistema legal permite que a sociedade civil entre com ações contra o Estado, entes privados e indivíduos para assegurar direitos difusos, ou o direito a um ambiente saudável.

Nos EUA, as leis ambientais introduzidas no final dos anos 1960 e nas duas décadas seguintes, somadas a decisões em cortes federais que estabeleceram jurisprudência, deixam claro que a sociedade pode acionar o Judiciário sempre que houver danos individuais ou coletivos causados por ação ou omissão de outras partes, incluído aí o próprio Estado. No Brasil, destacam-se a Política Nacional de Meio Ambiente (1981), a Lei dos Interesses Difusos (1985) e a Constituição Federal (1988), que criaram ou consolidaram instrumentos e definições legais que permitem aos cidadãos, associações ou ao Ministério Público propor ações na Justiça relacionadas ao meio ambiente.

Buscar direitos na Justiça é uma prática usual na sociedade norte-americana. Segundo Coggins (2001), o americano sempre foi "um povo litigioso, e a litigação em cima de questões de interesse público se encaixa (...) no modelo nacional" (p.165 - tradução minha). Adicionalmente, é natural que o movimento ambientalista recorra aos tribunais com certa frequência, uma vez que em muitas questões ambientais, devido à incompatibilidade dos interesses entre as partes, o acordo não é um caminho realista. "Os valores e premissas dos envolvidos nas polêmicas sobre alocação de recursos, talvez na maioria das vezes, têm diferenças irreconciliáveis, e não importa o quanto conversarem, isso não mudará" (p.166 tradução minha), restando a Justiça como instância de resolução.

Esta pesquisa demonstrou que a principal estratégia judicial dentro do movimento ambientalista norte-americano consiste nas ações contra o Estado. Isso ocorre quando as ONGs entendem que os órgãos governamentais não estão cumprindo sua função legal de executar ou fazer valer a legislação ambiental vigente. Alvos comuns das ações são a EPA, por conta de problemas ligados à poluição atmosférica ou hídrica, o Bureau of Land Management, vinculado ao Departamento de Interior, que lida com a administração de terras públicas, e o Fish and Wildlife Service, envolvendo a inclusão ou exclusão de animais na lista de espécies ameaçadas e providências para proteger os respectivos hábitats (Bevington 2009, pp.9-10). 
A Justiça norte-americana, na segunda metade do Século 20, durante o período em que a agenda ambiental se fortalecia, respondeu positivamente às demandas do crescente movimento ambientalista, tanto para promover a aplicação das leis, quanto para bloquear tentativas de flexibilizá-las. Conforme Lazarus (2004),

...as cortes (...) serviram como grandes baluartes contra reformas da legislação ambiental durante os anos 1970 e boa parte dos 1980. O Judiciário abriu as cortes para as ações populares, ampliou a avaliação do trabalho das agências federais e promoveu uma aplicação estrita dos prazos e determinações legais que impunham condições inegociáveis para os setores regulados e para os próprios reguladores federais. (pp.1823-1825 - tradução minha).

Nesse contexto, as organizações ambientalistas assumiram o protagonismo na garantia da aplicação das diversas legislações. Tanto as grandes ONGs como as organizações regionais de base obtiveram uma série de conquistas nos tribunais. Houve uma mudança clara nos debates envolvendo o meio ambiente. "A questão fundamental não mais seria, por exemplo, se a concessão para explorar petróleo e gás seria obtida pela empresa $A$ ou $B$, e sim se a exploração poderia acontecer e, em caso positivo, sob quais condições", resumiu Coggins (2001, p.165).

\subsubsection{Impactos no Legislativo}

Essa atuação das cortes no sentido de assegurar o cumprimento da legislação também impactou o Congresso norte-americano, que se viu obrigado a agregar, nas leis, diversas provisões alavancadas pela sociedade civil nos tribunais. Peter Kirby, advogado ambiental com quase 50 anos de atuação no movimento ambientalista, em entrevista para esta pesquisa ${ }^{120}$ afirmou que a Lei de Manejo de Florestas Nacionais (National Forests Management Act), votada em 1976, foi claramente influenciada pelas ações judiciais. "Grupos ambientalistas ganharam uma ação em 1974, que definiu que o corte raso era ilegal. Essa decisão acabou com o corte raso em florestas nacionais e, essencialmente, forçou o Congresso a agir", lembrou.

Algumas organizações ambientalistas nos EUA se destacaram ao longo da história nos repertórios judiciais. O Environmental Defense Fund, que surgiu com o principal objetivo de atuar no Judiciário, inaugurou em 1967 uma trajetória que seria acompanhada por outros grupos. O Sierra Club, primogênita entre as grandes ONGs ambientalista do país, e o NRDC, também passaram a contar com advogados em suas fileiras (Wellock 2008, p.171).

\footnotetext{
${ }^{120}$ Entrevista concedida em 20 de junho de 2014.
} 
Atualmente, diversas outras organizações também têm posição de destaque na esfera judicial. A Defenders of Wildlife, que atua principalmente na defesa da aplicação da Lei das Espécies Ameaçadas, é uma delas A Earthjustice, criada a partir de uma divisão do Sierra Club, também é uma das ONGs mais atuantes em termos de ações na Justiça, predominantemente no sentido de obrigar o Estado a fazer cumprir a legislação ambiental. "A maior parte do trabalho da Earthjustice é em torno da Lei de Espécies Ameaçadas, envolvendo sua reautorização ${ }^{121}$, designação de hábitats críticos e temas florestais" (Gunter Jr. 2004, p.59 - tradução minha).

Algumas das grandes ONGs ambientalistas também procuram atuar como advogados para outras organizações, frequentemente de base comunitária, ou mesmo para comunidades menores. Seth Johnson, advogado sênior da Earthjustice, em entrevista para esta pesquisa ${ }^{122}$, descreveu um episódio envolvendo a polêmica do fracking ${ }^{123}$ no estado de Nova York:

\begin{abstract}
Uma pequena cidade naquele estado passou uma lei local banindo fracking em seu território e nós acabamos fazendo a defesa deles, que foram processados por empresas do setor de gás. Isso aconteceu na corte daquele estado e nós ganhamos. E a questão evoluiu porque o governador definiu que fracking não pode acontecer no estado de Nova York.
\end{abstract}

É bastante relevante o fato de grandes ONGs ambientalistas representarem, sem custos, comunidades ou organizações de base em ações judiciais. Afinal, conforme apurado ao longo desta pesquisa, acionar a Justiça pode ter altos custos. Na verdade, o problema maior não são as chamadas custas judiciais, e sim quando há necessidade — frequente em disputas ambientais - de provar cientificamente o nexo causal entre práticas produtivas e impactos no meio ambiente, por exemplo. Isso, frequentemente, envolve complexos estudos, que demandam exames médicos ou laboratoriais, amostras da qualidade do ar e da água, testemunhas e depoimentos de experts, algo que costuma custar caro, especialmente para comunidades, indivíduos e organizações locais menos estruturadas.

A relativa rapidez da Justiça nos EUA é outro fator que encoraja a atuação das ONGs, assim como a perspectiva de se obterem vitórias contra corporações gigantescas, que

\footnotetext{
${ }^{121}$ Nos EUA, o processo chamado de reautorização de uma lei pode ser entendido como uma atualização dos preceitos, renovando a validade da legislação em conformidade com a nova realidade.

${ }^{122}$ Entrevista concedida em 27 de janeiro de 2015.

${ }^{123}$ Procedimento de fratura hidráulica, que consiste em injetar no subsolo, sob alta pressão, substâncias químicas em estado líquido para fraturar rochas e, assim, extrair gás de xisto
} 
conseguem ser mais fortes no lobby junto ao parlamento ou no Executivo, mas que, de acordo com entrevistados, disputam nas cortes em igualdade de condições com a sociedade civil.

\subsubsection{Protagonismo do MP}

No Brasil, as organizações ambientalistas judicializam muito menos que as dos EUA, conforme pontuado acima. A partir das entrevistas foi possível constatar que, nos anos 1980 e 1990, o movimento recorria às ações judiciais um pouco mais do que nos tempos atuais, e que a maior parte dessas ações era feita por organizações de alcance local, como a Liga Ambiental e a Meio Ambiente Equilibrado, ambas paranaenses, para citar dois exemplos. Atualmente, ainda há casos em que as organizações judicializam, mas isso vem diminuindo, conforme dito por mais de um entrevistado.

Os entrevistados apontaram algumas justificativas para que as ONGs ambientalistas brasileiras não entrem tanto na Justiça para alcançar seus objetivos. Uma delas é a lentidão do sistema judicial. Com grande frequência, os processos se arrastam por 10, 15, 20 ou mais anos, situação que inviabiliza o instrumento como solução para diversos casos com necessidade de intervenção em curto ou médio prazo, como por exemplo, para reverter ou prevenir danos ambientais.

Outro obstáculo são os custos envolvidos. Maurício Guetta, advogado do Instituto Socioambiental, em entrevista para esta pesquisa ${ }^{124}$, afirmou que muitas ONGs não têm a estrutura necessária para esse tipo de repertório. "Falta financiamento, a verba é reduzida. Ter um advogado, ajuizar ações que tramitam longamente, isso demanda um corpo de advogados por muito tempo e os resultados não são tão previsíveis", observou.

De acordo com algumas entrevistas realizadas com representantes de ONGs, foi possível deduzir que, em alguns casos, organizações optam por não litigar contra o governo para não sacrificar projetos que dependam de recursos públicos.

Mas a principal razão para a pouca judicialização por parte das organizações pesquisadas é o papel exercido pelo Ministério Público (MP). "Muito do que as ONGs ambientalistas fazem nos EUA, no Brasil quem faz é o Ministério Público", afirmou o advogado ambiental Raul Valle, em entrevista para esta pesquisa ${ }^{125}$.

O órgão federal foi consagrado pela Constituição de 1988 como responsável por assegurar a ordem jurídica, a democracia e os direitos políticos, civis e sociais, se firmando

\footnotetext{
${ }^{124}$ Entrevista concedida em 8 de julho de 2015.

${ }^{125}$ Entrevista concedida em 15 de janeiro de 2015.
} 
como importante defensor de direitos difusos e, consequentemente, do meio ambiente (Chermont 2013, p.332).

Ainda segundo Chermont, as funções do MP relacionadas às questões socioambientais são:

- acompanhar processos de licenciamento de projetos com potencial de impacto ambiental;

- investigar atividades que coloquem em risco o meio ambiente;

- elaborar termo de ajuste de conduta (TAC) para impedir ou reparar atividade lesiva ao meio ambiente;

- propor ação cautelar, para impedir dano;

- propor ação civil pública para obrigar a parte que lesa o meio ambiente a fazer ou deixar de fazer algo, ou mesmo a indenizar por dano e

- propor ação penal para punir agentes degradadores (pp.332-333).

Como é possível observar, trata-se de um amplo escopo de atuação, que demanda uma instituição estruturada, especialmente em termos de recursos humanos e financeiros. Segundo Machado (2011), o

...meio ambiente passou a ter no delineamento constitucional do Ministério Público um robusto suporte... Ganha muito o meio ambiente em ter como um dos atores da ação civil pública um Ministério Público bem preparado, munido de poderes para uma atuação eficiente e independente. Aponte-se que essa Instituição vem propondo uma grande quantidade de ações civis públicas ambientais em que no polo passivo estão os Governos Federal ou Estaduais, além de poderosas empresas públicas e privadas (pp.144-145).

Embora conte com boa estrutura operacional e um corpo profissional altamente qualificado, o MP não seria capaz de desempenhar, sozinho, todas as tarefas necessárias para cumprir suas funções constitucionais. As parcerias com as organizações da sociedade civil surgiram como um desdobramento natural desse contexto. O Ministério Público precisava das ONGs para obter informações científicas, sobre as realidades locais e para fazer uma ponte entre o órgão e as comunidades.

Nesse processo interativo, "cabe aos movimentos ambientalistas levar ao Ministério Público o conhecimento de fatos, irregularidades e problemas que prejudiquem os direitos dos cidadãos e das coletividades" (Aguiar 1998, p.99). 
Raul Valle, advogado ambiental, exemplificou em entrevista para esta pesquisa como se dá essa aliança entre MP e movimento socioambiental:

Um procurador muito capacitado, que estudou muito para passar em um concurso difícil, de repente cai de paraquedas em Altamira, no Pará, e depende da informação que as ONGs vão trazer para ele, com problemas, leitura da paisagem etc. Sem uma participação do movimento social - e o MP tem sido muito aberto à sociedade civil — muitos procuradores ficariam de braços cruzados.

João Akira Omoto, procurador regional da República no Ministério Público Federal, conhecido pela atuação em questões ambientais, explicou em entrevista para esta pesquisa ${ }^{126}$ que, diante de projetos com potencial impacto ao meio ambiente e a comunidades, o MP entra em cena tipicamente em duas situações: quando não há, nos processos de licenciamento e estudos de impacto, participação democrática e informação adequada, e quando, apesar dos impactos ambientais, econômicos e sociais, não há medidas de compensação e mitigação. "Durante as duas fases há interação com o movimento social", afirmou o procurador.

Um exemplo recente da atuação do MP em parceria com o movimento ambientalista é o projeto da usina hidrelétrica de Belo Monte. Segundo João Akira Omoto, o pedido da licença de operação foi feito sem levar em conta problemas das comunidades locais, mesmo com potenciais impactos em centenas ou milhares de famílias. "Entramos para que o licenciamento não seja concedido até que se resolva a questão. As ONGs, além de terem importante informação sobre o projeto e a região, mobilizam as comunidades. O MP não tem pernas para informar as pessoas no campo", relatou.

\subsubsection{Intercâmbio de informações}

O papel do MP como promotor dos direitos ambientais é destacado por representantes de outras organizações estudadas. Segundo Paulo Barreto, pesquisador do IMAZON, entrevistado em 23 de setembro de 2015, a ONG conversa diariamente com os procuradores. "A relação com o Ministério Público ficou mais intensa, até porque parte do Executivo não cumpre sua função. Temos grande base de dados, capacidade de análises rápidas, imagens de satélite e o MP tem poder", afirmou.

\footnotetext{
${ }^{126}$ Entrevista concedida em 7 de julho de 2015.
} 
Rubens Gomes (Rubão), do GTA, e Sérgio Guimarães, do ICV, entrevistados para esta pesquisa ${ }^{127}$, dão eco às opiniões de representantes do ISA e do IMAZON. Segundo Rubão, a troca de informações entre GTA e MP é permanente. Sérgio Guimarães, por sua vez, disse que, em projetos de hidrelétricas, o ICV faz "o meio de campo entre as comunidades potencialmente ou já impactadas e o Ministério Público, além da capacitação dessas comunidades com informações e estratégias de mobilização".

O MP também pode ingressar com Ações Diretas de Inconstitucionalidade (ADIs) no Supremo. Em janeiro de 2013, por meio da Procuradoria Geral da República (PGR), o órgão entrou com três ADIs contestando o novo Código Florestal, aprovado no Congresso e sancionado pela Presidência da República no ano anterior. Até o encerramento deste capítulo, as ações ainda não haviam sido julgadas no STF.

Representantes de ONGs também sinalizaram uma relação com o Tribunal de Contas da União (TCU), órgão vinculado ao Poder Legislativo com atribuição de fiscalizar as contas do Executivo. De acordo com Paulo Barreto, do IMAZON, o TCU tem feito auditorias no IBAMA e no ICMBIO, em parceria com tribunais de contas dos estados, com objetivo de auditar a gestão das unidades de conservação. "O TCU consulta várias instituições nesse processo e cria painéis de revisão, dos quais temos participado. Importante dizer que operamos onde há abertura. Mais recentemente, esse espaço está limitado aos órgãos supervisores, como o MP e o TCU", analisou Paulo Barreto.

Por fim, outra atuação usual das ONGs ambientalistas, tanto no Brasil como nos Estados Unidos, é desempenhar o papel de amigo da corte, ou amicus curiae. Nesse caso, um representante da ONG testemunha no tribunal, em favor de uma das partes envolvidas, normalmente dando contribuições técnicas e depoimentos de vivências de campo, com objetivo de assegurar o cumprimento da legislação ambiental ou a reparação de danos causados a ecossistemas ou comunidades.

O Instituto Socioambiental foi amigo da corte com objetivo de apoiar uma Ação Direta de Inconstitucionalidade ajuizada pela PGR contra o Decreto 6.640/2008, assinado pelo presidente Lula, autorizando projetos de infraestrutura e atividades econômicas, como hidrelétricas e mineração, próximas de áreas de cavernas, anteriormente protegidas por lei. A ADI apontava que o decreto colocava em risco o patrimônio natural, histórico, turístico e cultural.

Além do ISA, foram amici curiae neste caso, no âmbito do STF, o Instituto Brasileiro de Mineração (IBRAM), a Confederação Nacional das Indústrias, a Associação Brasileira dos

\footnotetext{
${ }^{127}$ Entrevistas concedidas em 15 de janeiro e 27 de agosto de 2015, respectivamente.
} 
Investidores em Autoprodução de Energia Elétrica (ABIAPE) e a Sociedade Brasileira de Espeleologia (SBE). O STF decidiu, em 2011, pela extinção da ADI, desagradando ao movimento ambientalista.

Frequentemente, as ações na Justiça conseguem igualar correlações assimétricas de poder entre duas ou mais forças. No caso ambiental, pequenas comunidades conseguem sair vencedoras diante de um time inteiro de advogados de grandes corporações, por exemplo. Seth Johnson, advogado da ONG norte-americana Earthjustice, resumiu, em entrevista para esta pesquisa ${ }^{128}$, a situação:

Muitos dos poluidores são ricos e muito grandes e pode ser difícil confrontá-los diretamente. Eles têm todo incentivo para tornar o mais difícil possível responsabilizá-los por algo. Nas cortes, essa vantagem é minimizada. Eles podem contratar advogados muito bons e muito inteligentes, nós também. Isso empodera comunidades. Não se pode comprar um juiz com viagens, dinheiro e doações, eles não estão concorrendo a nenhum cargo. A gente tem direito a 14 mil palavras para argumentar, o outro lado também. Dinheiro não vai comprar mais palavras e nem melhores argumentos. A disputa é mais equilibrada. Na maioria dos casos nossas ações são contra o governo, que tem a responsabilidade de regular as empresas. As empresas são como um urso gigante, e nós somos um rato com uma vareta. Podemos cutucar o urso ou podemos encontrar o nosso próprio urso e cutucá-lo para que ele combata o outro urso. O governo é o nosso urso. De acordo com a lei, ele tem que fazer isso, e se não fizer, nós podemos força-lo a fazer.

No caso brasileiro, pode-se dizer que o papel desse urso, acionado pelo movimento ambientalista, é desempenhado pelo Ministério Público.

Quadro 10: Nos tribunais pelos índios Panará

No ano de 1973, a etnia indígena dos Panará, contactada antes da abertura da BR-163, sofreu significativa perda de população por conta de doenças levadas pelos trabalhadores da obra rodoviária. Diante do problema, os índios que sobreviveram foram levados em 1975 pelo Estado para o parque indígena do Xingu, com objetivo de evitar o desaparecimento do grupo.

Porém, os Panará tiveram imensas dificuldades de adaptação ao novo local. Era um espaço diferente, que ainda por cima, passou a abrigar tribos historicamente inimigas. A etnia manifestou o desejo de retornar ao seu território tradicional, conforme assegurado pela Constituição, e o Instituto Socioambiental apoiou a reivindicação por meio de duas ações judiciais: uma, para retomar o território, e outra para o reconhecimento, pelo Estado, dos danos causados à etnia.

O ISA, então, editou um livro sobre a situação para sensibilizar a opinião pública, o Legislativo e o Executivo. Foi produzido, também, um filme sobre a história dos Panará. A ONG, então, pleiteou

\footnotetext{
${ }^{128}$ Entrevista concedida em 27 de janeiro de 2015.
} 
junto ao Executivo o procedimento administrativo de demarcação da terra indígena via FUNAI. O ISA também organizou a ida de uma delegação Panará ao território original, para que as lideranças indígenas pudessem verificar qual parte guardava ainda as características do território tradicional.

O lobby no Executivo foi bem-sucedido, e a demarcação do território foi alcançada antes do julgamento da ação na Justiça, a partir da cessão de uma gleba pelas Forças Armadas na região da serra do Cachimbo.

A ação dos danos causados à etnia pelo Estado, por meio do contato, foi julgada até a última instância e o ISA saiu vitorioso, com o reconhecimento do direito dos índios.

O último desafio era persuadir o Estado a não recorrer ao Supremo, por meio da Advocacia Geral da União (AGU). O Instituto Socioambiental, então, negociou com o advogado-geral da União, à época Gilmar Mendes, e com o presidente Fernando Henrique Cardoso. O argumento dos representantes da ONG era de que o Estado brasileiro, sob liderança de um presidente antropólogo, poderia, pela primeira vez, reconhecer os danos causados pelo contato com uma etnia indígena. A Presidência e a AGU concordaram em não recorrer e foi paga uma indenização de $R \$ 1$ milhão, depositada em um fundo para a implementação das novas aldeias e para a mudança da comunidade para seu espaço tradicional.

Fonte: Adriana Ramos, coordenadora do programa de Política e Direito do ISA

Quadro 11: Vencendo nas cortes a indústria do cimento

Nos Estados Unidos, é atribuição da EPA estabelecer padrões para emissões de poluentes pela indústria, que precisam atender a pré-requisitos mínimos. Por um tempo, a agência decidiu que, se uma fábrica de cimento estivesse começando as atividades, fechando as portas ou com algum problema técnico, não teria que atender aos padrões mínimos de emissões. Em 2008, a Earthjustice ganhou uma ação que definiu que a indústria cimenteira teria que atender aos limites estabelecidos pela Lei do Ar Puro (Clean Air Act) em todos as fases de sua operação.

Porém, a EPA, atendendo a pressões da indústria, questionou o resultado, dizendo que, se a fábrica passa por problemas técnicos, não há nada a ser feito, e multas não poderiam ser aplicadas. A Earthjustice entendia que a alegação não fazia sentido e, portanto, era um desrespeito à lei. Afinal, defeitos técnicos poderiam ser usados como desculpa para exceder os níveis de emissões e seria muito difícil provar que o suposto defeito inexistia, fora superestimado ou causado de propósito.

Em setembro de 2010 a Earthjustice entrou com a primeira ação, após o fracasso das negociações com uma coalizão dos fabricantes de cimento. A EPA respondeu, insistindo que estava agindo dentro da lei. Os representantes da indústria de cimento reafirmaram estar de acordo com a agência, como era de se esperar. Em outubro de 2013, as partes interessadas (Earthjustice, EPA e Associação dos Fabricantes de Cimento) se pronunciaram diante de um painel com três juízes. A Earthjustice saiu vencedora e a EPA teve que se adequar, eliminando essa brecha que permitia que a indústria poluísse mais por conta de problemas técnicos.

Fonte: Depoimento de Seth Johnson, advogado sênior da ONG Earthjustice

\subsection{CAMPANHAS ELEITORAIS: ESVERDEANDO O LEGISLATIVO E O EXECUTIVO}

O envolvimento em campanhas eleitorais, com objetivo de colocar em instâncias decisórias do Legislativo e do Executivo representantes sintonizados com a promoção do desenvolvimento sustentável, é um repertório amplamente adotado pelo movimento ambientalista norte-americano e praticamente não utilizado por seus pares no Brasil.

Importante mencionar que, pela lei eleitoral brasileira, ONGs e entidades consideradas de utilidade pública, que recebam recursos do exterior ou qualquer tipo de verba pública, 
não podem doar ou fazer publicidade para candidatos. Esse fator, em si, é importante limitador para o envolvimento das organizações do Terceiro Setor em processos eleitorais.

Pela legislação norte-americana, as organizações podem apoiar abertamente, contraindicar e até fazer doações para candidaturas, desde que estejam enquadradas na categoria de ONG que não possa receber doações dedutíveis do Imposto de Renda. Tratase da mesma situação discutida anteriormente neste capítulo, das organizações que praticam ações de lobby. Ou seja, algumas organizações criam uma segunda entidade jurídica, para a qual cidadãos e empresas podem doar, mas sem abater do IR, e esta outra entidade poderá fazer ações ilimitadas de lobby e se envolver em campanhas eleitorais.

Nos Estados Unidos, o envolvimento em eleições acompanha o movimento ambientalista praticamente desde 1970, quando a League of Conservation Voters - a mesma organização que faz o ranking da atuação ambiental dos parlamentares — escolheu 12 candidatos nos quais os eleitores comprometidos com o meio ambiente não deveriam votar. A iniciativa, denominada "The Dirty Dozen"129, permanece nos dias de hoje.

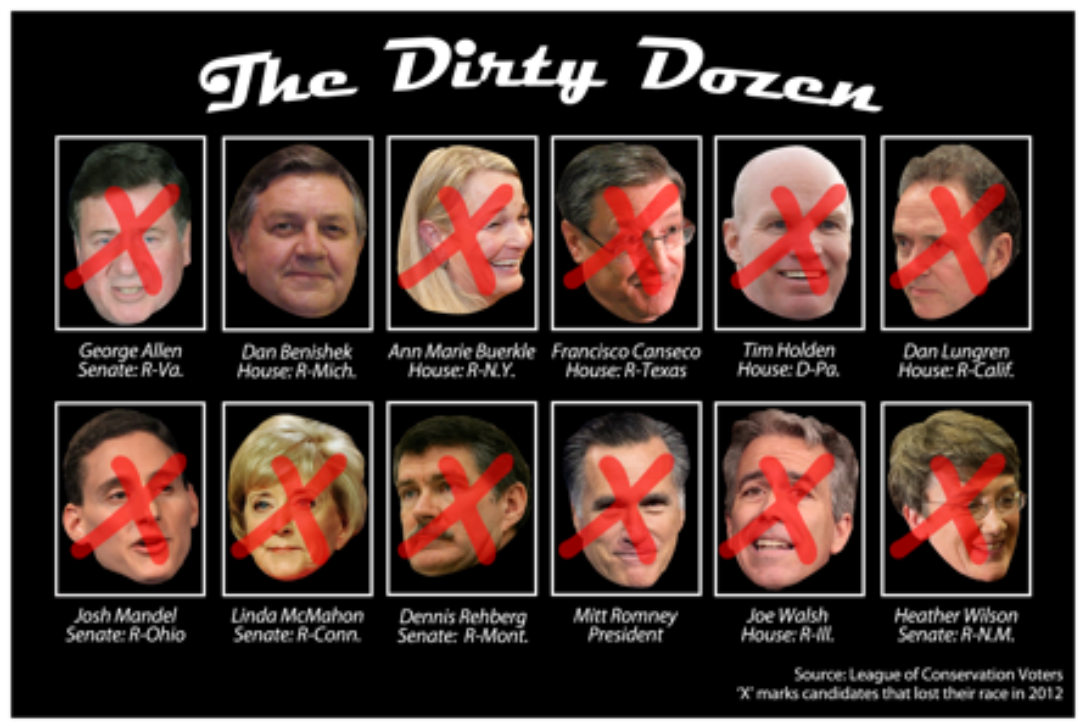

Figura 21: Apenas um dos 12 candidatos da lista suja da LCV foi eleito nas eleições de 2012 Fonte: site da LCV

Além de contraindicar candidatos, tanto nas eleições nacionais, quanto nas regionais, a LCV endossa candidatos favoráveis às ideias ambientalistas. Isso também é feito por

\footnotetext{
${ }^{129}$ A campanha The Dirty Dozen, ou "os 12 sujos", em tradução livre, é feita em cada eleição para o Congresso, de dois em dois anos. O nome é o mesmo de um filme de guerra de 1967, traduzido para o português como "Os 12 Condenados".
} 
outras organizações, como Sierra Club, Defenders of Wildlife, EDF e Friends of the Earth, entre outras.

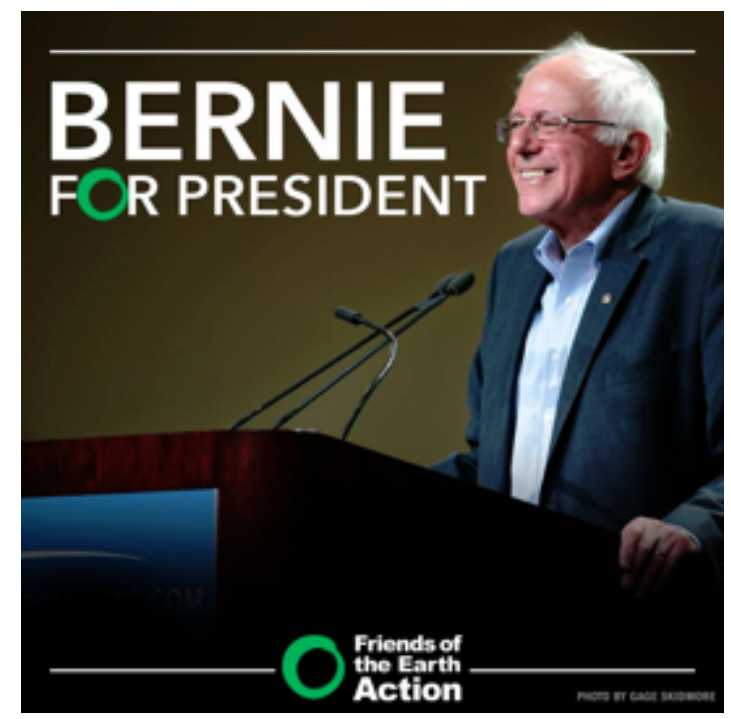

Figura 22: Peça da Friends of the Earth com endosso ao pré-candidato Bernie Sanders à Casa Branca Fonte: Facebook da Friends of the Earth

\subsubsection{Dinheiro para campanhas verdes}

Adicionalmente, algumas dessas entidades organizam os chamados comitês de ação política (PACs, na sigla em inglês), que levantam doações para candidatos considerados amigos da causa ambiental. A LCV angariou, junto com outras organizações, e doou para candidatos ou investiu em publicidade para candidaturas, cerca de US\$30 milhões nas eleições parlamentares de 2014 (Eilperin, novembro de 2015).

Segundo Sara Chieffo, diretora legislativa da LCV, entrevistada para esta pesquisa ${ }^{130}$, a organização tem alguns critérios para definir apoios a candidatos. A nota do político no ranking da ONG é um dos mais importantes. Também leva-se em conta se há uma possibilidade real de vitória e se a participação da organização na campanha pode fazer alguma diferença. "Há estados em que as campanhas são muito caras e há tanto dinheiro na disputa que nós não obteremos crédito ao final do processo", observou.

Por fim, é entregue a vários candidatos um questionário com diversas perguntas sobre temas ambientais considerados essenciais pela LCV, e as respostas dadas precisam comprovar a sintonia do político com as pautas defendidas pela ONG e pelo movimento ambientalista de maneira geral.

\footnotetext{
${ }^{130}$ Entrevista concedida em 9 de dezembro de 2014.
} 
De acordo com as entrevistas feitas com ambientalistas e pesquisadores, a decisão de 2010 da Suprema Corte americana, de não limitar doações por parte de empresas, alegando que contribuições de campanhas são uma forma de liberdade de expressão (Hacker e Pierson 2010, p.293), prejudicou bastante a representatividade social nas eleições do país. Afinal, o dinheiro passa a ter ainda mais poder nos processos políticos.

Os representantes de ONGs que participam de campanhas eleitorais, especialmente aquelas que arrecadam recursos para fazer doações, afirmaram categoricamente, nas entrevistas para esta pesquisa, serem contra as atuais regras do sistema eleitoral, mas que o movimento precisa se esforçar para aumentar sua influência no processo eleitoral. Wesley Warren, diretor de política e advocacy do NRDC, analisou ${ }^{131}$ a estratégia da ONG nesse sentido:

É importante dizer que o NRDC é a favor de reformas no financiamento de campanhas. Gostaríamos de ver uma redução do poder do dinheiro e um maior nivelamento desse campo de disputas. $O$ ideal seria que pessoas com menos recursos conseguissem fazer suas vozes serem ouvidas sem terem que gritar tanto. Mas nós temos que jogar de acordo com as regras vigentes, é uma forma de participarmos do processo. Assim sendo, nós ajudamos a arrecadar dinheiro para candidatos, e recomendamos às pessoas como elas podem contribuir financeiramente para campanhas. De toda forma, entendemos que a participação popular é o melhor antídoto contra as grandes contribuições financeiras.

Para Andrew Linhardt ${ }^{132}$, lobista do Sierra Club, as contribuições financeiras empresariais ilimitadas são algo que "corrói o sistema democrático", mas a ONG para a qual trabalha, além de arrecadar, também desenvolve uma série de outras ações buscando influenciar os resultados das eleições:

Endossamos e apoiamos candidatos com os quais concordamos e que estão de acordo com a nossa agenda, que é composta de energias renováveis, redução de emissões, proteção de áreas, ar puro e água limpa. Arrecadamos para isso. Mandamos voluntários nos distritos e pessoas usam seu tempo para trabalhar em campanhas de candidatos nos quais acreditamos. Parte importante do que fazemos é convencer ativistas do Sierra Club a trabalhar em campanhas. Não é só o dinheiro que conta. Também faz a diferença

\footnotetext{
${ }^{131}$ Entrevista concedida em 15 de janeiro de 2015.

${ }^{132}$ Entrevista concedida em 15 de janeiro de 2015.
} 
angariar pessoas para votar, para bater de porta em porta e fazer ligações telefônicas.

Similar trabalho, de mobilizar ativistas para as eleições, é desenvolvido pelo Greenpeace nos Estados Unidos. Nas eleições de 2008 a ONG trabalhou com ativistas em mais de 50 distritos eleitorais para demandar de candidatos o compromisso com a pauta do aquecimento global (Davies 2010, p.198).

Outro campo fértil para a atuação das ONGs são as propostas de lei colocadas em consulta popular, chamadas de proposições, prática comum no sistema político norteamericano ${ }^{133}$ que pode partir do Legislativo ou de iniciativa popular. Segundo Guber (2003), as proposições "oferecem aos cidadãos maiores chances de lidar com problemas ambientais de forma direta" (p.125) e, aos ambientalistas, possibilidades de melhorar a legislação ambiental fora das caras batalhas eleitorais (p.152).

Nas eleições presidenciais, em algumas ocasiões, os ambientalistas americanos têm conseguido êxito. A indicação, nas primárias Democratas, do ambientalista Al Gore como vice na chapa vitoriosa de Bill Clinton, em 1992, foi apoiada pelo movimento (Neuzil e Kovarik 1996, p.10). Barack Obama, tanto em sua campanha para o Senado, em 2004, como nas eleições presidenciais de 2008 e 2012, foi endossado pela LCV e por outras ONGs.

\subsubsection{O caso brasileiro: atuação tímida}

No Brasil, como mencionado, o movimento ambientalista tem uma atuação modesta nos processos eleitorais. Para ser mais exato, institucionalmente falando, até por conta das restrições legais, as organizações não apoiam candidatos em eleições.

Individualmente, sem o lastro das organizações a que estão vinculados, ambientalistas se mobilizaram em algumas eleições para apoiar candidaturas consideradas verdes. Em 1982, um "setor minoritário do ecologismo decide participar diretamente na arena política nas eleições de 1982 apoiando candidatos que levantam bandeiras ecológicas para deputado estadual", nos estados de São Paulo, Rio de Janeiro e Rio Grande do Sul (Viola 1987, p.96). Em 1986, Fábio Feldmann é eleito deputado federal, representante dos ambientalistas, e reeleito nas duas eleições seguintes (Mittermeier et al 2005, p.18)

Como abordado no Capítulo 3 desta tese, ambientalistas brasileiros fundaram, nos anos 1980, o Partido Verde que, embora não figure entre as maiores agremiações do país, sempre ocupa cadeiras na Câmara dos Deputados. Em 2010, integrantes do movimento

\footnotetext{
${ }^{133} \mathrm{Na}$ seção 4.1 deste capítulo algumas linhas foram dedicadas à proposição 65, votada na Califórnia em 1986.
} 
ambientalista apoiaram, em sua maioria, a candidatura de Marina Silva à Presidência da República pelo PV, que ficou em terceiro lugar e obteve $20 \%$ do total de votos, número que se repetiu nas eleições de 2014 para presidente, quando Marina candidatou-se pelo PSB. Mas o apoio, como já observado, era de indivíduos alinhados à causa ambiental, e não de organizações ambientalistas.

Uma ação comum das ONGs em eleições no Brasil é a tentativa de obter compromissos dos principais candidatos. Nas eleições presidenciais de 2010 e 2014, por exemplo, as organizações, em alianças ou individualmente, prepararam questionários sobre questões consideradas fundamentais para o movimento, com o objetivo de obter a adesão dos principais candidatos. Isso também é feito em todas as eleições por diversos grupos de interesse nos Estados Unidos.

A fundação da Rede Sustentabilidade, partido político cujo registro no Tribunal Superior Eleitoral (TSE) foi homologado em setembro de 2015, também representa uma estratégia não institucional (portanto, sem o envolvimento formal das organizações) de aumentar a influência dos ambientalistas na política nacional. De acordo com André Lima, secretário de Meio Ambiente do Distrito Federal desde janeiro de 2015, em entrevista para esta pesquisa ${ }^{134}$, o movimento buscou, com a criação da Rede, preencher um espaço no cenário político:

Não víamos nenhum partido defender a agenda da sustentabilidade. Tínhamos que ir para o front. A candidatura da Marina em 2010 foi uma decisão deliberada de abrir esse front, tanto é que ela teve $20 \%$ dos votos. E depois tivemos necessidade de institucionalizar esse grupo político. Como secretário de Meio Ambiente do DF, estou na linha de frente da política ambiental da capital do país, o que não é pouca coisa. Aqui pode ser uma importante força política para a Rede.

Alguns entrevistados defenderam um posicionamento mais agressivo do movimento ambientalista no sentido de ter mais representatividade na política. "Médicos, evangélicos, ruralistas, todos eles estão representados no parlamento, mas nós não. Isso é um problema, as ONGs deveriam assumir isso e se envolver", afirmou João Paulo Capobianco, exsecretário de Biodiversidade e Florestas do MMA $^{135}$. José Carlos Carvalho ${ }^{136}$, ex-ministro do Meio Ambiente, pensa de forma semelhante:

\footnotetext{
${ }^{134}$ Entrevista concedida em 10 de abril de 2015.

${ }^{135}$ Entrevista concedida em 5 de maio de 2015.
} 
O movimento ambientalista no Brasil quer ter uma falsa neutralidade, fica todo mundo em cima do muro. A democracia implica escolher lados. Com isso, o ambientalismo não tem deputados no parlamento. Aí, quando não há acesso ao Executivo, fica como uma colmeia sem abelha-rainha.

Quadro 12: Devolva o nosso dinheiro!

Nem sempre o envolvimento com candidatos por parte das organizações ambientalistas nos Estados Unidos traz resultados positivos. Às vezes, quando o candidato está estreando na política nacional, e não tem uma trajetória de defesa das questões ambientais, o apoio é dado com base em compromissos assumidos durante a campanha, o que não deixa de ser uma aposta.

A LCV apoiou, nos anos 2000, com doações de campanha, um candidato de um distrito com muitas usinas a carvão no estado de Illinois. Ele se comprometeu com a organização ambientalista a apoiar ações de combate às mudanças climáticas e de controle da poluição causada por usinas térmicas a carvão. Seis meses após sua eleição, ele confirmou à LCV o compromisso assumido na campanha.

Porém, meses depois, ele foi coautor de um projeto de lei propondo que a EPA não regulasse as emissões de carbono das usinas a carvão. A LCV entrou em contato com o gabinete do parlamentar pedindo explicações, que não convenceram. Dias depois, a ONG publicou, em um jornal de grande circulação, uma carta direcionada ao deputado, com os dizeres: "devolva nosso dinheiro! Você assumiu compromissos e não os cumpriu". Naturalmente, o parlamentar não devolveu o dinheiro, mas sofreu um constrangimento público na imprensa. Além disso, outros políticos puderam ver que a LCV monitora de perto o trabalho deles e cobra o cumprimento das promessas feitas na campanha.

Fonte: Depoimento de Sara Chieffo, diretora legislativa da LCV.

\subsection{DENÚNCIAS, AÇÃO DIRETA, BOICOTES E PROTESTOS: ORGANIZAÇÕES CÃES DE GUARDA}

O monitoramento de governos e entidades privadas é uma das mais importantes atribuições das organizações do Terceiro Setor nos sistemas democráticos. Assim como uma imprensa forte é um contrapeso crucial para limitar o grande poder do Estado e das corporações, um conjunto de ONGs saudáveis e atuantes é fundamental para cobrar transparência e profissionalismo das instituições públicas e privadas.

Tanto no Brasil como nos Estados Unidos há registros de importantes ações das ONGs no sentido de monitorar atores públicos e privados em relação ao cumprimento das leis ambientais. "As ONGs devem poder participar da tarefa pública de inspeção e monitoramento das fontes poluidoras. Não basta o Poder Público executar essa função que deve continuar a ser sua obrigação — de forma solitária" (Machado 2011, p.109).

As organizações com foco em campanhas - notadamente Greenpeace, 350.org e diversas entidades de base comunitária dos EUA - têm a importante função de alertar a

\footnotetext{
${ }^{136}$ Entrevista concedida em 23 de julho de 2015.
} 
sociedade sobre graves problemas ambientais causados por ação ou omissão de atores públicos e privados. ONGs de maior porte ou com postura mais conciliadora, embora desempenhem papéis importantíssimos para a promoção do desenvolvimento sustentável, frequentemente costumam ter dificuldades em passar mensagens mais agressivas e fazer cobranças duras dirigidas a governos e empresas.

Lois Gibbs, principal articuladora da célebre mobilização de Love Canal em 1978, hoje diretora da ONG norte-americana CHEJ, entende que as táticas mais efetivas são aquelas que começam nas bases, e depois se ampliam, colocando pressão em tomadores de decisão e corporações. Com os protestos de Love Canal, denunciando depósitos irregulares de lixo tóxico em áreas residenciais, o presidente Jimmy Carter chegou a visitar o local e determinou a realocação das famílias prejudicadas (Sirianni e Friedland 2001, p.117). A ativista recorda um episódio que se iniciou localmente, e depois cresceu:

Fizemos uma campanha para a Sears parar de usar PVC. E várias pessoas foram às lojas da Sears dizendo que boicotariam a empresa se eles não deixassem de usar PVC [em suas embalagens]. Se impactarmos a receita das companhias, elas farão a coisa certa, não porque é a coisa certa, mas para não perderem dinheiro.

Nesse contexto, repertórios de desobediência civil e ações diretas ${ }^{137}$ costumam se fazer presentes, embora com menor incidência que nos anos 1970 e 1980 (Gunter Jr. 2004, p.47). Para Wapner (1996), ações como escalar plataformas de petróleo, abordar navios que pescam baleias, entupir chaminés que emitem poluentes ou pendurar banners em sedes de empresas "podem ser divulgadas pelas mídias para despertar interesse e a preocupação de grandes audiências. O Greenpeace consegue a atenção da mídia porque suas ações são visualmente espetaculares " (p.50 - tradução minha).

Um exemplo de ação de protesto bem-sucedida foi o bloqueio da saída de um porto, em Portland, estado do Oregon (EUA), por 13 ativistas do Greenpeace, em julho de 2015. Eles se penduraram em uma ponte, sob a qual um navio da Shell, ancorado no porto de Portland, teria que passar para chegar ao Ártico. O objetivo da ONG era impedir, por meio de obstáculos humanos - ação direta, portanto - que houvesse exploração de petróleo no Ártico.

\footnotetext{
${ }^{137}$ Segundo Bevington (2009), ação direta é a intervenção com o objetivo de parar alguma atividade (p.1).
} 


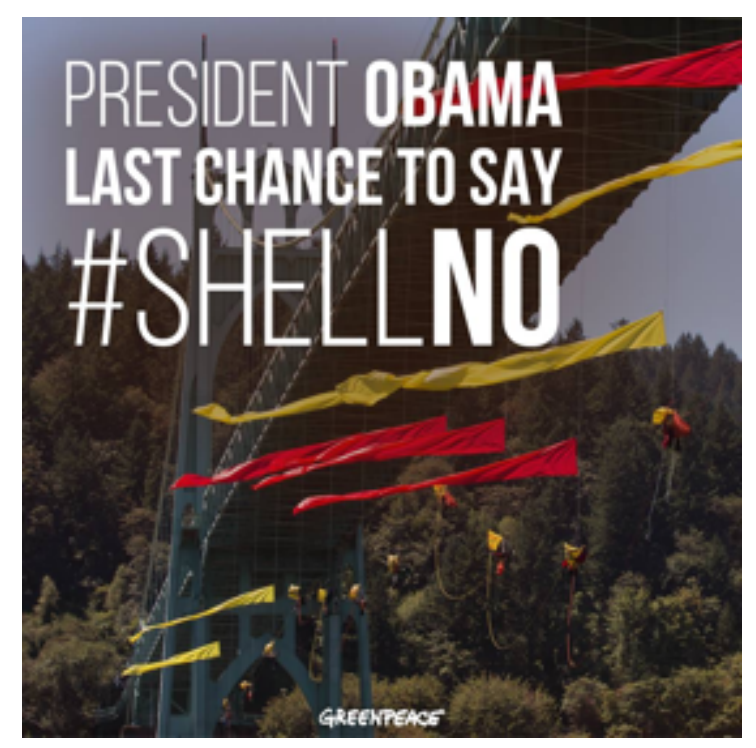

Figura 23: Peça sobre bloqueio à passagem do navio da Shell rumo ao Ártico e apelo ao presidente para proibir a exploração de petróleo na região

Fonte: Facebook do Greenpeace, julho de 2015

O navio da Shell acabou não passando e, menos de dois meses depois do protesto, a multinacional suspendeu os planos de retirar petróleo da região. Em outubro, o presidente dos EUA, Barack Obama, cancelou os leilões para exploração do petróleo no Ártico, que aconteceriam em 2016 e 2017. Não é possível afirmar com certeza que a mobilização do Greenpeace foi a responsável pelas decisões da multinacional e da Casa Branca, mas não é absurdo construir essa correlação. Afinal, a ação da ONG foi acompanhada de petições com milhões de assinaturas em todo o mundo, ampla divulgação de mídia e pressão de ativistas de vários países dirigidas à petrolífera e ao presidente dos EUA (Brait 2015; Glaser 2015; Mooney 2015).

No Brasil, além de importantes pesquisas e denúncias que revelam, por exemplo, o tráfico ilegal de madeira da Amazônia para diversos locais do Brasil e do mundo, o Greenpeace também organiza ações públicas chamando atenção para relevantes temas ambientais. Recente exemplo foi a manifestação em frente ao Palácio do Planalto, em abril de 2015, oferecendo a instalação, pela ONG, de painéis de energia solar na sede do Executivo Federal. O protesto pedia redução nas alíquotas de impostos sobre painéis solares para incentivar a fonte de energia limpa no país (Aquino 2015). 


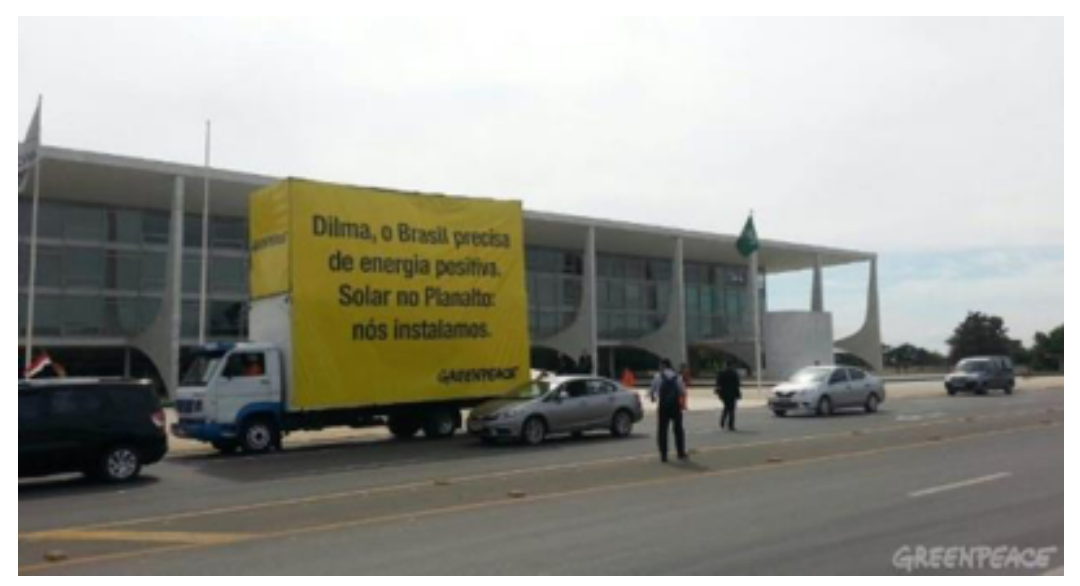

Figura 24: Protesto do Greenpeace em frente ao Planalto pede incentivos à energia solar Foto: Greenpeace

Frequentemente, denúncias e manifestações são capazes de produzir alterações nas políticas públicas. Em 2001, o Greenpeace elaborou uma denúncia sobre a extração ilegal de mogno no Pará, na forma de um detalhado relatório. Como resultado, o Governo Federal anunciou uma moratória à extração e à comercialização da espécie madeireira. Três anos depois, foram criadas, na região das denúncias, duas reservas extrativistas (Hochstetler e Keck 2007, pp.176-177).

Tomadores de decisão entrevistados informaram que mobilizações e denúncias, quando bem fundamentadas ou envolvendo grande número de cidadãos, acabam impactando os processos decisórios. Roberto Messias Franco ${ }^{138}$, que presidiu o IBAMA entre 2008 e 2010, disse que a decisão de licenciar a usina nuclear de Angra 3, em decorrência da mobilização liderada pelo Greenpeace, foi difícil.

Tentei dialogar com eles. O Greenpeace divulgou meu e-mail para toda a rede Greenpeace, entupiram minha caixa de e-mails. Eu licenciei com convicção. Acredito que a equação energética tenha que ser múltipla, com energia hidrelétrica, solar, eólica e também nuclear. Era preciso ter de $3 \%$ a $5 \%$ de nuclear na equação brasileira para evitarmos outras fontes mais poluentes. Mas a ação direta e os protestos, como foi o caso do que o Greenpeace fez em relação a Angra, de fato influenciam. Quando o processo não tem agenda oculta e é transparente, isso torna a decisão muito dura. Mais ainda no caso do IBAMA, em que a decisão é monocrática, está nas mãos do presidente. A responsabilidade é toda do presidente e há informações fundamentadas dos dois lados. Sem dúvida, a pressão

\footnotetext{
${ }^{138}$ Entrevista concedia em 3 de junho de 2015.
} 
dos movimentos influencia e muitas vezes faz com que sejam colocadas diversas condicionantes muito importantes, que não apareceriam se não fossem as organizações.

O deputado Sarney Filho ${ }^{139}$ também relatou que denúncias bem fundamentadas de organizações sérias acabam gerando decisões por parte de parlamentares. Como exemplo, o congressista, considerado um aliado pelo movimento ambientalista, citou as cobranças diretas que ele fez ao ministro da Justiça, à presidente do IBAMA e ao governador do Maranhão diante de informações sobre a exploração madeireira ilegal dentro da terra indígena Alto Turiaçu, no Maranhão, denunciada pelo Greenpeace.

Segundo Márcio Astrini, coordenador de políticas públicas do Greenpeace, em entrevista para esta pesquisa ${ }^{140}$, outro objetivo das denúncias e dos protestos do Greenpeace, além de eliminar práticas predatórias, é contribuir para mudanças na forma coletiva de pensar.

Há 150 anos era natural comprar batata produzida por um escravo. Os valores da sociedade mudam, e o valor que a sociedade dá para o meio ambiente vem mudando muito. Isso nos permite mudar o discurso: o meio ambiente pode gerar emprego ou o mau uso pode tirar empregos, gerar inflação etc. Ao inserir esse tema, permite-se ganhar mais espaço na opinião pública e, com isso, influencia-se mais o Legislativo e o Executivo.

Outro ponto que confere credibilidade ao Greenpeace é o fato de a organização não aceitar contribuições de empresas ou governos. Ou seja, a ONG é mantida por contribuições de pessoas físicas. Assim, há maior independência para criticar e denunciar governos e empresas.

\subsection{GRANDES EMPRESAS, GRANDES ALIADOS}

As parcerias entre as organizações ambientalistas e a iniciativa privada vêm aumentando, tanto no Brasil como nos Estados Unidos. De acordo com a literatura pesquisada e com entrevistas realizadas para esta tese, esse tipo de aliança é a grande marca do que se chamou de terceira onda do ambientalismo norte-americano, intensificada nos anos 1990. O movimento brasileiro, em muitos pontos influenciado pelas organizações

\footnotetext{
${ }^{139}$ Entrevista concedida por e-mail em 24 de setembro de 2015.

${ }^{140}$ Entrevista concedida em 9 de junho de 2015.
} 
norte-americanas e europeias, também seguiu tendência parecida e as chamadas parcerias corporativas se multiplicaram.

As críticas a esse tipo de aliança são bastante comuns, não apenas entre os ambientalistas que defendem o ativismo como essência do movimento, como também entre pesquisadores (Dowie 1995, p.106). Muitos críticos entendem que a raiz da crise climática está no sistema capitalista e que nenhuma mudança será efetiva se este modelo não for combatido. Outros analistas, também críticos às alianças entre ONGs e corporações, afirmam que boa parte dessas parcerias consiste, por um lado, em dar a poluidores a chance de limpar a imagem e aumentar os lucros associando a marca a uma causa bem vista pela sociedade e, por outro, de prover recursos financeiros para que as ONGs possam manter suas grandes estruturas.

Os defensores das parcerias entre ONGs e indústrias entendem que, se o setor produtivo não melhorar as práticas, nenhuma mudança será suficiente para deter o aquecimento global. Por isso, é determinante que os movimentos adotem uma estratégia pragmática. Por exemplo, um novo critério de escolha de fornecedor com base na sustentabilidade, por parte do Walmart, maior rede supermercadista do mundo, é capaz de gerar redução de emissões em larga escala, produzindo mudanças significativas em benefício da coletividade.

É importante observar que as parcerias entre ambientalistas e o setor privado têm uma multiplicidade de facetas. Na atuação voltada ao setor privado, ONGs podem recompensar ou punir de acordo com a conduta das empresas, uma vez que o Terceiro Setor costuma ter mais credibilidade que a iniciativa privada (Lyon 2010, p.8; Maxwell 2010 p.158).

Em relação à possibilidade de parcerias corporativas modificarem políticas públicas, as perspectivas são muitas e é disso que esta seção da tese vai tratar. Inicialmente, cabe observar que, entre as grandes organizações ambientalistas, a maioria tem algum tipo de aliança com empresas. ONGs como Cl, EDF, NRDC, NWF, TNC, TWS e WWF, entre outras, reconhecidamente dialogam e mantêm uma série de parcerias com grandes empresas, apesar de também realizarem denúncias de práticas predatórias (Lyon 2010, p.169). O EDF chegou ao ponto, inclusive, de abrir um escritório na pequena Bentonville (população de 40 mil habitantes), estado de Arkansas, com o objetivo de fortalecer a parceria com a rede supermercadista Walmart, cuja sede fica naquela cidade, e tornar a corporação mais "verde" (Humes 2011, pp.85-86). 


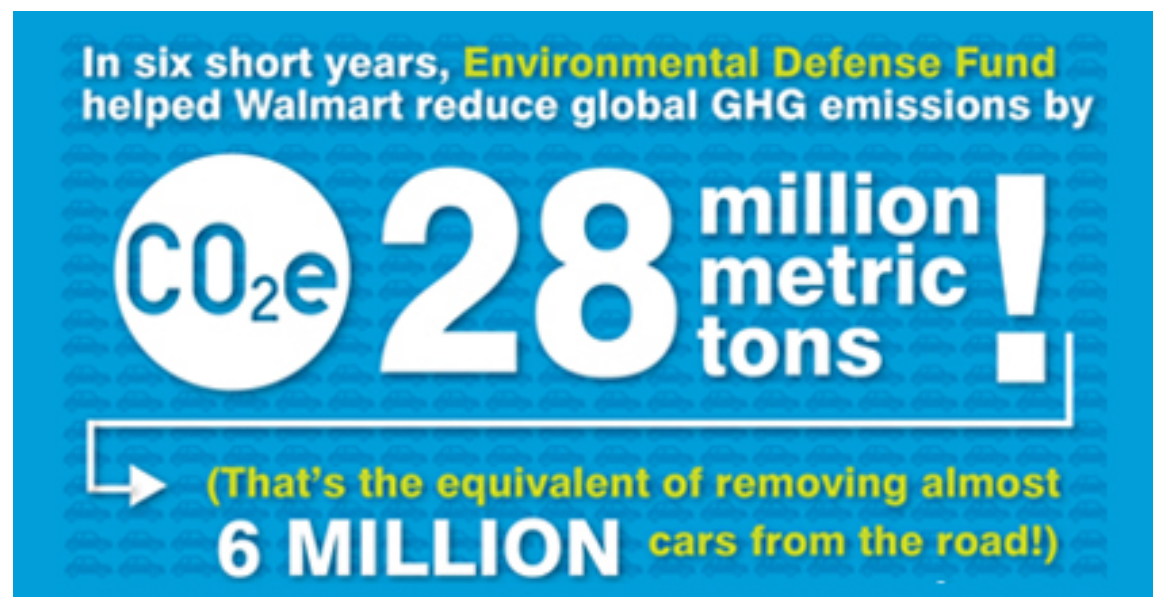

Figura 25: Material do EDF afirmando que a parceria com o Walmart, em seis anos, evitou a emissão de 28 milhões de toneladas métricas de $\mathrm{CO} 2$ Fonte: site da EDF

O Greenpeace, embora dialogue com empresas, não recebe dinheiro delas, concentrando sua fonte de receitas em contribuições de pessoas físicas (Humes 2011, pp.85-86). Organizações brasileiras como ICV, IMAZON, IPAM, ISA e SOS Mata Atlântica, entre outras, também mantêm parcerias com empresas e têm nelas, ou em fundações por elas mantidas, importantes fontes de arrecadação. No Capítulo 5 discutirei a influência das empresas no movimento ambientalista, bem como algumas causas e consequências ligadas a esta questão.

De acordo com Wesley Warren, diretor de política e advocacy do NRDC, em entrevista para esta pesquisa ${ }^{141}$, ter grandes empresas como aliadas, em um sistema político em que elas têm tanto poder, significa acesso a núcleos políticos que podem decidir importantes questões ligadas ao meio ambiente.

Corporações são muito influentes e politicamente poderosas, e podem algumas vezes canalizar muito dinheiro no sistema político. Elas têm grande credibilidade em alguns círculos e nós temos em outros. Com eles, podemos conversar com os congressistas mais conservadores. Política tem a ver com somar, não com subtrair.

Trata-se, assim, de postura pragmática, com potencial de sucesso em diversas iniciativas, desde que não envolvam, naturalmente, políticas em que fortes conflitos de interesse estejam presentes. Wesley Warren fez questão de observar, ainda, que o NRDC já

${ }^{141}$ Entrevista concedida em 15 de janeiro de 2015. 
fez e faz diversas ações para denunciar práticas empresariais que promovam impactos negativos ao meio ambiente e a comunidades ${ }^{142}$.

Uma importante faceta das parcerias entre ONGs e empresas, que frequentemente redundam em mudanças nas políticas, são as certificações de boas práticas empresariais. Nesse caso, as ONGs fornecem uma espécie de consultoria para que as indústrias passem a produzir com base em parâmetros sustentáveis, do ponto de vista ambiental, social e econômico. As transformações em políticas acontecem, por exemplo, quando governos modificam critérios de compras públicas, passando a adquirir apenas produtos de origem sustentável, de acordo com os padrões implementados na parceria entre ONGs e empresas.

Nos EUA e no Canadá, uma iniciativa de Greenpeace, NRDC e Rainforest Network fez com que os padrões internacionais de certificação, assegurados pelo Conselho de Manejo Florestal (FSC), pudessem ser adotados por indústrias dos dois países (Elkington e Beloe 2010, p.41). Políticas como as emendas ao Lacey Act, de 2008, discutidas no item 4.6 deste capítulo, apoiadas tanto por ONGs como por setores da indústria, legitimaram a parceria.

No Brasil, as parcerias entre movimento ambientalista e indústria foram referendadas por diversas políticas subnacionais, notadamente no âmbito de estados e municípios. Governos de estados como Acre, Amazonas, Minas Gerais e São Paulo assinaram políticas de compras governamentais sustentáveis, em iniciativas conjuntas com ONGs e indústria madeireira, segmento anteriormente marginalizado pela comunidade ambientalista.

Há, ainda, diversos registros de alianças entre movimento ambientalista e indústrias no sentido de organizar coalizões de lobby para promover a aprovação de determinada legislação. Neste capítulo já foram discutidas duas leis que passaram graças a essas parcerias: a Lei de Gestão de Florestas Públicas, no Brasil (2006), e as emendas ao Lacey Act, nos EUA (2008).

O WWF Estados Unidos iniciou, em 2014, uma parceria com grandes empresas como Walmart, Facebook, Mars (chocolates) e Sprint (operadora de telefonia), no sentido de aumentar a oferta de energia renovável, para que essas companhias possam usar menos fontes fósseis. Para isso, ajustes no sistema de distribuição seriam necessários, e a parceria conseguiu expor esse descompasso entre oferta e demanda em diversos veículos de mídia.

Em entrevista ${ }^{143}$, Christopher Conner, comunicador do WWF, me disse que, a partir dessa articulação, tornou-se mais fácil convencer governos e parlamentares dos dois

\footnotetext{
${ }^{142}$ Durante esta pesquisa tomei conhecimento de uma série de campanhas da NRDC denunciando, por exemplo, práticas predatórias, frequentemente ilegais, por parte da indústria do petróleo.

${ }^{143}$ Entrevista concedida em 17 de dezembro de 2014.
} 
partidos a fazer as mudanças. "Se o setor produtivo está caminhando, tomadores de decisão acreditam que é preciso tomar algumas medidas. Às vezes o governo tem que liderar, mas em outras ocasiões, ele é movido por uma tendência”, observou.

A constatação de que boas relações com o setor empresarial encurtam caminhos no Executivo e no Legislativo também se aplica à realidade brasileira. Patrícia Baião, exdiretora de Política e Governança da Conservação Internacional (Cl-Brasil) entre 2012 e 2015, falou disso em entrevista para esta pesquisa ${ }^{144}$. "Nossa parceria com a Alcoa, por exemplo, nos abre portas no Ministério de Minas e Energia", afirmou.

Segundo ela, a $\mathrm{Cl}$ sofre pesadas críticas por parcerias com empresas como a Monsanto, multinacional do setor de agricultura e biotecnologia, com imagem ligada a agrotóxicos e organismos geneticamente modificados. "Se não trouxermos a conservação para dentro da produção, as chances de fazer mudanças em grande escala são pequenas", justificou.

Outra estratégia observada em grandes organizações ambientalistas, tanto no Brasil como nos EUA, é a presença de empresários nos conselhos administrativos das ONGs. Em um rápido acesso aos sites da maioria das organizações abordadas nesta tese, é possível ver os nomes de representantes de importantes indústrias. Além de facilitar o acesso das organizações a fontes de financiamento, os empresários viabilizam contatos das ONGs com formuladores de políticas públicas. "A ligação das ONGs com grandes empresários, que muitas vezes até fazem parte do conselho, também é importante e ajuda a construir políticas e a aprová-las", declarou, em entrevista para esta pesquisa ${ }^{145}$, Roberto Messias Franco, expresidente do IBAMA e ex-secretário geral do WWF-Brasil.

Jorge Viana, responsável por importantes políticas de desenvolvimento sustentável quando era governador do Acre, e atual vice-presidente do Senado, comento ${ }^{146}$ a aproximação do movimento ambientalista com o setor produtivo.

Tem uma certa movimentação em curso, que a gente consegue identificar em algumas entidades. Elas se aproximaram do setor produtivo. A ideia é buscar dar soluções, eu acho isso fantástico. Elas começam a lidar com o mundo real. O trabalho das ONGs tem que ser mais sofisticado. Não pode ser algo que se confunda com partido político.

\footnotetext{
${ }^{144}$ Entrevista concedida em 12 de maio de 2015.

${ }^{145}$ Entrevista concedida em 3 de junho de 2015.

${ }^{146}$ Entrevista concedida em 27 de agosto de 2015.
} 
Rachel Biderman, diretora do World Resources Institute no Brasil, afirmou em entrevista $^{147}$, que o país já conta com um conjunto de empresários progressistas que, juntamente com o movimento ambientalista, pode pressionar os tomadores de decisão por políticas voltadas para a sustentabilidade. Uma realidade que é comprovada diariamente por diversas iniciativas empresariais voltadas para a sustentabilidade.

\subsection{COMUNICAÇÃO PARA SENSIBILIZAR E MOBILIZAR}

A mais transversal entre as linhas estratégicas usadas pelo movimento ambientalista é a da comunicação. Em todos os grandes repertórios analisados neste capítulo é possível incluir um componente de comunicação. Afinal, organizações que precisam aglutinar pessoas em torno de uma causa, convencer tomadores de decisão e, adicionalmente, dependem do apoio de indivíduos e instituições para sobreviver, precisam ter a habilidade de sensibilizar e mobilizar interlocutores.

Muitos pesquisadores que analisam as organizações ambientalistas destacam que um dos principais sucessos do movimento no mundo tem sido levar a agenda ambiental para os debates públicos e, consequentemente, gerar mudanças comportamentais na sociedade (Neuzil e Kovarik 1996, p.10; Wapner 1996, p.13). De acordo com Bernardes e Ferreira (2007),

...o estilo de vida da classe média ocidental está sendo transformado e o consumo de mercadorias ecológicas está aumentando, o tamanho das famílias diminuiu, a economia doméstica de recursos energéticos é uma realidade, em todos os cantos do mundo aumentam as implantações de reservas naturais e a preservação de áreas históricas, há um crescimento de agências governamentais (...) relacionadas à questão ambiental e aumento de leis ambientais. (...) [O]s movimentos ecológicos contribuíram para uma nova visão das relações sociedade/natureza (pp.34-35).

Wapner (1996) diz que as mudanças de atitude geradas pelas ONGs acontecem porque o movimento consegue, de forma efetiva, disseminar a "sensibilidade ecológica", algo por ele considerado como "uma forma de soft law ${ }^{148}$ em contraste com a hard law caracterizada por diretivas governamentais, políticas etc" (p.13).

\footnotetext{
${ }^{147}$ Entrevista concedida em 3 de agosto de 2015.

${ }^{148}$ O termo soft law é usado para caracterizar normas sem o efeito vinculante das leis formais, estas chamadas de hard law.
} 
Não é exagero dizer que esse sucesso em disseminar comportamentos ambientalmente corretos é diretamente ligado à capacidade de comunicação do movimento ambientalista. Em diversas entrevistas realizadas no Brasil e nos EUA, representantes de organizações que integram o lobby do setor produtivo e parlamentares (ou seus assessores) considerados avessos à causa ambiental afirmaram que as organizações não governamentais conseguem uma excelente inserção nos veículos de comunicação e nas mídias sociais, obtendo o que muitos deles classificaram como uma projeção desproporcional em relação à representatividade social do movimento.

Dizer que uma opinião pública mais favorável à proteção do meio ambiente gera políticas ambientalmente corretas é uma verdade, mas ainda se trata de uma associação um tanto genérica para os propósitos deste estudo. Uma vez que este trabalho busca analisar os repertórios por meio dos quais o movimento ambientalista influencia as políticas públicas, é necessário fazer um aprofundamento desta relação. Ou seja, de como as ações de comunicação contribuem para que os tomadores de decisão, estejam eles no Executivo, no Legislativo ou no Judiciário, elaborem, aprovem, implementem ou apliquem políticas em prol do desenvolvimento sustentável.

Uma das respostas é o fato de que a opinião pública, quando canalizada na forma de pressão popular, acaba sensibilizando os tomadores de decisão, que em geral, dependem de votos para se manterem em cargos políticos. É uma espécie de consenso, tanto entre ambientalistas quanto ruralistas, que a campanha Veta, Dilma, que teve na comunicação seu componente primordial, foi a principal responsável pelos 12 vetos e 32 alterações feitas pela presidente no texto aprovado pelo Congresso. Foram citados, em seções anteriores deste capítulo, outros episódios em que a mobilização de públicos estratégicos produziu importantes mudanças em políticas na direção desejada pelos ambientalistas.

\subsubsection{Mídias novas e tradicionais}

Outro ponto observado como de grande influência no trabalho dos tomadores de decisão do Legislativo e do Executivo é o conteúdo dos veículos de imprensa e, mais recentemente, aquilo que ganha grande visibilidade nas mídias sociais. Assessores de parlamentares nos EUA e os próprios congressistas, no Brasil, indicaram claramente que os temas pautados na mídia recebem atenção especial nos gabinetes.

Alguns parlamentares destacaram prestar atenção apenas aos veículos de comunicação de seus estados ou distritos, outros enfatizaram mais o papel da grande imprensa nacional. Houve assessores que disseram prestar atenção apenas quando o nome do parlamentar é diretamente mencionado. Mas nenhum entrevistado subestimou o caráter 
estratégico das mídias nos processos de tomada de decisão e, quando um movimento consegue acesso a esses meios, seja via assessoria de imprensa, ou via especialistas que se posicionam sobre algum tema, pode-se dizer que as possibilidades de influenciar políticas aumentam.

Ao entrevistar Christopher Conner ${ }^{149}$, do WWF-EUA, o primeiro aspecto que me chamou a atenção foi seu cargo: comunicador para políticas ambientais. Isso, por si só, já demonstra que a estrutura da ONG possibilita ações de comunicação especificamente voltadas para influenciar políticas. No Brasil, em meus seis anos de atuação no movimento ambientalista, e em posteriores pesquisas, jamais vi algo parecido. Nas organizações que aqui atuam, os profissionais de comunicação, normalmente, cuidam de diversas áreas, ou são divididos entre temas de conservação, como biomas, desenvolvimento sustentável, recursos hídricos e outros, e acabam trabalhando pontualmente com políticas públicas, de maneira geral.

De acordo com Christopher Conner, o trabalho de seu departamento tem dois focos principais: elevar o interesse público em assuntos estratégicos com que o departamento de relações governamentais da ONG esteja trabalhando e fazer com que os experts do WWF se tornem referências de mídia para falar sobre esses temas. "Quanto mais as pessoas falarem sobre esses assuntos, mais atenção eles recebem. Isso faz com que seja mais fácil para os políticos tomar decisões polêmicas e avançar melhores políticas sob a nossa perspectiva", resumiu o comunicador.

Cabe observar que a exposição nas mídias convencionais e sociais pode ter efeitos positivos ou negativos na imagem dos políticos. As ONGs ambientalistas analisadas conseguem trabalhar bem essa tática de parabenizar aliados e expor negativamente opositores, como uma forma de deixar claro que, na próxima votação, só depende do próprio deputado figurar junto ao lado "bom" da disputa. "A estratégia de mídia pode alavancar o apoio das bases para constranger os parlamentares ou para fazer com que se sintam reconhecidos", resumiu o assessor legislativo de um senador Democrata da Costa Leste dos EUA, em entrevista para esta pesquisa ${ }^{150}$.

A escolha das mídias-alvo das ações de comunicação é outro fator importante para determinar os resultados a serem alcançados. Josh Saks, diretor legislativo da National

\footnotetext{
149 Entrevista concedida em 17 de dezembro de 2014.

${ }^{150}$ Entrevista realizada em 23 de outubro de 2014.
} 
Wildlife Federation (NWF), declarou em entrevista para esta pesquisa ${ }^{151}$ que a segmentação de estratégias otimiza custos e refina os resultados alcançados.

Segundo ele, os jornais segmentados para tomadores de decisão de Washington D.C. ${ }^{152}$, por exemplo, são utilizados para avançar estratégias políticas que consistem em convencer um parlamentar ou um grupo de burocratas da administração pública. Para a mobilização em torno de assuntos de escala nacional, grandes veículos como The Washington Post, New York Times, L.A. Times, canais de TV como CBS, NBC, Fox News, CNN e MSNBC são acionados. No caso de um assunto de interesse essencialmente local no estado de lowa, por exemplo, é mais relevante o espaço no Des Moines Register que em um grande jornal nacional.

As ONGs também recorrem a anúncios publicitários para atingir a opinião pública e os tomadores de decisão. O critério de escolha dos veículos de mídia é similar ao explicado no parágrafo acima: veículos especializados para atingir tomadores de decisão específicos, veículos locais para sensibilizar audiências regionais e veículos de massa para alcançar o grande público. De toda forma, os anúncios publicitários são um recurso raramente utilizado pelas ONGs ambientalistas, devido aos elevados custos, conforme dito por vários entrevistados. Eventualmente, as organizações obtêm espaços publicitários gratuitos, as chamadas parcerias pro bono.

\footnotetext{
${ }^{151}$ Entrevista concedida em 22 de janeiro de 2015.

152 Publicações como Politico, The Hill e Roll Call, por exemplo.
} 


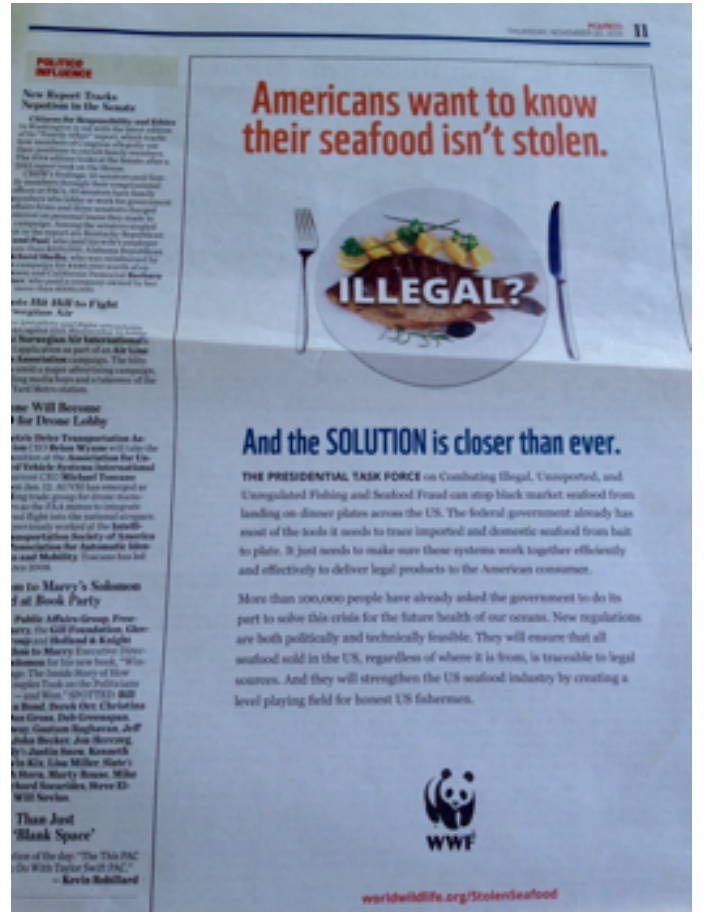

Figura 26: Anúncio do WWF no Politico, jornal dirigido a tomadores de decisão em Washington, reivindicando leis mais duras em relação à origem do pescado importado pelos EUA.

Fonte: Jornal Politico, novembro de 2014

Os anúncios pagos perderam um pouco do sentido após o boom dos meios online, especialmente as chamadas mídias sociais. Em lugar de um caro comercial de TV, uma organização consegue atingir uma grande audiência por meio de vídeos em seu canal no Youtube, site oficial ou perfil nas mídias sociais. Assim, o movimento tem incluído entre suas estratégias de comunicação as plataformas online.

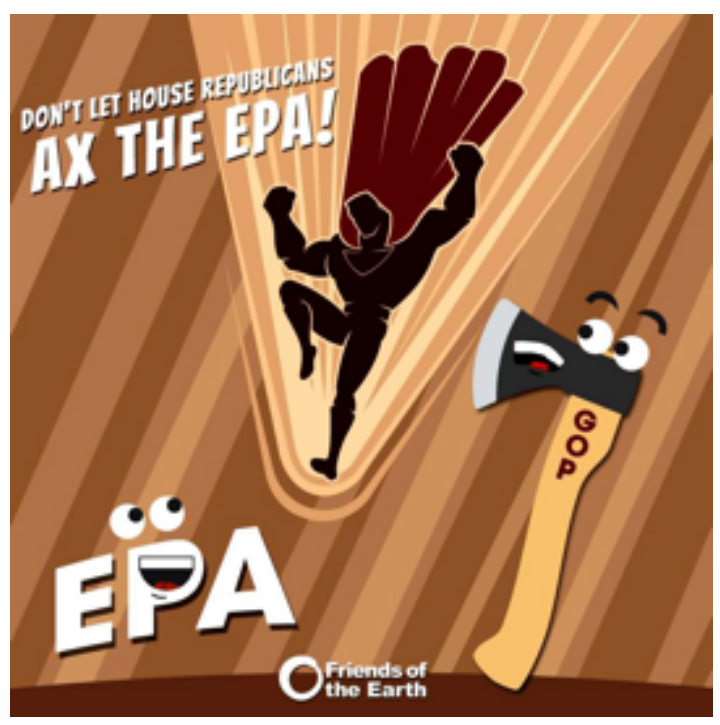

Figura 27: Campanha denunciando suposta determinação do Partido Republicano em destruir a EPA. Fonte: Facebook da Friends of the Earth 


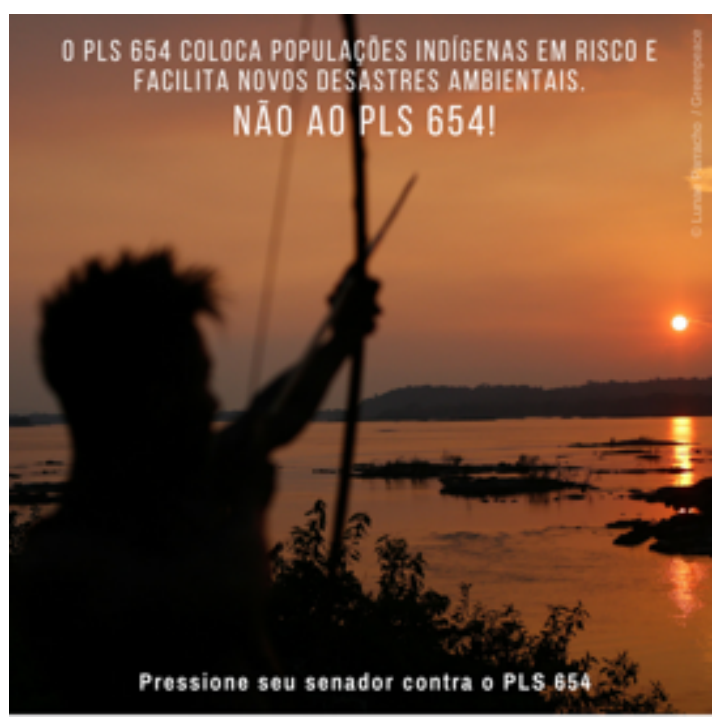

Figura 28: Campanha online pela rejeição do PLS 654, do Senado, que flexibiliza o licenciamento ambiental. Foto: Luana Parracho/Greenpeace

Devido ao seu foco em campanhas, denúncias e conscientização, o Greenpeace tem na comunicação um de seus pontos fortes. Desde sua fundação, em 1971, a organização buscava dar a maior projeção possível para suas iniciativas. Na primeira ação que deu origem ao Greenpeace, quando embarcações foram ao local de testes nucleares do governo americano para impedir as explosões, havia conexões diretas com redações por meio de rádio instalado nos barcos (Hunter 2004, p.43).

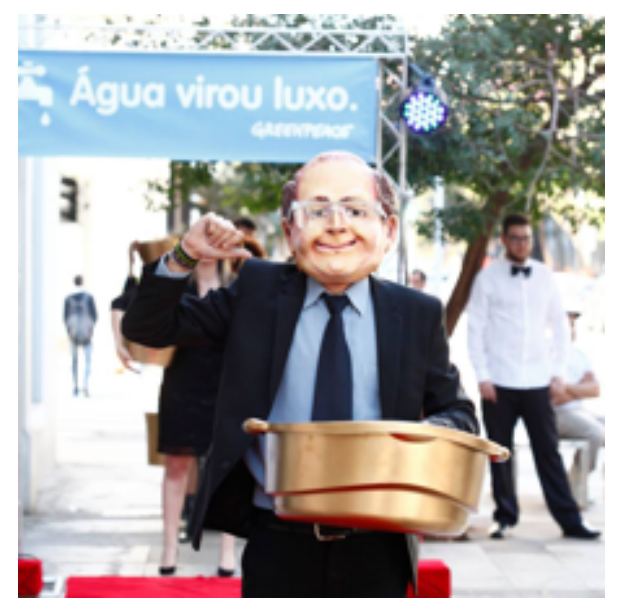

Figura 29: Crítica ao governador de São Paulo, Geraldo Alckmin, em alusão à crise hídrica. Fonte: Facebook do Greenpeace Brasil, agosto de 2015 


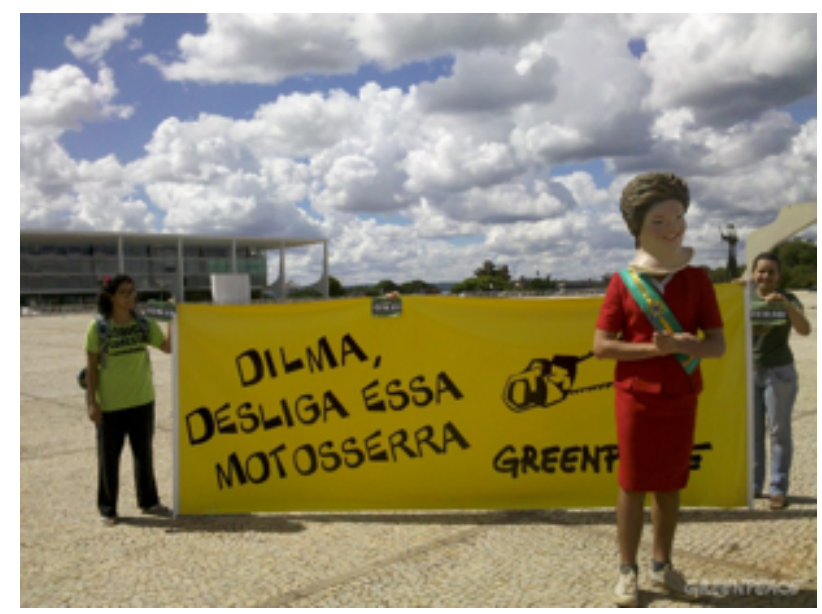

Figura 30: crítica à presidente Dilma Rousseff durante aprovação do novo Código Florestal. Fonte: Site do Greenpeace Brasil, abril de 2012

\subsection{2. $\quad$ Arquitetura de redes}

Atualmente, tanto no Brasil como nos EUA, o Greenpeace utiliza amplamente as mídias sociais para atrair adesões ou ampliar os impactos de suas campanhas. Organizações como 350.org, fundada em 2008 já com foco em mobilizações por meio das novas tecnologias, também têm conseguido importantes resultados em termos de comunicação, certamente com impactos na opinião pública.

Bill McKibben, fundador da $350.0 r g$, em entrevista para esta pesquisa ${ }^{153}$, explicou que a estrutura da organização tenta se igualar à arquitetura da internet, com total descentralização das decisões e autonomia para os diversos pontos que integram a rede, seja nos estados e municípios norte-americanos, seja nos outros países:

A primeira vez em que tentamos fazer uma ação global, fizemos 5.200 manifestações em 181 países simultaneamente. A maioria delas não foi enorme, mas havia tantas que isso se assemelhou à internet ou ao sistema de geração e distribuição de energia que queremos, com milhões de painéis solares nos telhados, conectados. Essa tática permite a todos sentirem que são parte de algo.

Assim, a comunicação da 350.org também é descentralizada o que, por um lado, faz com que exista menor controle sobre mensagens, mas, por outro, assegura grande capilaridade. Perguntado sobre a forma como a ação da 350.org influencia políticas públicas, e como isso se dá quando tomadores de decisão são contrários às legislações ambientais, McKibben destacou que as mudanças provavelmente ocorram por meio da

\footnotetext{
${ }^{153}$ Entrevista concedida em 25 de fevereiro de 2015.
} 
pressão causada pelas mobilizações e pela mudança no comportamento da sociedade. "Não gasto tempo pensando em quem é o presidente hoje. Movimentos mudam a forma como o cenário político funciona e ajudam a determinar quem será o presidente, quem terá poder", observou.

Quadro 13: O oleoduto Keystone: vitória após sete anos de luta

Em 2008, a empresa Transcanada apresentou o ambicioso projeto de construir um oleoduto de 2.700 quilômetros de extensão, saindo do estado canadense de Alberta e passando pelos estados americanos de Dakota do Norte, Dakota do Sul, Nebraska, Kansas, Oklahoma e Texas. O objetivo era exportar o petróleo canadense pelo Golfo do México.

Rapidamente, o projeto colocou em lados opostos ambientalistas e desenvolvimentistas, Democratas e Republicanos, comunidades indígenas e indústria petrolífera, fazendeiros e empreiteiras. Entre protestos, discussões na imprensa, ações na justiça e votações no Congresso, o movimento ambientalista, liderado pela ONG 350.org, levou adiante uma campanha com grande mobilização popular.

As mobilizações aconteceram, primeiramente, por meio das mídias sociais das diversas organizações, mas devido à quantidade de adesões, rapidamente se espalharam pelos grandes veículos de mídia. Manifestações de rua aconteceram em diversas cidades do país. Indígenas dos EUA e do Canadá, sob mediação dos ambientalistas, se uniram a fazendeiros que não queriam suas terras cortadas por dutos transportando um combustível sujo.

O argumento dos ambientalistas se dava em diferentes linhas: impactos em ecossistemas, violações a direitos de povos tradicionais, riscos de vazamento e aumento de emissões de $\mathrm{CO} 2$ a partir do uso de um grande volume de petróleo. O outro lado argumentava que o oleoduto teria potencial de gerar empregos e arrecadação de royalties e tributos, e que o petróleo será extraído de toda forma, passando ou não pelos EUA, fazendo com que as emissões sejam inevitáveis.

Até 2014, quando os Democratas ainda detinham a maioria no Senado, muitos apelos eram feitos para o Congresso. Após a conquista das duas casas pelos Republicanos, a campanha se destinou a sensibilizar o presidente Barack Obama no sentido de vetar o oleoduto. Novamente, com poderosas estratégias de comunicação, os ambientalistas levaram milhares de pessoas às ruas. $O$ presidente Barack Obama vetou o projeto em fevereiro de 2015, após aprovação da matéria pelo Congresso, e o veto foi mantido. Em novembro de 2015, a Casa Branca deu o tiro de misericórdia no oleoduto Keystone, rejeitando formalmente a solicitação da Transcanada.

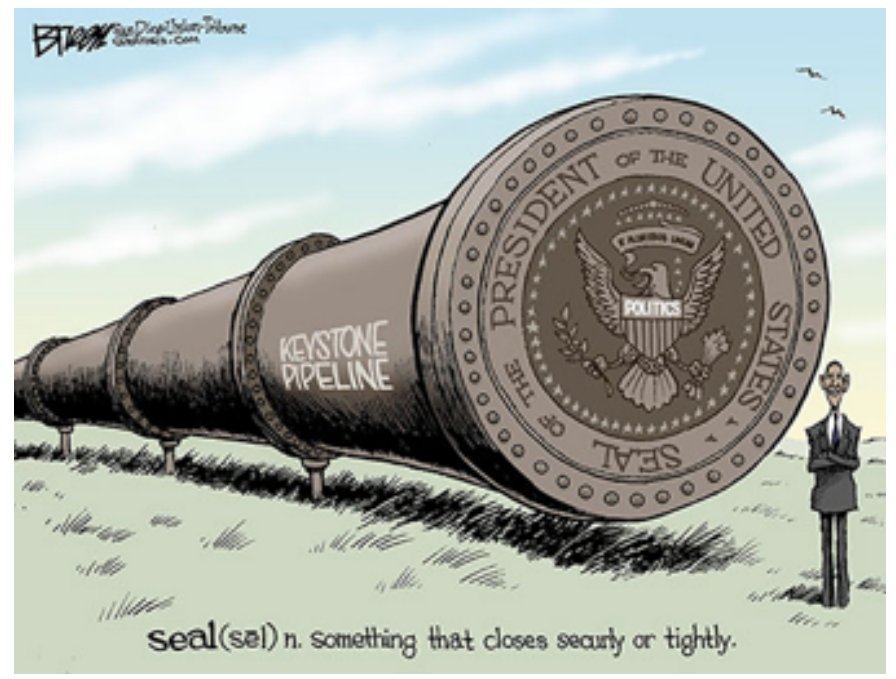

Figura 31: Presidente Obama "lacra" as pretensões dos defensores da construção do oleoduto Keystone. Fonte: San Diego Union Tribune, 14/11/2014 
No próximo capítulo será feita uma análise desse conjunto de repertórios usados pelo movimento à luz das teorias escolhidas para este trabalho. Procurarei mostrar que a diversidade de atuação das organizações, discutida neste Capítulo 4 e manifestada pelo uso de tantos repertórios, com distinta intensidade e resultados alcançados, é reflexo de um movimento ambientalista diversificado, que amadureceu ao longo da história. 


\section{BRASIL E EUA: DIFERENÇAS E SEMELHANÇAS}

Países com um conjunto de organizações ambientalistas fortes e dotadas de equipes técnicas são normalmente aqueles com as melhores e mais numerosas políticas ambientais.

(David Snow, 1992, p.34 - tradução minha)

A partir dos repertórios e casos discutidos em páginas anteriores deste trabalho e sob a lógica de algumas das correntes teóricas abordadas no capítulo teórico, será feita nas próximas páginas uma análise dos principais fatores que diferenciam ou tornam similares os resultados alcançados pelas organizações não governamentais ambientalistas no Brasil e nos Estados Unidos.

Durante esta pesquisa tornou-se claro que, de maneiras diferentes, o movimento ambientalista nos dois países consegue influenciar as políticas públicas, com distintos graus de efetividade e por meio de uma diversidade de repertórios. Importantes fatores que determinam o sucesso ou o fracasso de uma ação, ou que viabilizam o uso de certos repertórios e o abandono de outros, também estão neste capítulo.

Uma das ideias é mostrar que grande parcela do sucesso do movimento em influenciar políticas se dá em virtude da capacidade de as organizações realizarem uma leitura da realidade política, econômica e cultural em que atuam, bem como de suas limitações e fortalezas e, a partir daí, apostar mais fichas em uma estratégia em detrimento de outras.

Uma crítica comumente feita ao movimento se baseia, exatamente, naquilo que acredito ser sua maior fortaleza: a diversidade. De um lado, críticos diversos diagnosticam uma perda da alma do movimento, caracterizada pelas parcerias com governos e, principalmente, grandes empresas. Isso teria feito com que o ambientalismo perdesse sua veia ativista, deixando de combater as causas principais dos problemas ambientais e passando a aceitar e a contribuir para o cenário menos pior, fazendo acordos com aqueles que, para muitos, deveriam ser ferozmente combatidos.

De outro lado, analistas e tomadores de decisão, nas diversas entrevistas e fontes pesquisadas, entendem que o movimento é radical e inflexível, e que isso impede soluções negociadas que, de fato, possam ser postas em prática, envolvendo governos e setor produtivo.

Não me atreveria a dizer que as duas análises são incorretas e devem ser descartadas. Há momentos em que ambas as críticas são pertinentes e precisam ser atentamente observadas pelo movimento. Não é incomum observar organizações 
demasiado próximas a governos e grandes empresas (muitas vezes poluidoras), e que por isso perdem o distanciamento necessário para criticar esses setores. Em outros momentos há, sem sombra de dúvida, organizações que se posicionam de maneira pouco inteligente em uma negociação ou processo político, demarcando uma posição correta do ponto de vista ambiental, mas inviável do ponto de vista político, impossibilitando qualquer tipo de ganho e, assim, contribuindo para a manutenção de um status quo indesejado.

É importante, ainda, verificar que, em determinadas ocasiões, a postura ativista é a mais bem-sucedida em termos de ganhos ambientais, especialmente quando se quer chamar atenção da opinião pública para certos temas. Em outras, claramente uma parceria que busque modificações graduais nos processos produtivos alcança melhores resultados. E em alguns momentos, diferentes abordagens simultaneamente podem produzir mais êxitos, daí a vantagem do atual formato do movimento, tanto no Brasil como nos EUA, e em outras democracias ocidentais.

Essa linha analítica foi defendida por Dalton (1994) em estudo que discute os movimentos ambientalistas da Europa Ocidental, mas que poderia, em vários aspectos, ser aplicado às realidades das organizações nos dois países pesquisados. Segundo o autor, um movimento mais diversificado pode arrebanhar seguidores com diferentes interesses e perfis políticos, e consegue pressionar empresas, Estado e tomadores de decisão de inúmeras formas, aumentando as chances de sucesso. "O movimento ambientalista precisa se assemelhar a uma hidra que ataca simultaneamente por todos os lados" (pp.247-248).

Quando, nos EUA, o Earthjustice processa o governo, o Greenpeace denuncia grandes empresas, WWF e EDF se aliam a organizações que buscam obter a certificação de processos produtivos, TNC e NRDC fazem lobby no Congresso e na Casa Branca, por exemplo, os ambientalistas multiplicam as possibilidades de sucesso dos pleitos do movimento.

No caso brasileiro, a excelente analogia da hidra, feita por Dalton, pode se aplicar à coalizão que se formou para lutar contra as modificações no Código Florestal. O movimento ambientalista, por meio das diversas organizações participantes da aliança, ora levava ciência para a mesa, ora mobilizava ativistas, ora fazia um lobby técnico científico no Legislativo e no Executivo. O MST mobilizava agricultores e militantes nas ruas para pressionar os tomadores de decisão. A CNBB fazia a articulação junto a diversos setores da sociedade que normalmente não se envolveriam com questões ambientais. Certamente - e isso foi comprovado por meio de entrevistas com tomadores de decisão de diferentes correntes políticas - essa mobilização foi essencial para que as mudanças no Código não tivessem sido ainda mais radicais. 
Nas próximas páginas será feita uma discussão em torno dos principais aspectos que definem o emprego dos repertórios usados pelo movimento ambientalista para influenciar políticas públicas e que determinam o grau de sucesso ou o fracasso dessa gama de ações em ambos os países.

\subsection{A ESTRUTURA DAS ORGANIZAÇÕES E SEUS IMPACTOS}

A teoria da mobilização de recursos, discutida no Capítulo 2, mostrou-se de extrema relevância para analisar o comportamento das ONGs ambientalistas no Brasil e nos Estados Unidos. Tornou-se bastante claro que, para atuar em boa parte dos canais disponíveis para influenciar políticas públicas, é necessário um certo grau de sofisticação, caracterizado principalmente pelo acesso a recursos humanos qualificados e a orçamentos que permitam incidência, continuidade e capilaridade nessas ações.

Também foi observado que diversas ONGs de menor porte conseguem relevantes resultados no nível local, especialmente nos EUA, onde a cultura associativista permanece como um traço da sociedade (O'Connell 1999; Skocpol 2002; Wuthnow 2002), mesmo levando-se em conta o fato de que importantes pesquisadores apontem para uma redução na intensidade desta característica (Putnam 2000; Putnam e Feldstein 2003; Wolfe 2006). Mesmo organizações de menor porte, consideradas de base, como o CHEJ, sediada no estado da Virgínia, que conta com orçamento anual que varia entre US\$600 mil e US\$1 milhão, têm estruturas organizadas, com profissionais qualificados e departamentos administrativos e financeiros estruturados.

No Brasil as ONGs ambientalistas conseguiram, ao longo do tempo, se estruturar, alcançando resultados significativos, e isso se deve, em grande medida, à profissionalização das equipes e à capacidade de elaborar projetos e prestar contas, obtendo assim a confiança de doadores nacionais e internacionais. Dentre as organizações brasileiras pesquisadas, aquelas com receita anual mais baixa arrecadaram valores anuais superiores a R $\$ 10$ milhões em 2014. É claro que há uma grande diversidade de organizações com estruturas menores e receitas mais modestas, mas é possível afirmar que as principais ONGs ambientalistas do país - aquelas que, regularmente, conseguem influenciar políticas - contam com uma boa estrutura de trabalho e recursos suficientes para desenvolver um trabalho relevante.

Tanto nas pesquisas bibliográficas, quanto nas dezenas de entrevistas feitas ao longo dos quatro anos desta pesquisa, ficou claro que a estruturação e a profissionalização do 
movimento ambientalista estão diretamente relacionadas ao grau de sucesso no sentido de influenciar políticas públicas. Segundo Lang (2013),

$$
\begin{aligned}
& \text {...há evidências de que em sociedades civis pouco } \\
& \text { profissionalizadas, a influência política das ONGs é baixa [e que] } \\
& \text { mesmo uma alta densidade de organizações locais não é capaz de } \\
& \text { compensar o profissionalismo e a continuidade proporcionados por } \\
& \text { profissionais remunerados com dedicação exclusiva e pela divisão de } \\
& \text { tarefas (p.72 - tradução minha). }
\end{aligned}
$$

Dentre os 11 repertórios para influenciar políticas ambientais levantados nesta pesquisa, todos requerem, em maior ou menor grau, recursos e estrutura para que alcancem bons resultados. Para obter sucesso nas ações de lobby - um dos principais repertórios usados por ONGs ambientalistas norte-americanas- é necessário contar com equipes numerosas e qualificadas para acompanhar a agenda do Executivo e do Legislativo e municiar os tomadores de decisão com dados técnicos e científicos, bem como mobilizar cidadãos para exercer pressão externa nos representantes. Tudo isso demanda equipes e orçamento, fazendo com que as ONGs com boa capacidade de mobilização de recursos possam se destacar mais do que as outras.

As ações encabeçadas por organizações de voluntários - que dedicavam algumas horas por semana aos movimentos e tinham outros empregos - mostraram-se pouco capazes de influenciar o cada vez mais complexo jogo político, tanto no contexto norteamericano como no brasileiro. Vaitsman e colegas (2013) ressaltam uma maior especialização dos problemas, que requerem das organizações "novas competências (...) como uma condição para ganhar legitimidade no (...) campo das políticas públicas", demandando equipes maiores e mais qualificadas, capazes de elaborar projetos de excelência técnica e científica (pp.19-20).

A correlação entre estrutura e sucesso no lobby se torna ainda mais evidente se for analisado o caso brasileiro. Embora as grandes organizações ambientalistas tenham boa capacidade de arrecadar, foi constatada nesta pesquisa grande dificuldade por parte do movimento em levantar recursos especificamente para ações de advocacy e lobby. Assim sendo, a atuação das ONGs dentro desse repertório não ocorre com a intensidade necessária, especialmente no Legislativo (federal, estadual e municipal) e no Executivo (especialmente estadual e municipal).

Segundo Lee (1995), "o lobby bem-sucedido requer consideráveis recursos financeiros, conhecimento especializado sobre o funcionamento dos governos e presença ativa no governo; o sucesso desses esforços também requer compromissos com outros 
grupos de interesse e com o Congresso" (p.26 - tradução minha). Isso demanda, naturalmente, um perfil muito mais profissionalizado e, em grande medida, conciliador, presente nas grandes organizações ambientalistas pesquisadas.

No caso dos projetos de campo - repertório em que as ONGs brasileiras, de maneira geral, alcançam maior sucesso no sentido de influenciar políticas - o movimento tem enorme capacidade de arrecadar e montar equipes qualificadas e competentes, financiadas por doadores internos e externos. À luz da teoria da mobilização de recursos, esse diferencial ajuda a explicar o elevado grau de sucesso do repertório "projetos de campo" no movimento ambiental brasileiro.

Quase todas as organizações com atuação no Brasil - a única exceção fica por conta do Greenpeace - têm nos projetos a esmagadora maioria de suas fontes de financiamento. Isso não quer dizer que o recurso arrecadado com projetos não possa financiar ações ligadas a outros repertórios elencados no Capítulo 4 deste trabalho, mas a ONG, em tese, não pode empregar o dinheiro em atividades que não tenham correlação com o projeto ao qual o recurso está vinculado, o que acaba tirando a flexibilidade da organização em escolher as áreas e maneiras como atua.

Nas campanhas eleitorais, por exemplo, em que o movimento ambientalista compete com doações bilionárias de grandes empresas, a capacidade de mobilizar recursos se torna algo ainda mais importante. Isso se aplica à realidade norte-americana, uma vez que no Brasil as organizações da sociedade civil não podem doar para candidaturas, mas essa assimetria de forças na política, causada por doações empresariais, também é vista no caso brasileiro.

Nos EUA, uma rede de instituições financiadas pelos empresários Charles e David Koch, que financiam campanhas conservadoras e, via de regra, contrárias às regulações ambientais, anunciou em janeiro de 2015 que vai "investir" cerca de US\$ 900 milhões no processo eleitoral de 2016 (Gold 2015), quantia recorde na história do país.

Conforme observado por Josh Saks, diretor legislativo da National Wildlife Federation, em entrevista para esta pesquisa ${ }^{154}$, ONGs ambientalistas estruturadas e profissionalizadas são fundamentais para atenuar a gigantesca influência do capital nas eleições: "Um grupo ad hoc de voluntários jamais poderá levantar US\$ 15 milhões para uma campanha. E isso traz um grande benefício", analisou, em referência ao valor de doações feitas por um grupo de ONGs ambientalistas para candidatos na eleição para o parlamento em 2014.

\footnotetext{
${ }^{154}$ Entrevista concedida em 22 de janeiro de 2015.
} 
Outro aspecto que acaba por vincular o grau de sucesso das ONGs ambientalistas que atuam no Brasil e nos EUA à estrutura e à capacidade de arrecadação são as dimensões continentais dos dois países e o modelo descentralizado de tomada de decisões, uma característica das repúblicas federativas ${ }^{155}$. Assim, organizações que tenham capítulos, escritórios de campo ou sub-sedes conseguem aumentar o alcance de seus projetos e reivindicações, além de terem interlocução regular com atores políticos locais. Isso requer equipamentos, recursos humanos e financeiros.

Adicionalmente, a disponibilidade de recursos influencia, em maior ou menor grau, os resultados alcançados em ações na Justiça, mobilização do público, comunicação, campanhas, produção de informações técnico-científicas, parcerias corporativas para modificar práticas produtivas e no fornecimento de quadros para atuar no Estado.

É importante ressaltar que há diversos exemplos de organizações da sociedade civil — não apenas as ambientalistas - que obtêm sucesso ao influenciar políticas públicas a despeito de terem orçamentos reduzidos. As mobilizações de associações comunitárias norte-americanas nos anos 1970 e 1980 contra os depósitos de lixo tóxico próximo a áreas residenciais ou pela recente rejeição ao oleoduto Keystone demonstram isso. Mas não há dúvidas de que essas iniciativas tendem a ser mais bem-sucedidas quando resultam de parcerias que permitem um maior fluxo de recursos para ações de comunicação, por exemplo.

No Brasil, as mobilizações indígenas contra a PEC 215 também comprovam que o sucesso, às vezes, pode vir sem grandes orçamentos. Mas o que tento assinalar nesta seção é que, em determinados campos de atuação, e de forma crescente, influenciar políticas requer ações sofisticadas e persistentes, algo que, via de regra, demanda recursos e equipes qualificadas.

Isso reforça, ainda, a importância das coalizões em prol de causas ambientais, que unem organizações com diferentes habilidades e promove a soma de recursos humanos e financeiros para alcançar metas conjuntas. O modelo de coalizões de advocacy, discutido por Sabatier (2007) e debatido no Capítulo 2 deste trabalho, ajuda a entender a importância das alianças para o trabalho dos ambientalistas.

De acordo com Gunter Jr. (2004), que fez abrangente estudo sobre ONGs que trabalham pela conservação da biodiversidade nos EUA, os recursos financeiros são

\footnotetext{
${ }^{155}$ No caso brasileiro, será observado mais adiante que o Poder Executivo, especialmente o federal, tem, na prática, mais poderes que o Legislativo no jogo político. De toda forma, é possível dizer que, a despeito dessa centralização, muitas das decisões, especialmente no tocante à implementação da legislação ambiental, ficam a cargo de municípios e, sobretudo, estados.
} 
fundamentais para ações judiciais, lobby e mesmo iniciativas descentralizadas de mobilização, além do recrutamento e da manutenção, com salários competitivos, de profissionais qualificados. "Viabilidade financeira é inegavelmente um componente de efetividade" (p.143 - tradução minha).

Outro aspecto fundamental que favorece o crescimento e a estruturação do Terceiro Setor nos EUA, e que não se faz presente no Brasil, é uma legislação elaborada claramente com o objetivo de estimular doações de pessoas físicas e jurídicas para essas organizações. Embora nos dois países haja um regime especial de tributação para esse tipo de instituição, no Brasil apenas as doações para projetos culturais e "fundos controlados pelos conselhos nacional, distrital, estaduais e municipais dos Direitos da Criança e do Adolescente" são passíveis de dedução (Terra 2013). Nos EUA, as contribuições para as ONGs ambientalistas podem ser abatidas do IR (Libby 1998, p.12), gerando importante estímulo para que cidadãos, fundações e empresas doem para as organizações.

Seria inadequado afirmar que a disponibilidade de recursos é o único fator determinante para o sucesso nos processos de formulação, aprovação e implementação de políticas públicas. Afinal, isso automaticamente levaria à conclusão de que, nos embates com grupos de interesse que representam indústria, agronegócio, mineração e outros segmentos, normalmente com mais dinheiro - os ambientalistas sempre sairiam perdendo, e não é isso que acontece. Nas próximas páginas serão discutidos outros fatores de grande importância para definir o grau de sucesso dos repertórios adotados pelo movimento ambientalista.

\subsection{O CONTEXTO POLÍTICO DETERMINANDO ESTRATÉGIAS E RESULTADOS}

A teoria das oportunidades políticas também se mostrou de central importância para o tema deste trabalho. Em ambos os países me deparei com situações em que o êxito ou o fracasso de ações propostas por ONGs com o objetivo de influenciar políticas ambientais dependeu enormemente do contexto político.

Sobretudo em relação a temas ambientais, que frequentemente envolvem mudanças de comportamentos enraizados, regulações sobre processos produtivos lucrativos ou proibições que desagradam a segmentos da economia, as mudanças propostas pelos ambientalistas estão muitas vezes condicionadas à vontade política de tomadores de decisão. Isso ficou muito claro na passagem de seis anos que tive no movimento ambientalista e nas entrevistas que fiz para esta pesquisa, tanto com ambientalistas quanto com tomadores de decisão e analistas. 
De acordo com a teoria das oportunidades políticas, os movimentos sociais e as organizações da sociedade civil utilizam-se de alguns contextos para ampliar sua atuação ou influência. Como visto no Capítulo 2 deste trabalho, Tilly (2008) apresentou seis componentes que dão condições para que os movimentos atuem: (i) abertura do regime; (ii) coerência das elites; (iii) estabilidade dos arranjos políticos; (iv) disponibilidade de aliados dentro do Estado; (v) ausência de repressão e (vi) ritmo das mudanças (p.91 - tradução minha).

No caso de Brasil e Estados Unidos - duas democracias estáveis - os fatores i, ii, iii, v e vi, atualmente, já não apresentam grandes variações. Não há golpes de estado (nos EUA, praticamente em toda a história, e no Brasil, desde a redemocratização). As respectivas constituições, legítimas do ponto de vista das democracias ocidentais representativas, são, a grosso modo, respeitadas no tocante aos direitos civis e políticos, inclusive em relação a garantias ligadas à atuação das grandes ONGs ambientalistas aqui estudadas, que raramente adotam repertórios de confronto.

Alonso e colegas (2007), que definiram a redemocratização dos anos 1980, a Constituição de 1988 e a conferência Rio 92 como as três principais oportunidades políticas para a atuação do movimento ambientalista brasileiro, também elencaram contextos que favorecem a influência por parte da sociedade civil em processos decisórios, que se aproximam da análise de Tilly acima mencionada: (i) aumento da permeabilidade das instituições políticas e administrativas à sociedade civil; (ii) mudanças nas interações políticas entre Estado e movimentos e (iii) fortalecimento dos aliados dos movimentos, por meio de presença no próprio Estado, em partidos políticos ou na imprensa (p.153).

Um fator que tem definido, nos dois países, o sucesso ou o fracasso dos repertórios adotados pelas organizações da área ambiental, é a disponibilidade de aliados dentro do Estado, tanto no âmbito do Executivo, quanto do Legislativo e do Judiciário. Por aliados não se deve entender apenas ambientalistas, mas tomadores de decisão sensíveis às questões ligadas ao desenvolvimento sustentável, sejam eles vereadores, deputados, senadores, juízes, promotores, secretários, ministros, prefeitos, governadores ou presidentes, entre outros.

Conforme lembrou Adriana Ramos, coordenadora do programa de Política e Direitos do ISA, em entrevista para esta pesquisa ${ }^{156}$, o ambientalismo nunca foi um movimento de massas e, por isso, necessita ser respaldado nas esferas decisórias. Similar constatação foi feita por José Carlos Carvalho, ex-ministro do Meio Ambiente, em entrevista para esta

\footnotetext{
${ }^{156}$ Entrevista concedida em 26 de março de 2015
} 
pesquisa ${ }^{157}$ : "Se não tem um governo que abra as portas por iniciativa própria, o movimento ambientalista não está articulado nacionalmente para abrir essas portas".

No caso brasileiro, considerando-se o período iniciado na redemocratização, somente durante a Constituinte o Congresso não foi hostil a questões ambientais. Pode-se dizer, com a exceção da Constituição de 1988, que os avanços na legislação ambiental e os bloqueios aos retrocessos foram assegurados por figuras políticas com elevado grau de compreensão e sensibilidade em relação às questões ambientais, especialmente no Executivo: o presidente Fernando Henrique Cardoso e os ministros do Meio Ambiente Sarney Filho, José Carlos Carvalho, Marina Silva e Carlos Minc, respaldados pelo próprio Fernando Henrique e por Lula, além de tomadores de decisão no primeiro escalão (presidentes de órgãos como IBAMA e ICMBIO, ou titulares de secretarias do MMA), magistrados e parlamentares sensíveis à causa ambiental.

Os depoimentos colhidos ao longo desta pesquisa deixaram essa situação bastante clara. As diversas tentativas de flexibilizar o Código Florestal foram seguidamente barradas por uma clara orientação do Executivo Federal durante a administração de Fernando Henrique e no primeiro mandato do presidente Lula, mas a partir do segundo mandato, após a saída da ministra Marina Silva, e especialmente durante o governo Dilma Rousseff, o Governo Federal deixou de ser um anteparo às mudanças e a nova legislação foi facilmente aprovada na Câmara e no Senado.

A imensa dificuldade de o movimento influenciar políticas a partir do final do segundo mandato de Lula e, especialmente, ao longo da gestão Dilma, foi apontada por praticamente todos os ambientalistas ouvidos nesta pesquisa, e também por tomadores de decisão, inclusive alguns vinculados ao próprio PT, como o ex-presidente do ICMBIO, Roberto Vizentin.

Paulo Barreto, pesquisador do IMAZON, em entrevista para esta pesquisa ${ }^{158}$, relatou a perda de espaço da organização: "Durante os governos de Fernando Henrique e sob a gestão Marina Silva, o Imazon quase que prestava uma assistência técnica aos órgãos governamentais. Nunca recebemos uma solicitação da área ambiental deste governo". O mesmo tipo de queixa foi reforçado por representantes de Conservação Internacional, Greenpeace, ICV, IPAM, ISA, SOS Mata Atlântica e WWF-Brasil, dentre outras ONGs, que também foram ouvidos nesta pesquisa.

\footnotetext{
${ }^{157}$ Entrevista concedida em 23 de julho de 2015

${ }^{158}$ Entrevista concedida em 23 de setembro de 2015.
} 
Importante aspecto mencionado pelos ambientalistas brasileiros é a capacidade de o Ministério do Meio Ambiente "brigar" pelas causas ambientais dentro do Governo Federal e ser capaz de persuadir o(a) presidente da República. Minha experiência profissional no WWF-Brasil lidando com políticas públicas, que se deu durante o final do primeiro e a totalidade do segundo mandato Lula, e na primeira metade do mandato Dilma, bem como dezenas de entrevistas feitas com ambientalistas, tomadores de decisão e analistas, permitem-me concluir que uma das razões que fazem do momento atual a antítese de uma oportunidade política é exatamente a falta de força do Ministério do Meio Ambiente dentro do governo.

Mauro Armelin, ex-superintendente de conservação do WWF-Brasil, com passagens pela ONG Amigos da Terra Amazônia Brasileira e pelo Governo Federal, afirmou em entrevista para esta pesquisa ${ }^{159}$ que "Marina Silva tinha maior poder e contexto favorável no sentido de convencer o núcleo duro do governo do que tem Izabella Teixeira".

Aliás, esta conclusão não é tirada apenas a partir da opinião de ambientalistas. O deputado Luiz Carlos Heinze (PP-RS), considerado importante representante da agricultura e integrante da bancada ruralista, afirmou categoricamente, em entrevista para esta pesquisa $^{160}$, que a gestão de Izabella Teixeira representou um avanço em relação às anteriores.

Fabíola Nader Motta, gerente de relações institucionais da Organização das Cooperativas Brasileiras (OCB), entidade alinhada aos interesses do setor agropecuário e geralmente em lados opostos aos dos ambientalistas, me disse em entrevista ${ }^{161}$ que a nova gestão do MMA representou uma melhoria na interlocução com o setor produtivo, algo que, segundo ela, ficou claro durante as discussões envolvendo as mudanças no código Florestal:

Quando o Código foi aprovado tivemos grande interação com o Ministério do Meio Ambiente e a Ministra Izabella Teixeira, uma parceira nossa. (...) Izabella é conciliadora, temos acesso. Há um diálogo para construir. (...) Antes não era tanto, mudou muito. $O$ Código não foi momento de ruptura com o MMA. Saímos com acordo de cooperação.

\footnotetext{
${ }^{159}$ Entrevista concedida em 4 de setembro de 2015

${ }^{160}$ Entrevista concedida em 10 de junho de 2015.

${ }^{161}$ Entrevista concedida em 26 de junho de 2015.
} 
Curiosamente, os ambientalistas se queixaram exatamente de não terem sido ouvidos nas discussões do Código, em grande medida por um descrédito da parte do Ministério do Meio Ambiente. Adriana Ramos, do ISA, relatou sua percepção daquele momento:

A nossa presença no Congresso, que historicamente foi valorizada, mesmo pelos inimigos, na época do Código desapareceu. Muitas vezes, no passado, o Executivo nos ajudou a estar presentes dentro do Legislativo. Quando o Executivo começa a nos desconsiderar, e diz para o Legislativo que eles não precisam nos ouvir, porque o governo está lá, isso enfraquece nossa presença.

Lideranças regionais comprometidas com a questão ambiental também podem representar importantes oportunidades políticas para a atuação do movimento ambientalista. Durante esta pesquisa e em minha experiência no movimento ambientalista pude comprovar a importância de governos subnacionais - estaduais e municipais - não só estarem abertos a políticas em prol do desenvolvimento sustentável, como também adotarem uma postura proativa e proporem essas políticas.

Um importante exemplo desse contexto favorável às políticas ambientais no nível subnacional pode ser observado no estado do Acre, a partir do governo de Jorge Viana, iniciado em 1999 (Mittermeier et al 2005, p.17; Walker e Schwartzman 2014, Toni et al 2015). Conforme observado em páginas anteriores, foram desenvolvidas diversas políticas estaduais de promoção do desenvolvimento sustentável, por meio da valorização da floresta em pé e do incentivo a cadeias produtivas sustentáveis, tanto no âmbito comunitário quanto no empresarial.

Outra característica das administrações estaduais do PT no Acre são as parcerias com organizações da sociedade civil. Tanto ONGs locais, como SOS Amazônia, Comissão PróÍndio e PESACRE, quanto organizações de atuação nacional e internacional, como WWFBrasil, IPAM e EDF, participaram ativamente da formulação e da implementação de políticas socioambientais.

IPAM e WWF-Brasil, inclusive, abriram e mantêm escritórios de campo em Rio Branco para apoiar as diversas atividades das duas organizações no estado. Assim como uma empresa abre filiais apenas em locais onde encontra condições ideais de trabalho, uma ONG ambientalista investe em escritórios de campo, com equipes locais e equipamentos, em regiões com potencial de sucesso para projetos de conservação e promoção de desenvolvimento sustentável.

Além de Rio Branco, o WWF-Brasil chegou a abrir, nos anos 2000, escritórios de campo em Manaus, Macapá e Belém, mas destes, somente o das capitais acriana e 
amazonense continuam. Uma das razões para os fechamentos foi exatamente a dificuldade na implementação de políticas e projetos, por diferentes razões, que também incluíam incompatibilidades com governos locais.

Adicionalmente, o WWF-Brasil iniciou, em 2007, projetos voltados para o desenvolvimento sustentável em Rondônia, mas a ONG ambientalista também desistiu de atuar no estado pouco depois, por conta de condições desfavoráveis ao trabalho das organizações da sociedade civil, em grande medida devido à negligência do governo estadual à época em relação às questões ambientais ${ }^{162}$.

A pesquisadora Ana Margarida de Castro Euler, da EMBRAPA, que atuou na ONG WWF-Brasil e na área ambiental do governo do Amapá, descreveu em entrevista para esta pesquisa ${ }^{163}$ a situação naquele estado, ressaltando as oportunidades políticas representadas por aliados do ambientalismo dentro dos governos e problemas ocasionados pela ausência de "ambientalistas" nas administrações:

As articulações entre ONGs e governos têm a ver com as pessoas que ocupam o cargo. Eu, por exemplo, era vista como ambientalista dentro do governo do Amapá. Eu fazia o diálogo com movimentos sociais e ONGs. (...) Hoje quem mais pauta as políticas públicas no Amapá, bem como no Governo Federal, é o agronegócio, e as grandes ONGs não fazem enfrentamento, querem parceria com o governo para captar.

André Lima, secretário de Meio Ambiente do Distrito Federal, com passagens pelo MMA e pelo movimento ambientalista, em entrevista para esta pesquisa ${ }^{164}$, salientou que, com frequência, a receptividade por parte do tomador de decisão é mais relevante para a aprovação de políticas em prol do desenvolvimento sustentável pleiteadas pelas ONGs que o próprio trabalho de convencimento das organizações.

Posso ter uma organização com baixíssima capacidade de formulação técnica, mas posso receber e internalizar algo dela. Está mais na permeabilidade do gestor do que na qualidade da

\footnotetext{
${ }^{162}$ Em junho de 2008, organizações da sociedade civil com atuação na área socioambiental publicaram o relatório "O Fim da Floresta?", com diversas denúncias de desrespeito à legislação ambiental e a direitos humanos em Rondônia, muitas delas envolvendo ação ou omissão do governo estadual. O documento pode ser acessado no link http://stat.correioweb.com.br/cbonline/junho/ofimdafloresta.pdf (acessado em 31 de dezembro de 2015)

${ }^{163}$ Entrevista concedida em 19 de maio de 2015.

${ }^{164}$ Entrevista concedida em 10 de abril de 2015
} 
formulação. A capacidade técnica de um movimento vira um argumento do gestor para justificar aceitar ou não.

O poderio dos governos subnacionais em liderar mudanças em favor do desenvolvimento sustentável também é nítido no caso norte-americano, talvez até de maneira mais intensificada que no Brasil, devido à força que os estados têm para legislar. As experiências se multiplicam por lá, como no caso da Califórnia, que estipulou unilateralmente metas de redução de emissões de $\mathrm{CO} 2$ e padrões mais rígidos de emissões veiculares que aqueles nacionalmente em vigor. Tanto que, quando há cenários desfavoráveis no Capitólio ou na Casa Branca, as ONGs ambientalistas reforçam os trabalhos de lobby no Legislativo e no Executivo estaduais, como mencionado anteriormente.

Essas experiências reforçam o fato de que governos nacionais e subnacionais sensíveis à questão ambiental são determinantes para o sucesso das organizações ambientalistas, da mesma forma que governos que não priorizam o tema contribuem diretamente para o insucesso do movimento.

No caso dos Estados Unidos, as mesmas conclusões foram alcançadas: a importância de tomadores de decisão abertos aos inputs do movimento ambientalista é enorme para o sucesso dos repertórios das organizações. Os ambientalistas entrevistados nesta pesquisa, unanimemente, afirmaram que o mandatário que ocupa a Presidência da República e a divisão entre Democratas e Republicanos no Congresso exercem influência sobre as estratégias adotadas pelo movimento ambientalista para influenciar políticas.

Diversos episódios pesquisados e entrevistas demonstraram que, de maneira geral, os governos Republicanos de Reagan, Bush pai e George W. Bush trouxeram algumas dificuldades para os pleitos dos ambientalistas, enquanto administrações Democratas como as de Carter, Clinton e Obama representaram algumas facilidades nas reivindicações junto ao Executivo Federal. Naturalmente, trata-se aqui de uma generalização, feita com a ciência de que existiram e existem significativos conflitos dos ambientalistas com gestões Democratas, bem como concordâncias e parcerias com governos Republicanos.

Uma diferença fundamental entre os dois países é que, nos EUA, há uma maior oscilação dentro do Congresso em relação à presença de aliados dos ambientalistas nas duas casas. Uma importante razão para isso é o bipartidarismo, somado à polarização das questões climáticas, conforme observado no Capítulo 3. Ou seja, quando os Republicanos dominam a Câmara ou o Senado, os ambientalistas, conforme eles próprios disseram nas entrevistas, assumem postura defensiva no Legislativo. Quando os Democratas são maioria, é hora de tentar aprovar ou fortalecer legislações ambientais. 
Anteriormente, a situação era diferente. A questão partidária não era tão determinante para o ambientalismo como é hoje. Líderes Republicanos, tanto no Executivo quanto no Legislativo, como os presidentes Theodore Roosevelt e Richard Nixon, e o senador Richard Lugar, por exemplo, defendiam leis de proteção ao meio ambiente.

Segundo Jeffry Burnam, do Departamento de Governo da Universidade de Georgetown, em entrevista para esta pesquisa ${ }^{165}$, as alas mais radicais do Partido Republicano, hoje simbolizadas por uma coalizão denominada Tea Party, não permitiriam a aprovação de leis ambientais como aquelas dos anos 1960, 1970 e 1980. "Atualmente é preciso que alguém tenha a coragem de propor algo no meio, que provavelmente será detestado pelos ambientalistas e pela indústria", observou.

Os ambientalistas entrevistados também deixaram claro que uma Casa Branca aliada ao ambientalismo significa que o lobby no Executivo tornar-se-á mais intenso e propositivo. Assim, do lado das ONGs verdes, o que costuma ocorrer é uma ocupação dos espaços abertos pela administração, e uma participação mais ativa nos processos de elaboração das políticas, como observado, por exemplo, no governo Obama, nos EUA, e no primeiro mandato de Lula, no Brasil.

Libby (1998) levantou que, entre 1983 e 1992, nos governos de Reagan e Bush pai, foram preparados 15 planos de conservação de hábitats, que preveem ações para recuperar espécies ameaçadas. Apenas nos primeiros três anos da administração seguinte, do Democrata Bill Clinton, 30 planos foram concluídos e outros 100 estavam em andamento (p.171).

Bevington (2009) também definiu o governo Clinton como um contexto favorável às organizações defensoras do desenvolvimento sustentável. "Os ambientalistas puderam gastar menos tempo na defensiva e ser mais proativos. Organizações de base (...) ficaram livres para levar adiante propostas (...) mais baseadas na ciência que em estratégias políticas" (p.29 - tradução minha).

A grande maioria dos ambientalistas entrevistados classificou a administração de Barack Obama como favorável ao meio ambiente, e muitos classificaram o presidente como "aliado" ou "amigo" do movimento e até como o melhor presidente da história do país em termos ambientais. Por outro lado, atualmente há um domínio Republicano nas duas casas legislativas, o que acaba equilibrando os processos decisórios no nível federal. Nesse caso, o lobby ambientalista propositivo assume uma postura defensiva no Congresso e centra

\footnotetext{
${ }^{165}$ Entrevista concedida em 4 de fevereiro de 2015.
} 
fogo nas ações do Executivo, especialmente nas agências que lidam com temas ambientais, como a EPA, o USFS, o BLM e o FWS, que têm uma série de poderes regulatórios.

As inúmeras ações da EPA para estabelecer limites mais rigorosos de poluição industrial durante a administração Obama, com base na Lei do Ar Puro de 1990, demonstram que a predisposição do chefe de Estado em assegurar proteções contra práticas produtivas poluidoras pode ser decisiva para a implementação de políticas ambientais. A mesma legislação já existia durante a administração de George W. Bush (2001-2008), mas o Republicano não se esforçou para ampliar o alcance da EPA nesse aspecto (Haskell et al 2014, pp.373-374).

Se nos EUA há uma alternância na Câmara (House of Representatives) e no Senado entre Republicanos e Democratas, com rebatimentos diretos na questão ambiental, no Brasil a situação é diferente. Aqui, as esperanças dos ambientalistas se concentram, normalmente, em um Executivo amigável em relação ao meio ambiente, uma vez que o Congresso, historicamente, tende mais para o conservadorismo e, se não houver uma pressão do Executivo, via de regra aprovará legislações contrárias aos princípios da sustentabilidade.

Além do mais, embora seja, assim como os EUA, uma federação, no Brasil, o poder de decisão é bastante concentrado nas mãos do Executivo Federal (Almeida 2007, p.17; Anastasia et al 2007, p.122). Em entrevista para esta pesquisa ${ }^{166}$, o senador Jorge Viana (PT-AC), com longas experiências no Executivo e no Legislativo, resume a situação:

Fui prefeito, governador e agora sou senador. Não tem dúvida. É muito melhor estar no Executivo. O Brasil é um país que é presidencialista mesmo. Apesar de uma dependência que quem governa tem do Parlamento, as coisas acontecem, no geral, por iniciativa dos executivos. É muito forte a presença do Executivo. Apesar de o Congresso ter muito peso e muita força, tem pouco protagonismo, pouca iniciativa de propor debates. A agenda do Congresso é muito pobre. E sobram para o Executivo todos os problemas e todos os desafios, mas também as iniciativas.

No caso das mudanças no Código Florestal essa correlação de forças entre os poderes ficou clara. Anteriormente bloqueada por vontade dos presidentes Fernando Henrique e Lula, a matéria foi aprovada facilmente no Congresso na gestão Dilma, a partir

\footnotetext{
${ }^{166}$ Entrevista concedida em 27 de agosto de 2015.
} 
do momento em que deixou de ser priorizada pelo Executivo, desagradando profundamente aos ambientalistas, como já observado anteriormente neste trabalho.

No contexto brasileiro, pude concluir que, além das oportunidades políticas da redemocratização, da Constituinte de 1988 e da Rio 92, citadas por Alonso e colegas (2007), posteriormente surgiram duas importantes oportunidades políticas, que proporcionaram a união do movimento ambientalista em torno de pleitos ou adversários comuns, bem como uma posição de destaque na agenda da sociedade brasileira: a gestão de Marina Silva frente ao Ministério do Meio Ambiente (2003-2008) e o processo de modificação do Código Florestal (2009-2012). Nesses dois momentos, de maneiras diferentes - o primeiro foi uma oportunidade surgida a partir de um contexto positivo, e a segunda, a partir de uma ameaça - as organizações ambientalistas assumiram protagonismo em importantes debates públicos, tornando-se referência para jornalistas e adquirindo ou ampliando sua relevância perante a sociedade.

Em relação aos EUA, é possível concluir que a administração Democrata de Barack Obama, especialmente em seu segundo mandato, representa uma importante oportunidade política para a atuação do movimento ambientalista. Nesse período, ONGs conseguiram inserir quadros em importantes posições da administração federal, participar ativamente do processo de formulação de políticas e mobilizar setores da sociedade em torno de causas ambientais, como a campanha pela não construção do oleoduto Keystone $\mathrm{XL}$, que levaria petróleo canadense até o litoral texano, passando por diversos estados norte-americanos. Cabe dizer que a deliberação da Casa Branca neste caso, pelo veto ao oleoduto, atendeu às reivindicações dos ambientalistas.

Por fim, é importante salientar que, embora seja um fator de grande importância, o contexto político não é o único aspecto que define o sucesso ou o fracasso das ONGs ambientalistas. Frequentemente, tomadores de decisão são forçados a decidir em virtude de pressão por parte de eleitores, opinião pública, imprensa etc. Adicionalmente, o movimento ambientalista tem demonstrado, nos dois países, versatilidade no sentido de buscar outras vias quando as mais usuais se encontram interditadas. Assim, mesmo em momentos em que as oportunidades políticas para atuação do movimento são escassas, as organizações costumam obter conquistas importantes.

Nancy Gloman, vice-presidente de campo e conservação da Defenders of Wildlife, trabalhou na EPA durante uma gestão Republicana. Em entrevista para esta pesquisa ${ }^{167}$, ela afirmou que as agências que lidam com questões ambientais, independentemente do

\footnotetext{
${ }^{167}$ Entrevista concedida em 9 de janeiro de 2015
} 
partido político à frente do Executivo, contam com um corpo técnico de carreira com alguma autonomia, apesar de as coordenações serem politicamente indicadas.

Diferentes administrações têm distintas opiniões sobre o quão aberto você pode ser com os grupos ambientalistas. Eu costumava me encontrar com ambientalistas em estações do metrô. Algumas vezes, o encontro com ambientalistas pode ser, internamente, uma sentença de morte, então você tem que, literal e figurativamente, ir para o underground para obter informações.

Além disso, há fatores externos, como crises econômicas, desastres naturais ou industriais que ajudam a definir políticas com impactos ambientais, e que se sobrepõem ao contexto político-partidário. (Brulle e Henkins 2010, p.76). Vazamentos de petróleo, deslizamentos, enchentes, acidentes industriais e outros eventos criam condições para que vulnerabilidades das comunidades diante da falta de regulação fiquem expostas, abrindo possibilidades para o avanço de políticas ambientais, mesmo em um contexto político desfavorável.

Por fim, é fundamental observar que, mesmo que as oportunidades políticas sejam amplamente favoráveis, é essencial que o movimento ambientalista esteja organizado e estruturado para influenciar os processos decisórios.

\subsection{O PESO DAS QUESTÕES LEGAIS, HISTÓRICAS E CULTURAIS}

Um estudo comparado entre dois países, em área multidisciplinar como a do desenvolvimento sustentável, que envolve campos como ciências política e social, direito, meio ambiente, comunicação e outros, não pode ignorar os aspectos históricos e culturais que diferenciam os países analisados. Tornou-se claro, ao longo desta pesquisa, que essas questões influenciaram o surgimento e a consolidação do movimento ambientalista no Brasil e nos EUA, assim como os resultados alcançados pelas ONGs estudadas.

Conforme mencionado no Capítulo 3, a escola transcendentalista, cujos principais nomes são de Ralph Waldo Emerson e de Henry David Thoreau, influenciou enormemente o pensamento da sociedade norte-americana em relação à natureza e disseminou o debate sobre as relações pouco harmoniosas entre o homem, os recursos naturais e comunidades frequentemente marginalizadas, como indígenas e afrodescendentes.

Em obra na qual discute as raízes históricas e filosóficas norte-americanas que influenciaram o ambientalismo no país, Martinez (2014) afirma que Thoreau, além de defensor da desobediência civil, do pacifismo e da abolição da escravatura, foi "a mais 
reconhecida figura do ambientalismo americano" até meados do Século 19 (p.150 tradução minha).

Em uma sociedade majoritariamente alfabetizada como a norte-americana - segundo Grubb (1990), os percentuais de alfabetização nos EUA em 1800 eram maiores que os de todos os países europeus, à exceção da Escócia (pp.458-459) -a existência de um grupo de intelectuais como os transcendentalistas foi um importante contraponto às ideias de desenvolvimento industrial e expansão a qualquer custo. $\mathrm{E}$, naturalmente, havia condições para que as pessoas que compartilhavam aquelas ideias pudessem participar da vida política por meio de organizações da sociedade civil, uma característica marcante dos Estados Unidos.

A educação é um dos principais pré-requisitos para que uma quantidade relevante de cidadãos se envolva com questões de interesse público. Segundo Putnam e Feldstein (2003),

...a educação é frequentemente o principal indicador de altos níveis de capital social. Pessoas e comunidades educadas têm habilidades e recursos que as possibilitam formar e explorar redes sociais mais prontamente, enquanto comunidades menos educadas têm mais dificuldades para isso (p.272 - tradução minha).

Especificamente em relação às questões ambientais, a importância da educação para compreender os temas e para participar dos processos de tomada de decisão é ainda maior. Afinal, conforme visto no Capítulo 3 , muitas questões ligadas ao meio ambiente e às políticas ambientais envolvem complexidade técnica e científica, além de um raciocínio de longo prazo incomum em outros assuntos da agenda política. Assim, a compreensão de problemas ambientais complexos e o envolvimento público com organizações ambientalistas têm maiores chances de ocorrer em sociedades com melhores níveis educacionais (Guber 2003, p.73).

A tendência ao associativismo é outro traço importante da sociedade norte-americana que se correlaciona diretamente com o tema deste trabalho. Os EUA lideram os rankings mundiais de voluntarismo, importante indicador de participação em assuntos de interesse coletivo. Em 2013 havia 62,3 milhões de voluntários no país, ou seja, mais de $20 \%$ da população (Lang 2013, p.118). Esse ambiente favorece enormemente, como será visto mais adiante, o crescimento e a consolidação de uma sociedade civil robusta e atuante.

Uma importante característica do tecido social norte-americano - e aqui uma fundamental diferença em relação ao Brasil - era a existência de uma "sociedade relativamente sem classes", com chances de ascensão educacional e econômica a um 
grande número de indivíduos para os padrões da época (Martinez 2014, p.147). Essa situação possibilitou o surgimento de diversos intelectuais e líderes de origens humildes, como John James Audubon, que ajudou a disseminar ideias que contestavam o modelo de desenvolvimento e expansão sem quaisquer cuidados com o ambiente ou com comunidades tradicionais. Isso também fomentou a criação de associações que, em alguma medida, questionavam o status quo, como grupos que mais tarde seriam denominados como ambientalistas.

Assim, as ideias dos transcendentalistas e, posteriormente, de intelectuais como John James Audubon, John Muir e Gifford Pinchot, entre outros, encontraram ressonância em um grupo considerável de cidadãos. Eram pessoas com acesso a padrões mínimos de educação, que valorizavam aspectos estéticos da natureza ou apreciavam os espaços naturais para atividades de lazer como caça, pesca e observação de pássaros. Como resultado, já ao final do Século 19, tem-se notícia do surgimento dos primeiros grupos e associações de defesa do meio ambiente, o mais conhecido deles o Sierra Club, fundado em 1892 e até hoje uma das mais fortes organizações ambientalistas do país.

Poderosos incentivos legais para que a sociedade civil organizada se desenvolva existem há bastante tempo nos Estados Unidos. Além do próprio sistema político e institucional, que prevê diversos mecanismos participativos e a possibilidade de se eleger representantes para os mais variados cargos - desde os mais tradicionais como prefeito, governador, deputado, senador e presidente, até juiz, xerife, promotor e contador público, dentre muitos outros - há ainda um regime tributário pensado para que o Terceiro Setor consiga se viabilizar financeiramente.

Já em 1894 foi aprovada legislação que eximia de pagar impostos diversos tipos de organizações não governamentais. Em 1917, com objetivo de incentivar doações de empresas e indivíduos para associações sem fins lucrativos, instituiu-se a dedução no IR desse tipo de contribuição. "Organizações caritativas de voluntários ou associações com filiados floresceram nos Estados Unidos desde o surgimento do país" (Arnsberger et al 2008, p.106 - tradução minha).

Steve Schwartzman, diretor de política florestal do EDF, em entrevista para esta pesquisa ${ }^{168}$, frisou a importância dos incentivos legais para o movimento:

As ONGs ambientalistas tiraram grande vantagem desse sistema legal. Isso torna possível para organizações como o EDF arrecadar diretamente de cidadãos que conseguem dedução de impostos a

\footnotetext{
${ }^{168}$ Entrevista concedida em 21 de janeiro de 2015.
} 
partir de doações a organizações da sociedade civil. Em outros países isso não existe, nem no Brasil. Hoje, nos EUA, temos fundações como Gordon Moore e Bill Gates, que financiam atividades de grande escala em muitas áreas. Isso também tem origem em nosso Código Tributário. Isso faz uma enorme diferença. No Brasil, a maior consequência de não se ter uma legislação como esta, é que as principais organizações ambientalistas dependem de doações internacionais.

As medidas surtiram efeito e o papel do Terceiro Setor cresceu ao longo da história norte-americana. Segundo Libby (1998), desde a década de 1890 há registros de contribuições significativas de organizações não governamentais nos processos de formulação de políticas públicas (pp.6-7). A sequência ininterrupta de regimes democráticos fortaleceu a sociedade civil e as instituições políticas essenciais ao bom funcionamento da democracia, facilitando a atuação das ONGs de diversas áreas, inclusive as ambientalistas.

No Brasil, a consolidação da sociedade civil organizada se deu apenas após a redemocratização do país, já na década de 1980. Embora existam registros de organizações surgidas antes desse período, não se podia falar em um Terceiro Setor consolidado e atuante. A explicação para muitos dos fatores que geraram essa atrofia na sociedade civil brasileira encontra-se na história.

O Brasil chegou a ter intelectuais que falavam da natureza e até da importância de que os recursos naturais não fossem exauridos, como José Bonifácio e Euclides da Cunha (Pádua 1987, pp.31,43). Bonifácio, inclusive, assim como o norte-americano Thoreau, defendia o abolicionismo (Dolhnikoff 2012, p.11). Mas, como discutido no Capítulo 3, esse tipo de ideia encontrava pouca ressonância na sociedade brasileira, predominantemente analfabeta e hierarquizada, ao contrário da norte-americana.

Enquanto nos EUA e na Europa o Século 19 foi marcado por uma expansão da cidadania, o Brasil manteve-se uma sociedade desigual (Holston 2008, pp.20-21). Além de o acesso à educação pelas camadas populares ter demorado séculos para acontecer — ainda assim, com padrões de ensino público fundamental e médio atualmente entre os piores do mundo (Reiter 2009, p.61) ${ }^{169}$ - havia historicamente uma sociedade predominantemente oligarquizada, hierárquica e dependente do Estado (Rouquié 2006, p.165).

\footnotetext{
${ }^{169}$ Diversos rankings mundiais demonstram que, embora o Brasil esteja entre as seis ou sete maiores economias do mundo, o país encontra-se, invariavelmente, junto com os $50 \%$ dos países pior colocados no que se refere à qualidade da educação fundamental e média. Mais informações sobre o tema podem ser acessadas nos seguintes links: http://www.cartacapital.com.br/educacao/brasil-e-60o-de-76-paises-em-ranking-de-educacao8400.html; http://www.bbc.com/portuguese/noticias/2014/05/140508 brasil_educacao_ranking_dg;
} 
A ex-ministra do Meio Ambiente e ex-senadora Marina Silva, que também é historiadora, comentou, em entrevista para esta pesquisa ${ }^{170}$, esse aspecto e seus efeitos para a sociedade civil organizada:

No Brasil há uma tradição de muita dependência de tudo em relação ao Estado. Essa estrutura do Estado provedor, que herdamos da tradição da casa grande e da senzala, de certa forma nunca estimulou a participação autônoma da sociedade. Sempre tem aquela coisa do patrocínio, que dá um certo controle ao patrocinador.

Outro aspecto que freou o crescimento dos movimentos sociais no Brasil foram os longos períodos de regimes ditatoriais, em que direitos políticos e civis sofreram restrições diversas. Desde 1500, é possível afirmar que o Brasil teve regimes democráticos apenas entre 1945 e 1964 e de 1985 em diante (Melo e Sáez 2007, p.7), ou seja, em menos de 10\% de sua história. Esse contexto em nada favoreceu o surgimento e o fortalecimento de associações e grupos de interesse, instituições normalmente voltadas para participar dos processos políticos, questionar o status quo e a propor mudanças políticas e institucionais.

Como lembra Dagnino (2006), os regimes autoritários dificultaram o envolvimento da sociedade na formulação de políticas públicas, mesmo quando passaram a existir instrumentos formais para isso: "Na maior parte da América Latina, a sociedade política local fundou sua hegemonia em diferentes modalidades de clientelismo, o que implicou subordinação e dependência de parte dos atores sociais em relação às elites políticas" (p.28).

Enquanto a sociedade civil crescia a olhos vistos na Europa e na América do Norte durante os anos 1960 e 1970, a partir de significativas mudanças culturais em várias partes do mundo, o Brasil vivia uma ditadura militar. Assim, enquanto o movimento ambientalista dos EUA se multiplicava em tamanho, recursos, apoio popular e influência nas políticas públicas, no Brasil havia poucas organizações, desarticuladas entre si, com pouco alcance social, estrutura incipiente e quase nenhuma influência política, conforme observado em páginas anteriores.

Cabe ressaltar que esse processo de castração de movimentos contestatórios no Brasil não foi uma exclusividade da ditadura que vigorou entre 1964 e 1985. "Se considerarmos o curso de cinco séculos, é um padrão na história brasileira que o protesto

http://www.dw.com/pt/unesco-aponta-m\%C3\%A1-qualidade-como-principal-problema-daeduca\%C3\%A7\%C3\%A3o-no-brasil/a-17392179 Acesso em 5 de janeiro de 2015.

${ }^{170}$ Entrevista concedida em 31 de julho de 2015. 
popular seja esmagado. Ocasionalmente, ele é cooptado" (Holston 2008, p.18 - tradução minha). Um dos resultados desse processo histórico foi "uma sociedade civil prostrada e incapaz de expressar seus desejos sob regimes autoritários" (Brown 2006, p.199 - tradução minha).

Importante mencionar, também, que o modelo de desenvolvimento levado adiante durante o regime militar, de caráter autoritário e não discutido pela sociedade, incentivou o avanço da agropecuária sobre áreas inexploradas, especialmente nos biomas Cerrado e Amazônia, de forma "bem mais nitidamente predatória que racional" (Monteiro 1981, pp.23,38). Ou seja, eram comuns as situações em que a devastação do meio ambiente era patrocinada pelo Estado. Ademais, as eventuais forças que poderiam se opor a isso praticamente não existiam e não tinham espaço para se manifestar.

Com a redemocratização do país, novos instrumentos de participação popular nos processos decisórios, além das eleições periódicas para os poderes Executivo e Legislativo, foram introduzidos. Diversos estados e municípios passaram a contar com conselhos de cultura, política, saúde, meio ambiente e outras áreas. Municípios implementaram, muitas vezes de forma bem-sucedida, orçamentos participativos para definir a aplicação de parte dos recursos do orçamento público e em alguns casos houve significativa participação popular nos processos (Avritzer, 2002, p.137).

Porém, de um lado, a simples existência dos instrumentos não quer dizer que a participação ocorra. Por outro, mesmo a bem-sucedida experiência do orçamento participativo, passados mais de 20 anos de seu surgimento, infelizmente se tornou mais a exceção do que a regra se for considerado o conjunto dos municípios do país.

Conforme Rennó e colegas (2011), "a qualidade da democracia não se define só pelo direito de participação. Uma democracia na qual todos têm o direito de participar, mas ninguém o faz, não é, sustentamos, uma democracia de qualidade" (p.57). Os autores lembram que, para haver envolvimento da sociedade com processos de formulação de políticas, é fundamental conhecer o sistema político, algo diretamente vinculado à escolaridade de uma população (p.57).

Adicionalmente, houve poucos incentivos do Estado brasileiro à criação e ao fortalecimento de uma sociedade civil robusta e participativa. Coelho (2000), em um estudo comparado sobre o Terceiro Setor no Brasil e nos EUA, ressaltou algumas diferenças: "No caso brasileiro, o incentivo ao associativismo data das últimas décadas e certamente nunca foi tão expressivo e vigoroso como nos Estados Unidos" (p.192).

A Constituição de 1988, juntamente com peças de legislação aprovadas a partir dos anos 1980 , introduziram no país estruturas legais modernas, que buscavam democratizar os 
processos de tomada de decisão. Porém, o modelo transplantado não foi perfeitamente assimilado na realidade brasileira, conforme analisado por Avritzer (2005): "O sistema político incorporou elementos como hierarquia, nepotismo e particularismo em um modelo formalmente racional e democrático, assim, criando um híbrido político" (p.44 - tradução minha).

A despeito de alguns contextos desfavoráveis, é importante observar que, progressivamente, a partir dos anos 1970, e especialmente nos 1980 e 1990, a sociedade civil brasileira cresceu em importância, o que contribuiu para o desenvolvimento de alguns mecanismos democráticos de tomada de decisão (Avritzer 2005, p.51). A sociedade civil, especialmente aquela constituída nos grandes centros urbanos, conquistou considerável autonomia e poder de influência (Melo e Sáez 2007, pp.8-9). No caso das ONGs ambientalistas, isso se torna nítido em oportunidades políticas específicas, como a Constituição de 1988 e a Conferência Rio 92 (Alonso et al 2007) e em alguns períodos dentro dos governos dos presidentes Fernando Henrique Cardoso e Luiz Inácio Lula da Silva, conforme já discutido neste trabalho.

Ademais, a criação de diversos mecanismos legais e espaços participativos ampliou as oportunidades de participação por parte das organizações ambientalistas (Vaitsman et al 2013, p.19). Exemplos disso são os fóruns específicos que fomentam o envolvimento da sociedade civil nas decisões, como conselhos e comitês ambientais nas esferas nacional, estadual, municipal e no âmbito de bacias hidrográficas, bem como a obrigatoriedade da transparência por meio de audiências públicas no planejamento e no licenciamento de projetos e atividades com potencial impacto ao meio ambiente.

Desta forma, é possível dizer que, com a redemocratização, o Brasil foi capaz de qualificar os processos decisórios na área ambiental, não só por meio de mecanismos formais, estabelecidos por lei, como também pela crescente qualificação do movimento ambientalista. Trata-se, pois, de uma evolução gradativa, e os mecanismos tendem a se aperfeiçoar com a consolidação das práticas democráticas, que no Brasil ainda são recentes.

A seção seguinte deste capítulo, diretamente relacionada a esta, trata de um fator fundamental para o surgimento, a sobrevivência, a efetividade e o crescimento do movimento ambientalista: o apoio da população. 


\subsection{APOIO PÚBLICO: TRUNFO NOS EUA, OBSTÁCULO NO BRASIL}

"A principal influência do Sierra Club vem do apoio das bases. O Sierra Club é a maior organização ambiental de base dos Estados Unidos, temos algo como 2,4 milhões de filiados. É daí que a maior parte de nosso apoio vem e é daí que vem nossa habilidade de fazer lobby". Essas foram as primeiras palavras de Andrew Linhardt, lobista da ONG ambientalista norte-americana Sierra Club, na entrevista que deu para esta pesquisa ${ }^{171}$.

Linhardt se referia àquela que pode ser classificada como uma das principais fortalezas do movimento ambientalista norte-americano no sentido de influenciar políticas públicas: o apoio público. Em um regime democrático, com elevado grau de accountability dos tomadores de decisão, os pleitos encaminhados por organizações com milhares ou milhões de apoiadores têm boa chance de serem bem-sucedidos.

$\mathrm{Na}$ maioria das entrevistas com tomadores de decisão nos EUA, ficou clara a relevância dada por políticos às reivindicações apoiadas por seus eleitores. Ao longo desta pesquisa observei exemplos em que propostas com amplo embasamento científico, porém sem grande apoio público, foram rejeitadas pelo Legislativo ou Executivo. Também não faltam, de outro lado, situações em que um projeto defendido por milhares de eleitores, mesmo sem ter por trás sólida evidência científica, é aprovado no Congresso e sancionado pelo Executivo.

Nos Estados Unidos, a combinação de uma sociedade com elevado grau de associativismo, leis que incentivam as doações (e, consequentemente, a filiação popular às organizações) e um movimento ambientalista técnica e cientificamente qualificado, com habilidade de se comunicar e capaz de representar interesses coletivos com eficiência, fez com que as ONGs da área ambiental conseguissem atrair milhões de apoiadores. Isso faz com que o movimento tenha grande legitimidade para atuar como grupo de interesse nas diversas instâncias decisórias da democracia norte-americana.

Das 18 ONGs ambientalistas com atuação nos EUA estudadas com maior detalhamento para esta tese, apenas três contam com menos de 100 mil filiados. Onze têm mais de meio milhão de apoiadores e sete, 1 milhão ou mais de filiados. Ou seja, é possível afirmar que uma relevante parcela da sociedade norte-americana é representada pelos ambientalistas.

Esses números, por si só, são extremamente importantes para conferir legitimidade às ONGs ambientalistas, mas ganham ainda mais relevância quando são traduzidos em e-

\footnotetext{
${ }^{171}$ Entrevista concedida em 15 de janeiro de 2015.
} 
mails, cartas, petições, retuítes ${ }^{172}$, compartilhamentos ${ }^{173}$ e outros tipos de manifestação que impactam as escolhas feitas por tomadores de decisão, ou quando se convertem em marchas, protestos ou manifestações de rua.

A Marcha pelo Clima, evento global que busca chamar a atenção de pessoas, imprensa e governos em relação à crise climática, é um interessante exemplo da atenção dada a convocações feitas pelo movimento ambientalista nos diversos países. Em Nova York, cidade norte-americana com maior adesão ao evento, a marcha de 2014, ocorrida em setembro, levou mais de 400 mil pessoas às ruas (Visser 2014). No Rio de Janeiro, no mesmo dia, a marcha teve cerca de 300 participantes (Folha Redação 2014), apesar do apelo das organizações ambientalistas.

Outra enorme vantagem usufruída por organizações apoiadas por grandes contingentes é uma maior independência financeira e, consequentemente, autonomia para se posicionar. Quando uma grande parcela desses apoiadores faz contribuições financeiras anuais ou mensais, as ONGs passam a contar com mais recursos para custear ações, equipes e estrutura administrativa, possibilitando maior incidência e efetividade para influenciar as políticas públicas, por exemplo.

Importante observar que, quando o recurso vem de filiados, a organização decide como melhor utilizá-lo. Quando a verba é arrecadada por meio de um projeto de conservação, a ONG pode utilizá-lo, geralmente, apenas em atividades que guardem alguma relação, mesmo que indireta, com esse projeto. Adicionalmente, quando conta com uma ampla base de doadores pessoas físicas, a organização tem mais condições de adotar uma postura crítica em relação a governos e grandes corporações, uma vez que não depende de recursos de empresas ou do Estado para sobreviver. Um enorme diferencial em se tratando de influenciar políticas públicas.

Cabe aqui uma ressalva: mesmo entre as ONGs norte-americanas que contam com milhares de apoiadores, a independência mencionada no parágrafo acima não é simples de ser alcançada. Afinal, mesmo com muitos filiados, boa parte delas recebe numerosas somas de empresas ou fundações ligadas a corporações. O Greenpeace, por aceitar apenas recursos de pessoas físicas, sem sobra de dúvidas é a organização - dentre as que

\footnotetext{
${ }^{172}$ Retuitar algo na rede social Twitter é reproduzir, no seu próprio perfil, uma mensagem publicada por outro perfil, de modo que todos os seus seguidores poderão ter acesso a ela. Se um grande número de pessoas retuíta uma mensagem, a divulgação se dá por progressão geométrica, atingindo audiências ainda maiores, possibilitando que o conteúdo seja viralizado.

${ }^{173}$ Similarmente ao retuíte, o compartilhamento é a reprodução de um conteúdo publicado por terceiros, porém na rede social Facebook.
} 
pesquisadas no Brasil e nos EUA - que mais pode se afirmar independente, no sentido de não depender financeiramente de governos, empresas e fundações.

Alguns analistas do movimento ambientalista norte-americano entendem que o tipo de filiação às organizações não representa um lastro social do movimento, uma vez que esses filiados não participam do processo de tomada de decisões (Bevington 2009, pp.25-26). Algo diferente, por exemplo, dos movimentos sociais, cujos integrantes seriam, de fato, não apenas representados, mas também parte das organizações.

A análise faz algum sentido, uma vez que a relação entre os filiados e as ONGs ambientalistas, muitas vezes, se limita ao pagamento de anuidades ou mensalidades, em troca de uma carteirinha, adesivos, camisetas e o envio de um boletim mensal pela organização. Ainda assim, a representação desses indivíduos pelas organizações me parece perfeitamente legítima. Afinal, as contribuições são voluntárias e, se forem renovadas, demonstram a satisfação do filiado em relação ao trabalho desenvolvido ao longo do ano.

Assim como os sacrifícios físicos ou de autoflagelação por uma causa religiosa foram substituídos nos tempos modernos por contribuições financeiras como o dízimo, não surpreende que, em um mundo em que as pessoas têm pouco tempo livre, as horas de voluntariado ou dedicadas a marchas e manifestações de rua sejam trocadas por mensalidades debitadas no cartão de crédito. Ainda assim, caracteriza-se a representatividade.

Segundo Wesley Warren, diretor de policy e advocacy da ONG NRDC, em entrevista para esta pesquisa ${ }^{174}$, a relação com os 1,25 milhão de filiados da organização segue uma lógica de mercado. "Se começarmos a trabalhar em temas que não são de interesse, eles vão encontrar uma outra organização para apoiar. Temos de responder àquilo que os filiados demandam", relatou.

Putnam (2000) tem razão quando afirma que as organizações de filiados não promovem a democracia participativa e nem a relação entre seus filiados, mas representam interesses de seus apoiadores. "Pode ser mais eficiente do ponto de vista técnico contratar outras pessoas para agir politicamente em nosso nome" (pp.159-160).

No Brasil, as ONGs ambientalistas, em comparação com suas correspondentes norteamericanas, têm um número muito baixo de filiados. Dentre todas as organizações com atuação no Brasil estudadas com maior detalhamento nesta pesquisa, apenas Greenpeace

\footnotetext{
${ }^{174}$ Entrevista concedida em 15 de janeiro de 2015.
} 
e SOS Mata Atlântica contam com mais de 10 mil filiados $(50$ mil e 300 mil, respectivamente). No caso do Greenpeace, os 50 mil filiados pagam contribuições mensais a partir de $\mathrm{R} \$ 30$. Na SOS, 5 mil pagam mensalidades e o restante doa apenas um percentual da anuidade de um cartão de crédito à ONG.

Quando é feita a comparação entre organizações que atuam nos dois países, a discrepância se torna mais clara. O WWF, por exemplo, tem 1,1 milhão de filiados nos EUA, e cerca de 6 mil no Brasil. A TNC conta com 1 milhão de apoiadores nos EUA, e praticamente não tem afiliados no Brasil. O Greenpeace, por sua vez, tem 250 mil filiados nos EUA e 50 mil no Brasil.

Em livro que conta a história da ONG SOS Mata Atlântica (Guimarães e Campanili 2012) encontra-se um relato emblemático sobre as dificuldades do movimento ambientalista brasileiro em obter apoiadores junto à sociedade: "Uma campanha realizada entre 2008 e 2009, por exemplo, com o objetivo de aumentar o número de filiados, divulgou um número de telefone que não recebeu uma só chamada" (p.77). Experiências malsucedidas como esta - já vividas, em diferentes escalas, por várias ONGs ambientalistas no país, conforme apurei em entrevistas - desencorajam as organizações a investir em ações mais ousadas de filiação, que são caras, e a apostar as fichas cada vez mais nos projetos de conservação, aumentando a dependência em relação a recursos de empresas, governos e fundações.

Rachel Biderman, diretora do WRI no Brasil, acrescentou, em entrevista para esta pesquisa $^{175}$, que a numerosa base de apoio das organizações ambientalistas nos EUA é fundamental para a saúde financeira do movimento. "As ONGs não quebraram nem mesmo em 2008 com a crise. Esse apoio da sociedade dá uma flexibilidade bem grande às organizações", opinou.

As consequências da falta de apoio popular às ONGs ambientalistas no Brasil são inúmeras. Uma delas é a ausência de suporte para pressionar tomadores de decisão. Outra é uma maior dependência financeira em relação a empresas, governos e doadores internacionais (Elkington e Beloe 2010, p.30). Mauro Armelin, ex-superintendente de Conservação do WWF-Brasil, afirmou em entrevista para esta pesquisa ${ }^{176}$ que o movimento ambientalista "não tem legitimidade de representação social", o que acaba gerando dificuldades para o trabalho das organizações.

Uma das razões é o lugar marginal que as questões ambientais ocupam na agenda da sociedade brasileira (Little 2013, p.14). Isso pode ter correlação com os graves problemas

\footnotetext{
${ }^{175}$ Entrevista concedida em 3 de agosto de 2015.

${ }^{176}$ Entrevista concedida em 4 de setembro de 2015.
} 
sociais do país, que impediriam que mais pessoas se preocupassem com o meio ambiente. "Que respeito ou preocupação com a natureza pode ter quem está faminto e ignorante?", indagou Monteiro (1981, p.110).

As ideias de Inglehart (1995) vão em similar caminho. Para ele, apenas sociedades que tenham suas necessidades básicas (segurança e renda, por exemplo) atendidas podem se preocupar com valores considerados pós-materialistas como o meio ambiente, a liberdade de expressão, a promoção da cultura e a qualidade de vida, por exemplo (p.57 _ tradução minha).

Outra questão que contribui para que o movimento ambientalista não tenha apoio público no Brasil, já discutida em páginas anteriores desta tese, é a evidente falta de tradição associativista no país (Avritzer 2005, p.41). Roseli Senna Ganem, consultora legislativa da Câmara dos Deputados na área ambiental, ressaltou em entrevista para esta pesquisa ${ }^{177}$ que, além de não ter a cultura de participação, "a sociedade brasileira é desmobilizada e não se preocupa com a biodiversidade e o desmatamento".

O relevante apoio social às organizações ambientalistas norte-americanas, por um lado, e a falta dele em relação às ONGs brasileiras, por outro, representam uma das diferenças fundamentais entre os movimentos nos dois países. Essa situação acaba influenciando a escolha das estratégias adotadas pelas organizações, as fontes de arrecadação e, fundamentalmente, a forma como as reivindicações são recebidas pelos tomadores de decisão.

\subsection{A INFLUÊNCIA DO SISTEMA POLÍTICO E ELEITORAL}

Os dois países estudados têm sistemas políticos democráticos, com mecanismos que possibilitam a atuação da sociedade civil nos processos de formulação, aprovação e implementação de políticas públicas. Certamente, o pluralismo norte-americano tem as engrenagens mais azeitadas que o sistema brasileiro, em grande medida pela maior "quilometragem" percorrida, com uma democracia mais estável e duradoura ao longo da história. Mas é comumente aceita entre pesquisadores a visão, com a qual concordo, de que - Brasil é uma democracia estável, em rápida consolidação e aberta à participação da sociedade civil (Rennó et al 2011, p.31; Figueiredo e Limongi 2007, p.184; Melo e Sáez 2007, pp.8-9).

\footnotetext{
${ }^{177}$ Entrevista concedida em 24 de agosto de 2015.
} 
Ambos os países contam com eleições periódicas para os principais representantes dos poderes Executivo e Legislativo, cujos resultados são coletivamente aceitos e reconhecidos. Há, ainda, outros mecanismos formais que promovem a participação da sociedade civil, como conselhos municipais, estaduais e federais.

Falando-se especificamente das questões ambientais, no Brasil e nos Estados Unidos os processos de licenciamento são transparentes e devem ter, por força da lei, participação da sociedade, por meio de audiências públicas e da divulgação de informações. Organizações da sociedade civil que defendam interesses difusos podem, ainda, ingressar com ações na Justiça para prevenir ou reverter danos ambientais.

Há, porém, algumas diferenças importantes que influenciam diretamente o trabalho do movimento ambientalista no Brasil e nos EUA. Como já visto, o sistema norte-americano prevê, especialmente no nível estadual, uma série de consultas populares, por meio de voto, para questões de relevância pública. Muitas envolvem temas ambientais, e a sociedade é chamada a opinar diante de propostas de lei relacionadas a lixo tóxico, emissões de poluentes, resíduos sólidos, gerenciamento de recursos naturais etc. São referendos em que ONGs ambientalistas se envolvem diretamente, promovendo campanhas de conscientização.

As propostas podem partir do Legislativo ou de iniciativa popular, o que aumenta o raio de atuação do movimento ambientalista. Trata-se, portanto, de uma forma de democracia direta para decidir importantes questões ambientais. Levantamento feito por Guber (2003) analisou, entre 1964 e 2000, nada menos que 370 consultas populares a temas ambientais em 45 estados norte-americanos (p.127).

No Brasil, as únicas consultas públicas oficiais por voto ocorridas após a democratização foram um plebiscito que decidiu, em 1993, se o país seria uma monarquia ou uma república e se seria parlamentarista ou presidencialista, e um referendo sobre desarmamento em 2005. A não ser em audiências públicas ligadas a obras e projetos de infraestrutura, a população brasileira dificilmente é consultada diretamente em questões ambientais.

As audiências públicas são, de fato um importante momento de intervenção coletiva nos processos de licenciamento ou de formulação de políticas públicas ambientais. Conforme analisado no Capítulo 4, a EPA, principal órgão federal norte-americano que lida com o meio ambiente, abre espaços para que o público e as organizações da sociedade civil encaminhem comentários a respeito de diversos projetos ligados à emissão de poluentes e ao uso dos recursos naturais e resíduos, apenas para dar um exemplo. 
Segundo o advogado ambiental Peter Kirby, com passagem pelas ONGs National Wildlife Federation, The Wilderness Society e Earthjustice, entrevistado para esta pesquisa ${ }^{178}$, tanto o Executivo quanto o Legislativo são fortemente influenciados por comentários encaminhados pelo público. "Penso que isso seja algo em que os Estados Unidos são bons: trazer os cidadãos para as decisões burocráticas", opinou.

O advogado ambiental Raul Valle, com passagem de 14 anos pelo ISA, em entrevista para esta pesquisa ${ }^{179}$, observou que as regras da EPA têm um processo de elaboração muito mais participativo e transparente que as portarias do MMA ou do IBAMA no Brasil. Isso faz com que, nesse particular, o trabalho das ONGs brasileiras se torne mais árduo que o de suas correspondentes nos EUA.

No Brasil, o movimento ambientalista tem dificuldades frequentes em se envolver nos processos públicos de deliberação política. Durante o período em que trabalhei no WWFBrasil foram realizadas audiências públicas no estado de Rondônia, referentes ao projeto de se construírem hidrelétricas no rio Madeira. Em uma dessas audiências, em 2008, chegaram dezenas de ônibus com cidadãos que impediam com vaias que opositores das hidrelétricas se manifestassem e aplaudiam todas as falas favoráveis às usinas. Essa experiência, que se repete em inúmeros processos no país em que grandes projetos de infraestrutura são questionados, mostra alguns dos problemas enfrentados pelas organizações que buscam influenciar políticas no Brasil, especialmente que envolvam meio ambiente, comunidades tradicionais e direitos humanos.

Adicionalmente, as regras eleitorais vigentes nos EUA dão uma relevante contribuição para que a pressão popular tenha efetividade no sentido de convencer tomadores de decisão, especialmente no âmbito do Legislativo. Uma das principais conclusões a que cheguei durante esta pesquisa é que o sistema de voto distrital, adotado nos EUA, é um aspecto fundamental para a accountability dos deputados federais (representatives) e, consequentemente, para o sucesso das ONGs ambientalistas no sentido de influenciar políticas públicas.

Nos Estados Unidos, os distritos eleitorais concentram uma população entre 500 mil e 800 mil eleitores. Isso faz com que a prestação de contas de um parlamentar seja feita para um grupo mais reduzido, e que seu trabalho seja voltado especificamente para os interesses dessa população. E, naturalmente, a cobrança em relação aos posicionamentos, aos votos dados em plenário e aos projetos apresentados é muito mais direta do que no caso

\footnotetext{
${ }^{178}$ Entrevista concedida em 20 de junho de 2014.

${ }^{179}$ Entrevista concedida em 15 de janeiro de 2015.
} 
brasileiro, em que um deputado mineiro, por exemplo, representa mais de 850 municípios e pode receber votos em cada um deles. As chances desse parlamentar se reportar periodicamente para seus eleitores, criando uma relação de proximidade e transparência, são bem menores do que se houvesse o voto distrital.

Uma vez que a accountability é maior e a delimitação geográfica dos eleitores é clara e limitada, o trabalho das ONGs ambientalistas para influenciar os deputados (representatives) é facilitado. Se uma organização mapeia uma quantidade determinada de deputados que devem ser convencidos a votar a favor de um projeto de lei, ela buscará mobilizar diretamente os eleitores do distrito eleitoral de cada um desses parlamentares para exercer pressão sobre o político. Essa comunicação poderá ser feita por ligações, emails, cartas ou, até mesmo, reuniões de eleitores com assessores ou com o próprio político, muitas vezes agendadas pelas ONGs.

Adicionalmente, quando o deputado recebe votos apenas de um distrito, as manifestações advindas desse distrito assumem uma enorme importância para aquele parlamentar. No Brasil, para convencer eleitores a pressionar seus representantes, as organizações frequentemente fazem mensagens generalistas, de alcance nacional, que certamente têm menor efetividade que aquelas dirigidas especificamente a um limitado grupo de eleitores dentro de um distrito.

O assessor de uma deputada Republicana de um estado na região central dos EUA, em entrevista para esta pesquisa ${ }^{180}$, comentou a situação. "A primeira pergunta que fazemos aos lobistas que nos procuram é: quantas pessoas filiadas à sua organização são do nosso distrito?" Sobre as campanhas envolvendo mensagens de cidadãos para a parlamentar, realizadas por ONGs, o entrevistado foi taxativo: "Funcionam desde que o volume de mensagens seja grande e, apenas, se vierem de eleitores do nosso distrito".

Em outra entrevista ${ }^{181}$, a assessora de um parlamentar Republicano do Texas relatou que os encontros do deputado e dos assessores com cidadãos do distrito são constantes, bem como as mensagens enviadas para o gabinete. "Recebemos muitos e-mails e cartas. Se forem de eleitores de nosso distrito, respondemos. Se não, apenas enviamos um muito obrigado".

De acordo com Tim Aiken, ex-assessor do ex-deputado federal (representative) Jim Moran, Democrata da Virgínia, entrevistado para esta pesquisa ${ }^{182}$, prestar atenção às

\footnotetext{
${ }^{180}$ Entrevista concedida em 24 de fevereiro de 2015.

${ }^{181}$ Entrevista concedida em 23 de janeiro de 2015.

${ }^{182}$ Entrevista concedida em 24 de novembro de 2014.
} 
manifestações do distrito é, também, uma questão estratégica para o parlamentar. "Uma coisa é um grupo de fora bater à sua porta e pedir apoio, mas se é um eleitor seu, você não quer ser percebido como indiferente", ressaltou.

Outro fator que contribui ainda mais para reduzir o universo de eleitores e, portanto, para que o trabalho das ONGs ocorra de forma mais estratégica e dirigida, é o voto facultativo, adotado nos Estados Unidos. Entrevistas com analistas e assessores de parlamentares deixaram claro que, com a não-obrigatoriedade dos votos, normalmente os eleitores mais preocupados com a política são os que comparecem às urnas, especialmente nas votações exclusivamente para o Legislativo, quando o comparecimento costuma girar em torno dos $30 \%$ do total do eleitorado ${ }^{183}$.

Isso produz dois resultados: (i) esses cidadãos são mais conscientes e, portanto, mais abertos a mensagens de grupos de interesses, entre eles as ONGs ambientalistas e mais dispostos a monitorar e a cobrar dos seus representantes, algo desejável por parte de organizações que buscam influenciar processos de formulação de políticas; (ii) do lado do parlamentar - isso foi comprovado nas entrevistas - as manifestações de eleitores de seu distrito são muito valorizadas, por virem de integrantes de um grupo numericamente limitado, possivelmente daqueles com maior consciência política e, consequentemente, formadores de opinião e capazes de fazer a diferença no resultado de uma eleição.

Em relação às eleições, outro fator que contribui para que as pressões feitas aos deputados sejam mais efetivas é o fato de os mandatos terem a duração de apenas dois anos. Com o horizonte da reeleição sempre próximo, o parlamentar precisa prestar ainda mais atenção ao seu distrito e levar em conta as opiniões manifestadas pelos eleitores, algo que amplia as possibilidades de sucesso das campanhas do movimento ambientalista que mobilizam eleitores em torno de um projeto de lei.

Nos EUA, essa possibilidade maior de exercer, via eleitores, pressão sobre os deputados, é importante para os movimentos ambientalistas, uma vez que a Câmara, tradicionalmente, é uma Casa mais conservadora, por representar de maneira mais ampla todos as regiões e todos os segmentos da sociedade. O Senado, por sua vez, pode refletir uma maior representatividade de grandes centros populacionais, uma vez que os senadores recebem votos de todo o Estado.

\footnotetext{
${ }^{183}$ Nos EUA, o mandato dos deputados é de dois anos e o do presidente, de quatro. Portanto, as eleições para deputados, alternadamente, coincidem com as presidenciais. Em 2014 houve eleições exclusivamente para o Congresso. Em 2016, haverá, conjuntamente, para o Congresso e para a Casa Branca.
} 
No caso brasileiro, onde não há voto distrital, a Câmara acaba, também, sendo mais conservadora que o Senado e apresentando uma correlação de forças mais desfavorável aos ambientalistas. Isso ficou claro nas entrevistas com representantes de ONGs, analistas e tomadores de decisão. Alguns pesquisadores indicam como causa uma distorção na representatividade do sistema eleitoral brasileiro, que acaba fazendo com que, proporcionalmente, estados menos populosos e áreas rurais tenham mais representantes que grandes centros urbanos (Thomson 2014, p.80; Rouquié 2006, p.204; Anastasia et al 2007, p.121). Segundo Thomson (2014), se a regra da proporcionalidade numérica fosse seguida, São Paulo teria 114 deputados federais, em lugar dos 70 atuais (p.80), o que caracteriza um significativo déficit de representação.

Steve Schwartzman, diretor de política florestal do EDF, que trabalhou no Brasil nos anos 1980 e 1990, avaliou, em entrevista para esta pesquisa ${ }^{184}$, os efeitos dessa distorção:

O voto de um paulista vale bem menos que o de um amapaense. Uma vez estabelecido, é muito difícil de mudar um sistema assim, que é fundamentalmente anti-democrático. Isso é fundamental para explicar o poder dos ruralistas, que pôde ser visto na votação do Código Florestal, explicitamente contrária às manifestações da maioria da população brasileira.

Outra questão que dificulta a atuação dos movimentos ambientalistas no Brasil, especialmente nas ações de lobby, é a elevada fragmentação do sistema partidário brasileiro (Melo 2007, p.268), que produz uma série de efeitos negativos para a pauta ambiental.

A necessidade de o presidente governar com coalizões entre campos muito diversos no parlamento (Anastasia et al 2007, p.123) e, entre diferentes partidos de vários tamanhos, deixa de lado debates programáticos, como aqueles sobre temas ambientais, fazendo com que compromissos políticos assumam protagonismo. Assim, as pautas ligadas ao meio ambiente - via de regra com menor projeção na sociedade - vão a reboque de acordos maiores e o trabalho dos movimentos em convencer parlamentares por argumentos técnicos e científicos acaba, muitas vezes, caindo por terra.

Ademais, o uso de critérios políticos para a nomeação dos ocupantes de ministérios e cargos que demandariam um perfil técnico, para atender aos diversos partidos da coalizão de governo, também desqualifica os processos decisórios. Como consequência, saem

\footnotetext{
${ }^{184}$ Entrevista concedida em 21 de janeiro de 2015.
} 
prejudicados os atores e grupos que buscam influenciar políticas por meio da ciência, como o movimento ambientalista.

Em entrevista para esta pesquisa ${ }^{185}$ Sérgio Besserman Vianna, integrante de conselhos das ONGs WWF-Brasil, CI Brasil, ICLEI e FUNBIO, salienta que a quantidade de parlamentares brasileiros conectados a algum tema - não apenas o ambiental — é mínima, o que empobrece os debates. "A democracia brasileira é muito recente e de baixa qualidade, é muito difícil influenciar políticas no Brasil se você não representar um setor poderoso da economia" afirmou.

Robert Buschbacher, coordenador do programa Amazon Conservation Leadership da Universidade da Flórida e com experiências no WWF-EUA e WWF-Brasil, ressaltou em entrevista para esta pesquisa ${ }^{186}$ que o sistema político é um fator que produz grandes diferenças na capacidade das ONGs ambientalistas influenciarem políticas nos dois países.

Uma grande diferença entre os dois sistemas é que há muito mais transparência nos Estados Unidos. No Brasil os formuladores de políticas podem fazer praticamente tudo que querem. Eles não são tão accountable porque não há muitos holofotes no que fazem. Logo, a política depende mais de relações pessoais com os formuladores de políticas.

Considerando-se o sistema eleitoral, a estrutura partidária e o modelo político, é possível concluir que as ONGs ambientalistas que atuam no Brasil enfrentam um desafio muito maior que as que trabalham nos EUA para influenciar políticas públicas ambientais. Na próxima seção serão discutidas as complexas relações do movimento com o Estado.

\subsection{O MOVIMENTO E O ESTADO: PARCERIA, SUBSTITUIÇÃO E ENFRENTAMENTO}

Os projetos de campo são uma das maneiras mais efetivas com que as ONGs ambientalistas influenciam as políticas públicas no Brasil. Conforme visto no Capítulo 4 deste trabalho, não faltam iniciativas em que organizações assumem o papel de elaborar, custear ou mesmo implementar ações voltadas para o desenvolvimento sustentável.

A maior parte dessas iniciativas, no caso brasileiro, se dá em parceria com o Estado, nas esferas municipal, estadual e federal (Carvalho 2003, p.263). A participação das ONGs é variável em escala e intensidade. Em alguns momentos, elas acabam, inclusive,

\footnotetext{
${ }^{185}$ Entrevista concedida em 20 de maio de 2015.

${ }^{186}$ Entrevista concedida em 4 de setembro de 2014.
} 
substituindo o Estado e definindo políticas que, na opinião de alguns entrevistados, deveriam estar a cargo daqueles que foram legitimados pelo voto para tomar essas decisões. Mas, infelizmente, muitas dessas ações não se tornariam realidade sem o apoio das organizações ambientalistas.

Constatei que, na grande maioria das vezes, as grandes organizações ambientalistas acabam aportando valiosas contribuições para a conservação de ecossistemas, o uso racional de recursos naturais e a promoção do desenvolvimento sustentável. Muitas vezes, as ONGs acabam suprindo as frequentes carências de equipamentos, estrutura, recursos humanos e financeiros do aparato estatal brasileiro para lidar com o meio ambiente.

Não faltam exemplos, conforme visto no Capítulo 4, de ocasiões em que o aporte técnico, financeiro ou operacional das ONGs foi o diferencial que permitiu que determinada política ambiental saísse do papel. A expertise técnica levada pelas ONGs também é um aporte valioso para os tomadores de decisão nos governos, que acabam lançando mão do conhecimento produzido na academia e nas próprias organizações (Mittermeier et al 2005, p.18).

Ex-ministros do Meio Ambiente, de diferentes partidos, entrevistados para esta pesquisa, bem como ex-presidentes de órgãos ambientais federais, foram unânimes em ressaltar a importância do movimento ambientalista para apoiar o Estado em diversas políticas ambientais. De acordo com Marina Silva ${ }^{187}$, as ONGs têm sido fundamentais "para o processo de institucionalização e integração da governança do Estado brasileiro".

Roberto Messias Franco, que presidiu o IBAMA nos anos 2000 , afirmou ${ }^{188}$ que o Estado terceiriza, por meio das ONGs, tarefas que, originalmente, caberiam ao governo. "Isso funciona muito bem. Se deixar apenas para funcionário público [fazer], não vai sair", observou. Frequentemente, as soluções propostas pelas organizações são mais baratas, mais rápidas, desburocratizadas e eficientes que as iniciativas conduzidas pelo Estado. "[E]m muitos casos as instituições não-governamentais realizam um trabalho de qualificação da gestão estatal, atuando na ponta ou desburocratizando processos de captação de recursos e realização de ações" (Castro Junior et al 2009, pp.51-52).

Naturalmente, não se pode subestimar a importância dos governos para que a atuação das organizações seja sinônimo de eficiência. "O Estado continua com papel-chave mesmo na política ambiental executada pelo terceiro setor" (Castro Junior et al 2009, pp.5152). Isso é bastante nítido em estados amazônicos, onde a infraestrutura apresenta

\footnotetext{
${ }^{187}$ Entrevista concedida em 31 de julho de 2015.

${ }^{188}$ Entrevista concedida em 3 de junho de 2015.
} 
deficiências, a iniciativa privada ainda é pouco desenvolvida e, portanto, o governo é o principal motor de promoção do desenvolvimento.

Muitas vezes, as organizações ambientalistas desempenham um importante papel no sentido de canalizar recursos de organismos internacionais para projetos coordenados por governos, especialmente estaduais e federal. Isso é feito com grande frequência por organizações com atuação internacional, como WWF, Cl e TNC, que funcionam como intermediários nesse processo, por terem credibilidade junto à comunidade internacional, comumente mais credibilidade que os governos.

Com ou sem razão - não cabe neste trabalho uma discussão sobre este ponto doadores estrangeiros relutam em repassar recursos diretamente ao Governo Federal ou a governos estaduais, e se tranquilizam quando uma grande ONG faz essa intermediação. Em grandes projetos como o ARPA, por exemplo, além de apoio técnico, o WWF-Brasil conseguiu aglutinar recursos financeiros destinados à criação e à implementação de áreas protegidas, em um programa visto como extremamente bem-sucedido por analistas, representantes de ONGs e tomadores de decisão da área governamental.

Nas esferas estaduais o papel de organizações do movimento ambientalista tem sido também muito relevante no sentido de apoiar políticas ambientais. As ONGs se fazem presentes não apenas direcionando recursos para secretarias e órgãos estaduais de meio ambiente, como também treinam e qualificam gestores, financiam ou realizam estudos para criação e implementação de UCs ou para planos de manejo de áreas protegidas. Essas iniciativas foram comprovadas em entrevistas com gestores ambientais de diferentes estados amazônicos e representantes de organizações.

Cabe observar que, nos estados amazônicos, em comparação com aqueles do Sul e do Sudeste, a carência de recursos, pessoal e estrutura, é maior (Câmara 2013, p.135), tornando ainda mais importante a presença das ONGs ambientalistas. Assim, a atuação das organizações se amplia, contribuindo para a tendência de descentralização da governança ambiental (Câmara 2013, p.140; Bernardes e Ferreira 2007, p.35).

No caso dos Estados Unidos, embora existam casos de projetos de campo que se tornam políticas públicas - há alguns exemplos no Capítulo 4 desta tese -, o Estado se faz mais presente, e de forma mais estruturada que no Brasil. Não se tem notícias, por exemplo, de ONGs ambientalistas bancando a construção de sedes de unidades de conservação ou contratando consultores para realizar estudos de campo necessários à implementação de políticas por falta de recursos do Serviço de Parques Nacionais ou do Serviço Florestal dos Estados Unidos. 
Outro importante debate é o do papel fiscalizador do Terceiro Setor em relação ao Estado. Espera-se que ONGs, em virtude de sua posição fora dos segmentos público e privado, denunciem publicamente situações em que os governos não cumprem seu papel de garantir um ambiente saudável e de assegurar um desenvolvimento com base em padrões de sustentabilidade, ou mesmo que acionem judicialmente o Estado por conta disso.

No Brasil e nos Estados Unidos foram observadas diversas situações em que organizações ambientalistas assumiram uma postura crítica em relação aos governos. No caso norte-americano, foram discutidos, no Capítulo 4, momentos em que ONGs entram com ações na Justiça contra o Estado, para que, por exemplo, as agências federais exijam de grandes indústrias a obediência a padrões de emissões de poluentes, ou indenizem comunidades prejudicadas por resíduos descartados de maneira inadequada.

Há, também, protestos e campanhas feitos por organizações no sentido de pressionar o governo a tomar uma posição ou a criticar alguma ação ou omissão por parte do Estado. Porém, dentre as grandes ONGs ambientalistas estudadas, essa situação praticamente não foi observada, a exceção ficando por conta de organizações com perfil considerado mais agressivo ou menos conciliador, como CHEJ, Earthfirst, Friends of the Earth e Greenpeace.

No caso brasileiro, há muitas situações em que as organizações, em parceria com o Ministério Público, acionam judicialmente o Estado, especialmente para exigir o cumprimento da legislação ambiental em grandes projetos de infraestrutura, como estradas, hidrelétricas e portos. As campanhas e protestos contra a atual postura do Governo Federal - apontado pela grande maioria dos ambientalistas entrevistados como insensível ao tema ambiental - ocorrem com pouca frequência, geralmente sob liderança do Greenpeace. A última grande mobilização com participação da maioria das ONGs ambientalistas ocorreu durante a reforma no Código Florestal.

Notam-se alguns posicionamentos públicos de ONGs com atuação no Brasil, condenando posturas governamentais, seja por meio dos sites oficiais das organizações, canais nas mídias sociais, artigos e entrevistas concedidas à imprensa. Isso é observado especialmente em momentos como conferências do clima, quando o movimento, comumente, cobra metas mais ousadas de redução nas emissões de gases de efeito estufa.

Paulo Moutinho, diretor do IPAM, em entrevista para esta pesquisa ${ }^{189}$, lembrou que cerca de $40 \%$ do orçamento de sua organização estão vinculados a recursos do governo, por meio de projetos do Fundo Amazônia e de ministérios como MDA, MDS, MMA e MJ. "Há uma coerência histórica de como lidar com o governo: ter parcerias e bater pesado. A

\footnotetext{
${ }^{189}$ Entrevista concedida em 10 de agosto de 2015.
} 
ministra do Meio Ambiente quer a minha cabeça, mas eu estou lá ajudando suas secretarias em algumas coisas que são importantes", observou.

Sérgio Guimarães, coordenador do ICV, entrevistado para esta pesquisa ${ }^{190}$, adotou discurso semelhante. "Ao mesmo tempo em que tensionamos, fazemos alianças", relatou. Segundo ele, essa postura se repete nas esferas federal, estadual e municipal.

Embora os entrevistados indiquem uma situação que combine enfrentamento e parceria, pesquisadores relatam que os projetos financiados pelo governo costumam comprometer a independência do Terceiro Setor. "Quanto mais uma entidade passa depender de fontes de financiamento oficiais, menor sua capacidade de aglutinação e pressão política" (Arnt e Schwartzman 1992, p.132).

Algumas ONGs como $\mathrm{Cl}$, TNC e WWF-Brasil, em geral, não assumem posturas combativas em relação a governos e grandes empresas, por terem um perfil mais conciliador. No caso da TNC, nem mesmo durante as discussões do Código Florestal quando WWF-Brasil e $\mathrm{Cl}$, em uma ampla aliança com outras ONGs, criticaram pesadamente a postura do Governo Federal e dos ruralistas - a organização se posicionou de forma incisiva. A TNC nem mesmo integrou o Comitê Brasil em Defesa das Florestas, coalizão de organizações que lutou contra a flexibilização da legislação.

Segundo Ana Cristina Barros, ex-representante da TNC no Brasil, entrevistada para esta pesquisa ${ }^{191}$, a organização chegou a conversar com as outras ONGs à época da construção da aliança.

Participei das reuniões de formulação, fiz uma revisão do site, e achei que era agressivo demais, e tinha pouco a colaborar para uma negociação de interesses. Achei que ele extremava, dentro da lógica que já falei da polarização. A TNC tem como princípio muito claro não ser confrontacional. Isso não significa deixar de fazer críticas, isso significa fazer crítica educada e construtiva. Muitas vezes nos chegam posicionamento de grupos e coalizões de ONGs que a gente entende a mensagem, concorda, mas discorda da forma e a forma já nos fez não endossar muitos posicionamentos e não fazer parte dessas coalizões.

O WWF-Brasil, por exemplo, passou em 2010 a ter um grande projeto de conservação financiado pela Fundação Banco do Brasil, que respondia por significativo percentual da

\footnotetext{
${ }^{190}$ Entrevista concedida em 27 de agosto de 2015.

${ }^{191}$ Entrevista concedida em 1 de julho de 2014.
} 
receita da organização. Entrevistas realizadas com pessoas ligadas à ONG deixaram claro que a parceria criou amarras à atuação do WWF-Brasil em questões relacionadas ao governo. Também foi relatado um certo controle exercido pelo Conselho Deliberativo da ONG, órgão composto por representantes da academia, do movimento ambientalista e, principalmente, do setor empresarial.

Maria Cecília Wey de Brito, secretária-geral ${ }^{192}$ do WWF-Brasil entre 2011 e 2015, descreveu a situação em entrevista para esta pesquisa ${ }^{193}$, envolvendo inclusive ameaças à continuidade da parceria com a Fundação Banco do Brasil:

Quando assumi a secretaria-geral, entrei com objetivo de bater mais forte no governo. Algumas vezes fui pressionada pelo próprio governo via Conselho ${ }^{194}$, inclusive em relação ao projeto do Banco do Brasil. Também cheguei a pressionar o Conselho para criticar Geraldo Alckmim em relação à crise hídrica, mas não quiseram.

Esta opinião foi reforçada por entrevista concedida a esta pesquisa ${ }^{195}$ por Sérgio Besserman Vianna, que integrou por oito anos o Conselho Deliberativo do WWF-Brasil e atualmente integra o Conselho Consultivo. Segundo ele, a criação e a manutenção de vínculos com o Governo Federal demandam e também resultam de uma conduta menos contestadora por parte das organizações:

O WWF-Brasil, por exemplo, se fosse crítico ferrenho do governo, não teria o recurso da Fundação Banco do Brasil, ou mais adiante não teria o projeto renovado. A pouca institucionalidade da política brasileira exige boas relações com os tomadores de decisão.

Naturalmente, a questão do financiamento das organizações, que será discutida com mais profundidade na última seção deste capítulo, acaba tendo relação com a postura das ONGs. Afinal, se houvesse uma maior variedade de fontes de receita - inclusive a própria sociedade, por meio de filiações - o movimento dependeria menos de recursos de governos e empresas. Isso explica em grande medida a postura mais crítica demonstrada, por exemplo, pelo Greenpeace, que recebe recursos apenas de cidadãos. Por outro lado, organizações com perfil mais conciliador, mesmo não tendo parcerias com o Estado, não costumam ser críticas fervorosas do governo e de empresas.

\footnotetext{
192 Principal cargo no organograma da organização, comumente denominado internamente de CEO.

${ }^{193}$ Entrevista realizada em 5 de maio de 2015.

${ }^{194}$ Conselho deliberativo do WWF-Brasil.

${ }^{195}$ Entrevista concedida em 20 de maio de 2015.
} 
Também é importante pontuar que grandes organizações não são estruturas monolíticas, dotadas de um discurso único. É normal que haja diferentes pensamentos dentro de ONGs ambientalistas, cujas equipes tendem a ser multidisciplinares e compostas por indivíduos de diferentes gerações, formações e visões de mundo. Há ainda mudanças de estratégia que acontecem periodicamente dentro das organizações e, no caso daquelas que fazem parte de redes internacionais (WWF-Brasil e Greenpeace Brasil) ou que são internacionais (TNC e Cl), existem também algumas diretrizes que vêm de fora e são absorvidas pela instituição.

Em relação ao WWF-Brasil, por exemplo, durante as discussões do Código Florestal, a organização, em vários momentos, teceu severas críticas ao governo, mesmo depois de assinada a parceria com o Banco do Brasil ${ }^{196}$. Isso significa que, em algumas situações, integrantes da equipe têm grande autonomia. Nos debates do Código, por exemplo, eram necessários posicionamentos rápidos da ONG no site, nas mídias sociais e para a imprensa, fazendo com que os materiais publicados não tivessem que passar por aprovação nas instâncias superiores e fossem feitos de acordo com as convicções de momento dos analistas e jornalistas que acompanhavam o tema.

No caso norte-americano foi possível notar uma certa acomodação do movimento em relação ao governo de Barack Obama, considerado aliado dos ambientalistas. Em uma observação nos perfis oficiais no Facebook das ONGs estudadas, apenas o Greenpeace faz críticas contundentes, alternadas com elogios, a diferentes posturas adotadas pela Casa Branca, mesmo reconhecendo que o atual presidente tem feito, de maneira geral, um bom trabalho para o meio ambiente.

Kyle Ash, representante legislativo do Greenpeace-EUA, em entrevista para esta pesquisa ${ }^{197}$, demonstrou incômodo diante da postura de algumas organizações ambientalistas, que teriam, segundo ele, dificuldade em criticar o presidente da República:

O presidente Obama é provavelmente alguém do qual queremos manter uma distância, para que possamos fazer uma advocacy efetiva. Eu acho que ele já considera que pode contar com o apoio incondicional da comunidade ambientalista porque, de fato, nunca íamos querer um Republicano na Casa Branca.

\footnotetext{
${ }^{196}$ Alguns desses posicionamentos podem ser encontrados nos links http://www.wwf.org.br/?30302/movimentosocial-fecha-ministrio-do-meio-ambiente\#; http://www.wwf.org.br/informacoes/sala de imprensa/?30483/Vamosentupir-o-Planalto-de-cartas-e-e-mails; http://www.wwf.org.br/wwf brasil/?30244/Comit-cobra-veto-de-Dilma-adispositivos-que-anistiam-desmatamento (Acesso em 10 de janeiro de 2015)

${ }^{197}$ Entrevista concedida em 3 de outubro de 2015.
} 
Depoimentos similares em relação à postura de organizações do movimento ambientalista brasileiro diante da gestão de Marina Silva à frente do MMA foram colhidos durante esta pesquisa. Para alguns analistas, as ONGs ambientalistas, de maneira geral, foram pouco críticas ao governo no primeiro mandato de Lula.

\subsection{O ENQUADRAMENTO DAS MENSAGENS: QUEM VENCE A GUERRA DA INFORMAÇÃO?}

O framing é uma das teorias utilizadas neste trabalho para analisar o comportamento do movimento ambientalista. Conforme discutido no Capítulo 2, frames são "modelos ou esquemas de interpretação (...) que permitem ao interlocutor localizar, perceber, identificar e rotular uma infinidade de ocorrências concretas" (Goffman 1974, p.21 - tradução minha). Robert Entman, por sua vez, definiu que a prática do framing consiste na seleção de "aspectos de uma realidade percebida fazendo-os mais salientes em um texto de comunicação, de forma a promover uma definição particular de determinado problema" (1993, p.52 - tradução minha).

No caso do movimento ambientalista, o enquadramento das mensagens é um processo corriqueiro, com influência direta nos resultados alcançados. As técnicas de framing são empregadas desde o momento em que as organizações fazem um diagnóstico, definindo um problema, passando pela proposta de soluções até gerar uma motivação na sociedade, nas mídias e nos tomadores de decisão para que determinada ação seja tomada (Benford e Snow 2000, p.615). Esta ação pode ser a filiação a uma ONG, a assinatura de uma petição, a decisão de ir a uma manifestação de rua, o voto de um parlamentar a favor ou contra um projeto, entre outras.

Em 1969, o vazamento de petróleo em Santa Bárbara, Califórnia, foi de forma bemsucedida descrito pelos ambientalistas como um desastre ambiental, com graves impactos na fauna e nas populações locais. Isso parece óbvio sob a lógica atual, mas em épocas anteriores ao desastre, nos EUA, o mais usual seria interpretar apenas como um acidente que gerou "o desperdício de um valioso recurso que fornece energia" (Bomberg e Schlosberg 2009, p.19).

Com a opinião pública favorável, foi mais fácil para os ambientalistas elaborar novos framings voltados para a necessidade de medidas duras contra a indústria do petróleo e, simultaneamente, para a mobilização de ativistas, população de forma geral e imprensa a cobrar novas políticas voltadas para a proteção do meio ambiente frente àquela atividade econômica. Como resultado, foi aprovada meses depois uma moratória para a exploração petrolífera no litoral norte-americano (Walsh 2010). 
No caso da influência do movimento nas políticas públicas, o frame escolhido pode definir o fracasso ou o sucesso de um repertório. Em muitos casos, para sensibilizar opinião pública e os poderes Executivo e Legislativo, as organizações do movimento ambientalista buscam focar sua argumentação em belezas naturais e espécies de fauna e flora ameaçadas por atividades econômicas.

Em entrevista para esta pesquisa ${ }^{198}$, o assessor de um deputado federal (representative) Republicano de um estado produtor de petróleo lamentou o framing extremamente bem-sucedido dos ambientalistas para evitar que a extração de petróleo seja autorizada no Refúgio da Vida Selvagem do Ártico. A abordagem na campanha das ONGs historicamente tem sido a de mostrar belas paisagens da região, supostamente ameaçadas pela indústria petrolífera. Para o entrevistado, é uma mensagem que não reflete o contexto da região:

Eles têm sido absolutamente efetivos neste tema, que é algo distante da realidade deles. Se você é um parlamentar da região de Chicago, você vai votar com os ambientalistas, porque eles te mostram belas fotos de montanhas. Mas a área, na realidade, se parece com a superfície lunar. O local seria perfeito para explorar petróleo, ninguém exploraria petróleo na área das montanhas. Mas eles dizem que é a última grande área selvagem do Alaska, que será entrecortada por oleodutos. Só não passou no Senado porque senadores de estados azuis [Democratas] não querem carregar o peso da decisão, pois os eleitores deles são, predominantemente, Democratas. As ONGs têm sido inacreditavelmente efetivas.

No Brasil, um caso recente também ilustra o emprego de frames nas discussões de políticas. Em audiência pública no dia 24 de setembro de 2015, na Câmara dos Deputados, foi debatido o projeto de lei $1299 / 2015$, de autoria do deputado federal Toninho Pinheiro (PP-MG), que propõe alterações no Sistema Nacional de Unidades de Conservação. A proposta prevê, dentre outros pontos, que as zonas de amortecimento ao redor das unidades de conservação, necessárias para reduzir as ameaças externas às UCs, tenham um máximo de 2 quilômetros de extensão. Atualmente, a área é definida de acordo critérios técnicos, a partir de estudos e consultas públicas.

Durante a audiência, uma representante do ICMBIO explicou a posição do órgão, contrária à proposta, a partir de uma argumentação técnica, fundamentada na necessidade de proteção das UCs. Outra participante, Maria Dalce Ricas, coordenadora da ONG

\footnotetext{
${ }^{198}$ Entrevista concedida em 23 de janeiro de 2015.
} 
ambientalista mineira AMDA, optou por um frame que colocava em xeque a legitimidade moral do parlamentar e de seu projeto: a ambientalista afirmou que Toninho Pinheiro teria participação em uma empresa que comercializa lotes exatamente na atual zona de amortecimento do Parque Estadual da Serra do Rola-Moça, município de Ibirité, Minas Gerais, e que, portanto, a proposta traria um benefício pessoal ao parlamentar, pois legalizaria um empreendimento lançado por sua empresa ${ }^{199}$.

Assim, neste episódio, notou-se a utilização dos frames técnico, científico e moral para que o projeto 1299/2015 não avançasse. O texto foi rejeitado pela Comissão de Meio Ambiente e Desenvolvimento Sustentável em novembro de 2015 e arquivado pela Mesa Diretora da Câmara no mês seguinte ${ }^{200}$.

Outro frame explorado por ambientalistas no sentido de convencer atores políticos geralmente contrários a políticas ambientais são os dados econômicos. Correlacionar medidas de proteção de áreas naturais ou limites de emissão de poluentes a oportunidades econômicas é um exercício que às vezes encontra ressonância junto a Republicanos ou integrantes da bancada ruralista, por exemplo.

Segundo Mary Beth Beetham, diretora de assuntos legislativos da Defenders of Wildlife, em entrevista para esta pesquisa ${ }^{201}$, especialmente em momentos de crise econômica as organizações ambientalistas buscam defender propostas mostrando potenciais benefícios para a economia.

Elaboramos dados e factsheets mostrando como as atividades recreativas ligadas à vida selvagem geram US\$ 145 bilhões/ano para a a economia, além de outros benefícios econômicos. Esse é um exemplo de como são nossas abordagens, com pontos que os Republicanos querem escutar.

Provavelmente, muitos parlamentares do Partido Republicano não se sensibilizariam se o frame adotado se baseasse na importância da preservação de espécies para a manutenção dos ecossistemas. Mais uma mostra de que a escolha do frame a ser utilizado pode ser fundamental para os resultados alcançados em termos de políticas públicas.

\footnotetext{
${ }^{199}$ Mais informações sobre o projeto de lei 1299/2015 podem ser encontradas nos links

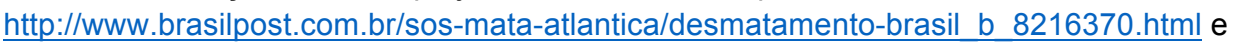
http://www.oeco.org.br/reportagens/projeto-de-lei-pretende-acabar-com-zona-de-amortecimento-das-unidadesde-conservacao-do-pais/ Acesso em 6 de janeiro de 2016.

200 Toda a tramitação do projeto pode ser encontrada no link http://www2.camara.leg.br/proposicoesWeb/fichadetramitacao?idProposicao=1215821 Acesso em 6 de janeiro de 2016.

${ }^{201}$ Entrevista concedida em 9 de janeiro de 2015.
} 
Frequentemente, por deter o conhecimento técnico e científico, as ONGs ambientalistas tendem a centrar seus argumentos nessa linha. Entretanto, diversas questões ambientais debatidas no Legislativo e no Executivo, embora de grande complexidade científica, também envolvem valores compartilhados por comunidades, segmentos industriais e grupos de tomadores de decisões. E, possivelmente, um framing contendo apelos emocionais seria mais bem-sucedido que uma linha argumentativa técnicocientífica.

Em seu diário pessoal, publicado em forma de livro em 2004, Jack Ward Thomas, chefe do Serviço Florestal dos EUA entre 1993 e 1996, responsável pela mediação de diversas disputas entre ambientalistas, madeireiros e grupos de caçadores sobre o uso de florestas públicas, discute o peso dos valores culturais dentro de uma sociedade nas disputas políticas:

É possível resolver uma questão ligada a valores com meios técnicos? Se a solução técnica não corresponder aos resultados desejados por grupos que têm esses valores, ela seria aceita meramente porque é técnica e cientificamente crível? A resposta é não, e a reação imediata seria questionar o mérito técnico da solução e/ou atacar a capacidade, a integridade e o viés daqueles que proveram a análise técnica. (Steen 2004, p.18 - tradução minha).

No caso da reforma do Código Florestal brasileiro, a guerra de frames aconteceu de maneira intensa. O relator do texto na Câmara, deputado Aldo Rebelo (PCdoB-SP), procurava defender sua proposta mostrando o "drama" de produtores rurais, incapazes de se adequarem a uma legislação "injusta" (o Código Florestal então em vigor, de 1965), que eram presos, multados e criminalizados. Os defensores do substitutivo também buscavam desqualificar as ONGs ambientalistas, taxando-as de defensoras de interesses estrangeiros, resumidos em inviabilizar a agricultura brasileira, beneficiando assim o agronegócio europeu e norte-americano.

O movimento ambientalista, por sua vez, colocava foco nos argumentos técnicos e científicos, buscando mostrar que a redução de APPs e a anistia a infrações cometidas antes de 2008 teriam como consequência o aumento do desmatamento, a escassez de recursos naturais e a multiplicação de desastres. Adicionalmente, era feita uma desqualificação dos defensores da proposta, classificando-os como representantes do agronegócio, responsáveis pelo desmatamento e pelo uso indiscriminado de agrotóxicos.

Os frames usados pelos ambientalistas conseguiram sensibilizar a opinião pública e boa parte da imprensa. Além disso, os verdes conseguiram evitar, especialmente no Senado 
e nos vetos presidenciais, a aprovação de alguns pontos defendidos pelo outro lado. Porém, no cômputo geral, os ruralistas saíram vencedores na votação no Congresso e na sanção presidencial.

\subsection{DIFICULDADES E DESAFIOS}

Pude observar alguns aspectos que impõem dificuldades ao trabalho do movimento ambientalista no Brasil e nos EUA no sentido de influenciar as políticas públicas. Alguns desses obstáculos resultam da conduta das próprias organizações, outros são fatores externos, como atores que se opõem às propostas dos ambientalistas e conjunturas políticas, econômicas, culturais ou sociais que representam barreiras ao crescimento das ONGs ambientalistas ou ao avanço de suas mensagens.

Um aspecto levantado em algumas entrevistas é uma suposta falta de unidade no movimento, no sentido de compartilhar esforços e integrar estratégias para superar obstáculos comuns. Isso foi pontuado como um problema em determinadas pautas em que o movimento atuou. Em outros momentos - conforme mostrado no Capítulo 4, na seção sobre coalizões e alianças - as organizações conseguiram atuar de forma concertada, atingindo bons resultados.

À época dos embates em torno do novo Código Florestal brasileiro, por exemplo, o alinhamento entre as ONGs ambientalistas, conforme observado por alguns entrevistados, demorou a ocorrer, e em alguns momentos, apresentou falhas que impediram um posicionamento unificado que fortaleceria o movimento. Nilo d'Ávila, coordenador de pesquisa do Greenpeace Brasil, coordenava a área de políticas públicas da ONG durante as discussões do Código. Em entrevista para este trabalho ${ }^{202}$, ele indicou uma falta de coordenação entre os ambientalistas:

A gente vai para a guerra com o exército que tem, sabíamos que não conseguiríamos ganhar. Isso abriu espaço para o surgimento de uma série de posições do movimento ambientalista: se um jornalista tomasse café da manhã com o André Lima [à época no IPAM], almoçasse com o Mario Mantovani [SOS Mata Atlântica] e jantasse comigo, terminaria o dia sem saber escrever uma matéria sobre a posição do movimento ambientalista.

\footnotetext{
${ }^{202}$ Entrevista concedida em 22 de maio de 2015.
} 
Claudio Maretti, atual presidente do ICMBIO e ex-superintendente de conservação do WWF-Brasil, em entrevista para esta pesquisa ${ }^{203}$, também analisou o problema.

Em geral não há no Brasil a aceitação de que a cooperação entre as ONGs possa ser benéfica. A disputa é maior, bem como a dificuldade de articulação. Entra-se mais em conflitos do que se une, o movimento ambientalista brasileiro tem algo de messiânico.

Assim, de acordo com Maretti, a luta entre as organizações seria, algumas vezes, pelo protagonismo nas iniciativas, para que a ONG $A$, e não a $B$, apareça como líder de determinado processo.

Pesquisadores norte-americanos também apontaram para a tendência concorrencial entre as organizações, tendo como pano de fundo a questão financeira. Os recursos aportados por filiados ou por fundações seria disputado entre as organizações, que competiriam entre si por esse "mercado" (Johnson e Prakash 2010, p.253). Isso dificultaria em alguns momentos a composição de alianças, reforçando duas correntes teóricas abordadas no Capítulo 2 deste trabalho: a teoria da mobilização de recursos e a teoria de empresas, pela qual as ONGs, em alguns momentos, se comportariam como firmas, buscando sobreviver e se consolidar e, em alguns momentos, superar concorrentes.

O aspecto do financiamento das organizações se correlaciona com outro problema amplamente discutido por pesquisadores do movimento ambientalista: a independência das organizações. Com a necessidade de estruturação e profissionalização para influenciar processos decisórios, as ONGs passaram a necessitar de orçamentos maiores, capazes de manter equipes qualificadas e departamentos financeiros e administrativos (Góis 2013, p.209).

A partir dos anos 1990, as fundações passaram a ser responsáveis por significativas parcelas dos orçamentos do movimento ambientalista, tanto no Brasil quanto nos Estados Unidos. Embora isso tenha representado mais uma opção para custear o trabalho das organizações, a nova fonte de financiamento também trouxe limitações ao trabalho do movimento.

Robert Brulle, que tem no movimento ambientalista uma de suas áreas de pesquisa, foi entrevistado para este trabalho ${ }^{204}$. Ele destacou as consequências negativas advindas da crescente presença das fundações - normalmente ligadas a grandes empresas ou grandes empresários - nas fontes de recursos do movimento ambientalista:

\footnotetext{
${ }^{203}$ Entrevista concedida em 28 de abril de 2015.

${ }^{204}$ Entrevista concedida em 27 de janeiro de 2015.
} 
Se a organização estiver disposta a fazer concessões e iniciar uma relação com essas grandes fundações, elas vão injetar dinheiro, A ONG obtém publicidade, escala e poder, mas abre mão de autonomia. As fundações não dão dinheiro simplesmente por dar. Elas doam e junto vêm amarras. Se a organização quer ser independente, ela termina sendo pequena e não terá muitos recursos.

De toda forma, a autonomia pode ser maior nas organizações que contam com uma grande base de filiados que contribuem mensal ou anualmente. Nos Estados Unidos, conforme levantado, boa parte das ONGs ambientalistas conta com milhares, e até milhões, de apoiadores. Isso permite que a organização, eventualmente, possa abrir mão de fontes de financiamento que demandem posicionamentos conflitantes com os princípios da ONG.

Mas foi possível constatar que a maior parte das grandes organizações, mesmo aquelas que têm ampla base de filiados, não abre mão de financiamentos de grandes fundações e empresas. Isso se dá, muitas vezes, pelo fato de essas ONGs utilizarem repertórios de parcerias com indústrias e governos, via de regra sem a presença do confronto, estratégia esta, vale notar, endossada por seus filiados.

Entrevistados de organizações percebidas como mais radicais, como Friends of the Earth, Greenpeace e CHEJ, revelaram preocupação com algumas parcerias de ONGs ambientalistas, que poderiam endossar indústrias e práticas prejudiciais ao meio ambiente. Segundo Benjamin Schreiber ${ }^{205}$, diretor do Programa de Clima e Energia da Friends of the Earth, organizações que se aliam com empresas também fazem um trabalho importante, mas algumas vezes as alianças são negativas:

Há sempre o perigo do greenwashing ${ }^{206}$, é um perigo real. Há também o risco de ficar parado observando e fazendo mudanças lentas, sem encarar os problemas com a seriedade necessária. Trabalhamos com várias dessas ONGs em muitas iniciativas. Elas mobilizam significante volume de recursos que nós, francamente, não temos.

\footnotetext{
${ }^{205}$ Entrevista concedida em 23 de dezembro de 2014.

${ }^{206}$ Greenwashing ocorre "quando um produto se diz sustentável, mas não é”. Fonte: http://super.abril.com.br/blogs/ideias-verdes/novas-normas-para-evitar-publicidade\%E2\%80\%9Cverde\%E2\%80\%9D-enganosa-comecam-a-valer-hoje/ Acesso em 6 de fevereiro de 2015
} 
Kyle $\mathrm{Ash}^{207}$, representante legislativo do Greenpeace-EUA, defendeu uma postura cautelosa nas parcerias com organizações:

É preciso pensar antes de colocar nossa marca. Na maioria das vezes em que participamos de projetos não colocamos nossa marca em nada. Fazemos muitas ações de bastidores porque sabemos que somos rotulados de radicais. Podemos trabalhar assim porque nosso dinheiro vem de doadores individuais. Isso nos permite fazer o que pensamos ser mais estratégico, e não aquilo que o doador quer. Várias ONGs fazem lobby porque têm o recurso para fazê-lo e não podem fazer outra coisa. É uma excelente flexibilidade que temos.

Lois Gibbs $^{208}$, diretora do CHEJ, que tem nos doadores individuais $50 \%$ de sua fonte de receita - o restante provém de fundações - também comentou a questão da flexibilidade de aplicação do orçamento:

Fundações vão dizer onde, geograficamente, você pode aplicar esse dinheiro ou o tema em que você pode aplicá-lo. Assim, às vezes você tem uma comunidade morrendo por conta de uma contaminação, mas não pode aplicar ali o dinheiro. Há fundações que não permitem colocar verba em protesto, por exemplo.

No caso brasileiro, como discutido em seção anterior deste capítulo, a falta de adesão da sociedade aos movimentos e, consequentemente, o predomínio de empresas e governos entre os doadores, impede que o movimento atue de forma mais incisiva influenciando políticas públicas. Ao contrário do que ocorre nos EUA, fundações e grandes doadores não apoiam ações de lobby, de modo que o movimento acaba focando sua atuação em projetos, atividade para a qual há maior disponibilidade de doadores.

Uma grande quantidade de representantes de ONGs com atuação no Brasil, entrevistados para esta pesquisa, destacaram que a questão do financiamento representa um grave gargalo para a atuação do movimento, especialmente na área de políticas públicas. A seguir, algumas falas sobre o assunto:

Nilo Dávila, coordenador de pesquisa do Greenpeace, entrevistado em 22 de maio de 2015:

As ONGs ambientalistas sofrem daquilo se costuma chamar de projetismo. Há uma dificuldade para se conseguir financiamento para

\footnotetext{
${ }^{207}$ Entrevista concedida em 3 de outubro de 2014.

${ }^{208}$ Entrevista concedida em 5 de fevereiro de 2015.
} 
políticas públicas. Grande parte do financiamento de um departamento de políticas públicas tem que ser para cobrir salários, e isso é um problema para arrecadar.

Claudio Maretti, ex-diretor de conservação do WWF-Brasil, entrevistado em 28 de abril de 2015: "O WWF-Brasil se tornou uma máquina de produzir projetos. Há um poder maior da estrutura do que da estratégia".

Sérgio Guimarães, coordenador do Instituto Centro de Vida (ICV), entrevistado em 27 de agosto de 2015:

A luta, mais do que nunca, é de David contra Golias. Temos uma dificuldade ligada ao nosso financiamento. O nível de investimento das organizações que atuam na Amazônia é muito menor que os investimentos do agronegócio, do petróleo, do desmatamento etc. Além do mais, não tem muito financiamento na área de articulação da sociedade civil e de influência nas políticas públicas. Há financiamento para projetos, mas quase nada para processos. Isso limita a eficácia do movimento nas políticas públicas. No Brasil não temos pessoa física apoiando, não há esta cultura na sociedade brasileira.

Márcio Santilli, sócio-fundador do Instituto Socioambiental, entrevistado em 16 de junho de 2015:

O mercado de projetos é desmobilizador, leva as organizações a uma lógica de atividades e resultados quantitativos. Como vou dizer em um projeto que vou derrubar uma PEC? Quando fundamos o ISA, tínhamos financiadores institucionais que apostavam no conjunto da obra. Hoje isso não existe mais. A base de financiamento das ONGs de primeiro mundo faz toda diferença. É um recurso solto. Estamos tentando fundar no ISA um setor de membresia. Mesmo com o recurso representando um percentual pequeno no todo, ele é mais flexível. Com esse recurso é possível investir em comunicação, política pública e novidades. Com a lógica de projetos é muito difícil encaixar uma campanha em uma oportunidade que surge. Até fazer o projeto, levar para o doador e argumentar, a oportunidade passou.

Mauro Armelin, ex-diretor de conservação do WWF-Brasil, entrevistado em 4 de setembro de 2015:

Nem mesmo as grandes ONGs conseguem fazer um monitoramento adequado de políticas públicas. Não há recursos. Isso demanda investimento alto e permanente, tem mais de 50 projetos de lei com 
alguma relação com o meio ambiente. Como acompanhar isso? O movimento ambiental não encontra mais financiamento como antes. As empresas conseguem porque se associam em torno de federações, confederações etc, como CNI e CNA. A sociedade brasileira não tem cultura de doação para essas organizações. Não recebemos o recurso livre.

Raul Valle, advogado ambiental, com 14 anos de atuação no ISA, entrevistado em 15 de janeiro de 2015:

No Brasil, as grandes ONGs são todas financiadas por projetos fora o Greenpeace, que acaba também dependendo de cidadãos de outros países. Muitas têm grana de cooperação, de empresas etc. $E$ esses meios de financiamento não gostam de lobby. O lobby benfeito é litigioso, você vai se posicionar contra alguém. Isso limita muito a atuação e acaba influindo na composição das equipes e nos trabalhos, fazendo com que as organizações prezem pouco em ter uma estrutura mais sistemática dentro do parlamento.

Outro aspecto que pode representar um obstáculo a mais ao trabalho do movimento ambientalista no Brasil é um distanciamento das instituições políticas em relação aos interesses coletivos. "O sistema político é incapaz de traduzir e implementar de maneira fiel os anseios da maioria da população" (Figueiredo e Limongi 2007, p.184). Isso ficou claro no episódio da reforma do Código Florestal quando pesquisa da Datafolha demonstrou que cerca de $80 \%$ da população brasileira era contrária às mudanças na legislação (Lopes 2011). Entretento, em caminho contrário, a esmagadora maioria dos deputados federais votou favoravelmente ao substitutivo.

Os numerosos problemas sociais brasileiros e a desigualdade (Reiter 2009, p.2) também contribuem para que os temas ambientais estejam mais distantes das prioridades da sociedade (Martinez 2014, pp.146-147). Isso dificulta o trabalho das ONGs ambientalistas no sentido de sensibilizar a opinião pública e, em última análise, os tomadores de decisão. Afinal, temas sociais acabam, não sem razão, ocupando espaço prioritário na agenda pública (Inglehart 1995, p.57). E a população acaba participando menos da vida política, por ter assuntos considerados mais urgentes com que se ocupar (Anastasia et al 2007, p.136).

Por fim, tanto no Brasil como nos Estados Unidos, as ONGs ambientalistas enfrentam o trabalho de fortes grupos que representam interesses de diferentes setores. Essas organizações trabalham com grandes volumes de recursos, e contam muitas vezes com boa estrutura, além de numerosas e qualificadas equipes. 
Nos EUA, já nos anos 1960, a indústria começou a mobilizar recursos para enfrentar os ambientalistas. Segundo Wills (2013), a Associação Nacional de Química Agrícola (NACA) "gastou US\$250 mil em panfletos, publicidade e relações públicas" para tentar deselegitimar o livro Primavera Silenciosa, de Rachel Carson (p.107).

Nos anos 1980 e 1990, conforme mencionado no Capítulo 3, surgiram diversos movimentos - ligados ao agronegócio e ao setor madeireiro, principalmente - para combater as pautas ambientalistas, que ganhava espaço na sociedade norte-americana. Segundo Brulle e Henkins (2010), esses grupos tiveram grande influência sobre as políticas adotadas pela administração do presidente George H. W. Bush (Bush pai, 1989-1992) para o meio ambiente (p.79).

Um caso emblemático em que a indústria se uniu para derrotar uma política ambientalista ocorreu em 1990, na Califórnia. A Proposição 128, submetida a referendo popular no estado, propunha a eliminação do uso, na agricultura, de pesticidas relacionados ao câncer, de clorofluorcarbonos pela indústria, além da proibição de extrair petróleo na costa californiana, dentre outras medidas em defesa do meio ambiente. As indústrias química, madeireira, da mineração, de transportes, associações de produtores rurais, a Câmara de Comércio e outros setores se uniram e investiram US\$ 17 milhões em uma campanha vitoriosa, e o público rejeitou a proposta (Libby 1998, pp.94-95).

Tive a oportunidade, durante esta pesquisa, de entrevistar representantes de três organizações que têm frequentes embates com o movimento: a Coalizão Americana pela Energia Limpa a Carvão (ACCCE) e a Associação Nacional da Mineração (NMA), nos EUA, e a Organização das Cooperativas Brasileiras (OCB). Todas elas dispõem de um bom orçamento para trabalhar com políticas públicas, equipes qualificadas e desenvolvem um trabalho de monitoramento permanente dos parlamentos, com profissionais permanentemente envolvidos em lobby direto.

No caso brasileiro, é possível dizer que nenhuma ONG ambientalista desenvolve, em termos de incidência e de quantidade de profissionais, trabalho similar ao que é feito pela OCB. No caso dos EUA, as ONGs ambientalistas conseguem se equiparar um pouco mais a essas organizações nas ações de lobby, embora as disparidades financeiras também sejam uma realidade.

Outra ação bastante sofisticada dessas instituições geralmente em conflito com os ambientalistas, tanto no Brasil quanto nos EUA, se dá no nível local. Esses grupos realizam lobby dirigido tanto a parlamentares de legislaturas estaduais, municipais ou dos condados (EUA), quanto com deputados federais e representatives em seus redutos eleitorais. 
Fabíola Nader Motta, gerente de relações institucionais da OCB, entrevistada para esta pesquisa ${ }^{209}$, informou que a organização tem representações em cada uma das unidades federativas brasileiras, que mantêm comunicação regular com os parlamentares de cada estado. No caso das ONGs ambientalistas brasileiras, o lobby regionalizado praticamente não ocorre.

Connor Gibson, pesquisador do Greenpeace-EUA, em entrevista para esta pesquisa $^{210}$, salientou que as organizações que representam os interesses da indústria dos combustíveis fósseis nos Estados Unidos têm orçamentos infinitamente superiores aos do movimento ambientalista. De acordo com os entrevistados, esses grupos conseguem, por meio de doações para campanhas, eleger representantes nos legislativos estaduais e até locais que, por sua vez, apresentam inúmeros projetos de lei de interesse da indústria, que talvez não fossem aprovados no nível federal. No sistema federalista norte-americano, que dá grande poder aos estados, os impactos dessa estratégia não podem ser subestimados.

Nos dois países, os desafios enfrentados pelo movimento ambientalista para influenciar as políticas públicas são consideráveis e de diversas naturezas. Alguns, como a necessidade de maior articulação por parte das organizações, podem ser mais facilmente equacionados. Outros, ligados ao financiamento, às prioridades coletivas e aos grupos opositores, são mais complexos, e em alguns casos, requerem uma maior capacidade de adaptação por parte das ONGs ambientalistas.

\footnotetext{
${ }^{209}$ Entrevista concedida em 26 de junho de 2015.

${ }^{210}$ Entrevista concedida em 30 de janeiro de 2015.
} 


\section{CONSIDERAÇÕES FINAIS: UM MOVIMENTO NECESSÁRIO}

O ambientalismo está entre os mais nobres e generosos movimentos socais. Ele se preocupa com as fundações biológicas da vida, trabalha para proteger as gerações presentes e futuras de danos ecológicos e da injustiça ambiental, e estende seu senso de preservação para o mundo não-humano.

Paul Wapner 2010, p. 35 Living Through the End of Nature: The Future of American

Environmentalism

É importante observar que, tanto no Brasil quanto nos Estados Unidos, o ambientalismo não pode ser visto como um movimento monolítico, dotado de um discurso único e de posicionamentos coordenados a respeito dos temas (Dalton 1994 p.246; Brulle 2009, pp.211-212; Stone 2010, p.143; Torsello 2012: p.183; Rothenberg 2010, p.118; Hoffman e Bertels 2010, p.51; Wapner 2010, pp.37-38). Há uma enorme quantidade de organizações, com diferentes estruturas de funcionamento, percepções da realidade, distintas abordagens e soluções para os problemas ambientais e variadas subáreas de atuação dentro do ambientalismo. Ainda assim, conforme já salientado em outras páginas deste trabalho, é possível dizer que as ONGs que lidam com questões ambientais fazem parte de algo que pode ser chamado de um movimento, mesmo que com algum grau de heterogeneidade.

Entendo que as inúmeras diferenças existentes dentro do movimento - tanto no Brasil como nos EUA - não podem ser confundidas com falta de unidade ou como sinal de fraqueza ou fragmentação. Defendo, inclusive, que essa diversidade, que chamo de "50 tons de verde", é a principal riqueza do movimento ambientalista no mundo. Ou seja, são inúmeras variedades de ambientalismo, e repertórios empregados de maneiras diferentes, com diferentes intensidades. E esse amplo espectro de ONGs ambientalistas deve ser visto como uma vantagem, na medida em que permite que a complexidade e a diversidade dos problemas ambientais sejam enfrentadas de forma multidisciplinar, com soluções amplas e multifacetadas.

Um movimento diversificado é capaz de atrair atenção e apoio de vários setores da sociedade. Cidadãos com visão de mundo mais progressista provavelmente vão se filiar a organizações mais voltadas para campanhas, denúncia e protestos. Fundações e pessoas sensíveis à vida selvagem vão apoiar projetos de ONGs ligadas à fauna e à flora. Empresários sensíveis à causa ambiental, certamente, tenderão a se alinhar com entidades mais moderadas, que buscam solucionar problemas ambientais a partir de uma transformação do setor produtivo.

Em resumo, a grande variedade de questões ambientais - lixo tóxico, poluição do ar e das águas, emissão de gases de efeito estufa por agricultura, indústria e transportes, 
desmatamento, extinção de espécies, economia verde etc - requer organizações com diferentes expertises, táticas, repertórios, abordagens, estruturas, recursos e abrangências territoriais. E isso só é viável dentro de um movimento amplo, diversificado e com reconhecimento público, como é possível observar nos dois países abordados neste estudo.

Para definir essa diversidade positiva e as vantagens de um movimento que ocupa um amplo espectro temático, ideológico e tático, transitando pelos 50 tons de verde, a metáfora da hidra - serpente da mitologia grega que tinha várias cabeças, usando-as simultaneamente contra seus inimigos —, usada por Snow (1992) e por Dalton (1994) parece ser adequada. Um conjunto de organizações que pode enfrentar grandes poluidores e governos ambientalmente irresponsáveis por meio de campanhas educativas, denúncias, protestos, ações na Justiça, lobby, petições, mobilização popular e de celebridades, parcerias corporativas, artigos científicos e inúmeras outras formas, frequentemente usadas ao mesmo tempo, é capaz de produzir notáveis transformações.

Brasil e Estados Unidos têm um avançado arcabouço de leis e regulamentos ambientais construídos, quase sempre, com apoio ou participação direta dos movimentos ambientalistas. As organizações participaram diretamente da elaboração e da aprovação da avalanche de leis ambientais aprovadas nos EUA nos anos 1960, 1970 e 1980, bem como das recentes políticas levadas adiante na administração Obama. O espaço alavancado pelo movimento no atual governo - apontado frequentemente por ambientalistas, pesquisadores e setores da imprensa como o mais sensível à questão ambiental da história dos EUA também merece destaque.

No Brasil, os ambientalistas influenciaram decisivamente a Constituição de 1988, e participaram da formulação e da aprovação de importantes peças de legislação aprovadas nas décadas seguintes, especialmente nos governos dos presidentes Fernando Henrique Cardoso e Luiz Inácio Lula da Silva, com contribuição direta para a redução dos índices de desmatamento na Amazônia. Nos dois países, as organizações têm conseguido, com diferentes graus de sucesso, bloquear retrocessos nas leis ambientais.

Os temas ambientais, em ambas sociedades, ocupam um lugar muito mais importante que há 10, 20 ou 30 anos na opinião pública, nos governos, na imprensa, no segmento industrial e no setor agrícola, para citar alguns. Os méritos para essa mudança de mentalidade, sem dúvida podem ser atribuídos, em grande medida, ao trabalho dos ambientalistas de sensibilizar a população, formadores de opinião e tomadores de decisão. A credibilidade técnica e científica alcançada pelos movimentos - especialmente pelas organizações mais estruturadas - é ponto crucial para isso. Já há algum tempo, no Brasil e 
nos EUA, ambientalistas são reconhecidos pela imprensa como referências para opinar sobre diversos assuntos que se relacionam ao meio ambiente.

Nos Estados Unidos o tema ambiental está presente e é discutido em campanhas eleitorais, tanto para o Executivo quanto para o Legislativo, algo que no Brasil, lamentavelmente, ainda não ocorre. Em nenhum momento, nos debates do segundo turno das eleições presidenciais de 2014 no Brasil, por exemplo, falou-se de meio ambiente. Mas os temas ambientais, diferentemente do que ocorria no passado, já fazem parte dos programas de governos dos principais candidatos ao Executivo Federal.

O alto grau de profissionalização alcançado pelas ONGs ambientalistas é um traço comum ao movimento nos dois países, determinante para o sucesso ao influenciar políticas públicas, o que comprova a validade da teoria da mobilização de recursos para esta pesquisa. Equipes multidisciplinares, altamente qualificadas, se fazem presentes nas principais organizações, tanto as nacionais como as com atuação internacional.

Setores administrativos e financeiros bem estruturados, que asseguram a correta aplicação de recursos e a transparência demandada ao Terceiro Setor em democracias modernas, são também uma realidade. Por fim, eficientes aparatos de captação são capazes de assegurar não só a sobrevivência, como também a consolidação e a ampliação do alcance das organizações.

Outro ponto em comum observado no ambientalismo brasileiro e norte-americano foi a capacidade de transformação do movimento (Radkau 2014, p.8). Inicialmente com preocupações essencialmente preservacionistas e com composição predominantemente elitista, o movimento ampliou seu raio de atuação e se diversificou. Várias organizações passaram a incluir em suas pautas temas como inclusão social, justiça ambiental, direitos de povos tradicionais, feminismo, imigração e refugiados.

Cabe aqui uma observação: o ambientalismo não se tornou um movimento de massas, e continua, predominantemente, composto e apoiado por homens e mulheres geralmente brancos e de classe média. Dois pontos chamaram atenção em relação a essa "demografia" das organizações. O primeiro dele é a forte presença feminina em posições de gerência, diretoria e presidência das ONGs estudadas.

O segundo aspecto é que, dentre os 45 representantes de ONGs entrevistados nos dois países, apenas um é negro (integrante da equipe do Sierra Club, organização cujo presidente é, também, um afrodescendente). Penso que este dado, que certamente diz algo a respeito da composição das organizações, mesmo que reflita um problema presente de forma geral nas duas sociedades estudadas, merece ser mencionado. Ainda assim, é importante salientar que as organizações estão diversificando seus perfis e seus campos de 
atuação, uma preocupação que foi demonstrada, inclusive por meio de exemplos concretos, em uma dezena de entrevistas com integrantes das ONGs pesquisadas.

Voltando aos repertórios analisados, notou-se no movimento ambientalista norteamericano uma elevada capacidade de influenciar políticas por meio de lobby, muito maior que a observada no Brasil. Isso se deve, em grande medida, à estrutura das organizações, que contam com equipes dedicadas exclusivamente à atividade. O lobby, por ser há muito regulamentado nos Estados Unidos, é desenvolvido há mais tempo, de maneira aberta, sendo plenamente aceito pela opinião pública como uma maneira legítima de diferentes grupos dentro da sociedade participarem da definição dos rumos políticos do país.

Por conta disso, torna-se, também, mais fácil encontrar financiadores para o lobby, algo que não ocorre no caso brasileiro. Adicionalmente, as grandes ONGs ambientalistas estudadas nos EUA, em sua maioria, contam com grande número de filiados, algo que aumenta a efetividade do lobby, conforme os próprios assessores de deputados e senadores entrevistados confirmaram. Ou seja, uma abordagem feita por uma organização a um tomador de decisão, no Executivo ou no Legislativo, mesmo que cientificamente embasada, tem maiores chances de ser bem-sucedida quando a ONG tem o apoio de um número relevante de cidadãos, seja via filiações, assinaturas em uma petição, telefonemas ou e-mails enviados ao político, ou pelo simples fato de a organização ter uma grande base de filiados e os tomadores de decisão saberem disso.

Nos EUA, as ONGs pesquisadas demonstraram impressionante competência nas práticas de lobby direto e indireto, mobilizando, além de informações científicas de qualidade, cidadãos e celebridades simpáticos às causas. Ao contrário do que observei no Brasil, o movimento norte-americano consegue, em termos de presença, incidência e recursos humanos, competir em pé de igualdade com o lobby dos chamados contramovimentos, que são as associações que representam indústria, agronegócio e outros segmentos normalmente em lado opostos ao dos ambientalistas nos debates políticos.

Uma causa fundamental para que a sociedade civil norte-americana, de maneira geral, consiga ser mais bem-sucedida que a brasileira no sentido de influenciar a Câmara dos Deputados (House of Representatives), é a transparência e a accountability proporcionadas pelo voto distrital e pelo voto facultativo. Os parlamentares respondem a um número menor de eleitores, que residem em um território limitado e que tendem a participar e a se preocupar mais com a política, já que ir às urnas não é uma obrigação legal. Como a taxa de comparecimento às eleições para o Legislativo gira em torno de $30 \%$ dos eleitores, de 
fato um grupo de cidadãos mais interessados em participar do processo acaba votando e, posteriormente, acompanhando o trabalho dos representantes.

Com o voto distrital e facultativo, as organizações da sociedade civil têm um universo menor, composto por cidadãos mais propensos à participação, para sensibilizar e mobilizar. No caso do parlamentar, uma comunicação vinda de um eleitor de seu distrito receberá enorme atenção tendo, portanto, mais chances de influenciar seu processo decisório. Os mandatos mais curtos - dois anos para deputados e seis para senadores - também aumentam o controle social do Parlamento, uma vez que a maior frequência das eleições faz com que o político tenda a ser mais sensível aos desejos dos eleitores. Afinal, especialmente para os deputados, a perspectiva da reeleição está sempre próxima. As entrevistas com os assessores de deputados federais (representatives) e com lobistas das ONGs deixaram claro o quadro descrito neste parágrafo.

O competente trabalho de monitoramento dos tomadores de decisão, feito por ONGs como LCV e Sierra Club, que acompanham as votações de todas as matérias relacionadas à questão ambiental no Congresso e nos parlamentos estaduais, também merece destaque. Essa fiscalização do Poder Legislativo pelo Terceiro Setor, por meio de relatórios publicados anualmente (scorecards), avaliando com notas de 0 a 100 o trabalho de cada parlamentar de acordo com os votos dados em projetos relacionados ao tema ambiental, amplia a transparência e a accountability dos mandatos, fazendo com que a população preste mais atenção e cobre mais de seus representantes.

O monitoramento do Legislativo cria condições para que outro importante repertório do movimento ambientalista norte-americano para influenciar políticas públicas se concretize: o apoio das ONGs, por meio de doações ou de endosso formal, a candidaturas alinhadas com a pauta ambiental, bem como a contraindicação de candidaturas contrárias aos interesses ambientalistas. Isso coloca, desde as eleições, a questão ambiental na agenda dos candidatos e dos eleitores, fazendo com que o tema ganhe força junto aos tomadores de decisão e à sociedade como um todo.

Outra fortaleza das ONGs norte-americanas, também proporcionada pela boa estrutura e pelo apoio da sociedade ao movimento, é observada na atuação regional. A maior parte das organizações estudadas nos EUA conta com escritórios ou capítulos em muitos estados, fazendo com que as ações no nível subnacional, fundamentais para a promoção da conservação e do desenvolvimento sustentável no mundo, possam ser também influenciadas com maior efetividade pelo movimento.

No Brasil, as ONGs demonstraram elevada capacidade em influenciar políticas públicas em determinadas instâncias. O maior destaque em termos de efetividade 
observado ao longo desta pesquisa fica por conta dos projetos de campo, algo feito em intensidade muito menor pelo movimento norte-americano.

Não faltam exemplos de projetos liderados pelas ONGs ambientalistas, em várias regiões brasileiras, que acabaram se tornando políticas públicas, tanto no âmbito municipal, quanto no estadual e no federal. O movimento conseguiu, tanto ocupando lacunas deixadas pelo Estado, como realizando parcerias com governos, ter protagonismo em políticas voltadas para criação e implementação de áreas protegidas, apoio a cadeias produtivas sustentáveis, recuperação de áreas degradadas, pagamento por serviços ambientais, fortalecimento e capacitação de gestores públicos e regularização fundiária.

Muitas organizações ambientalistas brasileiras também demonstram efetividade no fornecimento de dados e informações técnico-científicas que contribuem enormemente para promover a transparência nos números oficiais e subsidiar políticas públicas mais adequadas à realidade. Os números do desmatamento fornecidos pelo IMAZON (Sistema de Alerta de Desmatamento - SAD) e os dados das emissões de gases de efeito estufa (SEEG) levantados pelo Observatório do Clima - rede composta por 38 entidades da sociedade civil, entre elas a maioria das ONGs com atuação no Brasil aqui estudadas - são importantes contribuições do movimento ambientalista brasileiro para as políticas ambientais do país.

É necessário salientar que o movimento ambientalista brasileiro, embora surgido muito depois do norte-americano, rapidamente se fortaleceu e conquistou importante espaço na sociedade, sendo publicamente reconhecido como importante ator no cenário político nacional. As ONGs com atuação no Brasil souberam absorver o valioso know-how das organizações estrangeiras, que vieram para o país em maior número a partir da redemocratização, e construíram importantes parcerias com as organizações nacionais.

Adicionalmente, o ambientalismo brasileiro surgiu a partir de alianças com organizações de base comunitária, como associações de seringueiros, indígenas, quebradeiras de coco e extrativistas de maneira geral. Isso ajudou a forjar uma identidade própria para o ambientalismo brasileiro, ligada às comunidades tradicionais, fortalecendo a corrente socioambiental.

Essas alianças fizeram com que o movimento ambientalista brasileiro, embora predominantemente branco e de classe média, a exemplo do norte-americano, sempre tivesse conexões com movimentos populares - algumas organizações mais que outras, naturalmente. Trata-se de algo menos comum no ambientalismo dos EUA, que às vezes faz alianças pontuais com o movimento indígena, sindicatos e associações de latinos, afroamericanos e outros grupos étnicos, tendência que nos últimos anos começou a ganhar 
força, especialmente por conta de organizações como Greenpeace, Sierra Club, Friends of the Earth, CHEJ e ONGs de base local e comunitária.

Uma das importantes conclusões deste trabalho foi que a efetividade do movimento ambientalista está fortemente vinculada aos ocupantes de cargos públicos do Executivo, algo que reafirma a importância da teoria das oportunidades políticas para o tema desta pesquisa. No caso norte-americano, esta situação se manifesta quando a correlação de forças no Congresso se torna desfavorável aos ambientalistas. Em outras palavras, quando - Partido Republicano vira maioria no Parlamento. Essa correspondência partidária Democratas a favor de proteções ao meio ambiente e Republicanos, contra - passou a existir nos anos 1980, se fortalecendo nas décadas seguintes e atingindo seu auge nesta década.

Com o atual desenho do Congresso norte-americano - domínio Republicano em ambas as casas - as importantes políticas ambientais adotadas recentemente nos EUA, limitando emissões de poluentes pelo setor energético, só foram possíveis graças a uma enorme vontade política da Casa Branca. O presidente Obama - com justiça reconhecido como um aliado das causas ambientais -, além de levar adiante, em meio a uma forte oposição do Partido Republicano, novas políticas ambientais, vetou diversos retrocessos à legislação propostos pelo Congresso. Certamente, sem a presença de uma liderança como o atual presidente, os ambientalistas teriam amargado algumas derrotas impostas pelo Legislativo Federal.

No caso brasileiro, a correlação entre um Executivo Federal amigável às causas ambientais e o sucesso dos pleitos do movimento ambientalista é ainda mais nítida. Se nos EUA o Congresso alterna composições contrárias e favoráveis ao meio ambiente, no Brasil o Legislativo Federal é quase sempre hostil às políticas de defesa do meio ambiente e de promoção do desenvolvimento sustentável, conforme dito pela quase totalidade dos analistas, representantes de ONGs e tomadores de decisão entrevistados para esta pesquisa.

Assim, as esperanças dos ambientalistas, em termos de políticas federais, se concentram, principalmente, no Poder Executivo, notadamente na figura do(a) presidente da República e do(a) titular da pasta ambiental. Quando o Executivo abre pouco espaço às organizações da sociedade civil - como ocorre no momento atual, algo reportado por quase todos os representantes de ONGs entrevistados - a influência das organizações é muito diminuída, pois não se esperam avanços vindos do Congresso.

Tampouco faltam exemplos de políticas que tiveram participação direta do movimento ambientalista, seja na fase de formulação, de aprovação, de implementação e de 
monitoramento, ou em todas essas etapas, quando o Executivo Federal se abriu à influência das ONGs. Isso se deu, de forma mais acentuada - conforme comprovado em fontes bibliográficas, jornalísticas e nas entrevistas com representantes de ONGs e tomadores de decisão - no segundo mandato de Fernando Henrique Cardoso, especialmente quando Sarney Filho e José Carlos Carvalho foram ministros, e no primeiro mandato de Luiz Inácio Lula da Silva, quando Marina Silva esteve à frente do MMA.

$\mathrm{Na}$ escala estadual, a presença de governadores e secretários aliados do movimento também multiplica as chances de sucesso das iniciativas do movimento ambientalista no sentido de influenciar as políticas. O exemplo observado no Acre é emblemático. Seguidos governos abertos à sociedade civil - notadamente nas gestões Jorge Viana e Binho Marques, mas com considerável grau de continuidade nas gestões de Tião Viana proporcionaram a aprovação e a implementação de uma série de políticas de promoção do desenvolvimento sustentável, com participação direta das ONGs ambientalistas em todas as etapas dos processos decisórios.

Há, sem sombra de dúvidas, críticas pertinentes às políticas ambientais de todos esses líderes classificados, nesta tese, como verdadeiramente sensíveis às questões ambientais, como Barack Obama, Fernando Henrique Cardoso, Marina Silva e Jorge Viana. Não se trata, aqui, de um endosso incondicional à forma com que essas lideranças trataram do meio ambiente.

Porém, este trabalho não se propõe a analisar a qualidade das diversas gestões, e por isso não cabe aqui discutir eventuais críticas a esses mandatários, embora seja esta uma importante discussão para pesquisadores da área. De toda forma os fatos levam à constatação de que esses líderes se destacaram em relação aos demais quanto à atenção dada aos temas ambientais e, principalmente, pelo espaço que abriram à influência das ONGs ambientalistas nas políticas ambientais.

Uma das lacunas deste trabalho foi a impossibilidade de abordar a atuação dos numerosos movimentos de base comunitária, que trazem relevante contribuição para as políticas ambientais, especialmente nas esferas locais. Mesmo ciente dessa limitação, defini meu objeto de estudo como as grandes ONGs ambientalistas que atuam no Brasil e nos EUA, um universo já bastante amplo e de complexa análise.

$\mathrm{Na}$ entrevista com Benjamin Schreiber, lobista da ONG Friends of the Earth nos EUA, após resumir para ele o meu tema de estudo, ouvi do entrevistado que, ao limitar meu objeto de estudo às principais organizações, criaria um viés ("bias" foi a palavra por ele utilizada) na pesquisa. Pensei bastante naquela observação e não pude deixar de concordar com ele em alguns aspectos. Entretanto, devido à amplitude característica dos estudos comparados, 
mesmo sabedor de que parte do movimento ambientalista não seria contemplada, segui adiante com um recorte que inclui as organizações ambientalistas que maior influência exercem sobre as políticas ambientais no Brasil e nos Estados Unidos, exatamente aquelas mais estruturadas e profissionalizadas.

Com o andamento da pesquisa, procurei atenuar a ausência das ONGs locais de menor porte. Fiz algumas análises do trabalho de organizações de base, especialmente nos momentos em que fazem alianças com as organizações maiores. Adicionalmente, procurei ampliar o escopo das organizações pesquisadas, incluindo ONGs como CHEJ, 350.org, AMDA e ICV, que embora grandes e influentes, têm estruturas e orçamentos menores que as demais.

Para se fortalecer como importante ator nos processos políticos, o movimento precisa explorar dois de seus maiores trunfos: a diversidade das organizações que o compõem e sua indiscutível expertise técnica e científica. Ampliando as frentes de atuação, o leque de soluções e o espectro de seus interlocutores, as ONGs ambientalistas conseguirão, cada vez mais, ser reconhecidas como importantes integrantes das comunidades de políticas ambientais, às vezes recorrendo ao ativismo, às vezes à capacidade de negociação, às vezes caminhando entre essas duas vias, lastreadas pela credibilidade conferida pela ciência e, sempre que possível, pelas experiências de campo.

Cabe destacar que, nos dois países, o movimento ambientalista tem conseguido, ao influenciar diariamente processos políticos, ser um ator necessário para o fortalecimento da democracia e para a construção de modelos de desenvolvimento que levem em conta princípios de sustentabilidade. As organizações vêm desempenhando o papel de fiscalizar ações do Estado, contribuir para a promoção do desenvolvimento sustentável e assegurar o equilíbrio de forças dentro da sociedade, atenuando ou revertendo impactos negativos causados por atividades predatórias. Os desafios atuais e futuros são imensos. 


\section{REFERÊNCIAS}

ABERS, Rebecca e Marisa Von Bülow. "Movimentos sociais na teoria e na prática: como estudar o ativismo através da fronteira entre Estado e sociedade?" in Sociologias, Porto Alegre, ano 13, no. 28, set./dez. 2011 (pp.52-84).

AGUIAR, Roberto Armando Ramos de. Direito do Meio Ambiente e Participação Popular. Edições IBAMA, Brasília, 1998.

ALMEIDA, Maria Hermínia Tavares de. "O Estado no Brasil Contemporâneo. Um passeio pela história" in Carlos Ranulfo Melo e Manuel Alcántara Sáez (orgs.). A Democracia Brasileira. Balanço e perspectivas para o século 21. Editora UFMG, Belo Horizonte, 2007 (pp.17-37).

ALONSO, Angela, Valeriano Costa e Débora Maciel. "Identidade e Estratégia na Formação do Movimento Ambientalista Brasileiro" in Novos Estudos CEBRAP, no. 79. São Paulo, novembro de 2007 (pp.151-167).

"Repertório, segundo Charles Tilly: a evolução de um conceito" in Sociologia \& Antropologia. Vol. 2, número 3. Rio de Janeiro, 2012 (pp.21-41).

ANASTASIA, Fátima, Mônica Mata Machado de Castro e Felipe Nunes. "De lá para cá. As condições e as instituições da democracia depois de 1988" in Carlos Ranulfo Melo e Manuel Alcántara Sáez (orgs.). A Democracia Brasileira. Balanço e perspectivas para o século 21. Editora UFMG, Belo Horizonte, 2007 (pp.106-136).

ANDERSON, James E. Public Policymaking. Cengage Learning, Stamford, Connecticut, 2015.

ARNSBERGER, Paul, Melissa Ludlum, Margaret Riley e Mark Stanton. "A History of the taxexempt Sector: An SOI Perspective" in Statistics of Income Bulletin. Internal Revenue Service, Washington, D.C., inverno de 2008 (pp.105-135).

ARNT, Ricardo Azambuja e Stephan Schwartzman. Um Artifício Orgânico. Transição na Amazônia e Ambientalismo. Rocco, Rio de Janeiro, 1992.

AVRITZER, Leonardo. Democracy and the Public Space in Latin America. Princeton University Press, Princeton, 2002.

"Culture, Democracy and the Formation of the Public Space in Brazil" in Jessé Souza e Valter Souza (eds.). Imagining Brazil. Lexington Books, Lanham, Maryland, 2005 (pp.37-59).

BALESTRO, Moises Villamil, Eduardo Raupp de Vargas e Eliseu Vieira Machado Junior. Estratégias Comparativas em Estudos de Caso em Administração. Artigo apresentado no I Encontro de Ensino e Pesquisa em Administração e Contabilidade. Recife, 21 a 23 de novembro de 2007.

BANKS, Matthew. "World Wildlife Fund" in Thomas P. Lyon (ed.). Good Cop Bad Cop. Environmental NGOs and their Strategies toward business. RFF Press, Washington, D.C., 2010 (pp.171-183). 
BARAKSO, Maryann. "Brand identity and the tactical repertoires of advocacy organizations" in Aseem Prakash e Mary Kay Gugerty (Eds.) Advocacy Organizations and Collective Action. Cambridge University Press, Nova York, 2010 (pp.155-176).

BENDELL, Jem (Ed.). Terms for Endearment. Greenleaf Publishing, Sheffield, Reino Unido, 2000.

BENFORD, Robert D. e David A. Snow. "Framing Processes and Social Movements: An Overview and Assessment" in Annual Review of Sociology, no. 26. Annual Reviews, Palo Alto, Califórnia, 2000 (pp. 611-639).

BENJAMIN, Antônio Herman V. "Introdução ao direito ambiental brasileiro" in Revista de Direito Ambiental, vol.4, número 14, abr/jun 1999 (pp.48-82).

BERNARDES, Júlia Adão e Francisco Pontes de Miranda Ferreira. "Sociedade e Natureza" in Sandra Baptista da Cunha e Antonio José Teixeira Guerra (orgs.). A Questão Ambiental. Diferentes Abordagens. 3a. edição. Bertrand Brasil, Rio de Janeiro, 2007 (pp.17-42).

BEVINGTON, Douglas. The rebirth of environmentalism: grassroots activism from the spotted owl to the polar bear. Island Press, Washington, D.C., 2009.

BOEIRA, Sérgio Luís. Política e Gestão Ambiental no Brasil: da Rio-92 ao Estatuto da Cidade. Trabalho apresentado no II Encontro da ANPPAS - Associação Nacional de PósGraduação e Pesquisa em Ambiente e Sociedade, de 26 a 29 de maio de 2004, em Campinas (SP).

BOMBERG, Elizabeth e David Schlosberg. Environmentalism in the United States. Changing Conceptions of Activism. Routledge, Nova York, 2009.

BOSSO, Christopher. Environment, Inc. From Grassroots to Beltway. University Press of Kansas, Lawrence, Kansas, 2005.

BREUER, Lindsey. Conservation Directory 2015. The Guide to Worldwide Environmental Organizations. Carrel Books, Nova York, 2005.

BRIDGE, Gavin e Tom Perreault. "Environmental Governance" in Noel Castree, David Demeritt, Diana Liverman e Bruce Rhoads. A Companion to Environmental Geography. Wiley-Blackwell, Malden, Massachusetts, 2009 (pp. 475-497).

BROWN, Dee. Bury My Heart at Wounded Knee. An Indian History of the American West. 9a. edição. Holt, Reinhart and Winston, Nova York, 1971.

BROWN, J. Christopher. "Placing Local Environmental Protest within Global Environmental Networks. Colonist Farmers and Sustainable Development in the Brazilian Amazon" in Christof Mauch, Nathan Stolzfus e Douglas R. Weiner (orgs). Shades of Green.

Environmental Activism Around the Globe. Roman \& Littleffeld Publishers, Lanham, Maryland, 2006 (pp.197-218).

BRULLE, Robert. "The U.S. Environmental Movement" in Kenneth A. Gould e Tammy L. Lewis (ed.). Twenty Lessons in Environmental Sociology. Oxford University Press, Nova York, 2009 (pp.211-227).

e J. Craig Henkins. "Civil Society and the Environment: Understanding the Dynamics and Impacts of the U.S. Environmental Movement" in Thomas P. Lyon (ed.). Good 
Cop Bad Cop. Environmental NGOs and their Strategies toward business. RFF Press, Washington, D.C., 2010 (pp.73-102).

BURSZTYN, Maria Augusta e Marcel. Fundamentos de Política e Gestão Ambiental. Caminhos para a sustentabilidade. Garamond, Rio de Janeiro, 2013.

CÂMARA, João Batista Drummond. "Governança Ambiental no Brasil: Ecos do Passado" in Revista de Sociologia e Política vol.21, no. 46. Curitiba, junho de 2013 (pp.125-146).

CAMARgo, Aspásia, João Paulo Capobianco e José Antonio Puppim de Oliveira. Meio Ambiente Brasil. Avanços e obstáculos pós Rio-92. Estação Liberdade, São Paulo, 2002.

CAMPBELL, John. "Where Do We Stand? Common Mechanisms in Organizations and Social Movements Research" in G.F. Davis, D. Mc Adam, W.R. Scott e M.N. Zald (eds.). Social Movements and Organization Theory, Cambridge University Press, Cambridge, 2005 (pp. 41-68).

CARDOSO, Ruth C. L. "Movimentos sociais na América Latina" in Revista Brasileira de Ciências Sociais, no.3, vol I. Cortez, São Paulo, 1987 (pp.27-37).

CARSON, Rachel. Silent Spring. Edição do 40․ aniversário. Houghton Mifflin Harcourt, Boston, 2002.

CARVALHO, José Carlos. "A Vocação Democrática da Gestão Ambiental Brasileira e o Papel do Poder Executivo" in André Trigueiro (coord.). Meio Ambiente no Século 21. Sextante, Rio de Janeiro, 2003.

CARVALHO, José Murilo de. Cidadania no Brasil. O longo caminho. 11a. edição. Civilização Brasileira, Rio de Janeiro, 2008.

CASTRO JÚNIOR, Evaristo de, Bruno Henriques Coutinho e Leonardo Esteves de Freitas. "Gestão da Biodiversidade e Áreas Protegidas" in Antônio José Teixeira Guerra e Maria Célia Nunes Coelho. Unidades de Conservação. Abordagens e Características Geográficas. Bertrand Brasil, Rio de Janeiro, 2009 (pp.25-65).

CHARTIER, Denis et Véronique Van Tilbeurgh. "Réseaux d'acteurs et développements durable" in François-Michel Le Tourneau e Martine Droulers. L'Amazonie Brésilienne et le Développement Durable. Belin, Paris, 2010 (pp.367-394).

CHERMONT, Leane. "O papel do Ministério Público na defesa do meio ambiente" in Paul E. Little (org.) Políticas Ambientais no Brasil. Análises, instrumentos e experiências. Peirópolis, São Paulo, 2003 (pp.332-354).

CHILVERS, Jason. "Deliberative and Participatory Approaches in Environmental Geography" in Noel Castree, David Demeritt, Diana Liverman e Bruce Rhoads. A Companion to Environmental Geography. Wiley-Blackwell, Malden, Massachusetts, 2009 (pp. 400-417).

CHONG, Dennis e James N. Druckman. "A Theory of Framing and Opinion Formation in Competitive Elite Environments" in Journal of Communication, no. 57. International Communication Association, Atlanta, Georgia, 2007 (pp. 99-118).

COELHO, Simone de Castro Tavares. Terceiro Setor: um estudo comparado entre Brasil e Estados Unidos. Editora Senac, São Paulo, 2000. 
COGGINS, George Cameron. "Of Californicators, Quislings, and Crazies: Some Perils of Devolved Collaboration" in Philip Brick, Donald Snow e Sarah Van de Wetering (Eds.).

Across the Great Divide. Explorations in Collaborative Conservation and the American West. Island Press, Washington, D.C., 2001 (pp.163-171).

CORDEIRO, João. Accountability: a evolução da responsabilidade pessoal. Évora, São Paulo, 2013.

CROSSA, Marcelo e Antonio Oviedo. Manejo do Pirarucu: sustentabilidade nos lagos do Acre. WWF-Brasil, Brasília, 2011.

DAGNINO, Evelina (org.). Sociedade Civil e Espaços Públicos no Brasil. Paz e Terra, São Paulo, 2002 (pp. 279-302).

DALTON, Russell J. The Green Rainbow. Environmental Groups in Western Europe. Yale University Press, New Haven, MA, 1994.

DAVIES, Kert. "Greenpeace" in Thomas P. Lyon (ed.). Good Cop Bad Cop. Environmental NGOs and their Strategies toward business. RFF Press, Washington, D.C., 2010 (pp.195207).

DE ANTONI, Giorgio. "O Programa Piloto para Proteção das Florestas Tropicais do Brasil (PPG-7) e a globalização da Amazônia" in Ambiente \& Sociedade vol.XIII, no.2. Campinas, julho a dezembro de 2010 (pp.299-313).

DEL MAR, David Peterson. Environmentalism. Pearson, Harlow, Reino Unido, 2006.

DEVALL, Bill. "The End of American Environmentalism?" in Nature and Culture, Vol. 1, No. 2. Berghahn, Nova York, 2006 (pp. 157-180).

DOLHNIKOFF, Miriam. Perfis brasileiros: José Bonifácio. Companhia das Letras, São Paulo, 2012.

DOWIE, Mark. Losing Ground. American Environmentalism at the Close of the Twentieth Century. The MIT Press, Cambridge, Massachusetts, 1995.

DRUCKMAN, James N. "The implications of framing effects for citizen competence" in Political Behavior, Vol. 23, No. 3. Springer, Berlim, setembro de 2001 (pp.225-256).

DUARTE FILHO, Francisco Henrique e José Otávio Aguiar. "Baleias e ecologistas na Paraíba: uma história do fortalecimento do movimento ambientalista e o debate sobre a crise da economia baleeira (1970-1980)" in Revista Topoi, vol.15, no. 28. Programa de PósGraduação em História Social da UFRJ, Rio de Janeiro, janeiro a junho de 2014 (pp-116142).

ELKINGTON, John e Seb Beloe. "The Twentieth-Century NGO" in Thomas P. Lyon (ed.). Good Cop Bad Cop. Environmental NGOs and their Strategies toward business. RFF Press, Washington, D.C., 2010 (pp.17-47).

ENTMAN, Robert. "Framing: Toward clarification of a fractured paradigm" in Journal of Communication. Wiley, Hoboken, Nova Jersey, 1993 (pp.51-58). 
ENVIRONMENTAL PROTECTION AGENCY. "Milestones in Auto Emissions Control" in Factsheet OMS 5. Ann Arbor, Michigan, agosto de 1994.

FERREIRA, Leila da Costa. A Questão Ambiental: Sustentabilidade e políticas públicas no Brasil. Boitempo, São Paulo, 2012.

FIGUEIREDO, Angelina Cheibub e Fernando Limongi. "Instituições Políticas e Governabilidade. Desempenho do governo e apoio legislativo na democracia brasileira" in Carlos Ranulfo Melo e Manuel Alcántara Sáez (orgs.). A Democracia Brasileira. Balanço e perspectivas para o século 21. Editora UFMG, Belo Horizonte, 2007 (pp. 152-187).

FISHER, Dana R. "Civil society protest and participation: civic engagement within the multilateral governance regime" in Norichika Kanie e Peter M. Haas (orgs.), Emerging forces in Environmental Governance. United Nations University Press, Tóquio, 2004 (pp.176-203).

FISHER, Julie. The Road from Rio. Sustainable Development and the Nongovernmental Movement in the Third World. Praeger, West Port, Connecticut, 1993.

Non Governments: NGOs and the Political Development of the Third World. Kumarian, West Hartford, Connecticut, 1998.

FOREMAN, Dave. Confessions of an Eco-Warrrior. Crown Trade Paperbacks, Nova York, 1991.

FRANCO, José Luiz de Andrade e José Augusto Drummond. "O cuidado da natureza: a Fundação Brasileira para a Conservação da Natureza e a experiência conservacionista no Brasil: 1958-1992" in Textos de História, vol.17, no. 1. Brasília, 2009 (pp.59-84).

GARCIA, Yara Manfrin. "O Código Florestal Brasileiro e suas Alterações no Congresso Nacional" in Revista Geografia em Atos, no.12, vol.1. Departamento de Geografia da FCT/Unesp, Presidente Prudente (SP), janeiro a junho de 2012 (pp.54-74).

GARFIELD, Seth. In search of the Amazon. Brazil, the United States, and the Nature of a Region. Duke University Press, Durham, 2013.

GOFFMAN, Erving. Frame Analysis. An Essay on the Organization of an Experience. Harper \& Row, Nova York, 1974 (Reimpressão: Northeastern University Press, Boston, 1986).

GOHN, Maria da Glória. Teorias dos Movimentos Sociais. Paradigmas clássicos e contemporâneos. Edições Loyola. São Paulo, 2006, $5^{\text {a }}$. ed.

GÓIS, João Bosco Hora. "Policy analysis in non-governmental organisations and the implementation of pro-diversity policies" in Jeni Vaitsman, José Mendes Ribeiro e Lenaura Lobato (ed.). Policy Analysis in Brazil. Policy Press, Bristol, Reino Unido, 2013 (pp.205216).

GOLDSTEIN, Kenneth M. Interest Groups, Lobbying, and Participation in America. Cambridge University Press, Cambridge, Reino Unido, 1999.

GRUBB, Farley W. "Growth of Literacy in Colonial America: Longitudinal Patterns, Economic Models, and the Direction of Future Research" in Social Science History vol,14 no. 4.

Cambridge University Press, Cambridge, inverno de 1990 (pp.451-482). 
GUBER, Deborah Lynn. The Grassroots of a Green Revolution. Polling America on the Environment. MIT Press, Cambridge, MA, 2003.

GUIMARÃES, Erika e Maura Campanili. 25 anos de mobilização. Vol. 1. Fundação SOS Mata Atlântica, São Paulo, 2012

GUNTER JR, Michael M. Building the Next Ark. How NGOs work to protect biodiversity. Dartmouth College Press. Lebanon, New Hampshire, 2004.

HACKER, Jacob S. e Paul Pierson. Winner-Take-All Politics. How Washington Made the Rich Richer - And turned Its Back on the Middle Class. Simon \& Schuster, Nova York, 2010.

HADDEN, Jennifer. Networks in Contention: The Divisive Politics of Global Climate Change. Cambridge University Press, New York, 2015.

HANSEN, Paul Walden. Green in Gridlock. Common Goals, Common Ground, and Compromise. Texas A\&M University Press, College Station, Texas, 2013.

HARDIN, Garrett. "The Tragedy of the Commons" in Science vol. 162, no.3859. American Association for the Advancement of Science, Nova York, 1968 (pp.1243-1248).

HASKELL, John, Marian Currinder e Sara A. Grove. Congress in Context. Westview Press, Boulder, Colorado, 2014.

HAYWARD, Steven F. The Age of Reagan. The fall of the old liberal order: 1964-1980. Three Rivers Press, Nova York, 2001.

HELVARG, David. The War Against the Greens. The "Wise Use" Movement, the New Right, and Anti-Environmental Violence. Sierra Club Books, San Francisco, 1994.

HERCULANO, Selene. Políticas Ambientais. Editora da UFF, Niterói, RJ, 2013.

HOCHSTETLER, Kathryn e Margaret E. Keck. Greening Brazil. Environmental Activism in State and Society. Duke University Press, Durham e Londres, 2007.

HOFFMAN, Andrew J. e Stephanie Bertels. "Who is Part of the Environmental Movement?" in Thomas P. Lyon (ed.). Good Cop Bad Cop. Environmental NGOs and their Strategies toward business. RFF Press, Washington, D.C., 2010 (pp.48-69).

HOLSTON, James. Insurgent Citizenship. Disjunctions of Democracy and Modernity in Brazil. Princeton University Press, Princeton, Nova Jérsei, 2008.

HUMES, Edward. Force of Nature. The Unlikely Story of Walmart's Green Revolution. Harper-Collins, Nova York, 2011.

HUNTER, Robert. The Greenpeace to Amchitka. An environmental Odyssey. Arsenal Pulp Press, Vancouver, Canadá, 2004.

INÁCIO, Magna. "Estrutura e Funcionamento da Câmara dos Deputados" in Carlos Ranulfo Melo e Manuel Alcántara Sáez (orgs.). A Democracia Brasileira. Balanço e perspectivas para o século 21. Editora UFMG, Belo Horizonte, 2007 (pp.200-215). 
INGLEHART, Ronald. "Public Support for Environmental Protection: Objective Problems and Subjective Values in 43 Societies" in Political Sciences and Politics vol.28, no.1.

Cambridge, Reino Unido, março de 1995 (pp.57-72).

IPCC, Intergovernmental Panel on Climate Change. "Summary for policymakers" in Climate Change 2014: Impacts, Adaptation, and Vulnerability. UK / NY, 2014b. 34p.

JENKINS, J. Craig e Charles Perrow. "Insurgency of the Powerless: Farm Worker Movements (1946-1972)" in American Sociological Review, vol. 42, abril de 1977 (pp. 249268).

JOHNSON, Erica and Aseem Prakash. An NGO Research Program: A Collective Action Perspective in Thomas P. Lyon(ed.). Good Cop Bad Cop. Environmental NGOs and their Strategies toward business. RFF Press, Washington, D.C., 2010 (pp.239-266).

KASA, Sjur, Anne T. Gullberg e Gorild Heggelund. "The group of 77 in the international climate negotiations: recent developments and future directions" in International Environmental Agreements, vol.8. Springer, Berlim, 2008 (pp.113-127).

KLINE, Benjamin. First Along the River. A Brief History of the American Environmental Movement. Rowman and Littlefield, Lanham, Maryland, 2011. 4a. ed. (Edição do Kindle).

KRILL, Jennifer. "Rainforest Action Network" in Thomas P. Lyon (ed.). Good Cop Bad Cop. Environmental NGOs and their Strategies toward business. RFF Press, Washington, D.C., 2010 (pp.208-220).

KUBASEK, Nancy K. e Gary S. Silverman. Environmental Law. 5a. ed. Prentice Hall, Upper Saddle River, Nova Jersey, 2005.

LANG, Sabine. NGOs, Civil Society, and the Public Sphere. Cambridge University Press, Nova York, 2013.

LAZARUS, Richard J. The Making of Environmental Law. The University of Chicago Press, Chicago, 2004 (Edição do Kindle).

LEE, Martha F. Earth First! Environmental Apocalypse. Syracuse University Press, Syracuse, Nova York, 1995.

LEMOS, Leany Barreiro de Sousa. Controle Legislativo em Democracias Presidencialistas: Brasil e EUA em perspectiva comparada. 243 p. Tese de doutoramento (Instituto de Ciências Sociais/Centro de Estudos e Pós-Graduação sobre as Américas - CEPPAC) - Universidade de Brasília, Brasília, dezembro de 2005. [Orientadora: Profa. Dra. Maria das Graças Rua].

LE TOURNEAU, François-Michel et Martine Droulers. L'Amazonie Brésilienne et le Développement Durable. Belin, Paris, 2010.

LIBBY, Ronald T. Eco-Wars. Political Campaigns and Social Movements. Columbia University Press, Nova York, 1998.

LITTLE, Paul E. (org.) Políticas Ambientais no Brasil. Análises, instrumentos e experiências. Peirópolis, São Paulo, 2003. 
LOSEKANN, Cristiana. "Participação da Sociedade Civil na Política Ambiental do Governo Lula" in Ambiente e Sociedade, vol.XV, no.1. ANPPAS, São Paulo, janeiro a abril de 2012 (pp.179-200).

LOWI, Theodore J. "Distribution, Regulation, Redistribution: The Functions of Government" in Stella Z. Theodoulou e Matthew A. Cahn (org.). Public Policy: The Essential Readings. Prentice Hall, Upper Saddle River, Nova Jersey, 1995 (pp.15-25).

LYON, Thomas P. (ed.). Good Cop Bad Cop. Environmental NGOs and their Strategies toward business. RFF Press, Washington, D.C., 2010.

MACHADO, Paulo Affonso Leme. Direito Ambiental Brasileiro. Malheiros Editores, São Paulo, 2011.

MANCUSO, Wagner Pralon e Andréa Cristina Oliveira Gozetto. "Lobby: instrumento democrático de representação de interesses?" in Organicom, Volume 8, no.14. ECA-USP, São Paulo, 1o. semestre de 2011 (pp.118-128).

MARTINEZ, J. Michael. American Environmentalism. Philosophy, History, and Public Policy. CRC Press, Boca Raton, Flórida, 2014.

MAXWELL, John W. "An Economic Perspective on NGO Strategies and Objectives" in Thomas P. Lyon (ed.). Good Cop Bad Cop. Environmental NGOs and their Strategies toward business. RFF Press, Washington, D.C., 2010 (pp.136-163).

MC ADAM, Doug. Political Process and the Development of Black Insurgency, 19301970. $2^{\text {a }}$. edição. University of Chicago Press, Chicago, 1982.

Publishers, Boulder, CO, 2001

Sidney Tarrow, and Charles Tilly. Dynamics of Contention. Paradigm

MC CORMICK, John. "The Role of Environmental NGOs in International Regimes" in Norman J. Vig e Regina S. Axelrod, The Global Environment. Institutions, Law, and Policy. CQ Press, Washington, DC, 1999 (pp.52.71).

MC FARLAND, Andrew S. "Neopluralism" in Annual Review of Political Science. Annual Reviews, Palo Alto, Califórnia, 2007.

MC GANN, James e Mary Johnstone. "The Power Shift and the NGO Credibility Crisis" in The International Journal of Not-for-Profit Law, Volume 8, Edição 2. International Center for Not-for-Profit Law, Washington, DC, Janeiro de 2006.

MELO, Carlos Ranulfo. "Nem tanto ao Mar, nem tanto à Terra. Elementos para uma análise do sistema partidário brasileiro" in Carlos Ranulfo Melo e Manuel Alcántara Sáez (orgs.). A Democracia Brasileira. Balanço e perspectivas para o século 21. Editora UFMG, Belo Horizonte, 2007 (pp.267-292).

e Manuel Alcántara Sáez (orgs.). A Democracia Brasileira. Balanço e perspectivas para o século 21. Editora UFMG, Belo Horizonte, 2007.

MENEZES, Claudino Luiz. "Emergência e evolução da política ambiental urbana no Brasil: do Estado Novo à Nova República" in Revista de Administração Pública, vol. 31, no.1. Fundação Getúlio Vargas, Rio de Janeiro, 1997 (pp.70-95). 
MILLER, Char. Gifford Pinchot. The Evolution of an American Conservationist. Grey Towers Press, Milford, Pensilvânia, 1992.

MITTERMEIER, Russell, Patrícia Carvalho Baião, Lina Barrera, Theresa Buppert, Jennifer McCullough, Olivier Langrand, Frank Wugt Larson e Fabio Rubio Scarano. "O Protagonismo do Brasil no Histórico Acordo Global de Proteção à Biodiversidade" in Natureza \& Conservação 8(2). Rio de Janeiro, Dezembro de 2010 (pp.197-200).

, Gustavo A. B. da Fonseca, Anthony B. Rylands e Katrina

Brandon. "Uma breve história da conservação da biodiversidade no Brasil" in Megadiversidade vol.1, no.1. Conservação Internacional, Belo Horizonte, julho de 2005 (pp.14-21).

MONTEIRO, Carlos Augusto de Figueiredo. A Questão Ambiental no Brasil: 1960-1980. Universidade de São Paulo, São Paulo, 1981.

NELSON, Jane. "The Operation of Non-Governmental Organizations (NGOs) in a World of Corporate and Other Codes of Conduct" in Corporate Social Responsibility Initiative, Working Paper No. 34. John F. Kennedy School of Government, Harvard University, Cambridge, Massachusetts, 2007.

NEUZIL, Mark e William Kovarik. Mass Media \& Environmental Conflict. America's Green Crusades. Sage, Thousand Oaks, Califórnia, 1996.

NOGUEIRA-NETO, Paulo. Uma Trajetória Ambientalista. Diário de Paulo NogueiraNeto. Empresa das Artes, São Paulo, 2009.

O'CONNELL, Brian. Civil Society. The Underpinnings of American Democracy. University Press of New England, Hanover, New Hampshire, 1999.

OLIVEIRA, Ana Leonardo Nassar. Ação coletiva na redução de emissões de carbono por desmatamento e degradação: a atuação de organizações da sociedade civil brasileira entre 2005 e 2010. 195 p. Dissertação de mestrado (Instituto de Ciência Política - IPOL) - Universidade de Brasília, Brasília, 2012. [Orientadora: Profa. Dra. Marisa von Bülow].

OPP, Karl-Dieter. Theories of Political Protest and Social Movements. A Multidisciplinary Introduction, Critique, and Synthesis. Routledge, Nova York, 2009.

OSTROM, Elinor. Governing the Commons: The Evolution of Institutions for Collective Action. Cambridge University Press, Nova York, 1990.

PÁDUA, José Augusto (org.). Ecologia e Política no Brasil. 2a. edição. Espaço e Tempo, Rio de Janeiro, 1987.

PATRIOTA, Antonio de Aguiar. "An introduction to Brazilian environmental law" in The George Washington International Law Review vol. 40, no. 3. The George Washington University Law School, Washington, D.C., 2009 (pp.611-617).

PERITORE, N. Patrick. Third World Environmentalism. Case Studies from the Global South. University Press of Florida, Gainesville, Flórida, 1999.

PRAKASH, Aseem e Mary Kay Gugerty (Eds.) Advocacy Organizations and Collective Action. Cambridge University Press, Nova York, 2010. 
PUTNAM, Robert D. Bowling Alone. The Collapse and Revival of American Community. Simon \& Schuster; New York, 2000.

e Lewis M. Feldstein. Better Together. Restoring the American

Community. Simon \& Schuster, New York, 2003.

RADKAU, Joachim. The Age of Ecology. A Global History. Polity Press, Cambridge, Reino Unido, 2014.

REITER, Bernd. Negotiating Democracy in Brazil. The Politics of Exclusion. First Forum Press, Boulder, Colorado, 2009.

RENNÓ, Lucio R., Amy E. Smith, Matthew L. Layton e Frederico Batista Pereira. Legitimidade e Qualidade da Democracia no Brasil. Uma visão da cidadania. Intermeios, São Paulo, 2011.

ROTHENBERG, Lawrence S. "Environmental Groups: What Political Science Has to Offer" in Thomas P. Lyon (ed.). Good Cop Bad Cop. Environmental NGOs and their Strategies toward business. RFF Press, Washington, D.C., 2010 (pp.103-135).

ROUQUIÉ, Alain. Le Brésil au XXle siècle. Naissance d'un nouveau grand. Éditions Fayard, Paris, 2006.

RUTA, Gwen. "Environmental Defense Fund" in Thomas P. Lyon (ed.). Good Cop Bad Cop. Environmental NGOs and their Strategies toward business. RFF Press, Washington, D.C., 2010 (pp.184-194).

SABATIER, Paul A. (ed.), Theories of the Policy Process. Westview, Boulder, CO, 2007.

SANTILLI, Juliana. Socioambientalismo e Novos Direitos. Proteção jurídica à diversidade biológica e cultural. Peirópolis, São Paulo, 2005.

SCARCELLO, Miguel. "O Conselho Nacional do Meio Ambiente (CONAMA)" in Paul E. Little (org.) Políticas Ambientais no Brasil. Análises, instrumentos e experiências. Peirópolis, São Paulo, 2003 (pp.355-369).

SCHREURS, Miranda A. Environmental Politics in Japan, Germany and the United States. Cambridge University Press, Cambridge, Reino Unido, 2002.

SKOCPOL, Theda. "United States: From Membership to Advocacy" in Robert D. Putnam (Ed.). Democracies in Flux. The evolution of Social Capital in Contemporary Society. Oxford University Press. New York, 2002 (pp.103-136)

SILVA-SÁNCHEZ, Solange S. Cidadania Ambiental. Novos direitos no Brasil. 2a. edição. Annablume, São Paulo, 2010.

SIRIANNI, Carmen e Lewis Friedland. Civic Innovation in America. Community Empowerment, Public Policy, and the Movement for Civic Renewal. University of California Press, Berkeley, 2001.

SNOW, David A. "Framing Processes, Ideology, and Discoursive Fields" in David A. Snow, Sarah A. Soule e Hanspeter Kriesi (eds.). The Blackwell Companion to Social Movements Blackwell Publishing, Malden, Massachusetts, 2004. 
, E. Burke Rochford, Jr., Steven K. Worden, and Robert D. Benford. "Frame Alignment Processes, Micromobilization, and Movement Participation" in American Sociological Review, vol. 51, no. 4, agosto de 1986 (pp. 464-481).

SNOW, Donald. Inside the Environmental Movement. Meeting the Leadership Challenge. Island Press, Washington, D.C., 1992.

STEEN, Harold K. (ed.) Jack Ward Thomas. The journals of a Forest Service Chief. University of Washington Press, Seattle, 2004.

STINE, Jeffrey K. "Environmental Policy During the Carter Presidency" in Gary M. Fink e Hugh Davis Graham. Carter Presidency. Policy Choices in the Post-New Deal Era. University Press of Kansas, 1998 (pp.179-201).

STONE, Christopher D. Should Trees Have Standing? Law, morality and the environment. Oxford, New York, 2010.

THOMSON, Vivian E. Sophisticated Interdependence in Climate Policy. Federalism in the United States, Brazil, and Germany. Anthem Press, Nova York, 2014.

TILLY, Charles. Contentious Performances. Cambridge University Press, Nova York, 2008.

Colorado, 2007.

e Sidney Tarrow. Contentious Politics. Paradigm Publishers, Boulder,

TOCQUEVILLE, Alexis de. Democracia na América. Itatiaia, Belo Horizonte, 1998 (reedição traduzida da obra original de 1835).

TONI, Fabiano. "Novos Rumos e Possibilidades para os Estudos dos Movimentos Sociais" in BIB, São Paulo, no. 52, 2o. semestre de 2001 (pp.79-104).

. "Party Politics, Social Movement, and Local Democracy: Institutional Choices in the Brazilian Amazon" in Representation, Equity, and the Environment. Working Paper Series. No. 32. World Resources Institute, Washington, D.C., outubro de 2007.

Larissa C.L. Villarroel e Bruno Taitson Bueno. "State governments and forest policy: a new elite in the Brazilian Amazon?" in Benedicte Bull e Mariel Aguilar-Stoen. Environmental Policy in Latin America. Elite dynamics, the left tide and sustainable development. Routledge, Abingdon, Reino Unido, 2015 (pp.190-205).

TORSELLO, Davide. The New Environmentalism? Civil Society and Corruption in the Enlarged EU. Ashgate, Farnham, Reino Unido, 2012.

TUREK, Michael F. "Three Case Studies: The Arctic National Wildlife Refuge, Managing the Tongass National Forest, and Wolf Management" in Clive S. Thomas (ed). Alaska Public Policy Issues - Background and Perspectives. The Denali Press, Juneau, Alaska, 1999 (pp.195-204).

VAITSMAN, Jeni, Lenaura Lobato e Gabriela Andrade. "Professionalization of policy analysis in Brazil" in Jeni Vaitsman, José Mendes Ribeiro e Lenaura Lobato (ed.). Policy Analysis in Brazil. Policy Press, Bristol, Reino Unido, 2013. 
VIEIRA, Friederick Brum. "A Geopolítica Brasileira: um caso de "Destino Manifesto"? in Revista de Economia Política e História Econômica, número 06. GEEPHE, Maceió, dezembro de 2006 (pp.51-65).

VIG, Norman J. e Michael E. Kraft (Ed.). Environmental Policy. New Directions for the Twenty-First Century. 6a. ed. CQ Press, Washington, D.C., 2006.

VILLAS BÔAS, Orlando e Cláudio. A Marcha para o Oeste. A Epopeia da Expedição Roncador-Xingu. Companhia das Letras, São Paulo, 2012.

VIOLA, Eduardo J. "O movimento ecológico no Brasil (1974-1986): do ambientalismo à ecopolítica" in José Augusto Pádua (org.). Ecologia e Política no Brasil. 2a. edição. Espaço e Tempo, Rio de Janeiro, 1987 (pp.63-109).

WAPNER, Paul. Environmental Activism and World Civic Politics. State University of New York, Albany, NY, 1996.

Living Through the End of Nature. The future of American

environmentalism. The MIT Press, Cambridge, Massachusetts, 2010 (Edição do Kindle).

WELLOCK, Thomas R. Preserving the Nation. The Conservation and Environmental Movements. 1870-2000. Harlan Davidson, Wheeling, Illinois, 2007.

WILLS, John. US Environmental History. Inviting Doomsday. Edinburgh University Press, Edimburgo, Escócia, 2013.

WOLFE, Alan. Does American Democracy Still Work? Yale University Press, New Haven, Connecticut, 2006.

WOOD, Gordon. The idea of America. Reflections on the birth of the United States. Penguin, Nova York, 2012.

WUTHNOW, Robert. "The United States: Bridging the Privileged and the Marginalized" in Robert D. Putnam (Ed.). Democracies in Flux. The evolution of Social Capital in Contemporary Society. Oxford University Press. New York, 2002 (pp.59-102).

YAFFEE, Steven Lewis. The Wisdom of the Spotted Owl. Policy Lessons for a New Country. Island Press, Washington, D.C., 1994.

YAZIJI, Michael e Jonathan Doh. NGOs and Corporations. Conflict and Collaboration. Cambridge University Press, Nova York, 2009.

YOUNG, McGee. "The price of advocacy: mobilization and maintenance in advocacy organizations" in Aseem Prakash e Mary Kay Gugerty (Eds.) Advocacy Organizations and Collective Action. Cambridge University Press, Nova York, 2010 (pp.31-57).

ZELKO, Frank. "The Origins of Postwar Environmental Protest in the United States" in Christof Mauch, Nathan Stolzfus e Douglas R. Weiner (orgs). Shades of Green.

Environmental Activism Around the Globe. Roman \& Littleffeld Publishers, Lanham, Maryland, 2006 (pp.13-40). 


\section{REPORTAGENS E POSTAGENS EM BLOGS/PLATAFORMAS ONLINE}

AQUINO, Yara. ONG encaminha ao governo abaixo-assinado que pede veto total ao Código Florestal. Agência Brasil, 24 de maio de 2012. Disponível em

<http://memoria.ebc.com.br/agenciabrasil/noticia/2012-05-24/ong-encaminha-ao-governoabaixo-assinado-que-pede-veto-total-ao-codigo-florestal> Acesso em 6 de dezembro de 2015.

Greenpeace faz ato em frente ao Planalto em defesa do uso de energia solar. Agência Brasil, 23 de abril de 2015. Disponível em <http://agenciabrasil.ebc.com.br/geral/noticia/2015-04/greenpeace-faz-ato-em-frente-aoplanalto-por-incetivo-energia-solar> Acesso em 16 de dezembro de 2015.

Assessoria de Comunicação do Sistema CNA/Senar. Modernização do Código Florestal deve ser votada hoje. Site Canal do Produtor, 24 de maio de 2011. Disponível em <http://www.canaldoprodutor.com.br/comunicacao/noticias/modernizacao-do-codigoflorestal-deve-ser-votada-hoje> Acesso em 17 de julho de 2015.

BARRON-LOPEZ, Laura. Obama reverses Reagan, puts solar panels on White House roof. The Hill, 9 de maio de 2014. Disponível em <http://thehill.com/policy/energyenvironment/205683-solar-panels-return-to-white-house-roof-after-three-decades> Acesso em 16 de outubro de 2015.

BRAGANÇA, Daniele. O Eco mostra qual foi o presidente que criou mais Unidades de Conservação. O Eco, 2 de outubro de 2014. Disponível em <http://www.oeco.org.br/blogs/oeco-data/28692-o-eco-mostra-qual-foi-o-presidente-quecriou-mais-ucs/> Acesso em 8 de dezembro de 2015.

BRAIT, Ellene Adam Vaughan. Activists hang from bridge in Portland to block Shell's Arctic vessel. The Guardian, 29 de julho de 2015. Disponível em $<$ http://www.theguardian.com/environment/2015/jul/29/activists-hang-from-bridge-portlandblock-shells-arctic-oil-vessels> Acesso em 16 de dezembro de 2015.

COLMAN, Zack. States will challenge Obama's climate rules. Washington Examiner, 5 de janeiro de 2015 (p.8).

CORWIN, Miles. The Oil Spill Heard 'Round the Country. Los Angeles Times, 28 de janeiro de 1989. Disponível em <http://articles.latimes.com/1989-01-28/news/mn-1162_1_oil-spill> Acesso em 14 de outubro de 2015.

DALY, Matthews. EPA sets new ozone standards, disappointing all sides. Phys.org, 1 de outubro de 2015. Disponível em <http://phys.org/news/2015-10-epa-tightening-limits-smogcausing-ozone.html> Acesso em 14 de dezembro de 2015.

EILPERIN, Juliet. Obama moves to shield refuge. The Washington Post, 26 de janeiro de 2015 (pp. A1 e A14).

League of Conservation Voters Action Fund to endorse Clinton. The

Washington Post, 8 de novembro de 2015. Disponível em

https://www.washingtonpost.com/politics/league-of-conservation-voters-action-fund-toendorse-clinton/2015/11/08/4020cc9c-862d-11e5-be39-0034bb576eee_story.html> Acesso em 4 de fevereiro de 2016. 
FOLHA REDAÇÃO. Mau tempo esvazia caminhada pelo clima, no Rio. Folha Online, 21 de setembro de 2014. Disponível em <http://www1.folha.uol.com.br/ciencia/2014/09/1519622mau-tempo-esvazia-caminhada-pelo-clima-no-rio.shtml> Acesso em 5 de janeiro de 2016.

FUSER, Laura. Quem aprovou a destruição do Código Florestal. Site do Greenpeace Brasil, 25 de maio de 2011. Disponível em <http://www.greenpeace.org/brasil/pt/Blog/quemaprovou-a-destruio-do-cdigo-florestal/blog/34971/> Acesso em 17 de julho de 2015.

GLASER, April. You did it! Shell abandons Arctic drilling. Site do Greenpeace EUA, 28 de setembro de 2015. Disponível em < http://www.greenpeace.org/usa/shell-abandoning-arcticdrilling-thanks/> Acesso em 16 de dezembro de 2015.

GOLD, Matea. Koch-backed network aims to spend nearly 1 billion on 2016 elections. The Washington Post, 26 de janeiro de 2015. Disponível em <https://www.washingtonpost.com/politics/koch-backed-network-aims-to-spend-nearly-1billion-on-2016-elections/2015/01/26/77a44654-a513-11e4-a06b-9df2002b86a0_story.html> Acesso em 31 de dezembro de 2015.

GREENPEACE. Massacre da motosserra é consumado. Site do Greenpeace Brasil, 25 de maio de 2011. Disponível em <http://www.greenpeace.org/brasil/pt/Noticias/Massacre-damotosserra-e-consumado/> Acesso em 6 de dezembro de 2015.

GUILLÉN, Alex. Interior proposes boosting stream protections from coal mining Politico, 16 de julho de 2015. Disponível em <http://www.politico.com/story/2015/07/interior-proposes-boosting-stream-protections-fromcoal-mining-120232> Acesso em 19 de outubro de 2015.

JORNAL DA RECORD. Senador ligado a ruralistas é confirmado relator do novo Código Florestal. Portal R7, 2 de junho de 2011. Disponível em <http://noticias.r7.com/record-news/jornal-da-record-news/videos/senador-ligado-aruralistas-e-confirmado-relator-do-novo-codigo-florestal-20102015> Acesso em 6 de dezembro de 2015.

KILLIUS, Markus. Wie sich Deutschland gegen Atomkraft entschied. Focus Online, 9 de março de 2012. Disponível em <http://www.focus.de/panorama/welt/tsunami-injapan/atomkatastrophe-von-fukushima-wie-deutschland-sich-gegen-die-atomkraftentschied_aid_722373.html> Acesso em 16 de julho de 2015.

LATSON, Jennifer. The Burning River That Sparked a Revolution. Time Magazine, 22 de junho de 2015. Disponível em <http://time.com/3921976/cuyahoga-fire/> Acesso em 14 de agosto de 2015.

LEMONICK, Michael D. Will Bush go to Rio? Time Magazine, 30 de março de 1992. Disponível em <http://content.time.com/time/subscriber/article/0,33009,975198,00.html> Acesso em 22 de outubro de 2015.

LINDEN, Eugene. The Green Factor. Time Magazine, 12 de outubro de 1992. Disponível em <http://content.time.com/time/subscriber/article/0,33009,976710,00.html> Acesso em 22 de outubro de 2015.

LOPES, Reinaldo José. Datafolha indica que $80 \%$ rejeitam corte de proteção a matas. Folha de São Paulo, 13 de junho de 2011. Disponível em <http://www1.folha.uol.com.br/ambiente/929142-datafolha-indica-que-80-rejeitam-corte-deprotecao-a-matas.shtml> Acesso em 6 de janeiro de 2016. 
METCALFE, John. The 1969 Oil Spill That Launched the Modern Environmental Movement. The Atlantic Citylab, 29 de janeiro de 2014. Disponível em

<http://www.citylab.com/work/2014/01/1969-oil-spill-launched-modern-environmentalmovement/8233/> Acesso em 14 de outubro de 2015.

MOONEY, Chris. In a major setback for Arctic drilling, the Obama administration cancels two oil lease sales. The Washington Post, 16 de outubro de 2015. Disponível em $<$ https://www.washingtonpost.com/news/energy-environment/wp/2015/10/16/oil-drilling-inthe-arctic-just-received-another-major-setback/> Acesso em 16 de dezembro de 2015.

PEREIRA, Pablo. Ministra fraca leva Código a um desastre. O Estado de S. Paulo, 4 de março de 2012. Disponível em

<http://www.estadao.com.br/noticias/geral,ministra-fraca-leva-codigo-a-um-desastre-imp,843788> Acesso em 16 de outubro de 2015.

RESTUCCIA, Andrew. Murkowski: Thisi is 'War on Alaska'. Politico, 27 de janeiro de 2015.

2015. Disponível em White House climate strategy hits its stride. Politico, 22 de junho de

< http://www.politico.com/story/2015/06/white-house-climate-strategy-hits-its-stride-119310> Acesso em 26 de outubro de 2015.

SCHOR, Elana. House endorses oil exports amid echoes of Keystone fight. Politico, 9 de outubro de 2015. Disponível em

$<$ http://www.politico.com/story/2015/10/house-approves-oil-exports-keystone-

214612\#ixzz3p1SpsUT5> Acesso em 19 de outubro de 2015.

SHOGREN, Elizabeth. For 30 years, a political battle over oil and ANWR. NPR, 10 de novembro de 2005. Disponível em

<http://www.npr.org/templates/story/story.php?storyld=5007819> Acesso em 23 de outubro de 2015.

TAITSON, Bruno. Acre: Manejo de pesca conserva ecossistemas e aumenta renda de pescadores. Site do WWF-Brasil, 26 de agosto de 2009. Disponível em

<http://www.wwf.org.br/?21120/Acre-Manejo-de-pesca-conserva-ecossistemas-e-aumentarenda-de-pesca> Acesso em 15 de outubro de 2015.

Manejo de pesca alcança resultados e é ampliado no Acre. Site do WWF-Brasil, 24 de agosto de 2010. Disponível em $<$ http://www.wwf.org.br/wwf_brasil/?25800/Manejo-de-pesca-alcana-resultados-e--ampliadono-Acre> Acesso em 15 de outubro de 2015.

Movimento social fecha Ministério do Meio Ambiente. Site do WWF-

Brasil, 15 de dezembro de 2011. Disponível em

<http://www.wwf.org.br/wwf_brasil/?30302/Movimento-social-fecha-Ministrio-do-Meio-

Ambiente> Acesso em 16 de julho de 2015.

Povo nas ruas diz não às mudanças no Código Florestal. Site do WWF-

Brasil, 29 de novembro de 2011. Disponível em

<http://www.wwf.org.br/informacoes/noticias_meio_ambiente_e_natureza/?30242> Acesso em 6 de dezembro de 2015.

TERRA. Saiba como doar parte de seu imposto de renda a ONGs. Portal Terra, 
25 de julho de 2013. Disponível em <http://economia.terra.com.br/operacoes-cambiais/pessoafisica/saiba-como-doar-parte-de-seu-imposto-de-renda-aongs,cc425ecf88210410VgnVCM5000009ccceb0aRCRD.html> Acesso em 30 de dezembro de 2015.

UOL. O que se sabe sobre o rompimento da barrage em Mariana. Portal Uol, 11 de dezembro de 2015. Disponível em <http://noticias.uol.com.br/cotidiano/ultimas-noticias/2015/11/06/o-quese-sabe-sobre-o-rompimento-das-barragens-em-mariana-mg.htm> Acesso em 2 de fevereiro de 2016.

VISSER, Nick. Hundreds Of Thousands Turn Out For People's Climate March in New York City. Huffington Post, 21 de setembro de 2014. Disponível em <http://www.huffingtonpost.com/2014/09/21/peoples-climate-march_n_5857902.html> Acesso em 5 de janeiro de 2016.

WALKER, Derek e Steve Schwartzman. Does the future of the Amazon rainforest lie in California? EDF Talks Global Climate, 30 de janeiro de 2014. Disponível em $<$ http://blogs.edf.org/climatetalks/2014/01/30/does-the-future-of-the-amazon-rainforest-lie-incalifornia/?_ga=1.28523195.629563914.1439321882> Acesso em 13 de outubro de 2015.

WALSH, Bryan, Is the oil spill good for environmentalism? Time Magazine, 22 de junho de 2010. Disponível em

<http://search.time.com/results.html? $\mathrm{Ntt=ls+the+oil+spill+good+for+environmentalism \% 3F>}$ Acesso em 14 de agosto de 2015.

Battle Brews over EPA's Emission Regulations. Time Magazine, 3 de janeiro de 2010. Disponível em <http://content.time.com/time/health/article/0,8599,2040485,00.html> Acesso em 25 de outubro de 2015. 
ANEXO I - LISTA DE ENTREVISTAS

REPRESENTANTES DE ONGS - ESTADOS UNIDOS

\begin{tabular}{|c|c|c|c|c|}
\hline DATA & $\begin{array}{l}\text { ENTREVISTADO } \\
\text { (A) }\end{array}$ & DESCRIÇÃO & $\begin{array}{l}\text { LOCAL DA } \\
\text { ENTREVISTA }\end{array}$ & DURAÇÃO \\
\hline 27.MAI.2014 & Jessica McGlyn & $\begin{array}{l}\text { Ex-lobista do WWF- } \\
\text { EUA (2006-2010) e } \\
\text { diretora do World } \\
\text { Business Council for } \\
\text { Sustainable } \\
\text { Development }\end{array}$ & $\begin{array}{l}\text { Sede do World } \\
\text { Business Council } \\
\text { for Sustainable } \\
\text { Development, em } \\
\text { Washington, D.C. }\end{array}$ & $\begin{array}{l}34^{\prime} 16 " \\
\text { (entrevista } \\
\text { gravada) }\end{array}$ \\
\hline 11.JUN.2014 & Vanessa Dick & $\begin{array}{l}\text { Analista de políticas } \\
\text { sênior no WWF-EUA }\end{array}$ & $\begin{array}{l}\text { Illy Cafe no Hotel } \\
\text { Renaissance, em } \\
\text { Washington, D.C. }\end{array}$ & $\begin{array}{l}30 ' 18 " \\
\text { (entrevista } \\
\text { gravada) }\end{array}$ \\
\hline 20.JUN.2014 & Peter Kirby & $\begin{array}{l}\text { Advogado } \\
\text { ambiental, com } \\
\text { passagens pela } \\
\text { National Wildlife } \\
\text { Federation (1977- } \\
\text { 1980), The } \\
\text { Wilderness Society } \\
\text { (1980-2003) e } \\
\text { Earthjustice (2003- } \\
\text { 2004). }\end{array}$ & $\begin{array}{l}\text { Entrevista por } \\
\text { Skype }\end{array}$ & $\begin{array}{l}4536 " \\
\text { (entrevista } \\
\text { gravada) }\end{array}$ \\
\hline 04.SET.2014 & Randall Snodgrass & $\begin{array}{l}\text { Diretor de } \\
\text { cooperação com o } \\
\text { governo americano } \\
\text { no World Resources } \\
\text { Institute (WRI, desde } \\
2007) \text {, ex-diretor da } \\
\text { The Wilderness } \\
\text { Society, ex-diretor } \\
\text { de políticas para a } \\
\text { vida selvagem na } \\
\text { National Audubon } \\
\text { Society (1990-1995) } \\
\text { e ex-diretor de } \\
\text { relações } \\
\text { governamentais no } \\
\text { WWF-EUA (1996- } \\
\text { 2007) }\end{array}$ & $\begin{array}{l}\text { Sede da World } \\
\text { Resources Institute } \\
\text { (WRI), em } \\
\text { Washington, D.C. }\end{array}$ & $\begin{array}{l}69 \text { '09" } \\
\text { (entrevista } \\
\text { gravada) }\end{array}$ \\
\hline 25.SET.2014 & Bill Millan & $\begin{array}{l}\text { Conselheiro sênior } \\
\text { de política na The } \\
\text { Nature Conservancy } \\
\text { (TNC) entre julho de } \\
1996 \text { e maio de } \\
2015\end{array}$ & $\begin{array}{l}\text { Cosi Café, em } \\
\text { Arlington, Virgínia. }\end{array}$ & $\begin{array}{l}38^{\prime} 06 " \\
\text { (entrevista } \\
\text { gravada) }\end{array}$ \\
\hline 03.OUT.2014 & Kyle Ash & $\begin{array}{l}\text { Representante } \\
\text { legislativo sênior do } \\
\text { Greenpeace-EUA } \\
\text { desde setembro de } \\
2009 .\end{array}$ & $\begin{array}{l}\text { Sede do } \\
\text { Greenpeace em } \\
\text { Washington, D.C. }\end{array}$ & $\begin{array}{l}52 ' 50 " \\
\text { (entrevista } \\
\text { gravada) }\end{array}$ \\
\hline
\end{tabular}




\begin{tabular}{|c|c|c|c|c|}
\hline 19.NOV.2014 & Sara Thomas & $\begin{array}{l}\text { Estrategista sênior } \\
\text { para advocacy } \\
\text { digital no WWF-EUA } \\
\text { desde outubro de } \\
\text { 2013. Ex-gerente de } \\
\text { marketing digital da } \\
\text { Ocean Conservancy } \\
\text { (2007-13). }\end{array}$ & $\begin{array}{l}\text { Sede do WWF- } \\
\text { EUA em } \\
\text { Washington, D.C. }\end{array}$ & $\begin{array}{l}37 ’ 55^{\prime \prime} \\
\text { (entrevista } \\
\text { gravada) }\end{array}$ \\
\hline 09.DEZ.2014 & Sara Chieffo & $\begin{array}{l}\text { Diretora legislativa } \\
\text { da League of } \\
\text { Conservation Voters } \\
\text { (LCV) desde } 2009 \text { e } \\
\text { ex-associada de } \\
\text { relações } \\
\text { governamentais na } \\
\text { Defenders of Wildlife } \\
\text { (2007-2009). }\end{array}$ & $\begin{array}{l}\text { Sede da League of } \\
\text { Conservation } \\
\text { Voters (LCV), em } \\
\text { Washington, D.C. }\end{array}$ & $\begin{array}{l}58^{\prime} 21 " \\
\text { (entrevista } \\
\text { gravada) }\end{array}$ \\
\hline 17.DEZ.2014 & Christopher Conner & $\begin{array}{l}\text { Especialista em } \\
\text { assuntos de mídia e } \\
\text { comunicação no } \\
\text { WWF-EUA, desde } \\
2011 \text { e ex-diretor de } \\
\text { comunicação do } \\
\text { Chesapeake Bay } \\
\text { Program (Maryland, } \\
\text { EUA, 2000-2006). }\end{array}$ & $\begin{array}{l}\text { Sede do WWF- } \\
\text { EUA em } \\
\text { Washington, D.C. }\end{array}$ & $\begin{array}{l}39^{\prime} 56 " \\
\text { (entrevista } \\
\text { gravada) }\end{array}$ \\
\hline 22.DEZ.2014 & Scott Slesinger & $\begin{array}{l}\text { Diretor legislativo no } \\
\text { Natural resources } \\
\text { Defense Council } \\
\text { (NRDC) desde 2009, } \\
\text { ex-diretor de } \\
\text { assuntos } \\
\text { governamentais no } \\
\text { Environmental } \\
\text { Technology Council } \\
\text { (1998-2009) e ex- } \\
\text { assessor legislativo } \\
\text { do senador Frank } \\
\text { Lautenberg } \\
\text { (Democrata, Nova } \\
\text { Jersey, 1995-1998) }\end{array}$ & $\begin{array}{l}\text { Sede do Natural } \\
\text { Resources } \\
\text { Defense Council } \\
\text { (NRDC), em } \\
\text { Washington, D.C. }\end{array}$ & $\begin{array}{l}46 ' 12 " \\
\text { (entrevista } \\
\text { gravada) }\end{array}$ \\
\hline 23.DEZ.2014 & Benjamin Schreiber & $\begin{array}{l}\text { Diretor do programa } \\
\text { de Clima e Energia } \\
\text { na Friends of the } \\
\text { Earth - EUA desde } \\
2009 \text { e ex-advogado } \\
\text { na Environment } \\
\text { America (2007-- } \\
\text { 2009) }\end{array}$ & $\begin{array}{l}\text { Sede da Friends of } \\
\text { the Earth em } \\
\text { Washington, D.C. }\end{array}$ & $\begin{array}{l}53 \text { '52" } \\
\text { (entrevista } \\
\text { gravada) }\end{array}$ \\
\hline 09.JAN.2015 & Mary Beth Beetham & $\begin{array}{l}\text { Diretora de assuntos } \\
\text { legislativos na } \\
\text { Defenders of Wildlife }\end{array}$ & $\begin{array}{l}\text { Sede da Defenders } \\
\text { of Wildlife, em } \\
\text { Washington, D.C. }\end{array}$ & $\begin{array}{l}53^{\prime} 07^{\prime \prime} \\
\text { (entrevista } \\
\text { gravada) }\end{array}$ \\
\hline 09.JAN.2015 & Nancy Gloman & $\begin{array}{l}\text { Vice-presidente de } \\
\text { campo e }\end{array}$ & $\begin{array}{l}\text { Sede da Defenders } \\
\text { of Wildlife, em }\end{array}$ & $\begin{array}{l}533^{\prime} 07 " \\
\text { (entrevista }\end{array}$ \\
\hline
\end{tabular}




\begin{tabular}{|c|c|c|c|c|}
\hline & & $\begin{array}{l}\text { conservação na } \\
\text { Defenders of Wildlife }\end{array}$ & Washington, D.C. & gravada) \\
\hline 09.JAN.2015 & Michael Senatore & $\begin{array}{l}\text { Vice-presidente de } \\
\text { direito para a } \\
\text { conservação na } \\
\text { Defenders of Wildlife }\end{array}$ & $\begin{array}{l}\text { Sede da Defenders } \\
\text { of Wildlife, em } \\
\text { Washington, D.C. }\end{array}$ & $\begin{array}{l}533^{\prime} 07 \\
\text { (entrevista } \\
\text { gravada) }\end{array}$ \\
\hline 13.JAN.2015 & Chase Huntley & $\begin{array}{l}\text { Diretor sênior de } \\
\text { relações } \\
\text { governamentais na } \\
\text { The Wilderness } \\
\text { Society (TWS) }\end{array}$ & $\begin{array}{l}\text { Sede da The } \\
\text { Wilderness Society } \\
\text { (TWS) }\end{array}$ & $\begin{array}{l}51^{\prime} 53 " \\
\text { (entrevista } \\
\text { gravada) }\end{array}$ \\
\hline 15.JAN.2015 & Wesley Warren & $\begin{array}{l}\text { Diretor de política e } \\
\text { advocacy no Natural } \\
\text { Resources Defense } \\
\text { Council (NRDC) } \\
\text { desde } 2001 . \\
\text { Trabalhou por sete } \\
\text { anos na Casa } \\
\text { Branca (governo } \\
\text { Clinton) como diretor } \\
\text { de recursos naturais } \\
\text { e chefe de equipe no } \\
\text { Council of } \\
\text { Environmental } \\
\text { Quality. Trabalhou } \\
\text { por seis anos na } \\
\text { House of } \\
\text { Representatives nos } \\
\text { comitês de Ciência, } \\
\text { Espaço \& } \\
\text { Tecnologia e } \\
\text { Energia \& Comércio. }\end{array}$ & $\begin{array}{l}\text { Sede do Natural } \\
\text { Resources } \\
\text { Defense Council } \\
\text { (NRDC), em } \\
\text { Washington, D.C }\end{array}$ & $\begin{array}{l}54^{\prime} 56 " \\
\text { (entrevista } \\
\text { gravada) }\end{array}$ \\
\hline 15.JAN.2015 & Andrew Linhardt & $\begin{array}{l}\text { Representante } \\
\text { associado (lobista) } \\
\text { do Sierra Club em } \\
\text { Washington, D.C. }\end{array}$ & $\begin{array}{l}\text { Sede do Sierra } \\
\text { Club em } \\
\text { Washington, D.C. }\end{array}$ & $\begin{array}{l}\text { 45'33" } \\
\text { (entrevista } \\
\text { gravada) }\end{array}$ \\
\hline 21.JAN.2015 & $\begin{array}{l}\text { Steve } \\
\text { Schwartzman }\end{array}$ & $\begin{array}{l}\text { Diretor de política } \\
\text { florestal no } \\
\text { Environmental } \\
\text { Defense Fund (EDF) }\end{array}$ & $\begin{array}{l}\text { Sede do EDF em } \\
\text { Washington, D.C. }\end{array}$ & $\begin{array}{l}\text { 55'27" } \\
\text { (entrevista } \\
\text { gravada) }\end{array}$ \\
\hline 22.JAN.2015 & Josh Saks & $\begin{array}{l}\text { Diretor legislativo da } \\
\text { National Wildlife } \\
\text { Federation (NWF). }\end{array}$ & $\begin{array}{l}\text { Café Starbucks da } \\
\text { esquina de } 22 \text { nd e } \\
\text { K Street, em } \\
\text { Washington, D.C. }\end{array}$ & $\begin{array}{l}58 \text { '59" } \\
\text { (entrevista } \\
\text { gravada) }\end{array}$ \\
\hline 27.JAN.2015 & Seth Johnson & $\begin{array}{l}\text { Advogado Sênior na } \\
\text { EarthJustice. }\end{array}$ & $\begin{array}{l}\text { Café Starbucks da } \\
\text { Avenida } \\
\text { Connecticut, em } \\
\text { Washington, D.C }\end{array}$ & $\begin{array}{l}588^{\prime} 03^{\prime \prime} \\
\text { (entrevista } \\
\text { gravada) }\end{array}$ \\
\hline 29.JAN.2015 & Brian Willis & $\begin{array}{l}\text { Secretário de } \\
\text { imprensa para } \\
\text { assuntos federais do } \\
\text { Sierra Club. }\end{array}$ & $\begin{array}{l}\text { Sede da Agência } \\
\text { Ambiental Norte- } \\
\text { Americana (EPA), } \\
\text { durante audiência } \\
\text { pública sobre } \\
\text { limites de }\end{array}$ & $\begin{array}{l}\text { 15’37" } \\
\text { (entrevista } \\
\text { gravada) }\end{array}$ \\
\hline
\end{tabular}




\begin{tabular}{|c|c|c|c|c|}
\hline & & & $\begin{array}{l}\text { emissões de } \\
\text { ozônio }\end{array}$ & \\
\hline 30.JAN.2015 & Connor Gibson & $\begin{array}{l}\text { Pesquisador do } \\
\text { Greenpeace, com } \\
\text { foco nas indústrias } \\
\text { poluentes e suas } \\
\text { ações de } \\
\text { comunicação e } \\
\text { lobby. }\end{array}$ & $\begin{array}{l}\text { Entrevista por } \\
\text { telefone }\end{array}$ & $\begin{array}{l}\text { Aprox. } 20 \\
\text { min }\end{array}$ \\
\hline 04.FEV.2015 & Laura Sheenan & $\begin{array}{l}\text { Diretora de } \\
\text { comunicação da } \\
\text { American Coalition } \\
\text { for Clean Coal } \\
\text { Energy }\end{array}$ & Sede da ACCCE & $\begin{array}{l}366^{\prime} 57^{\prime \prime} \\
\text { (entrevista } \\
\text { gravada) }\end{array}$ \\
\hline 05.FEV.2015 & Lois Gibbs & $\begin{array}{l}\text { Diretora do Centro } \\
\text { para Saúde, Meio } \\
\text { Ambiente e Justiça } \\
\text { (CHEJ), liderou a } \\
\text { famosa mobilização } \\
\text { que realocou mais } \\
\text { de } 800 \text { residências } \\
\text { em virtude de } \\
\text { contaminação por } \\
\text { tóxicos no Love } \\
\text { Canal, em Nova } \\
\text { York, em } 1978 .\end{array}$ & $\begin{array}{l}\text { Sede do CHEJ, em } \\
\text { Falls Church, } \\
\text { Virgínia }\end{array}$ & $\begin{array}{l}\text { 63'19" } \\
\text { (entrevista } \\
\text { gravada) }\end{array}$ \\
\hline 06.FEV.2015 & Kate Addleson & $\begin{array}{l}\text { Diretora de } \\
\text { conservação do } \\
\text { capítulo do estado } \\
\text { da Virgínia do do } \\
\text { Sierra Club }\end{array}$ & $\begin{array}{l}\text { Sede do capítulo } \\
\text { do Sierra Club na } \\
\text { cidade de } \\
\text { Richmond, capital } \\
\text { do estado da } \\
\text { Virgínia. }\end{array}$ & $\begin{array}{l}47 \text { '38" } \\
\text { (entrevista } \\
\text { gravada) }\end{array}$ \\
\hline 24.FEV.2015 & Luke Popovich & $\begin{array}{l}\text { Vice-presidente de } \\
\text { Comunicação da } \\
\text { National Mining } \\
\text { Association }\end{array}$ & $\begin{array}{l}\text { Sede da NMA, em } \\
\text { Washington, D.C. }\end{array}$ & $\begin{array}{l}53 \text { '32" } \\
\text { (entrevista } \\
\text { gravada) }\end{array}$ \\
\hline 25.FEV.2015 & Bill McKibben & $\begin{array}{l}\text { Fundador e diretor } \\
\text { da ONG 350.org. }\end{array}$ & $\begin{array}{l}\text { Entrevista feita por } \\
\text { Skype }\end{array}$ & $\begin{array}{l}22 \text { '10" } \\
\text { (entrevista } \\
\text { gravada) }\end{array}$ \\
\hline 25.FEV.2015 & Jeremy Symons & $\begin{array}{l}\text { Vice-presidente de } \\
\text { Clima e Assuntos } \\
\text { Políticos do } \\
\text { Environmental } \\
\text { Defense Fund }\end{array}$ & $\begin{array}{l}\text { Sede do EDF, em } \\
\text { Washington, D.C. }\end{array}$ & $\begin{array}{l}35^{\prime} 15^{\prime \prime} \\
\text { (entrevista } \\
\text { gravada) }\end{array}$ \\
\hline
\end{tabular}


REPRESENTANTES DE ONGS - BRASIL

\begin{tabular}{|c|c|c|c|c|}
\hline DATA & $\begin{array}{l}\text { ENTREVISTADO } \\
\text { (A) }\end{array}$ & DESCRIÇÃO & $\begin{array}{l}\text { LOCAL DA } \\
\text { ENTREVISTA }\end{array}$ & DURAÇÃO \\
\hline 01.JUL.2014 & $\begin{array}{l}\text { Ana Cristina } \\
\text { Barros }\end{array}$ & $\begin{array}{l}\text { Atuou na TNC entre } \\
2003 \text { e } 2015 . \\
\text { Durante a } \\
\text { entrevista, era } \\
\text { diretora de } \\
\text { infraestrutura para } \\
\text { a América Latina da } \\
\text { TNC. Foi nomeada } \\
\text { secretária de } \\
\text { Biodiversidade e } \\
\text { Florestas do } \\
\text { Ministério do Meio } \\
\text { Ambiente em abril } \\
\text { de } 2015 \text {. }\end{array}$ & $\begin{array}{l}\text { Sede da TNC no } \\
\text { Setor de } \\
\text { Indústrias } \\
\text { Gráficas, em } \\
\text { Brasília (DF). }\end{array}$ & $\begin{array}{l}77^{\prime} 50 " \\
\text { (entrevista } \\
\text { gravada) }\end{array}$ \\
\hline 15.JAN.2015 & Raul Valle & $\begin{array}{l}\text { Advogado } \\
\text { ambiental, com } 14 \\
\text { anos de atuação no } \\
\text { Instituto } \\
\text { Socioambiental } \\
\text { (2000-2014), } \\
\text { coordenando o } \\
\text { programa de } \\
\text { Políticas Públicas } \\
\text { da ONG. }\end{array}$ & $\begin{array}{l}\text { Restaurante do } \\
\text { Museu Nacional } \\
\text { do Índio } \\
\text { Americano, em } \\
\text { Washington, D.C. }\end{array}$ & $\begin{array}{l}64^{\prime} 56 " \\
\text { (entrevista } \\
\text { gravada) }\end{array}$ \\
\hline 26.MAR.2015 & Adriana Ramos & $\begin{array}{l}\text { Coordenadora do } \\
\text { programa de } \\
\text { Política e Direitos } \\
\text { do Instituto } \\
\text { Socioambiental }\end{array}$ & $\begin{array}{l}\text { Escritório do ISA, } \\
\text { na Asa Norte, em } \\
\text { Brasília (DF) }\end{array}$ & $\begin{array}{l}110 ’ 36 " \\
\text { (entrevista } \\
\text { gravada) }\end{array}$ \\
\hline 28.ABR.2015 & Mário Mantovani & $\begin{array}{l}\text { Diretor de políticas } \\
\text { públicas da ONG } \\
\text { ambientalista SOS } \\
\text { Mata Atlântica. }\end{array}$ & $\begin{array}{l}\text { Gabinete do } \\
\text { deputado federal } \\
\text { Sarney Filho, que } \\
\text { coordena a Frente } \\
\text { Parlamentar } \\
\text { Ambientalista, no } \\
\text { Anexo IV da } \\
\text { Câmara dos } \\
\text { Deputados, em } \\
\text { Brasília (DF) }\end{array}$ & $\begin{array}{l}\text { Aprox. } 35 \\
\text { minutos. }\end{array}$ \\
\hline 5.MAI.2015 & $\begin{array}{l}\text { Maria Cecília Wey } \\
\text { de Brito }\end{array}$ & $\begin{array}{l}\text { Ex-secretária-geral } \\
\text { do WWF-Brasil } \\
\text { (2011 a 2015), } \\
\text { ONG na qual } \\
\text { também coordenou } \\
\text { o programa Mata } \\
\text { Atlântica. Ex- } \\
\text { secretária de } \\
\text { Biodiversidade e } \\
\text { Florestas do } \\
\text { Ministério do Meio }\end{array}$ & $\begin{array}{l}\text { Livraria Cultura do } \\
\text { Conjunto } \\
\text { Nacional, em São } \\
\text { Paulo (SP) }\end{array}$ & $\begin{array}{l}77^{\prime} 25 " \\
\text { (entrevista } \\
\text { gravada) }\end{array}$ \\
\hline
\end{tabular}




\begin{tabular}{|c|c|c|c|c|}
\hline & & $\begin{array}{l}\text { Ambiente (2007- } \\
\text { 2010). }\end{array}$ & & \\
\hline 6.MAI.2015 & Carlos Rittl & $\begin{array}{l}\text { Secretário } \\
\text { executivo do } \\
\text { Observatório do } \\
\text { Clima, ex- } \\
\text { coordenador do } \\
\text { programa de } \\
\text { Mudanças } \\
\text { Climáticas do } \\
\text { WWF-Brasil, com } \\
\text { passagem por } \\
\text { Greenpeace (dois } \\
\text { anos à frente da } \\
\text { Campanha de } \\
\text { Clima, entre abril de } \\
\text { 2005 e fevereiro de } \\
\text { 2007) Brasil e } \\
\text { Fundação Vitória } \\
\text { Amazônica. }\end{array}$ & $\begin{array}{l}\text { Frans Café Vila } \\
\text { Madalena, São } \\
\text { Paulo (SP) }\end{array}$ & $\begin{array}{l}59^{\prime} 28 " \\
\text { (entrevista } \\
\text { gravada) }\end{array}$ \\
\hline 12.MAI.2015 & Patrícia Baião & $\begin{array}{l}\text { Ex-diretora de } \\
\text { Política e } \\
\text { Governança na } \\
\text { Conservação } \\
\text { Internacional Brasil } \\
\text { entre } 2012 \text { e } 2015 \text {, } \\
\text { ex-diretora do } \\
\text { programa } \\
\text { Amazônia da Cl } \\
\text { Brasil entre } 2009 \text { e } \\
2012 \text {. }\end{array}$ & $\begin{array}{l}\text { Entrevista feita } \\
\text { por Skype }\end{array}$ & $\begin{array}{l}55^{\prime} 42 " \\
\text { (entrevista } \\
\text { gravada) }\end{array}$ \\
\hline 15.MAI.2015 & $\begin{array}{l}\text { Rubens Gomes, } \\
\text { conhecido como } \\
\text { Rubão. }\end{array}$ & $\begin{array}{l}\text { Presidente do } \\
\text { Grupo de Trabalho } \\
\text { Amazônico (GTA) } \\
\text { desde } 2008 \text {. Está } \\
\text { desde } 1998 \text { no GTA } \\
\text { e tem mais de } 30 \\
\text { anos no movimento } \\
\text { social, } \\
\text { anteriormente na } \\
\text { área de cultura e } \\
\text { arte. }\end{array}$ & $\begin{array}{l}\text { Restaurante do } \\
\text { Hotel Garvey, na } \\
\text { região central de } \\
\text { Brasília (DF). }\end{array}$ & $\begin{array}{l}\text { Aprox. } 40 \\
\text { minutos. }\end{array}$ \\
\hline 22.MAI.2015 & Nilo d'Ávila & $\begin{array}{l}\text { Coordenador de } \\
\text { pesquisa do } \\
\text { Greenpeace, onde } \\
\text { foi também } \\
\text { coordenador de } \\
\text { políticas públicas. }\end{array}$ & $\begin{array}{l}\text { Restaurante } \\
\text { Nanquim, no } \\
\text { Jardim Botânico, } \\
\text { Rio de Janeiro } \\
\text { (RJ) }\end{array}$ & $\begin{array}{l}\text { Aprox. } 110 \\
\text { minutos }\end{array}$ \\
\hline 9.JUN.2015 & Márcio Astrini & $\begin{array}{l}\text { Coordenador de } \\
\text { políticas públicas } \\
\text { do Greenpeace } \\
\text { desde } 2014 \text {. } \\
\text { Trabalha há oito } \\
\text { anos na }\end{array}$ & $\begin{array}{l}\text { Entrevista feita } \\
\text { por Skype. }\end{array}$ & $\begin{array}{l}\text { Aprox. } 45 \\
\text { minutos. }\end{array}$ \\
\hline
\end{tabular}




\begin{tabular}{|c|c|c|c|c|}
\hline & & $\begin{array}{l}\text { organização, onde } \\
\text { foi campaigner por } \\
\text { seis anos na } \\
\text { Campanha } \\
\text { Amazônia. }\end{array}$ & & \\
\hline 16.JUN.2015 & Márcio Santilli & $\begin{array}{l}\text { Sócio-fundador do } \\
\text { Instituto } \\
\text { Socioambiental } \\
\text { (ISA) e ex-deputado } \\
\text { federal, eleito em } \\
\text { 1982 (mandato } \\
\text { 1983-1986). }\end{array}$ & $\begin{array}{l}\text { Escritório do } \\
\text { Instituto } \\
\text { Socioambiental, } \\
\text { na Asa Norte, em } \\
\text { Brasília (DF). }\end{array}$ & $\begin{array}{l}79^{\prime} 46 " \\
\text { (entrevista } \\
\text { gravada) }\end{array}$ \\
\hline 26.JUN.2015 & $\begin{array}{l}\text { Fabíola Nader } \\
\text { Motta }\end{array}$ & $\begin{array}{l}\text { Gerente de } \\
\text { relações } \\
\text { institucionais da } \\
\text { Organização das } \\
\text { Cooperativas } \\
\text { Brasileiras (OCB). }\end{array}$ & $\begin{array}{l}\text { Sede da OCB, na } \\
\text { região central de } \\
\text { Brasília (DF). }\end{array}$ & $\begin{array}{l}78^{\prime} 14 " \\
\text { (entrevista } \\
\text { gravada) }\end{array}$ \\
\hline 8.JUL.2015 & Maurício Guetta & $\begin{array}{l}\text { Advogado do } \\
\text { Instituto } \\
\text { Socioambiental } \\
\text { (ISA) }\end{array}$ & $\begin{array}{l}\text { Escritório do } \\
\text { Instituto } \\
\text { Socioambiental, } \\
\text { na Asa Norte, em } \\
\text { Brasília (DF). }\end{array}$ & $\begin{array}{l}48^{\prime} 28 " \\
\text { (entrevista } \\
\text { gravada) }\end{array}$ \\
\hline 03.AGO.2015 & Rachel Biderman & $\begin{array}{l}\text { Diretora-executiva } \\
\text { do World } \\
\text { Resources Institute } \\
\text { (WRI) no Brasil, } \\
\text { atuando na } \\
\text { instituição desde } \\
2011 .\end{array}$ & $\begin{array}{l}\text { Entrevista feita } \\
\text { por Skype }\end{array}$ & $\begin{array}{l}44^{\prime} 07 " \\
\text { (entrevista } \\
\text { gravada) }\end{array}$ \\
\hline 10.AGO.2015 & Paulo Moutinho & $\begin{array}{l}\text { Diretor-executivo e } \\
\text { pesquisador-sênior } \\
\text { do Instituto de } \\
\text { Pesquisa Ambiental } \\
\text { da Amazônia } \\
\text { (IPAM), atuando na } \\
\text { instituição desde } \\
1998 .\end{array}$ & $\begin{array}{l}\text { Sede do IPAM no } \\
\text { Lago Norte, em } \\
\text { Brasília (DF) }\end{array}$ & $\begin{array}{l}76 \text { '23" } \\
\text { (entrevista } \\
\text { gravada) }\end{array}$ \\
\hline 27.AGO.2015 & Sérgio Guimarães & $\begin{array}{l}\text { Coordenador do } \\
\text { Instituto Centro de } \\
\text { Vida (ICV) e } \\
\text { secretário-executivo } \\
\text { da Articulação } \\
\text { Regional } \\
\text { Amazônica (ARA). } \\
\text { Também ocupou } \\
\text { por quatro } \\
\text { mandatos assento } \\
\text { no Conama. }\end{array}$ & $\begin{array}{l}\text { Centro Cultural de } \\
\text { Brasília, na Asa } \\
\text { Norte, Brasília } \\
\text { (DF), durante } \\
\text { reunião do Grupo } \\
\text { de Trabalho } \\
\text { Infraestrutura. }\end{array}$ & Aprox. 20' \\
\hline 04.SET.15 & Mauro Armelin & $\begin{array}{l}\text { Superintendente de } \\
\text { conservação do } \\
\text { WWF-Brasil desde } \\
\text { 2012. Vinculou-se } \\
\text { ao WWF-Brasil em }\end{array}$ & $\begin{array}{l}\text { Entrevista feita } \\
\text { por Skype }\end{array}$ & $\begin{array}{l}52^{\prime} 43 " \\
\text { (entrevista } \\
\text { gravada) }\end{array}$ \\
\hline
\end{tabular}




\begin{tabular}{|c|c|c|c|c|}
\hline & & $\begin{array}{l}\text { 2005, onde foi } \\
\text { coordenador de } \\
\text { políticas públicas, } \\
\text { do Programa de } \\
\text { Apoio ao } \\
\text { Desenvolvimento } \\
\text { Sustentável e do } \\
\text { Programa } \\
\text { Amazônia. Atuou, } \\
\text { entre } 1998 \text { e } 2002 \text {, } \\
\text { na ONG Amigos da } \\
\text { Terra Brasil. }\end{array}$ & & \\
\hline 23.SET.2015 & Paulo Barreto & $\begin{array}{l}\text { Pesquisador-sênior } \\
\text { do Imazon, na } \\
\text { instituição desde } \\
1990\end{array}$ & $\begin{array}{l}\text { Entrevista por } \\
\text { Skype }\end{array}$ & $\begin{array}{l}65 ’ 58 " \\
\text { (entrevista } \\
\text { gravada) }\end{array}$ \\
\hline 24.SET.2015 & Maria Dalce Ricas & $\begin{array}{l}\text { Superintendente } \\
\text { executiva da AMDA }\end{array}$ & $\begin{array}{l}\text { Auditório Nereu } \\
\text { Ramos da } \\
\text { Câmara dos } \\
\text { Deputados }\end{array}$ & $\begin{array}{l}\text { Aprox. } 15 \\
\text { minutos }\end{array}$ \\
\hline 27.NOV.2015 & Roberto Smeraldi & $\begin{array}{l}\text { Diretor da Amigos } \\
\text { da Terra - } \\
\text { Amazônia Brasileira }\end{array}$ & $\begin{array}{l}\text { Entrevista por e- } \\
\text { mail }\end{array}$ & $\mathrm{N} / \mathrm{A}$ \\
\hline
\end{tabular}

TOMADORES DE DECISÃO - ESTADOS UNIDOS

\begin{tabular}{|c|c|c|c|c|}
\hline DATA & $\begin{array}{l}\text { ENTREVISTADO } \\
\text { (A) }\end{array}$ & DESCRIÇÃO & $\begin{array}{l}\text { LOCAL DA } \\
\text { ENTREVISTA }\end{array}$ & DURAÇÃO \\
\hline 10.OUT.2014 & $\begin{array}{l}\text { Nome omitido pelo } \\
\text { autor da tese por } \\
\text { solicitação do } \\
\text { entrevistado }\end{array}$ & $\begin{array}{l}\text { Assessor } \\
\text { legislativo de um } \\
\text { deputado federal } \\
\text { (representative) do } \\
\text { Partido Democrata, } \\
\text { estado da } \\
\text { Califórnia* }\end{array}$ & $\begin{array}{l}\text { Gabinete do } \\
\text { parlamentar, } \\
\text { localizado no } \\
\text { Cannon Building, } \\
\text { House of } \\
\text { Representatives, } \\
\text { Washington, D.C. }\end{array}$ & $\begin{array}{l}\text { Aprox. } 40 \\
\text { minutos }\end{array}$ \\
\hline 23.OUT.2014 & $\begin{array}{l}\text { Nome omitido pelo } \\
\text { autor da tese por } \\
\text { solicitação do } \\
\text { entrevistado }\end{array}$ & $\begin{array}{l}\text { Assessor } \\
\text { legislativo de um } \\
\text { senador de um } \\
\text { estado na Costa } \\
\text { Leste*. }^{*}\end{array}$ & $\begin{array}{l}\text { Gabinete do } \\
\text { senador, no } \\
\text { Dirksen Building, } \\
\text { Senado dos EUA, } \\
\text { Washington, D.C. }\end{array}$ & $\begin{array}{l}\text { Aprox. } 35 \\
\text { minutos }\end{array}$ \\
\hline 24.NOV.2014 & Tim Aiken & $\begin{array}{l}\text { Diretor legislativo } \\
\text { do gabinete do } \\
\text { deputado federal } \\
\text { (representative) } \\
\text { Jim Moran (Partido } \\
\text { Democrata), eleito } \\
\text { pelo } 8^{\circ} \text {. Distrito do } \\
\text { estado da Virgínia } \\
\text { (exerceu nove } \\
\text { mandatos entre } \\
1991 \text { e } 2015 \text { e não } \\
\text { concorreu à } \\
\text { reeleição em 2014) }\end{array}$ & $\begin{array}{l}\text { Café Northside } \\
\text { Social, em } \\
\text { Arlington, Virgínia }\end{array}$ & $\begin{array}{l}49^{\prime} 05^{\prime \prime} \\
\text { (entrevista } \\
\text { gravada) }\end{array}$ \\
\hline 26.NOV.2015 & Nome omitido pelo & Assessora & Gabinete do & Aprox. 20 \\
\hline
\end{tabular}




\begin{tabular}{|c|c|c|c|c|}
\hline & $\begin{array}{l}\text { autor da tese por } \\
\text { solicitação da } \\
\text { entrevistada }\end{array}$ & $\begin{array}{l}\text { legislativa de um } \\
\text { deputado federal } \\
\text { (representative) do } \\
\text { Partido Democrata, } \\
\text { de um estado na } \\
\text { Costa Leste*. }\end{array}$ & $\begin{array}{l}\text { deputado, } \\
\text { localizado no } \\
\text { Rayburn Building, } \\
\text { House of } \\
\text { Representatives, } \\
\text { Washington, D.C. }\end{array}$ & minutos. \\
\hline 08.JAN.2015 & $\begin{array}{l}\text { Nome omitido pelo } \\
\text { autor da tese por } \\
\text { solicitação da } \\
\text { entrevistada }\end{array}$ & $\begin{array}{l}\text { Assessora } \\
\text { legislativa de uma } \\
\text { senadora do } \\
\text { Partido Democrata, } \\
\text { de um estado da } \\
\text { Costa Leste }\end{array}$ & $\begin{array}{l}\text { Gabinete da } \\
\text { senadora, no Hart } \\
\text { Building, Senado } \\
\text { Federal, } \\
\text { Washington, D.C. }\end{array}$ & $\begin{array}{l}\text { Aprox. } 25 \\
\text { min. }\end{array}$ \\
\hline 23.JAN.2015 & $\begin{array}{l}\text { Nome omitido pelo } \\
\text { autor da tese por } \\
\text { solicitação do } \\
\text { entrevistado }\end{array}$ & $\begin{array}{l}\text { Assessor sênior de } \\
\text { uma deputada } \\
\text { federal } \\
\text { (representative) do } \\
\text { Partido } \\
\text { Republicano, de } \\
\text { um estado na } \\
\text { região central dos } \\
\text { EUA* }\end{array}$ & $\begin{array}{l}\text { Gabinete da } \\
\text { deputada, } \\
\text { localizado no } \\
\text { Longworth } \\
\text { Building, House of } \\
\text { Representatives, } \\
\text { Washington, D.C. }\end{array}$ & $\begin{array}{l}\text { Aprox. } 25 \\
\text { min. }\end{array}$ \\
\hline 23.JAN.2015 & $\begin{array}{l}\text { Nome omitido pelo } \\
\text { autor da tese por } \\
\text { solicitação do } \\
\text { entrevistado }\end{array}$ & $\begin{array}{l}\text { Diretor legislativo } \\
\text { de um deputado } \\
\text { federal } \\
\text { (representative) do } \\
\text { Partido } \\
\text { Republicano, de } \\
\text { um estado } \\
\text { produtor de } \\
\text { petróleo* }\end{array}$ & $\begin{array}{l}\text { Gabinete do } \\
\text { deputado, } \\
\text { localizado no } \\
\text { Rayburn Building, } \\
\text { House of } \\
\text { Representatives, } \\
\text { Washington, D.C. }\end{array}$ & $\begin{array}{l}\text { Aprox. } 30 \\
\text { min. }\end{array}$ \\
\hline 23.JAN.2015 & $\begin{array}{l}\text { Nome omitido pelo } \\
\text { autor da tese por } \\
\text { solicitação da } \\
\text { entrevistada }\end{array}$ & $\begin{array}{l}\text { Assessora sênior } \\
\text { de um deputado } \\
\text { federal } \\
\text { (representative) do } \\
\text { Partido } \\
\text { Republicano do } \\
\text { estado do Texas* }\end{array}$ & $\begin{array}{l}\text { Lanchonete do } \\
\text { Rayburn Building, } \\
\text { House of } \\
\text { Representatives, } \\
\text { Washington, D.C. }\end{array}$ & $\begin{array}{l}\text { Aprox. } 20 \\
\text { min. }\end{array}$ \\
\hline 23.JAN.2015 & $\begin{array}{l}\text { Nome omitido pelo } \\
\text { autor da tese por } \\
\text { solicitação do } \\
\text { entrevistado }\end{array}$ & $\begin{array}{l}\text { Assessor sênior de } \\
\text { um deputado } \\
\text { federal } \\
\text { (representative) do } \\
\text { Partido } \\
\text { Republicano do } \\
\text { estado de Utah }\end{array}$ & $\begin{array}{l}\text { Gabinete do } \\
\text { deputado, } \\
\text { localizado no } \\
\text { Rayburn Building, } \\
\text { House of } \\
\text { Representatives, } \\
\text { Washington, D.C. }\end{array}$ & $\begin{array}{l}\text { Aprox. } 15 \\
\text { min. }\end{array}$ \\
\hline 24.FEV.2015 & $\begin{array}{l}\text { Nome omitido pelo } \\
\text { autor da tese por } \\
\text { solicitação do } \\
\text { entrevistado }\end{array}$ & $\begin{array}{l}\text { Assessor sênior de } \\
\text { uma senadora do } \\
\text { Partido } \\
\text { Republicano }\end{array}$ & $\begin{array}{l}\text { Gabinete da } \\
\text { senadora, no Hart } \\
\text { Building, Senado } \\
\text { Federal, } \\
\text { Washington, D.C. }\end{array}$ & $\begin{array}{l}\text { Aprox. } 30 \\
\text { min. }\end{array}$ \\
\hline
\end{tabular}

*Entrevistado(a) aceitou falar sob a condição de que seu nome e do parlamentar para o qual trabalha não fossem citados em nenhuma hipótese. Em alguns casos, o(a) assessor(a) não autorizou a divulgação do estado do parlamentar, em um caso demandou que o partido do parlamentar fosse omitido. 
TOMADORES DE DECISÃO - BRASIL

\begin{tabular}{|c|c|c|c|c|}
\hline DATA & $\begin{array}{l}\text { ENTREVISTADO } \\
\text { (A) }\end{array}$ & DESCRIÇÃO & $\begin{array}{l}\text { LOCAL DA } \\
\text { ENTREVISTA }\end{array}$ & DURAÇÃO \\
\hline 03.JUL.2014 & Kenzo Jucá & $\begin{array}{l}\text { Cientista político, } \\
\text { assessor para meio } \\
\text { ambiente da } \\
\text { liderança do Partido } \\
\text { Socialista Brasileiro } \\
\text { (PSB), Câmara dos } \\
\text { Deputados }\end{array}$ & $\begin{array}{l}\text { Gabinete da } \\
\text { liderança do PSB } \\
\text { na Câmara dos } \\
\text { Deputados, } \\
\text { Brasília, DF }\end{array}$ & $\begin{array}{l}58^{\prime} 58^{\prime \prime} \\
\text { (entrevista } \\
\text { gravada) }\end{array}$ \\
\hline 29.ABR.2015 & Claudio Maretti & $\begin{array}{l}\text { Presidente do } \\
\text { Instituto Chico } \\
\text { Mendes de } \\
\text { Conservação da } \\
\text { Biodiversidade } \\
\text { (ICMBio) desde } \\
\text { abril de 2015, ex- } \\
\text { líder da Iniciativa } \\
\text { Amazônica (LAI) da } \\
\text { Rede WWF, ex- } \\
\text { diretor de } \\
\text { Conservação do } \\
\text { WWF-Brasil. }\end{array}$ & $\begin{array}{l}\text { Sede do WWF- } \\
\text { Brasil, no Lago } \\
\text { Sul, em Brasília } \\
\text { (DF) }\end{array}$ & $\begin{array}{l}68^{\prime} 06^{\prime \prime} \\
\text { (entrevista } \\
\text { gravada) }\end{array}$ \\
\hline 5.MAI.2015 & $\begin{array}{l}\text { João Paulo } \\
\text { Capobianco }\end{array}$ & $\begin{array}{l}\text { Ex-secretário } \\
\text { Executivo e ex- } \\
\text { secretário de } \\
\text { Floresta e } \\
\text { Biodiversidade do } \\
\text { Ministério do Meio } \\
\text { Ambiente entre } \\
2003 \text { e 2008, } \\
\text { durante a gestão } \\
\text { Marina Silva. } \\
\text { Ocupou cargos } \\
\text { diversos nas ONGs } \\
\text { SOS Mata Atlântica, } \\
\text { ISA, FBONs. } \\
\text { Atualmente é diretor } \\
\text { da ONG Instituto } \\
\text { Democracia e } \\
\text { Sustentabilidade } \\
\text { (IDS). }\end{array}$ & $\begin{array}{l}\text { Sede do Instituto } \\
\text { Democracia e } \\
\text { Sustentabilidade, } \\
\text { no bairro da } \\
\text { Consolação, em } \\
\text { São Paulo (SP) }\end{array}$ & $\begin{array}{l}74^{\prime} 46 " \\
\text { (entrevista } \\
\text { gravada) }\end{array}$ \\
\hline 19.MAI.2015 & $\begin{array}{l}\text { Ana Margarida de } \\
\text { Castro Euler }\end{array}$ & $\begin{array}{l}\text { Engenheira } \\
\text { florestal, doutora } \\
\text { em ecologia } \\
\text { florestal pela } \\
\text { Universidade } \\
\text { Nacional de } \\
\text { Yokohama, Japão. } \\
\text { Pesquisadora da } \\
\text { Embrapa, ex- } \\
\text { presidente do } \\
\text { Instituto Estadual de }\end{array}$ & $\begin{array}{l}\text { Instituto Israel } \\
\text { Pinheiro, em } \\
\text { Brasília (DF), } \\
\text { durante evento } \\
\text { sobre agricultura } \\
\text { familiar. }\end{array}$ & Aprox. 35" \\
\hline
\end{tabular}




\begin{tabular}{|c|c|c|c|c|}
\hline & & $\begin{array}{l}\text { Florestas do Amapá } \\
\text { (2011-2014), ex- } \\
\text { analista de } \\
\text { conservação do } \\
\text { WWF-Brasil (2005- } \\
\text { 2008). }\end{array}$ & & \\
\hline 10.ABR.2015 & André Lima & $\begin{array}{l}\text { Secretário de Meio } \\
\text { Ambiente do Distrito } \\
\text { Federal, com } \\
\text { passagens pelas } \\
\text { ONGs ISA e IPAM }\end{array}$ & $\begin{array}{l}\text { Sede da } \\
\text { Secretaria de } \\
\text { Meio Ambiente do } \\
\text { Distrito Federal }\end{array}$ & $\begin{array}{l}42 ' 57 " \\
\text { (entrevista } \\
\text { gravada) }\end{array}$ \\
\hline 3.JUN.2015 & $\begin{array}{l}\text { Roberto Messias } \\
\text { Franco }\end{array}$ & $\begin{array}{l}\text { Ex-presidente do } \\
\text { IBAMA (junho de } \\
2008 \text { a abril de } \\
2010 \text { ), ex-secretário } \\
\text { especial do meio } \\
\text { ambiente (entre } \\
1986 \text { e } 1988, \text { o } \\
\text { segundo do país, } \\
\text { substituindo Paulo } \\
\text { Nogueira Neto, que } \\
\text { ocupou o cargo por } \\
12 \text { anos). Foi } \\
\text { secretário-geral do } \\
\text { WWF-Brasil entre } \\
2002 \text { e } 2003 \text { e } \\
\text { diretor do Ibama. } \\
\text { Atualmente é o } \\
\text { secretario municipal } \\
\text { de meio ambiente } \\
\text { de Nova Lima, } \\
\text { Minas Gerais. }\end{array}$ & $\begin{array}{l}\text { Secretaria de } \\
\text { Meio Ambiente do } \\
\text { Município de Nova } \\
\text { Lima (MG) }\end{array}$ & $\begin{array}{l}60^{\prime} 59 " \\
\text { (entrevista } \\
\text { gravada) }\end{array}$ \\
\hline 10.JUN.2015 & Luis Carlos Heinze & $\begin{array}{l}\text { Deputado federal } \\
\text { pelo Partido } \\
\text { Progressista (PP), } \\
\text { estado do Rio } \\
\text { Grande do Sul, } \\
\text { preside a Comissão } \\
\text { de Agricultura e } \\
\text { Política Rural da } \\
\text { Câmara, } \\
\text { considerado um dos } \\
\text { principais nomes da } \\
\text { chamada bancada } \\
\text { ruralista. }\end{array}$ & $\begin{array}{l}\text { Gabinete do } \\
\text { deputado, Anexo } \\
\text { IV da Câmara dos } \\
\text { Deputados, } \\
\text { Brasília (DF) }\end{array}$ & $\begin{array}{l}40 ' 26 " \\
\text { (entrevista } \\
\text { gravada) }\end{array}$ \\
\hline 15.JUN.2015 & Nilto Tatto & $\begin{array}{l}\text { Deputado federal } \\
\text { pelo Partido dos } \\
\text { Trabalhadores (PT), } \\
\text { estado de São } \\
\text { Paulo, foi diretor da } \\
\text { ONG ambientalista } \\
\text { Instituto } \\
\text { Socioambiental } \\
\text { (ISA) }\end{array}$ & $\begin{array}{l}\text { Gabinete do } \\
\text { deputado, Anexo } \\
\text { III da Câmara dos } \\
\text { Deputados, } \\
\text { Brasília (DF) }\end{array}$ & $\begin{array}{l}53^{\prime} 11^{\prime \prime} \\
\text { (entrevista } \\
\text { gravada) }\end{array}$ \\
\hline
\end{tabular}




\begin{tabular}{|c|c|c|c|c|}
\hline 17.JUN.2015 & Ricardo Trípoli & $\begin{array}{l}\text { Deputado federal } \\
\text { pelo Partido a } \\
\text { Social Democracia } \\
\text { Brasileira (PSDB), } \\
\text { estado de São } \\
\text { Paulo. Considerado } \\
\text { um aliado pelo } \\
\text { movimento } \\
\text { ambientalista. }\end{array}$ & $\begin{array}{l}\text { Entrevista feita } \\
\text { por e-mail. }\end{array}$ & N/A \\
\hline 23.JUN.2015 & José Luiz Penna & $\begin{array}{l}\text { Deputado federal } \\
\text { pelo Partido Verde } \\
\text { (PV), estado de São } \\
\text { Paulo. }\end{array}$ & $\begin{array}{l}\text { Gabinete do } \\
\text { deputado, Anexo } \\
\text { IV da Câmara dos } \\
\text { Deputados, } \\
\text { Brasília (DF) }\end{array}$ & $\begin{array}{l}56{ }^{\prime} 02 " \\
\text { (entrevista } \\
\text { gravada) }\end{array}$ \\
\hline 23.JUN.2015 & João Capiberibe & $\begin{array}{l}\text { Senador pelo } \\
\text { Partido Socialista } \\
\text { Brasileiro (PSB), } \\
\text { eleito em 2010. Ex- } \\
\text { prefeito de Macapá } \\
\text { e ex-governador do } \\
\text { Amapá. É visto } \\
\text { como um dos } \\
\text { principais aliados do } \\
\text { movimento } \\
\text { socioambiental no } \\
\text { Senado. }\end{array}$ & $\begin{array}{l}\text { Gabinete do } \\
\text { senador no } \\
\text { Senado Federal, } \\
\text { em Brasília (DF) }\end{array}$ & $\begin{array}{l}27 ’ 57^{\prime \prime} \\
\text { (entrevista } \\
\text { gravada) }\end{array}$ \\
\hline 7.JUL.2015 & João Akira Omoto & $\begin{array}{l}\text { Procurador } \\
\text { Regional da } \\
\text { República no } \\
\text { Ministério Público } \\
\text { Federal e Membro } \\
\text { da 6a Câmara de } \\
\text { Coordenação e } \\
\text { Revisão do } \\
\text { Ministério Público } \\
\text { Federal - } \\
\text { Populações } \\
\text { indígenas e } \\
\text { Comunidades } \\
\text { Tradicionais. }\end{array}$ & $\begin{array}{l}\text { Sede da } \\
\text { Procuradoria } \\
\text { Regional da } \\
\text { República da 1a. } \\
\text { Região, em } \\
\text { Brasília (DF) }\end{array}$ & $\begin{array}{l}\text { Aprox. } 45 \\
\text { min. }\end{array}$ \\
\hline 8.JUL.2015 & Roberto Vizentin & $\begin{array}{l}\text { Ex-presidente do } \\
\text { Instituto Chico } \\
\text { Mendes de } \\
\text { Conservação da } \\
\text { Biodiversidade } \\
\text { (ICMBio) }\end{array}$ & $\begin{array}{l}\text { Bar Armazém do } \\
\text { Mineiro, na Asa } \\
\text { Norte, Brasília } \\
\text { (DF). }\end{array}$ & $\begin{array}{l}45^{\prime} 10 " \\
\text { (entrevista } \\
\text { gravada) }\end{array}$ \\
\hline 23.JUL.2015 & $\begin{array}{l}\text { José Carlos } \\
\text { Carvalho }\end{array}$ & $\begin{array}{l}\text { Ministro do meio } \\
\text { ambiente do } \\
\text { governo Fernando } \\
\text { Henrique entre } \\
\text { março e dezembro } \\
\text { de } 2002 \text {, ex- } \\
\text { secretário-executivo } \\
\text { do MMA entre } 1999\end{array}$ & $\begin{array}{l}\text { Residência do } \\
\text { entrevistado no } \\
\text { bairro Anchieta, } \\
\text { em Belo } \\
\text { Horizonte, MG. }\end{array}$ & $\begin{array}{l}\text { 53'18" } \\
\text { (entrevista } \\
\text { gravada) }\end{array}$ \\
\hline
\end{tabular}




\begin{tabular}{|c|c|c|c|c|}
\hline & & $\begin{array}{l}\text { e 2002. Foi ainda o } \\
\text { primeiro secretário } \\
\text { estadual de meio } \\
\text { ambiente de Minas } \\
\text { Gerais, entre } 1995 \\
\text { e } 1998 \text { (governo } \\
\text { Eduardo Azeredo) e } \\
\text { ocupou novamente } \\
\text { o cargo entre } 2007 \\
\text { e } 2010 \text { (governo } \\
\text { Aécio Neves). }\end{array}$ & & \\
\hline 31.JUL.2015 & Marina Silva & $\begin{array}{l}\text { Ministra do meio } \\
\text { ambiente no } \\
\text { governo Lula entre } \\
\text { janeiro de } 2003 \text { e } \\
\text { maio de } 2008, \\
\text { senadora entre } \\
1995 \text { e } 2002 \text { e entre } \\
2008 \text { e } 2010, \\
\text { candidata a } \\
\text { presidente nas } \\
\text { eleições de } 2010 \text { e } \\
2014, \\
\text { respectivamente } \\
\text { pelo PV e pelo PSB, } \\
\text { obtendo, em cada } \\
\text { um dos pleitos, } \\
\text { mais de } 20 \text { milhões } \\
\text { de votos. } \\
\text { Considerada uma } \\
\text { das principais } \\
\text { líderes } \\
\text { ambientalistas } \\
\text { mundiais da } \\
\text { atualidade. }\end{array}$ & $\begin{array}{l}\text { Sede do Instituto } \\
\text { Marina Silva, na } \\
\text { Asa Norte, } \\
\text { Brasília. }\end{array}$ & $\begin{array}{l}\text { 42'49" } \\
\text { (entrevista } \\
\text { gravada) }\end{array}$ \\
\hline AGO.2015 & Ronaldo Caiado & $\begin{array}{l}\text { Senador pelo } \\
\text { Democratas (DEM), } \\
\text { estado de Goiás, } \\
\text { em primeiro } \\
\text { mandato. Deputado } \\
\text { federal entre } 1999 \text { e } \\
2015 \text {, considerado } \\
\text { um dos principais } \\
\text { nomes da bancada } \\
\text { ruralista. }\end{array}$ & $\begin{array}{l}\text { Entrevista feita } \\
\text { por meio de } \\
\text { questionário } \\
\text { impresso, } \\
\text { entregue no } \\
\text { gabinete do } \\
\text { senador. }\end{array}$ & $\mathrm{N} / \mathrm{A}$ \\
\hline AGO.2015 & Chico Alencar & $\begin{array}{l}\text { Deputado federal } \\
\text { pelo Partido } \\
\text { Socialismo e } \\
\text { Liberdade (PSOL), } \\
\text { no terceiro mandato } \\
\text { consecutivo. } \\
\text { Considerado um } \\
\text { aliado pelo } \\
\text { movimento }\end{array}$ & $\begin{array}{l}\text { Entrevista feita } \\
\text { por e-mail }\end{array}$ & $\mathrm{N} / \mathrm{A}$ \\
\hline
\end{tabular}




\begin{tabular}{|c|c|c|c|c|}
\hline & & ambientalista. & & \\
\hline 19.AGO.2015 & $\begin{array}{l}\text { Alberto Tavares, } \\
\text { conhecido como } \\
\text { Dande }\end{array}$ & $\begin{array}{l}\text { Diretor da } \\
\text { Companhia de } \\
\text { Desenvolvimento de } \\
\text { Serviços Ambientais } \\
\text { do Estado do Acre, } \\
\text { analista de } \\
\text { conservação do } \\
\text { WWF-Brasil entre } \\
2005 \text { e } 2013 \text {, tendo } \\
\text { coordenado o } \\
\text { escritório do WWF- } \\
\text { Brasil no Acre entre } \\
2007 \text { e } 2013 \text {. }\end{array}$ & $\begin{array}{l}\text { Entrevista feita } \\
\text { por telefone }\end{array}$ & Aprox. 30' \\
\hline 14.AGO.2015 & $\begin{array}{l}\text { Roseli Senna } \\
\text { Ganem }\end{array}$ & $\begin{array}{l}\text { Consultora } \\
\text { legislativa da } \\
\text { Câmara dos } \\
\text { Deputados na área } \\
\text { de meio ambiente, } \\
\text { doutora em } \\
\text { Desenvolvimento } \\
\text { Sustentável pelo } \\
\text { Centro de } \\
\text { Desenvolvimento } \\
\text { Sustentável da } \\
\text { Universidade de } \\
\text { Brasília (CDS/UnB). }\end{array}$ & $\begin{array}{l}\text { Restaurante do } \\
\text { Anexo III da } \\
\text { Câmara dos } \\
\text { Deputados, em } \\
\text { Brasília, DF }\end{array}$ & Aprox. 25' \\
\hline 27.AGO.2015 & Jorge Viana & $\begin{array}{l}\text { Senador pelo } \\
\text { Partido dos } \\
\text { Trabalhadores (PT), } \\
\text { estado do Acre, } \\
\text { eleito em 2010. É } \\
\text { vice-presidente do } \\
\text { Senado. Ex-prefeito } \\
\text { de Rio Branco e ex- } \\
\text { governador do Acre } \\
\text { (1999-2005), } \\
\text { responsável por } \\
\text { inovadores projetos } \\
\text { voltados para o } \\
\text { desenvolvimento } \\
\text { sustentável quando } \\
\text { governava o Acre. }\end{array}$ & $\begin{array}{l}\text { Gabinete do } \\
\text { senador no } \\
\text { Senado Federal, } \\
\text { em Brasília, DF }\end{array}$ & $\begin{array}{l}16^{\prime} 10 " \\
\text { (entrevista } \\
\text { gravada) }\end{array}$ \\
\hline 24.SET.2015 & Sarney Filho & $\begin{array}{l}\text { Deputado Federal } \\
\text { pelo Partido Verde } \\
\text { (PV), estado do } \\
\text { Maranhão, em } \\
\text { oitavo mandato. Ex- } \\
\text { ministro do Meio } \\
\text { Ambiente (1999- } \\
\text { 2002). Preside a } \\
\text { Frente Parlamentar } \\
\text { Ambientalista e é } \\
\text { visto como aliado }\end{array}$ & $\begin{array}{l}\text { Entrevista por e- } \\
\text { mail }\end{array}$ & $\mathrm{N} / \mathrm{A}$ \\
\hline
\end{tabular}




\begin{tabular}{|l|l|l|l|}
\hline & $\begin{array}{l}\text { pelo movimento } \\
\text { ambientalista. }\end{array}$ & & \\
\hline
\end{tabular}

ACADÊMICOS - EUA

\begin{tabular}{|c|c|c|c|c|}
\hline DATA & $\begin{array}{l}\text { ENTREVISTADO } \\
\text { (A) }\end{array}$ & DESCRIÇÃO & $\begin{array}{l}\text { LOCAL DA } \\
\text { ENTREVISTA }\end{array}$ & DURAÇÃO \\
\hline 03.SET.2014 & $\begin{array}{l}\text { Robert } \\
\text { Buschbacher }\end{array}$ & $\begin{array}{l}\text { Coordenador do } \\
\text { programa Amazon } \\
\text { Conservation } \\
\text { Leadership, na } \\
\text { Universidade da } \\
\text { Flórida. Trabalhou } \\
\text { por } 14 \text { anos no } \\
\text { WWF Estados } \\
\text { Unidos e no WWF- } \\
\text { Brasil, onde dirigiu o } \\
\text { programa de } \\
\text { Florestas Tropicais } \\
\text { e foi diretor técnico. }\end{array}$ & $\begin{array}{l}\text { Entrevista feita } \\
\text { por Skype }\end{array}$ & $\begin{array}{l}45^{\prime} 26 " \\
\text { (entrevista } \\
\text { gravada) }\end{array}$ \\
\hline 27.JAN.2015 & Robert J. Brulle & $\begin{array}{l}\text { Professor de } \\
\text { Sociologia e Ciência } \\
\text { Ambiental na } \\
\text { Universidade } \\
\text { Drexel, na Filadélfia, } \\
\text { com dezenas de } \\
\text { publicações sobre o } \\
\text { movimento } \\
\text { ambientalista norte- } \\
\text { americano. }\end{array}$ & $\begin{array}{l}\text { Entrevista feita } \\
\text { por Skype }\end{array}$ & $\begin{array}{l}36^{\prime} 48^{\prime \prime} \\
\text { (entrevista } \\
\text { gravada) }\end{array}$ \\
\hline 04.FEV.2015 & Jeffry Burnam & $\begin{array}{l}\text { Professor adjunto } \\
\text { no Departamento de } \\
\text { Governo da } \\
\text { Universidade de } \\
\text { Georgetown, } \\
\text { assessorou o } \\
\text { deputado federal } \\
\text { (representative) } \\
\text { Mickey Edwards } \\
\text { (Republicano de } \\
\text { Oklahoma) entre } \\
\text { 1979 e 1981, } \\
\text { assessor do } \\
\text { senador Richard } \\
\text { Lugar (Republicano } \\
\text { de Indiana) entre } \\
\text { 1981 e 2001 e } \\
\text { assessor no } \\
\text { Departamento de } \\
\text { Estado para temas } \\
\text { ambientais entre } \\
2001 \text { e 2007. }\end{array}$ & $\begin{array}{l}\text { Gabinete do } \\
\text { professor, no } \\
\text { Intercultural } \\
\text { Center, na } \\
\text { Universidade de } \\
\text { Georgetown }\end{array}$ & $\begin{array}{l}366^{\prime} 47^{\prime \prime} \\
\text { (entrevista } \\
\text { gravada) }\end{array}$ \\
\hline
\end{tabular}


ACADÊMICOS - BRASIL

\begin{tabular}{|c|c|c|c|c|}
\hline DATA & $\begin{array}{l}\text { ENTREVISTADO } \\
\text { (A) }\end{array}$ & DESCRIÇÃO & $\begin{array}{l}\text { LOCAL DA } \\
\text { ENTREVISTA }\end{array}$ & DURAÇÃO \\
\hline 20.MAI.2015 & $\begin{array}{l}\text { Sérgio Besserman } \\
\text { Vianna }\end{array}$ & $\begin{array}{l}\text { Professor do } \\
\text { Departamento de } \\
\text { Economia da } \\
\text { PUC-RJ, } \\
\text { integrante do } \\
\text { conselho diretivo } \\
\text { do WWF-Brasil } \\
\text { por oito anos, } \\
\text { atualmente } \\
\text { integrante do } \\
\text { conselho } \\
\text { consultivo do } \\
\text { WWF-Brasil. } \\
\text { Também membro } \\
\text { dos conselhos } \\
\text { consultivos da } \\
\text { Conservação } \\
\text { Internacional e do } \\
\text { ICLEl e do } \\
\text { conselho diretivo } \\
\text { da Funbio, além } \\
\text { de ONGs } \\
\text { regionais. } \\
\text { Funcionário de } \\
\text { carreira do } \\
\text { BNDES, } \\
\text { atualmente cedido } \\
\text { à Prefeitura do Rio } \\
\text { de Janeiro. }\end{array}$ & $\begin{array}{l}\text { Centro de } \\
\text { Desenvolvimento } \\
\text { Sustentável, no } \\
\text { câmpus da } \\
\text { Universidade de } \\
\text { Brasília, na Asa } \\
\text { Norte, em Brasília } \\
\text { (DF) }\end{array}$ & $\begin{array}{l}68 \text { '33" } \\
\text { (entrevista } \\
\text { gravada) }\end{array}$ \\
\hline
\end{tabular}




\section{ANEXO II - LISTA DE ONGS PESQUISADAS}

Os quadros seguintes apresentam uma descrição das principais organizações ambientalistas analisadas neste trabalho. Os dados foram obtidos a partir de pesquisas nos relatórios anuais e nos sites das próprias ONGs, na publicação Conservation Directory 2015 (Breuer 2015) e no site do International Revenue Service (IRS, órgão norte-americano correspondente à Receita Federal no Brasil).

EUA

\begin{tabular}{|c|c|c|c|c|c|c|}
\hline Nome & $\begin{array}{l}\text { Ano de } \\
\text { funda- } \\
\text { ção }\end{array}$ & $\begin{array}{l}\text { Receita } \\
\text { anual em } \\
2014\end{array}$ & $\begin{array}{l}\text { Funcio- } \\
\text { nários }\end{array}$ & $\begin{array}{l}\text { Filiados/ } \\
\text { ativistas }\end{array}$ & $\begin{array}{l}\text { Escritórios/ } \\
\text { capítulos }\end{array}$ & $\begin{array}{l}\text { Atuação } \\
\text { internacional }\end{array}$ \\
\hline Sierra Club & 1892 & $\begin{array}{l}\text { US\$ } 104,3 \\
\text { milhões }\end{array}$ & 739 & $\begin{array}{l}2,4 \\
\text { milhões }\end{array}$ & $\begin{array}{l}\text { Tem } 64 \text { escritórios, } \\
\text { está presente nos } \\
50 \text { estados dos } \\
\text { EUA. }\end{array}$ & Sim (Canadá) \\
\hline $\begin{array}{l}\text { National } \\
\text { Audubon } \\
\text { Society }\end{array}$ & 1896 & $\begin{array}{l}\text { US\$ } 92 \\
\text { milhões }\end{array}$ & 1.050 & $400 \mathrm{mil}$ & $\begin{array}{l}\text { Tem } 22 \text { escritórios } \\
\text { estaduais, } 41 \\
\text { centros e } \\
\text { santuários para } \\
\text { conservação e } \\
\text { mais de } 450 \\
\text { capítulos regionais }\end{array}$ & $\begin{array}{l}\text { Atuação } \\
\text { indireta via } \\
\text { apoio a áreas } \\
\text { protegidas }\end{array}$ \\
\hline $\begin{array}{l}\text { Izaak Walton } \\
\text { League }\end{array}$ & 1922 & $\begin{array}{l}\text { US\$ 2,8 } \\
\text { milhões }\end{array}$ & 22 & $44 \mathrm{mil}$ & $\begin{array}{l}\text { Sim, } 23 \text { capítulos } \\
\text { em diferentes } \\
\text { regiões dos EUA. }\end{array}$ & Não \\
\hline $\begin{array}{l}\text { The } \\
\text { Wilderness } \\
\text { Society }\end{array}$ & 1935 & $\begin{array}{l}\text { US\$ } 29,7 \\
\text { milhões }\end{array}$ & 181 & $800 \mathrm{mil}$ & $\begin{array}{l}\text { Presente em } 48 \\
\text { estados norte- } \\
\text { americanos }\end{array}$ & Não \\
\hline $\begin{array}{l}\text { National } \\
\text { Wildlife } \\
\text { Federation } \\
\text { (NWF) }\end{array}$ & 1936 & $\begin{array}{l}\text { US\$ } 86 \\
\text { milhões }\end{array}$ & 360 & $\begin{array}{l}4 \\
\text { milhões }\end{array}$ & $\begin{array}{l}\text { Tem sete } \\
\text { escritórios } \\
\text { regionais e } \\
\text { trabalha no } \\
\text { sistema de } \\
\text { organizações } \\
\text { autônomas } \\
\text { afiliadas, que } \\
\text { perfazem um total } \\
\text { de } 49 \text { instituições } \\
\text { espalhadas pelos } \\
\text { EUA. A sede é em } \\
\text { Reston, Virgínia, } \\
\text { com um escritório }\end{array}$ & $\begin{array}{l}\text { Sim, atua no } \\
\text { México, } \\
\text { América } \\
\text { Central e do } \\
\text { Sul, por meio } \\
\text { de estudos } \\
\text { técnicos. }\end{array}$ \\
\hline
\end{tabular}




\begin{tabular}{|c|c|c|c|c|c|c|}
\hline & & & & & $\begin{array}{l}\text { de políticas } \\
\text { públicas em } \\
\text { Washington, D.C. }\end{array}$ & \\
\hline $\begin{array}{l}\text { Ducks } \\
\text { Unlimited }\end{array}$ & 1937 & $\begin{array}{l}\text { US\$ } 199 \\
\text { milhões }\end{array}$ & 577 & $691 \mathrm{mil}$ & $\begin{array}{l}\text { Atuação nos } 50 \\
\text { estados norte- } \\
\text { americanos, por } \\
\text { meio de } 2,6 \text { mil } \\
\text { capítulos. }\end{array}$ & $\begin{array}{l}\text { Sim, projetos } \\
\text { no Canadá e } \\
\text { no México. }\end{array}$ \\
\hline $\begin{array}{l}\text { Defenders of } \\
\text { Wildlife }\end{array}$ & 1947 & $\begin{array}{l}\text { US\$ } 32,2 \\
\text { milhões }\end{array}$ & 186 & $\begin{array}{l}1,215 \\
\text { milhão }\end{array}$ & $\begin{array}{l}\text { Tem sede em } \\
\text { Washington, D.C., } \\
\text { com escritórios } \\
\text { regionais nos } \\
\text { estados de Alaska, } \\
\text { Califórnia, } \\
\text { Colorado, Flórida e } \\
\text { Washington. }\end{array}$ & $\begin{array}{l}\text { Sim, tem } \\
\text { projetos no } \\
\text { México }\end{array}$ \\
\hline $\begin{array}{l}\text { The Nature } \\
\text { Conservancy }\end{array}$ & 1951 & $\begin{array}{l}\text { US\$ 1,114 } \\
\text { bilhão }\end{array}$ & $\begin{array}{l}.786, \\
\text { inclui } \\
648 \text { que } \\
\text { trabalha } \\
m \text { fora } \\
\text { dos } \\
\text { EUA }\end{array}$ & 1 milhão & $\begin{array}{l}\text { Presente nos } 50 \\
\text { estados dos EUA }\end{array}$ & $\begin{array}{l}\text { Sim, atuação } \\
\text { em } 35 \text { países, } \\
\text { em todos os } \\
\text { continentes. }\end{array}$ \\
\hline WWF-US & 1961 & $\begin{array}{l}\text { US\$ } 266 \\
\text { milhões }\end{array}$ & 604 & $\begin{array}{l}1,1 \\
\text { milhão }\end{array}$ & $\begin{array}{l}\text { Não tem escritórios } \\
\text { em outras regiões } \\
\text { dos EUA, mas } \\
\text { desenvolve um } \\
\text { projeto de } \\
\text { conservação nas } \\
\text { grandes planícies } \\
\text { do Norte, que } \\
\text { incluem Montana, } \\
\text { Dakota do Sul, } \\
\text { Dakota do Norte, } \\
\text { Nebraska e } \\
\text { Wyoming e parte } \\
\text { do Canadá. }\end{array}$ & $\begin{array}{l}\text { Sim, apoia } \\
\text { ações via } \\
\text { Rede WWF } \\
\text { na África, } \\
\text { Ásia, Europa, } \\
\text { Oceania e } \\
\text { Américas }\end{array}$ \\
\hline $\begin{array}{l}\text { Environment } \\
\text { al Defense } \\
\text { Fund (EDF) }\end{array}$ & 1967 & $\begin{array}{l}\text { US\$ } 130 \\
\text { milhões }\end{array}$ & 500 & $700 \mathrm{mil}$ & $\begin{array}{l}\text { Sede em Nova } \\
\text { York e escritórios } \\
\text { em Arkansas, } \\
\text { Califórnia (2), } \\
\text { Carolina do Norte, } \\
\text { Colorado, } \\
\text { Massachusetts, }\end{array}$ & $\begin{array}{l}\text { Sim, atua na } \\
\text { América } \\
\text { Latina, Reino } \\
\text { Unido e } \\
\text { China. }\end{array}$ \\
\hline
\end{tabular}




\begin{tabular}{|c|c|c|c|c|c|c|}
\hline & & & & & $\begin{array}{l}\text { Texas, } \\
\text { Washington, D.C., } \\
\text { China, México e } \\
\text { Reino Unido. }\end{array}$ & \\
\hline $\begin{array}{l}\text { Friends of } \\
\text { the Earth } \\
(\text { FoE) }\end{array}$ & 1969 & $\begin{array}{l}\text { US\$ } 7,5 \\
\text { milhões }\end{array}$ & 34 & $400 \mathrm{mil}$ & $\begin{array}{l}\text { Tem sede em } \\
\text { Washington, D.C. } \\
\text { e um escritório na } \\
\text { Califórnia }\end{array}$ & $\begin{array}{l}\text { Sim. Tem } \\
\text { organizações } \\
\text { afiliadas em } \\
\text { cerca de } 75 \\
\text { países }\end{array}$ \\
\hline $\begin{array}{l}\text { League of } \\
\text { Conservation } \\
\text { Voters (LCV) }\end{array}$ & 1969 & $\begin{array}{l}\text { US\$ } 50 \\
\text { milhões }\end{array}$ & 85 & $\begin{array}{l}1,2 \\
\text { milhão }\end{array}$ & $\begin{array}{l}\text { Tem sede em } \\
\text { Washington e } \\
\text { organizações } \\
\text { afiliadas em } 30 \\
\text { estados norte- } \\
\text { americanos. }\end{array}$ & Não \\
\hline $\begin{array}{l}\text { Natural } \\
\text { Resources } \\
\text { Defense } \\
\text { Council } \\
\text { (NRDC) }\end{array}$ & 1970 & $\begin{array}{l}\text { US } \$ 121,6 \\
\text { milhões }\end{array}$ & 589 & $\begin{array}{l}1,25 \\
\text { milhão }\end{array}$ & $\begin{array}{l}\text { Sede em } \\
\text { Washington, D.C., } \\
\text { com escritórios nos } \\
\text { estados de } \\
\text { Califórnia (2), } \\
\text { Illinois e Montana. }\end{array}$ & $\begin{array}{l}\text { Sim, tem um } \\
\text { escritório na } \\
\text { China }\end{array}$ \\
\hline Earthjustice & $1971^{211}$ & $\begin{array}{l}\text { US\$ 54,4 } \\
\text { milhões }\end{array}$ & 254 & Não tem & $\begin{array}{l}\text { Sede em San } \\
\text { Francisco, } \\
\text { Califórnia, com } \\
\text { outros } 11 \\
\text { escritórios em } \\
\text { Alaska (2), } \\
\text { Califórnia (Los } \\
\text { Angeles), } \\
\text { Colorado, Flórida, } \\
\text { Havaí, Montana, } \\
\text { Nova York, } \\
\text { Pensilvânia, } \\
\text { estado de } \\
\text { Washington e } \\
\text { Washington, D.C., }\end{array}$ & Não \\
\hline $\begin{array}{l}\text { Greenpeace } \\
\text { USA } \\
\text { (Greenpeace }\end{array}$ & 1971 & $\begin{array}{l}\text { US\$ } 33,5 \\
\text { milhões** }^{* *}\end{array}$ & 2.745 & $250 \mathrm{mil}$ & $\begin{array}{l}\text { Sede em } \\
\text { Washington, D.C. } \\
\text { e um escritório em }\end{array}$ & $\begin{array}{l}\text { Sim, a rede } \\
\text { Greenpeace } \\
\text { atua em mais }\end{array}$ \\
\hline
\end{tabular}

${ }^{211}$ A organização que deu origem à Earthjustice foi criada em 1971 como um braço judicial do Sierra Club (Sierra Club Legal Defense Fund). Desmembrou-se do Sierra Club e passou a ser denominada Earthjustice em 1997. 


\begin{tabular}{|c|c|c|c|c|c|c|}
\hline Inc) & & & & & $\begin{array}{l}\text { San Francisco, } \\
\text { Califórnia. }\end{array}$ & de 40 países \\
\hline $\begin{array}{l}\text { Center for } \\
\text { Health, } \\
\text { Environment } \\
\text { and Justice } \\
\text { (CHEJ) }\end{array}$ & 1981 & $\begin{array}{l}\text { US\$ } 678 \\
\text { mil }\end{array}$ & 11 & $40 \mathrm{mil}$ & $\begin{array}{l}\text { Sede em Falls } \\
\text { Church, estado da } \\
\text { Virgínia. Não tem } \\
\text { escritórios mas } \\
\text { trabalha em rede } \\
\text { com centenas de } \\
\text { organizações } \\
\text { locais } \\
\text { comunitárias. }\end{array}$ & Não \\
\hline $\begin{array}{l}\text { World } \\
\text { Resources } \\
\text { Institute } \\
\text { (WRI) }\end{array}$ & 1982 & $\begin{array}{l}\text { US\$ } 65 \\
\text { milhões }\end{array}$ & 450 & Não tem & $\begin{array}{l}\text { Sede em } \\
\text { Washington, D.C. }\end{array}$ & $\begin{array}{l}\text { Atua em cerca } \\
\text { de } 50 \text { países } \\
\text { e tem } \\
\text { escritórios no } \\
\text { Brasil, China, } \\
\text { Holanda, Índia } \\
\text { e Indonésia }\end{array}$ \\
\hline $\begin{array}{l}\text { Conservation } \\
\text { International } \\
\text { (Cl) }\end{array}$ & 1987 & $\begin{array}{l}\text { US\$ } 164 \\
\text { milhões }\end{array}$ & 415 & $4,7 \mathrm{mil}^{* * *}$ & $\begin{array}{l}\text { Além da sede em } \\
\text { Arlington, estado } \\
\text { da Virgínia, tem } \\
\text { escritórios em } \\
\text { Seattle, estado de } \\
\text { Washington, e em } \\
\text { Honolulu, no } \\
\text { Havaí. }\end{array}$ & $\begin{array}{l}\text { Sim, mais de } \\
30 \text { países em } \\
\text { todos os } \\
\text { continentes }\end{array}$ \\
\hline 350.org & 2008 & $\begin{array}{l}\text { US\$ } 5,7 \\
\text { milhões }\end{array}$ & 32 & 1 milhão & $\begin{array}{l}\text { Sede em Nova } \\
\text { York }\end{array}$ & $\begin{array}{l}\text { Presente, por } \\
\text { meio de } \\
\text { escritórios e, } \\
\text { principalmente } \\
\text {, redes } \\
\text { filiadas, em } \\
188 \text { países }\end{array}$ \\
\hline
\end{tabular}

* A organização que deu origem à Earthjustice foi criada em 1971 como um braço judicial do Sierra Club (Sierra Club Legal Defense Fund). Desmembrou-se do Sierra Club e passou a ser denominada Earthjustice em 1997.

** O Fundo Greenpeace, uma subdivisão do Greenpeace, que financia projetos de conservação apoiados pela organização em várias partes do mundo, teve receita de US\$ 15 milhões em 2014, mas é uma organização distinta da que se denomina Greenpeace USA, um dos objetos desta pesquisa.

*** Número de doadores divulgado em relatório de 2012 da organização, não inclui ativistas cadastrados ou doadores de valores considerados menores

**** Fonte: http://www.thenation.com/article/how-350org-still-changing-climate-justice-movement/ 
Brasil

\begin{tabular}{|c|c|c|c|c|c|c|}
\hline Nome & $\begin{array}{l}\text { Ano } \\
\text { de } \\
\text { funda- } \\
\text { ção }\end{array}$ & $\begin{array}{l}\text { Receita } \\
\text { anual } \\
2014\end{array}$ & $\begin{array}{l}\text { Funcio- } \\
\text { nários }\end{array}$ & $\begin{array}{l}\text { Filiados/ } \\
\text { ativistas }\end{array}$ & $\begin{array}{l}\text { Escritórios/ } \\
\text { capítulos }\end{array}$ & $\begin{array}{l}\text { Atuação } \\
\text { internacio- } \\
\text { nal }\end{array}$ \\
\hline $\begin{array}{l}\text { SOS Mata } \\
\text { Atlântica }\end{array}$ & 1986 & $\begin{array}{l}\mathrm{R} \$ 23,4 \\
\text { milhões }\end{array}$ & 70 & $\begin{array}{l}300 \text { mil* } \\
(5 \text { mil } \\
\text { filiados })\end{array}$ & $\begin{array}{l}\text { Sede em São } \\
\text { Paulo e um } \\
\text { escritório de } \\
\text { campo em Itu } \\
(\mathrm{SP}) .\end{array}$ & Não \\
\hline $\begin{array}{l}\text { The Nature } \\
\text { Conservanc } \\
\text { y (TNC- } \\
\text { Brasil) }\end{array}$ & 1988 & $\begin{array}{l}\mathrm{R} \$ 22,6 \\
\text { milhões** }\end{array}$ & 100 & Não tem & $\begin{array}{l}\text { Sede no Rio de } \\
\text { Janeiro, com } \\
\text { escritórios em } \\
\text { Belém, Brasília e } \\
\text { São Paulo. }\end{array}$ & $\begin{array}{l}\text { Sim, } \\
\text { atuação } \\
\text { em } 35 \\
\text { países, em } \\
\text { todos os } \\
\text { continentes }\end{array}$ \\
\hline $\begin{array}{l}\text { Amigos da } \\
\text { Terra } \\
\text { Amazônia } \\
\text { Brasileira }\end{array}$ & 1989 & $\begin{array}{l}\mathrm{R} \$ 2 \\
\text { milhões }\end{array}$ & 14 & Não tem & $\begin{array}{l}\text { Não trabalha com } \\
\text { o conceito de } \\
\text { escritórios, } \\
\text { diretoria trabalha } \\
\text { baseada em São } \\
\text { Paulo. }\end{array}$ & Não \\
\hline IMAZON & 1990 & $\begin{array}{l}\mathrm{R} \$ 13,6 \\
\text { milhões }\end{array}$ & 46 & Não tem & $\begin{array}{l}\text { Sede em Belém } \\
\text { (PA) }\end{array}$ & Não \\
\hline $\begin{array}{l}\text { Conservaçã } \\
\text { o } \\
\text { Internacional } \\
\text { (Cl-Brasil) }\end{array}$ & 1990 & $\begin{array}{l}\mathrm{R} \$ 11,3 \\
\text { milhões }\end{array}$ & 44 & Não tem & $\begin{array}{l}\text { Sede no Rio de } \\
\text { Janeiro, com } \\
\text { escritórios em } \\
\text { Belém, Brasília, } \\
\text { Caravelas (BA), } \\
\text { Macapá e } \\
\text { Mucugê (BA). }\end{array}$ & $\begin{array}{l}\text { Sim, a } \\
\text { organizaçã } \\
\text { o atua em } \\
\text { mais de } 30 \\
\text { países. }\end{array}$ \\
\hline $\begin{array}{l}\text { Instituto } \\
\text { Centro de } \\
\text { Vida (ICV) }\end{array}$ & 1991 & $\begin{array}{l}\mathrm{R} \$ 10,2 \\
\text { milhões }\end{array}$ & 51 & Não tem & $\begin{array}{l}\text { Três escritórios, } \\
\text { todos no estado } \\
\text { do Mato Grosso }\end{array}$ & Não \\
\hline $\begin{array}{l}\text { Greenpeace } \\
\text { Brasil }\end{array}$ & 1992 & $\begin{array}{l}\mathrm{R} \$ 28,1 \\
\text { milhões }\end{array}$ & 166 & $50 \mathrm{mil}$ & $\begin{array}{l}\text { Sede em São } \\
\text { Paulo, com } \\
\text { escritórios em } \\
\text { Brasília, Manaus } \\
\text { e Rio de Janeiro. }\end{array}$ & $\begin{array}{l}\text { Sim, } \\
\text { pertence à } \\
\text { rede } \\
\text { Greenpeac } \\
\text { e, presente } \\
\text { em mais de }\end{array}$ \\
\hline
\end{tabular}




\begin{tabular}{|c|c|c|c|c|c|c|}
\hline & & & & & & 40 países \\
\hline ISA & 1994 & $\begin{array}{l}\mathrm{R} \$ 22 \\
\text { milhões }\end{array}$ & 150 & 65 & $\begin{array}{l}\text { Sede em São } \\
\text { Paulo (SP) e } \\
\text { escritórios em } \\
\text { Brasília (DF), } \\
\text { Manaus (AM), } \\
\text { Boa Vista (RR), } \\
\text { São Gabriel da } \\
\text { Cachoeira (AM), } \\
\text { Canarana (MT), } \\
\text { Eldorado (SP) e } \\
\text { Altamira (PA). }\end{array}$ & Não \\
\hline IPAM & 1995 & $\mathrm{R} \$ 14.4$ & 140 & Não tem & $\begin{array}{l}\text { Sede em Belém } \\
\text { (PA), sete } \\
\text { escritórios de } \\
\text { campo na } \\
\text { Amazônia, um em } \\
\text { Brasília e um em } \\
\text { São Paulo }\end{array}$ & Não \\
\hline IMAFLORA & 1995 & $\begin{array}{l}\mathrm{R} \$ 16,2 \\
\text { milhões }\end{array}$ & 59 & Não tem & $\begin{array}{l}\text { Sede em } \\
\text { Piracicaba (SP). }\end{array}$ & Não \\
\hline WWF-Brasil & 1996 & $\begin{array}{l}\mathrm{R} \$ 50,3 \\
\text { milhões }\end{array}$ & 161 & $6 \mathrm{mil}$ & $\begin{array}{l}\text { Sede em Brasília } \\
\text { (DF), escritórios } \\
\text { em Campo } \\
\text { Grande (MS), } \\
\text { Manaus (AM), Rio } \\
\text { Branco (AC) e } \\
\text { São Paulo (SP). }\end{array}$ & $\begin{array}{l}\text { Sim, } \\
\text { pertence à } \\
\text { Rede } \\
\text { WWF, } \\
\text { presente } \\
\text { em cerca } \\
\text { de } 100 \\
\text { países. }\end{array}$ \\
\hline IIEB & 2000 & $\begin{array}{l}\mathrm{R} \$ 10,8 \\
\text { milhões*** }\end{array}$ & 34 & Não tem & $\begin{array}{l}\text { Sede em Brasília } \\
\text { (DF), escritórios } \\
\text { em Belém (PA) e } \\
\text { Humaitá (AM) }\end{array}$ & Não \\
\hline
\end{tabular}

* A ONG informa que este total corresponde a doadores pela parceria com o cartão Bradesco Visa SOS Mata Atlântica, por meio do qual o cliente doa parte da anuidade para a organização. O número de filiados não passa de 5 mil.

** Dado de 2012

*** Dado de 2013 